APARECIDO BATISTA DE OLIVEIRA

CRÍTICA DO PRINCÍPIO DA MELHORIA DA CONDIÇÃO SOCIAL DO TRABALHADOR

DISSERTAÇÃO DE MESTRADO

ORIENTADOR: PROF. DR. PAULO EDUARDO VIEIRA DE OLIVEIRA

FACULDADE DE DIREITO

UNIVERSIDADE DE SÃO PAULO

SÃO PAULO

2014 
APARECIDO BATISTA DE OLIVEIRA

\section{CRÍTICA DO PRINCÍPIO DA MELHORIA DA CONDIÇÃO SOCIAL DO TRABALHADOR}

DISSERTAÇÃO APRESENTADA À FACULDADE DE DIREITO DA UNIVERSIDADE DE SÃO PAULO COMO REQUISITO PARA A OBTENÇÃO DO TÍTULO DE MESTRE EM DIREITO DO TRABALHO E DA SEGURIDADE SOCIAL

ORIENTADOR: PROF. DR. PAULO EDUARDO VIEIRA DE OLIVEIRA 
Banca Examinadora 


\section{DEDICATÓRIA}

Para minha esposa Cleide e minha filha Helena, com amor. 


\section{AGRADECIMENTOS}

Ao meu orientador, Prof. Paulo Eduardo Vieira de Oliveira, pela confiança, incentivo e generosidade.

Aos Professores Jorge Luiz Souto Maior e Homero Batista Mateus da Silva, pelas importantíssimas observações e sugestões, no exame de qualificação.

Aos Professores Álvaro de Vita, Celso Fernandes Campilongo, Eduardo Carlos Bianca Bittar, Gilberto Bercovici, Jorge Luiz Souto Maior, Larissa Mies Bombardi, Otávio Pinto e Silva, Paulo Eduardo Vieira de Oliveira, Sérgio Luiz Adorno, Walküre Lopes Ribeiro da Silva e Walquiria Gertrudes Domingues Leão Rêgo, com os quais tive a honra e o prazer de cursar as matérias curriculares, pelos valiosíssimos ensinamentos.

Aos meus colegas companheiros das aulas, pelo grato convívio.

Ao E. Tribunal Regional do Trabalho da $15^{\text {a }}$ Região, pela concessão da licença para a realização deste estudo. 
"Quem quer agir racionalmente deve preparar-se para trabalhar; deve também ser capaz de aguentar o sofrimento, pois, para agir, é preciso também ter condições de suportar a paixão e de experimentar a compaixão, as quais estão na própria origem da faculdade de pensar ou, como diria Hannah Arendt, da "vida do espírito"”

(DEJOURS, Christophe. A banalização da injustiça social. Tradução de Luiz Alberto Monjardim. 7. ed. Rio de Janeiro: Editora FGV, 2006, p. 145).

“... na ordem do espírito, a crítica representa a mais poderosa arma e o mais fecundo meio de renovação da vida..."

(SOUZA, Sérgio Alberto de. Direito, globalização e barbárie - estudos críticos de temas de direito do trabalho e de direitos humanos sob a ótica de uma leitura não-liberal. São Paulo: LTr, 1998, p. 11). 
"Pois não estavam vendo que ele era de carne e osso? Tinha obrigação de trabalhar para os outros, naturalmente, conhecia o seu lugar. Bem. Nascera com esse destino, ninguém tinha culpa de ele haver nascido com um destino ruim. Que fazer? Podia mudar a sorte? Se lhe dissessem que era possível melhorar de situação, espantar-se-ia. Tinha vindo ao mundo para amansar brabo, curar feridas com rezas, consertar cercas de inverno a verão. Era a sina. O pai vivera assim, o avô também. E para trás não existia família. Cortar mandacaru, ensebar látegos - aquilo estava no sangue. Conformava-se, não pretendia mais nada. Se lhe dessem o que era dele, estava certo. Não davam. Era um desgraçado, era como um cachorro, só recebia ossos. Porque seria que os homens ricos ainda lhe tomavam uma parte dos ossos? Fazia até nojo pessoas importantes se ocuparem com semelhantes porcarias".

(RAMOS, Graciliano. Vidas secas. Rio, São Paulo: Record, 2000, p. 96) 


\section{SUMÁRIO}

INTRODUÇÃO.

1 - O TRABALHO NA ESTRUTURA SOCIAL..................................... 16

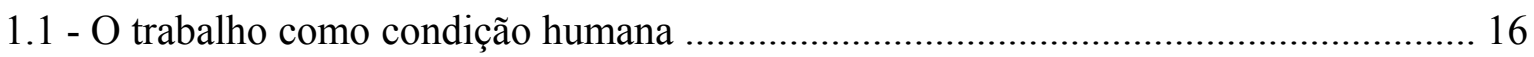

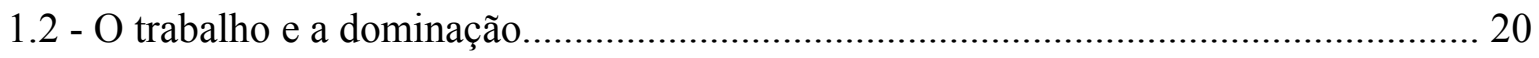

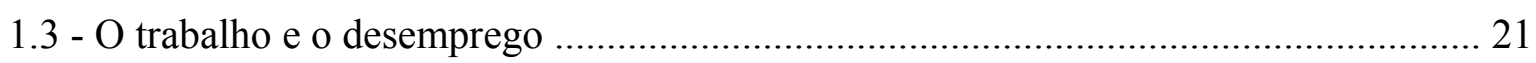

1.4 - A formação da classe trabalhadora - aspectos conceituais ........................................ 24

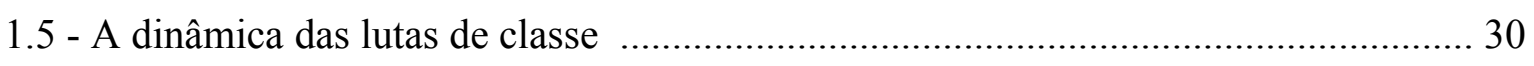

1.6 - O exemplo histórico de constituição da burguesia.................................................... 35

1.7 - Os outros segmentos sociais: a classe média, a "nova classe trabalhadora" brasileira, o

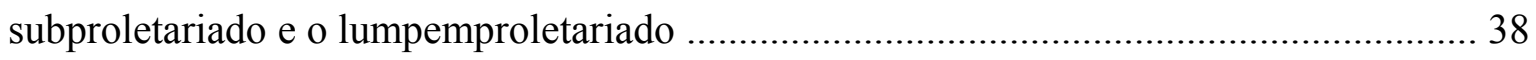

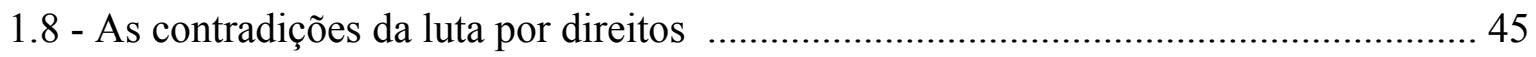

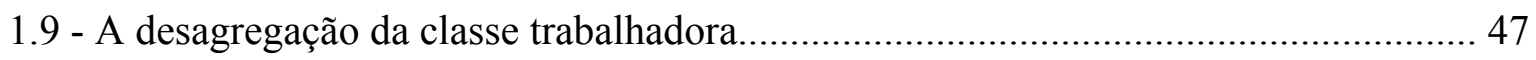

1.10 - O direito do trabalho como elemento de consciência de classe .............................. 51

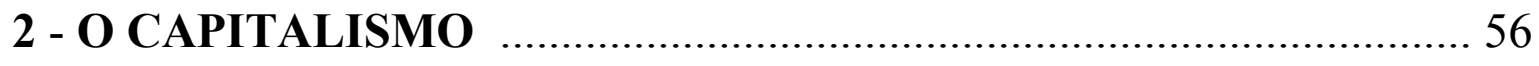

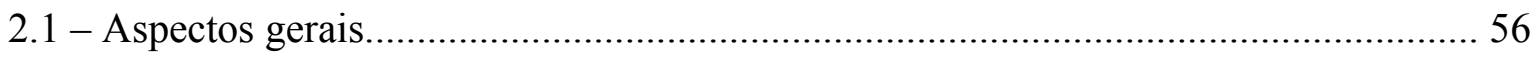

2.2 - A lógica de acumulação e de reprodução do capital ................................................. 57

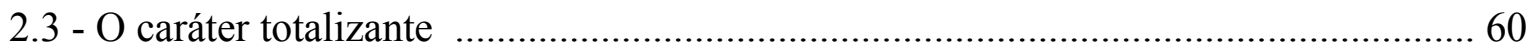

2.4 - A propriedade privada dos meios de produção .......................................................... 61

2.5 - A divisão social e técnica altamente organizada do trabalho ..................................... 62

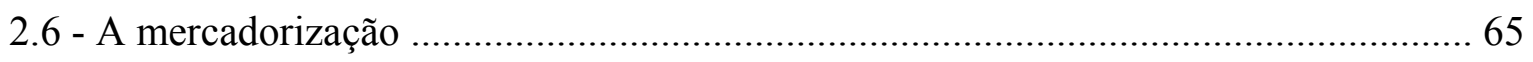

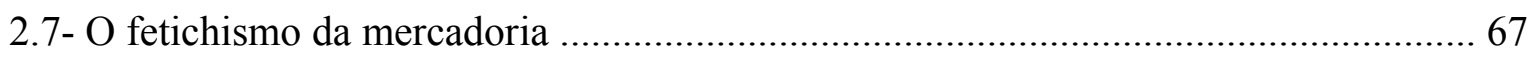

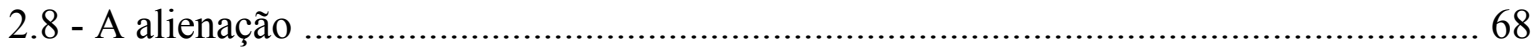

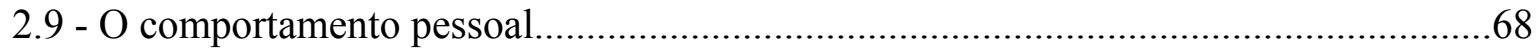

2.10 - A dinâmica de crises e de criação e recriação ...............................................................69

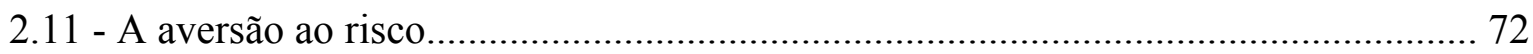

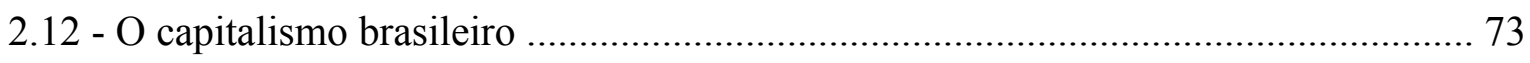




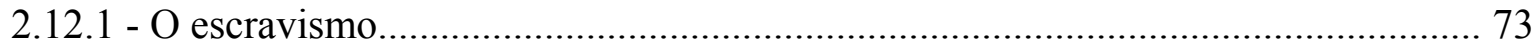

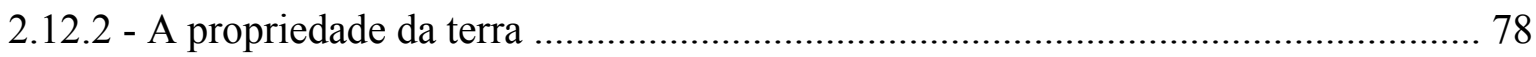

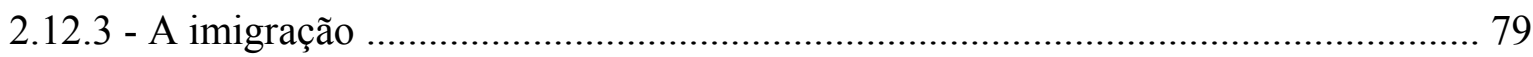

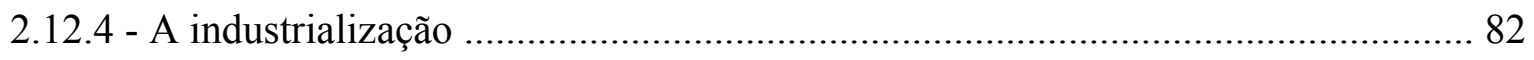

2.12.5 - Os movimentos sociais de trabalhadores na Primeira República...........................86

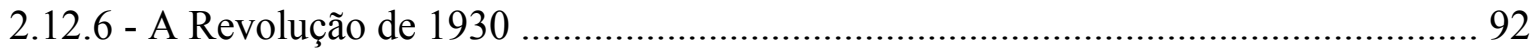

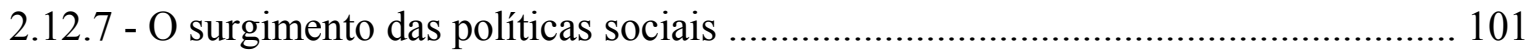

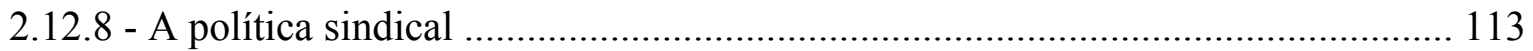

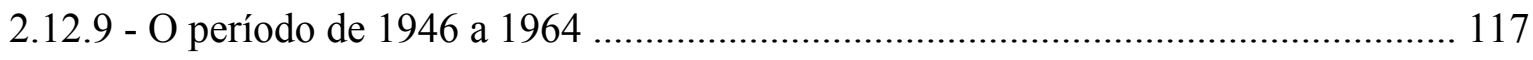

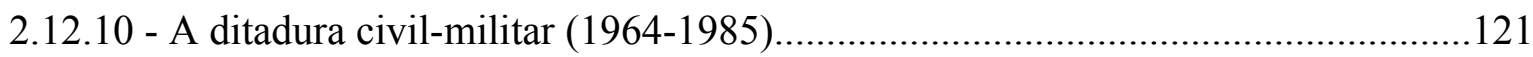

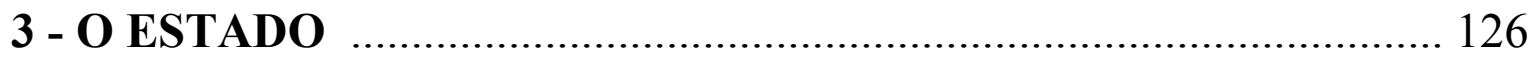

3.1 - Elemento estrutural do sistema capitalista ...................................................... 126

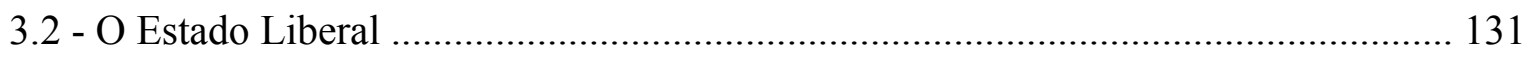

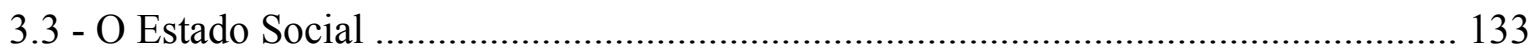

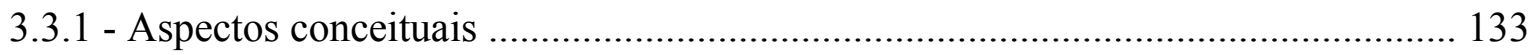

3.3.2 - Os principais modelos de Estado Social............................................................. 142

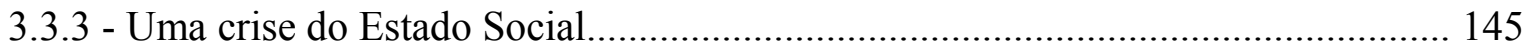

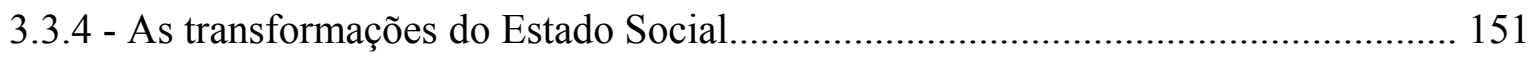

3.3.5 - A constituição de um Estado Social no Brasil ...................................................... 154

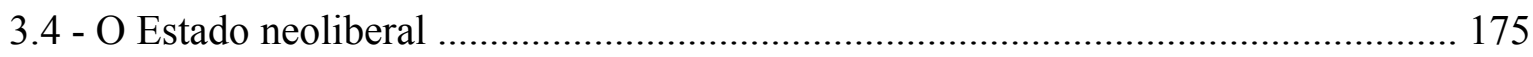

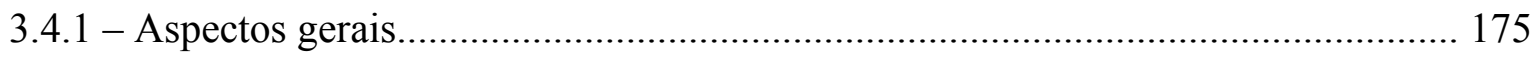

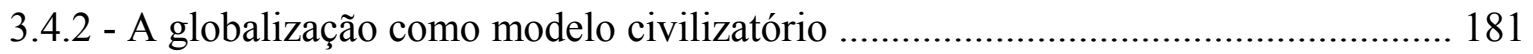

3.4.3 - A desprivatização do Estado brasileiro ................................................................. 184

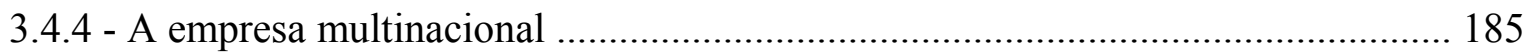

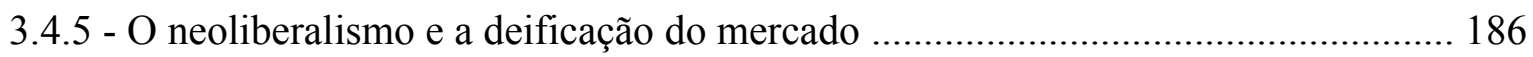

3.4.6 - As mudanças recentes nos processos de produção .................................................187

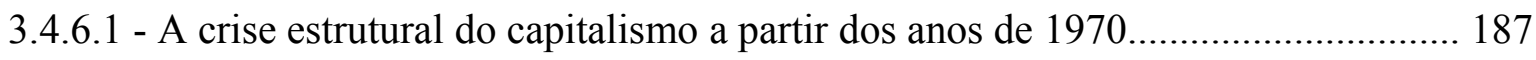

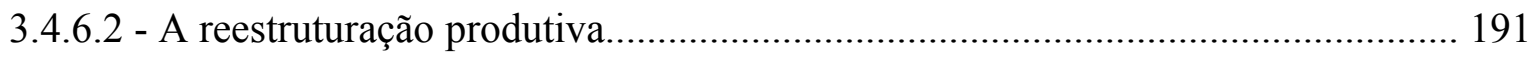

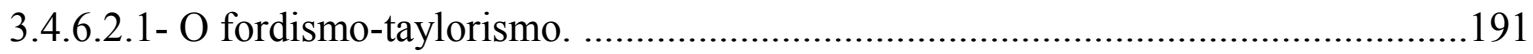

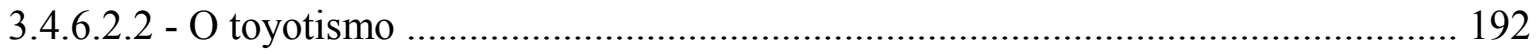

3.4.6.3 - As consequências para a classe trabalhadora da reestruturação do capital......... 194 


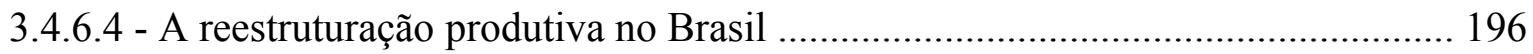

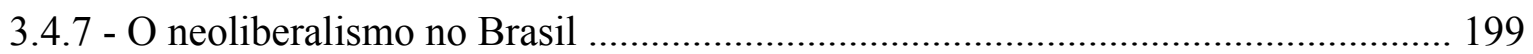

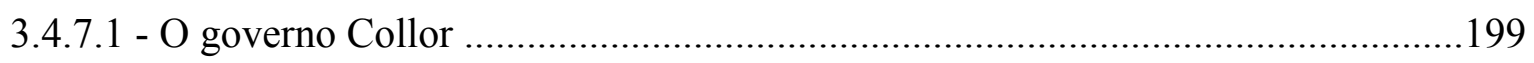

3.4.7.2 - FHC e a subserviência ao capital internacional ................................................. 201

3.4.8 - As principais mudanças organizacionais e inovações tecnológicas a partir da década

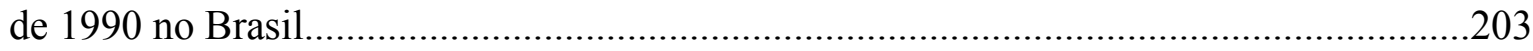

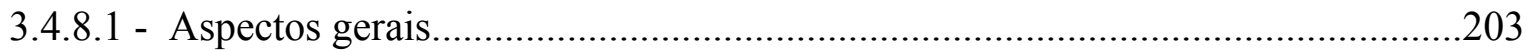

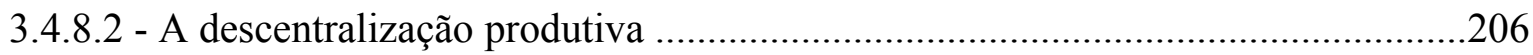

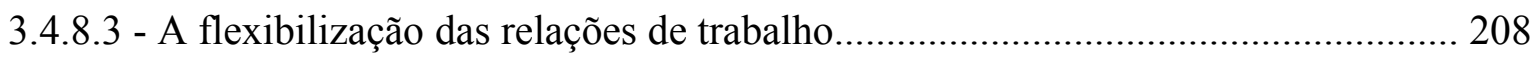

3.4.9 - A intensificação dos pressupostos econômicos e sociais para a aplicação do direito

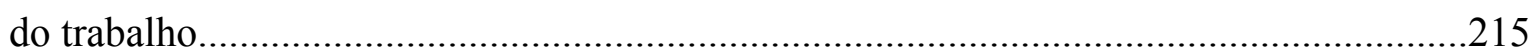

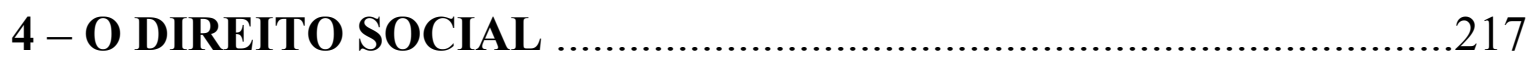

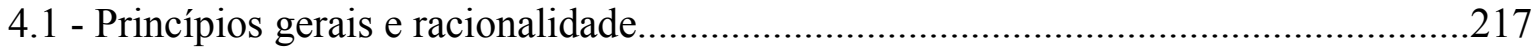

4.2 - As ideias embrionárias do direito social ..............................................................222

4.3 - Direitos sociais e economia - a questão da inflação ............................................... 225

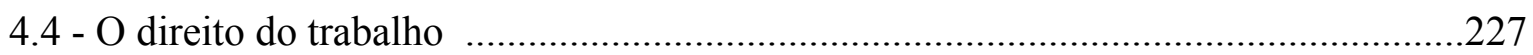

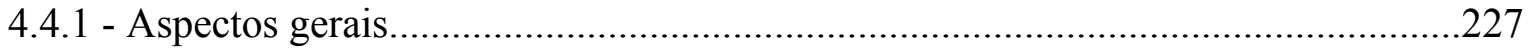

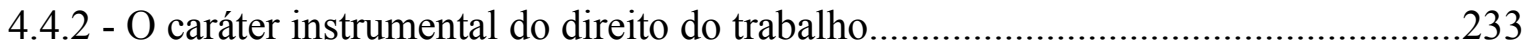

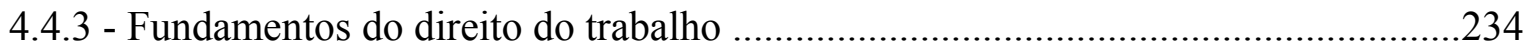

4.4.4 - O conceito e as características essenciais do direito do trabalho ..........................238

4.4.5 - O caráter expansivo do direito do trabalho...........................................................240

4.4.6 - O condicionamento político e econômico do direito do trabalho............................241

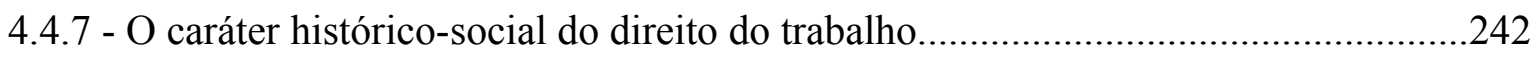

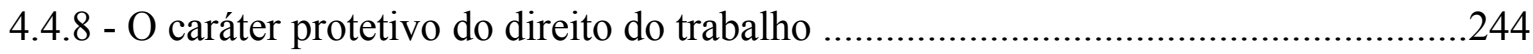

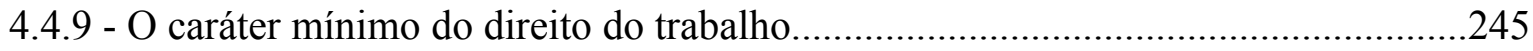

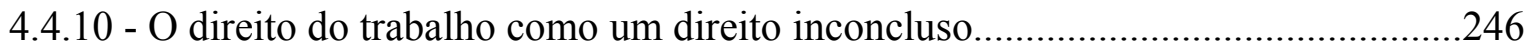

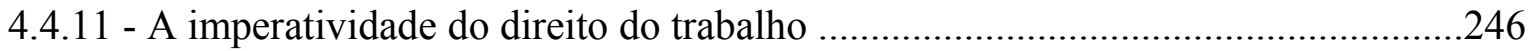

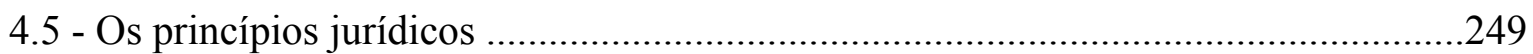

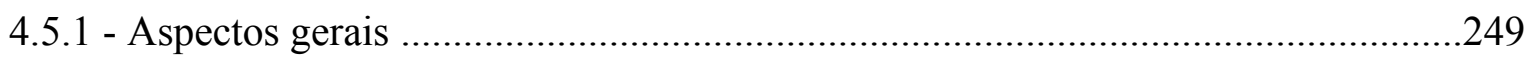

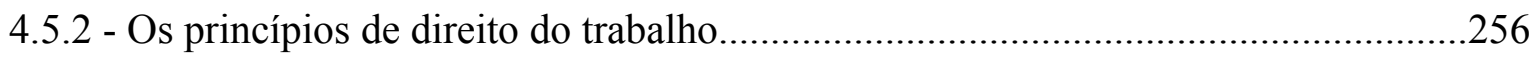

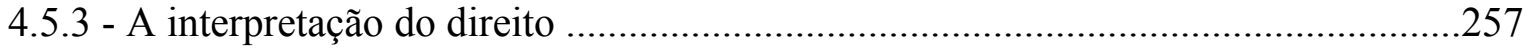


4.6 - A diretriz axiológica da Constituição Federal de 1988 - O paradigma da dignidade

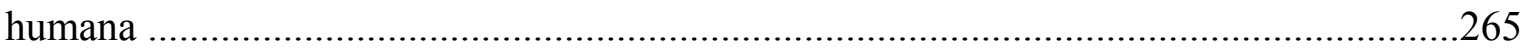

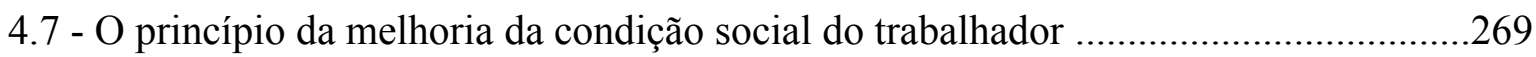

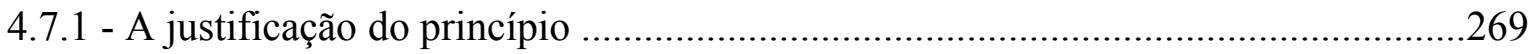

4.7.2 - A positivação do princípio da melhoria da condiçao social do trabalhador ...........282

4.7.3 - Contextualização principiológica e explicitação do conteúdo................................292

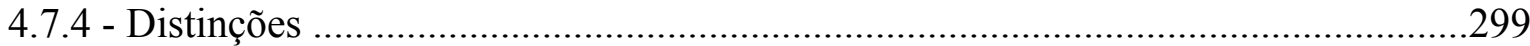

4.8 - Dilemas atuais do direito do trabalho à luz do princípio da melhoria da condição

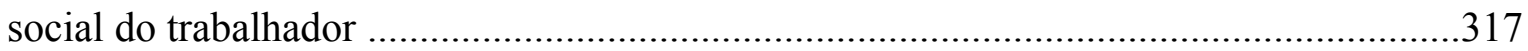

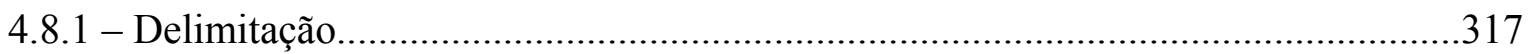

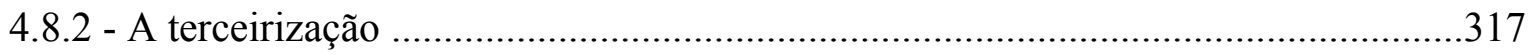

4.8.3 - O regime do FGTS e o problema da alta rotatividade da mão de obra....................323

4.8.4 - O banco de horas e o excesso de jornada de trabalho .............................................330

CONCLUSÃO

REFERÊNCIAS BIBLIOGRÁFICAS ....................................................358

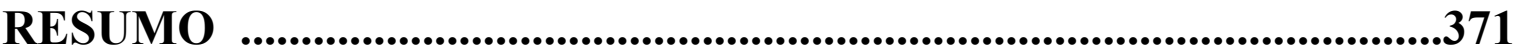

ABSTRACT 


\section{INTRODUÇÃO}

O direito do trabalho é um ramo jurídico muito dinâmico, conflituoso e de certa forma contraditório, o que torna complexa e desafiadora a tarefa de buscar a apreensão de seus traços essenciais e de sua finalidade social. Para começar a perceber isso, basta verificar a facilidade com que divergem duas pessoas que estejam dialogando sobre algum de seus institutos. Na verdade, a forma como são vistas as normas do direito do trabalho depende profundamente da maneira como cada um se posiciona perante a existência, a sociedade e o justo, e revela a dimensão que melhor atende à opção valorativa para o fim pretendido pelo cognoscente ou por quem vivencia a experiência jurídica trabalhista. Notadamente em se tratando de ciência jurídica, a escolha, a tomada de decisão e o lugar de onde se projeta o olhar representam elementos fundamentais para a análise.

Além disso, o direito do trabalho se insere no contexto de um momento candente do capitalismo, a produção, em que se configura a troca mercantil principal do sistema, da força de trabalho pelo salário, a apropriação da mais-valia e a principal divisão social, a de proprietários dos meios de produção e de não proprietários dos referidos meios. Vale dizer, insere-se na chave explicativa do modo de vida contemporâneo e isso é muito complexo e desafiador.

Os aspectos acima mencionados de dinamicidade, conflituosidade, contradição e complexidade são apenas alguns que decorrem dessa intrínseca ligação do direito do trabalho com o sistema capitalista de produção, que sempre revoluciona os meios tecnológicos e os processos produtivos, apresenta um conflito insuperável de interesses (entre burguesia e classe trabalhadora) e se revela frequentemente às voltas com inúmeras contradições, notadamente entre o que procura fazer acreditar que seja ou pretende e o que efetivamente é.

Dada essa complexidade do direito do trabalho, este estudo procura saber se existe um princípio nuclear desse ramo jurídico, um norte inspirador, e quais os seus conteúdo e dinâmica de atuação. Qual a finalidade desse ramo jurídico? Proteger o 
trabalhador, o capitalista, trabalhador e o capitalista, o trabalho, a relação de trabalho, o capital, o sistema capitalista, um método de superação do capitalismo, enfim, qual a sua teleologia? Trata-se de um estudo de elementos contextualizadores do direito do trabalho, sob os aspectos sociais, históricos e jurídicos, a fim de perquirir qual a finalidade desse ramo normativo e qual o papel do princípio da melhoria da condição social do trabalhador.

Se o direito do trabalho existe para proteger o trabalhador, será que ele tem conseguido atingir esse objetivo? E caso a resposta seja negativa, pergunta-se: por qual razão? Quais os motivos para terem ocorrido transformações no direito do trabalho brasileiro, notadamente nas últimas cinco décadas, favorecedoras de maior precarização das relações de trabalho?

Essas são algumas das indagações que motivaram a realização da pesquisa e a elaboração dessa dissertação.

A observação científica será realizada sob o prisma crítico argumentativo de busca de aprimoramento da justiça social e de fortalecimento da classe trabalhadora.

O título original era "O princípio da melhoria da condição social do trabalhador" e a palavra crítica foi acrescentada por ocasião do exame de qualificação. O sentido da crítica neste estudo não é obviamente o do senso comum de ataque ao princípio, mas, dentre muitos outros possíveis, o de análise, dotada de questionamento, explícito ou implícito, quanto às possibilidades de um processo construtivo de um direito do trabalho voltado para a justiça social, com vistas à reafirmação, defesa e fortalecimento do princípio.

No capítulo específico acerca do princípio da melhoria da condição social do trabalhador, a crítica adquire predominantemente o aspecto de indicação de uma racionalidade jurídica em prol do trabalhador e da classe trabalhadora, como modelação teórica de uma postura crítica que poderia, de certa forma, ser traduzida por "um outro mundo é possível". O olhar as relações sociais como algo mutável e passível de aperfeiçoamento revela-se, também, uma atitude crítica. 
Para o desenvolvimento da análise, parte-se de uma perspectiva que considera a dimensão de identidade do direito com o Estado prevalecente nas fases históricas dos dois últimos séculos (liberal, social e social/neoliberal) e a intrínseca relação do Estado com o modelo capitalista de produção, o qual integra em essência, juntamente com o capital e o trabalho assalariado.

Por isso, serão analisados aspectos relevantes do capitalismo, notadamente quanto à existência de divisão social em classes com interesses antagônicos e irreconciliáveis. Procurar-se-á manter a questão do conflito entre as classes sociais como o mote inspirador para as reflexões da maior parte dos tópicos.

Procurar-se-á abordar alguns aspectos históricos principais do surgimento do capitalismo brasileiro e de uma estrutura social tão desigual e injusta. Discutir-se-á a constituição de um Estado Social no Brasil e os efeitos da ideologia neoliberal.

Serão analisadas as principais características das alterações no sistema produtivo das últimas décadas, na passagem do modelo fordista-taylorista para o toyotista, e os atuais desafios da classe trabalhadora, frente à sua complexificação e fragmentação.

Buscar-se-á identificar o princípio da melhoria da condição social do trabalhador e verificar a sua dinâmica, como elemento de criação, interpretação e aplicação do direito, revisitando técnicas jurídicas já consolidadas doutrinariamente para essa dinâmica, à luz da perspectiva dos atuais desafios da classe trabalhadora.

Serão analisados os elementos conceituais, a contextualização principiológica e os principais aspectos que conduziram e justificaram a elaboração histórico-jurídico-institucional do princípio em estudo.

Serão lançadas reflexões sobre a possibilidade de o princípio expressar uma racionalidade de construção da justiça social, como transbordamento dos aspectos meramente contratuais das relações de trabalho, e como configuração de elemento 
norteador da experiência normativa trabalhista e de direito social, para a afirmação política do trabalhador, enquanto classe social.

Por fim, com a finalidade de localizar alguns dos principais desafios da atualidade para um direito do trabalho inspirado no princípio da melhoria da condição social do trabalhador, serão abordados alguns dos mais preocupantes dilemas desse ramo jurídico, tais como a problemática da terceirização, da alta rotatividade da mão de obra e do excesso de jornada de trabalho por meio da utilização do chamado banco de horas. 


\section{1 - O TRABALHO NA ESTRUTURA SOCIAL}

\section{1 - O TRABALHO COMO CONDIÇÃO HUMANA}

O trabalho é inerente à condição humana. Para sobreviver e satisfazer suas necessidades, o homem modifica a natureza por meio do trabalho e o trabalho modifica o homem, a sua forma de viver e a sua própria identidade. ${ }^{1}$

Para Emir Sader, o "trabalho é o ato através do qual o homem despende energia para transformar as condições que o cercam, com um fim determinado". ${ }^{2} \mathrm{O}$ referido autor observa que "O homem se distingue dos outros animais por várias coisas: pela música, pela literatura, pela filosofia. Porém, antes de filosofar, compor ou escrever, os homens se diferenciam dos outros animais por sua capacidade de trabalho". ${ }^{3}$

E por ser fundamentalmente um ser trabalhador, o homem é também um ser histórico. ${ }^{4}$ Diz Lacroix que o "homem não é propriamente uma natureza, nem sequer ontológica, mas uma história que se faz mediante o trabalho, a partir de uma determinada natureza". ${ }^{5}$ Nesse sentido, Emir Sader explica que ao "ser aquele que transforma a natureza quando produz as condições de sua sobrevivência, o homem é o único ser que tem história, isto é, cujas condições de existência são transformadas por sua própria ação". ${ }^{6}$

Pode-se chamar de processo primário essa busca do ser humano de satisfação das necessidades vitais por meio do trabalho. Desse processo, à luz das elaborações de Mészáros ${ }^{7}$, Ricardo Antunes $^{8}$ indica as seguintes características: "a

\footnotetext{
${ }^{1}$ CORREA, Jaime Montalvo. Fundamentos de derecho del trabajo. Madrid: Editorial Civitas, 1975, p. 19.

${ }^{2}$ SADER, Emir. A exploração. In: SADER, Emir (org.). Sete pecados do capital. Rio de Janeiro: Record, 2000 , p. 62.

${ }^{3}$ Ibid., p. 60.

${ }^{4}$ LACROIX, J. Por que o trabalho? Palestra apresentada na $51^{\mathrm{a}}$ sessão das Semanas Sociais da França, celebradas em Lyon em 1964, e publicada em Los Trabajadores en la sociedad contemporânea, Barcelona (Nova Terra), 1966, p. 83. Apud CORREA, Jaime Montalvo, op. cit., p. 19-20.

${ }^{5}$ Ibid., p. 20.

${ }^{6}$ SADER, Emir, op. cit., p. 61.

${ }^{7}$ MÉSZÁROS, István. Beyond capital (towards a theory of transition). Londres: Merlin Press, 1995, p.138. Apud ANTUNES, Ricardo. Os sentidos do trabalho. Ensaio sobre a afirmação e a negação do trabalho. São Paulo: Boitempo Editorial, 2006, p. 20.

${ }^{8}$ ANTUNES, Ricardo., op. cit., p. 20.
} 
necessária e mais ou menos espontânea regulação da atividade biológica reprodutiva em conjugação com os recursos existentes"; "a regulação do processo de trabalho, pela qual o necessário intercâmbio comunitário com a natureza possa produzir os bens requeridos, os instrumentos de trabalho, os empreendimentos produtivos e o conhecimento para a satisfação das necessidades humanas"; "o estabelecimento de um sistema de trocas compatível com as necessidades requeridas, historicamente mutáveis e visando otimizar os recursos naturais e produtivos existentes"; "a organização, coordenação e controle da multiplicidade de atividades, materiais e culturais, visando o atendimento de um sistema de reprodução social cada vez mais complexo"; "a alocação racional dos recursos materiais e humanos disponíveis, lutando contra as formas de escassez, por meio da utilização econômica (no sentido de economizar) viável dos meios de produção, em sintonia com os níveis de produtividade e os limites socioeconômicos existentes" e a "constituição e organização de regulamentos societais designados para a totalidade dos seres sociais, em conjunção com as demais determinações e funções de mediação primárias”.

Um traço muito relevante desse processo primário é que nele ainda não havia necessidade de "hierarquias estruturais de dominação e subordinação". 9

Para Emir Sader, "Enquanto a sociedade tinha um nível muito elementar de desenvolvimento econômico, todos necessitavam trabalhar. As diferenças vinham apenas das formas de trabalho, da divisão do trabalho". ${ }^{10}$ Com o progresso material da sociedade humana, nem todos precisavam trabalhar na produção material, surgindo, então, as figuras dos técnicos, sacerdotes, guerreiros, governantes, filósofos e artistas, "gente que se destacava da produção direta, seja para planificá-la, seja para protegê-la militarmente ou para se dedicar à elaboração sobre o significado do que os homens faziam". "11 Vale dizer, surgia a divisão entre o trabalho material e o trabalho intelectual, a chamada divisão social do trabalho, que introduz "privilégios claros, em que alguns ficam relegados à produção material, repetitiva, mecânica, enquantos outros se dedicam à direção da sociedade, concentrando assim poder sobre os outros". ${ }^{12}$

\footnotetext{
${ }^{9}$ ANTUNES, Ricardo. Os sentidos do trabalho. Ensaio sobre a afirmação e a negação do trabalho. São Paulo: Boitempo Editorial, 2006, p. 20.

${ }^{10}$ SADER, Emir. A exploração. In: SADER, Emir (org.). Sete pecados do capital. Rio de Janeiro: Record, 2000, p. 63.

${ }^{11}$ Ibid., p. 63-64.

${ }^{12}$ Ibid., p. 64.
} 
Sérgio Alberto de Souza observa que o trabalho sintetiza as relações dos homens com a natureza e dos homens entre si. ${ }^{13}$ Por isso, a divisão do trabalho não é uma simples divisão de tarefas. ${ }^{14}$ Ela engendra a desigualdade social e por ela é engendrada. ${ }^{15}$

A partir da constituição do sistema capitalista, houve a cisão entre o valor de uso ("tudo o que satisfaz alguma necessidade humana - necessidade material ou espiritual, do corpo ou da mente"16) e o valor de troca das coisas ("dado não diretamente pela utilidade de um objeto, mas pelas horas de trabalho necessárias para a sua produção" ${ }^{17}$ ) e surgiu a subordinação do valor de uso ao valor de troca. Vale dizer, aquela mediação voltada para a satisfação de necessidades vitais deu lugar a outra, voltada para os interesses da produção e reprodução do capital.

O advento dessa segunda ordem de mediações corresponde a um período específico da história humana, que acabou por afetar profundamente a funcionalidade das mediações de primeira ordem ao introduzir elementos fetichizadores e alienantes de controle social metabólico ${ }^{18}$ (...) Isso porque "a constituição do sistema de capital é idêntica à emergência de suas mediações de segunda ordem. De fato, o capital, como tal, nada mais é do que uma dinâmica, um modo e meio totalizante e dominante de mediação reprodutiva, articulado com um elenco historicamente específico de estruturas envolvidas institucionalmente, tanto quanto de práticas sociais salvaguardadas. É um sistema de mediações claramente identificável, o qual em suas formas convenientemente desenvolvidas subordina estritamente todas as funções reprodutivas sociais - das relações de gênero familiares à produção material, incluindo até mesmo a criação das obras de arte - ao imperativo absoluto da expansão do capital,

\footnotetext{
${ }^{13}$ SOUZA, Sérgio Alberto de. Direito, globalização e barbárie - estudos críticos de temas de direito do trabalho e de direitos humanos sob a ótica de uma leitura não-liberal. São Paulo: LTr, 1998, p. 66.

${ }^{14}$ Ibid., p. 66.

${ }^{15}$ Ibid., p. 66.

${ }^{16}$ SADER, Emir, op. cit., p. 70.

${ }^{17}$ Ibid., p. 71.

${ }^{18}$ MÉSZÁROS, István. Beyond capital (towards a theory of transition). London: Merlin Press, 1995, p. 139-140. Apud ANTUNES, Ricardo. Os sentidos do trabalho. Ensaio sobre a afirmação e a negação do trabalho. São Paulo: Boitempo Editorial, 2006, p. 20.
} 
ou seja, da própria expansão e reprodução como um sistema de metabolismo social de mediação", ${ }^{19}$

Para Marx, mesmo com a superação do capitalismo e do trabalho assalariado, continuaria a existir o trabalho para a produção de valores de uso e como “apropriação do natural para satisfazer as necessidades humanas, condição universal do metabolismo entre o homem e a natureza, condição natural eterna da vida humana..."20

Mario de la Cueva defende que o trabalho é um direito e um dever sociais: na "sociedade futura, o trabalho, entendido como o valor supremo, será um dever criador de direitos". ${ }^{21}$

Emir Sader explica que "Uma sociedade sem exploração é, antes de tudo, uma sociedade do trabalho, uma sociedade em que todos tenham garantido o direito ao trabalho, vivam do seu trabalho" 22 e em que "todos se tornem trabalhadores e ninguém viva da exploração do trabalho alheio." ${ }^{23}$ Nesse modelo de sociedade, os meios de produção "não poderiam ser propriedade privada, mas propriedade democrática do conjunto da sociedade" e a decisão a "respeito do que produzir, quanto produzir, por que preço produzir, para quem produzir" seria tomada coletiva e democraticamente. ${ }^{24}$ Nessa sociedade, o trabalho humano não será apenas instrumento de sobrevivência, mas também de liberdade e de emancipação. ${ }^{25}$

\footnotetext{
${ }^{19}$ MÉSZÁROS, István. Beyond capital (towards a theory of transition). London: Merlin Press, 1995, p. 117. Apud ANTUNES, Ricardo. Os sentidos do trabalho. Ensaio sobre a afirmação e a negação do trabalho. São Paulo: Boitempo Editorial, 2006, p. 20-21.

${ }^{20}$ MARX, Karl. O Capital, Vol. I, Livro 1 ${ }^{\circ}$, Tomo I, 3. ed. São Paulo: Ed. Nova Cultural, 1988, p. 146. Apud GRAZIA, Giuseppina Rosaria De. A redução e redistribuição do tempo de trabalho em questão. Tese de doutorado, Departamento de Sociologia da FFLCH-USP, São Paulo, 2003, p. 24.

${ }^{21}$ CUEVA, Mario de la. El nuevo derecho mexicano del trabajo. 4. edição. México: Editorial Porrúa, 1977, p.109.

${ }^{22}$ SADER, Emir. A exploração. In: SADER, Emir (org.). Sete pecados do capital. Rio de Janeiro: Record, 2000, p. 76

${ }^{23}$ Ibid., p. 76.

${ }^{24}$ Ibid., p. 76.

${ }^{25}$ Ibid., p. 77.
} 


\section{2 - O TRABALHO E A DOMINACÃO}

No decorrer da história e na sucessão de diversos processos produtivos, determinadas classes de trabalhadores, como, por exemplo, os escravos, os servos e os assalariados, tiveram sua força de trabalho colocada à disposição de outrem e, dada a exploração a que foram submetidas, integraram as classes mais desfavorecidas, as classes dominadas.

Os escravos na Grécia e na Roma antigas, como os servos da gleba na Idade Média, foram expressões mais claras das formas de subjugação e de dominação do trabalho humano por uma elite privilegiada. As riquezas sempre foram produzidas pelo trabalho humano, mas este foi concentrado nas camadas pobres da sociedade, sendo apropriado pelas minorias privilegiadas. A história da humanidade até aqui tem sido a história da exploração do trabalho da grande maioria por uma minoria. ${ }^{26}$

Emir Sader explica que "Mercadoria é tudo o que é produzido para o mercado, isto é, não para o consumo individual, mas para a venda, para o consumo alheio" 27 ou seja, é "algo produzido para o uso de outra pessoa, que a obtém mediante a troca por dinheiro ou por outra mercadoria que, por sua vez, atende à sua necessidade". ${ }^{28} \mathrm{E}$ acrescenta que o "trabalho humano foi transformado pelo capitalista numa mercadoria. $\mathrm{Na}$ forma de produção de mercadorias está contido o mecanismo de exploração". ${ }^{29}$

Com o advento do capitalismo, o trabalho continua sendo essencial, mas toma a forma de trabalho assalariado, elemento que se revela fundamental para o sistema na medida em que é por meio dele que o capital consegue se reproduzir, mediante a acumulação da mais-valia (diferença entre o valor obtido com a venda do produto e o valor pago ao trabalhador para produzi-lo).

${ }^{26}$ SADER, Emir. A exploração. In: SADER, Emir (org.). Sete pecados do capital. Rio de Janeiro: Record, 2000 , p. 64.

${ }^{27}$ Ibid., p. 70.

${ }^{28}$ Ibid., p. 70.

${ }^{29}$ Ibid., p. 69-70. 
Embora seja uma mercadoria, a força de trabalho é uma mercadoria especial, porque ela é a única mercadoria que produz mais valor. Toda mercadoria contém valor, que é o tempo de trabalho consumido para produzi-la. Mas a força de trabalho, além de conter valor, gera um valor a mais, tanto para sua própria remuneração, quanto a mais-valia, que fica com o capitalista. ${ }^{30}$

Nesse aspecto, cabe até mesmo uma outra reflexão, na linha do pensamento de Eduardo Monreal: "se é possível a um homem vender seu trabalho, algo que é parte da sua própria vida e que importa num tão profundo compromisso pessoal que poderia estimar-se que integra os direitos da personalidade". ${ }^{31}$

O trabalho assalariado é inerente ao capitalismo e o "fim do trabalho assalariado, portanto, só poderia ocorrer com o fim do sistema comandado pelo capital". ${ }^{32}$

\section{3 - O TRABALHO E O DESEMPREGO}

Dada a presença na vida das pessoas e a centralidade no modo de produção capitalista, a esfera do trabalho tem um poder privilegiado para determinar a consciência e a ação sociais. Além disso, na sociedade de consumo própria do referido modo de produção, o trabalho é condição de afirmação e participação do homem na sociedade. E ainda pode-se observar que a centralidade do trabalho trata-se de noção essencial para a concepção de Estado social ou Estado de bem-estar social.

\footnotetext{
${ }^{30}$ SADER, Emir. A exploração. In: SADER, Emir (org.). Sete pecados do capital. Rio de Janeiro: Record, 2000, , p. 74.

${ }^{31}$ MONREAL, Eduardo. El derecho como obstáculo al cambio social. Mexico: Siglo Veintiuno Editores. 1980, p. 137. Apud GENRO, Tarso Fernando. Contribuição à crítica do direito coletivo do trabalho. São Paulo: LTr, 1988, p. 99.

${ }^{32}$ GRAZIA, Giuseppina Rosaria De. A redução e redistribuição do tempo de trabalho em questão. Tese de doutorado, Departamento de Sociologia da FFLCH-USP, São Paulo, 2003, p. 24.
} 
Nas décadas de 1970, 1980 e 1990, conforme esclarece Giuseppina Rosária De Grazia, ${ }^{33}$ houve a propagação de teorias que indicavam o fim da centralidade do trabalho na sociedade. Alguns representantes dessas correntes foram Claus Offe ${ }^{34}$, André Gorz $^{35}$, Kurz ${ }^{36}$, Guy Aznar ${ }^{37}$ e Jeremy Riffkin ${ }^{38}$, entre outros, que elaboraram as suas linhas de pensamento em razão da constatação do impacto das inovações tecnológicas no mundo do trabalho e do crescente aumento do desemprego e, como consequência desses dois elementos, da diminuição do custo do fator trabalho por unidade de produção.

A extinção do trabalho, anunciada pelas referidas teorias, porém, não se confirmou. ${ }^{39} \mathrm{O}$ desemprego assolou diversas partes do mundo, mas o trabalho, em si, continua sendo categoria central no modo de produção capitalista.

Giuseppina Rosaria De Grazia observa que as transformações não apontam para o fim do trabalho, mas para uma complexificação do processo produtivo, que exige "conceito mais ampliado de trabalho e de classe trabalhadora, incluindo produtivos, improdutivos, estáveis, precarizados e desempregados". ${ }^{40}$ A autora esclarece que "o conjunto das atividades produtivas continua subordinado à lógica da produção de mercadorias do capital". ${ }^{41}$

Ricardo Antunes explica que "o capital é incapaz de realizar sua autovalorização sem utilizar-se do trabalho humano. Pode diminuir o trabalho vivo; mas, não eliminá-lo. Pode precarizá-lo e desempregar parcelas imensas; contudo, não pode extingui-lo". ${ }^{42}$ Além disso, no capitalismo, sob a perspectiva do capital, a força de trabalho revela-se essencial não apenas para a produção, mas também para o consumo. ${ }^{43}$

\footnotetext{
${ }^{33}$ GRAZIA, Giuseppina Rosaria De. A redução e redistribuição do tempo de trabalho em questão. Tese de doutorado, Departamento de Sociologia da FFLCH-USP, São Paulo, 2003, p. 18-19.

${ }^{34}$ OFFE, Claus. Trabalho: a categoria-chave da sociologia? Revista Bras. de Ciências Sociais, São Paulo, v. 4, n. 10, p. 5-20, junho 1989.

${ }^{35}$ GORZ, André. Adeus ao proletariado. Rio de Janeiro: Forense Universitária, 1982, s/p.

${ }^{36}$ GRUPO KRISIS. Manifesto contra o trabalho, 1999, mimeo, s/p.

${ }^{37}$ AZNAR, Guy. Trabalhar menos para trabalharem todos. São Paulo: Página Aberta, 1995, s/p.

${ }^{38}$ RIFKIN, Jeremy. O fim dos empregos. São Paulo: Makron Books, 1995, s/p.

${ }^{39}$ GRAZIA, Giuseppina Rosaria De., op. cit., p. 26.

${ }^{40}$ Ibid., p. 26.

${ }^{41}$ Ibid., p. 26.

${ }^{42}$ ANTUNES, Ricardo. O neoliberalismo e a precarização estrutural do trabalho na fase de mundialização do capital. In: SILVA, Alessandro da. et. al. (coord.). Direitos humanos: essência do direito do trabalho. São Paulo: L Tr, 2007, p. 41.

${ }^{43}$ Ibid., p. 47.
} 
Houve um tempo em que se acreditava que a luta dos trabalhadores seria capaz de fazê-los obter mais vantagens nas condições de trabalho e até mesmo a modificação do sistema de produção capitalista. A greve apresentou-se como um instrumento fortíssimo de luta.

Ocorre que os problemas referentes ao imenso exército de reserva de mão de obra atravessaram os séculos XIX e XX e permanecem no século XXI, diminuindo a força de combate dos trabalhadores. Não raro o medo de desemprego desune a classe trabalhadora, que passa a disputar entre si as vagas no mercado, dificultando uma ação de oposição ao capital.

Para Marx o desemprego é inerente ao capitalismo, uma vez que a tendência deste é empregar sempre maior parte do excedente na compra de meios de produção, em detrimento da absorção da força de trabalho. Ele expressa o choque entre as relações de produção capitalistas (que condicionam o investimento e o consumo) e o progresso das forças produtivas, que aumenta a produtividade do trabalho. O aumento do investimento, portanto, não significa aumento de emprego: poderá aumentar o volume de capital global, e mesmo assim diminuir o capital variável, com menor emprego de mão de obra. ${ }^{44}$

A formação de um vasto exército de reserva de mão de obra, ou seja, de uma imensão de despossuídos, cujo único meio de sobrevivência é a sua força de trabalho, integra os objetivos permanentes do capital, que lucra com a ampliação da competição entre os trabalhadores. Assim, o combate ao desemprego deve ser uma prioridade para a classe trabalhadora, mas nunca por meio da diminuição de direitos, que apenas acirraria a disputa entre os seus membros e a enfraqueceria com força jurídico-política e social.

\footnotetext{
${ }^{44}$ GRAZIA, Giuseppina Rosaria De. A redução e redistribuição do tempo de trabalho em questão. Tese de
} doutorado. Departamento de Sociologia da FFLCH-USP, 2003. p. 27. 


\section{4 - A FORMAÇÃO DA CLASSE TRABALHADORA - ASPECTOS CONCEITUAIS}

Podemos observar que faz parte da dinâmica central do modo de produção capitalista a divisão da sociedade em duas categorias básicas de pessoas, proprietários e não proprietários dos meios de produção. Não há como negar a existência dessa divisão como um dos traços mais marcantes do sistema.

Dessa realidade, com a divisão social baseada na propriedade dos meios de produção, surge a questão correlata da apropriação pelos proprietários da maior parte da riqueza produzida pela força de trabalho dos não proprietários, alijando-os até mesmo do produto de seu trabalho.

Considerando que o direito do trabalho lida com essa relação básica do capitalismo, torna-se relevante, para a compreensão desse ramo jurídico, descortinar a problemática das classes sociais.

A sociedade feudal caracterizou-se por ser uma sociedade explicitamente desigual e essa desigualdade às claras era fundamental para o funcionamento do sistema então vigente, porque possibilitava o reconhecimento do lugar de cada um na sociedade e a imposição da manutenção do status quo. Como sociedade de ordens que era, a divisão social era baseada em estamentos rígidos (nobreza, clero, comerciantes, pequenos artesãos e servos). O servo não tinha capacidade jurídica plena, “estava sujeito ao controle, às permissões e aos privilégios dos senhores feudais para que pudesse praticar os menores atos da vida civil". ${ }^{45}$

No capitalismo, houve a concessão a todos de capacidade jurídica formal plena e de igualdade perante a lei, o que, contudo, não afastou, subjacentemente, as distinções reais decorrentes da condição de proprietário ou não dos meios de produção, instalando-se, com isso, uma sociedade de classes antagônicas, em que o interesse de uma se contrapõe, necessariamente, ao interesse de outra.

${ }^{45}$ RUSSOMANO, Mozart Victor. Novos temas de direito do trabalho. Rio de Janeiro: Ed. Forense, 1985, p. 8 . 
Nesse novo modelo, a ocultação da desigualdade real passou a agir como instrumento para a preservação do sistema. Dos períodos anteriores permaneceu a divisão do mundo entre dominantes e dominados, exploradores e explorados, alterando-se, apenas, a forma de expressão e os mecanismos de manutenção da injustiça social.

A revolução burguesa representou, ao implantar a igualdade jurídica entre indivíduos pertencentes a classes sociais antagônicas, uma ruptura histórica com um passado milenar da humanidade. Algo até então impensável revelou-se possível: a manutenção da exploração de classe em sociedades (juridicamente) igualitárias. ${ }^{46}$

Com o capitalismo, a igualdade formal possibilitou ao trabalhador escolher para qual capitalista trabalhar, mas não possibilitou a escolha entre trabalhar ou não para algum capitalista, pois, desprovido dos meios de produção, trabalhar para outrem passou a ser a única forma de sobreviver. ${ }^{47}$ Trata-se, portanto, de uma liberdade limitada. Ao ocultar a exploração, o modo de produção capitalista possibilita que ela se preserve no tempo, na medida em que a aparência é de que a submissão à exploração foi escolha do trabalhador. Nesse modelo, "A igualdade de direitos políticos e sociais é contaminada pela desigualdade de classe". ${ }^{4}$

...O direito igualitário oculta a desigualdade de classe e a exploração que ocorrerá no plano da produção, e faz com que a exploração apareça, aos olhos do trabalhador, como escolha sua. É verdade que o trabalhador tem uma escolha, que não existia para o escravo ou para o servo; ele pode, dentro de limites estabelecidos pela conjuntura econômica, escolher o capitalista para o qual vai trabalhar, mas não pode escolher se trabalhará ou não para um capitalista. O direito civil igualitário não impõe a exploração, ao

\footnotetext{
${ }^{46}$ BOITO JR., Armando. Estado, política e classes sociais: ensaios teóricos e históricos. São Paulo: Editora UNESP, 2007, p. 258-259.

${ }^{47}$ Ibid., p. 257.

${ }^{48}$ Ibid., p. 257.
} 
contrário do que ocorria com o direito inigualitário ... mas a oculta e, desse modo, contribui para que ela se reproduza no tempo. ${ }^{49}$.

Dessa forma, a igualdade formal perante a lei, ocultando as diferenças materiais subjacentes, possibilita a manutenção do sistema, na medida em que retira a visibilidade da divisão em classes sociais e das circunstâncias de vida (difíceis, mas também unificadoras) da classe trabalhadora. Quando o antagonismo latente se torna expresso e a classe trabalhadora passa a lutar por seus interesses, começa a existir efetivamente enquanto classe, no sentido político do termo.

Marx e Engels ${ }^{50}$ definem a burguesia como a "classe dos capitalistas modernos" ou daqueles "que possuem meios da produção social e empregados assalariados" e o proletarido "a classe dos trabalhadores assalariados modernos que, por não ter meios de produção próprios, são reduzidos a vender a própria força de trabalho para poder viver".

A princípio, a classe social no capitalismo diz respeito à posição no processo produtivo, ou seja, os proprietários dos meios de produção representam uma classe enquanto os não proprietários destes meios representam outra e participam do processo apenas com sua força de trabalho.

O fato real da propriedade ou não dos meios de produção gera a divisão social em classes e faz com que cada uma possua interesses antagônicos e irreconciliáveis.

A condição essencial para a existência e para o poder da classe burguesa é a formação e o crescimento de capital. A condição para o capital é o trabalho assalariado. O trabalho assalariado fundamenta-se exclusivamente na competição entre os trabalhadores. ${ }^{51}$

\footnotetext{
${ }^{49}$ BOITO JR., Armando. Estado, política e classes sociais: ensaios teóricos e históricos. São Paulo: Editora UNESP, 2007, p. 257.

${ }^{50}$ MARX, Karl \& ENGELS, Friedrich. O Manifesto Comunista. Tradução de Maria Lúcia Como. Edição especial. Rio de Janeiro: Nova Fronteira, 2011, nota de rodapé, p. 49.

${ }^{51}$ Ibid., p. 24.
} 
O proletariado, a camada mais baixa da nossa sociedade atual, não pode sublevar-se, não pode se revoltar, sem que toda a camada dominante da sociedade oficial seja arremessada no ar. $^{52}$

Mas, se a mera participação no processo de produção permite a identificação dos trabalhadores, a sua constituição em classe política e, principalmente, em classe política ativa depende da aquisição de consciência de si e do que interessa para sua emancipação. Neste sentido, Lukács distingue consciência “de si” de consciência "para si”. A consciência da classe trabalhadora "em si" se refere ao seu aspecto quantitativo, enquanto a da "classe para si" diz respeito à sua "identidade própria e ação unificadora". 53

...Lukács opera com a distinção hegeliana "em si/ para si”: a partir do momento em que a classe operária, que já existe enquanto tal no terreno da economia, adquirir a consciência de sua própria existência e, portanto, da especificidade de seus interesses, ela deixará de ser apenas uma "classe em si” e passará a ser uma “classe para si”. A existência objetiva será complementada pela subjetiva, dada pela "consciência de classe". Mas a classe operária já existe, enquanto tal, do começo ao fim do processo.

André Singer ${ }^{54}$ explica que para $\operatorname{Marx}^{55}$, as “classes em si que não logram se unificar e conscientizar-se para a ação coletiva, tendem a aparecer na luta política como massa, estruturada de fora para dentro". Enquanto as classes fundamentais (no capitalismo, burguesia e proletariado), portadoras de uma projeto histórico, "tenderiam a se organizar enquanto classes; as demais a surgir na política como massa".

${ }^{52}$ MARX, Karl \& ENGELS, Friedrich. O Manifesto Comunista. Tradução de Maria Lúcia Como. Edição especial. Rio de Janeiro: Nova Fronteira, 2011, p. 23.

${ }^{53}$ GRAZIA, Giuseppina Rosaria De. A redução e redistribuição do tempo de trabalho em questão. Tese de doutorado. Departamento de Sociologia da FFLCH-USP, São Paulo, 2003, p. 29.

${ }^{54}$ SINGER, André Vitor. Os sentidos do Lulismo. Reforma gradual e pacto conservador. São Paulo: Companhia das Letras, 2012, p. 23-24.

${ }^{55}$ MARX, Karl. O 18 Brumário de Luís Bonaparte. In: MARX, Karl. A revolução antes da revolução. São Paulo: Expressão Popular, 2008, s/p. 
Armando Boito Júnior esclarece que "Para Lukács, a classe operária é um dado objetivo da economia capitalista" e "existe enquanto tal mesmo quando os próprios operários não têm consciência de tal existência". ${ }^{56}$ Explica, ainda, que para Lukács a questão da ausência de organização e luta da classe operária em diversos países decorre da distinção entre "falsa consciência" e "consciência verdadeira":

Lukács irá, então, estabelecer a célebre distinção entre "falsa consciência" e aquela que seria a "consciência verdadeira" da classe operária. Para a primeira, Lukács reserva uma série de qualificativos que visam evidenciar a falsidade de tal consciência: ela seria empírica, psicológica, efêmera e inadequada; já a segunda, a "consciência verdadeira", seria, na adjetivação de Lukács, racional, política, duradoura e adequada à posição objetiva ocupada pelos operários no processo de produção e aos interesses decorrentes de tal posição. O impasse teórico consiste no seguinte: a "falsa consciência" é uma aberrração que não deveria existir, fosse verdadeira a tese segundo a qual a classe social já está dada no terreno da economia. Por isso mesmo, Lukács nos diz, se prestarmos atenção, apenas aquilo que a "falsa consciência não é". E ele nos diz somente aquilo que já sabíamos: ela não é a "consciência verdadeira", aquela racional e adequada, mas, estranhamente, inexistente. ${ }^{58}$

A classe social pode ser analisada como fenômeno ao mesmo tempo econômico, político e social. ${ }^{59}$ Boito Júnior diz que a formação da classe dominante burguesa já está dada pela consolidação do Estado burguês, que consubstancia "a burguesia organizada e legitima a propriedade privada dos meios de produção, a exploração do trabalho assalariado, a desigualdade de riquezas e outras condições necessárias para o capitalismo" ${ }^{60}$. A estruturação do Estado burguês faz com que todo

\footnotetext{
${ }^{56}$ BOITO JR., Armando. Estado, política e classes sociais: ensaios teóricos e históricos. São Paulo: Editora UNESP, 2007, p. 194.

${ }^{57}$ Ibid., p. 194-195.

${ }^{58}$ Ibid., p. 194-195.

${ }^{59}$ Ibid., p. 195.

${ }^{60}$ Ibid., p. 195.
} 
capitalista individual conheça seus interesses de classe e aja nos limites dados por esses interesses. A classe dominada, por sua vez, tem a sua formação apenas como possibilidade real. ${ }^{61}$

A classe em potência é uma classe como virtualidade da economia, mas que precisa ser definida pelo processo de luta. O potencial existe na estrutura econômica. A classe em si já esta dada objetivamente no processo produtivo, falta a consciência de si.

Boito Júnior defende que o desenvolvimento das forças produtivas é insuficiente para a mudança histórica e que é necessário que haja "um agente social interessado nela e capaz de promovê-la". ${ }^{62}$ Esclarece que a "classe social que tem interesse na mudança histórica precisará organizar-se para promovê-la e precisará, também, vencer as classes interessadas na preservação do modo de produção vigente". ${ }^{63}$

Ainda para Boito Júnior, atualmente já não se pode definir a classe operária apenas a partir do lugar ocupado no processo de produção, uma vez que a análise que identifica a classe social como um fenômeno econômico baseia-se no pressuposto de que no terreno da economia ocorre sempre uma "contradição antagônica insuperável entre burguesia e classe operária". ${ }^{64}$ Defende que na economia podem ocorrer situações em que os trabalhadores manifestam uma consciência em prol do capitalista como reflexo de uma situação econômica particular, como a necessidade de manter os próprios empregos, podendo ocorrer interesses comuns provisórios entre a burguesia e determinados grupos de trabalhadores (mantendo o antagonismo apenas latente), em detrimento de outros grupos, e cita, como exemplo, o caso brasileiro dos acordos no setor automobilístico na década de $1990 .^{65}$

A respeito desses acordos do setor automobilístico, conhecidos como Acordos da Câmara Setorial, Giuseppina Rosária De Grazia ${ }^{66}$ explica que, por serem ${ }^{61}$ BOITO JR., Armando. Estado, política e classes sociais: ensaios teóricos e históricos. São Paulo: Editora UNESP, 2007, p. 195.

${ }^{62}$ Ibid., p. 202.

${ }^{63}$ Ibid., p. 202.

${ }^{64}$ Ibid., p. 193.

${ }^{65}$ Ibid., p. 197.

${ }^{66}$ GRAZIA, Giuseppina Rosaria De. A redução e redistribuição do tempo de trabalho em questão. Tese de Doutorado, Departamento de Sociologia da FFLCH-USP, São Paulo, 2003, p. 168. 
descentralizados por empresa, alguns sindicatos consideraram que "representaram 'significativos avanços' no sentido de permitir um 'processo de reestruturação produtiva negociada", mas que para outros analistas, como Giovanni Alves ${ }^{67}$, foram acordos essencialmente defensivos, em que os sindicatos tenderam a se dobrar às necessidades do capital, e que na medida em que se limitaram a algumas empresas, acabaram por legitimar a lógica de fragmentação própria do capital, o que resultou no prevalecimento dos interesses corporativos, em detrimento dos interesses de classe.

Compartilhamos do entendimento de que soluções fragmentadoras da classe trabalhadora, como as que intensificam a competição entre os próprios trabalhadores e colocam de um lado o capital junto com parcela da força de trabalho e, de outro, grande parcela dos trabalhadores, devem ser rechaçadas pelo direito do trabalho.

\section{5 - A DINÂMICA DAS LUTAS DE CLASSE}

Francisco de Oliveira explica que "a classe se faz na luta de classes"68 e que "Embora na linha Thompsoniana trabalhador não seja apenas um lugar na produção, inegavelmente há que concordar com Perry Anderson: sem esse lugar, ninguém é trabalhador, operário". ${ }^{9}$

Celso Naoto Kashiura Júnior ${ }^{70}$ esclarece que "entre capitalistas e proletários há dominação e antagonismo, mas também interação e dependência": há uma "ligação dialética entre o caráter social da produção, da qual todos dependem materialmente para sobreviver, e o caráter privado da apropriação, que beneficia uma minoria”.

Embora, sob o capitalismo, exista uma dependência recíproca entre o capital e o trabalho, o capital procura permanentemente desvincular-se dessa dependência por

${ }^{67}$ ALVES, Giovanni. O novo (e precário) mundo do trabalho. São Paulo: Boitempo Editorial, 2000, p. 243245. Apud GRAZIA, Giuseppina Rosaria De. A redução e redistribuição do tempo de trabalho em questão. Tese de Doutorado, Departamento de Sociologia da FFLCH-USP, São Paulo, 2003, p. 24.

${ }^{68}$ OLIVEIRA, Francisco de. Crítica à razão dualista - o ornitorrinco. São Paulo: Boitempo Editorial, 2006, p. 128

${ }^{69}$ Ibid., p. 145-146.

${ }^{70}$ KASHIURA JÚNIOR, Celso Naoto. Crítica da igualdade jurídica. Contribuição ao pensamento jurídico-marxista. Dissertação de mestrado. Faculdade de Direito da USP, São Paulo, 2008, p. 42. 
meio da inovação da tecnologia e dos métodos produtivos. A ciência e a tecnologia são usadas pelo capital para diminuir o custo da reprodução da força da de trabalho.

Marx e Engels revelaram o processo de formação do proletariado, a partir de sua luta contra a burguesia: inicialmente, "os trabalhadores ainda formam uma massa incoerente" e que é conduzida pelos próprios trabalhadores e operários de uma fábrica "contra o indivíduo burguês que os explora diretamente", dirigindo seus ataques não apenas "contra as relações burguesas de produção, mas também contra os próprios instrumentos de produção". É a fase de destruição de mercadorias, máquinas e fábricas. ${ }^{71}$

Durante essa fase inicial do capitalismo, que correspondia aos primórdios do período do Estado Liberal, os trabalhadores ainda não tinham uma consciência de classe muito desenvolvida, apenas buscavam a sobrevivência, submetendo-se às regras do mercado de trabalho e disputando as oportunidades, conforme disponibilizadas. Sequer identificavam o capitalista como sendo a causa de suas condições de vida. As agressões que sofriam em razão das precárias condições de trabalho, inclusive com frequentes acidentes, eram imputadas à própria máquina e não ao capitalista responsável pelo processo.

As revoltas promovidas pelos trabalhadores contra a implantação das novas máquinas, tanto sob a forma de petições encaminhadas ao Parlamento britânico, para que seu uso fosse proibido, como sob a forma de ataques às máquinas e às mercadorias por elas produzidas, foram infrutíferas. A utilidade da nova tecnologia levou o Parlamento a não atender às petições e o governo reprimiu, até com o auxílio de tropas militares, as violentas manifestações operárias. $^{72}$

\footnotetext{
${ }^{71}$ MARX, Karl \& ENGELS, Friedrich. O Manifesto Comunista. Tradução de Maria Lúcia Como. Edição especial. Rio de Janeiro: Nova Fronteira, 2011, p. 19.

${ }^{72}$ SILVA, Walküre Lopes Ribeiro da. Crise de representatividade e participação dos sindicatos em políticas ativas de emprego. Tese apresentada para concurso de Professor Titular de Direito do Trabalho da Faculdade de Direito da Universidade de São Paulo, São Paulo, 2001, p. 19.
} 
Até então não havia por parte dos trabalhadores consciência do que estava acontecendo e até mesmo a igreja, que na época possuía muita influência política e social, dificultava a formação da consciência da realidade, na medida em que propagava o conformismo e a resignação com as dificuldades terrenas e procurava apresentar as desigualdades sociais como naturais.

Uma fase posterior é aquela em que, para o proletariado, "sua força cresce e ele sente mais essa força", ${ }^{73}$ a partir do desenvolvimento da indústria e do aumento do número de trabalhadores e de sua concentração em massas maiores. As condições de vida, contudo, tornam-se mais precárias, em razão do uso mais intenso de máquinas no sistema produtivo. $^{74}$

A gravidade das condições do meio ambiente de trabalho e a excessiva exploração, associadas ao compartilhamento das dificuldades com companheiros de trabalho, muitas vezes vizinhos e familiares que trabalhavam nas mesmas condições, foram possibilitando a consciência do que estava acontecendo e a revolta.

Nesta fase de maior consciência e ação, "As colisões entre indivíduos trabalhadores e indivíduos burgueses tomam cada vez mais o caráter de colisão entre duas classes" 75 e os trabalhadores começam a formar sindicatos. O "verdadeiro fruto de suas batalhas repousa não no resultado imediato, mas na união cada vez mais abrangente dos trabalhadores". ${ }^{76}$

Todavia, naquele momento, a união dos trabalhadores e a organização em uma classe e em partidos políticos sofrem continuamente abalos pela competição entre os próprios trabalhadores. ${ }^{77}$ Apesar disso, essa união prossegue se fortalecendo e "força um reconhecimento legislativo dos interesses particulares dos trabalhadores, aproveitando-se

\footnotetext{
${ }^{73}$ MARX, Karl; ENGELS, Friedrich. O Manifesto Comunista. Tradução de Maria Lúcia Como. Edição especial. Rio de Janeiro: Nova Fronteira, 2011, p. 20.

${ }^{74}$ Ibid., p. 20.

${ }^{75}$ Ibid., p. 20.

${ }^{76}$ Ibid., p. 20

${ }^{77}$ Ibid., p. 21.
} 
das divisões no meio da própria burguesia". ${ }^{78}$ É a fase do início de obtenção de conquistas jurídicas.

Mario de la Cueva ressalta a grande novidade que os direitos sociais representaram na história, eis que "era a primeira vez que uma classe social obtinha o direito de lutar contra outra, sobressaindo-se, neste particular, o direito de greve, equivalente a uma declaração e operação de guerra". ${ }^{79}$

A burguesia impôs-se ao poder real e à nobreza. Com o constitucionalismo social do início do século XX, nas Constituições do México (1917) e de Weimar (1919) foi a classe trabalhadora que se impôs frente à burguesia, como um novo fator real de poder, por meio da organização em sindicatos, greves e negociações coletivas de trabalho. As diferenças entre os direitos da burguesia e dos trabalhadores são as existentes entre os direitos individuais do homem (direito imposto ao Estado para que assegurasse a livre exploração das riquezas e da força de trabalho) e os direitos sociais dos trabalhadores e camponeses (direitos de uma classe social de luta e pressão para diminuir a exploração do trabalho pelo capital). ${ }^{80}$

Os direitos sociais representam as condições mínimas para a classe trabalhadora participar do fenômeno da produção capitalista ${ }^{81}$ Mas, será que tais direitos são capazes de fazer desaparecer a divisão da sociedade em classes sociais (desaparecimento e não ocultamento), sem que esse desaparecimento signifique o sufocamento das aspirações dos trabalhadores e o entorpecimento de suas condições de vida e de trabalho?

\footnotetext{
${ }^{78}$ MARX, Karl \& ENGELS, Friedrich. O Manifesto Comunista. Tradução de Maria Lúcia Como. Edição especial. Rio de Janeiro: Nova Fronteira, 2011, p. 21.

${ }^{79}$ CUEVA, Mario de la. El nuevo derecho mexicano del trabajo. 4. ed. Mexico: Editorial Porrúa S.A., 1977, p.89.

${ }^{80}$ Ibid., p. 88- 89 .

${ }^{81}$ IDEM, Derecho mexicano del trabajo. 2. ed. Mexico: Libreria de Porrua Hnos. Y Cia., 1943, p. 213.
} 
A "pacificação social" pela colaboração de classes, sem compartilhamento da propriedade dos meios de produção e sem eliminação da injustiça subjacente ao processo produtivo, significa algo mais do que um mecanismo de favorecimento da classe detentora dos referidos meios?

Essas são algumas das indagações que direta ou indiretamente nos acompanharão no percurso deste estudo.

Mas, retomando a linha expositiva de formação da classe trabalhadora, constata-se que a consciência de classe dos trabalhadores veio acompanhada de lutas e derrotas, em um longo e sofrido processo de aprendizado, processo contraditório e dialético, no encontro dos proletários com os problemas impostos por sua evolução histórica.

Lukács parece acompanhar Thompson ao vincular a consciência de classe ao fluxo dos acontecimentos históricos. A consciência da classe não consiste, ressalta Lukács, na soma ou na média de pensamentos individuais dos integrantes da classe em questão, mas no encontro da classe com os problemas que lhe impõe sua evolução histórica. ${ }^{82}$

Para o futuro, Marx e Engels dizem que a luta de classes se intensifica e "uma pequena parcela da classe governante desprende-se e une-se à classe revolucionária". ${ }^{83}$ Esclarecem que "Os proletários não podem se tornar patrões das forças produtivas da sociedade, exceto abolindo seus próprios meios de apropriação anteriores e, de tal modo, também todos e quaisquer outros modos de apropriação anteriores". ${ }^{84}$ É a superação das classes sociais:

\footnotetext{
${ }^{82}$ BARBOSA, Thiago Ramos. Os movimentos sociais de trabalhadores e seus reflexos históricos no direito do trabalho: o papel da classe operária na formação do direito do trabalho. Dissertação de mestrado, Faculdade de Direito da USP, 2009, p. 31.

${ }^{83}$ MARX, Karl \& ENGELS, Friedrich. O Manifesto Comunista. Tradução de Maria Lúcia Como. Edição especial. Rio de Janeiro: Nova Fronteira, 2011, p. 21-22.

${ }^{84}$ Ibid., p.23.
} 
... Se o proletariado se eleva necessariamente à condição de classe dominante em sua luta contra a burguesia e, na condição de classe dominante, tira de cena as antigas relações de produção, então, com isto, ele tira também de cena a condição para a existência da oposição entre as classes e para a própria existência dessas classes. E acaba por abolir seu papel de classe dominante. ${ }^{85}$

Pela condição de dominada, a classe trabalhadora é a única que possui interesse em abolir as divisões de classes sociais.

\section{6 - O EXEMPLO HISTÓRICO DE CONSTITUIÇÃO DA BURGUESIA}

No período pré-capitalista, as aspirações dos artesãos eram de manutenção da ordem corporativa e as da burguesia (ainda não consolidada como classe dominante) de supressão de toda regulamentação da economia. ${ }^{86}$

Os companheiros, nas corporações de ofício, eram trabalhadores explorados e por isso chegaram a reivindicar melhores condições de trabalho, mas não tinham a pretensão de mudar a ordem social vigente. ${ }^{87}$

As corporações, internamente, amparavam-se em normas estatutárias rigorosas, articuladas para defesa dos privilégios dos mestres, à custa do trabalho dos companheiros (que nunca seriam mestres) e da sofrida preparação profissional dos aprendizes (que, na melhor das hipóteses, poderiam chegar a companheiros). ${ }^{8}$

\footnotetext{
${ }^{85}$ MARX, Karl \& ENGELS, Friedrich. O Manifesto Comunista. Tradução de Maria Lúcia Como. Edição especial. Rio de Janeiro: Nova Fronteira, 2011, p. 34.

${ }^{86}$ CUEVA, Mario de la. Derecho mexicano del trabajo. 2. edicion. Mexico: Libreria de Porrua Hnos. Y Cia., 1943, p. 215.

${ }^{87}$ Ibid., p. 215.

${ }^{88}$ RUSSOMANO, Mozart Victor. Novos temas de direito do trabalho. Rio de Janeiro: Ed. Forense, 1985, p. 8 .
} 
Já os burgueses que começavam a existir tinham pretensões de maior impacto na organização da sociedade, no sentido de alteração da sua posição na ordem social, com a aquisição do poder político, a partir do paradigma da riqueza.

Durante o estado monárquico-feudal, a burguesia era uma classe social ainda latente e a classe política ativa era a nobreza. As revoluções burguesas fizeram da burguesia a classe dominante, cuja consagração se deu com a formação do Estado burguês, garantidor da propriedade e da liberdade contratual benéfica aos burgueses.

Marx esclarece que durante esse processo de tomada do poder político, a burguesia se viu em conflitos constantes, contra a aristocracia e contra parcelas da própria burguesia nacional ou da burguesia internacional, tendo solicitado ajuda do proletariado e o conduzido para as questões políticas, o que se constituiu preparação para o proletariado enfrentar a própria burguesia. ${ }^{89}$

Consolidado, o Estado capitalista se apresentou como um ente abstrato, coletivo e universalista, abarcando todas as pessoas. A igualdade jurídico-formal no plano civil constituiu a cidadania, atribuindo a todos a condição de membros do ente coletivo, o Estado capitalista ou burguês, "com instituições formalmente universalistas abertas aos membros de todas as classes sociais" $"$.

Tratava-se, ainda, de uma cidadania muito limitada, baseada em "direitos civis mínimos - de propriedade, de ir e vir, de realizar contratos e, em primeiro lugar, o contrato de trabalho, e, mais precariamente, de liberdade de pensamento, de expressão e de reunião". ${ }^{91} \mathrm{Na}$ época, os direitos políticos, excluídos dos trabalhadores, eram privilégio das camadas proprietárias ou de renda elevada. ${ }^{92}$

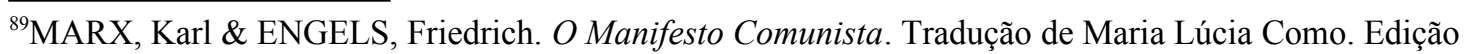
especial. Rio de Janeiro: Nova Fronteira, 2011, p.21.

${ }^{90}$ BOITO JR., Armando. Estado, política e classes sociais: ensaios teóricos e históricos. São Paulo: Editora UNESP, 2007, p.254.

${ }^{91}$ Ibid., p. 255.

${ }^{92}$ Ibid., p. 255.
} 
Armando Boito Júnior ${ }^{93}$ lembra que os primeiros ideólogos do liberalismo, como, por exemplo, Benjamin Constat, preconizaram que "somente os proprietários tinham interesses a defender em seu país”. Menciona que Stuart Mill chegou a defender um sufrágio universal, mas desigual, com o voto dos trabalhadores manuais valendo menos, sob o fundamento de que tinham pouca cultura. Porém, observa, que Tocqueville, em A democracia na América, já alertava que seria "impossível manter a igualdade confinada a uma única esfera da vida social", a civil, eis que naturalmente iria se estender aos domínios político, econômico e social.

De fato, concedidos os direitos civis mínimos e propalada a igualdade de todos perante a lei, os trabalhadores foram conquistando direitos políticos, no final do século XIX e início do século XX e, na sequência, direitos sociais, voltados para a superação da igualdade no plano meramente formal, constituindo-se o Estado social.

Paulo Eduardo Vieira de Oliveira observa que "o fato de celebrar um contrato de trabalho não retira do trabalhador a condição de cidadão, sendo garantidos todos os direitos fundamentais que lhe assistem enquanto pessoa humana, enquanto cidadão". ${ }^{94}$

Vale dizer, a ideologia burguesa da cidadania mínima e a estrutura do direito burguês continham a possibilidade de expansão da cidadania para os âmbitos político e social. Os operários podiam usar e usaram essa ideologia burguesa contra a burguesia, levando o capitalismo a uma cidadania ampliada, pois se a cidadania é um atributo de todos os indivíduos, como admitir que alguns fiquem na "marginalidade" econômica e social ${ }^{95}$

As armas, com as quais a burguesia abateu o feudalismo, voltaramse contra a própria burguesia. Mas ela não só forjou as armas que trazem a morte para si própria, como também criou os homens que

\footnotetext{
${ }^{93}$ BOITO JR., Armando. Estado, politica e classes sociais: ensaios teóricos e históricos. São Paulo: Editora UNESP, 2007, p. 255.

${ }^{94}$ OLIVEIRA, Paulo Eduardo Vieira de. Direito do trabalho e cidadania. Revista do Tribunal Regional do Trabalho da $15^{a}$ Região. Campinas, n. 31, p. 65, 2007.

${ }^{95}$ BOITO JR., Armando, op. cit., p. 256.
} 
irão empunhar estas armas: classe trabalhadora moderna, o proletariado. $^{96}$

A aceitação pela classe dominante da "participação organizada da classe dominada na luta política é uma particularidade do modo de produção capitalista". ${ }^{97}$ Somente no capitalismo o trabalhador explorado recebe personalidade jurídica plena. ${ }^{98}$ Anteriormente, as classes dominantes "não podiam estabelecer alianças com escravos ou servos" e a intelectualidade estava "fundida à classe dominante, não configurando uma camada social específica dotada de relativa autonomia". ${ }^{99}$ Esses aspectos mostram que "a matriz do modo de produção capitalista é um fator importante para que possa ocorrer o processo de constituição do proletariado em classe". ${ }^{100}$

\section{7 - OS OUTROS SEguimentos SOCIAIS: A CLASSE MÉDIA, A "NOVA CLASSE TRABALHADORA" BRASILEIRA, O SUBPROLETARIADO E O LUMPEMPROLETARIADO}

Embora a divisão básica das classes sociais no capitalismo continue sendo a dos proprietários dos meios de produção (a classe dominante ou burguesia) e a dos que não são proprietários dos referidos meios e vivem da venda da sua própria força de trabalho (classe trabalhadora), percebe-se que a complexidade social atual apresenta a participação de outros estratos.

Marilena Chaú explica que a classe social que não se situava entre a classe dominante e a classe trabalhadora foi denominada por Marx por pequena burguesia, a fim de afastar a noção inglesa de middle class, referente à burguesia, situada entre a nobreza e a massa trabalhadora, e também para indicar que embora não fosse proprietária dos meios de produção, poderia ser proprietária privada de bens móveis e imóveis, e, ainda, para

\footnotetext{
${ }^{96}$ MARX, Karl \& ENGELS, Friedrich. O Manifesto Comunista. Tradução de Maria Lúcia Como. Edição especial. Rio de Janeiro: Nova Fronteira, 2011, p. 17.

${ }^{97}$ BOITO JR., BOITO JR., Armando. Estado, política e classes sociais: ensaios teóricos e históricos.

São Paulo: Editora UNESP, 2007, p. 206.

${ }^{98}$ Ibid., p. 206.

${ }^{99}$ Ibid., p. 207.

${ }^{100}$ Ibid., p. 207.
} 
apontar a sua aproximação social e ideológica com a burguesia. ${ }^{101}$ Esse estrato social estava nas chamadas "profissões liberais, na burocracia estatal (ou nos serviços públicos) e empresarial (ou na administração e gerência), na pequena propriedade fundiária e no pequeno comércio". ${ }^{102}$

Quem introduziu a noção de classe média para esse setor, com base nos critérios de renda, escolaridade, profissão e consumo, bem como a pirâmide das classes A, B, C, D e E e a ideia de mobilidade social para descrever a passagem de um indívíduo de uma classe para outra foi a sociologia, principalmente a de inspiração estadunidense. ${ }^{103}$

Essa linha de classificação das classes sociais a partir de critérios como renda, escolaridade e consumo segue a tradição teórica de Weber ("adotada por um extenso segmento de sociólogos políticos americanos"104), para quem classe seria todo grupo humano que se encontra em uma mesma situação de "probabilidades típicas de acesso a bens, a status, e de destino pessoal dentro de uma determinada ordem econômica", 105 gerando possibilidades de surgimento de processos de associação. ${ }^{106}$

Marilena Chauí esclarece que o critério de localização no setor de serviços, como definidor da classe média, "não se mantém na forma atual do capitalismo porque a ciência e as técnicas (a chamada tecnociência) se tornaram forças produtivas e os serviços por elas realizados ou delas dependentes estão diretamente articulados à acumulação e reprodução do capital", ${ }^{107}$ de modo que "o crescimento de assalariados no setor de serviços não é crescimento da classe média, e sim de uma nova classe trabalhadora heterogênea, definida pelas diferenças de escolaridade e pelas habilidades e competências determinadas pela tecnociência". ${ }^{108}$

${ }^{101}$ CHAUÍ, Marilena. Uma nova classe trabalhadora. In: SADER, Emir (org.). 10 anos de governos pós-neoliberais no Brasil: Lula e Dilma. São Paulo: Boitempo; Rio de Janeiro: FLACSO Brasil, 2013, p. 128-129.

${ }^{102}$ Ibid., p. 129.

${ }^{103}$ Ibid., p. 129.

${ }^{104}$ ASCHCRAFT, Richard. A análise do liberalismo em Weber e Marx. In: COHN, G (org.). Sociologia: para ler os clássicos. Rio de Janeiro: Livros Técnicos e Científicos, 1977, p. 208. Apud SINGER, André. Os sentidos do Lulismo. Reforma gradual e pacto conservador. São Paulo: Companhia das Letras, 2012, p. 24.

${ }^{105}$ SINGER, André Vitor, op. cit., p. 24.

${ }^{106}$ Ibid., p. 24.

${ }^{107}$ CHAUÍ, Marilena, op. cit., p. 129.

${ }^{108}$ Ibid., p. 129. 
Acrescenta que o critério da profissão liberal também se tornou inadequado para definir a classe média porque "a nova forma do capital levou à formação de empresas de saúde, advocacia, educação, comunicação, alimentação etc., de maneira que seus componentes se dividem entre proprietários privados e assalariados" e os assalariados devem ser colocados na classe trabalhadora, "mesmo que vociferem contra isso". ${ }^{109}$

A figura da pequena propriedade familiar, ou seja, os pequenos empresários dependentes do capital transnacional não integram a classe média porque foram transformados na economia neoliberal em força produtiva, juntamente com os prestadores individuais de serviços.
A figura da pequena propriedade familiar também não é critério para definir a classe média porque a economia neoliberal, ao desmontar o modelo fordista, fragmentar e terceirizar o trabalho produtivo em milhares de microempresas (grande parte delas, familiares) dependentes do capital transnacional, transformou esses pequenos empresários em força produtiva que, juntamente com os prestadores individuais de serviços (seja na condição de trabalhadores precários, seja na condição de trabalhadores informais), é dirigida e dominada pelos oligopólios multinacionais, em suma, os transformou numa parte da nova classe trabalhadora mundial. ${ }^{110}$

Marilena Chauí conclui, portanto, que para alocar na classe média, restaram apenas "as burocracias estatal e empresarial, o serviço público, a pequena propriedade fundiária e o pequeno comércio não filiado às grandes redes de oligopólios transnacionais". ${ }^{111}$

\footnotetext{
${ }^{109}$ CHAUÍ, Marilena. Uma nova classe trabalhadora. In: SADER, Emir (org.). 10 anos de governos pós-neoliberais no Brasil: Lula e Dilma. São Paulo: Boitempo; Rio de Janeiro: FLACSO Brasil, 2013, p. 130.

${ }^{110}$ Ibid., p. 130.

${ }^{111}$ Ibid., p. 130.
} 
Francisco de Oliveira, analisando o Estado de bem-estar social, explica que a "função intermediadora do fundo público alterou as relações entre as classes e deu lugar à ampliação e fixação das funções das classes médias". ${ }^{112}$ A classe média "se especificou no decorrer dos processos do Welfare State como a classe cuja 'propriedade' reside na gestão da articulação entre o público e o privado", ou seja, foi constituída para operar essa articulação. ${ }^{113}$ Para o referido autor, os interesses dessa classe são reais e não correspondem aos do proletariado e da burguesia. ${ }^{114}$

Marilena Chauí esclarece que uma classe social "não é um dado fixo, definido apenas pelas determinações econômicas, mas um sujeito social, político, moral e cultural que age, se constitui, interpreta a si mesmo e se transforma por meio da luta de classes". ${ }^{115}$ Por estar "fora do núcleo econômico definidor do capitalismo, a classe média encontra-se também fora do núcleo do poder político: ela não detém o poder do Estado nem o poder social da classe trabalhadora organizada" ${ }^{116}$ e isso faz com que ela seja definida "menos por sua posição econômica e muito mais por seu lugar ideológico". ${ }^{117}$

A classe média é "Fragmentada, perpassada pelo individualismo competitivo, desprovida de um referencial social e econômico sólido e claro" e por isso tende a alimentar o imaginário da ordem e da segurança, porque aspira tornar-se parte da classe dominante, razão pela qual "seu papel social e político é o de assegurar a hegemonia ideológica da classe dominante, fazendo com que essa ideologia, por intermédio da escola, da religião, dos meios de comunicação, se naturalize e se espalhe pelo todo da sociedade". ${ }^{118}$

Parte constitutiva da sociedade brasileira, a classe média não só incorpora e propaga ideologicamente as formas autoritárias das

\footnotetext{
112 OLIVEIRA, Francisco de. Os direitos do antivalor. A economia política da hegemonia imperfeita. Petrópolis, RJ: Vozes, 1998, p. 42.

${ }^{113}$ Ibid., p. 42.

${ }^{114}$ Ibid., p. 42.

${ }^{115}$ CHAUÍ, Marilena. Uma nova classe trabalhadora. In: SADER, Emir (org.). 10 anos de governos pós-neoliberais no Brasil: Lula e Dilma. São Paulo: Boitempo; Rio de Janeiro: FLACSO Brasil, 2013, p. 130.

${ }^{116}$ Ibid., p. 131.

${ }^{117}$ Ibid., p. 131.

${ }^{118}$ Ibid., p. 131.
} 
relações sociais, como também incorpora e propaga a naturalização e valorização positiva da fragmentação e dispersão socioeconômica, trazidas pela economia neoliberal e defendidas ideologicamente pelo estímulo ao individualismo competitivo agressivo e ao sucesso a qualquer preço pela astúcia para operar com os procedimentos do mercado. ${ }^{119}$

Marilena Chauí aponta que entre outras medidas, os programas governamentais do período de 2003 a 2011, de transferência da renda, inclusão social e erradicação da pobreza, além de uma política econômica de garantia do emprego, elevação do salário mínimo, recuperação de parte dos direitos sociais das classes populares (sobretudo alimentação, saúde, educação e moradia), têm levado a uma profunda mudança na composição da sociedade brasileira. ${ }^{120}$

Os institutos de pesquisa de mercado e a sociologia costumam organizar a sociedade em uma pirâmide dividida em classes designadas como A, B, C, D e E, tomando como critério a renda, a propriedade de bens imóveis e móveis, a escolaridade e a ocupação ou profissão. ${ }^{121}$ Por esse critério, entre 2003 e 2011, as classes D e E diminuíram consideravelmente, passando de 96,2 milhões de pessoas a 63,5 milhões; as classes A e B, passaram de 13,3 milhões de pessoas a 22,5 milhões; e a classe C passou de 65,8 milhões de pessoas a 105,4 milhões, levando à afirmação de que cresceu a classe média brasileira ou de que teria surgido uma nova classe média no país. ${ }^{122}$

O economista Marcelo Neri, da FGV-RJ, por sua vez, indicou que pertenciam à classe $\mathrm{C}$ (pessoas com renda domiciliar entre 1126 e 4854 reais, a preços de 2009 na Grande São Paulo), cerca 38\% da população brasileira em 2003 e 50\% em 2009. ${ }^{123}$

\footnotetext{
${ }^{119}$ CHAUÍ, Marilena. Uma nova classe trabalhadora. In: SADER, Emir (org.). 10 anos de governos pós-neoliberais no Brasil: Lula e Dilma. São Paulo: Boitempo; Rio de Janeiro: FLACSO Brasil, 2013 p. 132.

${ }^{120}$ Ibid., p. 128.

${ }^{121}$ Ibid., p. 128.

${ }^{122}$ Ibid., p. 128.

${ }^{123}$ NERI, Marcelo. A nova classe média, o lado brilhante dos pobres. Rio de Janeiro: CPS/FGV, 2010, p. 31. Consultado em http://cps.fgv.br., em 26 de junho de 2012. Apud SINGER, André Vitor. Os sentidos do lulismo: reforma gradual e pacto conservador. São Paulo: Companhia das Letras, 2012, p. 135.
} 
Para André Singer, esse número crescente de cidadãos cujo nível de renda e de consumo os afasta da "classe baixa" ou dos "pobres" indica a formação por uma parte deles do que Juarez Guimarães ${ }^{124}$ chamou de "novo proletariado", uma vez que "a grande maioria dos empregos gerados no governo Lula oferecia baixa remuneração, sendo ocupados mais provavelmente por proletários do que por membros de uma classe média emergente". ${ }^{125}$

André Singer conclui que a visão de um Brasil de classe média tem um componente ideológico, pois na verdade o que está ocorrendo "é a diminuição da pobreza monetária, de um lado, e a ampliação de uma camada intermediária com um significativo componente proletário, de outro". ${ }^{126}$

Marilena Chauí também defende a tese de que se trata, na verdade, de uma nova classe trabalhadora, que começa a ter acesso aos direitos sociais e a se tornar participante ativa do consumo de massa. ${ }^{127}$ Diz que a tradição autoritária da sociedade brasileira não admite "a existência de uma classe trabalhadora que não seja constituída pelos miseráveis deserdados da terra, os pobres desnutridos, analfabetos e incompetentes", ${ }^{128}$ razão pela qual "passou-se a afirmar que surgiu uma nova classe média, pois isso é menos perigoso para a ordem estabelecida do que uma classe trabalhadora protagonista social e política". ${ }^{129}$

Uma vez que a nova classe trabalhadora brasileira se constituiu no interior desse momento do capitalismo, marcado pela fragmentação e dispersão do trabalho produtivo, de terceirização, precariedade e informalidade do trabalho, percebido como prestação de serviço de indivíduos independentes que se relacionam com outros indivíduos

\footnotetext{
${ }^{124}$ GUIMARÃES, Juarez. Comunicação oral em debate na UFMG, 14 out 2010. Apud SINGER, André Vitor. Os sentidos do lulismo: reforma gradual e pacto conservador. São Paulo: Companhia das Letras, 2012, p. 137.

${ }^{125}$ SINGER, André Vitor, op. cit., p. 137-138.

${ }^{126}$ Ibid., p. 138-139.

${ }^{127}$ CHAUÍ, Marilena. Uma nova classe trabalhadora. In: SADER, Emir (org.). 10 anos de governos pós-neoliberais no Brasil: Lula e Dilma. São Paulo: Boitempo; Rio de Janeiro: FLACSO Brasil, 2013, p. 130.

${ }^{128}$ Ibid., p. 130.

${ }^{129}$ Ibid., p. 130.
} 
independentes na esfera do mercado de bens e serviços, ela se torna propensa a aderir ao individualismo competitivo e agressivo difundido pela classe média. Em outras palavras, o ser do social permanece oculto e por isso ela tende a aderir ao modo de aparecer do social como conjunto heterogêneo de indivíduos e interesses particulares em competição. E ela própria tende a acreditar que faz parte de uma nova classe média brasileira. ${ }^{130}$

Ainda existe no Brasil forte precarização do mercado de trabalho, de modo que uma parcela significativa da força de trabalho, estima-se que mais de $40 \%$ da população economicamente ativa, ainda sequer conta com a formalização dos contratos. Essa gigantesca massa de trabalhadores sequer logrou obter as garantias sociais do proletariado. E o quadro ainda é pior, eis que existe ainda grande quantidade de pessoas marginalizadas que sequer se encontram inseridas no mercado.

Paul Singer ${ }^{131}$ chamou de subproletariado uma fração de classe constituída por uma "sobrepopulação trabalhadora superempobrecida permanente". Em 1981, correspondia a $48 \%$ da população economicamente ativa (PEA) enquanto o proletariado correspondia a apenas $28 \%$ (dados de 1976).

Assim, o subproletariado seria essa parcela de trabalhadores precarizados, notadamente do mercado de trabalho informal. André Singer observa que o grande desemprego das décadas de 1980 e 1990 jogou "parcela do proletariado formado na época do milagre de volta à precariedade do subproletariado, além de segmentos do subproletariado no lumpemproletariado", ${ }^{132}$ que seria aquela parcela de pessoas pobres e marginalizadas, que acima nos referimos, e que sequer trabalham em empregos precários informais.

\footnotetext{
${ }^{130}$ CHAUÍ, Marilena. Uma nova classe trabalhadora. In: SADER, Emir (org.). 10 anos de governos pós-neoliberais no Brasil: Lula e Dilma. São Paulo: Boitempo; Rio de Janeiro: FLACSO Brasil, 2013, p. 132.

${ }^{131}$ SINGER, Paul. Dominação e desigualdade. Estrutura de classe e repartição da renda no Brasil. Rio de Janeiro: Paz e Terra, 1981, s/p. Apud SINGER, André Vitor. Os sentidos do Lulismo. Reforma gradual e pacto conservador. São Paulo: Companhia das Letras, 2012, p. 19

${ }^{132}$ SINGER, André Vitor, op. cit., p. 20.
} 
André Singer explica que a "singularidade das classes no Brasil consiste no peso do subproletariado, cuja origem se deve procurar na escravidão, que ao longo do século XX não consegue incorporar-se à condição proletária". ${ }^{133}$ As aspirações do subproletariado estão voltadas para a diminuição da pobreza e para a integração ao modelo moldado por outras camadas sociais e sequer alcançam questões como a diminuição da desigualdade social. ${ }^{134}$

O subproletariado e o proletariado têm interesse comum no pleno emprego, pois ele cria condições de luta favoráveis à classe trabalhadora. ${ }^{135}$

\section{8 - AS CONTRADIÇÕES DA LUTA POR DIREITOS}

Armando Boito Jr. observa que a base da cidadania, que é a igualdade civil, não poderá ser extinta sem que isso represente a extinção do próprio capitalismo. ${ }^{136}$ Apesar disso, ou seja, da íntima relação com o sistema, até mesmo a igualdade civil não foi uma concessão serenamente desejada pela burguesia, que durante a revolução francesa tentou destruir os estamentos, mas pretendeu manter parte da estrutura de hierarquia de ordens, exigindo, por meio da legislação de agosto de 1789, "o pagamento em dinheiro para que o camponês pudesse se liberar de sua situação de servo". ${ }^{137}$ Foi a pequena burguesia (sanculottes), apoiada na guerra civil espontânea mantida pelos camponeses no campo entre 1789 e 1793 quem "estabeleceu a extinção incondicional do direito feudal”. ${ }^{138}$ É de se registrar, ainda, que os "capitalistas ingleses procuraram reimplantar, por vias as mais diversas, formas de trabalho compulsório" e a imposição do trabalho livre e da legislação de fábrica aos capitalistas foi realizada pelo movimento operário e pela burocracia do Estado. ${ }^{139}$

\footnotetext{
${ }^{133}$ SINGER, André Vitor. Os sentidos do Lulismo. Reforma gradual e pacto conservador. São Paulo: Companhia das Letras, 2012, p. 20-21.

${ }^{134}$ SINGER, André Vitor, op. cit., p. 156.

${ }^{135}$ Ibid., p. 166.

${ }^{136}$ BOITO JR., Armando. Estado, política e classes sociais: ensaios teóricos e históricos. São Paulo: Editora UNESP, 2007, p. 259.

${ }^{137}$ Ibid., p. 259-260.

${ }^{138}$ Ibid., p. 260.

${ }^{139}$ Ibid., p. 260.
} 
Constata-se, portanto, que a burguesia precisava destruir a sociedade estamental e hierarquizada e, para tanto, valeu-se do princípio da igualdade de todos perante a lei. Mas, à burguesia somente interessava uma igualdade que a levasse ao poder, eis que, se pudesse, manteria parte da estrutura estamental, impondo aos trabalhadores o trabalho compulsório (o que na atualidade tem sido muito praticado, com o crescimento do trabalho em condições análogas à de escravo e de certa forma, com a intensificação da precarização do trabalho, por meio da informalidade e da terceirização).

Preconizada a igualdade de todos perante a lei, a burguesia ainda hesitou e tentou excluir os trabalhadores de uma igualdade jurídica formal plena, mas, não tendo sido possível, procurou beneficiar-se dessa igualdade (que igualava o proprietário dos meios de produção ao trabalhador, proprietário apenas de sua força de trabalho, em um contexto de excesso de mão de obra), usufruindo a burguesia da exploração que a via contratual possibilitava.

Por outro lado, o trabalhador, explorado no contrato de trabalho, tinha no plano jurídico a cidadania básica, que garantia igualdade civil. A partir dela, tornou-se natural a luta pela cidadania política, econômica e social, em detrimento dos interesses da burguesia.

Mas, até mesmo essa cidadania ampla, com igualdade civil e política e proteção na dimensão econômica e social, pode revelar uma dimensão ideológica conservadora, no sentido de realizar uma ação de isolamento de cada trabalhador, que deixa de se ver como membro de uma classe social e passa a se considerar cidadão, integrante da nação e do Estado universal.

Conforme esclareceu Boito Jr., um aspecto de mistificação aparece nesse processo de constituição da cidadania: a função política e ideológica conservadora que a cidadania desempenha, porque a "ilusão de igualdade que ela pode produzir, e que geralmente produz, dissolve, aos olhos dos trabalhadores, a idéia de pertencimento de classe". ${ }^{140}$

${ }^{140}$ BOITO JR., Armando. Estado, política e classes sociais: ensaios teóricos e históricos. São Paulo: Editora UNESP, 2007, p. 258-259. 
A “cidadania individualiza os agentes da produção, dissolvendo, no plano ideológico, a realidade das classes e da luta de classes. Percebendo-se como cidadãos os trabalhadores deixam de se perceber como classe social". ${ }^{141}$ Trata-se do chamado efeito de isolamento (individualização dos agentes de classe) detectado por Nicos Poulantzas. ${ }^{142}$

Contudo, entendemos que dentro da estruturação político-jurídica da sociedade dos últimos séculos, a emancipação dos trabalhadores passa necessariamente pela intensificação e aprofundamento da cidadania, mediante a expansão de direitos sociais e a garantia de participação política dos dominados. Mesmo que os trabalhadores se vejam como integrantes de um todo abstrato, forjado para os interesses da classe dominante, a concretização do discurso da cidadania revelará as lutas de classe subjacentes. O problema, portanto, não está na elaboração formal de uma ordem jurídica universalista, mas em uma tomada de posição crítica pela classe trabalhadora, que não se satisfaça com a proclamação de direitos, mas exija a sua transformação em realidade.

Registre, porém, que o momento atual, notadamente das últimas quatro décadas, é de ataque da burguesia à cidadania ampliada, por meio da ideologia neoliberal, que tenta destruir os direitos sociais.

\section{9 - A DESAGREGRAÇÃO DA CLASSE TRABALHADORA}

Considerando que a classe trabalhadora não se constitui apenas por sua posição no processo produtivo e pela similitude de condições de vida, mas também por meio da consciência desses elementos e de um sentido de identidade, que faz com que seja possível a união dos trabalhadores e a elaboração de um projeto comum capaz de forçar o capital a recuar e capaz de alterar as balizas estruturais do sistema, em prol da justiça social, as últimas décadas trouxeram grandes desafios à classe trabalhadora $\mathrm{e}$ representaram, sob alguns aspectos, desagregação da referida classe.

\footnotetext{
${ }^{141}$ BOITO JR., Armando. Estado, política e classes sociais: ensaios teóricos e históricos. São Paulo: Editora UNESP, 2007, p. 258.

${ }_{142}$ POULANTZAS, Nicos. Pouvoir politique et classes sociales. Paris: François Maspero, 1968, s/p. Apud BOITO JR., Armando, op. cit., p. 259.
} 
A visualização pelos trabalhadores do conflito capital versus trabalho ao longo de mais de um século de experiência capitalista foi sendo construída e possibilitada pela luta por direitos políticos e sociais. A união para reivindicar melhores condições de vida foi possível a partir da consciência de classe e concomitantemente foi construindo essa consciência.

Ocorre que as circunstâncias de trabalho nas últimas décadas dificultaram essa consciência e essa união, resultando em forte desagregação da classe trabalhadora. Parte da energia do trabalho canalizada para o conflito com o capital passou a ser utilizada em disputa do trabalho com o próprio trabalho ${ }^{143}$, gerando recrudescimento do espaço do trabalho e fortalecimento do capital, em sua dimensão mais agressiva.

Dentro das próprias empresas se verifica a divisão entre o núcleo central de trabalhadores qualificados, com carreira ascendente, e o outro grupo rotativo, de trabalhadores "sem futuro". Dessa forma, segundo uma visão determinista, os operários qualificados, que na história do movimento operário assumiram posições de vanguarda, puxando o restante da classe nas lutas contra o capital, agora tenderiam a assumir uma posição conservadora, como resultado da necessidade de preservar seus privilégios. Eles teriam sucumbido de maneira irremediável à hegemonia burguesa ${ }^{144}$.

Esse enfraquecimento não resultou da diminuição da quantidade de trabalhadores utilizados pelo sistema no processo produtivo, mas da quebra da consciência de identidade de classe, por meio de nova dinâmica utilizada pelo capital para sua recomposição, impondo novas circunstâncias de execução das atividades laborais, fortemente fragmentadoras e desagregadoras da classe proletária. A fragmentação de interesses e até mesmo de linguagem apresenta-se como obstáculo para a ação unificada.

\footnotetext{
${ }^{143}$ GRAZIA, Giuseppina Rosaria De. A redução e redistribuição do tempo de trabalho em questão. Tese de doutorado, Departamento de Sociologia da FFLCH-USP, São Paulo, 2003, p. 32.

${ }^{144}$ Ibid., p. 32.
} 
Diversos fatores são apontados como responsáveis por esse processo de fragmentação e desagregação: a precarização das condições de trabalho, com utilização de trabalho informal, terceirizado, temporário, por prazo determinado, por tempo parcial, em condições análogas à de escravo; o aumento do desemprego, pela transferência de grande parte da força de trabalho para o mercado informal ou precarizado, e em parte pelo desenvolvimento tecnológico; a heterogeneidade entre os assalariados, a ampliação do setor de serviços e a diminuição do setor industrial; a polarização entre trabalhadores dos setores mais importantes e os trabalhadores não qualificados (dentro da empresa e entre categorias), subempregados e desempregados.

Nesse cenário, o desemprego passou a ser uma ameaça desagregadora. Uma arma de guerra do capital. Uma "tática pedagógico-punitiva"145, na medida em que utilizada pelo capital para combater qualquer foco de resistência por parte dos trabalhadores e para forçar a redução de direitos.

André Singer ${ }^{146}$ observa que já no início dos anos 1990, Perry Anderson ${ }^{147}$ apontava, entre as mudanças no mundo do trabalho, a ampliação do setor de serviços e a redução da classe trabalhadora manual para cerca de $1 / 4$ da força de trabalho, bem como 0 aumento da diversidade interna dos trabalhadores manuais, com "bons salários na ponta mais alta e longos períodos de desemprego na mais baixa”.

Enfim, nas últimas décadas, a classe trabalhadora se tornou mais complexa, embora o conceito de Marx e Engels de o conjunto dos assalariados que vivem da venda de sua força de trabalho continue válido.

O desafio atual da classe trabalhadora é vencer essa fragmentação do mundo do trabalho e unificar os "laços de pertencimento de classe existentes entre os diversos segmentos que compreendem o mundo do trabalho". ${ }^{148}$

\footnotetext{
${ }^{145}$ SOUZA, Sérgio Alberto de. Direito, globalização e barbárie - estudos críticos de temas de direito do trabalho e de direitos humanos sob a ótica de uma leitura não-liberal. São Paulo: LTr, 1998, p. 31.

${ }^{146}$ SINGER, André Vitor. Os sentidos do Lulismo. Reforma gradual e pacto conservador. São Paulo: Companhia das Letras, 2012, p. 25.

${ }^{147}$ ANDERSON, Perry \& CAMILLER, Patrick (orgs.). Um mapa da esquerda na Europa Ocidental. Rio de Janeiro: Contraponto, 1994, s/p. Apud SINGER, André Vitor, op. cit., p . 25.

${ }^{148}$ ANTUNES, Ricardo. O neoliberalismo e a precarização estrutural do trabalho na fase de mundialização do capital. In: SILVA, Alessandro da. et. al. (coord.). Direitos humanos: essência do direito
} 
A observação das condições de vida dos trabalhadores distribuídos por variadas peculiaridades, revela, contudo, que algo de comum ainda permanece, qual seja, o forte caráter exploratório do capital, gerando péssimas condições de vida e de trabalho a todos, com altos níveis de estresse pela pressão por aumento de produtividade e pela ameaça de desemprego, rebaixamento de salários, perda crescente de direitos, desregulamentações, enfim, a precarização é um processo que atinge gradativamente a todos. $^{149}$

Ricardo Antunes explica que os trabalhadores do setor industrial continuam tendo grande importância na luta contra o capital, por participarem diretamente da valorização do capital e, portanto, terem maior força reivindicativa. ${ }^{150}$ Os trabalhadores desempregados e precarizados também têm papel de destaque na luta contra o capital porque sentem de maneira mais intensa os efeitos de sua marginalização no processo produtivo e, ante sua condição de despossuídos e excluídos, "não têm mais nada a perder no universo da sociabilidade do capital". ${ }^{151}$

Dessa forma, constata-se que permanecem presentes os elementos para a união de forças e construção de um projeto comum. As desagregações deverão ser superadas pela consciência da exploração comum, que continua a mesma desde os primórdios do capitalismo.

O direito do trabalho pode continuar representando esse projeto comum e aglutinar os trabalhadores em torno de um mecanismo de luta. Da mesma forma que os esforços pela conquista de direitos sociais contribuíram para a formação da consciência e para a identidade da classe trabalhadora, poderão continuar a servir de instrumento para uma nova unificação de classe.

do trabalho. São Paulo: LTr, 2007, p. 46.

${ }_{149}$ GRAZIA, Giuseppina Rosaria De. A redução e redistribuição do tempo de trabalho em questão. Tese de doutorado, Departamento de Sociologia da FFLCH-USP, São Paulo, 2003, p. 33.

${ }^{150}$ ANTUNES, Ricardo. Os sentidos do trabalho: ensaio sobre a afirmação e a negação do trabalho. São Paulo: Bointempo Editorial, 1999, p. 102. Apud GRAZIA, Giuseppina Rosaria De, op. cit., p. 33-34.

${ }^{151}$ IDEM. Adeus ao trabalho? São Paulo, Campinas: Cortez/Unicamp, 1995, p. 90. Apud GRAZIA, Giuseppina Rosaria De, op. cit., p. 34. 
Neste ponto, um questionamento que surge é por que o direito do trabalho não foi capaz de evitar esse processo de precarização das condições de trabalho? De qualquer forma, esse ramo jurídico trata-se de um mecanismo (talvez o mais poderoso) de consciência e de afirmação da classe trabalhadora.

O princípio da melhoria da condição social do trabalhador, que será detalhado nesta pesquisa, elemento teleológico do direito do trabalho, pode oferecer aos mais variados grupos de trabalhadores um objetivo comum.

Neste sentido, conforme análise que será retomada no próximo item deste capítulo, o direito do trabalho possui grande potencial e grande responsabilidade como formador de consciência de classe dos trabalhadores e elemento de reunificação. Cabe ao direito do trabalho proteger os direitos conquistados e ampliar as conquistas. Entre esses direitos estão aqueles que poderão representar mudanças mais profundas, tais como o incentivo à união em associações de classe para uma atuação coletiva, greves e participação na gestão da empresa e do Estado.

\subsection{0 - O DIREITO DO TRABALHO COMO ELEMENTO DE CONSCIÊNCIA DE CLASSE}

É comum dizer-se que o direito busca a pacificação social e que entre os objetivos do direito do trabalho está a conciliação (e chegou-se até a dizer a colaboração) das classes sociais.

Mas, se é possível perceber nessas ideias o mérito de reconhecer que existe o conflito social e por isso o direito se apresenta para a pacificação, e de reconhecer a existência da dinâmica das classes sociais, seus antagonismos e suas lutas, é preciso também uma reflexão crítica a respeito dessa pacificação e conciliação de classes.

Cabe-nos perguntar: que pacificação social esperamos que o direito realize? A pacificação da ordem ou da justiça social? Ou quem sabe da ordem por meio da justiça 
social? Que conciliação é possível entre as classes sociais na sociedade capitalista? Que espécie de conciliação de classes tem realizado o direito do trabalho? A que classe social interessa a conciliação e a colaboração de classes sociais?

Consideramos, nesse estágio das nossas reflexões que, por razões de fácil intuição, é possível perceber que a violência física deve ser banida da vida em sociedade. Ela representa uma força destrutiva incompatível com a preservação das relações sociais, embora também seja possível observar que o rompimento para novas reconstruções seja parte da vida e da dinâmica da natureza. Mas o direito deve ser capaz de impedir que os conflitos se resolvam mediante tal espécie de violência. Consideramos que é possível ter conflitos, confrontação de interesses e formas de obtenção do consenso que se realizem pela comunicação e por condutas assertivas confrontativas, dotadas de tensão antagônica e de carga transformadora.

A greve, por exemplo, direito fundamental consagrado no $\operatorname{artigo} 9^{\circ} \mathrm{da}$ Constituição Federal, trata-se de um instrumento democrático de resolução de conflitos sociais e de formalização racional das lutas de classes. Nas palavras de Tarso Fernando Genro: "O direito de coalização e de greve, expressões do Direito Coletivo do Trabalho, enfrentam diretamente a propriedade privada que é instrumento de liberdade dos proprietários dos meios de produção" ${ }^{152}$.

...o direito de não trabalhar é manifestação de liberdade. A sociedade moderna centrou sua atenção no direito-dever de trabalhar. Fundamenta-se o direito de greve no direito de não trabalhar, em termos individualistas, i.e., "tenho o direito de não trabalhar porque tenho o direito de trabalhar", ou como manifestação de liberdade sindical e decorrência do direito de coalizão, é certo que o exercício de tal direito não busca liberação do trabalho como pena ou dever. Deixa-se de trabalhar para voltar a trabalhar. ${ }^{153}$

${ }^{152}$ GENRO, Tarso Fernando. Contribuição à crítica do direito coletivo do trabalho. São Paulo: LTr, 1988, p.16.

${ }^{153}$ LEITE, João Antônio Pereira. Estudos de direito do trabalho e direito previdenciário. Porto Alegre, Síntese, 1979, p. 51. Apud GENRO, Tarso. Introdução crítica ao direito. Estudos de filosofia do direito 
Lembramos que o direito do trabalho originou-se no bojo da sociedade capitalista e do correspondente modelo produtivo que se baseia na separação do trabalhador da propriedade dos meios de produção. Esse ramo jurídico surgiu das contradições do sistema, na medida em que a implantação dos postulados iniciais do capitalismo gerou problemas sociais que precisaram ser enfrentados por meio de uma nova racionalidade jurídica, mediante alteração de parte do arcabouço jurídico inicial, notadamente no que se refere à igualdade formal.

Diversos elementos do direito do trabalho, tais como, exemplificativamente, a proteção ao salário, a limitação de jornada e o exercício da greve, contribuíram para o desenvolvimento da consciência dos trabalhadores acerca das suas condições semelhantes de vida, da posição desvantajosa que o sistema lhes reserva e dos mecanismos para alterar essa posição.

Assim como o sistema capitalista é dinâmico e sempre está em busca de novas formas de implementar a sua meta de obtenção de lucros, o direito do trabalho também tem o caráter dinâmico, de buscar novas formas de proteção do trabalhador.

O direito do trabalho e de certa forma os direitos sociais em geral representam não apenas a tradução normativa dos processos de construção da classe trabalhadora, enquanto agente jurídico e, portanto, político, mas também mecanismos de viabilização do capitalismo (com a intrínseca exploração do trabalho pelo capital), em um processo que revela o caráter contraditório do sistema e, por extensão, do direito, notadamente do direito do trabalho.

O Direito do Trabalho, em geral, e o Direito Coletivo do Trabalho em particular, não são somente uma "autolimitação do capitalismo" na expressão de Bayon-Chacon. Profundamente contraditórios, eles, ao mesmo tempo que concretizam melhorias específicas nas condições de vida dos trabalhadores, impulsionam a manutenção da

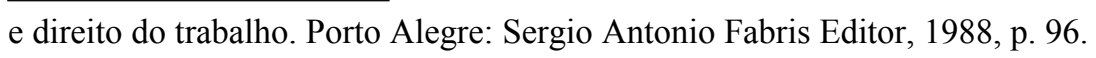


condição operária, afirmando a sua dependência e negando "sua própria emancipação" ${ }^{154}$. No pacto de paz que o Contrato Coletivo externa a classe operária se reconhece como a classe dominada. ${ }^{155}$

Tarso Fernando Genro faz uma reflexão comparativa entre os direitos trabalhistas individuais e os coletivos e observa que a maior expressão formal e material dos direitos individuais no cotidiano das relações de trabalho "sempre fez reproduzir com mais intensidade a ideologia do individualismo pequeno-burguês, presente no mundo ideológico do trabalhador brasileiro e sutilmente estimulada pela própria evolução legislativa concernente ao Direito Individual do Trabalho". ${ }^{156}$

Esta relação contraditória entre a legislação do direito individual que afirma o trabalhador como portador de direitos subjetivos que se esgotam na sua individualidade, e a legislação do direito sindical e coletivo, que concretamente é um obstáculo à consolidação de direitos subjetivos coletivos, traduz toda a deformação burocrática da cidadania burguesa gerenciada pela própria burguesia na época da contra-revolução. ${ }^{157}$

Entendemos que os direitos individuais e coletivos possuem uma intrínseca ligação dialética. Os direitos coletivos refletem-se na obtenção de conquistas individuais que vão afirmar a condição humana do trabalhador e garantir sua saúde e possibilidades de vida. Em se tratando de direitos sociais, a melhoria das condições individuais se dá em uma perspectiva coletiva e não individualista, sob pena de não se manter temporal e institucionalmente, frente às demais forças sociais antagônicas.

\footnotetext{
${ }^{154}$ CORREA, Jaime Montalvo. Fundamentos del derecho del trabajo. Madrid: Ed. Civitas, 1975, p. 149. Apud GENRO, Tarso Fernando. Contribuição à crítica do direito coletivo do trabalho. São Paulo: LTr, 1988, p. 17.

${ }^{155}$ GENRO, Tarso Fernando, op. cit., p. 17.

${ }^{156}$ IDEM. Introdução crítica ao direito. Estudos de filosofia do direito e direito do trabalho. Porto Alegre: Sergio Antonio Fabris Editor, 1988, p. 69.

${ }^{157}$ Ibid., p. 69.
} 
Dessa forma, valorizar o direito individual do trabalho é valorizar o direito coletivo e vice-versa, atentando-se na indivisibilidade de propósito da unidade, que é a de melhorar as condições de vida e de trabalho do trabalhador.

Por fim, é de se registrar que mesmo que existissem sindicatos fortes e proteção ao direito de greve e ao princípio da melhoria da condição social do trabalhador, o Estado deveria sempre atuar para garantir a plenitude do caráter associativo e reivindicativo dos trabalhadores e também deveria buscar o pleno emprego, porque o desemprego enfraquece o poder de negociação dos trabalhadores. Assim, políticas econômicas recessivas devem ser evitadas e também devem ser evitados os favorecimentos ao capital financeiro e internacional de modo geral. 


\section{2- O CAPITALISMO}

\section{1 - ASPECTOS GERAIS}

O capitalismo é o modelo de sociedade que suplantou o feudalismo e consagrou a burguesia como classe dominante. A essência do sistema reside nos processos de acumulação e de reprodução do capital, mediante a exploração, pela burguesia, da mão de obra de um vasto exército de pessoas que não detêm os meios de produção.

A existência de divisão de classes sociais com interesses antagônicos é elemento estrutural do sistema e foi abordada no item 1.4 desta dissertação. Outros aspectos aparecem na essência do modelo, tais como a transformação de tudo, inclusive do ser humano, em mercadoria, a divisão social e técnica do trabalho, a convivência permanente com crises e contradições e a participação do Estado.

O núcleo do sistema capitalista é constituído pelo capital, trabalho e Estado, elementos interrelacionados. O Estado será analisado no capítulo 3 deste estudo.

Tendo se constituído como o mais poderoso e abrangente sistema de metabolismo social, o seu sistema de mediação de segunda ordem tem um núcleo constitutivo formado pelo tripé capital, trabalho e Estado, sendo que essas três dimensões fundamentais do sistema são materialmente inter-relacionadas, tornando-se impossível superá-las sem a eliminação do conjunto dos elementos que compreende esse sistema. ${ }^{158}$

O "capitalismo realmente existente" é a experiência capitalista tal qual implementada e é sob a égide dessa experiência que vivemos. De modo que, conforme explica Sérgio Alberto de Souza, a causa da atual crise econômica e social (exclusão

\footnotetext{
${ }^{158}$ ANTUNES, Ricardo. Os sentidos do trabalho. Ensaio sobre a afirmação e a negação do trabalho. São Paulo: Boitempo Editorial, 2006, p. 22.
} 
social, desemprego, violência e barbárie, com impacto nos sentimentos das pessoas, de inquietação e desespero) é o desajustamento gerado por esse capitalismo. ${ }^{159}$

Nesse sistema, põe-se preço nas coisas e nas pessoas: quem tem mais é quem vale mais. ${ }^{160}$ Para ele, o ser humano não passa de um fator de produção e consumo e objeto de uso. ${ }^{161} \mathrm{O}$ tempo, apenas recurso econômico, e o planeta, fonte de renda. ${ }^{162}$ "A pobreza é multiplicada para que a riqueza possa se multiplicar". ${ }^{163}$

O capitalismo cria necessidades de consumo, favorece a acumulação de riquezas por uma minoria e estabelece um processo seletivo de inserção no sistema, gerando exclusões.

Enquanto se mantiver a lógica da engenharia capitalista, o trabalho fará parte da centralidade dos arranjos sociais. Esta lógica capitalista, ademais, para sobreviver, cria necessidades de consumo, favorece acumulação de riquezas e estabelece um processo seletivo de inserção ao sistema. Assim, o capitalismo produz riqueza, mas gera necessidades e exclusões. ${ }^{164}$

\section{2-A LÓGICA DE ACUMULAÇÃO E REPRODUÇÃO DO CAPITAL}

No capitalismo, a finalidade do sistema deixou de ser a satisfação das necessidades humanas e passou a ser a expansão do capital. Há permanentemente o objetivo de obtenção de lucro.

\footnotetext{
${ }^{159}$ SOUZA, Sérgio Alberto de. Direito, globalização e barbárie - estudos críticos de temas de direito do trabalho e de direitos humanos sob a ótica de uma leitura não-liberal. São Paulo: LTr, 1998, p. 11.

160 Ibid., p. 11.

${ }^{161}$ Ibid., p. 11.

162 Ibid., p. 11.

${ }^{163}$ Ibid., p. 11.

${ }^{164}$ SOUTO MAIOR, Jorge Luiz \& CORREIA, Marcus Orione Gonçalves. O que é Direito Social? In: CORREIA, Marcus Orione Gonçalves (org.). Curso de direito do trabalho - Volume I : teoria geral do direito do trabalho. São Paulo: LTr, 2007, p. 30.
} 
E essa reprodução do capital se faz pela acumulação pelo capitalista de uma parcela da riqueza produzida pelo trabalhador. Emir Sader explica que "Esse excedente de riqueza, esse excedente de valor produzido pelo trabalhador e que fica nas mãos do capitalista, o qual é denominado de mais-valia, é a alavanca do processo de reprodução do capital". ${ }^{165}$ Por esse mecanismo, o funcionamento da economia resulta em "concentração de riqueza no pólo capitalista e de pobreza ou de simples sobrevivência no pólo do trabalhador, na acumulação de capital em detrimento do produtor direto das riquezas". ${ }^{166}$

Para Jacob Gorender, a "regra de ouro do capitalismo se resume em que o salário não deve superar o valor da força de trabalho. De preferência, convém que seja inferior a esse valor e, para isso precisamente, existe o exército industrial de reserva". ${ }^{167}$

$\mathrm{Na}$ outra ponta, a do consumo, para essa expansão do capital, um dos artifícios utilizados foi a separação e a subordinação do valor de uso das coisas ao de troca. Para "converter a produção do capital em propósito da humanidade era preciso separar valor de uso ao valor de troca, subordinando o primeiro ao segundo". ${ }^{168}$ Ricardo Antunes esclarece que essa "característica constituiu-se num dos principais segredos do êxito dinâmico do capital, uma vez que as limitações das necessidades não podiam se constituir em obstáculos para a expansão reprodutiva do capital". ${ }^{169}$

Com a priorização do valor de troca, veio a divisão hierárquica do trabalho, procurando submeter o trabalho ao capital, a fim de "viabilizar o novo sistema de metabolismo social voltado para a necessidade da contínua, sistemática e crescente ampliação de valores de troca..."

O mecanismo de crescimento expansivo do capital está lastreado na utilização decrescente do valor de uso das coisas, inclusive com a redução da vida útil das

\footnotetext{
${ }^{165}$ SADER, Emir. A exploração. In: SADER, Emir (org.). Sete pecados do capital. Rio de Janeiro: Record, 2000, p. 66 
mercadorias, a fim de "agilizar o ciclo reprodutivo". ${ }^{171}$ "O capital não considera valor de uso (o qual corresponde diretamente à necessidade) e valor de troca como coisas separadas, mas como um modo que subordina radicalmente o primeiro ao último". ${ }^{172}$

Essa nova interação dos seres humanos entre si e com as coisas, sob o sistema capitalista, passou a contar com os seguintes aspectos, indicados por Ricardo Antunes ${ }^{173}$, à luz de Mészáros ${ }^{174}$ : "separação e alienação entre o trabalhador e os meios de produção"; "a imposição dessas condições objetivadas e alienadas sobre os trabalhadores, como um poder separado que exerce o mando sobre eles"; "a personificação do capital como um valor egoísta - com sua subjetividade e pseudopersonalidade usurpadas -, voltada para o atendimento dos imperativos expansionistas do capital"; "a equivalente personificação do trabalho, isto é, a personificação dos operários como trabalho, destinado a estabelecer uma relação de dependência com o capital historicamente dominante"; "essa personificação reduz a identidade do sujeito desse trabalho a suas funções produtivas fragmentárias".

Todo esse processo inerente aos mecanismos de funcionamento do capitalismo se radicalizou, a partir dos anos 1970, eis que o capital passou a buscar alternativas para resolver a crise estrutural que reduzia o seu processo de crescimento. Houve intensificação da exploração da força de trabalho. Houve intensificação da redução do valor de uso das mercadorias e busca de agilização do ciclo reprodutivo do capital e do valor de troca. ${ }^{175}$ Nesse último aspecto, as práticas produtivas foram direcionadas para diminuir a durabilidade dos produtos, a fim de acelerar a substituição pelo consumidor. ${ }^{176}$

\footnotetext{
171 ANTUNES, Ricardo. Os sentidos do trabalho. Ensaio sobre a afirmação e a negação do trabalho. São Paulo: Boitempo Editorial., 2006, p. 25-26.

${ }^{172}$ MÉSZÁROS, István. Beyond capital (towards a theory of transition). London: Merlin Press, 1995, p. 567. Apud ANTUNES, Ricardo, op. cit., p. 25-26.

${ }^{173}$ ANTUNES, Ricardo, op. cit. p. 21-22.

${ }^{174}$ MÉSZÁROS, István, op. cit., p. 617. Apud ANTUNES, Ricardo, op.cit., p. 21-22.

${ }^{175}$ ANTUNES, Ricardo, op.cit., p. 27.

${ }^{176}$ Ibid., p. 51.
} 


\section{3 - O CARÁTER TOTALIZANTE}

O capitalismo procura espraiar-se por todos os lugares do planeta e em todas as dimensões da experiência humana. Submete tudo ao seu critério de viabilidade produtiva $^{177}$ e favorece sempre os mais fortes em detrimento dos mais fracos. ${ }^{178}$ Influencia "todas as outras formas de organização do trabalho e da vida com as quais entra em contato". ${ }^{179}$ Marca "as configurações e os movimentos da sociedade, em níveis local, nacional, regional e mundial". ${ }^{180}$

As forças que impulsionam o capitalismo estão voltadas para a expansão e acumulação do capital. Essas forças, de certa forma incontroláveis, vão transformando as realidades locais, regionais e mundiais, submetendo-as à lógica da viabilidade econômica para a referida expansão.

Os sistemas anteriores ao capitalismo buscavam de alguma forma atender às necessidades sociais, mas o atual sistema busca prioritariamente a expansão do capital. Em razão dessa desvinculação das necessidades sociais, não há limites para a expansão e isso faz do sistema capitalista uma entidade incontrolável. ${ }^{181}$

Harvey observa a sujeição produzida pelo internacionalismo do mercado mundial:

No Manifesto Comunista, Marx e Engels afirmam que a burguesia criou um novo internacionalismo através do mercado mundial, ao lado da 'sujeição das forças da natureza ao homem, do maquinário, da aplicação da química à agricultura e à indústria, da navegação a vapor, das estradas de ferro, do telégrafo, da devastação de continentes inteiros para cultivo, da canalização de rios, do surgimento de populações inteiras como por encanto'. Fê-lo a um

\footnotetext{
${ }^{177}$ ANTUNES, Ricardo. Os sentidos do trabalho. Ensaio sobre a afirmação e a negação do trabalho. São Paulo: Boitempo Editorial., 2006, p. 25.

${ }^{178}$ Ibid., p. 25.

${ }^{179}$ IANNI, Octavio. Teorias da globalização. 8. edição. Rio de Janeiro: Civilização Brasileira, 2000, p. 198.

${ }^{180}$ Ibid., p. 199.

${ }^{181}$ ANTUNES, Ricardo, op. cit., p. 23.
} 
alto custo: violência, destruição de tradições, opressão, redução da avaliação de toda atividade ao frio cálculo do dinheiro e do lucro. ${ }^{182}$

Enfim, a energia do capital revela-se totalizante e totalitária.

\section{4 - A PROPRIEDADE PRIVADA DOS MEIOS DE PRODUÇÃO}

No sistema capitalista, a propriedade dos meios de produção foi separada do trabalhador. Os meios de produção foram apropriados por uma pequena minoria, forçando a imensa maioria de não proprietários a se relacionar com os proprietários e a vender sua força de trabalho para sobreviver.

A burguesia coloca obstáculos cada vez maiores à dispersão da população, dos meios de produção e da propriedade. Aglomerou populações, centralizou meios de produção e concentrou a propriedade em algumas poucas mãos. A conseqüência necessária disto foi a centralização política. ${ }^{183}$

Conforme observa Alysson Leandro Mascaro, diferentemente da lógica feudal e escravista, em que a exploração do trabalhador ocorria mediante o uso direto da força, no capitalismo, o trabalhador é impulsionado a vender sua força de trabalho, porque não possui o domínio direto dos meios de produção. ${ }^{184}$

Marx trata da opressão que o sistema capitalista impõe aos trabalhadores, submetendo-os a intenso despotismo:

A indústria moderna converteu a pequena oficina do mestre patriarcal na grande fábrica do industrial capitalista. Massas de

\footnotetext{
${ }^{182}$ HARVEY, David. Condição pós-moderna. Uma pesquisa sobre as origens da mudança cultural. 12. edição. Tradução de Adail Ubirajara Sobral e Maria Stela Gonçalves. São Paulo: Loyola, 1992, p. 97.

${ }^{183}$ MARX, Karl \& ENGELS, Friedrich. O Manifesto Comunista. Tradução de Maria Lúcia Como. Edição especial. Rio de Janeiro: Nova Fronteira, 2011, p. 15.

${ }^{184}$ MASCARO, Alysson Leandro. Filosofia do Direito. 2. edição. São Paulo: Atlas, 2012, p. 286.
} 
trabalhadores, comprimidos nas fábricas, são organizados como tropas. Como soldados do exército industrial, são colocados sob o comando de uma hierarquia perfeita de oficiais e sargento. Não são somente escravos da classe burguesa e do Estado burguês, mas são, a todo dia e a toda hora, escravizados pela máquina, pelo supervisor e, acima de todos, pelo próprio indivíduo fabricante burguês. Quanto mais abertamente este despotismo proclama que o ganho é o seu fim e a sua meta, tanto mais mesquinho, tanto mais odioso e tanto mais amargo ele se torna. ${ }^{185}$

A questão da propriedade ou não dos meios de produção gera outras, quais sejam as posições da burguesia e dos trabalhadores no processo produtivo, a contradição de interesses e o surgimento de classes sociais distintas. A constituição política da classe trabalhadora depende da consciência desses aspectos e da luta pela afirmação dos seus interesses.

\section{5-A DIVISÃo SOCIAL E TÉCNICA ALTAMENTE ORGANIZADA DO TRABALHO}

No capitalismo, ocorre uma divisão social e técnica altamente organizada do trabalho, com fragmentação de tarefas e responsabilidades. O trabalho manual é separado do intelectual. O trabalhador é reduzido a mero apêndice da máquina e mero fragmento da produção coletiva. Há um empobrecimento do trabalhador do ponto de vista individual.

A atividade do trabalho é separada do resultado do trabalho e este resultado é alijado do trabalhador e apropriado pelo capitalista. O trabalhador é afastado também do comando do processo de produção.

\footnotetext{
${ }^{185}$ MARX, Karl \& ENGELS, Friedrich. O Manifesto Comunista. Tradução de Maria Lúcia Como. Edição especial. Rio de Janeiro: Nova Fronteira, 2011, p. 18.
} 
Harvey traz um panorama estrutural do capitalismo, à luz dos ensinamentos de Marx. Diz que "Uma divisão social e técnica altamente organizada do trabalho... é um dos princípios fundadores da modernização capitalista" ${ }^{186}$ e que esse mecanismo constitui "uma poderosa alavanca de promoção do crescimento econômico e da acumulação do capital"187. Nesse contexto, podem florescer o "individualismo possesssivo", o "empreendimentismo" e a "inovação e a especulação criativos", embora isso tudo "implique uma proliferante fragmentação de tarefas e responsabilidades" e "uma transformação necessária das relações sociais que chega a ponto de forçar os produtores a ver os outros em termos puramente instrumentais". ${ }^{188}$

Harvey diz que a existência de trabalho assalariado ("pessoas que têm que vender força de trabalho para viver" ${ }^{189}$ ) é uma condição histórica para o capitalismo e é "resultado de muitas revoluções, da extinção de toda uma série de modos de produção mais antigos". ${ }^{190}$ Nas origens do capitalismo está "uma ruptura radical, total e violenta com o passado". ${ }^{191}$

Explica que "a compra de força de trabalho com dinheiro dá ao capitalista certos direitos de dispor do trabalho dos outros sem considerar necessariamente o que estes possam pensar, precisar ou sentir". ${ }^{192}$ Nesse cenário, vislumbra-se a "onipresença dessa relação de domínio de classe, compensada somente na medida em que os trabalhadores lutem ativamente para afirmar seus direitos e exprimir seus sentimentos". ${ }^{193}$ Dessa forma, “o mundo da classe trabalhadora torna-se o domínio do 'outro', tornado necessariamente opaco e potencialmente não conhecível em virtude do fetichismo da troca de mercado". ${ }^{194}$

O trabalhador "costuma estar alienado do produto, do comando do processo de produção, bem como da capacidade de realizar o valor do fruto de seus esforços - esse

\footnotetext{
${ }^{186}$ HARVEY, David. Condição pós-moderna. Uma pesquisa sobre as origens da mudança cultural. 12. ed. Tradução de Adail Ubirajara Sobral e Maria Stela Gonçalves. São Paulo: Loyola, 1992, p. 100.

${ }^{187}$ Ibid., p. 100.

${ }^{188}$ Ibid., p. 100.

${ }^{189}$ Ibid., p.101.

${ }^{190}$ MARX, Karl. O Capital. V.1. New York: s/ed, 1967, p. 166-7. Apud HARVEY, David, op. cit., p. 101.

${ }^{191}$ HARVEY, David, op. cit., p. 101.

192 Ibid., p. 101.

${ }^{193}$ Ibid., p. 101.

${ }^{194}$ Ibid., p. 101.
} 
valor é apropriado pelo capitalista como lucro". ${ }^{195}$ Entre os poderes do capital, portanto, estão os manejados pelo capitalista para "mobilizar os poderes da cooperação, da divisão do trabalho e do maquinário", resultando em "uma detalhada divisão organizada do trabalho na fábrica, o que reduz o trabalhador a um fragmento de pessoa". 196

A divisão do trabalho apresenta efeitos diversos para o capitalista e para os trabalhadores. $\mathrm{Na}$ sociedade, ela "põe em contato produtores independentes de mercadorias, que não reconhecem outra autoridade além da competição, da coerção exercida pela pressão dos seus interesses mútuos", mas na fábrica, "implica a autoridade indisputada do capitalista sobre homens, que não passam de partes de um mecanismo que pertence a ele". Vale dizer, na fábrica “a anarquia da divisão social do trabalho é substituída pelo despotismo - levado a efeito por meio de hierarquia de autoridades e estreita supervisão de tarefas". ${ }^{197}$

Com a divisão do trabalho ocorre uma fragmentação forçada do processo produtivo, abrangendo os aspectos sociais e técnicos do processo de trabalho. $\mathrm{O}$ trabalhador perde o controle sobre os instrumentos de produção e transforma-se em “apêndice” da máquina. Há a separação do trabalho manual do intelectual. ${ }^{198}$

Conforme esclarece Emir Sader, "a especialização da produção faz com que o trabalhador realize operações cada vez menores, sem sequer se dar conta do tipo de mercadoria que está produzindo". ${ }^{199}$ Essa alienação impede que o trabalhador tenha consciência sobre o processo do trabalho por meio do qual deixa de ser "remunerado por uma parte substancial do valor que produz". ${ }^{200}$

\footnotetext{
195 HARVEY, David. Condição pós-moderna. Uma pesquisa sobre as origens da mudança cultural. 12. ed. Tradução de Adail Ubirajara Sobral e Maria Stela Gonçalves. São Paulo: Loyola, 1992, p. 101.

${ }^{196}$ Ibid., p. 101.

${ }^{197}$ Ibid., p. 101-102

${ }^{198}$ Ibid., p. 102.

${ }^{199}$ SADER, Emir. A exploração. In: SADER, Emir (org.). Sete pecados do capital. Rio de Janeiro: Record, 2000, p. 68-69.

${ }^{200}$ Ibid., p. 69.
} 


\section{6 - A MERCADORIZAÇÃO}

Harvey esclarece que para Marx a mercadoria “incorpora simultaneamente um valor de uso (ela atende a um desejo ou necessidade particular) e um valor de troca (posso usá-la como objeto de barganha para conseguir outras mercadorias)". ${ }^{201}$

À "medida que as relações de troca proliferam e se formam os mercados de fixação de preços, uma mercadoria é cristalizada tipicamente como dinheiro". ${ }^{202} \mathrm{O}$ surgimento do dinheiro traz maior complexidade à mercadoria, porque "o valor de uso do dinheiro está em sua representação do mundo do trabalho social e do valor de troca". ${ }^{203}$

O dinheiro é uma mercadoria que facilita a troca das mercadorias, ante seus aspectos de impessoalidade e objetividade, ocultando as relações sociais entre as coisas, tais como as "condições de trabalho e de vida, a alegria, a raiva ou frustração que estão por trás da produção de mercadorias, os estados de ânimo dos produtores, tudo isso está oculto de nós ao trocarmos um objeto (o dinheiro) por outro (a mercadoria)". 204 "Para realizar as suas funções com eficácia, o dinheiro deve ser substituído por meros símbolos de si mesmo (moedas, símbolos, papel-moeda, crédito) o que o leva a ser considerado um mero símbolo". ${ }^{205}$ "Na ausência do trabalho social, o dinheiro de nada valeria; mas é somente através do dinheiro que o trabalho social pode ser representado". ${ }^{206}$

Harvey explica que o dinheiro "confere o privilégio de exercer poder sobre outros - podemos comprar seu tempo de trabalho ou os serviços que oferecem, e até criar relações sistemáticas de domínio de classes exploradas apenas com o controle sobre o poder do dinheiro". ${ }^{207}$ A compra da força de trabalho fornece à burguesia um domínio de classe sobre o proletariado, de modo que "o dinheiro funde o político e o econômico numa genuína economia política de avassaladoras relações de poder..."208

\footnotetext{
${ }^{201}$ HARVEY, David. Condição pós-moderna. Uma pesquisa sobre as origens da mudança cultural. 12. ed. Tradução de Adail Ubirajara Sobral e Maria Stela Gonçalves. São Paulo: Loyola, 1992, p. 98.

${ }^{202}$ Ibid., p. 98.

${ }^{203}$ Ibid., p. 98.

${ }^{204}$ Ibid., p. 98.

${ }^{205}$ Ibid., p. 99.

${ }^{206}$ Ibid., p. 99.

${ }^{207}$ Ibid., p. 100.

${ }^{208}$ Ibid., p. 100.
} 
Enfim, o sistema capitalista tende a transformar tudo em mercadoria de comércio, inclusive o trabalho humano. No capitalismo (e só no capitalismo) a força de trabalho se transforma em mercadoria. O valor da força de trabalho é determinado, assim como outras mercadorias, pelo tempo de trabalho necessário à sua produção e, por consequência, à sua reprodução. Mas, o que distingue a determinação do valor da força de trabalho do valor de outras mercadorias é a interferência de elementos históricos e morais. $^{209}$

Além disso, sob o capitalismo, o trabalhador passa a ser denominado "força de trabalho", recebe "salário" e produz "mercadoria", que tem "preço". O proprietário das condições de trabalho e do produto do trabalho passa a ser o "capital", que possui "capacidade de obter lucro". Vale dizer, os seres humanos passam a existir sob a forma de coisas. Trata-se da reificação. ${ }^{210}$

No capitalismo, as "coisas produzidas e as relações entre elas (produção, distribuição, circulação, consumo) se humanizam e passam a ter relações sociais: produzir, distribuir, comerciar, acumular, consumir, investir, poupar, trabalhar". ${ }^{211}$ As "atividades econômicas começam a funcionar e a operar sozinhas, por si mesmas, com uma lógica que emana delas próprias, independentemente dos homens que as realizam" e os homens se tornam meros "suportes dessas operações", "instrumentos delas". ${ }^{212}$ "Por meio da alienação, reificação e do fetichismo, as atividades humanas começam a comandar a vida dos seres humanos". ${ }^{213}$

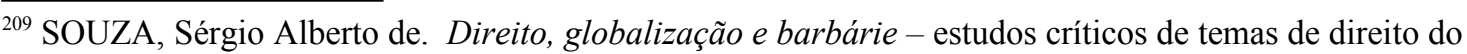
trabalho e de direitos humanos sob a ótica de uma leitura não-liberal. São Paulo: LTr, 1998, p. 44.

${ }^{210}$ Ibid., p. 45.

${ }^{211}$ Ibid., p. 45 .

${ }^{212}$ Ibid., p. 45.

${ }^{213}$ Ibid., p. 45.
} 


\section{7 - O FETICHISMO DA MERCADORIA}

No capitalismo, a mercadoria se torna um fetiche (no sentido religioso da palavra), ou seja, uma coisa que existe "em si" e "por si". Em um segundo momento, ela passa a dominar as pessoas pelo poder que exerce.

As relações de dominação e exploração entre sujeitos se ocultam sob o fetichismo da mercadoria, que regula as relações de troca e valor no mundo capitalista. $\mathrm{O}$ "fetichismo como modo de ocultamento das relações de dominação/exploração entre os homens nasceu com ele (o capitalismo), isto é: nasceu com a transformação dos produtos do trabalho humano em mercadorias". ${ }^{214}$

Maria Rita Kehl explica que o fetichismo da mercadoria "é resultado de uma operação que oculta, sob a aparente equivalência objetiva das mercadorias, as diferenças - sob as formas de dominação e exploração - entre os homens que as produziram". ${ }^{215}$ E acrescenta: "cada mercadoria que circula no mundo capitalista e que pode ser trocada por outras (...) traz em si mesma a história de um capitalista e de um operário; de um que comprou a força de trabalho e de um outro que a vendeu". ${ }^{216}$ A mercadoria oculta a expropriação do esforço do trabalhador. ${ }^{217}$

... o que faz com que as mercadorias possam se trocadas umas pelas outras, a medida comum entre elas - a tal semelhança na diferença surgue aqui outra vez como condição de toda troca - é o que todas elas têm em comum: trabalho humano investido. Trabalho que se mede em tempo, tempo de vida humana (pequenas quantidades de morte, poderíamos dizer)... ${ }^{218}$

\footnotetext{
${ }^{214}$ KEHL, Maria Rita. O fetichismo. In: SADER, Emir (org.). Sete pecados do capital. Rio de Janeiro: Record, 2000, p. 86.

${ }^{215}$ Ibid., p. 95.

${ }^{216}$ Ibid., p. $95-96$

${ }^{217}$ Ibid., p. 96.

${ }^{218}$ Ibid., p. 97.
} 


\section{8 - A ALIENAÇÃO}

Emir Sader explica que a alienação tem vários sentidos: a) econômico, em que "o trabalhador produz algo que é apropriado pelo não-trabalhador" 219 ; b) da não participação no processo de decisão: os trabalhadores "não decidem o que produzem, a que preço produzem, para quem produzem. Ao não possuir capital para produzir por conta própria, alienam sua força de trabalho" 220 ; c) ausência de consciência de seu papel no sistema: ao "valer-se de seu trabalho apenas para sobreviver, fazendo de seu poder de produção um meio de vida e não um instrumento para a transformação consciente do meio que o cerca, o trabalhador não tem consciência sequer de que ele é o produtor das riquezas da sociedade capitalista". 221

\section{9 - O COMPORTAMENTO PESSOAL}

A competição dos homens em torno da apropriação privada das riquezas impede os sujeitos de se reconhecerem universalmente. ${ }^{222} \mathrm{Na}$ sociedade burguesa, as pessoas veem-se cindidas por exigências contraditórias e ocorre uma peculiar "alienação". 223 Nela, o comportamento social é marcado por intenso individualismo possessivo, empreendimentismo e competição, em antagonismo ao sentido da solidariedade social.

A busca pelo lucro por meio das trocas de mercado faz com que os capitalistas incentivem o "excesso e a intemperança", a fim de ampliar as necessidades do outro e a crença na satisfação pela mercadoria:

... os produtores têm um permanente interesse em cultivar "o excesso e a intemperança" nos outros, em alimentar "apetites

\footnotetext{
${ }^{219}$ SADER, Emir. A exploração. In: SADER, Emir (org.). Sete pecados do capital. Rio de Janeiro: Record, 2000 , p. 66.

${ }^{220}$ Ibid., p. 68.

${ }^{221}$ Ibid., p. 68.

${ }^{222}$ SOUZA, Sérgio Alberto de. Direito, globalização e barbárie - estudos críticos de temas de direito do trabalho e de direitos humanos sob a ótica de uma leitura não-liberal. São Paulo: LTr, 1998, p. 28.

${ }^{223}$ Ibid., p. 28.
} 
imaginários" a ponto de as idéias sobre o que constitui a necessidade social serem substituídas pela "fantasia, pelo capricho e pelo impulso". 224

...o capitalismo "produz, de um lado, a sofisticação das necessidades e dos seus meios, e, de outro, uma bestial barbarização, uma completa, brutal e abstrata simplificação da necessidade". ${ }^{225}$ A propaganda e a comercialização destroem todos os vestígios da produção em suas imagens, reforçando o fetichismo que surge automaticamente no curso da troca no mercado. ${ }^{226}$

O dinheiro é um poder social passível de apropriação individual e por isso forma a base da liberdade individual, que pode ser exercida sem referência aos outros. ${ }^{227} \mathrm{~A}$ unificação que o dinheiro produz é "precisamente através de sua capacidade de acomodar o individualismo, a alteridade e uma extraordinária fragmentação social". ${ }^{228}$

\subsection{0 - A DINÂMICA DE CRISES E DE CRIAÇÃO E RECRIAÇÃO}

A existência de crises periódicas e a permanente autotransformação fazem parte da essência do capitalismo.

Para Marx, o capitalismo (...) Configura-se como um modo de produção que nasce, desenvolve-se e generaliza-se, atravessando as crises, realizando-se por ciclos de curta, média e longa durações, e transformando-se continuamente. Tanto cria e recria algumas de suas determinações estruturais, como transforma-se crescentemente. Além das forças produtivas que mobiliza todo o

\footnotetext{
${ }^{224}$ HARVEY, David. Condição pós-moderna. Uma pesquisa sobre as origens da mudança cultural. 12. ed. Tradução de Adail Ubirajara Sobral e Maria Stela Gonçalves. São Paulo: Loyola, 1992, p. 99.

${ }^{225}$ MARX, Karl. The economic and philosophic manuscript of 1844. New York, s/ed, 1964, s/p. Apud. HARVEY, David, op. cit., p. 99.

${ }^{226}$ HARVEY, David, op. cit., p. 99.

${ }^{227}$ Ibid., p. 100.

${ }^{228}$ Ibid., p. 100.
} 
tempo, tais como o capital, a tecnologia, a força de trabalho, a divisão do trabalho social, o mercado, o planejamento e a violência, entre outras, também desenvolve e recria simultânea e necessariamente as relações de produção, compreendendo as instituições em geral, as instituições jurídico-políticas em especial, envolvendo os padrões sócio-culturais, os valores e os ideais; tudo isso compondo um todo em movimento e complexo, integrado e contraditório. $^{229}$

Sob o capitalismo, há permanente alteração dos instrumentos de produção e das relações sociais.

\begin{abstract}
A burguesia não pode existir sem revolucionar continuamente os instrumentos de produção e, por conseguinte, as relações de produção, portanto todo o conjunto das relações sociais. (...) $\mathrm{O}$ contínuo revolucionar da produção, o abalo constante de todas as condições sociais, a incerteza e a agitação eternas distinguem a época burguesa de todas as precedentes. Todas as relações fixas e cristalizadas, com seu séquito de crenças e opiniões tornadas veneráveis pelo tempo, são dissolvidas, e as novas envelhecem antes mesmo de se consolidarem. Tudo o que é sólido e estável se volatiliza, tudo o que é sagrado é profanado, e os homens são finalmente obrigados a encarar com sobriedade e sem ilusões sua posição na vida, suas relações recíprocas. ${ }^{230}$
\end{abstract}

As constantes mudanças tecnológicas e organizacionais decorrem da competição de mercado e da busca por melhorar a lucratividade, "levando todos os capitalistas a salto de inovação dos processos de produção que só alcançam seu limite sob condições de maciços superávits de trabalho". ${ }^{231}$ Outro fator que impele o capitalista às alterações dos instrumentos de produção é "a necessidade de manter o trabalho sob

\footnotetext{
${ }^{229}$ IANNI, Octavio. Teorias da globalização. 8. ed. Rio de Janeiro: Civilização Brasileira, 2000, p. 198-199.

${ }^{230}$ Ibid., p. 23.

${ }^{231}$ HARVEY, David. Condição pós-moderna. Uma pesquisa sobre as origens da mudança cultural. 12. ed. Tradução de Adail Ubirajara Sobral e Maria Stela Gonçalves. São Paulo: Loyola, 1992, p. 102.
} 
controle na fábrica e de reduzir o seu poder de barganha no mercado (particularmente sob condições de relativa escassez de trabalho e ativa resistência de classe)". 232

Harvey esclarece que "O capitalismo é, por necessidade, tecnologicamente dinâmico, não por causa das míticas capacidades do empreendedor inovador (...) mas por causa das leis coercitivas da competição e das condições de luta de classes endêmicas". ${ }^{233}$ O "efeito da inovação contínua é, no entanto, desvalorizar, senão destruir, investimentos e habilidades de trabalho passados. A destruição criativa está embutida na própria circulação do capital"234. Assim, a "inovação exacerba a instabilidade e a insegurança, tornando-se, no final, a principal força que leva o capitalismo a periódicos paroxismos de crise"235.

A busca de lucratividade força os capitalistas não apenas a inovarem tecnológica e organizacionalmente, mas também a explorarem novas possibilidades, com novas fontes de matérias-primas, nova força de trabalho, novos desejos e necessidades. ${ }^{236}$ Esse processo traz insegurança e instabilidade "na medida em que massas de capital e de trabalho vão sendo transferidas entre linhas de produção, deixando setores inteiros devastados". ${ }^{237} \mathrm{O}$ "fluxo perpétuo de desejos, gostos e necessidades do consumidor se torna um foco permanente de incerteza e de luta". 238

Nessa busca por locais mais vantajosos, o capital modifica periodicamente a divisão territorial e internacional do trabalho. Na dimensão temporal, "os capitalistas tentam reduzir o tempo de giro do seu capital a um "piscar de olhos" ${ }^{239}$. Vale dizer, "o capitalismo é um sistema social que internaliza regras que garantem que ele permaneça uma força permanentemente revolucionária e disruptiva em sua própria história mundial". ${ }^{240}$

\footnotetext{
${ }^{232}$ HARVEY, David. Condição pós-moderna. Uma pesquisa sobre as origens da mudança cultural. 12. ed. Tradução de Adail Ubirajara Sobral e Maria Stela Gonçalves. São Paulo: Loyola, 1992, p. 102.

${ }^{233}$ Ibid., p. 102.

${ }^{234}$ Ibid., p. 102.

${ }^{235}$ Ibid., p. 102.

${ }^{236} \mathrm{Ibid}$., p. 103.

${ }^{237}$ Ibid., p. 103.

${ }^{238}$ Ibid., p. 103.

${ }^{239} \mathrm{Ibid}$., p. 103.

${ }^{240}$ Ibid., p. 103.
} 
Harvey esclarece que, para Marx, "há um princípio unitário que sustenta e dá forma a todo esse distúrbio revolucionário, à fragmentação e à insegurança perpétua" ${ }^{241}$ : trata-se do "valor em movimento", ou "a circulação do capital, incansável e eternamente em busca de novas maneiras de auferir lucros". ${ }^{242}$

Ricardo Antunes observa que a crise atual do capitalismo, iniciada no início da década de 1970, está marcada por precipitações mais frequentes e contínuas, diferentemente do que ocorria no passado, quando havia intervalos razoavelmente longos entre as grandes crises. ${ }^{243}$

\subsection{1 - A AVERSÃO AO RISCO}

A racionalidade capitalista da busca pelo lucro faz com que abstratamente seja natural e necessária a competição. A competição envolve risco. O capital, contudo, embora obrigado, por natureza, a se expor ao risco, busca permanentemente formas de escapar dele. Nesse intento, a máxima do fim justifica os meios é levada às últimas consequências, desconhecendo limites éticos ou morais e buscando flexibilizar tais limites ao extremo, muitas vezes cinicamente.

Nessa aversão ao risco, o capital busca proteger-se, abrigando-se no Estado e mesmo construindo uma ideologia de vincular os fins do Estado aos seus fins. Além disso, o capital tem forte tendência de transferir para os trabalhadores os riscos do empreendimento. É por isso que permanentemente se tenta construir uma racionalidade de flexibilização ou retirada dos direitos trabalhistas em momentos de crise ou de mera diminuição dos lucros. Na primeira adversidade, o empresariado se volta para os trabalhadores e lhes apresenta a conta dos potenciais prejuízos do negócio.

\footnotetext{
${ }^{241}$ HARVEY, David. Condição pós-moderna. Uma pesquisa sobre as origens da mudança cultural. 12. ed. Tradução de Adail Ubirajara Sobral e Maria Stela Gonçalves. São Paulo: Loyola, 1992, p. 103. ${ }^{242}$ Ibid., p. 103.

${ }^{243}$ ANTUNES, Ricardo. Os sentidos do trabalho. Ensaio sobre a afirmação e a negação do trabalho. São Paulo: Boitempo Editorial, 2006, p. 27-28.
} 
Em vista desse contexto, a Consolidação das Leis do Trabalho precisou mencionar expressamente que os riscos do negócio devem ser assumidos pelo empregador, conforme se observa no seu artigo $2^{\circ}$, "caput".

Esse aspecto jurídico de que os riscos pertencem ao empregador e não ao trabalhador muitas vezes é esquecido ou mitigado na doutrina e na jurisprudência, embora quando isso ocorre está-se diante de sério desvirtuamento valorativo, verdadeira subversão do sentido do direito do trabalho de civilizador do capital, transformando-o em instrumento de interesses imediatos da classe detentora dos meios de produção.

A título de exemplo, vide a utilização da "teoria da adaptação setorial e conjuntural", que, na definição de Ives Gandra Martins da Silva Filho, diz respeito à "necessidade de adaptação das normas legais à flutuação periódica das condições econômicas de um determinado setor ou em face das alterações estruturais desse segmento, de modo a preservar empregos, sem precarização das condições de trabalho". ${ }^{244}$

O princípio da melhoria da condição social do trabalhador busca reconstruir a racionalidade protetiva de direito do trabalho e fincar-se como um dos elementos jurídicos de recondução do capital ao seu papel fundamental de competidor, dentro de sua própria lógica, mas arcando com os riscos de sua atividade econômica.

\subsection{2 - O CAPITALISMO BRASILEIRO}

\subsection{1 - O ESCRAVISMO}

O surgimento do Brasil ocorreu nos moldes da lógica colonialista do século XVI, no contexto da formação do capitalismo europeu, e do atendimento dos interesses de acumulação de riqueza da metrópole portuguesa e das demais nações europeias que se relacionavam com Portugal. ${ }^{245}$ A metrópole portuguesa implantou uma política de empresa

${ }^{244}$ MARTINS FILHO, Ives Gandra da Silva. Os pilares do direito do trabalho - princípios e sua densidade normativa. Revista LTr, São Paulo, vol.76, n. 07, p. 781, julho de 2012.

${ }^{245}$ FAUSTO, Boris. História concisa do Brasil. 2. ed. São Paulo: Ed. da Universidade de São Paulo, 2009, p. 21. 
comercial baseada em poucos produtos exportáveis em larga escala, assentada na grande propriedade, evitando com isso a produção de subsistência, que geraria pouco excedente para a venda. ${ }^{246}$

Paul Singer explica que embora o território brasileiro integrasse o mercado mundial durante a colonização portuguesa, ainda não havia capitalismo no Brasil, eis que o denominado "capitalismo comercial" tratava-se apenas de "um modo de circulação de mercadorias provenientes de diversos modos de produção". ${ }^{247} \mathrm{O}$ modo de produção dominante no Brasil durante o período colonial e na maior parte do século XIX foi o escravismo colonial, com a produção realizada pela mão de obra escrava. ${ }^{248}$

Em todos os ciclos da economia brasileira, a produção foi sempre realizada pelo braço escravo. A escravidão predominou não apenas nos empreendimentos agrícolas, agromanufatureiros e minerais, mas também no mundo urbano, em que proprietários alugavam seus escravos a empreiteiros de obras públicas, donos de manufaturas etc. e em que até mesmo as atividades artesanais e o comércio de varejo estavam em sua maior parte a cargo de cativos. Sendo o capitalismo um modo de produção caracterizado pela alienação da força de trabalho por indivíduos livres em troca de salários, está claro que ele é incompatível com a escravidão e só adquire significado no Brasil após a abolição ... ${ }^{249}$

A introdução do trabalho compulsório escravo foi a forma encontrada pela classe dominante para fixar o trabalhador nas grandes propriedades, tendo em vista que havia grande quantidade de terras disponíveis, dificultando a fixação na condição de assalariado. ${ }^{250}$ Além disso, o tráfico de escravos aprisionados na costa africana revelou-se

\footnotetext{
${ }^{246}$ FAUSTO, Boris. História concisa do Brasil. 2. ed. São Paulo: Ed. da Universidade de São Paulo, 2009, p. 21.

${ }^{247}$ SINGER, Paul. O capitalismo: sua evolução, sua lógica e sua dinâmica. São Paulo: Moderna, 1987, p. 66.

${ }^{248}$ Ibid., p. 66.

${ }^{249}$ Ibid., p. 67.

${ }^{250}$ FAUSTO, Boris, op. cit., p. 22.
} 
também um negócio (fonte potencial de acumulução de riqueza) e atraiu os interesses comerciais da época. ${ }^{251}$

Conforme explica Jacob Gorender, em relação à renda produzida no Brasil, "uma parte muito considerável ficava na própria Colônia, seja para a ampliação direta da produção escravista, em mãos dos plantadores, seja sob a forma de capital mercantil, em mãos dos mercadores, que financiavam e comercializavam a produção das plantagens escravistas". ${ }^{252}$

Mesmo após a independência, não houve alteração no modo de produção escravista dominante no Brasil. O governo sofria influência dos proprietários de terras, de traficantes de escravos e da população livre, para a manutenção da escravidão. ${ }^{253}$ As classes dominantes se apegavam ao trabalho escravo porque não encontravam uma alternativa para a substituição da força de trabalho e manutenção das estruturas sociais da época. ${ }^{254}$ Além disso, praticamente não havia rebeliões de escravos, com exceção do Recôncavo e da cidade de Salvador. ${ }^{255}$ Jacob Gorender noticia que "A mais elevada forma de luta dos escravos consistiu na fuga das fazendas, o que se deu sobretudo em São Paulo". 256 "Em 1850, quando se extingiu o tráfico de escravos africanos, o quantitativo servil no País alcançou seu pico máximo (2.500.000 escravos, em termos estimativos)"257.

O interesse das classes dominantes na manutenção do sistema escravista foi um dos elementos principais para a preservação da integridade territorial do Brasil porque a unidade facilitava a resistência contra pressões internacionais, notadamente da Inglaterra. ${ }^{258}$ Essas pressões e o fim do tráfico foram centrais para a abolição da escravidão, notadamente em se considerando que os proprietários de escravos no Brasil nunca se preocuparam com sua reprodução. 259

\footnotetext{
${ }^{251}$ FAUSTO, Boris. História concisa do Brasil. 2. ed. São Paulo: Ed. da Universidade de São Paulo, 2009, p. 22.

${ }^{252}$ GORENDER, Jacob. A burguesia brasileira. São Paulo: Brasiliense (Col. Tudo é História), 2004, p. 9

${ }^{253}$ FAUSTO, Boris, op. cit., p. 104.

${ }^{254}$ Ibid., p. 105.

${ }^{255}$ Ibid., p. 105.

${ }^{256}$ GORENDER, Jacob, op. cit. p. 21-22.

${ }^{257}$ Ibid., p. 9.

${ }^{258}$ FAUSTO, Boris, op. cit., p. 100.

${ }^{259}$ Ibid., p. 107.
} 
Até 1888, os libertos adquiriam liberdade com restrições: a alforria podia ser revogada pelo antigo senhor pela alegação de ingratidão (até 1865); a libertação muitas vezes era acompanhada da obrigação de prestar serviços ao antigo dono; a legislação que previa a liberdade de crianças e velhos após 1870 estabelecia condições à liberdade. ${ }^{260}$

Jacob Gorender esclarece que "a acumulação do capital mercantil se incrementou, no Brasil independente, por conseqüência da expansão do próprio escravismo colonial" ${ }^{261}$ e que a "burguesia mercantil prospera nas formações sociais anteriores ao capitalismo", ${ }^{262}$ mas "o agente organizador do modo de produção capitalista é somente a burguesia industrial"263, na medida em que o capital industrial "é a única forma do capital cuja função não consiste apenas na apropriação da mais-valia, pois também é o promotor da sua criação". ${ }^{264}$

A superação do modelo de sociedade escravista não se fez apenas por razões humanitárias. Decorreu principalmente da formação de uma burguesia liberal, no século XIX, que iniciou a construção de um projeto de formação do capitalismo no Brasil. Os abolicionistas estavam engajados na formação do Estado capitalista brasileiro.

Jacob Gorender explica que o modo de produção capitalista é absolutamente incompatível com o trabalho escravo, porque o desenvolvimento do capitalismo "depende da formação de um mercado de mão-de-obra despossuída, abundante e juridicamente livre para ser assalariada, sob contratos de trabalho rescindíveis quando convier ao empregador". ${ }^{265}$

É possível observar, ainda, que o capital mobilizado no escravo era muito alto, de modo que para os tomadores de serviço era mais barato o assalariamento, nas bases da época, do que a compra e manutenção do escravo.

\footnotetext{
${ }^{260}$ FAUSTO, Boris. História concisa do Brasil. 2. ed. São Paulo: Ed. da Universidade de São Paulo, 2009, p. 126.

${ }^{261}$ GORENDER, Jacob. A burguesia brasileira. São Paulo: Brasiliense (Col. Tudo é História), 2004, p. 9.

${ }^{262}$ Ibid., p. 11.

${ }^{263}$ Ibid., p. 11.

${ }^{264}$ Ibid., p. 11.

${ }^{265}$ Ibid., p. 19-20.
} 
No período dos anos 40 aos 80 do século XIX, centenas de pequenos e médios empresários instalaram e administraram fábricas em vários pontos do país, em setores como o da produção têxtil, vestuário, produtos alimentícios, materiais de construção, implementos para a agricultura, entre outros, e algumas dessas fábricas, a princípio "empregaram escravos ao lado de operários livres". ${ }^{266}$ Esse quadro teve grande importância para a formação da burguesia industrial e a afirmação do modo de produção capitalista, embora os produtos fossem de baixa qualidade e concorressem apenas com a produção local artesanal, não representando substituição de importações. ${ }^{267}$

Jacob Gorender observa que a abolição contribuiu para a eliminação de formas esgotadas de exploração do trabalhador, mas novas modalidades de exploração estavam sendo instauradas e se expandiram após a abolição. ${ }^{268}$ Diz que essas novas formas eram "adequadas ao nível mais elevado das forças produtivas": todos os trabalhadores se tornaram juridicamente livres e, com isso, a difusão das relações de produção capitalistas ficou desembaraçada". ${ }^{269}$

A historiografia econômica identifica três possíveis efeitos da abolição dos $\operatorname{escravos}^{270}:$ a) transformação do escravo em trabalhador assalariado, naquelas situações em que fosse impossível o seu deslocamento ou aproveitamento em outra atividade, e nessa hipótese o latifundiário despendia menos com o liberto do que despendia antes com o escravo; b) excesso de mão de obra nas regiões que já dispunham de setores que operavam com base no trabalho assalariado, reduzindo-se o custo, e para o liberto, já trabalhador assalariado, não havia transferência de renda porque a oferta abundante de mão de obra fazia com que seu salário se mantivesse em níveis de subsistência; c) possibilidade de transferência de renda à massa assalariada, nas regiões em que havia grande disponibilidade de terra em áreas acessíveis aos libertos, mas nessas regiões, a “demonização" do trabalho gerada pela escravidão fez com que os libertos preferissem

\footnotetext{
${ }^{266}$ GORENDER, Jacob. A burguesia brasileira. São Paulo: Brasiliense (Col. Tudo é História), 2004, p. 13.

${ }^{267}$ Ibid., p. 13.

${ }^{268}$ Ibid., p. 22

${ }^{269}$ Ibid., p. 22.

${ }^{270}$ SALOMÃO FILHO, Calixto et. al. Concentração, estruturas e desigualdade. As origens coloniais da pobreza e da má distribuição de renda. São Paulo: Grupo Direito e Pobreza - Instituto de Direito do Comércio Internacional e Desenvolvimento - IDCID, 2008, p. 50-51.
} 
apenas manter o mesmo nível econômico de subsistência, diminuindo suas horas de trabalho.

As relações sociais no Brasil foram profundamente marcadas pela experiência da escravidão, que legitimou as desigualdades e hierarquizações sociais, mesmo após 1888, por meio da constituição de uma cidadania estratificada, reforçadora da hierarquia e das diferenças sociais, excluindo setores populares das instituições políticas, religiosas, sociais e econômicas mais relevantes. ${ }^{271}$

Pode-se dizer que a desigualdade social brasileira tem raízes profundas na forma como foi sendo construída a história brasileira.

\subsection{2 - A PROPRIEDADE DA TERRA}

Nos períodos colonial e imperial, a ocupação das terras se fazia pela "lei do mais forte" e era mantida pela força, eis que os limites das propriedades eram indefinidos e os títulos de propriedade se sobrepunham uns aos outros. ${ }^{272}$

A relação entre a força de trabalho e a propriedade da terra era intensa, tanto que duas semanas após a extinção formal do tráfico de escravos, foi editada a Lei de Terras (1850), a fim de dificultar que os futuros imigrantes, substitutos da mão de obra escrava, pudessem se tornar proprietários: as "terras públicas deveriam ser vendidas por um preço suficientemente elevado para afastar posseiros e imigrantes pobres" 273 e "estrangeiros que tivessem passagens financiadas para vir ao Brasil ficariam proibidos de adquirir terras antes de três anos após a chegada". ${ }^{274}$

\footnotetext{
${ }^{271}$ VIOLA, Eduardo \& MAINWARING, Scott. Novos movimentos sociais - cultura política e democracia: Brasil e Argentina. In: SCHERER-WARREN, Ilse \& KRISCHKE, Paulo J. (orgs.). Uma revolução no cotidiano? Os novos movimentos sociais na América Latina. São Paulo: Brasiliense, 1987, p. 126.

${ }^{272}$ FAUSTO, Boris. História concisa do Brasil. 2. ed. São Paulo: Ed. da Universidade de São Paulo, 2009, p.101.

${ }_{273}^{27 b i d ., p . ~} 107$.

${ }^{274}$ Ibid,. p. 107-108.
} 


\subsection{3 - A IMIGRAÇÃO}

Um dos aspectos mais relevantes das mudanças socioeconômicas do Brasil, a partir das últimas décadas do século XIX, foi a imigração em massa, com a vinda de milhões de europeus e asiáticos em busca de trabalho e ascensão social: cerca de 3,8 milhões de estrangeiros entraram no Brasil entre 1887 e 1930, principalmente no período de 1887 a 1914, em que ingressaram 2,74 milhões, em razão da forte demanda de força de trabalho para a lavoura de café. ${ }^{275}$

O imigrante foi a alternativa inicial para a implementação do projeto de substituição da mão de obra escrava. As condições de trabalho dos imigrantes eram precárias e o grau de exploração semelhante ao da fase inicial do capitalismo na Europa.

A preferência em atrair mão de obra europeia em vez de transformar escravos em trabalhadores livres decorria do preconceito dos grandes fazendeiros e do fato de que os libertos provavelmente não iriam se submeter a situação semelhante à da escravidão. ${ }^{276}$ Até mesmo os imigrantes tiveram que pressiomar os fazendeiros por condições de trabalho melhores que a dos escravos. ${ }^{277}$

Para Boris Fausto, o deslocamento de pessoas das áreas pobres do Nordeste para o Centro-Sul não se revelou uma alternativa viável, ante a "argumentação racista" que vigorava e que excluía não apenas escravos e ex-escravos como também os mestiços, e o fato de que os senhores de engenho e plantadores de algodão do Nordeste também necessitavam de mão de obra. ${ }^{278}$ Além disso, muitos nordestinos foram recrutados para a extração da borracha no Norte do país ou nos cacauais da Bahia. ${ }^{279}$

Uma primeira tentativa de imigração foi realizada em 1847, pelo fazendeiro Nicolau de Campos Vergueiro, que, utilizando-se de recursos do governo imperial, trouxe imigrantes alemães e suíços para trabalhar em suas fazendas e em outras do Oeste Paulista,

\footnotetext{
${ }^{275}$ FAUSTO, Boris. História concisa do Brasil. 2. ed. São Paulo: Ed. da Universidade de São Paulo, 2009, p. 155.

${ }^{276}$ Ibid., p. 113.

${ }^{277}$ Ibid., p. 113.

${ }^{278}$ Ibid., p. 113.

${ }^{279}$ Ibid., p. 113.
} 
pelo regime de parceria, experiência que se revelou conflituosa, ante as condições de vida e de trabalho encontradas no Brasil, que incluíam disciplina estrita, com censura de correspondência e bloqueio da locomoção. ${ }^{280}$ As parcerias cessaram após uma revolta na fazenda Ibicaba, de propriedade de Vergueiro, em $1856 .{ }^{281}$

Os imigrantes italianos começaram a chegar a partir de $1874 .{ }^{282}$ As dificuldades de sobrevivência dos trabalhadores do campo e dos pequenos proprietários rurais do norte da Itália (principalmente das regiões do Vêneto e da Lombardia), em razão das transformações capitalistas e da crise econômica posterior à unificação, forçavam a emigração. ${ }^{283}$

Assim, a maior parte da mão de obra imigrante para a lavoura cafeeira foi de italianos, incentivados pelos subsídios oferecidos pelo governo paulista. ${ }^{284}$ Mas esses imigrantes também enfrentaram péssimas condições de vida, a ponto de o governo italiano divulgar uma circular, em 1885, desaconselhando a emigração, ${ }^{285}$ de tomar medidas contra o recrutamento, entre março de 1889 e julho de 1891, e de proibir a imigração subsidiada para o Brasil, a partir de março de 1902, autorizando apenas a emigração sem obtenção de outros pequenos benefícios. ${ }^{286}$

Durante a Primeira Guerra Mundial e após 1930 (com a crise econômica de 1929 e as mudanças políticas do Brasil e da Europa) houve redução do fluxo imigratório, com exceção dos japoneses, cujo principal período de chegada foi o de 1931 a $1940 .{ }^{287}$

A fórmula para a estabilização das relações de trabalho na lavoura cafeeira foi o colonato: a família de trabalhadores imigrantes se responsabilizava pelo trato do cafezal e pela colheita, recebendo um pagamento anual pelo trato e outro por ocasião da colheita, além de moradia e de pequenas parcelas de terra, nas quais podia produzir

\footnotetext{
${ }^{280}$ FAUSTO, Boris. História concisa do Brasil. 2. ed. São Paulo: Ed. da Universidade de São Paulo, 2009, p. 114.

${ }^{281}$ Ibid., p. 114.

${ }^{282}$ Ibid., p. 114.

${ }^{283}$ Ibid., p. 114.

${ }^{284}$ Ibid., p. 157.

${ }^{285}$ Ibid., p. 114.

${ }^{286}$ Ibid., p. 157.

${ }^{287}$ Ibid., p. 156.
} 
gêneros alimentícios. ${ }^{288}$ Não havia divisão dos lucros da venda do café e isso era um dos aspectos que distinguia o colonato da parceria, vigente anteriormente. ${ }^{289}$

Mesmo sob o regime do colonato, ocorreram frequentes atritos entre os colonos e os fazendeiros, inclusive greves. ${ }^{290}$ Os colonos realizavam "uma intensa mobilidade espacial, deslocando-se de uma fazenda para outra, ou para os centros urbanos, em busca de melhores oportunidades". ${ }^{291}$ Mas de modo geral, segundo Boris Fausto, a oferta de mão de obra imigrante e as possibilidades de ganho proporcionadas pelo colonato "garantiram a produção cafeeira e a relativa estabilidade das relações de trabalho na cafeicultura". ${ }^{292}$

Nas cidades, os imigrantes encontraram certa mobilidade social, atuando em atividades comerciais e industriais em Estados como São Paulo, Rio Grande do Sul, Paraná e Santa Catarina. ${ }^{293}$ Mas no campo isso não ocorreu da mesma forma, eis que, conforme já mencionado, os imigrantes, em São Paulo, por exemplo, nos primeiros anos da imigração em massa, "foram submetidos a uma dura existência, resultante das condições gerais de tratamento dos trabalhadores no país, onde eles quase equivaliam aos escravos". ${ }^{294}$

Boris Fausto noticia que com o passar do tempo, houve ascensão social de muitos imigrantes, principalmente para a condição de pequenos e médios proprietários, "abrindo caminho para que seus descendentes viessem a ser figuras centrais da agroindústria paulista". ${ }^{295}$ Diz que em 1934, o censo agrícola de São Paulo revelou que $30,2 \%$ das terras estavam em mãos de estrangeiros, cabendo aos italianos 12,2\%, aos espanhóis 5,2\%, aos japoneses 5,1\%, aos portugueses $4,3 \%$ e o restante a outras nacionalidades. ${ }^{296}$

\footnotetext{
${ }^{288}$ FAUSTO, Boris. História concisa do Brasil. 2. ed. São Paulo: Ed. da Universidade de São Paulo, 2009 , p. 159.

${ }^{289}$ Ibid., p. 159.

${ }^{290}$ Ibid., p. 160.

${ }^{291}$ Ibid., p. 160.

${ }^{292}$ Ibid., p. 160.

${ }^{293}$ Ibid., p. 158.

${ }^{294}$ Ibid., p. 158.

${ }^{295}$ Ibid., p. 158.

${ }^{296}$ Ibid., p. 158.
} 
Jacob Gorender, porém, esclarece que os imigrantes bem sucedidos como capitalistas não eram os trabalhadores manuais, mas aqueles que trouxeram algum capital, mesmo que modesto, ou "chegaram ao Brasil contratados como representantes de firmas estrangeiras (...) ou como técnicos e administradores, que traziam um equipamento cultural favorável à montagem de pequenos negócios comerciais e pequenas oficinas, etc". ${ }^{297}$ Enfim, conclui, concordando com Warren Dean, ${ }^{298}$ que "as linhas de classe já vinham de antemão traçadas na massa imigrante". ${ }^{299}$

\subsection{4 - A INDUSTRIALIZAÇÃO}

A produção cafeeira, os investimentos em ferrovias, bancos e no comércio, em conjunto com a entrada em massa de imigrantes (a partir de 1880) e a formação de núcleos urbanos, deram início à formação do capitalismo, na região de São Paulo, mediante um "processo de acumulação de capitais, de diversificação da economia, de formação de um mercado de terras, de produção e de consumo". ${ }^{300}$

Durante a Primeira República, o Brasil continou a ser predominante agrícola. ${ }^{301} \mathrm{O}$ censo de 1920 revelou que de 9,1 milhões de pessoas em atividade, 6,3 milhões $(69,7 \%)$ se dedicavam à agricultura, 1,2 milhões $(13,8 \%)$ à indústria e 1,5 milhão $(16,5 \%)$ aos serviços (inclusive domésticos). ${ }^{302}$ Mas, segundo Boris Fausto, no período, não houve um predomínio absoluto das atividades agroexportadoras, eis que a produção agrícola para o mercado interno foi significativa e a indústria foi-se implantando. ${ }^{303}$

No que se refere aos primórdios da industrialização, "as poucas fábricas que surgiram no Brasil em meados do século XIX destinavam-se principalmente a produzir

\footnotetext{
${ }^{297}$ GORENDER, Jacob. A burguesia brasileira. São Paulo: Brasiliense (Col. Tudo é História), 2004, p. 40. ${ }^{298}$ DEAN, Warren. A industrialização de São Paulo. s/ed, s/d, s/p. Apud GORENDER, Jacob, op. cit., p. 40 e 114.

${ }^{299}$ GORENDER, Jacob, op. cit., p. 40.

${ }^{300}$ FAUSTO, Boris. História concisa do Brasil. 2. ed. São Paulo: Ed. da Universidade de São Paulo, 2009, p. 111.

${ }^{301}$ Ibid., p. 159.

${ }^{302}$ Ibid., p. 159.

${ }^{303}$ Ibid., p. 159.
} 
tecidos de algodão de baixa qualidade, consumidos pela população pobre e pelos escravos". 304

O crescimento industrial paulista já se esboçava desde a década de 1870 , mas ocorreu predominantemente após a abolição e contou com a base do setor cafeeiro, na medida em que os negócios desse setor estimulavam as transações em moeda e o crescimento da renda; criavam um mercado para produtos manufaturados; ampliavam e integravam o mercado consumidor, em razão do investimento em estradas de ferro; desenvolviam o comércio de exportação e importação e assim contribuíam para a criação de um sistema de distribuição de produtos manufaturados e com os recursos necessários para a importação de máquinas; e por fim, tais negócios promoviam a imigração, assegurando a oferta de mão de obra. ${ }^{305}$

Nas palavras de Boris Fausto, a "principal preocupação do Estado não estava voltada para a indústria, mas para os interesses agroexportadores", 306 apesar de que “em certos períodos houve proteção governamental à importação de maquinaria, reduzindo-se as tarifas da alfândega"307 e concessão de "empréstimos e isenção de impostos para a instalação de indústrias de base". ${ }^{308}$ Enfim, no período, o Estado não foi um adversário da indústria, mas também não desenvolveu uma política industrial. ${ }^{309}$

Segundo Jacob Gorender, “Ao proclamar-se a República, a indústria reunia pouco mais de 54 mil operários e sua produção representava uma fração pequena do produto nacional". ${ }^{310}$ Após quase duas décadas, em 1907, "cabiam à agricultura quatro quintos do valor líquido da produção física do País, ficando a indústria com o quinto restante". ${ }^{311}$ Informa que "Na primeira década do século XX, dois terços da produção

\footnotetext{
${ }^{304}$ FAUSTO, Boris. História concisa do Brasil. 2. ed. São Paulo: Ed. da Universidade de São Paulo, 2009, p. 161.

${ }^{305}$ Ibid., p. 161-162.

${ }^{306}$ Ibid., p. 163.

${ }^{307}$ Ibid., p. 163.

${ }^{308}$ Ibid., p. 163.

${ }^{309}$ Ibid., p. 163.

${ }^{310}$ GORENDER, Jacob. A burguesia brasileira. São Paulo: Brasiliense (Col. Tudo é História), 2004, p. $24-25$.

${ }^{311}$ Ibid., p. 24-25.
} 
agrícola nacional, em termos de valor, eram exportados e, no total da exportação, o café participava com 53\% (seguido pela borracha, com 26\%)". ${ }^{312}$

O processo de substituição de importações de produtos manufaturados pela produção interna começara já nas décadas anteriores a 1930, embora as dificuldades de importação, decorrentes da crise mundial de 1929, e a existência posterior "de uma indústria de base e de capacidade ociosa das indústrias, principalmente no setor têxtil, impulsionaram o processo de substituição". ${ }^{313}$ Posteriormente, no Estado Novo (19371945), a estratégia de industrialização por substituição de importações foi coordenada pelo Estado. ${ }^{314}$

Em 1920, a agricultura detinha 79\% do valor da produção total e a indústria $21 \%{ }^{315}$ Em 1940, as proporções correspondiam a 57\% e 43\%, respectivamente, como resultado de taxas anuais de crescimento da indústria bem superiores às da agricultura. ${ }^{316}$ No período posterior a 1930, houve no Brasil expansão do setor industrial, notadamente após a guerra, com acentuação no período de 1956-60. ${ }^{317}$ A produção industrial quase dobrou entre 1955 e $1960 .{ }^{318}$

Para a industrialização, além das condições econômicas, foi relevante a modificação das relações do Brasil com as nações dominantes, ou seja, com o imperialismo. ${ }^{319}$ No período entre 1930-55, com oscilações em alguns momentos, o governo tentou conservar na economia nacional os lucros produzidos com a agricultura e a indústria nascente. ${ }^{320}$ A política econômica que propiciou a substituição das importações de

\footnotetext{
${ }^{312}$ GORENDER, Jacob. A burguesia brasileira. São Paulo: Brasiliense (Col. Tudo é História), 2004, p. 2526.

${ }^{313}$ FAUSTO, Boris. História concisa do Brasil. 2. ed. São Paulo: Ed. da Universidade de São Paulo, 2009, p. 216.

${ }^{314}$ KERSTENETZKY, Celia Lessa. O Estado do bem-estar social na idade da razão. A reinvenção do Estado Social no mundo contemporâneo. Rio de Janeiro: Elsevier, 2012, p. 196.

${ }^{315}$ FAUSTO, Boris, op. cit. p.216.

${ }^{316}$ Ibid., p. 216.

${ }^{317}$ IANNI, Octavio. O Estado e o desenvolvimento econômico no Brasil. Tese apresentada ao concurso para provimento da cadeira de Professor de Sociologia II da FFLCH-USP, São Paulo, 1964, p. 144.

${ }^{318}$ Ibid., p. 144.

${ }^{319}$ Ibid., p. $79-80$

${ }^{320}$ Ibid., p. 80.
} 
meios de consumo foi implementada aproveitando-se das condições criadas com as crises do capitalismo. ${ }^{321}$

O “crescimento vegetativo das populações urbanas não seria suficiente para prover os setores secundários e terciários em expansão" ${ }^{\text {322, }}$, motivo pelo qual havia necessidade de "intensa movimentação ecológica de populações nacionais". ${ }^{323}$ A possibilidade, verificada nos centros urbanos, de elevação do padrão de subsistência e a promessa de ascensão social atraíam trabalhadores de outras localidades. ${ }^{324}$

Segundo Boris Fausto, "Entre 1920 e 1940, a população brasileira passou de 30,6 milhões de habitantes a 41,1 milhões. ${ }^{325}$ Tratava-se de uma população jovem, correpondendo os menores de 20 anos a algo em torno de 54\% do total, tanto em 1920 quanto em 1940". 326

O proletariado brasileiro cresceu cerca de 60\%, entre 1940 e 1950, principalmente por meio do deslocamento de trabalhadores rurais. ${ }^{327}$ Esse trabalhador em transição do campo ainda mantinha muita influência da vida rural anterior, o que representava um elemento de complexidade da estrutura da classe operária, juntamente com outros, como a urbanização, a secularização da cultura, a individualização, as modificações na estrutura da família, a alfabetização etc. ${ }^{328}$

Apesar da expansão da industrialização e do surgimento dos direitos sociais, o poder aquisitivo do salário do trabalhador não crescia proporcionalmente à produvidade e sofria em função da depreciação monetária. ${ }^{329}$ A industrialização impunha a realização de poupanças, por meio da inflação, e necessitava de lucros crescentes, razão pela qual o poder aquisitivo dos salários tendia a aumentar em ritmo menor que a produtividade do

${ }^{321}$ IANNI, Octavio. O Estado e o desenvolvimento econômico no Brasil. Tese apresentada ao concurso para provimento da cadeira de Professor de Sociologia II da FFLCH-USP, São Paulo, 1964, p. 80.

${ }^{322}$ Ibid., p. 145.

${ }^{323}$ Ibid., p. 145.

${ }^{324}$ Ibid., p. 145.

${ }^{325}$ FAUSTO, Boris. História concisa do Brasil . 2. ed. São Paulo: Ed. da Universidade de São Paulo, 2009, p. 215.

${ }^{326}$ Ibid., p. 215.

${ }^{327}$ IANNI, Octavio, op. cit. p. 156.

${ }^{328}$ Ibid., p. 156.

${ }^{329}$ Ibid., p. 160. 
trabalho, chegando a ocorrer a pauperização do trabalhador em alguns setores. ${ }^{330} \mathrm{Na}$ base desse fenômeno, estava a grande quantidade de reserva de mão de obra, no ambiente rural e em subempregos. ${ }^{331}$

Conforme esclareceu Octavio Ianni, "Por essas razões é que a quase totalidade da atividade política do proletariado se organiza em função de reivindicações econômicas"332, embora a classe operária também manifestasse "seu ponto de vista sobre as tendências das transformações econômico-sociais e políticas" do país. ${ }^{333}$ De todo modo, a classe operária também estava "empenhada nas lutas relacionadas à constituição do sistema capitalista, com base na produção industrial". ${ }^{334}$ Vale dizer, a constituição da estrutura capitalista brasileira contou com a aprovação política e ideológica da classe trabalhadora.

\subsection{5 - OS MOVIMENTOS SOCIAIS DE TRABALHADORES NA PRIMEIRA REPÚBLICA}

Jacob Gorender observa que pelas condições de vida e de trabalho atuais já se pode imaginar como eram "durante o longo período em que inexistiu qualquer legislação trabalhista ou em que esta mal começava a ser elaborada". 335

...os salários eram muito baixos e, por sinal, segundo dados do Censo de 1920, situavam-se em São Paulo em nível inferior ao do Rio de Janeiro e do Rio Grande do Sul, o que acrescentava mais uma vantagem para os industriais paulistas. A jornada de trabalho habitual se estendia de onze a doze horas e as condições higiênicas e de segurança, dentro das fábricas, só podem ser caracterizadas como calamitosas. $\mathrm{Na}$ indústria têxtil, em particular, o proletariado

\footnotetext{
${ }^{330}$ IANNI, Octavio. O Estado e o desenvolvimento econômico no Brasil. Tese apresentada ao concurso para provimento da cadeira de Professor de Sociologia II da FFLCH-USP, São Paulo, 1964, p. 161.

${ }^{331}$ Ibid., p. 161.

${ }^{332}$ Ibid., p. 161.

${ }^{333}$ Ibid., p. 162.

${ }^{334}$ Ibid., p. 162.

${ }^{335}$ GORENDER, Jacob. A burguesia brasileira. São Paulo: Brasiliense (Col. Tudo é História), 2004, p. 48.
} 
era constituído, em sua maioria, por mulheres e crianças. Segundo testemunho insuspeito do começo do século $\mathrm{XX}$, a idade mínima para o trabalho fabril era de ... cinco anos! Numa das fábricas de Matarazzo, foram encontradas máquinas de proporções apropriadas ao manejo infantil. Pior ainda: os menores viam-se forçados a horários noturnos de onze horas e, com freqüência, sofriam espancamento dentro das fábricas. Não havia descanso semanal remunerado, férias remuneradas, seguro contra acidentes, previdência social, nada, enfim, que impusesse algum limite legal à taxa de exploração da força de trabalho. ${ }^{336}$

O patronato procurava demonstrar benevolência para com os trabalhadores, mas apenas de "fachada", na medida em que construía vilas operárias e fornecia alguns serviços, como escolas e assistência médica, realizando, em contrapartida, descontos salariais, "não raros arbitrários e excessivos". ${ }^{337}$

Durante a Primeira República, houve movimentos sociais de trabalhadores. No campo, se destacaram os movimentos que combinaram conteúdo religioso com carência social (por exemplo, Canudos), os que combinaram conteúdo religioso com reivindicação social (por exemplo, movimento do contestado) e os que expressaram reivindicações sociais sem conteúdo religioso (por exemplo, as greves por salários e melhores condições de trabalho ocorridas nas fazendas de café de São Paulo). ${ }^{338}$

No caso das greves nas fazendas de café de São Paulo, houve centenas delas, sendo a mais importante a de 1913, que reuniu milhares de colonos da região de Ribeirão Preto, por ocasião da safra, pretendendo a revisão de seus contratos de trabalho, mas no final não tiveram seus objetivos alcançados. ${ }^{339}$

\footnotetext{
${ }^{336}$ GORENDER, Jacob. A burguesia brasileira. São Paulo: Brasiliense (Col. Tudo é História), 2004, p. 48. ${ }^{337}$ Ibid., p. 49.

${ }^{338}$ FAUSTO, Boris. História concisa do Brasil. 2. ed. São Paulo: Ed. da Universidade de São Paulo, 2009, p.166-167.

${ }^{339}$ Ibid., p. 167.
} 
Para a constituição de um movimento da classe trabalhadora, houve a contribuição do crescimento das cidades e da diversificação das atividades econômicas urbanas, na medida em que centenas de trabalhadores se concentravam nas fábricas e no setor de serviços e compartilhavam de condições de vida e de trabalho comuns, com maior liberdade de locomoção, em relação ao campo, e também maior circulação de ideias, apesar das diferenças de instrução entre eles e da ausência de veículos de ampla divulgação. ${ }^{340}$

Mas, segundo Boris Fausto, durante a Primeira República, diversos fatores contribuiram para que o movimento operário alcançasse pouco êxito: as greves somente tinham "forte repercussão quando eram gerais ou em setores-chave do sistema agroexportador, como as ferrovias e os portos", ${ }^{341}$ o "jogo político oligárquico podia ser feito sem necessidade de agradar a massa operária nascente". ${ }^{442}$ Além disso, "os operários se dividiam por rivalidades étnicas e estavam pouco propensos a organizar-se, pois a simples sindicalização já os colocava na 'lista negra' dos industriais" "343 e as divergências ideológicas e de métodos de ação entre os partidos operários do Rio de Janeiro e de São Paulo (embora possuíssem idênticas reivindicações) debilitavam "o já frágil movimento operário". 344

Na capital da República, a estrutura social era mais complexa, os setores sociais eram menos dependentes das classes agrárias ${ }^{345}$ e a classe trabalhadora era composta principalmente por setores vitais dos serviços (ferroviários, marítimos, doqueiros), que eram tratados com certa consideração pelo governo. ${ }^{346}$ Os movimentos de protesto no Rio de Janeiro até 1917 tiveram um conteúdo mais popular do que especificamente operário, como se constata no jacobinismo e na "revolta da vacina", ocorrida em 1904, no governo de Rodrigues Alves, contra a introdução da vacina contra a varíola. $^{347}$

\footnotetext{
${ }^{340}$ FAUSTO, Boris. História concisa do Brasil. 2. ed. São Paulo: Ed. da Universidade de São Paulo, 2009, p. 167.

${ }^{341}$ Ibid., p. 168.

${ }^{342}$ Ibid., p. 168.

${ }^{343}$ Ibid., p. 168.

${ }^{344}$ Ibid., p. 168.

${ }^{345}$ Ibid., p. 168.

${ }^{346}$ Ibid., p. 169.

${ }^{347}$ Ibid., p. 168.
} 
Em São Paulo, a estrutura social era menos diversificada. ${ }^{348}$ Conforme explica Boris Fausto, a classe média girava em torno da burguesia do café e não havia grupos militares inquietos, dispostos a se aliar com os integrantes dos estratos sociais mais baixos. ${ }^{349}$ "A maior presença de operários estrangeiros, sem raízes na nova terra, favorecia a influência difusa do anarquismo: os patrões e o governo, principalmente este último, eram o ‘outro', o inimigo". 350

Desde o início da Primeira República houve tentativas de organização e mobilização dos trabalhadores por meio de partidos operários, sindicatos e greves, mas os movimentos eram esparsos e raramente despertavam a atenção e a preocupação da elite. ${ }^{351}$ Passado o momento de pressão junto aos empregadores, os direitos se perdiam porque não haviam sido assegurados em lei. ${ }^{352}$

O jovem proletariado brasileiro resistia como podia à exploração capitalista e como reação o patronato se utilizava dos serviços dos órgãos de repressão do Estado. ${ }^{353}$

Operários estrangeiros, que se destacavam na liderança sindical ou política, eram sumariamente deportados como rufiões ou sob outras acusações infamantes. Outros eram confinados em locais isolados e insalubres da Amazônia. As reuniões de trabalhadores costumavam ser dissolvidas a patas de cavalo e golpes de sabre, não raro com mortos e feridos. O refinamento da repressão se aperfeiçoou com a organização das listas negras, nas quais a polícia e as entidades patronais incluíam os operários suspeitos de "subversão" e os condenavam, dessa maneira, ao desemprego permanente. ${ }^{354}$

${ }^{348}$ FAUSTO, Boris. História concisa do Brasil. 2. ed. São Paulo: Ed. da Universidade de São Paulo, 2009, p. 169.

${ }^{349}$ Ibid., p. 169.

${ }^{350}$ Ibid., p. 169.

${ }^{351}$ Ibid., p.169.

${ }^{352}$ Ibid., p. 169.

${ }^{353}$ GORENDER, Jacob. A burguesia brasileira. São Paulo: Brasiliense (Col. Tudo é História), 2004, p.49-50.

${ }^{354}$ Ibid., p. 50. 
A Constituição de 1891 consagrara o espírito liberal e deixara as relações de trabalho para o âmbito do direito civil, eximindo o Estado de intervir nessas relações, desde que não degenerassem em ameaça à ordem pública. Na prática, havia a intervenção policial contra manifestações operárias e a intermediação de autoridades públicas apenas em momentos de crise. ${ }^{355}$

Para Celia Lessa Kerstenetzky, todavia, o movimento operário estruturou-se minimamente no período, em razão da livre sindicalização, obtida em 1903. ${ }^{356}$ Em 1906 foi criada a Confederação Operária Brasileira, liderada por imigrantes italianos anarquistas, mas apenas em 1917 é que movimentos significativos de trabalhadores urbanos ocorreram, com um ciclo importante de greves entre 1917 e 1920, reivindicando reajustes salariais, melhores condições de trabalho e direitos trabalhistas. ${ }^{357}$ Boris Fausto indica que as causas do movimento grevista foram o agravamento da carestia, em consequência das perturbações causadas pela Primeira Guerra Mundial e pela especulação com gêneros alimentícios, além da influência das Revoluções Russas de fevereiro e de outubro de $1917 . .^{358}$

Os trabalhadores brasileiros não pretendiam revolucionar a sociedade, mas melhorar suas condições de vida e conquistar um mínimo de direitos, embora muitos se inspirassem no ideal de uma sociedade igualitária. ${ }^{359}$ Foram três greves gerais no período de 1917 a 1920, sendo a mais lembrada a de São Paulo, de junho/julho de 1917. ${ }^{360}$ A partir de 1920, a onda grevista enfraqueceu, em razão da dificuldade de alcançar os objetivos e por causa da repressão, principalmente sobre os dirigentes operários estrangeiros, inclusive com expulsão de muitos deles do país. ${ }^{361}$

\footnotetext{
${ }^{355}$ KERSTENETZKY, Celia Lessa. O Estado do bem-estar social na idade da razão. A reinvenção do Estado Social no mundo contemporâneo. Rio de Janeiro: Elsevier, 2012, p. 185.

${ }^{356}$ Ibid., p. 185.

${ }^{357}$ Ibid., p. 186.

${ }^{358}$ FAUSTO, Boris. História concisa do Brasil. 2. ed. São Paulo: Ed. da Universidade de São Paulo, 2009, p.169.

${ }^{359}$ Ibid., p. 169.

${ }^{360}$ Ibid., p. 169.

${ }^{361}$ Ibid., p. 169-170.
} 
Foi durante as referidas greves que o movimento operário passou a ser objeto de preocupação da elite ${ }^{362}$ e pela primeira vez o Estado cogitou seriamente de elaborar uma legislação trabalhista. ${ }^{363}$ "As principais propostas foram reunidas em um projeto de Código de Trabalho que previa jornada de oito horas, o limite ao trabalho de mulheres e menores, as licenças para as mulheres grávidas", ${ }^{364}$ mas o "projeto foi bombardeado pelos industriais e pela maioria dos congressistas". ${ }^{365}$ A maioria das entidades patronais preferia o entendimento de que era inconstitucional a intervenção do Estado nas relações trabalhistas. ${ }^{366}$

Do período restou apenas a lei que regulava a indenização por acidentes de trabalho, aprovada em 1919, ${ }^{367}$ que, todavia, fixava o seguro de modo facultativo e transferia aos empregadores a decisão quanto ao montante do depósito e a escolha das companhias seguradoras. ${ }^{368}$

Jacob Gorender explica que por estarem "Protegidos pelo Estado dos fazendeiros, os industriais mantiveram-se inteiramente surdos às reivindicações dos operários, até a explosão" dessas grandes greves. ${ }^{369}$ Diz que "Por isso mesmo, não é casual que, justamente em 1919, o Congresso aprove a Lei de Acidentes de Trabalho - a primeira lei trabalhista do Brasil - e seja criada, na Câmara dos Deputados, a primeira Comissão de Legislação Social". ${ }^{370}$

Contra a tese de que "a legislação trabalhista brasileira não representou conquista do movimento operário, mas outorga do Governo presididos por Getúlio Vargas", ${ }^{371}$ Jacob Gorender argumenta que "Estudos historiográficos recentes incumbiramse de revelar as vigorosas lutas travadas pelo proletariado antes de 1930 e a conexão de tais

\footnotetext{
${ }^{362}$ FAUSTO, Boris. História concisa do Brasil. 2. ed. São Paulo: Ed. da Universidade de São Paulo, 2009, p. 169.

${ }^{363}$ KERSTENETZKY, Celia Lessa. O Estado do bem-estar social na idade da razão. A reinvenção do Estado Social no mundo contemporâneo. Rio de Janeiro: Elsevier, 2012, p. 186.

${ }^{364}$ FAUSTO, Boris. História concisa do Brasil . 2. ed. São Paulo: Ed. da Universidade de São Paulo, 2009, p.170.

${ }^{365}$ Ibid., p. 170 .

${ }^{366}$ KERSTENETZKY, Celia Lessa, op. cit., p. 186.

${ }^{367}$ FAUSTO, Boris, op. cit., p. 170 .

${ }^{368}$ KERSTENETZKY, Celia Lessa, op. cit., p. 186.

${ }^{369}$ GORENDER, Jacob. A burguesia brasileira. São Paulo: Brasiliense (Col. Tudo é História), 2004, p. 50.

${ }^{370} \mathrm{Ibid} .$, p. 50

${ }^{371}$ Ibid., p. 50.
} 
lutas com as leis trabalhistas aprovadas também antes daquela data", tais como a lei que criou as Caixas de Aposentadorias e Pensões para os Ferroviários (1923) - a primeira que tratou da estabilidade do empregado após dez anos de serviço - a lei de férias remuneradas de 15 dias (1925) e a lei de regulamentação do trabalho de menores (1927). ${ }^{372}$

A tática do patronato deixara de ser a da rejeição liminar da legislação trabalhista em nome do liberalismo - ideologia política e econômica oficial na Primeira República. Admitida, em face das lutas operárias, a legitimidade da discussão do assunto, o patronato procurou ganhar tempo, conceder muito pouco em matéria legal e aplicar o mínimo ou mesmo nada do que ficasse registrado na lei. Basta dizer que a lei de acidentes do trabalho só teve sua regulamentação em 1935, quando começou a ser posta em prática. A lei de férias ficou quase no papel até $1932 .{ }^{373}$

Também Boris Fausto também observa que a lei de férias dependia de regulamentação e até 1930 ainda não havia sido aplicada na área da indústria, por pressão dos industriais. ${ }^{374}$

\subsection{6 - A REVOLUÇÃO DE 1930}

Para Octavio Ianni, a Revolução de 1930 representou uma derrota, mesmo que parcial, das oligarquias até então dominantes e uma ruptura estrutural na sociedade brasileira, que tornou possível uma alteração nas funções e na própria estrutura do Estado. ${ }^{375}$ Ela criou "condições para o desenvolvimento do Estado burguês, como um sistema que engloba instituições políticas e econômicas, bem como padrões e valores sociais e culturais de tipo prioritariamente burguês". 376 "Foi a ascensão das classes sociais

\footnotetext{
${ }_{372}$ GORENDER, Jacob. A burguesia brasileira. São Paulo: Brasiliense (Col. Tudo é História), 2004, p. 51.

${ }^{373}$ Ibid., p. 51.

${ }^{374}$ FAUSTO, Boris. História concisa do Brasil. 2. ed. São Paulo: Ed. da Universidade de São Paulo, 2009, p. 170 .

${ }^{375}$ IANNI, Octavio. Estado e planejamento econômico no Brasil (1930-1970). Rio de Janeiro: Civilização Brasileira SA, 1971, p. 13.

${ }^{376}$ Ibid., p. 13.
} 
urbanas, com a deposição do Governo Washington Luis, em 1930, que criou novas condições sociais e políticas para a conversão do Estado oligárquico em Estado burguês". 377

O poder público passou a funcionar de forma mais adequada às exigências e possibilidades estruturais do sistema capitalista, reformando as condições de funcionamento das forças produtivas, as relações internas de produção e as relações com a economia internacional. ${ }^{378}$ Exemplo desse processo foi o estabelecimento formal, pelo Estado, dos limites básicos para o funcionamento do mercado da força de trabalho, ou seja, o desenvolvimento da legislação trabalhista e sindical, fixando "as condições e os limites sociais e políticos da atuação dos assalariados". 379

Partindo da concepção de que "toda revolução consiste na substituição de um modo de produção antiquado por outro novo e pela derrubada da velha classe dominante do Poder político e sua conquista por uma nova classe dominante", ${ }^{380}$ Jacob Gorender defende que em 1930 não houve revolução no Brasil: nenhuma alteração ocorreu na estrutura econômica da sociedade e o controle do Poder político nacional não mudou de classe, apenas passou da "fração cafeicultora dos latifundiários para uma composição diferente da mesma classe de latifundiários, na qual predominavam os segmentos ligados ao mercado interno." ${ }^{\prime 31}$

Para Boris Fausto, “A revolução de 1930 não foi feita por representantes de uma suposta nova classe social, fosse ela a classe média ou a burguesia industrial". ${ }^{382}$ Diz que a classe média era muito heterogênea e dependente das forças agrárias para dar suporte à formulação de um programa político. ${ }^{383}$

\footnotetext{
${ }^{377}$ IANNI, Octavio. Estado e planejamento econômico no Brasil (1930-1970). Rio de Janeiro: Civilização Brasileira SA, 1971, p.34.

${ }^{378}$ Ibid., p.14.

${ }^{379}$ Ibid., p. 14.

${ }^{380}$ GORENDER, Jacob. A burguesia brasileira. São Paulo: Brasiliense (Col. Tudo é História), 2004, p. 62.

${ }^{381}$ Ibid.., p. 62-63.

${ }^{382}$ FAUSTO, Boris. História concisa do Brasil. 2. ed. São Paulo: Ed. da Universidade de São Paulo, 2009, p.181.

${ }^{383}$ Ibid., p. 181.
} 
$\mathrm{Na}$ indústria, havia a marca regional dos diferentes setores de classe, embora São Paulo tivesse iniciado uma diferenciação entre a burguesia industrial e o setor agrário, com a criação do Centro das Indústrias do Estado de São Paulo, em 1928, mas essa “diferenciação não rompeu o acordo da classe dominante em nome dos interesses paulistas". ${ }^{384}$ As associações industriais apoiaram a candidatura de Júlio Prestes. ${ }^{385}$

"No Rio de Janeiro, os industriais estavam organizados no Centro Industrial do Brasil (CIB)". 386 "Nos últimos anos da década de 1920 havia nomes representativos da burguesia industrial carioca nos postos de governo", ${ }^{387}$ como, por exemplo, a eleição do industrial têxtil Manuel Guilherme da Silveira para a presidência do Banco do Brasil, em 1929. ${ }^{388}$ Quando estourou a Revolução de 1930, o CIB expressou sua solidariedade a Washington Luís e considerou a insurreição um "fato muito prejudicial à situação econômica do país", ${ }^{389}$ embora logo após a vitória dos revolucionários os industriais do Rio de Janeiro tivessem se aproximado do governo, o que demonstra a percepção de que a "aproximação com o Estado era fator decisivo para o fortalecimento da burguesia industrial". 390

Segundo Boris Fausto, o grupo dos “vitoriosos de 1930" era heterogêneo social e politicamente, eis que composto por representantes do movimento tenentista (defendiam "a centralização do poder e algumas reformas sociais"), do Partido Democrático (pretendiam "o controle do governo do Estado de São Paulo e a efetiva adoção dos princípios do Estado Liberal”), de jovens civis ("inclinavam-se a reformular o sistema político") e velhos oligarcas (“desejavam apenas um maior atendimento à sua área, maior soma pessoal de poder, com um mínimo de transformações"), todos unidos contra um mesmo adversário. ${ }^{391}$

\footnotetext{
${ }^{384}$ FAUSTO, Boris. História concisa do Brasil. 2. ed. São Paulo: Ed. da Universidade de São Paulo, 2009, p. 181.

${ }^{385}$ Ibid., p. 181.

${ }^{386}$ Ibid., p. 181.

${ }^{387}$ Ibid., p. 181.

${ }^{388}$ Ibid., p. 181.

${ }^{389}$ Ibid., p. 181.

${ }^{390}$ Ibid., p. 182.

${ }^{391}$ Ibid., p. 182.
} 
Conforme explica Jacob Gorender, "Desde que adquiriu densidade e consistência, a burguesia industrial se viu a si mesma como uma das 'classes conservadoras" ${ }^{392}$ eis que "Após as transformações promovidas pela Abolição e pela República, a burguesia industrial não possuía motivos para revolucionar a ordem social estabelecida". 393

O conservadorismo social dos industriais era idêntico em todo o País. Paulistas não se distinguiam de gaúchos ou cariocas, nem estes de mineiros e pernambucanos. De modo geral, durante a Primeira República e ainda depois, os industriais se vinculavam mais estreitamente com as oligarquias estaduais do que com os industriais de outras regiões. O que dificultava a formação da consciência burguesa de classe com uma visão nacional. ${ }^{394}$

Octavio Ianni observa que durante o movimento de 1930, os "elementos identificados com um ponto de vista proletário eram poucos e secundários".395 O proletariado, à época, era incipiente e disperso, e não possuía condições de impor "uma visão global do futuro da sociedade". 396 "O Partido Comunista do Brasil, fundado em 1929 esteve praticamente fora da revolução de 30 ". ${ }^{397} \mathrm{Na}$ ocasião, os que estavam interessados em modificações institucionais concretas eram grupos da classe média e setores da classe dominante, particularmente os industriais. ${ }^{398} \mathrm{O}$ proletariado estava interessado apenas em "reivindicações de classe relativas à organização do mercado de trabalho conveniente ao progresso do capitalismo industrial" e somente no final do Estado Novo é que surgiu como força política básica na sustentação do poder. ${ }^{399}$

Ianni menciona que "analisando cuidadosamente o conteúdo das reivindicações políticas da revolução de 30, encontramos alguns dos temas mais típicos da

\footnotetext{
${ }^{392}$ GORENDER, Jacob. A burguesia brasileira. São Paulo: Brasiliense (Col. Tudo é História), 2004, p. 45.

${ }^{393}$ Ibid., p. 45.

${ }^{394}$ Ibid., p. 46.

${ }^{395}$ IANNI, Octavio. O Estado e o desenvolvimento econômico no Brasil. Tese apresentada ao concurso para provimento da cadeira de Professor de Sociologia II da FFLCH-USP, São Paulo, 1964, p. 136.

${ }^{396}$ Ibid., p. 136.

${ }^{397}$ Ibid., p. 136.

${ }^{398}$ Ibid., p. 136.

${ }^{399}$ Ibid., p. 136.
} 
democracia burguesa" ${ }^{400}$, que "se consubstanciaram na Constituição de 34 e em muitas realizações governamentais no período $1930-45 " .401$

Defende que a "corrente política mais vigorosa no processo revolucionário não se cristalizou senão em torno de uma ideologia ambígua. O tenentismo foi a sua expressão mais acabada". ${ }^{402}$ Essa ideologia conciliava "as tensões e as tendências possíveis do sistema numa época propícia à inclinação estrutural no sentido de revalorizar as forças produtivas nacionais". ${ }^{403}$ Ela exprimia "a consciência possível de uma situação em que a reaglutinação das classes sociais não era vigorosamente determinada pela substituição de uma classe por outra". ${ }^{404}$

A estrutura do poder novo, significando uma derrota da burguesia agrário-comercial, não significa uma derrota completa nem de amplas proporções. Era uma vitória parcial das outras classes, em conjunto, obrigadas a pactuar com aquela. Portanto, não se podia negar totalmente à burguesia agrária exportadora (sic). Foi necessário conciliar as diversas classes, no novo círculo de poder. $^{405}$

Boris Fausto explica que "A partir de 1930 ocorreu uma troca da elite do poder sem grandes rupturas. Caíram os quadros oligárquicos tradicionais; subiram os militares, os técnicos diplomados, os jovens políticos e, um pouco mais tarde, os industriais". ${ }^{406}$ "O poder de tipo oligárquico, baseado na força dos Estados, perdeu terreno", ${ }^{407}$ mas as "oligarquias não desapareceram, nem o padrão de relações clientelistas deixou de existir". ${ }^{408}$

\footnotetext{
${ }^{400}$ IANNI, Octavio. O Estado e o desenvolvimento econômico no Brasil. Tese apresentada ao concurso para provimento da cadeira de Professor de Sociologia II da FFLCH-USP, São Paulo, 1964, p. 136.

${ }^{401}$ Ibid., p. 136.

${ }^{402}$ Ibid., p. 137.

${ }^{403}$ Ibid., p. 137.

${ }^{404}$ Ibid., p. $137-138$.

${ }^{405}$ Ibid., p. 138.

${ }^{406}$ FAUSTO, Boris. História concisa do Brasil. 2. ed. São Paulo: Ed. da Universidade de São Paulo, 2009, p.182.

${ }^{407}$ Ibid., p. 182.

${ }^{408}$ Ibid., p. 182.
} 
Para Jacob Gorender, "O movimento político-militar de 30 realizou uma tarefa importante para desobstruir o caminho ao desenvolvimento do capitalismo: apeou do Poder a oligarquia dos fazendeiros de café e dos seus associados do capital bancário e comercial". 409

O Estado nascente distinguia-se do anterior pela centralização do poder, pela atuação econômica voltada para a promoção da industrialização, pela "atuação social, tendente a dar algum tipo de proteção aos trabalhadores urbanos, incorporando-os a uma aliança de classes promovida pelo poder estatal" e por atribuir papel de destaque às forças armadas, principalmente ao Exército, “como suporte da criação de uma indústria de base e como fator de garantia da ordem interna". 410

Boris Fausto observa que "As transformações (...) não ocorreram da noite para o dia, nem corresponderam a um plano de conjunto do governo revolucionário. Foram sendo realizadas ao longo dos anos, com ênfase maior neste ou naquele aspecto". ${ }^{411}$ Nesse mesmo sentido, a posição de Ianni, de que as medidas econômicas e as inovações institucionais do período de 1930 a 1945 não foram resultado de um plano preestabelecido ou análise sistemática das condições reais existentes, mas representaram respostas aos problemas e dilemas que iam surgindo em razão de "interesses e pressões econômicos, políticos, sociais e militares", inclusive externos. ${ }^{412}$

Jacob Gorender esclarece que "ao assumir o Poder em seguida ao vitorioso movimento político-militar de outubro de 1930, Getúlio Vargas e sua equipe ministerial não possuíam qualquer projeto de incentivo especial à industrialização"413, como se pode notar pelas medidas iniciais, que se destinaram “à proteção de vários setores da agropecuária, inclusive a cafeicultura, cujos estoques invendáveis passaram a ser comprados e queimados pelo Governo Federal". ${ }^{114}$ Mas pondera: “é inegável que, nos anos 30, a indústria brasileira deu um salto à frente e se reforçou a influência política da

\footnotetext{
${ }^{409}$ GORENDER, Jacob. A burguesia brasileira. São Paulo: Brasiliense (Col. Tudo é História), 2004, p. 64.

${ }^{410}$ FAUSTO, Boris, op. cit., p.182.

${ }^{411}$ Ibid., p. 183.

${ }^{412}$ IANNI, Octavio. Estado e planejamento econômico no Brasil (1930-1970). Rio de Janeiro: Civilização Brasileira SA, 1971, p. 14-15.

${ }^{413}$ GORENDER, Jacob, op. cit., p. 63.

${ }^{414}$ Ibid., p. 63.
} 
burguesia industrial. Se não houve uma revolução, é também inegável que ocorreu uma virada na evolução histórica do País". ${ }^{415}$

Para Boris Fausto, o Estado passou a promover o capitalismo nacional mediante o suporte no aparelho de Estado e em uma aliança entre a burguesia industrial e setores da classe trabalhadora urbana ${ }^{416}$ Defende que foi por isso que a burguesia industrial passou a ter vez e força no interior do governo, e não porque tivesse participado da Revolução de 1930 e diz que "o projeto de industrialização, foi aliás muito mais dos quadros técnicos governamentais do que dos empresários". 417

Octavio Ianni explica que após a revolução de 1930, paulatinamente, a burguesia industrial foi procurando interferir nas decisões governamentais, no sentido de estimular a industrialização e planificar o desenvolvimento econômico nacional. ${ }^{418}$

A revolução burguesa em curso transformou as instituições governamentais, tornando-as esferas centrais da economia, notadamente para a acumulação do capital, por meio de políticas fiscal, tarifária, cambial e monetária, com vistas ao fornecimento de crédito e incentivos. ${ }^{419}$ Mas porque a reprodução do capital se funda na força de trabalho, também essa força "ganha um estatuto especial na época da industrialização". ${ }^{420}$ Vargas, logo após a vitória diz que "o problema proletário não é mais questão de polícia, mas sim uma questão de política". ${ }^{421} \mathrm{O}$ proletariado passa a ser tratado como interlocutor legítimo. ${ }^{422}$ "Legitimam-se certas reivindicações do proletariado e o poder público se insere como mediador das relações de classe". ${ }^{423}$ "O poder público se arroga a função mediadora, destinada a pacificar as relações de classe" ${ }^{424} \mathrm{e}$ as leis trabalhistas passam a ser destinadas à

${ }^{415}$ GORENDER, Jacob. A burguesia brasileira. São Paulo: Brasiliense (Col. Tudo é História), 2004, p. 64.

${ }^{416}$ FAUSTO, Boris. História concisa do Brasil. 2. ed. São Paulo: Ed. da Universidade de São Paulo, 2009, p.182.

${ }^{417}$ Ibid., p. 183 .

${ }^{418}$ IANNI, Octavio. O Estado e o desenvolvimento econômico no Brasil. Tese apresentada ao concurso para provimento da cadeira de Professor de Sociologia II da FFLCH-USP, São Paulo, 1964, p. 97.

${ }^{419}$ Ibid., p. 139.

${ }^{420}$ Ibid., p. 139.

${ }^{421}$ Ibid., p. 139.

${ }^{422}$ Ibid., p. 140.

${ }^{423}$ Ibid., p. 140.

${ }^{424}$ Ibid., p. 140. 
harmonia social. ${ }^{425} \mathrm{Na}$ ocasião, "O Estado não quer, não reconhece luta de classes". ${ }^{426}$ As entidades sindicais passam a ser consideradas "elemento proveitoso de colaboração no mecanismo dirigente do Estado". 427

Essa é maneira pela qual o Estado se insere nas relações de classe: poder moderador com sentido e inclinação orientados de modo a favorecer a constituição e consolidação do capitalismo industrial. Em boa parte, essa orientação vai na mesma direção das sugestões dos empresários. ${ }^{428}$

A partir de 10 de novembro de 1937 foi outorgada uma nova Constituição e instituído o Estado Novo, que, sob o aspecto socioeconômico, representou uma aliança da burocracia civil e militar com a burguesia industrial, a fim de "promover a industrialização do país sem grandes abalos sociais". ${ }^{429}$ Segundo Boris Fausto, a aproximação entre a burguesia industrial e o governo Vargas ocorreu principalmente a partir de 1933, após a derrota da revolução paulista, ${ }^{430}$ sendo que no período de 1930-1937 não houve uma linha clara de incentivo do Estado ao setor industrial, ${ }^{431}$ eis que o governo equilibrou-se entre os diferentes interesses, inclusive agrários e foi também bastante sensível às pressões externas. ${ }^{432}$ Mas, a partir de novembro de 1937, o Estado aprofundou a política de substituição de importações pela produção interna e de estabelecimento de uma indústria de base. ${ }^{433}$

Francisco de Oliveira observa que "A revolução de 1930 marca o fim de um ciclo e o início de outro na economia brasileira: o fim de hegemonia agrário-exportadora e o início da predominância da estrutura produtiva de base urbano-industrial", ${ }^{434}$ embora a

\footnotetext{
${ }^{425}$ IANNI, Octavio. O Estado e o desenvolvimento econômico no Brasil. Tese apresentada ao concurso para provimento da cadeira de Professor de Sociologia II da FFLCH-USP, São Paulo, 1964, p. 140.

${ }^{426}$ DIAS, Everardo. História das Lutas Sociais no Brasil. São Paulo: Edaglit, 1962, p. 41. Apud IANNI, Octavio, op. cit., p. 140.

${ }^{427}$ IANNI, Octavio, op. cit., p. 140.

${ }^{428}$ Ibid., p. 149.

${ }^{429}$ FAUSTO, Boris. História concisa do Brasil. 2. ed. São Paulo: Ed. da Universidade de São Paulo, 2009, p.201.

${ }^{430}$ Ibid., p. 201.

${ }^{431}$ Ibid., p. 203.

${ }^{432}$ Ibid., p. 203.

${ }^{433}$ Ibid., p. 203.

${ }^{434}$ OLIVEIRA, Francisco de. Crítica à razão dualista - o ornitorrinco. São Paulo: Boitempo, 2006, p. 35.
} 
predominância do setor industrial na renda nacional somente tenha se concretizado em 1956, quando superou a agricultura. ${ }^{435}$

... o processo mediante o qual a posição hegemônica se concretizará é crucial: a nova correlação de forças sociais, a reformulação do aparelho e da ação estatal, a regulamentação dos fatores, entre os quais o trabalho ou o preço do trabalho, têm o significado, de um lado, de destruição das regras do jogo segundo as quais a economia se inclinava para as atividades agrárioexportadoras e, de outro, de criação das condições institucionais para a expansão das atividades ligadas ao mercado interno. ${ }^{436}$

A participação do Estado nas atividades econômicas já ocorria desde o início do século, por meio da "regulação e proteção de determinados setores produtivos, com vistas à defesa em face de oscilações bruscas de renda e emprego decorrentes de distúrbios na produção ou na comercialização", como nos casos dos institutos do café, do sal, do pinho, do cacau, do mate, do açúcar e do álcool. ${ }^{437}$ As medidas adotadas em 1931 para a proteção da indústria e do comércio do açúcar se destinavam a "assegurar o equilíbrio dos fatores de mercado, ameaçados pela superprodução, e preservar o fluxo da renda do setor, conciliando os interesses de produtores e consumidores". ${ }^{438}$ Até mesmo "em atividades de menor peso na produção nacional, o Estado assumiu funções de proteção, como as atividades econômicas e populações atingidas pela seca" ${ }^{439}$, mediante a criação de órgãos como comissões e superintendências. ${ }^{440}$

As alterações nas políticas econômicas do governo retratavam as transformações do país, de uma economia dominada pelo setor primário para uma economia em que o setor secundário adquiria preponderância. ${ }^{441} \mathrm{O}$ poder público passava

\footnotetext{
${ }^{435}$ OLIVEIRA, Francisco de. Crítica à razão dualista - o ornitorrinco. São Paulo: Boitempo, 2006, p .35. ${ }^{436}$ Ibid., p. 35 .

${ }^{437}$ IANNI, Octavio. O Estado e o desenvolvimento econômico no Brasil. Tese apresentada ao concurso para provimento da cadeira de Professor de Sociologia II da FFLCH-USP, São Paulo, 1964, p. 34.

${ }^{438}$ Ibid., p. 35.

${ }^{439} \mathrm{Ibid} .$, p. 36.

${ }^{440} \mathrm{Ibid} ., \mathrm{p} .37$.

${ }^{441}$ Ibid., p. 44.
} 
a adquirir relevância especial na formação do capitalismo industrial, como "mediação num sistema de relações de classes sociais". ${ }^{442}$

\subsection{7 - O SURGIMENTO DAS POLÍTICAS SOCIAIS}

Na década de 1930, o projeto de construção do capitalismo brasileiro avançava e necessitava de mudanças políticas e econômicas, a fim de consagrar uma determinada classe social dominante.

Para Octavio Ianni, a legislação trabalhista adotada nos anos de 1930-45 foi "proposta e aplicada com o objetivo precípuo de sistematizar e formalizar as relações políticas entre as classes sociais urbanas", ${ }^{443}$ principalmente para "pacificar as relações entre os vendedores e os compradores de força de trabalho no mercado urbano (setores secundário e terciário)". ${ }^{444}$

"Desde a Primeira Guerra Mundial haviam se intensificado os movimentos e as lutas operárias", ${ }^{445}$ mas "o governo e os compradores de força de trabalho pouco se interessavam pela institucionalização dos direitos e obrigações nas relações políticas e econômicas entre empregados e empregadores"446, eis que, até 1930, governo e compradores de força de trabalho compartilhavam "quase que a mesma concepção oligárquica de poder e mando característica da sociedade agrária de então" ${ }^{447}$ e por isso "as leis trabalhistas eram principalmente leis repressivas". ${ }^{448}$

As razões políticas alegadas para a adoção da legislação trabalhista foram as de "congregar todas as classes, em uma colaboração efetiva e inteligente", ${ }^{449}$ reunir "numa

\footnotetext{
${ }^{442}$ IANNI, Octavio. O Estado e o desenvolvimento econômico no Brasil. Tese apresentada ao concurso para provimento da cadeira de Professor de Sociologia II da FFLCH-USP, São Paulo, 1964, p. 44.

${ }^{443}$ IDEM. Estado e planejamento econômico no Brasil (1930-1970). Rio de Janeiro: Civilização Brasileira SA, 1971, p. 34.

${ }^{444}$ Ibid., p. 34.

${ }^{445}$ Ibid., p. 34.

${ }^{446}$ Ibid., p. 34.

${ }^{447}$ Ibid., p. 34.

${ }^{448}$ Ibid., p .34.

${ }^{449}$ VARGAS, Getúlio. As diretrizes da nova política do Brasil. Rio de Janeiro: José Olympio, 1942, p.209; citação do discurso proferido em 4 de maio de 1931. Apud IANNI, Octavio, op. cit., p. 35.
} 
mesma assembléia (sic), plutocratas e proletários, patrões e sindicalistas, todos representantes das corporações de classe, integrados, assim, no organismo político do Estado", ${ }^{450}$ "orientar e promover a coordenação das classes patronais e operárias em órgãos permanentes, legalmente constituídos, visando à defesa dos seus próprios interêsses (sic) e à solução suasória dos dissídios de classe". ${ }^{451}$ A legislação trabalhista vinha para "estabelecer a harmonia e a tranqüilidade (sic) entre empregados e empregadores no Brasil". ${ }^{452}$ Octavio Ianni defende que no "cerne da doutrina da 'paz social' havia uma política de contrôle (sic) e dominação da atividade e organização política do proletariado". ${ }^{453}$

Para Celia Lessa Kerstenetzky, as políticas sociais foram concebidas pelas novas elites e eram coerentes com a produção de condições para um assalariamento em bases sustentáveis. ${ }^{454}$ Isso era necessário para a expansão industrial. ${ }^{455}$ Houve alguma redistribuição da renda, mas compatível com os elevados ganhos das elites agrárias e industriais, que foram fortemente incentivas no período. ${ }^{456} \mathrm{~A}$ política social contribuiu para viabilizar as condições mínimas de constituição e reprodução da força de trabalho industrial. $^{457}$

Criou-se o Ministério do Trabalho, Indústria e Comércio. Estabeleceram-se normas referentes à limitação da jornada diária de trabalho em oito horas (Decreto $\mathrm{n}$. 21.364, de 4 de maio de 1932) e de proteção à mulher e ao menor (Decretos n. 21.417-A, de 17-5-1932 e n. 22.042, de 3-11-1932), ${ }^{458}$ entre outras. Foram normatizadas as

\footnotetext{
${ }^{450}$ VARGAS, Getúlio. As diretrizes da nova política do Brasil. Rio de Janeiro: José Olympio, 1942, p. 209; citação do discurso proferido em 4 de maio de 1931. Apud IANNI, Octavio. Estado e planejamento econômico no Brasil (1930-1970). Rio de Janeiro: Civilização Brasileira SA, 1971, p. 35.

${ }^{451}$ IDEM. Mensagem apresentada ao Poder Legislativo, em 3 de maio de 1935. Rio de Janeiro; Imprensa Nacional, 1935, p. 101. Apud IANNI, Octavio. op. cit., p. 35.

${ }^{452}$ IDEM. As diretrizes da nova politica do Brasil. Rio de Janeiro: José Olympio, 1942, p. 227. Apud IANNI, Octavio, op. cit., p. 36.

${ }^{453}$ IANNI, Octavio, op. cit. p. 36.

${ }^{454}$ KERSTENETZKY, Celia Lessa. $O$ Estado do bem-estar social na idade da razão. A reinvenção do Estado Social no mundo contemporâneo. Rio de Janeiro: Elsevier, 2012, p. 195.

${ }^{455}$ Ibid., p. 195.

${ }^{456}$ Ibid., p. 196.

${ }^{457}$ Ibid., p. 196-197.

${ }^{458}$ IANNI, Octavio. O Estado e o desenvolvimento econômico no Brasil. Tese apresentada ao concurso para provimento da Cadeira de Professor de Sociologia II da FFLCH-USP, 1964, p. 140.
} 
convenções coletivas de trabalho e estendida "a estabilidade aos dez anos de serviço à generalidade das categorias profissionais". ${ }^{459}$

A legislação trabalhista atendia "a várias dentre as reivindicações econômicas e políticas do operariado", tais como salário mínimo; jornada máxima de oito horas de trabalho; igualdade salarial, sem distinção de idade, sexo, nacionalidade ou estado civil; repouso semanal remunerado; férias anuais remuneradas; proibição de trabalho noturno a menores; proibição de trabalho a menores de 14 anos; assistência médica ao trabalhador e à gestante; carteira profissional; regras jurídicas para a criação e o funcionamento de sindicatos, federações e confederações; etc. ${ }^{460}$. Essa "legislação foi reelaborada, ampliada e sistematizada na Consolidação das Leis do Trabalho (CLT), em 1943." 461

A decisão sobre questões trabalhistas ficou a cargo da Justiça do Trabalho, criada em maio de 1939, a partir das Juntas de Conciliação e Julgamento, ${ }^{462,}$ instituídas em 1932. A criação da Justiça do Trabalho já estava prevista pelas Constituições de 1934 e 1937, mas a sua integração ao Poder Judiciário ocorreu apenas em 1946. Jacob Gorender associa a implementação da Justiça do Trabalho à percepção do Estado de que "a legislação trabalhista não devia ficar no papel, mas precisava ser aceita e aplicada pelo patronato a fim de que atingisse sua finalidade de submissão ideológica e organizativa da classe operária". 463

O salário mínimo foi instituído e representou importante inovação no campo da política salarial, tendo-se estabelecido em maio de 1940 que tal salário deveria ser capaz de satisfazer as necessidades básicas do trabalhador, o que somente ocorreu quando de sua fixação inicial, eis que com o passar do tempo o valor foi-se deteriorando. ${ }^{464}$

\footnotetext{
${ }_{459}^{45 O R E N D E R, ~ J a c o b . ~ A ~ b u r g u e s i a ~ b r a s i l e i r a . ~ S a ̃ o ~ P a u l o: ~ B r a s i l i e n s e ~(C o l . ~ T u d o ~ e ́ ~ H i s t o ́ r i a), ~ 2004, ~ p . ~} 67$. ${ }^{460}$ IANNI, Octavio. Estado e planejamento econômico no Brasil (1930-1970). Rio de Janeiro: Civilização Brasileira SA, 1971, p. 37-38.

${ }^{461}$ Ibid., p. 38.

${ }^{462}$ FAUSTO, Boris. História concisa do Brasil. 2. ed. São Paulo: Ed. da Universidade de São Paulo, 2009, p. 206 .

${ }^{463}$ GORENDER, Jacob, op. cit., p. 67.

${ }^{464}$ FAUSTO, Boris, op. cit., p. 207.
} 
Segundo Ianni, ${ }^{465}$ havia a intenção de "disciplinar o comportamento dos 'fatores' no mercado de trabalho, em particular, para evitar-se a concorrência incontrolada entre as diferentes categorias de trabalhadores", "preservar a oferta excedente" de mão de obra, "estabelecer limites dentro dos quais se dará a mercantilização da força de trabalho", evitar a pauperização da classe operária e a "subversão da ordem capitalista". Naquele momento, "A intervenção governamental na esfera do trabalho está apoiada na necessidade de favorecer a instauração da racionalidade possível e adequada à máxima mercantilização dos fatores" de produção. ${ }^{466}$

Torna-se evidente, nessa linha de intervenção, que o Estado é, a um tempo, mediação preservadora de relações hierarquizadas. Por seu intermédio, a classe dominante, em particular a burguesia industrial, joga com a classe operária, na sustentação do poder e do pacto em que se apoia. Por isso é que o Ministério do Trabalho é um órgão político e o pelego se tornou uma das mais importantes figuras da política de massas. Apesar do conflito evidente entre a prática estatal e os valores liberais em que se apoia ideologicamente o regime, a política operária do governo está orientada na direção da "paz social", nos termos em que está caracterizada nestas reflexões. ${ }^{467}$

A pauperização do trabalhador seria um elemento de intensificação das contradições de classes sociais. ${ }^{468}$ As tendências pauperizadores levaram o proletariado às greves significativas de 1917 a $1920 .{ }^{469}$ A sociedade de então era recém-saída da ordem escravocrata, de modo que "as relações de trabalho estavam fortemente influenciadas pelos padrões herdados daquele sistema. E a situação dos trabalhadores se tornava ainda mais séria devido à escassez de ocupações em face da crescente procura". 470

\footnotetext{
${ }^{465}$ IANNI, Octavio. O Estado e o desenvolvimento econômico no Brasil. Tese apresentada ao concurso para provimento da cadeira de Professor de Sociologia II da FFLCH-USP, 1964, p. 140-143.

${ }^{466}$ Ibid., p. 141-142.

${ }^{467}$ Ibid., p. 148.

${ }^{468}$ Ibid., p. 142.

${ }^{469}$ Ibid., p. 142.

${ }^{470}$ Ibid., p. 142.
} 
Em um primeiro momento, as precárias condições de vida dos trabalhadores no final do século XIX e início do século XX os levaram à organização em associações assistenciais, mas depois as manifestações políticas foram canalizadas para a forma sindical. ${ }^{471}$

A Primeira Guerra Mundial (1914-18), a Grande Depressão Econômica (1929-33) e a Segunda Guerra Mundial (1930-45) favoreceram a expansão e a diferenciação da estrutura econômica brasileira, os vários surtos de industrialização e a aceleração do crescimento populacional dos centros urbanos. ${ }^{472}$

“Além dessa expansão industrial, as exigências da economia de guerra das "nações aliadas" (incluindo-se aí o Brasil e os Estados Unidos) criaram novos estímulos à produção e exportação de produtos minerais e extrativos" ${ }^{\prime 73}$ e dessa forma acentuou-se ainda mais a expansão das atividades produtivas no Brasil, no período de 1939-45. ${ }^{47}$ Durante "todo o período 1930-45 houve uma expansão real das forças produtivas no Brasil" 475 e "esse foi o contexto econômico em que se desenvolveu a legislação trabalhista e a política operária governamental". ${ }^{476}$

Mas a política social do Estado tinha também outra finalidade além de favorecer a expansão industrial, a de preservar a massa operária de uma excessiva pauperização. ${ }^{477}$ Ao mesmo tempo em que o governo formalizava as condições políticas de oferta e demanda no mercado de força de trabalho, ele também estabelecia os limites inferiores de exploração do operariado. ${ }^{478}$ Referindo-se à legislação trabalhista adotada durante o Estado Novo (1937-45), Ignácio Rangel escreveu o seguinte:

\footnotetext{
${ }^{471}$ IANNI, Octavio. O Estado e o desenvolvimento econômico no Brasil. Tese apresentada ao concurso para provimento da Cadeira de Professor de Sociologia II da FFLCH-USP, 1964, p.142.

${ }_{472}$ IDEM. Estado e planejamento econômico no Brasil (1930-1970). Rio de Janeiro: Civilização Brasileira SA, 1971, p. 40.

${ }^{473}$ Ibid., p. 41.

${ }^{474}$ Ibid., p. 41.

${ }^{475}$ Ibid., p. 41.

${ }^{476}$ Ibid., p. 41.

${ }^{477}$ Ibid., p. 41.

${ }^{478}$ Ibid., p. 41.
} 
Êsse direito trabalhista não se limitava a criar uma estabilidade de tipo corporativo ou feudal, no pessoal da emprêsa. Impunha às massas trabalhadoras, compulsòriamente, uma organização. Ora, era inevitável que essa organização fôsse usada como instrumento de pressão econômica e de ação política, pelas massas trabalhadoras. Graças a isso, o padrão salarial tornou-se relativamente independente das condições criadas pela presença de um enorme exército industrial de reserva, isto é, do desemprego urbano, suscitado pela transferência de populações deslocadas na agricultura. $^{479}$ (sic)

Ianni reconhece que a política operária da legislação trabalhista, por meio de direitos como salário mínimo, estabilidade no emprego, aviso prévio, descanso semanal e férias anuais remunerados, entre outros, favorecia, em certa escala, também aos próprios trabalhadores. ${ }^{480}$ Mas registra que, "A despeito disso, no entanto, as condições reais de vida de algumas categorias operárias não melhoraram, nos anos 1930-45. Ao contrário, essas condições pioraram." ${ }^{\sharp 41}$

...a interferência do Estado nas relações entre os operários e empresários não evitou a pauperização de boa parte do proletariado. Aliás, também uma parte da classe média (funcionalismo público e privado) teve o seu salário real rebaixado nesses anos. Ao mesmo tempo, entretanto, a atuação governamental delimitou as condições, as possibilidades e os limites da atividade sindical do operariado. Mais que isso, a política operária do governo brasileiro nos anos 1930-45 vinculou o sindicato ao aparelho estatal, como elemento básico das estruturas de dominação (política) e apropriação (econômica) vigentes na

\footnotetext{
${ }^{479}$ RANGEL, Ignacio. A inflação brasileira. Rio de Janeiro: Tempo Brasileiro, 1963, p. 44-45. Apud IANNI, Octavio. Estado e planejamento econômico no Brasil (1930-1970). Rio de Janeiro: Civilização Brasileira SA, 1971, p. 41.

${ }^{480}$ IANNI, Octavio, op. cit., p. 42.

${ }^{481}$ Ibid., p. 42.
} 
época. Essa era uma das manifestações mais importantes da presença do Estado no sistema econômico do País. ${ }^{482}$

Após a revolução de 1930, o poder público "procurou controlar os processos fundantes da luta de classes", ${ }^{483}$ estabelecendo diretrizes legais sistematizadas, organizando e disciplinando "as relações de trabalho, de modo a pacificar as relações antagônicas das classes" ${ }^{\prime 484}$, conforme expressamente declarou Getúlio Vargas:

Num país sem espírito associativo, onde os projetos de legislação social não tinham andamento nas Câmaras e onde apenas logravam execução algumas Leis de assistência, a organização do trabalho impunha, como providência elementar de parte do Estado, orientar e promover a coordenação das classes patronais e operárias em órgãos permanentes, legalmente constituídos, visando a defesa de seus próprios interesses e a solução suassória dos dissídios de classe. ${ }^{485}$

Boris Fausto diz que as associações de industriais e comerciantes acabaram por aceitar a legislação trabalhista, embora a princípio combatessem as medidas governamentais, especialmente aquelas que concediam direitos aos trabalhadores. ${ }^{486}$

Para Jacob Gorender, a burguesia não aceitou automática e plenamente a nova política trabalhista do Estado, mas discutiu "acirradamente ínfimos detalhes" da elaboração da legislação e seguiu "a tática de reduzir ao mínimo e protelar ao máximo as concessões aos trabalhadores". ${ }^{487} \mathrm{O}$ que ela procurou foi "expressar afinidade ideológica com as autoridades governamentais na linha da colaboração de classes e da paz social” ou,

\footnotetext{
${ }^{482}$ IANNI, Octavio. Estado e planejamento econômico no Brasil (1930-1970). Rio de Janeiro: Civilização Brasileira SA, 1971, p. 42-43.

483 IDEM. O Estado e o desenvolvimento econômico no Brasil. Tese apresentada ao concurso para provimento da cadeira de Professor de Sociologia II da FFLCH-USP, 1964, p. 143.

${ }^{484}$ Ibid., p. 143.

${ }^{485}$ VARGAS, Getúlio. Mensagem apresentada ao Poder Legislativo, em 3-5-1935, p. 101. Apud IANNI, Octavio, op. cit., p. 143.

${ }^{486}$ FAUSTO, Boris. História concisa do Brasil. 2. ed. São Paulo: Ed. da Universidade de São Paulo, 2009, p. 188 .

${ }^{487}$ GORENDER, Jacob. A burguesia brasileira. São Paulo: Brasiliense (Col. Tudo é História), 2004, p. 68.
} 
ainda, "na linha da criação das condições ideais para explorar a força de trabalho e extrair dela a mais-valia". ${ }^{488}$

Segundo Boris Fausto, as tentativas das organizações operárias sob controle das correntes de esquerda de oporem-se ao seu enquadramento pelo Estado fracassaram porque houve pressão do governo e da própria base dessas organizações, na medida em que vários direitos, como férias e a possibilidade de acionar as Juntas de Conciliação e Julgamento, dependiam da condição de membro de "sindicato reconhecido pelo governo". 489

Gorender explica que a tática da repressão estatal aos trabalhadores não se atenuou após 1930, aperfeiçoou-se “com a criação das Delegacias de Ordem Política e Social, especializadas no combate ao movimento sindical independente, ao Partido Comunista e à esquerda em geral". ${ }^{490}$

A novidade, observa Gorender, foi a implantação de "uma linha coerente e sistemática de conquista ideológica da classe operária e de disciplinamento de suas organizações sindicais sob o controle direto do Estado". 491 Enquanto a burguesia ainda estava presa a seus interesses imediatos de classe, Vargas e sua equipe percebiam a gravidade da "questão operária" e buscavam "enfrentá-la com a aplicação de uma orientação que, se aparentemente conflitava com os interesses imediatistas da burguesia, correspondia aos seus objetivos gerais e de longo prazo". 492

Durante o Governo Vargas, sobretudo na fase do Estado Novo, foram ampliados os mecanismos de previdência social, que ganharam proporções desconhecidas no período anterior a 30 , sendo que os vários institutos previdenciários surgidos no período construíram hospitais e conjuntos residenciais para operários e setores da baixa classe média. ${ }^{493}$

\footnotetext{
${ }^{488}$ GORENDER, Jacob. A burguesia brasileira. São Paulo: Brasiliense (Col. Tudo é História), 2004, p.68-69. ${ }^{489}$ FAUSTO, Boris. História concisa do Brasil. 2. ed. São Paulo: Ed. da Universidade de São Paulo, 2009, p.188.

${ }^{490}$ GORENDER, Jacob, op. cit., p. 66.

${ }^{491}$ Ibid., p. 66-67.

${ }^{492}$ Ibid., p. 67.

${ }^{493}$ Ibid., p. 67-68.
} 
Jacob Gorender registra que a proibição rigorosa de greves e a repressão policial observadas no período conduziram à "supressão da independência dos sindicatos e sua estruturação corporativista de inspiração fascista, segundo os princípios de unicidade, verticalidade e enquadramento oficial tutelado pelo Estado". 494

Salienta que a preocupação da política trabalhista na época estava voltada somente para os trabalhadores urbanos, que "dispunham de organização, realizavam lutas de massa e já recebiam a influência de idéias (sic) revolucionárias. A situação dos trabalhadores do campo permaneceu intocada", 495 com a "tradicional dominação latifundiária". ${ }^{496}$

Uma primeira forma legal de seguro coletivo obrigatório foi criada em 1923, por meio da Lei Eloy Chaves, instituindo a Caixa de Aposentadoria e Pensão dos empregados de empresas ferroviárias e obrigando as empresas do setor a estabelecer para os empregados um fundo para aposentadoria por idade, invalidez e tempo de serviço, pensão para os sobreviventes dependentes e assistência médica. ${ }^{497} \mathrm{O}$ fundo seria provido por contribuições de empregados e empregadores e administrado por representantes das partes. $^{498}$

A Lei Eloy Chaves é considerada o marco da criação da previdência social no Brasil. ${ }^{499}$ Posteriormente, o modelo implantado para os ferroviários foi seguido por diversas outras categorias. ${ }^{500}$

Celia Lessa Kerstenetzky defende que a constituição de um estado do bemestar social no Brasil ocorreu inicialmente com a proteção social dos servidores públicos, mediante a instituição de seguros coletivos, no final do século XIX, e a ampliação dessa

\footnotetext{
${ }^{494}$ GORENDER, Jacob. A burguesia brasileira. São Paulo: Brasiliense (Col. Tudo é História), 2004, p. 68.

${ }^{495}$ Ibid., p. 68.

${ }^{496}$ Ibid., p. 68.

${ }^{497}$ KERSTENETZKY, Celia Lessa. O Estado do bem-estar social na idade da razão. A reinvenção do Estado Social no mundo contemporâneo. Rio de Janeiro: Elsevier, 2012, p. 187.

${ }^{498}$ Ibid., p. 187.

${ }^{499}$ Ibid., p. 187.

${ }^{500}$ Ibid., p. 187.
} 
proteção aos empregados da indústria e do comércio, na primeira metade do século XX. ${ }^{501}$ $\mathrm{O}$ acesso à proteção seguia as ocupações e cobria riscos associados à participação no mercado de trabalho. ${ }^{502}$ Diz que a introdução do seguro social modificou a atividade sindical, que até então possuía um caráter contestatório e passou a realizar uma interação colaborativa com o poder público, inaugurando a cidadania sindical como forma de cidadania política, composta, entre outros aspectos, pela sindicalização como requisito para acesso a certos direitos trabalhistas. ${ }^{503}$

Segundo Francisco de Oliveira, ${ }^{504}$ a regulamentação da relação entre o trabalho e o capital implementada contribuiu para o novo processo de acumulação capitalista, na medida em que transformava os trabalhadores que se deslocavam do campo para a cidade em exército de reserva de mão de obra, e nivelava, reduzindo, o valor da força de trabalho.

a legislação trabalhista igualava reduzindo - antes que incrementando - o preço da força de trabalho. Essa operação de igualar pela base reconvertia inclusive trabalhadores especializados à situação de não-qualificados, e impedia - ao contrário do que pensam muitos - a formação precoce de um mercado dual de força de trabalho. Em outras palavras, se o salário fosse determinado por qualquer espécie de "mercado livre", na acepção da teoria da concorrência perfeita, é provável que ele subisse para algumas categorias operárias especializadas; a regulamentação das leis do trabalho operou a reconversão a um denominador comum de todas as categorias, com que, antes de prejudicar a acumulação, beneficiou-a ${ }^{505}$.

Esclarece que mesmo não tendo rebaixado os salários vigentes até então, a regulamentação equalizou os salários dos novos trabalhadores, e com isso, a média dos

\footnotetext{
${ }^{501}$ KERSTENETZKY, Celia Lessa. O Estado do bem-estar social na idade da razão. A reinvenção do Estado Social no mundo contemporâneo. Rio de Janeiro: Elsevier, 2012, p. 177.

${ }^{502}$ Ibid., p. 177.

${ }^{503}$ Ibid., p.178.

${ }^{504}$ OLIVEIRA, Francisco de. Crítica à razão dualista - o ornitorrinco. São Paulo: Boitempo, 2006, p. 38-39.

${ }^{505}$ Ibid., p. 38-39.
} 
salários. ${ }^{506}$ Argumenta, para corroborar sua tese, que após a implantação da legislação trabalhista, houve impulso à acumulação capitalista e não crise..$^{507}$

Enfim, constata-se que o direito do trabalho no Brasil foi sendo criado como parte desse novo modelo incipiente, a fim de contribuir para o desenvolvimento da economia industrial e para a consolidação do capitalismo.

A partir de Getúlio Vargas, o problema proletário deixou de ser considerado apenas questão de polícia, para começar a ser tratado também como questão de política. $\mathrm{O}$ proletariado passou a ser visto como interlocutor legítimo e foram legitimadas certas reivindicações suas. O poder público se inseriu como mediador, com o objetivo de pacificação das classes sociais e de busca de cooptação das entidades sindicais para colaboração no mecanismo dirigente do Estado). Inicialmente, o acesso a certos direitos trabalhistas era dependente da condição de sindicalizado e até mesmo para ingressar com ação na Justiça do Trabalho havia o requisito da sindicalização.

A legislação trabalhista vinha para estabelecer a harmonia e a tranquilidade entre empregados e empregadores urbanos. No cerne da doutrina da "paz social" havia uma política de controle e dominação da atividade e organização política do proletariado, repressão dos esforços organizatórios da classe trabalhadora urbana fora do controle do Estado e atração dessa classe para o apoio ao governo. Tudo isso contribuía para a expansão industrial e para a racionalidade da máxima mercantilização dos fatores de produção.

Chama a atenção o fato de a legislação trabalhista ter inicialmente ficado restrita aos trabalhadores urbanos. Os trabalhadores rurais eram a maioria da força de trabalho e juntamente com o empregados domésticos não receberam nenhuma proteção. É claro que para isso também contribuiu o aspecto de que os trabalhadores urbanos já se encontravam mais organizados e com maior capacidade reivindicativa. Mas essa segmentação tão drástica corrobora a percepção de que não era predominantemente no interesse dos trabalhadores que o Estado estava preocupado na época.

${ }^{506}$ OLIVEIRA, Francisco de. Crítica à razão dualista - o ornitorrinco. São Paulo: Boitempo, 2006, p. 39.
${ }^{507}$ Ibid., p. 39. 
Mas, por outro lado, é inegável que a legislação representou para os trabalhadores a obtenção de antigas reivindicações e sinalizou um marco inicial de proteção normativa em face dos empregadores. Mais que isso, o estabelecimento de um salário mínimo, do direito a férias, da limitação de jornada, entre outros aspectos, e posteriormente a elaboração da Consolidação das Leis do Trabalho, iniciaram a construção de uma nova ordem jurídica (lastreada em uma nova racionalidade), transformando as relações de trabalho de privadas em relações dotadas de certo caráter público, nas quais o Estado podia e devia intervir, para evitar a superexploração do trabalhador, a sua pauperização, a competição incontrolada entre as diversas categorias profissionais e a canalização das insatisfações para o confronto.

A Consolidação das Leis do Trabalho, em 1943, mais do que mera sistematização, representou a construção de um monumento normativo de intensa transformação na concepção jurídica brasileira. O princípio da liberdade contratual absoluta, no sentido de celebrar os contratos e de fixar o conteúdo, deixava de existir nas relações de trabalho. Era uma racionalidade que reconhecia a desigualdade material entre empregado e empregador e a vulnerabilidade a que o sistema havia lançado uma multidão de despossuídos, que tinham na venda da força de trabalho o único meio de sobrevivência.

Por isso, o artigo $9^{\circ}$ da CLT estabeleceu a nulidade de atos que desvirtuassem, impedissem ou fraudassem a Consolidação. O artigo 444 impediu a estipulação de cláusulas contrárias às disposições estatais e de normas coletivas de proteção ao trabalhador. O artigo 468 impediu a alteração contratual unilateral pelo empregador e aquela que, mesmo pactuada, fosse prejudicial ao trabalhador. Vale dizer, estava ganhando corpo no direito do trabalho uma estruturação positiva que indicava expressamente a finalidade de proteção do trabalhador e de melhoria de sua condição social. Não era apenas um conglomerado de direitos, mas um instrumental poderoso de nova expressão das relações de trabalho no plano normativo. A ordem jurídica decididamente tomava partido em prol do trabalhador, mesmo que também existissem outras intenções do Estado e da classe dominante. 
Deve-se observar que a possibilidade de rompimento da ordem capitalista pelo excesso de exploração dos trabalhadores não nos parece uma certeza mecânica. A miséria pode representar forte elemento de subjugação e enfraquecimento dos dominados. A fome e o desespero conduzem à insatisfação social, mas não necessariamente à luta. Por isso, a tensão que se pode fazer nos antagonismos de classe deve partir do pressuposto de ampliação de direitos dos trabalhadores. A ampliação de direitos poderá representar o fortalecimento da classe trabalhadora e a possibilidade de questionamento da ordem muito mais do que a retirada de direitos e a pauperização dos dominados.

Nas décadas de 1930 e 1940, os direitos sociais, que durante muito tempo foram excluídos dos trabalhadores rurais e domésticos, incentivavam o processo de busca de trabalho urbano e de preservação de oferta excedente de mão de obra. Mas, a grande quantidade de reserva de mão de obra que passou a se formar na cidade e também a existente no campo (disponível para ser transferida para os centros urbanos), e em subempregos nas cidades, contribuíam para que o poder aquisitivo dos trabalhadores urbanos não crescesse com o advento da legislação trabalhista, e grande parte da atividade política do proletariado continuasse vinculada à luta por reivindicações econômicas.

Mas, de qualquer modo, a normatização de direitos sociais, notadamente trabalhistas e previdenciários, passou a constituir o Estado Social brasileiro, alterando a racionalidade jurídica que vigorava até então.

\subsection{8 - A POLÍTICA SINDICAL}

Armando Boito Jr. explica que a necessidade de reconhecimento oficiallegal do sindical por um ramo do aparelho do Estado, a unicidade sindical, as contribuições sindicais obrigatórias e a tutela da Justiça do Trabalho sobre a ação reivindicativa geraram a figura do sindicato oficial, que é a célula da estrutura sindical. ${ }^{508}$

\footnotetext{
508 BOITO JR., Armando. Reforma e persistência da estrutura sindical. In: BOITO JR., Armando et. al. $O$ sindicalismo brasileiro nos anos 80. Rio de Janeiro: Paz e Terra, 1991, p. 51.
} 
Para representar um segmento de trabalhadores, receber recursos financeiros e ajuizar dissídio coletivo perante a Justiça do Trabalho, o sindicato necessita ser oficialmente reconhecido. ${ }^{509}$ Essa estrutura torna os sindicatos independentes dos trabalhadores e dependentes do Estado, na medida em que sua "representatividade, suas finanças e seu reconhecimento público pelo patronato e pela mídia dependem do registro." 510

Observa, porém, que essa estrutura sindical possui efeitos tutelares estatais mais ou menos rígidos, dependendo do modelo ditatorial ou democrático de controle do Estado sobre os sindicatos oficiais. ${ }^{511} \mathrm{O}$ sindicalismo que se desenvolveu nessa estrutura é uma espécie de sindicalismo, que pode ser chamada de sindicalismo de Estado. ${ }^{512}$

Dando suporte ao sindicalismo de Estado está a ideologia estatista, sob a forma de legalismo sindical: o sindicato somente pode ser considerado sindicato se reconhecido por lei, pelo Estado, como sindicato. ${ }^{513} \mathrm{O}$ legalismo é uma ideologia que legitima o elemento essencial da estrutura sindical..$^{514}$

Boito Júnior explica que a tutela sobre os sindicatos não é imposta pelo Estado: os sindicalistas desejam essa tutela, embora os sindicalistas mais combativos não queiram um controle rígido sobre a vida sindical. ${ }^{515}$ Esses sindicalistas combativos desejam um modelo "democrático" de tutela do Estado. ${ }^{516}$ Essa ideologia legalista funciona como "cimento" da estrutura sindical, isto é, permite a reprodução dessa estrutura, implantada a partir de março de 1931 quando foi imposta a necessidade de oficialização dos sindicatos. ${ }^{517}$

\footnotetext{
${ }^{509}$ BOITO JR., Armando. Reforma e persistência da estrutura sindical. In: BOITO JR., Armando et. al. O sindicalismo brasileiro nos anos 80. Rio de Janeiro: Paz e Terra, 1991, p. 52.

${ }^{510} \mathrm{Ibid}$., p. 52.

${ }^{511}$ Ibid., p. 54.

${ }^{512}$ Ibid., p. 54.

${ }^{513}$ Ibid., p. 54-55.

${ }^{514}$ Ibid., p. 55.

${ }^{515}$ Ibid., p. 55.

${ }^{516}$ Ibid., p. 55.

${ }^{517}$ Ibid., p. 55.
} 
Segundo Boris Fausto, a política trabalhista do governo Vargas teve por objetivos principais reprimir os esforços organizatórios da classe trabalhadora urbana fora do controle do Estado e atraí-la para o apoio difuso ao governo. ${ }^{518}$ No que diz respeito ao primeiro objetivo, a repressão se abateu sobre partidos e organizações de esquerda, especialmente o PCB, logo após 1930, tornando-se mesmo mais sistemática do que a existente na Primeira República. ${ }^{519}$ Quanto ao segundo objetivo, a esporádica atenção ao problema da classe trabalhadora urbana na década de 1920, deu lugar a uma política governamental específica, que foi-se delineando desde novembro de 1930, quando da criação do Ministério do Trabalho, Indústria e Comércio, da edição das leis de proteção ao trabalhador, de enquadramento dos sindicatos pelo Estado e da criação das Junta de Conciliação e Julgamento, órgãos para arbitrar conflitos entre patrões e operários. ${ }^{520}$

Boito Júnior observa que a classe operária até a década de 1950 era uma classe em formação. ${ }^{521}$ Os trabalhadores de classe média, como bancários, comerciários, trabalhadores de escritório, funcionários públicos, não tinham praticamente nenhuma tradição de organização e luta sindical. ${ }^{522}$ Diz que esse conjunto de trabalhadores era excluído do sistema político da República Oligárquica e, principalmente no caso da classe operária, vítima do "forte preconceito existente, numa sociedade recém-saída da escravidão, contra o trabalho manual e contra o trabalhador imigrante. ${ }^{523}$

O Estado saído da Revolução de 1930, que se propõe a organizar sindicalmente os trabalhadores, é o que implementa a política de expansão dos direitos sociais e que procura integrar esses trabalhadores ao sistema político, "ainda que de modo periférico e controlado". ${ }^{524}$ Por isso, a maioria dos sindicalistas e trabalhadores que aderiram ao "estatismo sindical" percebia nele um aspecto reformista, como "instrumento da implementação de reformas que melhorassem as condições de trabalho e de vida dos

\footnotetext{
${ }^{518}$ FAUSTO, Boris. História concisa do Brasil. 2. ed. São Paulo: Ed. da Universidade de São Paulo, 2009, p.187.

${ }^{519}$ Ibid., p.187.

${ }^{520}$ Ibid., p. 187.

${ }^{521}$ BOITO JR., Armando. Reforma e persistência da estrutura sindical. In: BOITO JR., Armando et. al. O sindicalismo brasileiro nos anos 80. Rio de Janeiro: Paz e Terra, 1991, p. 55.

${ }^{522}$ Ibid., p. 55.

${ }^{523}$ Ibid., p. 56.

${ }^{524}$ Ibid., p. 56.
} 
trabalhadores", ${ }^{525}$ diferentemente da regulação estatal sindical realizada a partir do golpe de 1964, de matiz conservadora, instrumentalizada "para barrar a ascensão das correntes reformistas e revolucionárias no movimento sindical". ${ }^{526}$

Em 26 de novembro de 1930, pelo Decreto 19.433, foi criado o Ministério do Trabalho, Indústria e Comércio, para entre, outras finalidades, "superintender a questão social, cuidando do amparo necessário aos trabalhadores nacionais". ${ }^{527} \mathrm{O}$ Decreto $\mathrm{n}$. 19.671-A, de 4 de fevereiro de 1931, criou o Departamento Nacional do Trabalho, com o objetivo de "promover medidas de previdência social e melhorar as condições gerais do trabalho". 528 "Entretanto, foi o Decreto 19.770, de 19 de março de 1931, que se destinou especificamente a regular 'a sindicalização das classes patronais e operárias", 529 ocasião em já se estabeleceram, “de modo bastante explícito, os vínculos e obrigações do sindicato, em face do Estado". 530

O "sindicato começava a adquirir novo conteúdo político, como elemento essencial do sistema político-administrativo estatal" 531 , de modo que "a formalização da organização e atividade sindical estava sendo realizada em conformidade com objetivos e meios que escapavam ao controle do próprio operariado". 532

As comissões que elaboravam sugestões ou anteprojetos para decretos e leis trabalhistas, embora contassem com a participação de representantes operários, "eram sempre constituídas segundo as conveniências da doutrina da 'paz social', ou 'ordem e trabalho', destinada primordialmente a favorecer a expansão da empresa privada". ${ }^{533}$

${ }^{525}$ BOITO JR., Armando. Reforma e persistência da estrutura sindical. In: BOITO JR., Armando et. al. $O$ sindicalismo brasileiro nos anos 80. Rio de Janeiro: Paz e Terra, 1991, p. 56.

${ }^{526} \mathrm{Ibid}$., p. 57.

${ }^{527}$ MOARES FILHO, Evaristo de. O problema do sindicato único no Brasil. Rio de Janeiro: Ed. A Noite, 1952, p. 217. Apud IANNI, Octavio. Estado e planejamento econômico no Brasil (1930-1970). Rio de Janeiro: Civilização Brasileira SA, 1971, p. 36.

${ }^{528}$ Ibid., p. 36.

${ }^{529}$ IANNI, Octavio, op. cit., p. 36.

${ }^{530}$ Ibid., p. 36.

${ }_{531}^{531}$ Ibid., p. 37.

${ }_{532}$ Ibid., p. 37.

${ }_{533}$ Ibid., p. 37. 
Todos "os aspectos organizatórios e funcionais mais importantes da atividade sindical passaram a depender diretamente do Ministério do Trabalho, Indústria e Comércio" 534 , que "legalizava a existência e o funcionamento do sindicato; fiscalizava a eleição sindical e empossava a diretoria eleita". ${ }^{535}$ Os recursos financeiros indispensáveis ao funcionamento do sindicato passaram a ser gerados pelo imposto sindical (atual contribuição sindical), devido anualmente por todo assalariado, independentemente de sindicalização, correspondente a um dia de trabalho. ${ }^{536}$

Victor Russomano Júnior observa que “o Brasil, mesmo durante o 'Estado Novo', praticamente não teve feitio corporativista, a não ser em um ponto: a organização sindical". 537

\subsection{9 - O PERÍODO DE 1946 A 1964}

As greves operárias foram reprimidas durante o Estado Novo, mas começaram a reaparecer em 1945, em razão do agravamento da inflação nos últimos anos da guerra e da mobilização possibilitada pela gradativa restauração das liberdades democráticas. ${ }^{538}$

Todavia, durante o período Dutra, em nome do combate ao comunismo, o governo combateu as organizações de trabalhadores contrárias à sua orientação, por meio de intervenção em sindicatos e centrais sindicais: no mesmo dia da casssação do Partido Comunista pelo STF, em maio de 1947, o Ministério do Trabalho ordenou a intervenção em catorze sindicatos e fechou uma central sindical controlada pelos comunistas, seguindose, nos meses seguintes, "novas ações repressivas, a ponto de haver mais de duzentos sindicatos sob intervenção no último ano do governo". 539

\footnotetext{
${ }^{534}$ IANNI, Octavio. Estado e planejamento econômico no Brasil (1930-1970). Rio de Janeiro: Civilização Brasileira SA, 1971, p. 38.

${ }^{535}$ Ibid., p. 38.

${ }^{536}$ Ibid., p. 39.

${ }^{537}$ RUSSOMANO JÚNIOR, Victor. Política trabalhista brasileira: (análise crítica). Rio de Janeiro: Forense, 1998, p. 8-9.

${ }^{538}$ FAUSTO, Boris. História concisa do Brasil. 2. ed. São Paulo: Ed. da Universidade de São Paulo, 2009, p. 213-214.
} 
A repressão do movimento sindical facilitou a imposição de redução dos salários reais: entre 1949 e 1951 o aumento do custo de vida foi de 15\% em São Paulo e de $23 \%$ no Rio de Janeiro, mas o salário médio cresceu 10,5\% em São Paulo e 12\% no Rio de Janeiro. ${ }^{540}$

A "política econômica do Governo Dutra inspirou-se no liberalismo (ideologicamente) e na empresa privada (na prática). Por isso, não se configurou como uma política deliberada de desenvolvimento econômico nacional", de modo que "a industrialização verificada nesses anos era um processo em curso, a despeito das ações e omissões no poder público". ${ }^{541}$

Durante "todo o período governamental (1946-50) não houve qualquer elevação do salário mínimo, a despeito da crescente inflação de preços", ${ }^{542}$ nem qualquer alteração na base salarial, "salvo por iniciativa de empresários isolados, sob a pressão de reivindicações diretas dos operários, bem como de bancários e outros assalariados da classe média".543

\begin{abstract}
Nesses anos, no entanto, a inflação reduziu bastante o poder aquisitivo dos assalariados da indústria. Se tomarmos a Guanabara, como exemplo, verificamos que o índice do salário real evoluiu da seguinte forma: partindo-se de 1940, quando era igual a 100, no ano de 1943 passou a 104; mas em 1946 já era igual a 90 e no ano de 1949 havia baixado para $87 .^{544}$
\end{abstract}

A "política salarial adotada pelo governo era, de fato de confisco salarial ${ }^{1545}$ (grifo do autor), promovendo uma redistribuição altamente regressiva da renda,

\footnotetext{
${ }^{539}$ FAUSTO, Boris. História concisa do Brasil. 2. ed. São Paulo: Ed. da Universidade de São Paulo, 2009, p. 222.

${ }^{540}$ Ibid,. p. 223.

${ }^{541}$ IANNI, Octavio. Estado e planejamento econômico no Brasil (1930-1970). Rio de Janeiro: Civilização Brasileira SA, 1971, p. 99.

${ }^{542}$ Ibid., p. 100.

${ }^{543}$ Ibid., p. 100.

${ }^{544}$ Ibid., p. 100.

${ }^{545}$ Ibid., p. 101.
} 
que aumentava a taxa de lucro e acentuava o processo de acumulação do capital do setor privado. ${ }^{546}$

De fato, a política salarial fazia parte da política operária. E esta, por sua vez, exprimia o caráter das relações entre a classe dominante e os assalariados, principalmente o proletariado industrial. Afinal de contas, a política salarial diz respeito tanto ao mercado de força de trabalho como à produção de lucro; isto é, à reprodução do capital. ${ }^{547}$

Após o retorno de Vargas ao poder, houve elevação dos níveis do salário mínimo em 1952 e em 1954, mas suficiente apenas para repor uma parte do poder aquisitivo. ${ }^{548}$ Neste particular, Ianni explica que se "tomarmos o ano de 1940 como base (igual a 100), verificamos que em 1943 o salário real desses trabalhadores elevara-se para 104. Em 1946, no entanto, caíra para 90. No ano de 1949 baixara a 87, em 1952 chegara a 64 e em 1955 já era 58 ". 549

Esse contexto revela que as tensões sociais tendiam a desenvolver-se, eis que a "inflação, enquanto técnica de poupança monetária forçada, favorecia a mobilização política das massas urbanas" e por outro lado, "os setores políticos e econômicos mais conservadores e ligados ao capital estrangeiro pressionavam, para que o governo adotasse políticas de estabilidade financeira e social". ${ }^{550}$ As "oposições ao Governo Vargas falavam em 'República Sindicalista', para classificar negativamente o regime político" e assim amedrontava a classe média. ${ }^{551}$

Ianni diz que "Vargas continuava a desenvolver a política trabalhista, e conseguia ampliar o apoio das massas urbanas ao governo e à sua política econômica" ${ }^{552}, \mathrm{o}$ que "desagradava aos setores mais conservadores da sociedade brasileira" e "aos grupos

${ }^{546}$ IANNI, Octavio. Estado e planejamento econômico no Brasil (1930-1970). Rio de Janeiro: Civilização Brasileira SA, 1971, p. 101.

${ }^{547}$ Ibid., p. 101.

${ }^{548}$ Ibid., p. 119-120.

${ }^{549}$ Ibid., p. 120.

${ }^{550}$ Ibid., p. 120.

${ }^{551}$ Ibid., p. 120.

${ }^{552}$ Ibid., p. 120. 
estrangeiros interessados na economia do País e no 'alinhamento' político do Brasil, no contexto da Guerra Fria". 553

"A liberalização do movimento sindical e os problemas decorrentes da alta do custo de vida levaram a uma série de greves em 1953", 554 dentre as quais se destacaram a greve geral de março em São Paulo (que chegou a abranger 300 mil trabalhadores, teve como reivindicação principal um aumento de $60 \%$ dos salários e revelou conteúdo de desafio à legislação restritiva do direito de greve) e a greve dos marítimos no Rio de Janeiro, em Santos e Belém, no mês de junho. ${ }^{555}$

Durante o período JK as lideranças sindicais começaram a perceber a dificuldade de articular o movimento dos trabalhadores na "apertada" estrutura oficial e por isso surgiram organismos que passaram a atuar paralelamente à referida estrutura, como por exemplo o Pacto de Unidade Intersindical (PUI), criado em São Paulo em 1955, e o Pacto de Unidade e Ação (PUA), instituído no Rio de Janeiro. ${ }^{556}$

O período de 1956-60 foi uma fase importante da industrialização e nele o capital externo foi considerado pelo governo como essencial à expansão das atividades produtivas. ${ }^{557}$ Para o programa de substituição de importações de meios de produção, o Estado procurou atrair capitais externos, que passaram a ser admitidos em diferentes formas, inclusive máquinas e implementos. ${ }^{558}$

A posse de João Goulart na Presidência encontrou o país em um contexto de mobilizações e pressões sociais muito maiores do que no período Vargas. ${ }^{559}$ As reformas de base propostas não se destinavam a implantar uma sociedade socialista, ${ }^{560}$ representavam uma tentativa de modernizar o capitalismo e reduzir as profundas

${ }_{553}$ IANNI, Octavio. Estado e planejamento econômico no Brasil (1930-1970). Rio de Janeiro: Civilização Brasileira SA, 1971, p. 121.

${ }^{554}$ FAUSTO, Boris. História concisa do Brasil. 2. ed. São Paulo: Ed. da Universidade de São Paulo, 2009, p.227.

${ }_{555}^{55}$ Ibid., p. 228.

${ }^{556}$ Ibid., p. 237-238.

${ }^{557}$ IANNI, Octavio. O Estado e o desenvolvimento econômico no Brasil. Tese apresentada ao concurso para provimento da cadeira de Professor de Sociologia II da FFLCH-USP, 1964, p. 81.

${ }_{558}^{55}$ Ibid., p. 81.

${ }^{559}$ FAUSTO, Boris, op. cit., p. 245-246.

${ }^{560} \mathrm{Ibid}$., p. 246. 
desigualdades sociais do país, a partir da ação do Estado. ${ }^{561}$ Conforme explica Boris Fausto, isso porém implicava uma grande mudança, à qual as classes dominantes opuseram forte resistência. ${ }^{562}$

As greves aumentaram muito, tendendo à concentração no setor público e ao deslocamento de São Paulo para outras regiões do país: ${ }^{.63}$ em 1958 foram registrados 31 movimentos grevistas e eles chegaram a $172 \mathrm{em} 1963 .{ }^{564}$ Guillermo O’Donnell esclarece que o setor popular se encontrava ativado, no período. ${ }^{565}$

\subsubsection{0 - A DITADURA CIVIL-MILITAR (1964-1985)}

Conforme observam Celso Furtado ${ }^{566}$ e André Singer, ${ }^{567}$ o processo de mudança social iniciado por Vargas ainda não havia esgotado suas possibilidades quando do advento do golpe de 1964, que interrompeu o processo.

Chamamos de ditadura civil-militar o regime político instituído no Brasil a partir desse golpe porque hoje, a partir das descobertas das Comissões da Verdade em funcionamento no país, já se sabe da intensa participação civil, notadamente de representantes do capital, no movimento.

Conforme esclareceu Guillermo O’Donnell, no período, o Estado procurou garantir e organizar "a dominação exercida através de uma estrutura de classes subordinada às frações superiores de uma burguesia altamente oligopolista e transnacionalizada". ${ }^{568}$ Boris Fausto observa que desde o início do regime, o grupo castelista tinha como pretensão

\footnotetext{
${ }^{561}$ FAUSTO, Boris. História concisa do Brasil. 2. ed. São Paulo: Ed. da Universidade de São Paulo, 2009, p. 246.

562 Ibid., p. 246.

${ }^{563}$ Ibid., p. 247.

${ }^{564}$ Ibid.,p. 247.

${ }^{565}$ O’DONNELL, Guillermo. Análise do autoritarismo burocrático. São Paulo: Ed. Paz e Terra, 1990, p. 6061. Apud RUSSOMANO JÚNIOR, Victor. Política trabalhista brasileira: (análise crítica). Rio de Janeiro: Forense, 1998, p. 6.

${ }^{566}$ FURTADO, Celso. O longo amanhecer: reflexões sobre a formação do Brasil. Rio de Janeiro: Paz e Terra, 1999, p. 17. Apud SINGER, André Vitor. Os sentidos do lulismo: reforma gradual e pacto conservador. São Paulo: Companhia das Letras, 2012, p. 17.

${ }^{567}$ SINGER, André Vitor, op. cit., p. 17.

${ }^{568}$ O’DONNELL, Guillermo, op. cit., p. 60-61. Apud RUSSOMANO JÚNIOR, Victor, op. cit., p. 5.
} 
modernizar o sistema capitalista, como um fim em si mesmo, controlar a massa trabalhadora e evitar a ameaça comunista. ${ }^{569}$

A implantação da ditadura trouxe violenta repressão às Ligas Camponesas, intervenção em sindicatos (principalmente nos mais expressivos, abrangendo $70 \%$ das organizações que tinham mais de 5 mil membros), federações de trabalhadores e prisão de dirigentes sindicais. ${ }^{570}$

Foram adotadas medidas que comprimiam os salários (mediante fixação de fórmulas de reajuste inferiores à inflação), restringiam as greves (a lei de greve aprovada em junho de 1964 pelo Congresso criava exigências burocráticas que praticamente impossibilitavam as paralisações legais) e facilitavam a rotatividade da mão de obra no interesse das empresas, ${ }^{571}$ eis que a estabilidade no emprego após dez anos de serviço foi substituída pelo Fundo de Garantia por Tempo de Serviço. ${ }^{572}$

As forças empenhadas na luta pela democratização tentaram resistir à ditadura, realizando movimentos como a passeata dos 100 mil (junho de 1968) e greves operárias (Contagem-MG e Osasco-SP). ${ }^{573}$

O regime ditatorial reprimiu as direções sindicais, mas não desmantelou os sindicatos. ${ }^{574}$ Houve até aumento no número de sindicatos rurais ${ }^{575}$ e Boris Fausto explica que o aumento da sindicalização de trabalhadores rurais após 1973 "foi estimulado pela administração dos programas de previdência social por meio de sindicatos". ${ }^{576}$

A partir de 1968 houve grande crescimento da economia, dando início ao chamado "milagre econômico": crescimento do PIB de 11,2\% e 10\%, em 1968 e 1969,

\footnotetext{
${ }^{569}$ FAUSTO, Boris. História concisa do Brasil. 2. ed. São Paulo: Ed. da Universidade de São Paulo, 2009, p. 259 .

${ }^{570}$ Ibid., p. 258.

${ }^{571}$ Ibid., p. 260.

${ }^{572}$ Ibid., p. 260.

${ }^{573}$ Ibid., p. 264.

${ }^{574}$ Ibid., p. 276.

${ }^{575}$ Ibid., p. 276.

${ }^{576}$ Ibid., p. 276.
} 
respectivamente. ${ }^{577}$ O período do "milagre" estendeu-se de 1969 a 1973, com grande crescimento econômico e relativamente baixas taxas de inflação. ${ }^{578}$

Uma das razões do "milagre econômico" foi a obtenção de empréstimos externos, facilitada pela ampla disponibilidade de recursos na economia mundial. ${ }^{579}$ Além disso, houve o crescimento de investimentos de capital estrangeiro, notadamente no setor da indústria automobilística, incentivados pela ampliação do crédito ao consumidor e revisão de normas de produção com autorização para a fabricação de carros de tamanho médio. ${ }^{580}$ Nesse período, o comércio exterior expandiu-se, houve diversificação das exportações, incentivo à exportação de produtos industriais por meio da concessão de créditos em condições favoráveis e aumento da capacidade do Estado de arrecadar tributos. ${ }^{581}$

Mas, o "milagre" foi perverso, no campo social, aumentando a concentração de renda e as desigualdades sociais: a política econômica privilegiou a acumulação de capitais; os salários recebiam reajustes abaixo da inflação; o salário mínimo era desvalorizado ("tomando-se como 100 o índice do salário mínimo de janeiro de 1959, ele caíra para 39 em janeiro de 1973”), o que, conforme observa Boris Fausto, é ainda mais expressivo se observarmos que em 1972 " $52,5 \%$ da população economicamente ativa recebeu menos de um salário mínimo e $22,8 \%$ entre um e dois salários" ${ }^{582}$

Outro aspecto negativo do "milagre", que perdurou depois dele, foi a desproporção entre o avanço econômico e o retardamento ou mesmo o abandono dos programas sociais pelo Estado. O Brasil iria notabilizar-se no contexto mundial por uma posição relativamente destacada pelo seu potencial industrial e por

\footnotetext{
${ }^{577}$ FAUSTO, Boris. História concisa do Brasil. 2. ed. São Paulo: Ed. da Universidade de São Paulo, 2009, p. 266.

${ }^{578}$ Ibid., p. 268.

${ }^{579}$ Ibid., p. 268.

${ }^{580}$ Ibid., p. 268.

${ }^{581}$ Ibid., p. 268.

${ }^{582}$ Ibid., p. 269.
} 
indicadores muito baixos de saúde, educação, habitação, que medem a qualidade de vida de um povo. ${ }^{583}$

A primeira crise internacional do petróleo, em outubro de 1973, ocorreu como consequência da Guerra do Yom Kippur (Estados árabes contra Israel) e afetou o Brasil, que importava grande parte do produto que consumia (mais de $80 \%$ ). ${ }^{584}$

O Governo Geisel procurou completar o processo de substituição de importações, embora com novo enfoque, não mais substituir a importação de bens de consumo, mas de insumos básicos, como petróleo, aço, alumínio, fertilizantes etc. e de bens de capital. ${ }^{585}$

Embora o PIB tivesse crescido durante o período de Geisel, havia defasagem da massa salarial, agravada pela indexação anual dos salários, ${ }^{586}$ mediante concessão de reajustes salariais apenas de ano em ano e baseados na inflação. ${ }^{57}$ Além disso, houve manipulação dos índices oficiais de inflação de 1973 e 1974, aumentando a defasagem salarial (31,4\% do salário real de 1973 e 1974). ${ }^{588}$ A campanha do Sindicato dos Metalúrgicos de São Bernardo pela correção salarial abriu caminho para as grandes greves de 1978 e $1979 .{ }^{589}$

A partir de 1981 houve recessão e, pela primeira, desde 1947, o PIB teve índices negativos: queda de 3,1\% em 1981 e de 1,6\% no período de 1981 a 1983 . Houve desemprego. ${ }^{590}$ O Brasil recorreu ao FMI, em fevereiro de 1983, e aceitou aplicar as medidas recessivas (cortes de despesas) e compressivas de salários, preconizadas pelo referido órgão. ${ }^{591}$

\footnotetext{
${ }^{583}$ FAUSTO, Boris. História concisa do Brasil. 2. ed. São Paulo: Ed. da Universidade de São Paulo, 2009, p. 269.

${ }^{584}$ Ibid., p. 273.

${ }^{585}$ Ibid., p. 273.

${ }^{586}$ Ibid., p. 275.

${ }^{587}$ Ibid., p. 275.

${ }^{588}$ Ibid., p. 277.

${ }^{589}$ Ibid., p. 277.

${ }^{590}$ Ibid., p. 278.

${ }^{591}$ Ibid., p. 279.
} 
$\mathrm{Na}$ comparação da repartição individual da renda no Brasil, entre 1960 e 1986, José Paschoal Rossetti explica que houve grande concentração de renda:

aos $10 \%$ mais ricos da população cabiam, em 1960, 39,7\% do total da Renda Nacional; dez anos após, esta taxa de concentração da renda nas mãos do estrato mais rico ampliou-se para 47,8\%. Não obstante tenha acusado ligeira redução em 1980, para 45,2\%, expandiu-se novamente em 1986, atingindo 47,5\%. Este aumento de concentração processou-se em detrimento dos estratos inferiores, que registraram diminuições em suas taxas de participação na Renda Nacional. As perdas mais significativas nas participações relativas registraram-se nos estratos intermediários: no quarto, no quinto e no sexto segmentos as reduções foram superiores a 20\%, comparando-se os dados de 1960 com os de $1986 . .^{592}$

Por tudo isso, concordamos com Victor Russomano Júnior, quando diz que a política trabalhista brasileira no período de 1964 a 1985 caracterizou-se principalmente pela "contenção máxima dos movimentos individuais e coletivos dos trabalhadores" e pela "redução dos níveis salariais, dentro de táticas e técnicas de combate à inflação e redução dos custos de produção". 593

Conforme observa Guillermo O’Donnell, o Estado burocrático-autoritário do período da ditadura tinha a principal função de "subordinar e controlar estritamente o setor popular, reverter a tendência autonomista das suas organizações de classe e eliminar suas expressões na arena política". ${ }^{594}$ Russomano Júnior explica que, no período, praticamente foram eliminados os meios de atuação individual e coletiva dos trabalhadores, por meio de restrições à organização sindical, à greve, às convenções coletivas de trabalho e ao poder normativo da Justiça do Trabalho. ${ }^{595}$

\footnotetext{
${ }_{592}$ ROSSETTI, José Paschoal. Introdução à economia. 15. ed. São Paulo: Atlas SA, 1991, p. 622.

${ }^{593}$ RUSSOMANO JÚNIOR, Victor. Política trabalhista brasileira: (análise crítica). Rio de Janeiro: Forense, 1998, p. 5.

${ }^{594}$ O’DONNELL, Guillermo. Análise do autoritarismo burocrático. São Paulo: Paz e Terra, 1990, p.60-61. Apud RUSSOMANO JÚNIOR, Victor, op. cit., p. 5.

${ }^{595}$ RUSSOMANO JÚNIOR, Victor, op. cit., p. 6.
} 


\section{3- O ESTADO}

\section{1 - ELEMENTO ESTRUTURAL DO SISTEMA CAPITALISTA}

O Estado, juntamente com o trabalho assalariado e o capital constituem os elementos estruturais do capitalismo. Não é possível a existência de um deles sem a existência dos outros.

Harvey esclarece que "O Estado, constituído como sistema coercitivo de autoridade que detém o monopólio da violência institucionalizada, forma um segundo princípio organizador" do sistema capitalista ${ }^{596}$. Por meio do Estado, "a classe dominante pode tentar impor sua vontade não somente aos seus oponentes, mas também ao fluxo, à mudança e à incerteza anárquicos a que a modernidade capitalista sempre está exposta" ${ }^{, 597}$.

Explica que para essa atuação os instrumentos de que o Estado dispõe são ${ }^{598}$ : "regulação do dinheiro e das garantias legais de contratos de mercado leais às intervenções fiscais, à criação do crédito e às redistribuições de impostos"; "fornecimento de infra-estrutura sociais e físicas"; "controle direto das alocações de capital e de trabalho, bem como dos salários e dos preços, nacionalização de setores essenciais, restrições ao poder da classe trabalhadora, vigilância policial, repressão militar etc."

E acrescenta: "Mas o Estado é uma entidade territorial que se esforça por impor a sua vontade a um processo fluido e espacialmente aberto de circulação do capital". ${ }^{599}$ Ele enfrenta as forças "fragmentadoras do individualismo disseminado, da mudança social rápida e de toda a efemeridade que costumar estar associada à circulação do capital". ${ }^{600}$

\footnotetext{
${ }^{596}$ HARVEY, David. Condição pós-moderna. Uma pesquisa sobre as origens da mudança cultural. 12. ed. Tradução de Adail Ubirajara Sobral e Maria Stela Gonçalves. São Paulo: Loyola, 1992, p. 104.

${ }^{597}$ Ibid., p. 104.

${ }^{598}$ Ibid., p. 104.

${ }^{599}$ Ibid., p. 104.

${ }^{600}$ Ibid., p. 104.
} 
Fernando Marques de Campos explica que "O termo Estado tal qual hoje se conhece foi introduzido por Maquiavel, ao desenvolver preocupações práticas quanto à estabilização do poder na península itálica no século XVI"601. Diz que para Engels ${ }^{602}$, o Estado equipara-se "a um instrumento de classe, ao conjugar, sob os auspícios da classe dominante, os monopólios do econômico e do político, em virtude da premente necessidade do primeiro". ${ }^{603}$

O fenômeno histórico, denominado Estado, engendra-se da seguinte forma: o desenvolvimento das relações de produção, bem como da divisão social do trabalho nas diversas fases da humanidade que carreia consigo o rompimento dos laços de parentesco (passagem da gens à família individual) e a formatação da sociedade em classes, cuja contradição revela a necessidade do Estado, enquanto poder dissociado e alheio a esta, cujo mote é balizar por parâmetros (leis) o conflito da ordem social. ${ }^{604}$

Somente é possível falar em Estado, tal qual o conhecemos, a partir da Revolução Industrial e da implantação do capitalismo, eis que foi nesse momento que houve uma separação entre o poder político e o poder econômico, antes unificados na mesma pessoa, ou seja, no senhor feudal. A constituição desse ente abstrato e impessoal era parte do novo sistema baseado na igualdade formal de todos para facilitar as trocas de mercado.

Portanto, o Estado é uma realidade que surge com o sistema capitalista e atua como ente centralizador do poder político, exercendo-o teoricamente de modo impessoal. É possível defender que se trata de uma tentativa de constituição de um poder que não mais se confunda com a classe dominante e que guarde relativa autonomia quanto à sociedade.

\footnotetext{
${ }^{601}$ CAMPOS, Fernando Marques de. Os direitos sociais e sua função no capitalismo. Dissertação de mestrado. Faculdade de Direito da USP, 2010, p. 12.

${ }^{602}$ ENGELS, Friedrich. A origem da família, da propriedade privada e do Estado. Tradução de Ciro Mioranza. 2. ed. São Paulo: Escala, s.a, p.184-188. Apud CAMPOS, Fernando Marques de, op. cit., p. 13. ${ }^{603}$ CAMPOS, Fernando Marques de, op. cit., p. 13.

${ }^{604}$ Ibid., p. 13.
} 
O Estado surge como centralização do poder político que já não pode ser exercido diretamente no processo produtivo, portanto como um poder político que deixa de ser exercido por um homem diretamente sobre outro e passa a se manifestar como impessoal. ${ }^{605}$

A característica primordial do Estado é, portanto, constituir um poder que não mais se confunde com a classe dominante, que guarda relativa autonomia quanto à sociedade. A autoridade, que nas formações sociais pré-capitalistas não tem qualquer expressão jurídica, passa, no capitalismo, a expressar-se necessariamente como direito. ${ }^{606}$

Harvey explica que o dinheiro e a mercadoria criam uma base universal e social no capitalismo, unindo todas as pessoas a um sistema idêntico de avaliação de mercado e, com isso, promovem "a reprodução da vida social através de um sistema objetivo de ligação social". ${ }^{607}$

Mas, para criar a estratégia de acumulação do capital, o Estado busca criar um "sentido de comunidade que seja uma alternativa ao que se baseia no dinheiro, além de formular uma definição dos interesses públicos acima dos interesses e lutas de classes e setores contidos nas suas fronteiras" ${ }^{" 008}$. Enfim, o Estado para atingir seus objetivos, precisa "legitimar-se", engajando-se na "estetização da politica". ${ }^{609}$

Para Harvey, "a relação entre o desenvolvimento capitalista e o Estado tem de ser vista como mutuamente determinante, e não unidirecional" ${ }^{610}$, de modo que "o poder do Estado não pode ser mais nem menos estável do que o permite a economia política da modernidade capitalista" 611 . "A tensão entre a fixidez (e, portanto, estabilidade) que a

\footnotetext{
${ }^{605}$ KASHIURA JÚNIOR, Celso Naoto. Crítica da igualdade jurídica. Contribuição ao pensamento jurídico marxista. Dissertação de mestrado. Faculdade de Direito da USP, 2008, p. 48.

${ }^{606}$ Ibid., p. 52

${ }^{607}$ HARVEY, David. Condição pós-moderna. Uma pesquisa sobre as origens da mudança cultural. 12. ed. Tradução de Adail Ubirajara Sobral e Maria Stela Gonçalves. São Paulo: Loyola, 1992, p. 100.

${ }^{608}$ Ibid., p. 104.

${ }^{609}$ Ibid., p. 104.

${ }^{610}$ Ibid., p. 105.

${ }^{611}$ Ibid., p. 105.
} 
regulação do Estado impõe e o movimento fluido do capital permanece um problema crucial para a organização social e política do capitalismo". ${ }^{612}$

Nessa dificuldade de equacionar a estabilidade pretendida pelo Estado com a instabilidade própria do capital agem forças internas (nas quais o Estado baseia seu poder) e externas, tais como "competição na economia mundial, taxas de câmbio, movimentos de capital, migração, ou, às vezes, intervenções políticas diretas de potências superiores". ${ }^{613}$

A sociedade civil e a sociedade política (Estado) são dimensões da mesma realidade, diferindo no que se refere à forma de manifestação do poder nas relações, que na sociedade civil é exercido de modo hegemônico e consensual, enquanto no Estado de modo coercitivo.

Na sociedade política, as contradições se resolvem com decretos ou leis de acatamento obrigatório ou, em última instância, sob coerção pública. Na sociedade civil, o jogo é mais difuso, e as contradições tendem a resolver-se com o uso de mecanismos como a persuasão e a pressão. ${ }^{614}$

A separação entre Estado e sociedade civil trata-se de mera abstração, servindo apenas para diferenciar duas dimensões da mesma realidade, eis que os "homens e coisas que formam a sociedade civil constituem também a sociedade política ou, o que é a mesma coisa, o Estado - só que, neste último, suas relações têm a ver com o exercício coercitivo do poder". 615

Boaventura de Souza Santos diz que a dicotomia entre o Estado e sociedade civil trata-se de um pressuposto indemonstrável e que "a distinção Estado/sociedade civil e

\footnotetext{
${ }^{612}$ HARVEY, David. Condição pós-moderna. Uma pesquisa sobre as origens da mudança cultural. 12. ed. Tradução de Adail Ubirajara Sobral e Maria Stela Gonçalves. São Paulo: Loyola, 1992, p. 105.

${ }^{613}$ Ibid., p. 105.

${ }^{614}$ CAMACHO, Daniel. Movimentos sociais: algumas discussões conceituais. SCHERER-WARREN, Ilse \& KRISCHKE, Paulo J. (orgs.). Uma Revolução no Cotidiano? Os novos movimentos sociais na América Latina. São Paulo: Brasiliense, 1987, p. 219.

${ }^{615}$ Ibid., p. 219.
} 
os seus corolários são hoje uma 'ortodoxia conceptual' e, por isso, a sua predominância no discurso político é perfeitamente compatível com a sua falência teórica". ${ }^{616}$

É possível defender, com Kashiura Júnior, que existe uma ligação dialética entre o Estado e a sociedade civil:

O Estado e a sociedade civil se ligam dialeticamente: são ambos condição um do outro e são ambos determinados um pelo outro. E, a despeito da aparência de neutralidade, o Estado é uma entidade de dominação de classe, dominação esta que não pode ser exercida em favor dos capitalistas em particular, mas apenas em favor do capital em geral. ${ }^{617}$

Em razão dessa íntima e profunda relação entre Estado e sociedade civil, as transformações sociais que o Estado por meio do direito busca implementar recebem o impacto da consciência da sociedade civil, e isso deve ser levado em consideração quando se pensa na eficácia das normas jurídicas.

O dirigismo estatal, não encontrando sustentação material na realidade social - desde que esta se construa democraticamente -, acaba sendo desconsiderado, ou pelo menos tendo grande dificuldade de se fazer respeitar, o que serve para demonstrar, primeiro, que a vontade estatal não pode ser desvinculada da vontade social, e segundo, que o poder ou a coercibilidade, expressão máxima do Estado, que torna aplicáveis suas regras, não é mais um puro ato de força, precisamente, de convencimento. ${ }^{618}$

\footnotetext{
${ }^{616}$ SANTOS, Boaventura de Souza. Pela mão de Alice: o social e o político na pós-modernidade. São Paulo: Cortez, 1997, p. 117. Apud SOUTO MAIOR, Jorge Luiz. O direito do trabalho como instrumento de justiça social. São Paulo: LTr, 2000, nota de rodapé, p. 235.

${ }^{617}$ KASHIURA JÚNIOR, Celso Naoto. Crítica da igualdade jurídica. Contribuição ao pensamento jurídico marxista. Dissertação de mestrado. Faculdade de Direito da USP, São Paulo, 2008, p. 48.

${ }^{618}$ SOUTO MAIOR, Jorge Luiz. O direito do trabalho como instrumento de justiça social. São Paulo: LTr, 2000, p. 235-236.
} 


\section{2 - O ESTADO LIBERAL}

O Estado liberal tratava-se de um Estado estritamente burguês, Estado mínimo, forjado pela classe dominante burguesa para defender seus interesses e implementar a sociedade capitalista. Nele, a ação estatal voltava-se para reprimir os trabalhadores e garantir a liberdade de ir e vir, de contratar e de trabalhar, com a finalidade de construir relações sociais a partir da sacralidade do direito de propriedade e garantir uma sociedade seccionada entre dominantes (proprietários) e dominados (não proprietários).

Em sua formação, contou com as teorias de Locke, no aspecto político, preconizando a atuação do Estado para fomentar a lógica produtiva, além de Rousseau e Stuart Mill. Vale dizer, edificou-se teoricamente "pelo contratualismo social dos séculos XVII e XVIII que aspirava estatuir, racionalmente, a existência social do homem, depositando no direito privado a função de mediação entre a ingerência do soberano e o direito de propriedade" 619

Nesse novo Estado sustentava-se que cada indivíduo era o melhor julgador de seu destino, havendo, por isso, direitos naturais que deveriam ser obedecidos, como o direito à liberdade contratual e o direito de propriedade. ${ }^{620}$

Nas questões econômicas, valeu-se das teorias de Adam Smith, no sentido de não intervenção na economia, deixando que o mercado regido pela lei da oferta e da procura forjasse um modelo de sociedade bom para todos. As teorias de Smith decorriam de um contexto histórico em que o Estado monárquico extraía dinheiro do mercado para uma lógica de favorecimento da nobreza. Por isso, Smith preconizou a não intervenção do Estado na economia.

\footnotetext{
${ }^{619}$ CAMPOS, Fernando Marques de. Os direitos sociais e sua função no capitalismo. Dissertação de mestrado. Faculdade de Direito da USP, São Paulo, 2010, p. 17.

${ }^{620}$ SOUTO MAIOR, Jorge Luiz. O direito do trabalho como instrumento de justiça social. São Paulo: LTr, 2000, p. 241.
} 
O Estado liberal era um Estado mínimo. Nas palavras de Mário de la Cueva, pode-se "resumir a atitude do Estado em relação à vida social e humana na seguinte frase: a menor quantidade possível de Estado". ${ }^{2}{ }^{21}$

Por outro lado, o objetivo de construção de uma sociedade regulada pelo mercado esconde o fato de que tal modelo necessita permanentemente de recursos públicos, conforme bem observou Francisco de Oliveira: "para construir-se o pretenso mercado auto-regulado, que dispensaria tudo o mais a não ser os próprios critérios da lucratividade, faz-se necessário muito Estado, muitos recursos públicos". ${ }^{622}$

Richard Hyman esclarece que Polanyi, ${ }^{623}$ ao analisar a evolução histórica do capitalismo, verificou que em praticamente todas as sociedades complexas, os mercados a compra e venda (ou troca) de produtos, baseados em determinadas noções padronizadas de valor desempenham algum tipo de papel na vida econômica. ${ }^{624}$ Para Polanyi, a economia de mercado, contudo, é algo mais específico: "um sistema econômico controlado, regulado e dirigido apenas pelos mercados". ${ }^{625}$

Em uma sociedade de mercado, o sistema econômico retira a sua legitimação ideológica "do predomínio dos valores que exaltam a liberdade individual de estabelecer contratos e a busca individual do máximo proveito econômico dentro de mercados competitivos". ${ }^{626}$

Francisco de Oliveira observa que o chamado "mercado livre", ente abstrato, em que o "Estado não interfere, tomado de empréstimo da ideologia do

\footnotetext{
${ }^{621}$ CUEVA, Mario de La. Derecho mexicano del trabajo. Prologo da segunda edição. Mexico: Libreria de Porrua Hnos. Y Cia., 1943, p. 15.

${ }^{622}$ OLIVEIRA, Francisco de. Os direitos do antivalor. A economia política da hegemonia imperfeita. Petrópolis, RJ: Vozes, 1998, p. 13.

${ }^{623}$ POLANYI, K. The great transformation. Boston: Beacon, 1957, p. 68. Apud HYMAN, Richard. Europeização ou erosão das relações laborais? In: ESTANQUE, Elísio et. al (org.). Mudanças no trabalho e ação sindical: Brasil e Portugal no contexto da transnacionalização. São Paulo: Cortez, 2005, p. 20.

${ }^{624}$ HYMAN, Richard, op. cit., p. 20.

${ }^{625} \mathrm{Ibid}$., p. 20

${ }^{626}$ Ibid., p. 20.
} 
liberalismo econômico, certamente não é um mercado capitalista, pois precisamente o papel do Estado é 'institucionalizar' as regras do jogo". ${ }^{627}$

Polanyi explica que a criação de uma sociedade de mercado é "totalmente não natural, no sentido estritamente empírico de excepcional" ${ }^{28}$ e que "Não houve nada de natural no laissez-faire; nunca poderiam ter surgido mercados livres se se tivesse deixado as coisas seguirem o seu curso. (...) O próprio laissez-faire foi imposto pelo Estado". ${ }^{629}$

Hyman observa que, de acordo com Gray, o laissez-faire "constituiu um artefacto do poder e da estadística (...) Os mercados livres são criaturas do poder do Estado e só subsistem enquanto o Estado tiver a capacidade de evitar que as necessidades humanas de segurança e o controle do risco econômico encontrem expressão política". ${ }^{630}$

\section{3 - O ESTADO SOCIAL}

\subsection{1 - ASPECTOS CONCEITUAIS}

O Estado Social também é denominado Estado de bem-estar social, welfare state, pacto de compromisso social democrata, Estado Providência, Estado Desenvolvimentista e Estado Intervencionista, entre outras nomenclaturas. Trata-se de uma ordem jurídica na qual os cidadãos têm direitos sociais em face dos entes públicos (relação de cidadania) e em face dos empregadores e demais tomadores de serviço (relação de trabalho), com vistas à proteção frente a vulnerabilidades e desigualdades sociais.

\footnotetext{
${ }^{627}$ OLIVEIRA, Francisco de. Crítica à razão dualista. O ornitorrinco. São Paulo: Boitempo, 2008, p. 37. ${ }^{628}$ POLANYI, K. The great transformation. Boston: Beacon, 1957, p. 249. Apud HYMAN, Richard. Europeização ou erosão das relações laborais? In: ESTANQUE, Elísio et. al (org.). Mudanças no trabalho e ação sindical: Brasil e Portugal no contexto da transnacionalização. São Paulo: Cortez, 2005, p. 20.

${ }^{629}$ POLANYI, K., op. cit., p.139. Apud HYMAN, Richard, op. cit., p.20.

${ }^{630}$ GRAY, J. False Dawn: the delusions of global capitalism. London: Granta, 1998, p. 17. Apud HYMAN, Richard, op. cit., p. 20.
} 
Para Celia Lessa Kerstenetzky, o welfare state consiste em um "conjunto histórica e institucionalmente moldado de intervenções públicas visando à promoção do bem-estar e envolvendo redistribuição". ${ }^{631}$

Francisco de Oliveira observa que o welfare state "constituiu-se no padrão de financiamento público da economia capitalista", ${ }^{632}$ no sentido de que o fundo público passou a ser o pressuposto do financiamento da acumulação de capital (por exemplo, mediante subsídios para a produção, juros subsidiados, recursos para a ciência e tecnologia, valorização dos capitais pela via da dívida pública, entre outros) e de financiamento da reprodução da força de trabalho (saúde e educação públicas, previdência social, seguro-desemprego, entre outros), atingindo todos por meio dos gastos sociais. ${ }^{63}$

Esclarece que a formação do sistema capitalista é impensável sem a utilização de recursos públicos, que em certos casos funcionaram quase como uma “acumulação primitiva", como por exemplo, na expansão colonial, mediante a união dos tesouros reais ou imperiais com o dos banqueiros e mercadores. ${ }^{634}$

Noticia o crescimento das despesas públicas voltadas para a reprodução da força de trabalho nos países da OCDE, mesmo após $1960 .{ }^{635}$ Diz que "a transferência para o financiamento público de parcelas da reprodução da força de trabalho é uma tendência histórica de longo prazo no sistema capitalista", ${ }^{636}$ como socialização dos custos internos de produção. ${ }^{637} \mathrm{O}$ salário indireto (benefícios sociais assegurados pelo Estado) é um componente do salário real total ${ }^{638}$ e seu crescimento liberou a renda para o consumo. ${ }^{639}$

Observa que muitos críticos do welfare state ressaltam a presença de corporativismo, com cada classe social ou grupo específico defendendo seus próprios

\footnotetext{
${ }^{631}$ KERSTENETZKY, Celia Lessa. O Estado do bem-estar social na idade da razão. A reinvenção do Estado Social no mundo contemporâneo. Rio de Janeiro: Elsevier, 2012, p. 61.

${ }^{632}$ OLIVEIRA, Francisco de. Os direitos do antivalor. A economia política da hegemonia imperfeita. Petrópolis: Vozes, 1998, p. 19.

633 Ibid., p. 19-20.

634 Ibid., p. 20.

${ }^{635}$ Ibid., p. 21-22.

${ }^{636}$ Ibid., p. 22

${ }^{637}$ Ibid., p. 22

${ }^{638}$ Ibid., p. 30.

${ }^{639}$ Ibid., p. 22.
} 
interesses e impossibilitando políticas de caráter geral. ${ }^{640}$ "A direita vai mais longe, e aponta os direitos lato sensu trabalhistas como obstáculos ao investimento e à acumulação", revelando a aspiração de um retorno à "acumulação selvagem" e dos assalariados à mera condição de "pura força de trabalho". ${ }^{641}$ Diz que interpretações ingênuas vêem no welfare state a harmonia total, o fim das classes sociais, ${ }^{642}$ que a esquerda comunista via no welfare state cooptação do operariado e anulação do seu potencial revolucionário ${ }^{643}$ e que uma "esquerda infantil" entendia que os direitos como saúde e educação públicas, previdência social e outros contribuem para a reprodução do capital. $^{644}$

Para Francisco de Oliveira, com o ataque ao Estado Social, a direita pretende "dissolver as arenas específicas de confronto e negociação, para deixar o espaço aberto a um Estado mínimo", e com isso manter o fundo público como pressuposto apenas para o capital. ${ }^{645}$ Característico disso é o ataque aos gastos sociais públicos ${ }^{646}$ e a proposta de substituição do welfare state por um Estado caritativo ou assistencialista. ${ }^{647}$

$\mathrm{Na}$ crise do welfare state, o que a direita propõe é a "destruição da regulação institucional como a supressão das alteridades entre os sujeitos sócioeconômico-políticos". ${ }^{648}$ Mesmo nessa crise não houve a retirada do suporte do fundo público à acumulação do capital, como por exempo por meio do suporte à pesquisa e desenvolvimento tecnológico e aquisição pelo Estado dos produtos da indústria armamentista. $^{649}$

Por fim, Francisco de Oliveira defende que essa atuação do fundo público como suporte para a reprodução do capital e da força de trabalho tem produzido o deslocamento da esfera das relações privadas para um esfera pública, ou a transformação

\footnotetext{
${ }_{640}$ OLIVEIRA, Francisco de. Os direitos do antivalor. A economia política da hegemonia imperfeita. Petrópolis: Vozes, 1998, p. 38.

${ }^{641}$ Ibid., p. 38.

${ }^{642}$ Ibid., p. 38.

${ }^{643}$ Ibid., p. 38.

${ }^{644}$ Ibid., p. 38.

${ }^{645}$ Ibid., p. 44.

${ }^{646}$ Ibid., p. 44.

${ }^{647}$ Ibid., p. 44.

${ }^{648}$ Ibid., p. 46.

${ }^{649} \mathrm{Ibid}$., p. 46.
} 
das classes sociais de privadas para classes sociais públicas: há um deslocamento da luta de classes da esfera da produção para o orçamento do Estado. ${ }^{650}$

Jorge Luiz Souto Maior observa que a construção do Estado Social está baseada no pressuposto da busca do pleno emprego e das correspondentes garantias trabalhistas e previdenciárias, a fim de possibilitar o custeio necessário para a proteção social. $^{651}$ Trata-se de um projeto de sociedade que depende da eficácia dos direitos sociais. ${ }^{652}$

Entendemos que os direitos sociais que o Estado implementa dependem de arrecadação tributária. A desoneração da folha de pagamento, mediante isenções tributárias ou diminuição de alíquotas, agride a capacidade de obtenção dos recursos necessários para as políticas públicas sociais.

A lógica adequada deve ser a de maior contribuição coletiva para o benefício de todos e não a redução de tributos, que possa significar o enfraquecimento do Estado e de sua capacidade redistributiva.

Conforme observa André Singer, a pressão da burguesia e da classe média em favor da redução fiscal representa a opção por planos de saúde e escolas privadas e contrapõe-se às visões negativas a respeito do lucro no atendimento de necessidades fundamentais como medicina e educação, que se originam na postura anticapitalista do movimento operário dos anos $1980 .^{653}$

O que difere o Estado Social do Estado Liberal é o aspecto da solidariedade social, que deixa o campo da moral e passa a integrar a ordem jurídica, no sentido de que o vínculo social impõe responsabilidade de uns para com os outros e que cabe ao Estado

\footnotetext{
${ }^{650}$ OLIVEIRA, Francisco de. Os direitos do antivalor. A economia política da hegemonia imperfeita. Petrópolis: Vozes, 1998, p. 53.

${ }^{651}$ SOUTO MAIOR, Jorge Luiz. A supersubordinação - invertendo a lógica do jogo. Rev. Trib. Reg. Trab. $3^{a}$ Região. Belo Horizonte, v. 48, n. 78, p.171, jul/dez-2008.

${ }^{652}$ Ibid., p. 171.

${ }^{653}$ SINGER, André Vitor. Os sentidos do lulismo: reforma gradual e pacto conservador. São Paulo: Companhia das Letras, 2012, p. 168.
} 
promover valores que preservem a vida de todos, independentemente da situação econômica. ${ }^{654}$

No Estado Social as relações sociais passam a contar com uma dimensão de solidariedade, notadamente para com as pessoas mais fragilizadas, e de maior responsabilidade perante a coletividade. A dimensão estritamente individual cede espaço para uma perspectiva de sociedade.

Assim, o Estado passa a atuar levando em consideração a finalidade de priorizar os interesses coletivos e proteger os mais fragilizados, diretamente, por meio de serviços públicos e programas governamentais que dependam predominantemente da vontade estatal, mas também por meio de normas heterônomas, para todos os que estão submetidos ao ordenamento jurídico, com especial destaque para as relações de trabalho.

Uma dimensão de cidadania diz respeito à atuação mais direta do Estado para com o cidadão. Nela, sob o âmbito de direito social, sobressai o aspecto dos serviços públicos de qualidade, essenciais para a ampliação das oportunidades e para a construção de uma democracia qualificada, bem como a assistência social e programas de transferência de renda.

Uma segunda perspectiva, fundamental para a construção da justiça social, é a das relações de trabalho, eis que o modelo capitalista tem como pilares o individualismo, a competição, a desigualdade e a busca desenfreada por lucros, de modo que ao Estado Social competirá elaborar normas que vão contrariar o sistema, em muitos de seus aspectos destrutivos essenciais, com vistas à preservação da sociedade. O Estado Social interfere nas relações de trabalho, para proteger o trabalhador, o elemento humano dessa relação, devolvendo-lhe a humanidade que lhe é inerente, e para possibilitar a distribuição funcional da renda, que diz respeito a evitar que a apropriação das riquezas geradas com o trabalho sejam concentradas nas mãos apenas dos capitalistas.

\footnotetext{
${ }^{654}$ SOUTO MAIOR, Jorge Luiz. Os princípios do Direito do Trabalho e sua negação por alguns posicionamentos jurisprudenciais. In: MELO FILHO, Hugo Cavalcanti, et. al. (coord.). $O$ mundo do trabalho. Volume I: leituras críticas da jurisprudência do TST: em defesa do direito do trabalho. São Paulo: LTr, 2009, p. 226-227.
} 
No Brasil, após a saída dos governos radicalmente neoliberais (Collor, Itamar e FHC), os últimos anos representaram certo avanço na dimensão da cidadania, com expansão de benefícios de transferência de renda, assistência social e moradia, bem como ampliação da rede de serviços públicos, notadamente de educação e de saúde. No que se refere à dimensão de implementação do Estado Social nas relações de trabalho, os avanços também ocorreram, mas em intensidade muito menor, eis que o aumento da distribuição de renda por meio da redivisão do quinhão do capital e do trabalho tem crescido em ritmo bastante lento: observa-se redução do índice de Gini no período de 2003 a 2008 de apenas $5 \%(0,58$ para 0,55$) .{ }^{655}$ Em janeiro de 2012, o Brasil, com índice de Gini de 0,51, ${ }^{656}$ ainda não havia recuperado o patamar de 0,49 do índice de Gini de $1960 .{ }^{657}$

A criação de postos de trabalho formais e a valorização do salário mínimo deram impacto em favor de uma maior participação do trabalho na renda nacional. Segundo João Sicsú, essa participação em 2004 chegou a ser de apenas 30,8\% do PIB e atingiu 35,1\% em 2009, recuperando o patamar de 1995. ${ }^{658}$ Marcio Pochmann fornece números divergentes, mas indicativos da mesma situação: participação do trabalho na renda nacional de 56,6\% em 1959-1960, passando para 40\% em 1999-2000 e atingindo $41,3 \%$ no biênio $2005-2006 .{ }^{659}$

Conforme observa André Singer, o salário mínimo voltou, em 2009, “ao patamar de meados dos anos 1960". ${ }^{660}$ Diz que a partir de 2003, houve por parte do governo federal a "adoção de políticas para reduzir a pobreza - com destaque para o combate à miséria - e para a ativação do mercado interno, sem confronto com o capital" (grifos do autor).

\footnotetext{
${ }^{655}$ SINGER, André Vitor. Os sentidos do lulismo: reforma gradual e pacto conservador. São Paulo: Companhia das Letras, 2012, p. 139.

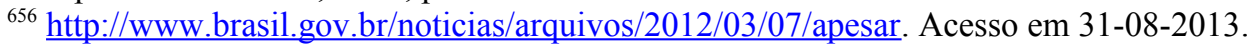

${ }^{657}$ SINGER, André Vitor, op. cit., p. 142; CACCIAMALI, Maria Cristina. Distribuição de renda no Brasil: persistência do elevado grau de desigualdade. In: PINHO, D \& VASCONCELlOS, M. A. S. Manual de Economia. São Paulo: Saraiva, 2002, p. 406-422, disponível em http://www.fea.usp.br/feaecon/media/livros/file_529.pdf, acesso em 31-08-2013.

${ }^{658}$ SICSÚ, João. Dois projetos em disputa. Teoria e Debate, n. 88, p. 14, maio/jun.2010. Apud SINGER, André Vitor, op. cit., p. 140.

${ }^{659}$ POCHMANN, Marcio. Desenvolvimento, trabalho e renda no Brasil. São Paulo: Fundação Perseu Abramo, 2010, p. 24. Apud. SINGER, André Vitor, op. cit., p. 140-141.

${ }^{660}$ SINGER, André Vitor, op. cit., p. 142-143.

${ }^{661}$ Ibid., p. 13.
} 
Ao lado da incipiente valorização do salário mínimo, que, embora lenta, produziu resultados em favor da distribuição da renda, o país continuou convivendo com intensa precarização das condições de trabalho, mediante altos índices de trabalho informal, disseminação da terceirização, do trabalho em condições análogas à de escravo e de outras formas de burla à tipicidade do contrato de trabalho legalmente protegido. Continuou convivendo com intensa rotatividade da mão de obra, com abuso nas jornadas de trabalho, mediante a habitualidade de jornadas extraordinárias, com bancos de horas, com altos índices de acidente de trabalho. O Estado continou cerceando o direito de greve e dando guarida ao descumprimento da legislação trabalhista, seja mediante aceitação de negociações coletivas destruidoras de direitos, seja mediante acordos judiciais prejudiciais ao trabalhador ou adotando postura leniente para com os descumpridores contumazes da referida legislação.

Kerstenetzky, ${ }^{662}$ à luz da teoria Keynesiana, observa que a redução das desigualdades é compatível com o crescimento econômico, eis que, para Keynes, a "redistribuição da renda, ao favorecer os que têm menor renda e maior propensão a consumir tende a estimular o consumo agregado, sendo, portanto, relevante como política desenvolvimentista quando há restrição de demanda". ${ }^{663}$

Explica que mesmo em sociedades capitalistas igualitárias, o estado de bem-estar social seria necessário, em razão dos riscos sociais próprios das economias de mercado, porque contribui "para a suavização do consumo, isto é, o equilíbrio entre despesa e poupança necessário para se atingir o mais alto padrão de consumo possível ao longo da vida" ${ }^{664}$; representa um seguro contra riscos médicos não cobertos pelo setor privado; ${ }^{665}$ e o "financiamento público à educação garante o arriscado e incerto investimento em educação no início da vida" ${ }^{666}$ Para a autora, existem riscos e incertezas nas economias de mercado contemporâneas que não são asseguráveis privadamente

${ }^{662}$ KERSTENETZKY, Celia Lessa. O Estado do bem-estar social na idade da razão. A reinvenção do Estado Social no mundo contemporâneo. Rio de Janeiro: Elsevier, 2012, p. 46.

${ }^{663}$ MARTINS, N. Sen's Capability Approach and Post Keynesianism: Simillarities, Distinctions, and the Cambridge Tradition. Journal of Post Keynesian Economics, v. 31, n. 4, p. 691-706, Summer 2009. Apud KERSTENETZKY, Celia Lessa, op. cit., p. 46.

${ }^{664}$ KERSTENETZKY, Celia Lessa, op. cit., p. 64.

${ }^{665}$ Ibid., p. 64.

${ }^{666}$ Ibid., p. 64. 
(desemprego e inflação). ${ }^{67}$ Além disso, "os programas de seguridade protegem contra a pobreza extrema". ${ }^{668}$

Para Esping-Andersen ${ }^{669}$, o welfare state contribui na "equalização das chances de vida, por meio da mais ampla oferta de oportunidades iguais e de proteção social", o que é "um ingrediente crucial para o crescimento econômico sustentado". ${ }^{670}$

Contudo, Suzanne de Brunhoff alerta que o estado do bem-estar social ainda é um estado capitalista e, por isso, reproduz as desigualdades existentes nas categorias sociais, procurando atenuá-las por meio de garantia às classes mais baixas de acesso ao consumo e com a diminuição da insegurança em caso de acidentes de trabalho, doença, desemprego e velhice. ${ }^{671}$ A melhoria das condições de vida dos trabalhadores decorre de um compromisso de classe, mantendo a dominação do capital e os privilégios dos mais favorecidos. ${ }^{672}$

Para Vicente de Paula Faleiros, "a política social é uma gestão estatal da força de trabalho, articulando as pressões e movimentos sociais dos trabalhadores com as formas de reprodução exigidas pela valorização do capital e pela manutenção da ordem social". ${ }^{673}$

Ricardo Antunes explica que após a Segunda Guerra Mundial, houve nos países capitalistas avançados um sistema de "compromisso" e de "regulação", consistente

\footnotetext{
${ }^{667}$ KERSTENETZKY, Celia Lessa. O Estado do bem-estar social na idade da razão. A reinvenção do Estado Social no mundo contemporâneo. Rio de Janeiro: Elsevier, 2012, p. 64.

${ }^{668}$ Ibid., p. 64.

${ }^{669}$ ESPING - ANDERSEN, G. Social Foundation of Postindustrial Economics. Oxford: Oxford University Press, 1999, s/p; The incomplete revolution: adapting to women's new roles. Cambridge: Polity Press, 2009, s/p. Apud KERSTENETZKY, Celia Lessa, op. cit., p. 64.

${ }^{670}$ KERSTENETZKY, Celia Lessa, op. cit., p.64.

${ }^{671}$ BRUNHOFF, Suzanne de. A hora do mercado, crítica do neoliberalismo. São Paulo: Ed. da UNESP, 1991, p. 104. Apud SOUZA, Sérgio Alberto de. Direito, globalização e barbárie - estudos críticos de temas de direito do trabalho e de direitos humanos sob a ótica de uma leitura não-liberal. São Paulo: LTR, 1998, nota de rodapé, p.100.

${ }^{672}$ BRUNHOFF, Suzanne de, op. cit., p. 104. Apud SOUZA, Sérgio Alberto de, op. cit., nota de rodapé, p.100.

${ }^{673}$ FALEIROS, Vicente de Paula. A política social do Estado capitalista. 7. edição. São Paulo: Cortez, s.d., p.57-62. Apud RUSSOMANO JÚNIOR, Victor. Política trabalhista brasileira: análise crítica. Rio de Janeiro: Forense, 1998, p. 4.
} 
em um pacto entre o capital e o trabalho, mediado pelo Estado. ${ }^{674}$ Esse compromisso foi resultado de mecanismos políticos elaborados após a crise de 1929, com influência das teorias de Keynes, e representava um equilíbrio relativo de forças entre a burguesia e o proletariado. Era intermediado por sindicatos e partidos políticos e o Estado atuava como árbitro, mas, na verdade, zelava pelos interesses do capital e cuidava de sua aceitação pelas entidades representativas do capital e do trabalho. ${ }^{675}$

Esse "compromisso" social-democrata, aplicado nos países centrais do capitalismo, tinha como sustentação a enorme exploração do trabalho nos países do Terceiro Mundo (excluídos do compromisso) e buscava afastar a temática do socialismo. ${ }^{676}$

Segundo Antunes, o movimento operário e seus organismos institucionalizados (sindicatos e partidos) acabaram sendo integrados como cogestores do processo global de reprodução do capital. ${ }^{677}$ Explica que, para Alain Bihr, ${ }^{678}$ o próprio movimento operário se tornou estrutura mediadora do comando do capital sobre o proletariado e contribuiu para manter as conquistas dos trabalhadores apenas nos limites do "compromisso" social-democrata. ${ }^{679}$ Desenvolveu-se no período um "fetichismo de Estado", atribuindo ao poder político estatal um sentido de exterioridade frente ao capital e ao trabalho. ${ }^{60}$ Também vieram a centralização da atividade sindical, a burocratização e o corporativismo (negociação por empresa ou por ramo), em razão da prática sistemática da negociação (transformada em finalidade exclusiva das instituições representativas e instrumentada como mecanismo do comando capitalista sobre o proletariado), exigindo tecnicidade e profissionalismo crescente dos negociadores e gerando a separação entre a base e a cúpula das organizações. ${ }^{681}$

\footnotetext{
${ }^{674}$ ANTUNES, Ricardo. Os sentidos do trabalho. Ensaio sobre a afirmação e a negação do trabalho. São Paulo: Boitempo, 2006, p. 38.

${ }^{675}$ Ibid., p. 38.

${ }^{676}$ Ibid., p. 38-39.

${ }^{677}$ Ibid., p. 39.

${ }^{678}$ BIHR, Alain. Du "Grand Soir" a "L 'Alternative": le Mouvement Ouvrier Européen en Crise. Les Editions Ouvriéres. Aris. (Edição Brasileira: 1998, Boitempo, Coleção Mundo do Trabalho, São Paulo), p. 50. Apud ANTUNES, Ricardo, op. cit., p. 39.

${ }^{679}$ ANTUNES, Ricardo, op. cit., p. 39.

${ }^{680}$ Ibid., p. 39.

${ }^{681}$ Ibid., p. 39-40.
} 
Para Antunes, houve um acréscimo da dependência prática e ideológica de importantes segmentos do proletariado europeu ao Estado, o Estado providência, que garante o direito ao trabalho e à seguridade social e fixa o estatuto mínimo dos assalariados, garante o respeito às convenções coletivas, além de moradia, saúde, educação, formação profissional e lazer. ${ }^{682}$

\subsection{2 - OS PRINCIPAIS MODELOS DE ESTADO SOCIAL}

As experiências mundiais de Estado Social são diversificadas, variando desde modelos com baixos níveis de gasto social e com aplicação de políticas sociais seletivas, destinadas a "complementar falhas não sistemáticas de famílias e mercado de trabalho no atendimento às necessidades básicas de indivíduos ou grupos específicos", ${ }^{683}$ até modelos que incorporaram "a noção de que o estado de bem-estar social, robusto e composto por um conjunto de intervenções de caráter universal, é um ingrediente essencial ao funcionamento normal da sociedade industrial” ${ }^{984}$.

Titmuss $^{685}$, em 1974, classificava os modelos de welfare state em: residual, baseado no princípio da subsidiariedade das instituições do bem-estar social (por exemplo, Estados Unidos); industrial, baseado no mérito/desempenho, reservando às instituições do bem-estar social o papel coadjuvante ao mercado, com a satisfação de necessidades com base no mérito, desempenho no trabalho e produtividade (por exemplo, Alemanha); e institucional, que atribui um papel central às instituições do bem-estar, principalmente na provisão de serviços universais (por exemplo, Inglaterra da época).

Kerstenetzky explica que a história de constituição dos arranjos institucionais de welfare state de cada país se confunde com os processos de construção do Estado nacional e com a incidência de forças políticas como o catolicismo, o

\footnotetext{
${ }^{682}$ ANTUNES, Ricardo. Os sentidos do trabalho. Ensaio sobre a afirmação e a negação do trabalho. São Paulo: Boitempo, 2006, p. 40.

${ }^{683}$ KERSTENETZKY, Celia Lessa. O Estado do bem-estar social na idade da razão. A reinvenção do Estado Social no mundo contemporâneo. Rio de Janeiro: Elsevier, 2012, p. 95.

${ }^{684}$ KERSTENETZKY, Celia Lessa, op. cit., p. 95.

${ }^{685}$ TITMUSS, R. Social Policy: An Introduction. New York: Pantheon Books, 1974, s/p. Apud KERSTENETZKY, Celia Lessa, op. cit. p. 96.
} 
conservadorismo e a social-democracia. ${ }^{686}$ Diz que o formato específico de cada estado do bem-estar social responde a variáveis políticas, relacionadas com coalizões de classe, ${ }^{687} \mathrm{e}$ que, para Esping-Andersen ${ }^{688}$, a variável mais importante é o poder de mobilização da classe trabalhadora.

Já a classificação de Esping-Andersen ${ }^{689}$ apresenta três modelos de welfare state: o liberal, com elevada provisão privada, baixo grau de desmercantilização e dualização do bem-estar; o conservador/corporativo, com forte provisão pública, grau intermediário de desmercantilização e segmentação ocupacional do bem-estar; e o socialdemocrata, com universalismo e elevadas provisão pública e desmercantilização. No liberal, o Estado está presente, mas apenas para garantir a centralidade do mercado, e os movimentos trabalhistas ocupam um papel menor. ${ }^{690}$

No regime liberal de welfare state, o acesso ao bem-estar se baseia no mercado, por meio do welfare ocupacional, com aposentadorias e planos de saúde fornecidos pelo emprego, ou por meio do welfare fiscal, com deduções tributárias, apoiando planos privados de pensão e/ou saúde. ${ }^{691}$ Nesse modelo, a intervenção pública busca apenas apoiar o mercado e garantir provisão residual apenas para as pessoas que não conseguem se inserir no mercado. ${ }^{692} \mathrm{O}$ mercado de trabalho é fortemente desregulamentado, com baixos salários e baixo nível de sindicalização. ${ }^{693}$

Castles $^{694}$ exemplifica os países do welfare state liberal como sendo os Estados Unidos, o Canadá, a Austrália, o Reino Unido e a Nova Zelândia e indica neles os seguintes aspectos: mercado de trabalho desregulamentado, baixa incidência de direitos sociais de cidadania e de carga tributária, baixo patamar de gasto público social bruto,

\footnotetext{
${ }^{686}$ KERSTENETZKY, Celia Lessa. O Estado do bem-estar social na idade da razão. A reinvenção do Estado Social no mundo contemporâneo. Rio de Janeiro: Elsevier, 2012, p. 97-98.

${ }^{687}$ Ibid., p. 98.

${ }^{688}$ ESPING-ANDERSEN, G. The Three Worlds of Welfare Capitalism. Princeton: Princeton University Press, 1990, s/p. Apud KERSTENETZKY, Celia Lessa, op. cit, p. 98.

${ }^{689}$ KERSTENETZKY, Celia Lessa, op. cit., p. $98 .$.

${ }^{690}$ Ibid., p. 98.

${ }^{691}$ Ibid., p. 105.

${ }^{692}$ Ibid., p. 105.

${ }^{693}$ Ibid., p. 106.

${ }^{694}$ CASTLES, F. G. The English Speaking Countries. In: CASTLES, F. G. et. al. (eds.). The Oxford Handbook of the Welfare State. Oxford: Oxford University Press, 2010, p. 630-644. Apud KERSTENETZKY, Celia Lessa, op. cit., p. 107-108.
} 
sistema de impostos e transferências pouco redistributivo, altos níveis de participação da força de trabalho, orientação para o alívio à pobreza e preferência pela provisão privada. ${ }^{695}$

Para Kerstenetzky, no regime conservador-corporativo (Alemanha, França, Áustria, Bélgica e em menor medida a Holanda) observam-se os seguintes traços: há um grau intermediário de desmercantilização, em razão da política de aposentadorias e pensões, de contribuição obrigatória para trabalhadores regulares e seus empregadores; importância diminuta do segmento privado de provisão de bem-estar; a seguridade social como o principal mecanismo de provisão de bem-estar, entre outros aspectos. ${ }^{696}$ Nesse regime, o acesso aos benefícios sociais, principalmente monetários, é baseado no trabalho e na duração da contribuição, e os benefícios são proporcionais aos ganhos passados. ${ }^{697} \mathrm{O}$ modelo baseia-se em formas coletivas de solidariedade ocupacional para cobrir os riscos sociais associados a uma sociedade industrial, mas nessa solidariedade não se inclui o desemprego duradouro. ${ }^{698}$ Nesse modelo, a cobertura da seguridade social se tornou quase universal nos anos 1970. ${ }^{699}$ Mas, o princípio distributivo que rege a alocação de benefícios é o da proporcionalidade à contribuição, o que reflete a segmentação na força de trabalho, com melhores benefícios para os trabalhadores industriais e servidores públicos e piores para os rurais, autônomos e imigrantes. ${ }^{700}$ Possui o maior grau de regulamentação do trabalho e a estrutura salarial é fortemente comprimida. ${ }^{701}$

Nos anos 1990, quando da formação da União Europeia, para que houvesse a redução de direitos, houve a negociação de substituição de benefícios (benefícios contributivos para benefícios estatais não contributivos). ${ }^{702}$ Foram introduzidas reformas, a partir dos anos 2000, como aposentadorias privadas, privatização parcial dos sistemas de saúde e busca de novas formas de financiamento, redução de aposentadorias precoces, ativação da população inativa e desfamiliarização do cuidado. ${ }^{703}$ Houve também certa

\footnotetext{
${ }^{695}$ KERSTENETZKY, Celia Lessa. O Estado do bem-estar social na idade da razão. A reinvenção do Estado Social no mundo contemporâneo. Rio de Janeiro: Elsevier, 2012, p. 107-108.

${ }^{696}$ Ibid., p. 113.

${ }^{697}$ Ibid., p. 113.

${ }^{698}$ Ibid., p. 113.

${ }^{699}$ Ibid., p. 114.

${ }^{700}$ Ibid., p. 114.

${ }^{701}$ Ibid., p. 114.

${ }^{702}$ Ibid., p. 115.

${ }^{703}$ Ibid., p. 116.
} 
alteração na forma de financiamento, com redução de contribuições sociais dos empregadores e aumento de impostos diretos e, principalmente, indiretos. ${ }^{704}$

As principais características do regime social-democrata (Dinamarca, Finlândia, Noruega e Suécia): alto grau de desmercantilização, com direitos sociais universais abrangentes e generosos; amplo conjunto de riscos sociais considerado digno de cobertura; nível generoso de benefícios; provisão pública de serviços sociais; estratificação social com elevado grau de universalização, com serviços iguais para todos; transferências universais para as famílias e aposentadorias e pensões básicas iguais, com diferenciação, dentro do sistema público, em função dos ganhos no mercado; e elevado grau de desfamiliarização, com a presença maciça de domicílios com dois trabalhadores e elevado emprego feminino e de idosos..$^{705}$

\subsection{3 - UMA CRISE DO ESTADO SOCIAL}

Muito tem sido falado a respeito de uma crise do Estado Social, no sentido de que este teria sofrido uma desfiguração nos últimos anos ou de que deveria alterar-se. A direita preconiza alteração para a redução do Estado Social, enquanto a esquerda observa preocupada que algo mudou na concepção original de Estado Social, com a ofensiva neoliberal de privatizações, de enfraquecimento da proteção jurídica aos trabalhadores, enfim, com uma opção menos velada do Estado pela defesa do capital, notadamente do capital financeiro.

Já nos anos de expansão do welfare state, os conservadores diziam que a intervenção social estatal possuía efeitos econômicos deletérios, mas a partir das últimas décadas do século XX esse discurso se intensificou. ${ }^{706}$

Marilena Chauí observa a reação dos ideólogos conservadores à crise do capitalismo:

\footnotetext{
${ }^{704}$ KERSTENETZKY, Celia Lessa. O Estado do bem-estar social na idade da razão. A reinvenção do Estado Social no mundo contemporâneo. Rio de Janeiro: Elsevier, 2012, p. 117.

${ }^{705}$ Ibid., p. 118.

${ }^{706}$ Ibid., p. 61
} 
...não foi por acaso, em meados dos anos 1970, quando o déficit fiscal do Estado e a estagflação abriram uma crise no capitalismo, que os ideólogos conservadores ofereceram uma suposta explicação para ela: a crise, disseram eles, foi causada pelo poder excessivo dos sindicatos e dos movimentos operários, que pressionaram por aumentos salariais e exigiram o aumento dos encargos sociais do Estado. Teriam, dessa maneira, destruído os níveis de lucro requeridos pelas empresas, desencadeado processos inflacionários incontroláveis e provocado o aumento colossal da dívida pública. ${ }^{707}$

Entre as teses mais difundidas nos anos 1970 e 1980 quanto às possíveis causas de uma crise do Estado Social foram as de contradição interna, na medida em que o Estado representava uma classe e seus interesses e buscava legitimidade na classe antagônica; de excesso de demandas sobre o Estado causadas pelas expectativas criadas pela democracia e de causas econômicas em razão da crise do petróleo. ${ }^{708}$

Segundo Ricardo Antunes, a crise do fordismo e de expansão do welfare state ocorreu por causa do esgotamento da fase de regulação keynesiana e em razão do ressurgimento de ações ofensivas do mundo do trabalho, gerando o transbordamento da luta de classes. ${ }^{709}$

O período de predomínio do sistema produtivo taylorista-fordista representou o surgimento de um novo proletariado (o operário-massa, parcela hegemônica do operariado, que atuava concentrada no espaço produtivo), com uma nova forma de

\footnotetext{
${ }^{707}$ CHAUÍ, Marilena. Uma nova classe trabalhadora. In: SADER, Emir (org.). 10 anos de governos pós-neoliberais no Brasil: Lula e Dilma. São Paulo: Boitempo; Rio de Janeiro: FLACSO Brasil, 2013, p. 124.

${ }^{708}$ KERSTENETZKY, Celia Lessa. O Estado do bem-estar social na idade da razão. A reinvenção do Estado Social no mundo contemporâneo. Rio de Janeiro: Elsevier, 2012, p. 62.

${ }^{709}$ ANTUNES, Ricardo. Os sentidos do trabalho. Ensaio sobre a afirmação e a negação do trabalho. São Paulo: Boitempo, 2006, p. 40.
} 
consciência de classe decorrente das novas condições de trabalho (perdera a identidade cultural da era artesanal e manufatureira e se ressocializara de modo homogeneizado). ${ }^{710}$

O novo proletariado, o "operário-massa", do período de welfare state, representou, segundo Ricardo Antunes, a base social para a expansão da social-democracia e também o principal elemento para a sua ruptura, notadamente a partir da luta pelo controle social da produção. ${ }^{711}$ Os trabalhadores, no final dos anos 60, questionavam intensamente o controle social da produção pelo capital, revoltando-se contra os métodos tayloristas e fordistas. ${ }^{712}$

O período de apogeu do processo de trabalho taylorista-fordista era marcado por grandes contradições (autonomia e heteronomia, produção e consumo). ${ }^{713} \mathrm{Na}$ produção, despotismo fabril e disciplina e no consumo a exaltação do individualismo e do indivíduo "realizador". ${ }^{714} \mathrm{O}$ aumento do consumo, contudo, já não entusiasmava as novas gerações a ponto de convencê-las a aceitarem as condições de trabalho. ${ }^{715}$

Intensificava-se a resistência dos trabalhadores ao trabalho despótico do método taylorista-fordista, por meio de absenteísmo, busca da condição de trabalho nãooperário e greves parciais, operações de zelo, formação de conselhos e propostas de controle autogestionárias. ${ }^{716}$

Assim, segundo Ricardo Antunes, a crise do sistema capitalista do fim dos anos 60 e início dos 70 decorreu das dificuldades de permanência do ciclo expansionista do capital e da intensificação das lutas de classes. ${ }^{717}$ Havia uma crise entre a base operária dos movimentos sociais e os organismos de representações desses movimentos, que se revelavam incapazes de incorporar as bases, pois tais representações eram respaldadoras do

\footnotetext{
${ }^{710}$ ANTUNES, Ricardo. Os sentidos do trabalho. Ensaio sobre a afirmação e a negação do trabalho. São Paulo: Boitempo, 2006, p. 40-41.

${ }^{711}$ Ibid., p. 41.

${ }^{712}$ Ibid., p. 41.

${ }^{713}$ Ibid., p. 41.

${ }^{714}$ Ibid., p. 41.

${ }^{715}$ Ibid., p. 41-42.

${ }^{716}$ Ibid., p. 42.

${ }^{717}$ Ibid., p. 42.
} 
capital. $^{718}$ A questão central da ação operária era o controle do processo produtivo, que estava em mãos do capital. ${ }^{719}$

Observa que os trabalhadores, contudo, não conseguiram impor um projeto hegemônico contrário ao do capital, nem conseguiram articular-se com os "novos movimentos sociais", tais como os ecológicos, urbanos, antinucleares, feministas, dos homossexuais e outros. ${ }^{720}$

A capacidade de organização dos trabalhadores conseguiu incomodar o sistema capitalista, que reagiu, com novas formas de organização do trabalho e inovações tecnológicas, utilizadas também para fins de concorrência. ${ }^{721}$ Essa nova reorganização do capital revelou-se muito mais desfavorável aos trabalhadores. ${ }^{722}$

A nova reorganização capitalista contava com uma exploração ainda mais intensa da força de trabalho, por meio da tecnologia eletrônica e da remodelagem dos sistemas de administração da empresa: tratava-se do toyotismo. ${ }^{723}$ Enquanto no taylorismo/fordismo cada trabalhador se limitava a um único tipo de operação, no toyotismo realizava um número maior de operações, era polivalente. ${ }^{724}$

Então, a partir dos anos 70, o capital deu início a um processo de reestruturação, para recuperar seu ciclo reprodutivo e impedir a conflituosidade do trabalho. ${ }^{725}$ A resposta do capital à sua crise estrutural ocorreu na forma de transformações do processo produtivo, tais como formas de acumulação flexível, downsizing, formas de gestão organizacional, avanço tecnológico, toyotismo. ${ }^{726}$

\footnotetext{
${ }^{718}$ ANTUNES, Ricardo. Os sentidos do trabalho. Ensaio sobre a afirmação e a negação do trabalho. São Paulo: Boitempo, 2006, p. 42-43.

${ }^{719}$ Ibid., p. 43-44.

${ }^{720}$ Ibid., p. 44.

${ }^{721}$ Ibid., p. 44.

${ }^{722}$ Ibid., p. 44.

${ }^{723}$ BERNARDO, João. Reestruturação capitalista e os desafios para os sindicatos. Lisboa, mimeo, 1996, p. 19-20. Apud ANTUNES, Ricardo, op. cit., p. 45.

${ }^{724}$ BERNARDO, João, op. cit., p. 19-20. Apud ANTUNES, Ricardo, op. cit., p. 45.

${ }^{725}$ ANTUNES, Ricardo, op. cit., p. 47.

${ }^{726}$ Ibid., p. 47-48.
} 
Para Celia Lessa Kerstenetzky, a tese mais convincente acerca da crise do welfare state foi a de uma crise causada por um choque externo (causa econômica), eis que os dois choques do petróleo da década de 1970 e mais uma série de transformações econômicas subsequentes contribuíram para a redução da atividade econômica e para um quadro de recessão e desemprego em diversos países, gerando diminuição das receitas, déficits e endividamento público. ${ }^{727}$ Ressalta, contudo, que a crise de financiamento do welfare state não ocorreu, eis que o gasto social continuou aumentando, ${ }^{728}$ sustentado em parte pela redução em outras áreas do gasto público, mas este, especificamente, teve retração relativa nos anos de 1980 e $1990 . .^{729}$

Perry Anderson observa que mesmo com a implantação das políticas neoliberais nos países da OCDE, durante os anos de 1980, "o peso do Estado de bem-estar não diminuiu muito, apesar de todas as medidas tomadas para conter os gastos sociais". ${ }^{730}$ Explica que, no período, a proporção absoluta consumida pelo Estado aumentou de aproximadamente $46 \%$ para $48 \%$ do PNB médio dos referidos países, em razão do "aumento dos gastos sociais com o desemprego, que custaram bilhões ao Estado, e o aumento demográfico dos aposentados na população, que levou o Estado a gastar outros bilhões em pensões". 731

Outra tese é a de crise como resultado do fim de uma "sociedade de crescimento", na medida em que durante o crescimento econômico dos anos dourados (1945-1975) houve consenso político para expansão de direitos sociais, mas posteriormente a economia perdeu dinamismo. ${ }^{732}$

Nos anos 1990, houve uma retomada da tese de crise do welfare state, dessa vez embasada no argumento de que a globalização representou transformações estruturais na economia mundial, com a eliminação de barreiras à competição mundial, com

\footnotetext{
${ }^{727}$ KERSTENETZKY, Celia Lessa. O Estado do bem-estar social na idade da razão. A reinvenção do Estado Social no mundo contemporâneo. Rio de Janeiro: Elsevier, 2012, p. 62-63.

${ }^{728}$ Ibid., p .63.

${ }^{729}$ CASTLES, F. G. The future of the welfare state - crisis myths and crisis realities. Oxford: Oxford University Press, 2004, s/p. Apud KERSTENETZKY, Celia Lessa, op. cit., p. 63.

${ }^{730}$ ANDERSON, Perry. Balanço do neoliberalismo. In: SADER, Emir \& GENTILI, Pablo (orgs.). Pós-neoliberalismo. As políticas sociais e o Estado democrático. 5. ed.. Rio de Janeiro: Paz e Terra, p. 16. ${ }^{731}$ Ibid., p. 16.

${ }^{732}$ KERSTENETZKY, Celia Lessa, op. cit., p. 63.
} 
mobilidade de capitais, redução de impostos e queda generalizada dos gastos sociais; e de que as mudanças demográficas, como aumento da expectativa de vida e a queda nas taxas de fecundidade, também pressionaram para o rompimento do estado de bem-estar. ${ }^{733}$

Com base em estudo de Arts \& Gelissen ${ }^{734}$, Célia Lessa Kerstenetzky conclui que não houve retração do welfare state. ${ }^{735}$ Os vinte e dois países da OCDE aumentaram os gastos públicos sociais, no período de 1965 a $1985 .{ }^{736}$ A autora noticia que também os estudos de Castles ${ }^{737}$ sobre os gastos sociais nos países da OCDE, no período de 1960 a 1988, revelaram expansão contínua e o gasto aumentou mais que o PIB, embora tenha sido observada uma redução parcial na seguridade social. ${ }^{738}$ Informa, ainda, que nos países da OCDE, no final dos anos 1990, o gasto social médio correspondia a mais de 50\% do gasto público, sendo que apenas os Estados Unidos e Reino Unido tinham gastos sociais inferiores a $50 \%$ dos gastos públicos. ${ }^{739}$

Kerstenetzky reconhece, contudo, como inegável que a partir de 1980 surgiram discursos políticos de austeridade e reformas redutoras de direitos. ${ }^{740}$ Nos países da OCDE, os gastos sociais tiveram certa redução, no período entre 1983 e 1989 e foram realizadas reformas previdenciárias cujos efeitos somente serão sentidos no futuro. ${ }^{741}$

Chauí observa que os ideólogos conservadores preconizavam:

... um Estado forte para quebrar o poder dos sindicatos e movimentos populares, controlar o dinheiro público e cortar drasticamente os encargos sociais e os investimentos na economia, tendo como meta principal a estabilidade monetária por meio da

\footnotetext{
${ }^{733}$ KERSTENETZKY, Celia Lessa. O Estado do bem-estar social na idade da razão. A reinvenção do Estado Social no mundo contemporâneo. Rio de Janeiro: Elsevier, 2012, p. 65.

${ }^{734}$ ARTS, W \& GELISSEN, J. Models of the welfare state. In: CASTLES, F. et. al. (eds). The Oxford Handbook of the welfare state. Oxford: Oxford University Press, 2010, p. 569-586. Apud KERSTENETZKY, Celia Lessa, op. cit., p. 66.

${ }^{735}$ KERSTENETZKY, Celia Lessa, op. cit., p.66-67.

${ }^{736}$ Ibid., p. 66-67.

${ }^{737}$ CASTLES, F. G. The Future of the Welfare State - Crisis Myths and Crisis Realities. Oxford:

Oxford University Press, 2004, s/p. Apud KERSTENETZKY, Celia Lessa, op. cit., p. 68.

${ }^{738}$ KERSTENETZKY, Celia Lessa, op. cit., p. 68.

${ }^{739}$ Ibid., p. 70.

${ }^{740}$ Ibid., p. 72.

${ }^{741}$ Ibid., p. 72.
} 
contenção dos gastos sociais e do aumento da taxa de desemprego para formar um exército industrial de reserva que acabasse com o poderio das organizações trabalhadoras. Tratava-se, portanto, de um Estado que realizasse uma reforma fiscal para incentivar os investimentos privados, reduzindo os impostos sobre o capital e as fortunas e aumentando os impostos sobre a renda individual e, assim, sobre o trabalho, o consumo e comércio. Finalmente, um Estado que se afastasse da regulação da economia, privatizando as empresas públicas e deixando que o próprio mercado operasse a desregulação, ou, traduzindo em miúdos, a abolição dos investimentos estatais na produção e do controle estatal sobre o fluxo financeiro, a drástica legislação antigreve e o vasto programa de privatização. Pinochet, no Chile, Thatcher, na Grã-Bretanha, e Reagan, nos Estados Unidos, tornaram-se a ponta de lança política desse programa. ${ }^{742}$

\subsection{4 - AS TRANSFORMAÇÕES DO ESTADO SOCIAL}

Celia Lessa Kerstenetzky explica que as reformas das décadas de 1980 e 1990 foram interpretadas como adaptações funcionais do welfare state ou remercantilização, recuo na responsabilidade pública e perda da efetividade. ${ }^{743}$

A teoria da adaptação consiste em argumentar que ocorreram mudanças econômicas, sociais e políticas, tais como a desindustrialização, a globalização, as novas estruturas de classe e composição das famílias, mudanças demográficas e novas relações de gênero, além de alterações de regime político, com democratização, reformas constitucionais e novos níveis de mobilização política. ${ }^{74}$ Teria havido uma reestruturação

\footnotetext{
${ }^{742}$ CHAUÍ, Marilena. Uma nova classe trabalhadora. In: SADER, Emir (org.). 10 anos de governos pós-neoliberais no Brasil: Lula e Dilma. São Paulo: Boitempo; Rio de Janeiro: FLACSO Brasil, 2013, p. 124.

${ }^{743}$ KERSTENETZKY, Celia Lessa. O Estado do bem-estar social na idade da razão. A reinvenção do Estado Social no mundo contemporâneo. Rio de Janeiro: Elsevier, 2012, p. 73.

${ }^{744}$ Ibid., p. 73-74.
} 
produtiva, fruto da desindustrialização, proeminência do setor de serviços e das novas tecnologias, além de envelhecimento da população e novos arranjos familiares. ${ }^{745}$

Para Francisco de Oliveira, o "rompimento do círculo perfeito do Estadoprovidência, em termos Keynesianos, é devido, em primeira instância, à internacionalização produtiva e financeira da economia capitalista". ${ }^{746}$

Uma outra teoria é de que houve mercantilização do welfare state, com perda de direitos. ${ }^{747}$ Celia Lessa Kerstenetzky menciona que Pierson ${ }^{748}$ indica diminuição de direitos ao longo das décadas de 1980 e 1990, queda do valor real dos benefícios, acesso mais restritivo aos programas e redução da participação governamental no custeio, redução das taxas médias de reposição de rendimentos nos diferentes ramos da seguridade social, notadamente de auxílio-doença, seguro-desemprego e aposentadorias. Houve remercantilização principalmente no aspecto "seguridade social" e alterações tributárias, com ampliação de impostos indiretos e de contribuições dos empregados, caracterizando o período como menos universalista e menos redistributivo.

Para a teoria da privatização, houve modificação no aspecto público-privado e esse seria o elemento definidor das transformações das últimas décadas. ${ }^{749} \mathrm{Na}$ primeira fase do welfare state, a provisão pública ocupou posição central, enquanto na nova fase houve um avanço da provisão privada. ${ }^{750}$ Contudo, nessa provisão privada existem financiamentos públicos, subsídios e renúncias tributárias - trata-se de um regime pouco progressivo, com baixo grau de redistribuição. ${ }^{751}$

Esse espírito de privatização e de desfiguração do Estado Social esteve na essência do neoliberalismo. Emir Sader explica que o neoliberalismo "nasce de uma

\footnotetext{
${ }^{745}$ KERSTENETZKY, Celia Lessa. O Estado do bem-estar social na idade da razão. A reinvenção do Estado Social no mundo contemporâneo. Rio de Janeiro: Elsevier, 2012, p. 73-74.

${ }^{746}$ OLIVEIRA, Francisco de. Os direitos do antivalor. A economia política da hegemonia imperfeita. Petrópolis: Vozes. 1998, p. 26.

${ }^{747}$ KERSTENETZKY, Celia Lessa. O Estado do bem-estar social na idade da razão. A reinvenção do Estado Social no mundo contemporâneo. Rio de Janeiro: Elsevier, 2012, p. 74-75.

${ }^{748}$ PIERSON, C. Beyond the Welfare State - The New Political Economy of Welfare. Cambridge: Polity Press, 2006, s/p. Apud. KERSTENETZKY, Celia Lessa, op. cit., p. 74.

${ }^{749}$ KERSTENETZKY, Celia Lessa, op. cit., p.76.

${ }^{750}$ Ibid., p.76.

${ }^{751}$ Ibid., p.76.
} 
crítica, antes do mais econômica, ao Estado de bem-estar" e se constitui em um "corpo doutrinário que desemboca num modelo de relações entre classes, em valores ideológicos e num determinado modelo de Estado". ${ }^{752}$ Sob o modelo hegemônico neoliberal, "existe um processo de reprivatização das relações de classe, antes fortemente permeadas pelo Estado". 753

Uma outra teoria é da perda da efetividade do welfare state, com aumento da desigualdade e da pobreza, a partir dos anos $1980 .{ }^{754}$ Contudo, Kerstenetzky observa que a análise dos países da OCDE indica que o impacto redistributivo médio do welfare state continuou elevado. ${ }^{755} \mathrm{O}$ "aumento da desigualdade observado no período de 1980 a 1990 foi puxado pela desigualdade da renda de mercado e apenas parcialmente compensado por transferências públicas e impostos sobre as famílias". ${ }^{756}$ Entre meados dos anos 1990 e meados dos anos 2000, houve redução inicial no crescimento da desigualdade da renda de mercado, mas posteriormente retornou o aumento da desigualdade da renda de mercado, sendo apenas parcialmente compensada por redistribuição e, ainda assim, em uma intensidade menor. ${ }^{757}$ A pobreza aumentou em metade dos países da área da OCDE e estagnou ou recuou levemente na outra metade. ${ }^{758} \mathrm{~A}$ pobreza relativa, em termos de renda de mercado aumentou nos países da Europa ocidental, entre 1980 e 2000 , e ela é um indicador de desigualdade social. ${ }^{759}$ A pobreza absoluta declinou, com exceção da Austrália. ${ }^{760}$

Nos países fora da área da OCDE observa-se um desenvolvimento social, no período posterior aos anos 1980, com redução de desigualdades e pobreza. ${ }^{761} \mathrm{O}$ "estado de bem-estar social começa a se expandir no Leste Asiático a partir de 1945, mas o crescimento se acelera a partir dos anos 1980, em muitos casos coincidindo com a

\footnotetext{
${ }^{752}$ SADER, Emir. A trama do neoliberalismo. Mercado, crise e exclusão social. In: SADER, Emir \& GENTILI, Pablo (orgs). Pós-neoliberalismo: as políticas sociais e o Estado democrático. 5. ed. Rio de Janeiro: Paz e Terra, p. 146.

${ }^{753}$ Ibid., p. 146.

${ }^{754}$ KERSTENETZKY, Celia Lessa. O Estado do bem-estar social na idade da razão. A reinvenção do Estado Social no mundo contemporâneo. Rio de Janeiro: Elsevier, 2012, p. 76.

${ }^{755}$ Ibid., p. 77.

${ }^{756}$ Ibid., p. 77.

${ }^{757}$ Ibid., p. 77.

${ }^{758}$ Ibid., p. 78.

${ }^{759} \mathrm{Ibid}$., p. 78.

${ }^{760} \mathrm{Ibid}$., p. 78.

${ }^{761}$ Ibid., p. 78.
} 
redemocratização dos países". ${ }^{762} \mathrm{Na}$ América Latina, a expansão ocorreu mais a partir dos anos 1990 e dos anos 2000, porque durante os anos 1980 houve a crise da dívida externa. ${ }^{763}$

A conclusão de Celia Lessa Kerstenetzky é de que o welfare state está sofrendo um processo de "remercantilização" relativa, ou seja, um trade off (barganha em que para ter-se mais de um obrigatoriamente tem-se menos de outro) entre aprofundamento vertical e expansão horizontal dos direitos para atender a uma clientela recente e individualizada; e privatização, ou seja, aumento da penetração do setor privado publicamente incentivado. ${ }^{764}$ Com isso, o welfare state está diminuindo menos a desigualdade social e a pobreza. ${ }^{765}$

Ainda que os gastos sociais não tenham sofrido diminuição financeira, ocorreu uma reforma na direção de maior provisão e governança privadas e remercantilização. ${ }^{766} \mathrm{O}$ discurso em favor da participação privada no provisão de bem-estar é cada vez mais influente, porque as necessidades sociais se elevaram e os governos tiveram dificuldades para aumentar a tributação. ${ }^{767}$ É por isso que surgiram alterações como sistemas previdenciários privados, serviços sociais privados e políticas ativas de mercado de trabalho. ${ }^{768}$ Atualmente, destaca-se a atuação do Estado na compra de serviços ao setor privado - trata-se da privatização das políticas sociais. ${ }^{769}$

\subsection{5 - A CONSTITUIÇÃO DE UM ESTADO SOCIAL NO BRASIL}

Celia Lessa Kerstenetzky observa que no período Vargas, assim como no período Bismarck, as políticas sociais tiveram múltiplas funções, no projeto de industrialização e de construção do Estado nacional. ${ }^{770}$

\footnotetext{
${ }^{762}$ KERSTENETZKY, Celia Lessa. O Estado do bem-estar social na idade da razão. A reinvenção do Estado Social no mundo contemporâneo. Rio de Janeiro: Elsevier, 2012, p. 78-79.

${ }^{763}$ Ibid., p. 79.

${ }^{764}$ Ibid., p. 79.

${ }^{765}$ Ibid., p. 79.

${ }^{766}$ Ibid., p. 80.

${ }^{767}$ Ibid., p. 80.

${ }^{768}$ Ibid., p. 80.

${ }^{769}$ Ibid., p. 80.

${ }^{770}$ Ibid., p. 178.
} 
$\mathrm{Na}$ Alemanha e demais países pioneiros do welfare state, houve durante o século XX a expansão acelerada do estado do bem-estar. ${ }^{771}$ No Brasil, essa expansão ocorreu de forma mais lenta, concentrada na legislação do trabalho e na seguridade social, podendo-se para isso citar as seguintes causas: o país partiu de uma economia agrárioexportadora de base escravista; ausência de providências significativas para incorporação dos ex-escravos à vida pública brasileira; abstinência de iniciativas de regulação das relações entre capital e trabalho, notadamente no campo. ${ }^{772}$

No período Vargas, a agenda dos direitos sociais atendeu às principais reivindicações operárias, tais como limitação da jornada de trabalho a oito horas, repouso remunerado, regulamentação do trabalho de mulheres, inclusive com remuneração igual para trabalho igual, proibição do trabalho de crianças, regulamentação do trabalho de menores, definição de um salário-mínimo, estabilidade no emprego, regulamentação das condições de trabalho quanto à segurança e higiene e regulamentação do salário em atividades insalubres, entre outros aspectos. ${ }^{773}$ Expandiu-se e modificou-se qualitativamente o padrão de proteção social iniciado timidamente com a Caixa de Aposentadoria e Pensão. ${ }^{774}$ Foram elaboradas pela primeira vez políticas sociais nacionais, abrangendo tanto a legislação trabalhista quanto a seguridade social. ${ }^{775}$

Em relação ao salário mínimo, o Decreto-lei de 1938 gerou em 1940 a primeira tabela efetiva. ${ }^{776}$ Estabeleceu-se a periodicidade trienal de reajustes. ${ }^{777} \mathrm{~A}$ partir da Constituição de 1946, incluiram-se as necessidades também da família a serem atendidas pelo salário mínimo. ${ }^{778} \mathrm{O}$ valor correspondia a $\mathrm{R} \$ 544$ ou US\$300 de 2011, chegando, em 1960, ao seu maior valor histórico, de R\$699,58 ou US\$400 de 2011.779

\footnotetext{
${ }^{771}$ KERSTENETZKY, Celia Lessa. O Estado do bem-estar social na idade da razão. A reinvenção do Estado Social no mundo contemporâneo. Rio de Janeiro: Elsevier, 2012, p. 178.

${ }^{772}$ Ibid., p. 178-179.

${ }^{773}$ Ibid., p. 189.

${ }^{774}$ Ibid., p. 189.

${ }^{775}$ Ibid., p. 189.

${ }^{776}$ Ibid., p. 190.

${ }^{777}$ Ibid., p. 190.

${ }^{778}$ Ibid., p. 190.

${ }^{779}$ Ibid., p. 190.
} 
Além disso, foram constituídos os primeiros Institutos de Aposentadoria e Pensão nacionais, os IAP's, organizados por categorias profissionais e com financiamento e governança tripartite. ${ }^{780} \mathrm{O}$ primeiro foi o IAPM, dos marítimos, em $1933 .{ }^{781} \mathrm{~A}$ novidade foi a gradativa substituição dos seguros coletivos privados por um seguro social público, representando a primeira forma de seguridade social do país, garantindo benefícios monetários e em muitos casos assistência médica. ${ }^{782}$ Significava "o reconhecimento da responsabilidade pública sobre riscos de perda de capacidade de gerar rendimentos associados ao trabalho assalariado, característico do estado do bem-estar" ${ }^{\text {"783 }}$. Anteriormente, com as Caxias de Aposentadoria e Pensão, essa responsabilidade recaía sobre a empresa e, antes delas, sobre o próprio trabalhador ou suas associações voluntárias. ${ }^{784}$

O Ministério do Trabalho regulamentava as categorias profissionais, reconhecia os sindicatos correspondentes e o exercício das profissões. ${ }^{785}$ A aquisição de direitos trabalhistas e previdenciários dependia da existência da CTPS e da sindicalização. ${ }^{786}$ Os sindicatos oficiais representavam os trabalhadores na gestão dos fundos de aposentadoria e pensão. ${ }^{787}$ A partir de 1937, a lei estabeleceu os sindicatos únicos, integrados ao Estado. ${ }^{788}$ Houve proibição de greves, forte repressão ao anarcossindicalismo e à penetração comunista na organização operária, bem como restrições à imigração e ao trabalho de estrangeiros. ${ }^{789}$ Os comunistas foram proscritos da política partidária. ${ }^{790}$ Conforme observa Kerstenetzky, esse arranjo colocou algumas pessoas dentro da proteção e outras fora, excluindo os trabalhadores rurais e os trabalhadores urbanos sem contratos formais de trabalho. ${ }^{791} \mathrm{Em} 1940$, cerca de $70 \%$ da população se encontravam no campo, o que limitava o alcance da legislação social. ${ }^{792}$

\footnotetext{
${ }^{780}$ KERSTENETZKY, Celia Lessa. O Estado do bem-estar social na idade da razão. A reinvenção do Estado Social no mundo contemporâneo. Rio de Janeiro: Elsevier, 2012, p. 190.

${ }^{781}$ Ibid., p. 190.

${ }^{782}$ Ibid., p. 191.

${ }^{783}$ Ibid., p. 191.

${ }^{784}$ Ibid., p. 191.

${ }^{785}$ Ibid., p. 193.

${ }^{786}$ Ibid., p. 193-194.

${ }^{787}$ Ibid., p. 194.

${ }^{788}$ Ibid., p. 194.

${ }^{789}$ Ibid., p. 194.

${ }^{790}$ Ibid., p. 194.

${ }^{791}$ Ibid., p. 194.

${ }^{792}$ Ibid., p. 194.
} 
No período limitadamente democrático de 1946 a 1964, houve escassas iniciativas de ativismo estatal para o desenvolvimento do estado do bem-estar no Brasil. ${ }^{793}$ Mas, houve a uniformização da previdência social e da assistência médica com a Lei Orgânica da Previdência de 1960 (um passo na direção da universalização da seguridade), a recuperação significativa do valor real do salário-mínimo (recebeu um reajuste em 1951 e três anos depois, um aumento de 100\%), a promulgação do Estatuto do Trabalhador Rural, em 1963 e a tentativa de uma reforma agrária. ${ }^{794}$ De modo geral, percebe-se uma tentativa de inflexão do modelo de bem-estar em direção a iniciativas universalistas redistributivistas. ${ }^{795}$

O Estatuto do Trabalhador Rural estendia direitos trabalhistas e previdenciários aos trabalhadores rurais, fora da lógica contributiva, mas foi revogado em 1973 e durante sua vigência teve baixa efetividade imediata. ${ }^{796}$ Em 1963, mais um benefício foi incorporado à seguridade dos trabalhadores brasileiros, o salário-família, constituindo-se no primeiro abono familiar da legislação social brasileira, com foco nas crianças e vinculado ao salário-mínimo ( $5 \%$ do salário-mínimo por dependente até a idade de 14 anos), representando outro pequeno passo na direção do universalismo. ${ }^{797}$

As políticas sociais do regime militar apontavam para um universalismo básico, mediante a incorporação de gigantesca clientela aos serviços sociais, sem a expansão proporcional da provisão de recursos financeiros. ${ }^{798}$ As novidades das políticas sociais do período foram a extensão aos trabalhadores rurais de certa proteção previdenciária (fora da lógica contributiva, no espírito do Estatuto do Trabalhador Rural) e às empregadas domésticas e autônomos; a unificação do sistema previdenciário público do país; e a montagem de segmentos públicos e privados de saúde complementares ao segmento contributivo. ${ }^{799}$

${ }^{793}$ KERSTENETZKY, Celia Lessa. O Estado do bem-estar social na idade da razão. A reinvenção do Estado Social no mundo contemporâneo. Rio de Janeiro: Elsevier, 2012, p. 180.

${ }^{794}$ Ibid., p. 180.

${ }^{795}$ Ibid., p. 180.

796 Ibid., p. 198.

${ }^{797}$ Ibid., p. 198.

${ }^{798}$ Ibid., p. 181.

${ }^{799}$ Ibid., p. 181. 
Podem-se indicar os seguintes traços distintivos do universalismo básico: expansão da previdência e assistência com inadequação dos benefícios para as novas categorias incorporadas e com diferenciação entre urbanos e rurais; no caso dos serviços, privatização e queda da qualidade do segmento público. ${ }^{800}$

Assim, durante o regime militar, a previdência social foi ampliada para incluir novos segmentos sem capacidade contributiva, como os trabalhadores rurais, mas com uma cobertura inferior à recebida pelo trabalhador urbano formal ${ }^{801} \mathrm{Na}$ saúde, uma provisão pública residual para os pobres e um vigoroso setor privado para os estratos médios e altos de renda foram somados ao segmento contributivo. ${ }^{802}$ Foram introduzidas no país as modalidades de welfare fiscal (na saúde e na educação) e ocupacional (na saúde), que implicaram aumento do "tipicamente regressivo gasto social tributário" ${ }^{803}$ Os welfare fiscal e ocupacional são, respectivamente, deduções e isenções tributárias a pessoas físicas, e deduções e isenções tributárias a empregadores. ${ }^{804}$ Vale dizer, no universalismo básico ocorreu massificação (sem universalização efetiva), com ampliação desigual de proteção e oportunidades. ${ }^{805}$

A repressão aos sindicatos e à liberdade de expressão e manifestação facilitou uma política de recomposição diferenciada dos níveis salariais, com perdas reais no salário mínimo (de mais de 30\% entre 1960 e 1970) e ganhos de mercado para os salários de profissionais qualificados. ${ }^{806}$ Além disso, houve o fim da estabilidade no emprego, mediante substituição pelo FGTS, que foi concebido para financiar políticas sociais, como habitação, saneamento e infraestrutura urbana, tendo estimulado o setor privado da construção civil, mas não foi direcionado para o deficitário segmento popular. ${ }^{807}$ Da mesma forma, outros fundos sociais, como o FAS (Fundo de Apoio ao Desenvolvimento Social), o PIS (Programa de Integração Social) e o PASEP (Programa de Formação do Patrimônio do Servidor Público) fizeram das políticas sociais boas

\footnotetext{
${ }^{800}$ KERSTENETZKY, Celia Lessa. O Estado do bem-estar social na idade da razão. A reinvenção do Estado Social no mundo contemporâneo. Rio de Janeiro: Elsevier, 2012, p. 205.

${ }^{801}$ Ibid., p. 201.

${ }^{802}$ Ibid., p. 201.

${ }^{803}$ Ibid., p. 201.

${ }^{804}$ Ibid., nota de rodapé, p. 201.

${ }^{805}$ Ibid., p. 201.

${ }^{806}$ Ibid., p. 205.

${ }^{807}$ Ibid., p. 206.
} 
oportunidades de negócio, mas reduzido instrumento de eficácia social. ${ }^{808}$ Problema de grande relevância foi o da informalidade no mercado de trabalho, que atingia cerca de $40 \%{ }^{809}$

A principal "política social" do período de 1964-1980 provavelmente foi o crescimento econômico: PIB cresceu a uma taxa média anual de $8 \%{ }^{810}$ A redução da pobreza superou a marca dos $40 \%$ entre 1970 , quando $70 \%$ da população estavam em situação de pobreza, e 1980 , quando eram $40 \%$ dos brasileiros nessa situação. ${ }^{811}$ A pobreza passou a concentrar-se nas áreas urbanas. ${ }^{812}$ No período, houve baixo índice de desemprego $(2,5 \%)$ e índices de informalidade menores do que os das décadas seguintes. ${ }^{813}$

Houve elevação do gasto social, praticamente triplicado entre 1960 e 1980, alcançando 9,2\% do PIB. ${ }^{814}$ Mas a desigualdade social aumentou: índice Gini de 0,50 em 1960 para 0,568 em 1970 e 0,59 em $1980 .{ }^{815}$ Celia Lessa Kerstenetzky indica as medidas que geraram essa desigualdade: transferências subsidiadas para o setor privado (urbano e rural; neste último, com a expansão do crédito rural para os grandes proprietários no âmbito do Estatuto da Terra); controle dos salários dos trabalhadores menos qualificados, com "subindexação" do salário-mínimo, o que também deprimiu os ganhos dos segmentos não contributivos da seguridade, indexados ao mínimo e os benefícios equivalentes ao mínimo; salários de mercado para os trabalhadores qualificados; concentração da propriedade rural e urbana e elevação de suas respectiva rendas; apropriação fortemente assimétrica de ganhos de produtividade e renda pelos lucros; regressividade do gasto social tributário (deduções fiscais em educação e saúde no imposto de renda e dedução de contribuições das empresas à previdência); pouca redistributividade do gasto social bruto, principalmente destinado aos benefícios contributivos cuja distribuição estava muito

\footnotetext{
${ }^{808}$ KERSTENETZKY, Celia Lessa. O Estado do bem-estar social na idade da razão. A reinvenção do Estado Social no mundo contemporâneo. Rio de Janeiro: Elsevier, 2012, p. 206.

${ }^{809}$ Ibid., p. 205.

${ }^{810}$ Ibid., p. 206.

${ }^{811}$ Ibid., p. 206.

${ }^{812}$ Ibid., p. 206.

${ }^{813}$ Ibid., p. 206.

${ }^{814}$ Ibid., p. 207.

${ }^{815}$ Ibid., p. 207.
} 
próxima da distribuição primária de renda e ao financiamento público dos segmentos privados de provisão de serviços; e neutralização de forças políticas de contestação. ${ }^{816}$

Em 1966, houve a criação do Instituto Nacional de Previdência Social INPS, que unificou e uniformizou os benefícios e serviços da seguridade em "uma única estrutura administrativa estatal centralizada" ${ }^{817}$ A gestão ficou apenas com o estado, sem a participação de empregados e empregadores. ${ }^{818} \mathrm{O}$ INPS representou uma expansão da cobertura de seguridade, porque anteriormente havia alto grau de diferenciação de benefícios e serviços entre os diferentes Institutos de Aposentadoria e Pensão. ${ }^{819}$

Com o Prorural, em 1971, houve o acesso do trabalhador rural à seguridade social. ${ }^{820}$ Reforçou-se o viés não contributivo do sistema. ${ }^{821}$ Contudo, o benefício previdenciário era de meio salário-mínimo e apenas para o chefe da família, além disso havia estrutura deficiente de provisão de assistência médica. ${ }^{822}$

Em 1974, houve a instituição da licença-maternidade como uma prestação da previdência social, estendendo o direito que já constava da CLT, e foi estabelecida a Renda Mensal Vitalícia, de meio salário mínimo, para idosos de 70 anos ou mais e inválidos pobres. ${ }^{823} \mathrm{~A}$ incorporação social que ocorria se dava principalmente "pela margem". 824

Em meados da década de 1970, houve suplementação da rede do INPS (setor contributivo) com uma camada pública de serviços de saúde voltada para o atendimento emergencial da população não segurada, basicamente, os trabalhadores informais. ${ }^{825}$ Durante o período de 1967 a 1975, o Estado apoiou o setor privado, com

\footnotetext{
${ }^{816}$ KERSTENETZKY, Celia Lessa. O Estado do bem-estar social na idade da razão. A reinvenção do Estado Social no mundo contemporâneo. Rio de Janeiro: Elsevier, 2012, p. 207.

${ }^{817}$ Ibid., p. 201.

${ }^{818}$ Ibid., p. 201.

${ }^{819}$ Ibid., p. 202.

${ }^{820}$ Ibid., p. 202.

${ }^{821}$ Ibid., p. 202.

${ }^{822}$ Ibid., p. 202.

${ }^{823}$ Ibid., p. 203.

${ }^{824}$ Ibid., p. 203.

${ }^{825}$ Ibid., p. 203.
} 
financiamento público, mediante compra dos serviços. ${ }^{826}$ No período entre 1974 e 1978 prevaleceram os convênios-empresa (welfare ocupacional): em troca de deduções fiscais à previdência, as empresas forneciam cobertura de saúde aos seus empregados, comprando-a do setor privado. ${ }^{827}$ A legislação introduzida entre os anos de 1966 e 1968 facultava a dedução das despesas pessoais com saúde do imposto de renda, o que beneficiava o setor privado de saúde. ${ }^{828}$ Em 1984, o PAIS (Plano de Ações Integradas da Saúde) representou uma "tentativa tardia de inflexão da expansão privatizante, com o sensível incremento da provisão pública". ${ }^{829}$

A partir de meados dos anos 1970, os problemas de endividamento externo e inflação ficaram mais intensos e emergiu um sindicalismo independente, sem raízes na tradição sindical anterior, e politizado graças à pedagogia repressora do regime, trazendo bandeiras de reajuste salarial e reivindicação por liberdades democráticas. ${ }^{830}$

A Constituição Federal de 1988 representou grandes avanços em matéria de direitos sociais, que passaram a integrar o capítulo dos direitos fundamentais.

O período de 1988 a 1994 deu início ao que Celia Lessa Kerstenetzky chamou de "universalismo estendido". ${ }^{831}$ As políticas sociais foram afetadas pelas determinações constitucionais no campo da seguridade social, que passou a abranger a previdência, a assistência social e a saúde. ${ }^{832}$ Entre as medidas mais importantes do período podem-se citar a criação do seguro desemprego e do Sistema Único de Saúde (SUS) e a aplicação das novas regras universalizantes da Previdência Rural. ${ }^{833}$

A previdência rural, regulamentada em 1991 e efetivamente implementada a partir de 1992, passou a incorporar o novo piso do salário-mínimo. ${ }^{834}$ Ela passou a

\footnotetext{
${ }^{826}$ KERSTENETZKY, Celia Lessa. O Estado do bem-estar social na idade da razão. A reinvenção do Estado Social no mundo contemporâneo. Rio de Janeiro: Elsevier, 2012, p. 203.

${ }^{827}$ Ibid., p. 204.

${ }^{828}$ Ibid., p. 204.

${ }^{829}$ Ibid., p. 204.

${ }^{830}$ Ibid,. p. 208.

${ }^{831}$ Ibid., p. 217.

${ }^{832}$ Ibid., p. 217.

${ }^{833}$ Ibid., p. 217.

${ }^{834}$ Ibid., p. 218.
} 
harmonizar-se com a previdência urbana. ${ }^{835}$ Houve a incorporação de um conjunto de novos "segurados especiais", os trabalhadores rurais em regime de economia familiar, sem contrapartida contributiva direta. ${ }^{836}$

Foram promulgadas as Leis Orgânicas da Saúde (1990) e da Assistência Social (1993), mas não foram regulamentadas no período de 1988 a $1994^{837}$. Os gastos totais per capita em saúde ficaram praticamente estagnados entre 1988 e 1990, aumentaram entre 1991 e 1993 e caíram em $1994 .{ }^{838}$

Em 1994, no contexto do Plano Real, foi criado um fundo de estabilização econômica - o Fundo Social de Emergência, posteriormente denominado de DRU "Desvinculação das Receitas da União", para garantir discricionariedade fiscal por meio da desvinculação de receitas da União e de suas destinações constitucionais, notadamente os gastos sociais (com o acordo com o FMI em 1998, o objetivo explícito passou a ser a geração de pré-fixados superávits fiscais). ${ }^{839}$ A União passou a utilizar fontes exclusivas da seguridade social para o refinanciamento da dívida pública. ${ }^{840}$ Além disso, o Fundo diminuiu sensivelmente a autonomia financeira dos Estados, Distrito Federal e Municípios. ${ }^{841}$

Os oito anos da presidência Fernando Henrique Cardoso se caracterizaram por um desenvolvimento limitado das políticas sociais, com modesta evolução do gasto social. ${ }^{842}$ Conforme observou Vladimir Safatle, durante o referido governo (1995-2002), a questão social "era tão ausente que seu presidente do Banco Central não via problemas em ir à televisão e sugerir pura e simplesmente a supressão do parágrafo da Constituição Federal que obrigava o Estado a garantir a universalização do serviço público de saúde". ${ }^{843}$

\footnotetext{
${ }^{835}$ KERSTENETZKY, Celia Lessa. O Estado do bem-estar social na idade da razão. A reinvenção do Estado Social no mundo contemporâneo. Rio de Janeiro: Elsevier, 2012, p. 218.

${ }^{836}$ Ibid., p. 218.

${ }^{837}$ Ibid., p. 218.

${ }^{838}$ Ibid., p. 219.

${ }^{839}$ Ibid., p. 219.

${ }^{840}$ Ibid., p. 219.

${ }^{841}$ Ibid., p. 219.

${ }^{842}$ Ibid., p. 220.

${ }^{843}$ SAFATLE, Vladimir. A esquerda que não teme dizer seu nome. São Paulo: Três Estrelas, 2012, p.13.
} 
Marilena Chauí explica que os dois governos de Fernando Henrique Cardoso adotaram o "neoliberalismo como princípio definidor da ação estatal (privatização dos direitos sociais, convertidos em serviços vendidos e comprados no mercado, privatização das empresas públicas, direcionamento do fundo público para o capital financeiro etc.)" ${ }^{844} \mathrm{~A}$ ideologia neoliberal preconizava e ainda defende que "o espaço público deve ser encolhido ao mínimo enquanto o espaço privado dos interesses de mercado deve ser alargado, pois considera o mercado portador de racionalidade para o funcionamento da sociedade". ${ }^{845}$

A consolidação dessa ideologia neoliberal no Brasil se fez com o discurso da modernização, "no qual modernidade significava apenas três coisas: enxugar o Estado (entenda-se: redução dos gastos públicos com os direitos sociais), importar tecnologias de ponta e gerir os interesses da finança nacional e internacional" ${ }^{846}$

Mas Marilena Chaú explica que o neoliberalismo não é a crença na racionalidade do mercado e no enxugamento do Estado, mas "sim a decisão de cortar o fundo público no polo de financiamento dos bens e serviços públicos (isto é, dos direitos sociais) e maximizar o uso da riqueza pública nos investimentos exigidos pelo capital". ${ }^{847}$

Esses períodos de governo FHC foram marcados pela priorização do controle inflacionário, tendo havido forte ajuste fiscal, sobretudo no segundo mandato (1999-2002). ${ }^{848}$ Os efeitos das medidas foram a obtenção de resultados negativos sobre o emprego e renda do trabalho; aumento do desemprego; crescimento da informalidade, com exceção do ano de 2001; interrupção da recuperação do salário médio, que vinha ocorrendo desde o início da década de 1990, mas que começou a cair em 1997 e seguiu esse movimento até 2003, com uma pequena elevação apenas em $2001 .^{849}$ Os gastos sociais tiveram redução de participação relativa no gasto público total: essa medida, que pode ser

${ }^{844}$ CHAUÍ, Marilena. Uma nova classe trabalhadora. In: SADER, Emir (org.). 10 anos de governos pós-neoliberais no Brasil: Lula e Dilma. São Paulo: Boitempo; Rio de Janeiro: FLACSO Brasil, 2013, p.127.

${ }_{845}^{\text {Ibid., p. } 127 .}$

${ }^{846}$ Ibid., p. 127.

${ }^{847}$ CHAUÍ, Marilena, op. cit., p. 127-128.

${ }^{848}$ KERSTENETZKY, Celia Lessa. O Estado do bem-estar social na idade da razão. A reinvenção do Estado Social no mundo contemporâneo. Rio de Janeiro: Elsevier, 2012, p. 220.

${ }^{849}$ Ibid., p. 220. 
utilizada como indicador da transformação do Estado moderno em um estado de bem-estar, e que supera a marca dos 50\% nos países da OCDE, declinou de 30\% em 1994 para o patamar de $26 \%$ em 2002. ${ }^{850}$ Além disso, houve prioridade dada não à expansão do gasto, mas à sua "recalibragem". 851

A recalibragem dos gastos sociais ocorreu em duas fases: no primeiro mandato: "recalibragem interna" às políticas sociais, com ênfase em um aumento da eficiência e da efetividade do gasto, revelando "a convicção por parte do governo quanto ao que considerava serem os vícios próprios das políticas sociais, em particular sua baixa efetividade". ${ }^{852}$ Nessa primeira fase, na educação, enfatizou-se o nível fundamental, na saúde, o foco recaiu sobre a atenção básica para os mais pobres, na previdência, sua reforma buscou "saneá-la" financeiramente e uniformizá-la entre aqueles que já se achavam incluídos e, na assistência, introduziram-se os até então desconhecidos programas de renda condicionais e focalizados nos pobres. ${ }^{853}$ No segundo mandato, à recalibragem interna acrescentou-se a recalibragem entre as políticas, para ganhar algum espaço no combate à pobreza, estratégia prioritária do governo: houve redução da importância relativa da previdência no gasto social, aumento significativo da assistência não constitucional (principalmente dos programas de renda condicional) e discreto aumento relativo das despesas com saúde, enquanto a educação permaneceu com prioridade inalterada. ${ }^{854}$

A previdência social foi a principal área reformada. ${ }^{855}$ A Emenda Constitucional n. 20, de 1998, alterou as suas regras, intensificando sua "consistência atuarial" ${ }^{856}$ Essa reforma resultou em diminuição da até então crescente participação da previdência no gasto social entre 1999 e 2001, com redução de $0,5 \% .{ }^{857}$

\footnotetext{
${ }^{850}$ KERSTENETZKY, Celia Lessa. O Estado do bem-estar social na idade da razão. A reinvenção do Estado Social no mundo contemporâneo. Rio de Janeiro: Elsevier, 2012, p. 221.

${ }^{851}$ Ibid., p. 221.

${ }^{852}$ Ibid., p. 221.

${ }^{853}$ Ibid., p. 221-222.

${ }^{854}$ Ibid., p. 222.

${ }^{855}$ Ibid., p. 222.

${ }^{856}$ Ibid., p. 223.

${ }^{857}$ Ibid., p. 222-223.
} 
A assistência social foi prevista como direito na Constituição Federal de 1988. Em 1996, o Benefício de Prestação Continuada (BPC) foi implantado, com a extinção da Renda Mínima Vitalícia (RMV) e sua substituição por um benefício mais adequado (no valor de um salário-mínimo) e com maior cobertura (a idade mínima para os idosos pobres caiu dos 70 anos previstos na Renda Mínima Vitalícia para 67 anos). ${ }^{858}$ Em 2003, o Estatuto do Idoso reduziu a idade de elegibilidade do benefício para 65 anos (como previsto na CF 1988) e, em 2007, houve o abrandamento do conceito de deficiência ${ }^{859}$, favorecendo o aumento no número de beneficiários. ${ }^{860}$

A assistência social passou a ser implementada, também, "em direção inusitada, com a introdução de vários programas de renda focalizados nos pobres e condicionais a contrapartidas, em geral em educação": de início, "o Programa de Erradicação do Trabalho Infantil (PETI) em 1996 e posteriormente, em 2001, com o programa Bolsa Escola, que chegou a beneficiar cinco milhões de famílias". ${ }^{861}$ Mas, conforme observa Kerstenetzky, o Benefício de Prestação Continuada "tem o valor de um salário mínimo, muito superior às transferências de renda nos demais programas e por esse motivo tende a ser mais efetivo para reduzir a incidência da pobreza". ${ }^{862}$

Para Celia Lessa kerstenetzky, durante o governo Lula buscou-se uma interação entre as políticas sociais e as políticas econômicas, ${ }^{863}$ com acelerado crescimento econômico e expansão dos gastos sociais, mediante transferências governamentais e valorização do salário mínimo. ${ }^{864}$

André Singer observa que no período do Governo Lula estabeleceu-se uma "pauta que, de um lado, manteve linhas de conduta do receituário neoliberal e, de outro, tomou decisões no sentido contrário, isto é, próprias da plataforma progressista". 865

\footnotetext{
${ }^{858}$ KERSTENETZKY, Celia Lessa . O Estado do bem-estar social na idade da razão. A reinvenção do Estado Social no mundo contemporâneo. Rio de Janeiro: Elsevier, 2012, p. 223.

${ }^{859}$ Ibid., p. 239.

${ }^{860}$ Ibid., p. 239.

${ }^{861}$ Ibid., p. 223.

${ }^{862}$ Ibid., p. 224.

${ }^{863}$ Ibid., p. 231.

${ }^{864}$ Ibid., p. 231-232.

${ }^{865}$ SINGER, André Vitor. Os sentidos do lulismo: reforma gradual e pacto conservador. São Paulo: Companhia das Letras, 2012, p. 143.
} 
Os aspectos neoliberais foram os relacionados à contenção da despesa pública, elevação dos juros, manutenção do câmbio flutuante, quase congelamento do salário mínimo e reforma previdenciária com redução de benefícios. ${ }^{866}$ Diz que tratava-se de uma escolha política para atender "as condições impostas pela classe dominante de sorte que não houvesse radicalização", 867

Explica que a plataforma progressista consistiu em iniciativas como o lançamento do Programa Bolsa Família (setembro de 2003), expansão do financiamento popular e valorização do salário mínimo (principalmente a partir de maio de 2005), entre outras medidas, ${ }^{868}$ que contribuíram para aliviar a pobreza e ativar o mercado interno de massa. ${ }^{869}$

No primeiro ano do governo Lula, 2003, houve baixo nível de atividade econômica, aumento do desemprego, queda dos salários médios, da massa salarial e dos salários reais. ${ }^{870}$ Isso foi resultado de intenso ajuste monetário e fiscal, eis que o real sofreu ataque especulativo, em razão da candidatura e vitória do candidato do PT. ${ }^{871}$ Por isso, houve aumento dos juros de 25\% para 26,5\% (nos dois primeiros meses de 2003) e aumento da meta de superávit primário de $3,75 \%$ em 2002 para $4,25 \%$ do PIB. ${ }^{872}$ O poder de compra do salário mínimo foi praticamente congelado em 2003 e $2004{ }^{873}$ Em 30 de abril de 2003 foi apresentado projeto de uma reforma conservadora da Previdência Social, a PEC 40, que entre outros aspectos, acabava com a aposentadoria integral dos futuros servidores públicos. ${ }^{874} \mathrm{O}$ crescimento do PIB caiu de 2,7\% nos últimos doze meses de Fernando Henrique Cardoso para $1,3 \%$ nos primeiros doze do PT. ${ }^{875} \mathrm{O}$ desemprego aumentou, passando de $10,5 \%$ em dezembro de 2002 para $10,9 \%$ em dezembro de $2003 .{ }^{876}$

\footnotetext{
${ }^{866}$ SINGER, André Vitor. Os sentidos do lulismo: reforma gradual e pacto conservador. São Paulo: Companhia das Letras, 2012, p. 144.

${ }^{867}$ Ibid., p. 144.

${ }^{868}$ Ibid., p. 144.

${ }^{869}$ Ibid., p. 144.

${ }^{870}$ KERSTENETZKY, Celia Lessa. O Estado do bem-estar social na idade da razão. A reinvenção do Estado Social no mundo contemporâneo. Rio de Janeiro: Elsevier, 2012, p. 232.

${ }^{871}$ Ibid., p.232-233.

${ }^{872}$ SINGER, André Vitor, op. cit., p. 10.

${ }^{873}$ Ibid., p. 10.

${ }^{874}$ Ibid., p. 10.

${ }^{875}$ Ibid., p. 10.

${ }^{876}$ Ibid., p. 11.
} 
A renda média do trabalhador caiu $12,3 \%{ }^{877}$ As instituições financeiras tiveram um resultado $6,3 \%$ maior. $^{878}$

Houve recuperação econômica no final de 2003 e ao longo de 2004, por causa das exportações, da elevação do salário mínimo real em 3,7\% em 2004, do aumento das transferências governamentais e da expansão do crédito. ${ }^{879}$ O Programa Bolsa Família foi implementado em 2004 em escala duas vezes maior que os programas de renda a que vinha paulatinamente unificar. ${ }^{880}$

Em 2004, o PIB cresceu 5,7\%. ${ }^{881}$ Em 2005, o salário mínimo foi aumentado em $8,2 \%$ acima da inflação, ${ }^{882}$ e teve um aumento real de $13 \%$ em $2006 .{ }^{883}$ A taxa de desemprego caiu para 7,4\% em dezembro de 2007 e 6,8\% em dezembro de $2009,{ }^{884}$ enquanto a média anual de desempregados em 2003 fora de 12,3\% ${ }^{885}$ "O governo Lula terminou com um desemprego na casa de 5,3\% (dezembro de 2010), próximo do pleno emprego. Foram gerados 2,5 milhões de vagas formais em 2010". 886

André Singer explica que, segundo o Ipea, entre 2003 e 2008 o percentual de pessoas abaixo da linha de pobreza absoluta no Brasil (aquelas com rendimento inferior ao "valor de uma cesta de alimentos com o mínimo de calorias neccessárias para suprir adequadamente uma pessoa, com base em recomendações da FAO e da OMS”) reduziu-se de $36 \%$ para $23 \%$ da população, enquanto no período de 1995 a 2002 a redução havia sido apenas de $35 \%$ para $34 \%{ }^{887}$

\footnotetext{
${ }^{877}$ SINGER, André Vitor. Os sentidos do lulismo: reforma gradual e pacto conservador. São Paulo: Companhia das Letras, 2012, p.11.

${ }^{878}$ Ibid., p.11.

${ }^{879}$ KERSTENETZKY, Celia Lessa. O Estado do bem-estar social na idade da razão. A reinvenção do Estado Social no mundo contemporâneo. Rio de Janeiro: Elsevier, 2012, p. 233.

${ }^{880}$ Ibid., p. 233.

${ }^{881}$ SINGER, André Vitor, op. cit., p. 145.

${ }^{882}$ Ibid., p. 145.

${ }^{883}$ Ibid., p. 148.

${ }^{884}$ Ibid., p. 147.

${ }^{885}$ Ibid., p. 147.

${ }^{886}$ Ibid., p. 147.

${ }^{887}$ Ibid., p. 131.
} 
Mas o Ipea constata que a redução da pobreza tem sido maior do que a da desigualdade, ${ }^{888}$ eis que, no período de 2003 a 2008, a taxa de pobreza absoluta teve uma redução de $36 \%$, enquanto o índice de Gini reduziu apenas de 0,58 para $0,55,{ }^{889}$ deixando o Brasil ainda em defasagem em relação a países como a Itália (Gini de 0,33), a Espanha $(0,32)$ e a França $(0,28$, em 2005), “embora se aproximasse dos EUA (0,46 em 2005), que passava por um conhecido aumento da desigualdade". ${ }^{890}$ Para Amir Khair, "apenas 1\% dos brasileiros mais ricos detém uma renda próxima dos 50\% mais pobres". ${ }^{891}$

Para Marcelo Neri, a queda do índice de Gini decorreu principalmente da ampliação dos "rendimentos do trabalho", eis que estes são responsáveis por $66 \%$ da redução da desigualdade, enquanto o aumento dos benefícios previdenciários respondem por $16 \%$ e os programas sociais $17 \%{ }^{892}$ Por isso, André Singer observa que "o fator fundamental na redução da desigualdade durante o governo Lula foi o expressivo aumento do emprego e da renda, na qual a valorização do salário mínimo teve rol crucial, e não as políticas compensatórias, fossem elas de corte neoliberal ou não". 893

Celia Lessa Kerstenetzky observa que a partir de 2006 houve crescente instrumentalização das políticas sociais para o crescimento econômico ${ }^{894}$ e uma das razões para isso pode ter sido a quitação da dívida com o FMI em 2005, ganhando o país maior discricionariedade na condução da política econômica. ${ }^{895}$

Essas políticas sociais economicamente orientadas foram as transferências governamentais (as aposentadorias dos trabalhadores do setor privado, urbano e rural, as políticas e programas assistenciais, como o BPC/LOAS e o programa Bolsa Família, o ${ }^{888}$ Ipea. Pobreza, desigualdade e políticas públicas. Comunicado da Presidência, n. 38, p. 7, 12. jan.2010. Apud SINGER, André Vitor. Os sentidos do lulismo: reforma gradual e pacto conservador. São Paulo: Companhia das Letras, 2012, p. 139.

${ }^{889}$ www.ipeadata.gov.br. Consultado em 7 fev. 2011. Apud SINGER, André Vitor, op. cit., p. 139. ${ }^{890}$ Ipea, Dimensão, evolução e projeção da pobreza por região e por estado do Brasil. Comunicados do Ipea, n.58, p.8, 13 jul. 2010. Apud SINGER, André, op. cit., p. 139.

${ }^{891}$ KHAIR, Amir. Entraves ao desenvolvimento. O Estado de S. Paulo, 4 jul. 2010, s/p. Apud SINGER, André Vitor, op. cit., p. 139.

${ }^{892}$ NERI, Marcelo. A nova classe média, o lado brilhante dos pobres. Rio de Janeiro: CPS/FGV, 2010, p.44. Disponível em www.cps.fgv.br. Consultado em 26 jun. 2012. Apud SINGER, André Vitor, op. cit., p. 184.

${ }^{893}$ SINGER, André Vitor, op. cit., p. 184.

${ }^{894}$ KERSTENETZKY, Celia Lessa. O Estado do bem-estar social na idade da razão. A reinvenção do Estado Social no mundo contemporâneo. Rio de Janeiro: Elsevier, 2012, p. 233.

${ }^{895}$ Ibid., p. 233-234. 
seguro-desemprego e o abono salarial) e a política de valorização do salário-mínimo. ${ }^{896} \mathrm{~A}$ partir de 2007 foi firmado o Pacto pela Valorização do Salário-Mínimo, com reajuste institucionalizado, com base na inflação e no PIB ${ }^{897}$ Os efeitos sociais (diminuição da desigualdade social de 0,572 no índice de Gini em 2004 para 0,538 em 2009) foram acompanhados de efeitos econômicos (crescimento do produto, emprego e formalização, aumento da arrecadação e do investimento privado, e estabilização do consumo). ${ }^{898}$ Houve uma expansão mais do que proporcional do emprego formal: a informalidade caiu continuamente entre 2005 e 2009 de $45,9 \%$ para $41,7 \%$, e a taxa de emprego formal cresceu em ritmo superior ao produto $(5,9 \%$ versus $5,1 \%){ }^{899}$

Kerstenetzky explica que a "maior reforma ocorreu nos programas de renda condicionada: estes foram unificados e significativamente ampliados com o Programa Bolsa Família, que já nasceu 60\% maior que o Bolsa Escola, atingindo 12,4 milhões de famílias em 2009". 900 "No âmbito da proteção previdenciária estavam contemplados, diretamente, $60 \%$ da população economicamente ativa (PEA) e, indiretamente, mais de $70 \%$ da população total". ${ }^{901}$ Contudo, mais de $40 \%$ da população economicamente ativa continuavam em 2009 sem qualquer proteção previdenciária direta, sendo apenas parcialmente alcançáveis pela rede de assistência. ${ }^{902}$

Segundo André Singer, "É provável que, isoladamente, a valorização do SM tenha sido a decisão mais importante da segunda fase, da mesma maneira que a criação do BF foi da primeira" do governo Lula. ${ }^{903}$ Observa que há entre os estudiosos uma convergência na percepção de que o salário mínimo é a chave para o combate à pobreza no Brasil, ${ }^{904}$ na medida em que, conforme assinala Sicsú, "estabelece o piso da remuneração do mercado formal de trabalho, influencia as remunerações do mercado informal e decide

\footnotetext{
${ }^{896}$ KERSTENETZKY, Celia Lessa. O Estado do bem-estar social na idade da razão. A reinvenção do Estado Social no mundo contemporâneo. Rio de Janeiro: Elsevier, 2012, p. 234.

${ }^{897}$ Ibid., p. 234.

${ }^{898}$ Ibid., p. 235.

${ }^{899}$ Ibid., p. 235.

${ }^{900}$ Ibid., p. 240.

${ }^{901}$ Ibid., p. 240.

${ }^{902}$ Ibid., p. 240.

${ }^{903}$ SINGER, André Vitor. Os sentidos do lulismo: reforma gradual e pacto conservador. São Paulo: Companhia das Letras, 2012, p. 148.

${ }^{904}$ Ibid., p. 148.
} 
o benefício mínimo pago pela Previdência Social". ${ }^{905}$ No Brasil, 68\% dos trabalhadores ganham até dois salários mínimos e parcela expressiva dos aposentados recebe somente um salário mínimo. ${ }^{906}$

No segundo mandato de Lula, o ritmo de expansão do PIB se acelerou, “acompanhado da ativação do emprego e do mercado interno": 907 6,1\% em 2007, 5,1\% em 2008 e 7,5\% em 2010. ${ }^{908}$ A Selic caiu de 19,75\% em agosto de 2005 para 11,25\% em setembro de 2007. ${ }^{909}$ André Singer afirma que "quatro elementos distinguiram a política econômica do 'segundo período': valorização do salário mínimo, desbloqueio do investimento público, redução da taxa de juros e queda do desemprego". 910

Após a quebra do Lehman Brothers (15 de setembro de 2008), a desorganização das finanças mundiais deixou ao setor público de cada país o encargo de impedir que houvesse ciclo de longa depressão econômica. ${ }^{911}$ No Brasil, Lula optou por ampliar o consumo popular mediante aumentos do salário mínimo, das transferências de renda, das desonerações fiscais e do alongamento do crediário. ${ }^{912}$ Com o estímulo ao mercado interno e o uso intensivo dos bancos públicos, o Estado obteve comando sobre a economia ${ }^{913}$ e conseguiu-se a geração de 1,3 milhão de vagas de empregos formais em 2009 e 2,5 milhões em $2010 .^{914}$

As medidas sociais representaram proteção contra a crise econômica mundial de 2008: manutenção do aumento real do mínimo, adição de duas parcelas extras para o seguro-desemprego, mudanças na linha de corte do Bolsa Família e no valor do benefício que permitiram o ingresso de novas famílias dentre as já constantes do cadastro único do MDS e aumentaram os repasses (a meta passou a ser o atendimento de 12,9

\footnotetext{
${ }^{905}$ SICSÚ, João. Re-visões do desenvolvimento. Inteligência, n. 49, p. 92, em www.insightnet.com.br, consultado em 20. jul.2010. Apud SINGER, André Vitor. Os sentidos do lulismo: reforma gradual e pacto conservador. São Paulo: Companhia das Letras, 2012, p. 148.

${ }^{906}$ Folha de S. Paulo, 13 jun. 2010, p. B4. Apud SINGER, André Vitor, op.cit., p. 148.

${ }^{907}$ SINGER, André Vitor, op. cit., p. 150.

${ }^{908}$ Ibid., p. 150.

${ }^{909}$ Ibid., p. 151.

${ }^{910}$ Ibid., p. 152.

${ }^{911}$ Ibid., p. 152.

${ }^{912}$ Ibid., p. 152.

${ }^{913}$ Ibid., p. 152.

${ }^{914}$ Ibid., p. 153.
} 
milhões de famílias), e aumento dos investimentos públicos do Programa de Aceleração do Crescimento (PAC) em habitação popular e para a classe média baixa. ${ }^{915}$

Foram implementadas, ainda, políticas econômicas socialmente orientadas: crédito consignado, que permitiu a inclusão financeira de milhões de aposentados do regime geral que não tinham acesso ao crédito e puderam acedê-lo tendo como colateral as transferências que recebiam do governo; o crédito subsidiado direcionado, que tornou a casa própria socialmente acessível e também se dirigiu à agricultura familiar; e a tendência à redução da taxa básica de juros, mais clara a partir de 2006, e que também impulsionou o crédito. $^{916}$

É possível observar, contudo, que a facilitação do crédito aos consumidores como medida integrante dos programas econômicos e sociais dos últimos anos gerou incentivo ao consumo e ao endividamento das famílias brasileiras. Na atualidade, constatase grande endividamento das famílias brasileiras.$^{917}$

Além de existir grande incentivo na mídia por parte do governo e das empresas para o consumo, as classes excluídas conhecem a lógica consumista do sistema capitalista e, na primeira oportunidade, tentam integrar-se ao modelo.

Para Vladimir Safatle, o aumento exponencial do endividamento das famílias demonstra como elas, atualmente, não têm renda suficiente para dar conta das novas exigências que a ascensão social coloca na mesa. O país precisa de uma nova repactuação salarial. As remunerações são, em geral, radicalmente baixas e corroídas por gastos que poderiam ser bancados pelo Estado. Por isso, ressalta que a próxima etapa do desenvolvimento nacional deverá passar pela recuperação dos salários. ${ }^{918}$

\footnotetext{
${ }^{915}$ KERSTENETZKY, Celia Lessa. O Estado do bem-estar social na idade da razão. A reinvenção do Estado Social no mundo contemporâneo. Rio de Janeiro: Elsevier, 2012, p. 236.

${ }^{916}$ Ibid., p. 237.

${ }^{917}$ http://economia.ig.com.br/2012-05-27/mais-de-14-milhões-de-famílias-estão-endividadas-no-Brasil. Acesso em 27/05/2012: "Quase um quarto das famílias se endividou mais do que deveria e foi obrigado a reduzir o padrão de vida ou a dar calote. Um estudo da consultoria MB Associados, com base na Pesquisa de Orçamento das Famílias (POF), do IBGE, mostra que 14,1 milhões de famílias comprometeram mais de 30\% da renda mensal com dívidas".

${ }^{918}$ SAFATLE, Vladimir. Os limites do lulismo. Folha de São Paulo, terça-feira, 17 de abril de 2012. A2 opinião.
} 
Os programas governamentais de transferência de renda, notadamente o Bolsa Família, tais quais implementados nos últimos dez anos, revelaram-se muito importantes para o combate à pobreza e à desigualdade social. Não seria admissível manter milhares de pessoas em situação de completo desamparo social.

As críticas que tais medidas merecem são à esquerda e não pelo viés da direita. Por isso, sem desprezar a grande importância de tais programas, no contexto de construção da justiça social, é preciso não descuidar da relação capital e trabalho e reconduzi-la à categoria de centralidade em nossa sociedade. Não podemos aceitar o desemprego como fatalidade, nem a precarização das relações de trabalho ou qualquer medida que signifique a intensificação da exploração da classe trabalhadora.

Com o obscurecimento e o abandono da luta focada contra o centro vital responsável pela estruturação econômica, política, jurídica e ideológica de toda a ordem - e caos - da sociedade capitalista, proliferam políticas e ações pontuais, fragmentadas e desconexas, dirigidas a "consertar" os maiores estragos provocados por aquela ordem, compensar, pelo menos em parte, as conseqüências "naturais" de um sistema inquestionável... Ações ou projetos sempre situados no terreno periférico das conseqüências (as inúmeras propostas de renda mínima, a volta da filantropia em larga escala, o incentivo a inúmeras formas de atividades vinculadas ao "terceiro setor", quase sempre mal remuneradas ou praticamente voluntárias, em troca de cestas básicas ou outros tipos de ajudas), enquanto o capital continua no comando da esfera produtiva e dos principais núcleos de poder sem qualquer restrição. ${ }^{919}$

${ }^{919}$ GRAZIA, Giuseppina Rosaria De. A redução e redistribuição do tempo de trabalho em questão. Tese de doutorado. Departamento de Sociologia da FFLCH-USP, São Paulo, 2003, p. 29. 
José Paulo Netto 920 observa que a renda mínima para "os menos afortunados", gerida pelo poder público, trata-se de uma ideia desenvolvida originalmente por Friedman, um dos principais teóricos do neoliberalismo, como um dos poucos papeis reservados ao Estado na política neoliberal.

Conforme observa Giuseppina Rosaria De Grazia, essa ideia "se ajusta perfeitamente ao novo modelo produtivo e político": 921

deixa intacto o sistema de exploração, não pressiona pela redistribuição dos lucros ... e diminui os perigos de convulsões sociais, mantendo a enorme parcela dos "beneficiários" de cabeça baixa e grata aos seus "benfeitores". ${ }^{922}$

Fernando Marques de Campos explica que o tratamento da pobreza pelos programas assistenciais, combinado com a privatização de serviços de seguridade, faz parte do discurso do grande capital, com vistas à obtenção de um Estado mínimo:

Ou seja, o discurso do grande capital gravita em torno da cultura política da crise, seu modus operandi pauta-se na criação e na busca de consenso entre as classes, advogando a premência do tratamento da pobreza pelos programas assistenciais, ao mesmo tempo em que prega a necessidade da privatização de alguns serviços da seguridade - previdência e saúde, de modo a ter como resultado final um Estado Mínimo, bem como reduzir os impactos sociais dos ajustes econômicos neoliberais ${ }^{923}$.

\footnotetext{
${ }^{920}$ NETTO, José Paulo. Crise do socialismo e ofensiva neoliberal. 3. ed. São Paulo: Cortez, 2001, p. 80. Apud GRAZIA, Giuseppina Rosaria De. A redução e redistribuição do tempo de trabalho em questão. Tese de doutorado. Departamento de Sociologia da FFLCH-USP, São Paulo, 2003, p. 29.

${ }^{921}$ GRAZIA, Giuseppina Rosaria De, op. cit., p. 29.

922 Ibid., p. 29.

${ }^{923}$ CAMPOS, Fernando Marques de. Os direitos sociais e sua função no capitalismo. Dissertação de mestrado. Faculdade de Direito da USP, São Paulo, 2010, p. 182.
} 
Para Ana Elizabete Simões da Mota Fernandes, ${ }^{924}$ as classes dominantes tentam se relacionar com a classe trabalhadora sob a perspectiva de cidadãos proprietários consumidores e/ou cidadãos pobres e assistidos.

o processo vem sendo molecularmente trabalhado pela burguesia, na medida em que as classes dominantes tentam socializar com as classes trabalhadoras um suposto dilema da justiça e equidade capitalistas, como sendo uma problemática dos assalariados, agora reconceituados como cidadãos proprietários consumidores e/ou cidadãos pobres e assistidos. Aliás, uma precondição para o desenvolvimento do que nomeamos de movimento sincrônico de assistencialização/privatização da seguridade social ${ }^{925}$.

André Singer observa que 56\% da população brasileira ainda não usufruem de acesso ao esgotamento sanitário e que "segundo o IBGE, em 2008, 43\% das moradias deveriam ser consideradas inadequadas". ${ }^{926}$

Há um embate constante entre trabalhadores e o capital (em particular o capital financeiro) sobre a destinação do gasto público, eis que o capital pressiona pela contenção dos gastos sociais e a alocação para pagamento de juros. ${ }^{927}$

\footnotetext{
${ }^{924}$ FERNANDES, Ana Elizabete Simões da Mota. Cultura da crise e seguridade social: um estudo sobre as tendências da previdência e da assistência social brasileira nos anos 80 e 90 . São Paulo: Cortez, 1995, p. 147. Apud CAMPOS, Fernando Marques de. Os direitos sociais e sua função no capitalismo. Dissertação de mestrado. Faculdade de Direito da USP, São Paulo, 2010, p. 182.

${ }_{925}$ CAMPOS, Fernando Marques de, op. cit., p. 182.

${ }^{926}$ SINGER, André Vitor. Os sentidos do lulismo: reforma gradual e pacto conservador. São Paulo: Companhia das Letras, 2012, p. 129-130.

${ }^{927}$ Ibid., p. 157.
} 


\section{4 - O ESTADO NEOLIBERAL}

\subsection{1 - ASPECTOS GERAIS}

No final dos anos 1960, com a recuperação da economia dos países europeus e com a inserção do Japão na realidade econômica, houve um certo abalo na hegemonia econômica norte-americana. A esse fator, associa-se a crise do petróleo, ocorrida a partir de outubro de 1973, quando os Estados integrantes da OPEP (Organização dos Países Exportadores de Petróleo) declararam a elevação do preço do "óleo cru", de 3 para 12 dólares, com posteriores e sucessivos aumentos. ${ }^{928}$ Como reação a essas circunstâncias foi forjado o neoliberalismo, com aprofundamento desse novo modelo a partir de 1989, após o esfacelamento da União Soviética, queda do "muro de Berlim" e "fim da guerra fria".

Trata-se de uma ideologia, acompanhada de um conjunto de medidas, propagados pelos Estados Unidos e impostos a muitos países, notadamente os da América Latina, a fim de defender os interesses de grandes empresas norte-americanas. Um de seus traços centrais é a campanha mundial contra os direitos dos trabalhadores.

O neoliberalismo atua contra a direção do estado de bem-estar social: preconiza teses consideradas pré-históricas, como a privatização dos serviços de saúde, do sistema educacional, a diminuição da proteção social ao trabalho, o incremento da desigualdade como fator de crescimento econômico. ${ }^{929}$ Ele "representa o projeto de realização máxima do capitalismo, na medida em que visa a mercantilização de todos os espaços das formações sociais". ${ }^{930}$

Conforme observou Sérgio Alberto de Souza, no Brasil, uma década de convivência com a incerteza econômica e a instabilidade política nos anos de 1980 transformaram em consenso, durante os anos 1990, a ideia de que a crise brasileira tinha

\footnotetext{
${ }^{928}$ SOUZA, Sérgio Alberto de. Direito, globalização e barbárie - estudos críticos de temas de direito do trabalho e de direitos humanos sob a ótica de uma leitura não-liberal. São Paulo: LTr, 1998, p. 30. ${ }^{929}$ Ibid., p. 51-52.

${ }^{930}$ SADER, Emir. A construção da hegemonia pós-neoliberal. In: SADER, Emir (org.) 10 anos de governos pós-neoliberais no Brasil: Lula e Dilma. São Paulo: Boitempo; Rio de Janeiro: FLACSO Brasil, 2013, p. 135.
} 
uma natureza que transcendia flutuações conjunturais e generalizou-se a convicção de que o epicentro da crise estava no Estado. ${ }^{931}$ Por aqui, o neoliberalismo foi muito intenso na década de 1990 e ainda hoje seu ideário permanece firme nos propósitos de parcela hegemônica do empresariado e da mídia nacionais.

Emir Sader explica que a transição democrática no Brasil teve força para convocar uma Assembleia e dotar-se de uma carta de democracia restaurada, restabelecendo direitos cassados pela ditadura, mas que tinha dificuldades de ser implementada porque nascia na contramão da onda neoliberal. ${ }^{932}$

Durante o governo Sarney aliaram-se "características políticas do velho e novo regime, que impediram que a democratização política se desdobrasse em democratização econômica, social e cultural"933 e esse traço "esgotou o impulso democratizador da sociedade brasileira, permitindo que a polarização democracia/ditadura saísse de cena, dando lugar aos paradigmas neoliberais, representados inicialmente por Fernando Collor". 934

O processo de transição democrática se esgotava assim sem ter democratizado o poder econômico no Brasil. Não se democratizou o sistema bancário, nem os meios de comunicação, nem a propriedade da terra, nem as grandes estruturas industriais e comerciais. O fim da ditadura não representou a democratização da sociedade brasileira. O país continou sendo o mais desigual do continente, um dos mais desiguais do mundo. ${ }^{935}$

\footnotetext{
${ }^{931}$ SOUZA, Sérgio Alberto de. Direito, globalização e barbárie - estudos críticos de temas de direito do trabalho e de direitos humanos sob a ótica de uma leitura não-liberal. São Paulo: LTr, 1998, p. 51-52.

${ }^{932}$ SADER, Emir. A construção da hegemonia pós-neoliberal. In: SADER, Emir (org.) 10 anos de governos pós-neoliberais no Brasil: Lula e Dilma. São Paulo: Boitempo; Rio de Janeiro: FLACSO Brasil, 2013, p. 137.

${ }^{933}$ Ibid., p. 137.

${ }^{934}$ Ibid., p. 137.

${ }^{935}$ Ibid., p. 137.
} 
O "neoliberalismo no Brasil promoveu dois fenômenos centrais, ambos negativos: a financeirização da economia e a precarização das relações de trabalho," ${ }^{936}$ eis que tais relações foram submetidas a processos de informalização e expropriação de direitos essenciais dos trabalhadores. ${ }^{937}$

Nas diretrizes do neoliberalismo, capitaneadas principalmente pelo Fundo Monetário Internacioal (FMI) e Banco Mundial (BIRD) estavam a desestatização, desregulação, privatização, liberalização e regionalização, com o deslocamento da soberania nacional (tomada como parâmetro pelo liberalismo) para as organizações, corporações e outras entidades de âmbito global. ${ }^{938}$

Paradoxalmente à teoria liberal, que preconizava a essencialidade do Estado, a ideologia neoliberal propunha o fim do Estado, não com o mesmo objetivo da corrente socialista, mas a fim de permitir o avanço do capital, sem limitações. Na verdade, o neoliberalismo pretende a omissão do poder público quanto aos programas sociais e a canalização dos recursos para o capital. Conforme pondera Jorge Luiz Souto Maior, se o Estado tem representado algum empecilho a esses objetivos neoliberais, então deve ser preservado, como algo importante para impedir injustiças na vida em sociedade. ${ }^{939}$

A primeira experiência neoliberal sistemática no mundo ocorreu durante a ditadura de Pinochet (implantada para destruir um projeto progressista de avanços sociais em andamento), no Chile, com a ajuda direta de economistas norte-americanos chamados “Chicagos Boys", mediante a implantação de desregulação, desemprego em massa, repressão sindical, redistribuição de renda em favor dos ricos e privatização de bens públicos, mas foi com os governos de Margareth Tatcher na Inglaterra (1979-1990) e Ronald Reagan nos Estados Unidos (1981-1989), que o neoliberalismo obteve projeção mundial. ${ }^{940}$

${ }^{936}$ SADER, Emir. A construção da hegemonia pós-neoliberal. In: SADER, Emir (org.) 10 anos de governos pós-neoliberais no Brasil: Lula e Dilma. São Paulo: Boitempo; Rio de Janeiro: FLACSO Brasil, 2013, p. 137-138.

${ }^{937}$ Ibid., p. 137-138.

${ }^{938}$ IANNI, Octavio. Teorias da globalização. 8. ed. Rio de Janeiro: Civilização Brasileira, 2000, p. 100.

${ }^{939}$ SOUTO MAIOR, Jorge Luiz. O direito do trabalho como instrumento de justiça social. São Paulo: LTr, 2000. p. 237.

${ }^{240}$ SOUZA, Sérgio Alberto de. Direito, globalização e barbárie - estudos críticos de temas de direito do trabalho e de direitos humanos sob a ótica de uma leitura não-liberal. São Paulo: LTr, 1998, p. 80. 
A elaboração da doutrina neoliberal contou com os "fundamentos das severas políticas econômicas elaboradas por Friedrich Hayek", ${ }^{441}$ em sua obra "O Caminho da Servidão", de 1944 e com a inspiração principal nas obras do economista Milton Friedman. ${ }^{942}$

Um momento de destaque na história da ofensiva neoliberal foi o Consenso de Washington, nome informalmente atribuído às conclusões de reuniões com formato acadêmico, ocorridas em novembro de 1989, em Washington, entre representantes do governo norte-americano direto, das agências norte-americanas, do FMI, Banco Mundial e BID e representantes dos países latino-americanos, a fim avaliar as reformas econômicas em andamento na América Latina, já como resultado de recomendações anteriores, sempre com a perspectiva de atribuir unicamente a fatores internos de cada país a crise econômica e preconizar um projeto de "Estado Mínimo".943

As elites políticas, empresariais e intelectuais da região sulamericana receberam as medidas neoliberais como sinônimo de modernidade. ${ }^{944}$ Em 1998, ainda durante o período de apogeu neoliberal no Brasil, Sérgio Alberto de Souza dizia que a "verdade do neoliberalismo é tida como moderna e quem não a aceita é apontado como herege". 945

As reformas comerciais liberalizantes recomendadas pelo Banco Mundial e avalizadas pela Fiesp foram fielmente encampadas pelo governo Collor, até mesmo no que se refere à postura assumida na denominada "Rodada Uruguai" (Criação da OMC Organização Mundial do Comércio), de alinhamento às posições norte-americanas na questão agrícola e nos novos temas normativos de serviços e de propriedade intelectual. ${ }^{946}$ A ata final da Rodada Uruguai foi assinada em 15 de abril de 1994, em Marrakesh,

\footnotetext{
${ }^{941}$ SOUZA, Sérgio Alberto de. Direito, globalização e barbárie - estudos críticos de temas de direito do trabalho e de direitos humanos sob a ótica de uma leitura não-liberal. São Paulo: LTr, 1998, p.30.

${ }_{942}$ ANDERSON, Perry et al. A trama do neoliberalismo - Mercado, crise e exclusão social. In: SADER, Emir \& GENTILI, Pablo (orgs). Pós-neoliberalismo: as políticas sociais e o Estado democrático. Rio de Janeiro: Paz e Terra, 1995, p. 139.

${ }^{943}$ SOUZA, Sérgio Alberto de, op. cit., p. 79.

${ }^{944}$ Ibid., p. 80.

${ }^{945}$ Ibid., p. 46.

${ }^{946}$ Ibid., p. 80.
} 
Marrocos, passados sete anos do início das negociações comerciais multilaterais em Punta del Este, Uruguai. ${ }^{947}$

A estratégia neoliberal foi passar a ideia de que as classes dirigentes latinoamericanas se deram conta, "espontaneamente", de que a gravíssima crise econômica que enfrentavam não tinha raízes externas - a alta dos preços do petróleo, a alta das taxas internacionais de juros, a deterioração dos termos de intercâmbio - e se devia, apenas às equivocadas políticas nacionalistas que adotavam e às formas autoritárias de governo que praticavam. ${ }^{948}$ Assim, a solução residiria em "reformas" neoliberais apresentadas como propostas "modernizadoras", contra o anacronismo de nossas estruturas econômicas e políticas. ${ }^{949}$

O neoliberalismo é a manifestação selvagem e agressiva do capital financeiro, mediante a abertura sem limites dos países para o capital financeiro globalizado, para a marginalização social e a ameaça às liberdades públicas, aos direitos sociais e à soberania das nações que não integram o grupo restrito das potências imperialistas. ${ }^{950}$ É a "volta à barbárie" ${ }^{951}$ e a busca de resolver as contradições do sistema capitalista pela fome, exclusão e violência, ${ }^{952}$ nas palavras de Sérgio Alberto Alberto de Souza, com as quais concordamos inteiramente. No mesmo sentido, Ricardo Antunes, que observa que o neoliberalismo possui um forte caráter destrutivo, tendo gerado problemas sociais, com a precarizacão do trabalho e o desemprego, e ambientais, com a degradação da natureza. ${ }^{953}$

Os neoliberais exigem que o direito revogue a disciplina e o regime de atuação do Estado, em busca de total desregulamentação, a fim de facilitar suas estratégias econômicas. ${ }^{954}$ Sérgio Alberto de Souza observa que o "mercado foi elevado ao nível de

${ }^{947}$ SOUZA, Sérgio Alberto de. Direito, globalização e barbárie - estudos críticos de temas de direito do trabalho e de direitos humanos sob a ótica de uma leitura não-liberal. São Paulo: LTr, 1998, p. 80.

${ }^{948}$ Ibid., p. 80.

${ }^{949}$ Ibid., p. 80.

${ }^{950}$ Ibid., p. 9.

${ }^{951}$ Ibid., p. 10.

${ }^{952}$ Ibid., p. 21.

${ }^{953}$ ANTUNES, Ricardo. O neoliberalismo e a precarização estrutural do trabalho na fase de mundialização do capital. In: SILVA, Alessandro da. et. al. (coords.). Direitos humanos: essência do direito do trabalho. São Paulo: LTr, 2007, p. 38-39.

${ }^{954}$ SOUZA, Sérgio Alberto de, op. cit., p. 10. 
divindade" ${ }^{955}$ e explica que o imperialismo fez três tentativas de dominar o mundo no século XX: as duas Guerras Mundiais e o neoliberalismo, que se estendeu a mais de cem países. ${ }^{956}$

Para Emir Sader, do "ponto de vista econômico, o diagnóstico dos neoliberais de que as regulamentações eram um obstáculo ao crescimento econômico levou a menos controles estatais e ao livre-comércio": 957

Porém, como o capital não foi feito para produzir, mas para acumular- como ensinou Marx - , houve um fantástico processo de transferência mundial de capitais do setor produtivo para o financeiro, sob a modalidade especulativa. A crise profunda dos países do centro do capitalismo, iniciada em 2008 e que se seguiu, ainda sem horizonte de superação, revelou a fragilidade da hegemonia de um modelo centrado na acumulação financeira. ${ }^{958}$

O neoliberalismo colocou em andamento uma reelaboração e redefinição das próprias formas de representação e significação social, da qual o desemprego dos trabalhadores é uma das "faces" mais cínicas. ${ }^{959}$ O projeto neoliberal envolve a criação de um espaço em que se torne impossível pensar o econômico, o político e o social fora das categorias que justificam o arranjo social capitalista. ${ }^{960}$

Economicamente, o neoliberalismo fracassou e não conseguiu nenhuma revitalização básica do capitalismo avançado, ${ }^{961}$ tendo conseguido gerar a partir de 2008 a maior crise do capitalismo desde 1929. Socialmente, o neoliberalismo conseguiu muitos objetivos: criou sociedades muito mais desiguais. ${ }^{962}$

\footnotetext{
${ }^{955}$ SOUZA, Sérgio Alberto de. Direito, globalização e barbárie - estudos críticos de temas de direito do trabalho e de direitos humanos sob a ótica de uma leitura não-liberal. São Paulo: LTr, 1998, p.10. ${ }^{956}$ Ibid., p. 21.

957 SADER, Emir. A construção da hegemonia pós-neoliberal. In: SADER, Emir (org.) 10 anos de governos pós-neoliberais no Brasil: Lula e Dilma. São Paulo: Boitempo; Rio de Janeiro: FLACSO Brasil, 2013, p. 135.

${ }^{958}$ Ibid., p. 135-136.

${ }^{959}$ SOUZA, Sérgio Alberto de, op. cit., p. 40.

${ }^{960}$ Ibid., p. 40.

${ }^{961}$ Ibid., nota de rodapé, p. 50.

${ }^{962} \mathrm{Ibid}$., nota de rodapé, p. 50.
} 


\subsection{2 - A GLOBALIZAÇÃO COMO MODELO CIVILIZATÓRIO}

O desenvolvimento do capitalismo sempre revelou uma tendência à internacionalização, conforme se constata pela análise do mercantilismo, colonialismo, imperialismo e processos de dependência e interdependência. ${ }^{963}$ Contudo, a intensificação da internacionalização do capital no pós Segunda Guerra Mundial deu os contornos de uma nova fase do capitalismo, que se tornou efetivamente global, alterando as condições dos movimentos e formas de reprodução do capital em âmbito nacional. ${ }^{964}$

Essa fase trouxe profundas influências não apenas nas relações de produção, mas no modo de vida das pessoas. ${ }^{965}$ O globo terrestre, nas palavras de Octavio Ianni, passou a ser uma figura histórica e não mais apenas astronômica, o que alterou o modo de "ser, pensar, fabular" $" 966$.

Houve uma mundialização do mercado, das forças produtivas, da nova divisão internacional do trabalho e da reprodução ampliada do capital. A economia nacional tornou-se província da economia global. ${ }^{967}$ A globalização passou a envolver a produção material e espiritual. ${ }^{968}$

Essa internacionalização do capital assentou-se na globalização da produção e do consumo (fábrica global e shopping center global), mediante a agilização e generalização das técnicas eletrônicas e representou intensificação do processo de concentração e centralização do capital ${ }^{969}$. Houve dispersão geográfica da produção ou das forças produtivas, incluindo o capital, a tecnologia, a força de trabalho, a divisão do trabalho social, o planejamento e o mercado. ${ }^{970}$

\footnotetext{
${ }^{963}$ IANNI, Octavio. Teorias da globalização. 8. ed. Rio de Janeiro: Civilização Brasileira, 2000, p. 14.

${ }^{964}$ Ibid., p. 55.

${ }^{965}$ Ibid., p. 55.

${ }^{966}$ Ibid., p. 14.

${ }^{967}$ Ibid., p. 18.

${ }^{968}$ Ibid., p. 18.

${ }^{969}$ Ibid., p. 19.

${ }^{970}$ Ibid., p. 57.
} 
A tecnologia de base microeletrônica teve profunda influência no processo de globalização da economia, na medida em que possibilitou maior velocidade da informação e da comunicação. ${ }^{971}$

A organização do trabalho e da produção recebeu os impactos da tecnologia de base microeletrônica: expansão da automação da linha de montagem fordista para diversos ramos da indústria e para o setor de serviços. ${ }^{972}$ Os avanços tecnológicos (microeletrônica, automação, robótica e a informática) intensificaram as capacidades dos processos de trabalho e de produção. ${ }^{973}$ Tais avanços tecnológicos, contudo, aprofundaram as desigualdades sociais. ${ }^{974}$

A mundialização do capital e da economia foi acompanhada da propagação de institutos e valores próprios das sociedades capitalistas dominantes. ${ }^{975}$ Houve generalização dos princípios envolvidos no mercado e no contrato, tais como mercado, livre empresa, produtividade, desempenho, consumismo, lucratividade, tecnificação, automação, robotização, flexibilização, informática, telecomunicações, redes, técnicas de produção de realidades virtuais. ${ }^{976}$

A propagação e imposição de valores e institutos das sociedades capitalistas dominantes dos Estados Unidos e da Europa Ocidental tendem ao predomínio do "homo economicus" e do "homo politicus", ao individualismo possessivo, relativo à propriedade e ao mercado. ${ }^{977}$

Essa propagação compartilha do pensamento de Adam Smith, no que se refere à "mão invisível" que garantiria o bem-estar de todos, mediante os princípios do mercado, do ideário do liberalismo e do neoliberalismo: economia e liberdade, liberdade

\footnotetext{
${ }^{971}$ SILVA, Walküre Lopes Ribeiro da. Crise de representatividade e participação dos sindicatos em políticas ativas de emprego. Tese apresentada para concurso de Professor Titular de Direito do Trabalho da Faculdade de Direito da USP, São Paulo, 2001, p. 27.

${ }_{972}$ Ibid., p. 27.

${ }^{973}$ IANNI, Octavio. Teorias da globalização. 8. ed. Rio de Janeiro: Civilização Brasileira, 2000, p. 195.

${ }^{974}$ Ibid., p. 195-196

${ }^{975}$ Ibid., p. 102.

${ }^{976}$ Ibid., p. 102.

${ }^{977}$ Ibid., p. 98.
} 
econômica como condição de liberdade política e liberdade e igualdade de proprietários garantidas pelo contrato codificado no direito. ${ }^{978}$

Para Octavio Ianni, na base ideológica da propagação desses valores, de modernização e globalização, encontram-se o princípio da precedência da liberdade econômica em face da política e a primazia da cidadania política em face da social e cultural, o estabelecimento das condições e limites para as mudanças sociais e as garantias contra as ideias revolucionárias traduzidas em práticas. ${ }^{979}$

Conforme esclarece Giuseppina Rosaria de Grazia, a globalização ou mundialização das economias tem sido marcada por uma concentração de riquezas e poder de decisão nunca vistos, com a consolidação da hegemonia norte-americana, do capital financeiro e das grandes corporações transnacionais no comando do sistema produtivo e da nova ordem internacional, por meio da monopolização dos investimentos em pesquisa e tecnologia, que os faz comandar a nova divisão internacional do trabalho, redefinir a organização da produção e do emprego a nível mundial e concentrar nos países de origem as atividades produtivas mais relacionadas a funções de comando e planejamento, deslocando para os países pobres as atividades de execução e produção que exigem ocupações mais simples e menos remuneradas ${ }^{980}$ (as economias não desenvolvidas transformam-se em uma grande feira mundial de concorrência pelos menores custos de trabalho possíveis, conforme alertou Márcio Pochmann ${ }^{981}$ ). Tudo isso confirmando as lições de Marx, no sentido de que o capital tem uma lógica de tendência à internacionalização, em busca de contínua e crescente valorização. ${ }^{982}$

Para Sérgio Alberto de Souza, os sinais de transformação na economia política do final do século XX estão presentes nos processos de trabalho, nos hábitos de consumo, nas configurações geográficas e geopolíticas e nos poderes e práticas do Estado,

\footnotetext{
${ }_{978}^{97 A N N I, ~ O c t a v i o . ~ T e o r i a s ~ d a ~ g l o b a l i z a c ̧ a ̃ o . ~ 8 . ~ e d . ~ R i o ~ d e ~ J a n e i r o: ~ C i v i l i z a c ̧ a ̃ o ~ B r a s i l e i r a, ~ 2000, ~ p . ~} 100$.

${ }^{979}$ Ibid., p. 99-100.

${ }^{980}$ GRAZIA, Giuseppina Rosaria De. A redução e redistribuição do tempo de trabalho em questão. Tese de doutorado. Departamento de Sociologia da Faculdade de FFLCH-USP, São Paulo, 2003, p. 147.

${ }^{981}$ POCHMANN, Márcio. O emprego na globalização. São Paulo, Boitempo, 2011, p. 8.

${ }^{982}$ GRAZIA, Giuseppina Rosaria De, op. cit., p. 147.
} 
entre outros. ${ }^{983}$ Há uma transição no regime de acumulação e no modo de regulamentação estatal, social e política, associado a tal regime de acumulação. ${ }^{984}$

\subsection{3 - A DESPRIVATIZAÇÃO DO ESTADO BRASILEIRO}

Conforme observa Sérgio Alberto de Souza, no Brasil, os empresários liberais são antiestatais, mas mantêm relações de dependência clientelista com o Estado, no sistema do "é dando que se recebe", que acabou por representar, no plano institucional, uma privatização do Estado e da ordem. ${ }^{985}$

Os capitalistas no Brasil sempre foram dependentes do Estado. Tiveram muito medo de correr risco. Apropriaram-se do Estado como se fosse coisa pertencente ao seu patrimônio, como se a finalidade dele fosse apenas servi-los.

Sérgio Alberto de Souza observa, que, na verdade, ao contrário do que prega a ideologia neoliberal, o Estado precisa é ser "desprivatizado", ${ }^{986}$ e deixar de ser um instrumento "dos interesses particulares, uma garantia dos interesses privados, um protetor deles, para ser instrumento da sociedade (...), isto é, do povo brasileiro". 987

No mesmo sentido, Vladimir Safatle, que, analisando as relações negociais, que mesmo em 2013, certos setores da burguesia nacional e da sociedade civil mantêm com o Estado, em um processo de "privatização branca", com "negócios de mãe para filho", questiona "se a crítica liberal clássica ao Estado-providência não é, no fundo, uma cortina de fumaça que visa esconder quem são os verdadeiros protegidos". 988

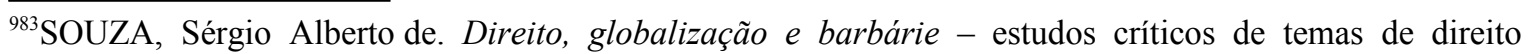
do trabalho e de direitos humanos sob a ótica de uma leitura não-liberal. São Paulo: LTr, 1998, p. 29-30.

${ }^{984}$ Ibid., p. 29-30.

${ }^{985}$ Ibid., p. 52.

${ }^{986}$ Ibid., p. 65.

${ }^{987}$ Ibid., p. 65.

${ }^{988}$ SAFATLE, Vladimir. Estado-mãe. Folha de São Paulo, 21 de maio de 2013, p.A2.
} 


\subsection{4 - A EMPRESA MULTINACIONAL}

Há um liame entre a multinacionalização das empresas e a globalização do capital, multinacionalização que é ao mesmo tempo produto e reprodução da lógica da globalização do capital, e esta lógica não é nova. ${ }^{989}$ Charles-Alberto Michalet mostra que a lógica da empresa multinacional revela a "metamorfose da economia internacional em economia mundial". ${ }^{990}$ A economia mundial em gestação está marcada pelo contínuo espaço da empresa e o descontínuo das disparidades nacionais. ${ }^{991}$

A concentração da produção em empresas cada vez maiores constitui uma das particularidades do capitalismo neoliberal. ${ }^{992}$ Quando o mercado é dominado de forma monopolista, a entrada de outras empresas no setor é barrada pela impossibilidade de conseguirem custos de produção competitivos (ou a colocação dos produtos junto ao público consumidor) com as empresas monopolizadoras. ${ }^{993}$ Estas, ao mesmo tempo, por sua condição, podem adotar práticas restritivas à concorrência, ficando livres para fixar preços que lhes propiciem maiores lucros ("preços de monopólio"). 994 O "capital financeiro" é a fusão e interpenetração do "capital industrial" e do "capital bancário"995 e o imperialismo ou a dominação do "capital financeiro" é o estágio supremo do capitalismo. ${ }^{996}$

Nesse processo de multinacionalização das empresas, o deslocamento do capital se faz no interesse de sua reprodução, de modo que se as relações de trabalho são desregulamentadas, a exploração da força de trabalho se intensifica, com ampliação da extração da mais-valia. A riqueza obtida com o trabalho é deslocada territorialmente para os países centrais do capitalismo, onde estão as sedes dessas empresas multinacionais.

\footnotetext{
989 SOUZA, Sérgio Alberto de. Direito, globalização e barbárie - estudos críticos de temas de direito do trabalho e de direitos humanos sob a ótica de uma leitura não-liberal. São Paulo: LTr, 1998, p. 28. ${ }^{990}$ MICHALET, Charles-Alberto. O Capitalismo Mundial. Rio de Janeiro: Paz e Terra, 1984, p. 16. Apud SOUZA, Sérgio Alberto de, op. cit., p. 28.

${ }^{991}$ SOUZA, Sérgio Alberto de, op. cit., p. 28.

${ }_{992}$ Ibid., p. 96.

${ }^{993}$ Ibid., p. 97.

${ }^{994}$ Ibid., p. 97.

${ }_{995}$ Ibid., p. 100.

${ }^{996}$ Ibid., p. 101.
} 
Vale dizer, se o direito do trabalho não intensifica o seu caráter protetivo do trabalhador, a empresa multinacional entra no país, explora a força de trabalho e também os recursos naturais, deixando no lugar apenas miséria, destruição e dependência econômica internacional.

\subsection{5 - O NEOLIBERALISMO E A DEIFICAÇÃO DO MERCADO}

Com o neoliberalismo, "o mercado foi elevado ao nível de divindade, entidade pela qual tudo é inevitável, não havendo força capaz de se opor às suas tendências ou de alterar seus cursos". ${ }^{997}$ Os governos deixaram de ser sujeitos do desenvolvimento e passaram a apenas administrar o fatalismo social da modernidade, em que o desemprego é visto como algo natural. ${ }^{998}$

Por outro lado, durante as décadas de 1980 e 1990, as iniciativas das ideologias neoliberais foram no sentido de que a participação do Estado se desse para imposição do laissez-faire. Por isso, G. Standing entende que é completamente errado designá-las por "desregulação". ${ }^{999}$ Richard Hyman fala sobre o exemplo britânico, em que a "retirada" do Estado da regulação econômica envolveu na realidade a intervenção sistemática do governo nos assuntos econômicos e exigiu um aumento sem precedentes da infiltração do poder estatal na sociedade. ${ }^{1000}$ Como o caso do Chile de Pinochet evidencia, o liberalismo de mercado da escola de Chicago só podia ser imposto por uma brutal explosão do poder coercitivo do Estado. ${ }^{1001}$

Hyman explica que a "desregulação" consagra efetivamente novas regras que intensificam a lei do valor, com efeitos que conferem poder a alguns atores

\footnotetext{
997 SOUZA, Sérgio Alberto de. Direito, globalização e barbárie - estudos críticos de temas de direito do trabalho e de direitos humanos sob a ótica de uma leitura não-liberal. São Paulo: LTr, 1998, p.31. ${ }^{998}$ Ibid., p. 32.

${ }^{999}$ STANDING, G. Globalization, labour flexibility and insecurity: the era of market regulation. European Journal of Industrial Relations, 3 (1), p. 7-37. Apud HYMAN, Richard. Europeização ou erosão das relações laborais? In: ESTANQUE, Elísio et. al (org.). Mudanças no trabalho e ação sindical: Brasil e Portugal no contexto da transnacionalização. São Paulo: Cortez, 2005, p. 20.

${ }^{1000}$ HYMAN, Richard, op. cit., p. 20-21.

${ }^{1001}$ Ibid., p.21.
} 
econômicos, ao mesmo tempo em que o retiram de outros, da maioria. ${ }^{1002}$ Assim, apesar da ideologia neoliberal, o Estado é inevitavelmente um ator nas economias de mercado. ${ }^{1003}$

Longe de constituir uma interferência desnecessária, o Estado é um elemento normal dos mercados reais, uma pré-condição da sua existência. ${ }^{1004}$ Os mercados dependem do Estado em termos de regulação, protecção dos direitos de propriedade e moeda". ${ }^{1005}$

\subsection{6 - AS MUDANÇAS RECENTES NOS PROCESSOS DE PRODUÇÃO}

\subsubsection{1 - A CRISE ESTRUTURAL DO CAPITALISMO A PARTIR DOS ANOS 1970}

A partir dos anos 1970, o capital começou a viver uma crise estrutural e a desenvolver um processo de reestruturação que abalou o mundo do trabalho. Passou a existir gradativo rebaixamento dos direitos e conquistas sociais dos trabalhadores, notadamente após o fim do "bloco socialista", interpretado pelo capital como o fim do "perigo socialista". ${ }^{1006}$ Conforme observa Ricardo Antunes, o "desmoronamento da União Soviética e do Leste europeu, ao final dos anos 80 , teve enorme impacto no movimento operário", abatendo-se grande crise sobre os partidos comunistas tradicionais e sobre o sindicalismo a eles vinculado. ${ }^{1007}$

O capitalismo começou a dar sinais de um quadro crítico, com os seguintes aspectos, indicados por Ricardo Antunes ${ }^{1008}$ : "queda da taxa de lucro, dada, dentre outros elementos causais, pelo aumento do preço da força de trabalho, conquistado durante o período pós-45 e pela intensificação das lutas sociais dos anos 60 , que objetivavam o

${ }^{1002}$ HYMAN, Richard. Europeização ou erosão das relações laborais? In: ESTANQUE, Elísio et. al (org.). Mudanças no trabalho e ação sindical: Brasil e Portugal no contexto da transnacionalização. São Paulo: Cortez, 2005, p.21.

${ }^{1003}$ Ibid., p. 21.

${ }^{1004}$ Ibid., p. 21.

${ }^{1005}$ SAYER, A. Radical political economy: a critique. Oxford: Blackwell, 1995, p. 87. Apud HYMAN, Richard., op. cit., p.21.

${ }^{1006}$ ANTUNES, Ricardo. O neoliberalismo e a precarização estrutural do trabalho na fase de mundialização do capital. In: SILVA, Alessandro da. et. al. (coord.). Direitos humanos: essência do direito do trabalho. São Paulo: LTr, 2007, p. 42.

${ }^{1007}$ HYMAN, Richard, op. cit., p. 42

${ }^{1008}$ ANTUNES, Ricardo. Os sentidos do trabalho. Ensaio sobre a afirmação e a negação do trabalho. São Paulo: Boitempo, 2006, p. 25-26. 
controle social da produção"; "redução nos níveis de produtividade do capital, acentuando a tendência decrescente da taxa de lucro"; "o esgotamento do padrão de acumulação taylorista/fordista de produção (que em verdade era a expressão mais fenomênica da crise estrutural do capital), dado pela incapacidade de responder à retração do consumo que se acentuava"; "hipertrofia da esfera financeira, que ganhava relativa autonomia frente aos capitais produtivos (...) colocando-se o capital financeiro como um campo prioritário para a especulação, na nova fase do processo de internacionalização"; "a maior concentração de capitais graças às fusões entre as empresas monopolistas e oligopolistas"; "a crise do 'welfare state' ou do 'Estado do bem-estar social' e dos seus mecanismos de funcionamento, acarretando a crise fiscal do Estado capitalista e a necessidade de retração dos gastos públicos e sua transferência para o capital privado"; "incremento acentuado das privatizações, tendência generalizada às desregulamentações e à flexibilização dos processos produtivos, dos mercados e da força de trabalho".

Essa crise estrutural atingiu destrutivamente o mecanismo de "regulação" normativa das relações entre o capital e o trabalho vigente no pós-guerra. ${ }^{1009} \mathrm{O}$ neoliberalismo (privatização do Estado, desregulamentação dos direitos do trabalho e desmontagem do setor produtivo estatal) representou a resposta do capital à sua crise estrutural, buscando um intenso processo de reestruturação da produção e do trabalho, a fim de retomar os seus anteriores patamares de expansionismo. ${ }^{1010}$ Traços essenciais desse período são a posição de centralidade do setor financeiro, desregulamentação e expansão dos capitais produtivos e financeiros (em parte capital financeiro especulativo), do comércio e da tecnologia, e o ataque aos direitos dos trabalhadores. ${ }^{1011}$

Esse processo, cujo núcleo central são os países capitalistas avançados, revelou-se centralizador, discriminador e destrutivo, por meio de novas técnicas de gerenciamento da força de trabalho, liberação comercial e novas formas de domínio técnico-científico. ${ }^{1012}$

\footnotetext{
${ }^{1009}$ ANTUNES, Ricardo. Os sentidos do trabalho. Ensaio sobre a afirmação e a negação do trabalho. São Paulo: Boitempo, 2006, p. 31.

${ }^{1010}$ Ibid., p. 31

1011 Ibid., p. 32.

1012 Ibid., p. 32
} 
Não havia possibilidade de incorporação dos países que não estavam no centro da economia capitalista ou, quando havia (por exemplo, o caso dos países asiáticos, chamados de "novos países industrializados"), a incorporação se dava em condição subordinada e dependente. ${ }^{1013}$

Na década de 1980, a crise chegou a afetar até os Estados Unidos, em razão da competição tecnológica com o Japão. ${ }^{1014}$ Nos anos 1990, houve recuperação da produção e expansão dos Estados Unidos e a crise se deslocou para o Japão e países asiáticos. $^{1015}$

A competição intercapitalista, o desenvolvimento da tecnologia concorrencial e expansão dos capitais financeiros dos países imperialistas geravam desestruturação dos países subordinados ou excluídos do núcleo do sistema, com desemprego e precarização da força de trabalho, seja pela ausência de base interna sólida (maioria dos pequenos países asiáticos) seja porque não conseguiam acompanhar a intensidade do ritmo tecnológico, controlado pelos países do núcleo. ${ }^{1016}$

A crise estrutural do capitalismo, iniciada na década de 1970 e ainda em andamento, é profunda, mas as soluções pensadas pelo capital são superficiais, sem alteração nos pilares essenciais do sistema. ${ }^{1017}$ Buscou-se apenas reestruturar o padrão produtivo taylorista-fordista e repor os patamares de acumulação, valendo-se de novos e velhos mecanismos de acumulação. ${ }^{1018}$

Vale dizer, o capital pretendeu superar a crise estrutural por meio de alterações no padrão de acumulação (e não no modo de produção), buscando maior dinamismo no processo produtivo, a partir de métodos diversos do modelo tayloristafordista, com vistas à acumulação flexibilizada. ${ }^{1019}$

1013 ANTUNES, Ricardo. Os sentidos do trabalho. Ensaio sobre a afirmação e a negação do trabalho. São Paulo: Boitempo, 2006, p. 32.

${ }^{1014}$ Ibid., p. 32.

1015 Ibid., p. 32.

1016 Ibid., p. 33.

${ }^{1017}$ Ibid., p. 36

${ }^{1018}$ Ibid., p. 36

${ }^{1019}$ Ibid., p. 36. 
Houve uma "regressão da própria socialdemocracia, que passou a atuar de maneira muito próxima da agenda neoliberal". ${ }^{1020}$ O ideário neolibeal contemplava "reestruturação produtiva, privatização acelerada, enxugamento do estado, políticas fiscais e monetárias, sintonizadas com os organismos mundiais de hegemonia do capital como o Fundo Monetário Internacional" ${ }^{1021}$. A partir do neoliberalismo, intensificaram-se a "desmontagem dos direitos sociais dos trabalhadores, o combate cerrado ao sindicalismo classista, a propagação de um subjetivismo e de um individualismo exacerbados". ${ }^{1022}$

As transformações implementadas pelo capital originaram-se da lógica de concorrência intercapitalista e da necessidade de controlar o movimento operário e a luta de classes. ${ }^{1023}$ Caracterizaram-se pelas "transformações no próprio processo produtivo, através do avanço tecnológico, da constituição das formas de acumulação flexível e dos modelos alternativos ao binômio taylorismo/fordismo, onde se destaca, para o capital, especialmente, o toyotismo" 1024.

A crise mundial iniciada a partir da década de 1970 é uma crise mais geral do processo civilizatório. ${ }^{1025} \mathrm{O}$ processo de globalização passou a ser uma expressão corrente na literatura e no noticiário cotidiano e nesse fato há forte conotação ideológica. ${ }^{1026} \mathrm{O}$ neoliberalismo, por meio da reestruturação produtiva (da era transicional da acumulação flexível) tem desenvolvido um monumental desemprego que atinge a humanidade que trabalha, em escala globalizada. ${ }^{1027}$ Quanto mais se avança na competitividade e na "integração mundial", mais explosivas tornam-se as taxas de precarização, exclusão e desemprego. ${ }^{1028}$

\footnotetext{
${ }^{1020}$ ANTUNES, Ricardo. O neoliberalismo e a precarização estrutural do trabalho na fase de mundialização do capital. In: SILVA, Alessandro da. et. al. (coord.). Direitos humanos: essência do direito do trabalho. São Paulo: LTr, 2007, p. 42.

${ }^{1021}$ Ibid., p. 42.

1022 Ibid., p. 43.

${ }^{1023}$ Ibid., p. 43.

${ }^{1024}$ Ibid., p. 43.

${ }^{1025}$ SOUZA, Sérgio Alberto de. Direito, globalização e barbárie - estudos críticos de temas de direito do trabalho e de direitos humanos sob a ótica de uma leitura não-liberal. São Paulo: LTr, 1998, p. 66. ${ }^{1026}$ Ibid., p. 67.

${ }^{1027}$ Ibid., p. 67.

${ }^{1028}$ Ibid., p. 67.
} 
As tendências do capitalismo nas últimas décadas têm sido a substituição do sistema de produção taylorista-fordista por outros flexibilizados e desregulamentados e a mudança do modelo normativo socialdemocrático pelo neoliberal. ${ }^{1029}$

Entendemos o taylorismo e o fordismo como o padrão produtivo capitalista desenvolvido ao longo do século XX e que se fundamentou basicamente na produção massa, em unidades produtivas concentradas e verticalizadas, com um controle rígido dos tempos e dos movimentos, desenvolvidos por um proletariado coletivo e de massa, sob forte despotismo e controle fabril. ${ }^{1030}$

As mudanças trazidas, como desregulamentação, flexibilização e terceirização representam desvalorização da força de trabalho, embora o capital, no limite, não possa eliminar a sua necessidade de utilização da referida força. ${ }^{1031}$

\subsubsection{2 - A REESTRUTURAÇÃO PRODUTIVA}

\subsubsection{1 - O FORDISMO-TAYLORISMO}

O sistema produtivo taylorista-fordista baseava-se na produção verticalizada e homogeneizada, em massa, de mercadorias, com predomínio de operações nas dependências internas da empresa (recorria-se apenas de maneira secundária ao fornecimento externo), e racionalização das operações, mediante combate ao desperdício na produção, redução do tempo e aumento do ritmo de trabalho. ${ }^{1032}$

Segundo o método taylorista-fordista, o trabalho deve ocorrer de forma parcelada, fragmentada, com decomposição das tarefas e repetição de atividades. ${ }^{1033}$ Ao

${ }^{1029}$ ANTUNES, Ricardo. O neoliberalismo e a precarização estrutural do trabalho na fase de mundialização do capital. In: SILVA, Alessandro da. et. al. (coord.). Direitos humanos: essência do direito do trabalho. São Paulo: LTr, 2007, p. 40.

${ }^{1030}$ Ibid., p. 40.

${ }^{1031}$ Ibid., p.41.

${ }^{1032}$ IDEM. Os sentidos do trabalho. Ensaio sobre a afirmação e a negação do trabalho. São Paulo: Boitempo, 2006, p. 36-37.

${ }^{1033}$ Ibid., p. 37. 
lado da intensificação da mais-valia relativa (extração intensiva) junta-se a extração extensiva da mais-valia, mediante o prolongamento da jornada. ${ }^{1034}$

O método taylorista-fordista caracterizou-se pelo controle do tempo (cronômetro) e pela gerência científica, próprios do taylorismo, adicionados à esteira (que dava o ritmo das tarefas) e à produção em série fordistas, além de uma nítida separação entre a elaboração e a execução do trabalho (a atividade do operário reduzia-se a ações mecânicas e repetitivas). ${ }^{1035}$ Como consequência, o operário perdia a destreza e se tornava mero apêndice da máquina. ${ }^{1036}$ Esse padrão produtivo taylorista-fordista vigorou durante várias décadas do século XX e apenas no final dos anos 60 e início dos anos 70 começou a dar sinais de esgotamento, ${ }^{1037} \mathrm{sem}$, contudo, ter desaparecido completamente até os nossos dias.

\subsubsection{2 - O TOYOTISMO}

O toyotismo trata-se de uma forma de organização produtiva desenvolvida pelo engenheiro Ohno, nas fábricas da Toyota, no Japão, no Pós-Segunda Guerra Mundial, propagando-se para as demais grandes empresas do Japão e para o mundo. ${ }^{1038}$ Representou a "via japonesa de expansão e consolidação do capitalismo monopolista industrial". ${ }^{1039}$

Ricardo Antunes indica os seguintes traços fundamentais do toyotismo: ${ }^{1040}$ produção muito vinculada à demanda; produção heterogênea; trabalho em equipe, multivariedade de funções; aplicação do princípio do just in time, com o melhor aproveitamento possível do tempo de produção; utilização do sistema Kanban, com placas ou senhas de comando para reposição de peças e de estoque que, no toyotismo, devem ser mínimos; apenas aproximadamente $25 \%$ da produção ocorrem no interior da fábrica;

${ }^{1034}$ ANTUNES, Ricardo. Os sentidos do trabalho. Ensaio sobre a afirmação e a negação do trabalho. São Paulo: Boitempo, 2006, p. 37.

${ }^{1035}$ Ibid., p. 37.

${ }^{1036}$ Ibid., p. 37.

${ }^{1037}$ Ibid., p. 38.

${ }^{1038}$ Ibid., p. 54.

${ }^{1039}$ Ibid., p. 54.

${ }^{1040}$ Ibid., p. 54. 
horizontalização do processo produtivo e transferência a "terceiros" de grande parte da produção e a implementação dos Círculos de Controles de Qualidade (CCQ’s).

Tentando reter seus traços constitutivos mais gerais, é possível dizer que o padrão de acumulação flexível articula um conjunto de elementos de continuidade e de descontinuidade que acabam por conformar algo relativamente distinto do padrão taylorista/fordista de acumulação. Ele se fundamenta num padrão produtivo organizacional e tecnologicamente avançado, resultado da introdução de técnicas de gestão da força de trabalho próprias da fase informacional, bem como da introdução ampliada dos computadores no processo produtivo e de serviços. Desenvolve-se em uma estrutura produtiva mais flexível, recorrendo frequentemente à desconcentração produtiva, às empresas terceirizadas etc. Utiliza-se de novas técnicas de gestão da força de trabalho, do trabalho em equipe, das "células de produção", dos 'times de trabalho", dos grupos “semi-autônomos', além de requerer, aos menos no plano discursivo, o "envolvimento participativo" dos trabalhadores, em verdade uma participação manipuladora e que preserva, na essência, as condições do trabalho alienado e estranhado. O "trabalho polivalente", "multifuncional", "qualificado", combinado com uma estrutura mais horizontalizada e integrada entre diversas empresas, inclusive nas empresas terceirizadas, tem como finalidade a redução do tempo de trabalho. ${ }^{1041}$

Os Círculos de Controles de Qualidade (CCQ’s) são grupos de trabalhadores "incentivados pelo capital para discutir o trabalho e o desempenho, com vistas a melhorar a produtividade da empresa. Em verdade, é a nova forma de apropriação do saber fazer intelectual do trabalho pelo capital". ${ }^{1042}$

1041 ANTUNES, Ricardo. Os sentidos do trabalho. Ensaio sobre a afirmação e a negação do trabalho. São Paulo: Boitempo, 2006, p. 52.

${ }^{1042}$ IDEM. O neoliberalismo e a precarização estrutural do trabalho na fase de mundialização do capital. In: SILVA, Alessandro da. et. al. (coord.). Direitos humanos: essência do direito do trabalho. 
No toyotismo, há uma intensificação da subordinação do trabalho ao capital, eis que o "despotismo torna-se então mesclado com a manipulação do trabalho, com o 'envolvimento' dos trabalhadores, através de um processo ainda mais profundo de interiorização do trabalho alienado (estranhado)", ${ }^{1043}$ de modo que "o operário deve pensar e fazer pelo e para o capital". ${ }^{1044}$

José Antônio Ribeiro de Oliveira defende que o toyotismo é singularizado "pela busca de cada vez maior redução do custo do trabalho, apresentando como característica no âmbito laboral a promoção da individualização das relações laborais ou, dito de outra maneira, a eliminação dos valores coletivos dos trabalhadores". ${ }^{1045}$ Explica que duas das principais característica do toyotismo, "a avaliação individualizada do rendimento e a exigência de qualidade total" 1046 geram "uma sobrecarga de trabalho, que conduz a uma explosão de doenças, dentre as quais o burn out, o Karoshi e os transtornos músculo-esqueléticos". ${ }^{1047}$

\subsubsection{3 - AS CONSEQUENCIAS PARA A CLASSE TRABALHADORA DA REESTRUTURAÇÃO DO CAPITAL}

Para Ricardo Antunes, ${ }^{1048}$ as consequências dessa reestruturação do capital são: ${ }^{1049}$ crescente redução do proletariado fabril estável, que se desenvolveu na vigência do binômio taylorismo/fordismo e que vem diminuindo com a reestruturação, flexibilização e desconcentração do espaço físico produtivo, típico da fase do toyotismo; enorme incremento do novo proletariado, do subproletariado fabril e de serviços, o que tem sido denominado mundialmente de trabalho precarizado ("terceirizados", subcontratados, "part-

São Paulo: LTr, 2007, p. 44.

1043 ANTUNES, Ricardo. O neoliberalismo e a precarização estrutural do trabalho na fase de mundialização do capital. In: SILVA, Alessandro da. et. al. (coord.). Direitos humanos: essência do direito do trabalho. São Paulo: LTr, 2007, p. 44.

${ }^{1044}$ Ibid., p. 44.

${ }^{1045}$ SILVA, José Antônio Ribeiro de Oliveira. A flexibilização da jornada de trabalho e seus reflexos na saúde do trabalhador. Revista LTr., São Paulo, vol.77, n. 02, p. 186, fevereiro de 2013.

${ }^{1046}$ Ibid., p. 186.

${ }^{1047}$ Ibid., p. 186.

1048 ANTUNES, Ricardo, op. cit., p. 44-45.

${ }^{1049}$ Ibid., p. 44-45. 
time"); aumento significativo do trabalho feminino, que atinge mais de $40 \%$ da força de trabalho nos países avançados, e que tem sido preferencialmente absorvido pelo capital no universo do trabalho precarizado e desregulamentado; incremento dos assalariados médios e de serviços, o que possibilitou um significativo incremento no sindicalismo destes setores, ainda que o setor de serviços já presencie também níveis de desemprego acentuado; exclusão dos jovens e dos idosos do mercado de trabalho dos países centrais; inclusão precoce e criminosa de crianças no mercado de trabalho, particularmente nos países de industrialização intermediária e subordinada, como nos países asiáticos, latinoamericanos etc; expansão do que Marx chamou de trabalho social combinado, onde trabalhadores de diversas partes do mundo participam do processo de produção e de serviços, o que caminha no sentido da precarização da classe trabalhadora e de sua utilização de maneira ainda mais intensificada.

Se no apogeu do taylorismo/fordismo a pujança de uma empresa mensurava-se pelo número de operários que nela exerciam sua atividade de trabalho, pode-se dizer que na era da acumulação flexível e da "empresa enxuta" merecem destaque, e são citadas como exemplos a ser seguidos, aquelas empresas que dispõem de menos contingente de força de trabalho e que apesar disso têm maiores índices de produtividade. ${ }^{1050}$

Ainda segundo Ricardo Antunes, a classe trabalhadora "fragmentou-se, heterogeneizou-se e complexificou-se ainda mais". ${ }^{1051}$ Encontra-se dividida entre "trabalhadores qualificados e desqualificados, do mercado formal e informal, jovens e velhos, homens e mulheres, estáveis e precários, imigrantes e nacionais, brancos e negros etc." ${ }^{1052}$ e também entre trabalhadores de países inseridos de maneira diferenciada na nova divisão internacional do trabalho. ${ }^{1053}$

\footnotetext{
${ }^{1050}$ ANTUNES, Ricardo. Os sentidos do trabalho. Ensaio sobre a afirmação e a negação do trabalho. São Paulo: Boitempo, 2006, p. 53.

${ }^{1051}$ IDEM. O neoliberalismo e a precarização estrutural do trabalho na fase de mundialização do capital. In: SILVA, Alessandro da. et. al. (coord.). Direitos humanos: essência do direito do trabalho. São Paulo: LTr, 2007, p. 45.

${ }^{1052}$ Ibid., p. 45.

${ }^{1053}$ Ibid., p. 45.
} 
A classe trabalhadora tornou-se mais qualificada em alguns setores, como o de siderurgia, mas desqualificou-se e precarizou-se em diversos ramos, como o da indústria automobilística. ${ }^{1054}$ De um lado, verifica-se um número reduzido de trabalhadores polivalentes e multifuncionais e de outro "uma massa de trabalhadores precarizados, sem qualificação, que hoje está presenciando as formas de part-time, emprego temporário, parcial, ou então vivenciando o desemprego estrutural."1055

\subsubsection{4 - A REESTRUTURAÇÃO PRODUTIVA NO BRASIL}

As transformações do mundo do trabalho no Brasil nas últimas décadas do século XX revelaram uma ligação “inseparável entre as transformações aqui verificadas e o desenrolar dos acontecimentos e tendências hegemônicas no plano econômico, político e ideológico em escala mundial". ${ }^{1056}$ Houve intensificação da reestruturacão produtiva e do modelo de política neoliberal, nos anos 1990 e essas mudanças apontaram "para uma maior intensificação e exploração do trabalho", ${ }^{1057}$ com perda de direitos, desregulamentação nas relações de trabalho e perda do poder de barganha dos trabalhadores. ${ }^{1058}$

Durante a década de 1980, o Brasil presenciou algumas mudanças tecnológicas e também no processo produtivo, embora em um "ritmo mais lento que aquele experimentado pelos países centrais". ${ }^{1059}$ Havia o ressurgimento do movimento sindical, dos partidos de esquerda e de setores populares organizados, que impediam transformações mais rápidas e profundas nos processos de reestruturação econômica e produtiva, além de existir uma parte da burguesia industrial com receio de perder a proteção do Estado. ${ }^{1060}$ Contudo, ocorre na referida década a interrupção "de uma trajetória de estruturação do

\footnotetext{
${ }^{1054}$ ANTUNES, Ricardo. O neoliberalismo e a precarização estrutural do trabalho na fase de mundialização do capital. In: SILVA, Alessandro da. et. al. (coord.). Direitos humanos: essência do direito do trabalho. São Paulo: LTr, 2007, p. 45.

${ }^{1055}$ Ibid., p. 45.

${ }^{1056}$ GRAZIA, Giuseppina Rosaria De. A redução e redistribuição do tempo de trabalho em questão. Tese de doutorado. Departamento de Sociologia da FFLCH-USP, São Paulo, 2003, p. 146.

${ }^{1057}$ Ibid., p. 146.

1058 Ibid., p. 146.

${ }^{1059}$ ANTUNES, Ricardo. Trabalho, reestruturação produtiva e algumas repercussões no sindicalismo brasileiro. In: ANTUNES, Ricardo (org.). Neoliberalismo, trabalho e sindicatos - reestruturação produtiva na Inglaterra e no Brasil. 2. ed. São Paulo: Boitempo, 2002, p. 79.

${ }^{1060}$ GRAZIA, Giuseppina Rosaria De, op. cit., p. 148.
} 
mercado de trabalho que vinha sendo observada até o final dos anos 70"1061 e uma preparação para as transformações da década seguinte. ${ }^{1062}$

O início da década de 1980 "foi marcado por profunda crise econômica, com destaque para o estouro da crise da dívida externa e um processo inflacionário sem precedentes"1063, com aplicação da política recessiva exigida pelo FMI e produção voltada para a exportação e para as camadas de maior poder aquisitivo do mercado interno. ${ }^{1064}$

No Brasil, a busca de competitividade no mercado internacional se fez mais com mudanças nas formas de gestão da produção do que na utilização de novas tecnologias. ${ }^{1065} \mathrm{O}$ principal objetivo era a redução de custos, com demissões em massa, aproveitando-se para incluir nelas as lideranças e os trabalhadores mais combativos, "para

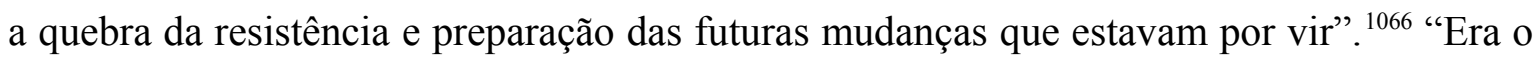
início da desestruturação do mercado de trabalho". 1067 "A reestruturação produtiva desse período praticamente se concentrou mais nas montadoras, subsidiárias das corporações transnacionais". ${ }^{1068}$

A baixa remuneração da força de trabalho sempre constituiu elemento de atração para o capital externo produtivo, representando em alguns setores obstáculos para o avanço tecnológico, mas a combinação da superexploração da força de trabalho com alguns padrões produtivos mais avançados se tornou elemento central para o aumento dos lucros do capital. ${ }^{1069}$

\footnotetext{
${ }^{1061}$ DEDECCA, Claudio S. Reestruturação Produtiva e Mercado de Trabalho. Seminário realizado pelo Cebrap e Desep/CUT. Cadernos de Pesquisa, Cebrap. São Paulo, n. 1, p. 29-59, 1994. Apud GRAZIA, Giuseppina Rosaria De. A redução e redistribuição do tempo de trabalho em questão. Tese de doutorado. Departamento de Sociologia da FFLCH-USP, São Paulo, 2003, p. 148.

${ }^{1062}$ GRAZIA, Giuseppina Rosaria De, op. cit., p. 148.

${ }^{1063}$ Ibid., p. 148.

${ }^{1064}$ Ibid., p. 148.

${ }^{1065}$ Ibid., p. 148-149.

${ }^{1066}$ Ibid., p. 149.

${ }^{1067}$ Ibid., p. 149.

${ }^{1068}$ Ibid., p. 149.

${ }^{1069}$ ANTUNES, Ricardo. Trabalho, reestruturação produtiva e algumas repercussões no sindicalismo brasileiro. In: ANTUNES, Ricardo (org.). Neoliberalismo, trabalho e sindicatos - reestruturação produtiva na Inglaterra e no Brasil. 2. ed. São Paulo: Boitempo, 2002, p. 79.
} 
Giuseppina Rosaria De Grazia observa que a "reestrutução do capitalismo brasileiro não ocorreu como uma fotocópia, nem de maneira automática e simultânea à dos países centrais", ${ }^{1070}$ mas os governos locais passaram a considerar fundamental, para facilitar a integração à economia internacional, a adesão às ideias de subtração do Estado de seu poder de regulação e planejamento e a adoção de mecanismos de anulação de qualquer tentativa de cerceamento ao livre movimento de capitais. ${ }^{1071}$

Esclarece que, com a pequena recuperação econômica gerada na segunda metade da década de 80, em razão do Plano Cruzado de 1986, houve crescimento de “inovações tecnológicas com a introdução um pouco mais significativa da automação industrial de base microeletrônica", ${ }^{1072}$ mas diversos estudos mostraram baixíssimos índices de utilização de robôs e de atividades automotizadas nas montadoras brasileiras no fim dos anos 80, quando comparados a outros países. ${ }^{1073}$ Grazia explica que essa defasagem tecnológica era em parte compensada pelo que Ruy Q. Carvalho chamou de "padrão predatório de uso do trabalho", ${ }^{1074}$ que conseguia aumentar a produtividade e melhorar a qualidade por meio da intensificação no ritmo de trabalho, do rígido controle e do autoritarismo das chefias. ${ }^{1075}$

No final da década de 1980, observam-se sinais de lenta, mas progressiva marcha em direção à implantação do toyotismo no Brasil, como a utilização do trabalho em células e o maior controle de qualidade por meio do Controle Estatístico do Processo CEP, entre outros métodos. ${ }^{1076}$

Mas, tendo em vista o "arraigado padrão autoritário que sempre marcou a relação capital e trabalho no Brasil", ${ }^{1077}$ as mudanças foram sempre "restritas e com

\footnotetext{
${ }^{1070}$ GRAZIA, Giuseppina Rosaria De. A redução e redistribuição do tempo de trabalho em questão. Tese de doutorado. Departamento de Sociologia da FFLCH-USP, São Paulo, 2003, p. 147.

${ }^{1071}$ Ibid., p. 147.

${ }^{1072}$ Ibid., p. 150.

${ }^{1073}$ CASTRO, Nadya A. Modernização e trabalho no complexo automotivo brasileiro. In: CASTRO, N. (org.). A máquina e o equilibrista: inovações na indústria automobilística brasileira. Rio de Janeiro: Paz e Terra, 1995, p. 17-49. Apud GRAZIA, Giuseppina Rosaria De, op. cit., p. 150.

${ }^{1074}$ CARVALHO, Ruy Quadros. Tecnologia e trabalho industrial. São Paulo: Ed. L. P. M, 1987, s/p. Apud GRAZIA, Giuseppina Rosaria De, op. cit., p. 150.

${ }^{1075}$ GRAZIA, Giuseppina Rosaria De, op cit., p. 150.

${ }^{1076}$ Ibid., p. 151.

${ }^{1077}$ Ibid., p. 151.
} 
adaptações às vezes grosseiras, principalmente quando os novos procedimentos implicavam em (sic) maior autonomia, maior qualificação ou maior participação dos trabalhadores nas decisões". ${ }^{1078}$

\subsection{7- O NEOLIBERALISMO NO BRASIL}

\subsubsection{1 - O GOVERNO COLLOR}

A partir de 1990, com o governo Collor, esse processo de mudança no mundo do trabalho se intensificou muito, combinando-se os "processos de enorme flexibilização, a desregulamentação e as novas formas de gestão da força de trabalho" com o "fordismo ainda dominante". ${ }^{1079}$

Começaram a ser criadas as condições político-institucionais para as necessidades de expansão do capital e esse processo atingiu seu auge no governo Fernando Henrique Cardoso. ${ }^{1080}$ Grazia lembra que isso ocorreu também em outros países da América Latina: México (Salinas, em 1988), Argentina (Menem, em 89), Venezuela (Andrés Perez, em 1990) e Peru (Fugimori, em 1990). ${ }^{1081}$

Assim, após a eleição de Collor, houve a liberalização comercial no Brasil e foi inaugurada a aplicação do receituário neoliberal (prosseguida por Itamar e intensificada por FHC), ${ }^{1082}$ mediante a edição de "diversas medidas de desregulamentação do comércio exterior, redução das alíquotas de importação", ao mesmo tempo em que eram "cortados incentivos físcais e subsídios à indústria nacional". ${ }^{1083}$ Os juros altos e o controle da

\footnotetext{
${ }^{1078}$ GRAZIA, Giuseppina Rosaria De. A redução e redistribuição do tempo de trabalho em questão. Tese de doutorado. Departamento de Sociologia da FFLCH-USP, São Paulo, 2003, p. 151.

${ }^{1079}$ ANTUNES, Ricardo. Trabalho, reestruturação produtiva e algumas repercussões no sindicalismo brasileiro. In: ANTUNES, Ricardo (org.). Neoliberalismo, trabalho e sindicatos - reestruturação produtiva na Inglaterra e no Brasil. 2. ed. São Paulo: Boitempo, 2002, p. 79.

${ }^{1080}$ GRAZIA, Giuseppina Rosaria De, op. cit., p. 148.

${ }^{1081}$ Ibid., p. 148.

${ }^{1082}$ Ibid., p. 152

${ }^{1083}$ Ibid., p. 152.
} 
liquidez foram medidas aplicadas concomitantemente e que completaram o quadro de uma política altamente recessiva. ${ }^{1084}$

No mercado interno, diversos setores industriais se viram diante de uma agressiva concorrência com produtos importados. ${ }^{1085}$ Tais setores não podiam mais contar com a proteção do Estado e não possuíam condições de concorrer no mercado internacional, onde permaneciam diversas formas de proteção, principalmente nos países mais desenvolvidos e que exigiam a abertura e a liberalização comercial no Brasil. ${ }^{1086}$

A "epidemia de competitividade" 1087 pressionava para "uma profunda reestruturação na produção que garantisse a redução nos custos e o aumento da produtividade". ${ }^{1088}$ Mas, o caminho adotado continou sendo o corte nos investimentos e a diminuição de custos por meio de dispensas e redução dos salários, eis que a política recessiva impedia investimentos em novas tecnologias. ${ }^{1089}$

Houve, então, "a busca generalizada de implementação dos novos métodos e técnicas organizacionais inspiradas no toyotismo", ${ }^{1090}$ que racionalizavam a produção para a redução de custos, articulavam a produção e a demanda e tentavam obter o “consentimento operário" para as reestruturações que interessavam ao capital. ${ }^{1091}$

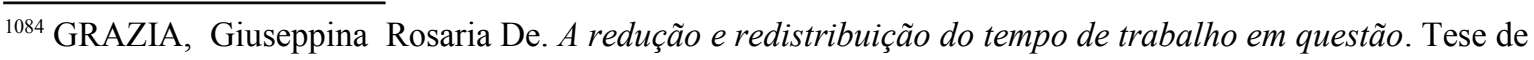
doutorado. Departamento de Sociologia da FFLCH-USP, São Paulo, 2003, p. 152.

${ }^{1085}$ Ibid., p. 152.

${ }^{1086}$ Ibid., p. 152.

${ }^{1087}$ RUAS, R. Notas acerca da implantação de programas de qualidade e produtividade em setores industriais brasileiros. Texto apresentado na II Reunião da Rede Franco-Latinoamericana sobre Trabalho e Tecnologias, Buenos Aires, nov. 1992. Apud GRAZIA, Giuseppina Rosaria De, op cit., p.153.

${ }^{1088}$ GRAZIA, Giuseppina Rosaria De, op. cit., p. 153.

1089 Ibid., p. 153.

${ }^{1090}$ Ibid., p. 153.

${ }^{1091}$ Ibid., p. 153.
} 


\subsubsection{2 - FHC E A SUBSERVIÊNCIA AO CAPITAL INTERNACIONAL}

A política do governo de Fernando Henrique Cardoso foi recessiva e marcada pela "preocupação obsessiva pela manutenção da estabilização monetária e dos ajustes exigidos pelo FMI". ${ }^{1092}$ Jorge Mattoso ${ }^{1093}$ esclareceu que a referida política, com abertura econômica e financeira indiscriminada, sobrevalorização cambial e juros elevados, resultou em baixíssimo crescimento econômico: a década de 90 teve um crescimento de apenas 1,5\%, enquanto a década de 1980 (chamada "década perdida") alcançara $2,9 \%$.

Com a abertura comercial, as importações se expandiram e as barreiras impostas pelos mercados dos Estados Unidos e da Europa dificultaram as exportações, o que gerou déficits crescentes na balança comercial brasileira. 1094 "A elevação dos juros para atrair capital externo e dólares para cobrir os déficits e pagar as dívidas"1095 aumentou ainda mais as dívidas externa e interna (a "dívida pública, que em 1994 correspondia a $20 \%$ do PIB, saltou para 53,3\% do PIB em 2001, alcançando a cifra de 660,9 bilhões de reais" ${ }^{" 1096}$ ) e tornou o país cada vez mais vulnerável e dependente do capital internacional. ${ }^{1097}$

Conforme bem observado por Giuseppina Rosaria De Grazia, para a implementação dessa política de "portas escancaradas e subserviência total aos interesses do capital internacional (grandes corporações, investidores especulativos, credores financeiros) era realmente necessário o desmonte do Estado"1098, com a "abdicação a um projeto de desenvolvimento para o país, para sua política industrial, para defesa da produção e muito menos do emprego". ${ }^{1099}$

\footnotetext{
1092 GRAZIA, Giuseppina Rosaria De. A redução e redistribuição do tempo de trabalho em questão. Tese de doutorado. Departamento de Sociologia da FFLCH-USP, São Paulo, 2003, p. 153.

${ }^{1093}$ MATTOSO, Jorge. O Brasil desempregado. São Paulo: Ed. Fund. Perseu Abramo, 1999, p.21-34. Apud GRAZIA, Giuseppina Rosaria De, op. cit., p. 153.

${ }^{1094}$ GRAZIA, Giuseppina Rosaria De, op. cit., p. 153.

${ }^{1095}$ Ibid., p. 153.

${ }^{1096}$ Ibid., p. 153.

${ }^{1097}$ Ibid., p. 153.

${ }^{1098}$ Ibid., p. 154.

${ }^{1099}$ Ibid., p. 154.
} 
A fundamentação dos teóricos do neoliberalismo a respeito da crise do Estado do bem-estar social, justificadora da necessidade de desregulação e da redução do papel do Estado, escondia o que realmente interessava: "deixar o campo livre para os agentes do capital internacional". ${ }^{1100}$

No período, houve redução dos gastos sociais (recuaram de 53,33\% do total de gastos da União em 1995, para 43,35\% em 2000) e aumento dos recursos para o pagamento de juros da dívida. ${ }^{1101}$

Quando disse que ia "virar a página do getulismo" na história do Brasil, FHC revelava a consciência clara de que o Estado regulador, protetor do mercado interno, indutor do crescimento econômico, que garantia os direitos sociais (...) era um obstáculo frontal ao modelo neoliberal. Buscou desarticulá-lo, reduzindo-o ao Estado mínimo, a favor da centralidade do mercado. Desregulamentou a economia, abriu o mercado interno, promoveu a precarização das relações de trabalho, privatizou o patrimônio público a preços mínimos, submeteu a política externa às orientações dos Estados Unidos. ${ }^{1102}$

Os capitais, então, deslocavam-se da esfera produtiva para a especulação financeira, ante a livre movimentação e o alto e rápido retorno. ${ }^{1103} \mathrm{O}$ país não possuía um projeto próprio de desenvolvimento e de defesa da produção e do emprego e isso gerou a financeirização da economia, a desestruturação produtiva, a ampliação da desnacionalização e o fechamento de linhas de produção ou de fábricas inteiras. ${ }^{1104}$

\footnotetext{
${ }^{1100}$ GRAZIA, Giuseppina Rosaria De. A redução e redistribuição do tempo de trabalho em questão. Tese de doutorado. Departamento de Sociologia da FFLCH-USP, São Paulo, 2003, p. 154.

${ }^{1101}$ Ibid., p. 154.

${ }^{1102}$ SADER, Emir. A construção da hegemonia pós-neoliberal. In: SADER, Emir (org.) 10 anos de governos pós-neoliberais no Brasil: Lula e Dilma. São Paulo,SP: Boitempo; Rio de Janeiro: FLACSO Brasil, 2013, p. 137-138.

${ }^{1103}$ GRAZIA, Giuseppina Rosaria De, op. cit., p. 155.

${ }^{1104}$ Ibid., p. 155.
} 
A queda no número de empregos na indústria manteve-se constante durante a década de $1990,{ }^{1105}$ independentemente da variação anual do PIB, o que demonstra que as causas não eram apenas o "baixo crescimento econômico, mas também as mudanças na estrutura da economia (abertura comercial, privatizações, financeirização, terceirização, etc)". ${ }^{1106}$

\subsection{8 - AS PRINCIPAIS MUDANÇAS ORGANIZACIONAIS E INOVAÇÕES TECNOLÓGICAS NA DÉCADA DE 1990 NO BRASIL}

\subsubsection{1 - ASPECTOS GERAIS}

A intensificação do trabalho era facilitada pela flexibilização no uso da força de trabalho, mediante facilidade para os empregadores realizarem "admissões e demissões, aumento ou diminuição de horas extras, mudanças nos horários, determinação do período de férias, definição de funções, etc". ${ }^{1107}$

As principais mudanças organizacionais na produção consistiram "na adaptação de alguns elementos do toyotismo, já muito mais incorporado ao processo produtivo nos países centrais" "108: CCQ's (Círculos de Controle de Qualidade) e o sistema de produção just-in-time/Kanban ${ }^{1109}$.

Os Círculos de Controles de Qualidade, contudo, fracassaram na tentativa de obter maior envolvimento dos trabalhadores, porque os temas tratados eram de pequena relevância (a principal função era apresentar sugestões para melhoria da qualidade dos produtos e economia de material e tempo) e a participação ficava restrita aos trabalhadores mais qualificados, técnicos, chefes e supervisores. ${ }^{1110}$ Não foi "percebida nenhuma

\footnotetext{
${ }^{1105}$ GRAZIA, Giuseppina Rosaria De. A redução e redistribuição do tempo de trabalho em questão. Tese de doutorado. Departamento de Sociologia da FFLCH-USP, São Paulo, 2003, p. 156.

${ }^{1106}$ Ibid., p. 156.

${ }^{1107}$ Ibid., p. 149.

${ }^{1108}$ Ibid., p. 149.

${ }^{1109}$ Ibid., p. 149.

${ }^{1110}$ Ibid., p. 149.
} 
democratização, nem alteração nas relações de poder nas empresas, continuando a predominar o modelo taylorista-fordista e a tradicional estrutura concentrada de poder". ${ }^{111}$

Marcia de Paula Leite, entre outros, indica que a introdução dos Círculos de Controle de Qualidade também possuía a motivação de tentar desviar o ímpeto participativo dos trabalhadores que pretendiam organizar Comissões de Fábrica independentes nos locais de trabalho. ${ }^{112}$

Com o sistema just-in-time/kanban, também pretendia-se a redução dos custos, por meio de um processo de racionalização da produção, eliminação de estoques, reorganização do espaço da fábrica, simplificação dos fluxos de informações e eliminação de tempos ociosos. ${ }^{1113}$ Esse sistema representava a flexibilização "de todo o processo de produção e do uso da força de trabalho em estreita conjugação com as necessidades do mercado". 1114

O avanço em automação industrial no Brasil se concentrou mais nas novas unidades instaladas pelo setor automotivo. ${ }^{1115}$ Houve crescimento, principalmente nas montadoras, do uso de máquinas CNC (Comando Numérico Computadorizado), dos sistemas de transporte automático e flexível de materiais, dos sistemas de movimentação e armazenagem controlados por computador e dos sistemas CAD/CAM (agilização de projetos de produtos e processos, e interligação entre programação e fabricação). ${ }^{1116}$ Além do investimento nos equipamentos automatizados, a informatização das atividades administrativas também foi bastante priorizada pelas empresas. ${ }^{117}$

Ruy Quadros explica que a implantação da automação microeletrônica, seletivamente apenas nas funções de controle da produção e para agilizar o fluxo entre as

${ }^{1111}$ GRAZIA, Giuseppina Rosaria De. A redução e redistribuição do tempo de trabalho em questão. Tese de doutorado. Departamento de Sociologia da FFLCH-USP, São Paulo, 2003, p. 149.

${ }^{1112}$ LEITE, Márcia de Paula. Inovação Tecnológica e relações de trabalho: a experiência brasileira à luz do quadro internacional. In: CASTRO, N. (org.). A máquina e o equilibrista: inovações na indústria automobilística brasileira. Rio de Janeiro: Paz e Terra, 1995, p. 335-360. Apud GRAZIA, Giuseppina Rosaria De, op. cit., p. 149.

${ }_{1113}$ GRAZIA, Giuseppina Rosaria De, op. cit., p. 150.

${ }^{1114}$ Ibid., p. 150.

1115 Ibid., p. 157.

${ }^{1116}$ Ibid., p. 158.

${ }^{1117}$ Ibid., p. 158. 
diversos operações das manufaturas, fez com que o fordismo não fosse superado, mas intensificado, eis que "as tarefas tornaram-se mais ritmadas pela máquina do que antes". 1118

Por meio da automação, obtém-se uma "produção com fluxo contínuo de tipo fordiano, mas com grau superior de racionalização", 1119 com "maior compactação temporal dos fluxos produtivos", ${ }^{1120}$ consistente na redução dos tempos mortos e dos pontos de estrangulamento que dependiam do ritmo de trabalho humano. ${ }^{121}$

Com a automação, houve uma mudança na qualificação exigida dos trabalhadores, eis que na seleção passaram a ser privilegiados trabalhadores com maior nível de escolaridade formal, ante o aumento das tarefas de programação e controle das máquinas. ${ }^{1122}$ Mas, por outro lado, a automação, em si, representou perda de qualificação (e do conteúdo do trabalho), pela simplificação e padronização ainda maior das tarefas. ${ }^{1123}$ Para Giovanni Alves, também o just-in-time criou uma "nova rotinização do trabalho", com uma maior simplificação e padronização das tarefas. ${ }^{1124}$

Giuseppina Rosaria De Grazia explica que uma outra mudança introduzida, a polivalência, "longe de significar uma maior qualificação e diversificação de habilidades, apenas intensificou o trabalho, exigindo que um mesmo operário se multiplicasse para cuidar de várias máquinas ao mesmo tempo". ${ }^{1125}$

A polivalência, exigida em função da interdependência das máquinas, dilui as funções específicas antes desempenhadas individualmente e intensifica muito o

\footnotetext{
${ }^{1118}$ CARVALHO, Ruy Quadros. Tecnologia e trabalho industrial. São Paulo: Ed. L.P.M, 1987; SCHMITZ, Hubert. O fordismo está vivo no Brasil. Novos Estudos Cebrap, São Paulo, n. $27,1990$. Apud GRAZIA, Giuseppina Rosaria De. A redução e redistribuição do tempo de trabalho em questão. Tese de doutorado. Departamento de Sociologia da FFLCH-USP, São Paulo, 2003, p. 151.

1119 CORIAT, Benjamin. Autômatos, robôs e a classe operária. Novos Estudos Cebrap. São Paulo, vol. 2, n. 2, jul. 1983, s/p. Apud GRAZIA, Giuseppina Rosaria De, op. cit., p. 158.

${ }^{1120}$ CORIAT, Benjamin, op. cit., s/p. Apud GRAZIA, Giuseppina Rosaria De, op. cit., p. 158.

${ }^{1121}$ GRAZIA, Giuseppina Rosaria De, op. cit., p. 158.

${ }^{1122}$ Ibid., p. 158.

${ }^{1123}$ CASTRO, Nadya A. Modernização e trabalho no complexo automotivo brasileiro. In: CASTRO, N.A. (org.) A Máquina e o equilibrista: inovações na indústria automobilística brasileira. Rio de Janeiro: Paz e Terra, 1995, p.17-49. Apud GRAZIA, Giuseppina Rosaria De, op. cit., p. 158.

${ }^{1124}$ ALVES, Giovanni. O novo (e precário) mundo do trabalho. São Paulo: Boitempo, 2000, p. 130. Apud GRAZIA, Giuseppina Rosaria De, op. cit., p. 151.

${ }^{1125}$ GRAZIA, Giuseppina Rosaria De, op. cit., p. 151.
} 
trabalho, ${ }^{1126}$ "uma vez que o mesmo trabalhador tem que operar várias máquinas ou executar várias funções em uma mesma máquina". ${ }^{1127} \mathrm{O}$ processo de automação representou "um aumento significativo da subordinação ao posto de trabalho e à disciplina de linha". ${ }^{128}$

Grazia observa que a versão "abrasileirada" do toyotismo não absorveu as inovações do referido método japonês, de maior autonomia, responsabilidade, qualificação e participação nas decisões (técnicas voltadas para o objetivo de obter maior comprometimento dos trabalhadores na realização dos interesses da empresa), de modo que não houve, no Brasil, principalmente na fase inicial, "alteração nas relações despóticas que sempre caracterizaram o uso da força de trabalho". ${ }^{1129}$

\subsubsection{2 - A DESCENTRALIZAÇÃO PRODUTIVA}

No Brasil, mais do que a utilização de novos equipamentos, os métodos japoneses de organizar a produção atraíram os empresários, por "anunciarem a concretização de uma verdadeira mágica - a possibilidade de reduzir os custos e multiplicar a produtividade sem necessidade de novos investimentos". ${ }^{1130}$

A flexibilização da produção e da força da trabalho era vista pelo capital como necessária para lidar "com as crescentes oscilações do mercado"1131 e com "as necessidades excessivamente diversificadas e instáveis da demanda". ${ }^{1132}$

A “descentralização produtiva, com o repasse para terceiros de todas as atividades não diretamente relacionadas ao foco essencial da empresa, e concentrando os

\footnotetext{
${ }^{1126}$ GRAZIA, Giuseppina Rosaria De. A redução e redistribuição do tempo de trabalho em questão. Tese de doutorado. Departamento de Sociologia da FFLCH-USP, São Paulo, 2003, p. 158.

${ }^{1127}$ Ibid., p. 159.

${ }^{1128}$ ABRAMO, Laís W. A subjetividade do trabalhador frente à automação. In: NEDER, R.T. et al. Automação e movimento sindical. São Paulo: Ed. Hucitec, 1988, p. 133-176. Apud GRAZIA, Giuseppina Rosaria De, op. cit., p. 159.

${ }^{1129}$ GRAZIA, Giuseppina Rosaria De, op. cit., p. 151-152.

${ }^{1130}$ Ibid., p. 159.

${ }^{1131}$ Ibid., p. 159.

${ }^{1132}$ Ibid., p. 159.
} 
investimentos em sua atividade-fim, seu 'negócio' mais estratégico" "1133, era um dos instrumentos adotados para alcançar uma "produção enxuta e flexível". ${ }^{1134}$ A terceirização de atividades de apoio à produção era uma prática conhecida desde os anos 50, mas nos anos 90 "o processo de transferência de atividades se acelera e atinge áreas de trabalho qualificado, incluindo aquelas diretamente vinculadas à produção, como ferramentaria, estamparia etc". ${ }^{1135}$

Giuseppina Rosaria De Grazia observa que a substituição de setores inteiros de uma indústria pela subcontratação temporária, vinculada à necessidade de produção de cada período do ano, apresentava ao capital as seguintes vantagens: economia nos custos administrativos; redução do custo fixo da força de trabalho para apenas alguns períodos do ano; facilidade para a fábrica adaptar as atividades às requisições do mercado; facilidade de controle sobre os trabalhadores não terceirizados, em razão da redução de seu número; dificuldade de ação conjunta dos terceirizados, em razão da divisão entre eles, e o enfraquecimento do seu poder reivindicativo. ${ }^{1136}$

Era a possibilidade de maior lucratividade que levava as empresas a repassar alguns serviços para serem efetuados em trabalho domiciliar, a subcontratar o fornecimento de determinados componentes ou a constituir uma ampla rede de subcontratação, incluindo seus produtos essenciais, interna ou externamente. ${ }^{1137}$ "Em grau extremo, ficar apenas com o gerenciamento da produção poderia ser uma saída mais racional e lucrativa". ${ }^{1138}$

Além disso, para o capital, a terceirização representava a possibilidade de eliminar as "gigantescas concentrações de trabalhadores nas grandes unidades fabris do fordismo", ${ }^{1139}$ que haviam produzido "os grandes sindicatos de massa" 1140 e com isso a

${ }^{1133}$ GRAZIA, Giuseppina Rosaria De. A redução e redistribuição do tempo de trabalho em questão. Tese de doutorado. Departamento de Sociologia da FFLCH-USP, São Paulo, 2003, p.160.

${ }^{1134}$ Ibid., p.160.

${ }^{1135}$ Ibid., p. 160.

${ }^{1136}$ Ibid., p. 160.

${ }^{1137}$ Ibid., p. 160.

${ }^{1138}$ Ibid., p. 160.

${ }^{1139}$ Ibid., p. 160-161.

${ }^{1140}$ OLIVEIRA, Francisco de. Para não passar de equlibrista a bêbado. In: CASTRO, N (org.). A máquina e o equilibrista: inovações na indústria automobilística brasileira. Rio de Janeiro: Paz e Terra, 1995, p.79. Apud GRAZIA, Giuseppina Rosaria De, op. cit., p. 161. 
conquista de um razoável poder de regulação dos trabalhadores sobre o capitalismo da época. ${ }^{1141}$

\subsubsection{3 - A FLEXIBILIZAÇÃO DAS RELAÇÕES DE TRABALHO}

Giuseppina Rosaria De Grazia observa que as "novas necessidades de expansão e acumulação do capital em escala mundial são incompatíveis com regulamentações, normas, direitos, ou qualquer outro entrave que lhe limite os movimentos agora em escala planetária". ${ }^{1142}$ Por isso, na "Europa, desde os anos 1970 começa o desmonte da série de normas que permitiam um maior controle público, dos trabalhadores e de suas organizações sobre o uso da força de trabalho". ${ }^{1143}$

A flexibilização das relações de trabalho, no Brasil, ocorrem por meio de negociações coletivas, de tentativas de mudanças na legislação trabalhista e "por imposição unilateral dos empregadores, a despeito de qualquer lei ou negociação". ${ }^{1144}$ As medidas de flexibilização de forma negociada, por negociação coletiva, muitas vezes antecipam-se às mudanças legislativas. ${ }^{1145}$

Conforme esclareceu Giovanni Alves, essa forma de flexibilização por negociação coletiva busca substituir as decisões impostas autoritariamente pela empresa, obtendo-se, com isso, o consentimento do trabalhador para garantir a sólida recomposição da hegemonia do capital, por meio do atendimento das novas exigências de qualidade e produtividade. ${ }^{1146}$

\footnotetext{
${ }^{1141}$ GRAZIA, Giuseppina Rosaria De. A redução e redistribuição do tempo de trabalho em questão. Tese de doutorado. Departamento de Sociologia da FFLCH-USP, São Paulo, 2003,op. cit., p. 161.

${ }^{1142}$ Ibid., p. 163.

1143 Ibid., p. 163.

${ }^{1144}$ Ibid., p. 163.

${ }^{1145}$ Ibid., p. 167.

${ }^{1146}$ ALVES, Giovanni. O novo (e precário) mundo do trabalho. São Paulo: Boitempo, 2000, p. 242-245. Apud GRAZIA, Giuseppina Rosaria De, op. cit., p. 167.
} 
Para Grazia, a flexibilização das relações de trabalho por negociação coletiva está em consonância com os novos paradigmas econômicos e políticos”, que enfatizam "o aspecto do diálogo e da parceria entre capital e trabalho". ${ }^{1147}$

O descumprimento reiterado da legislação trabalhista pelos empregadores pode ser considerado uma forma de flexibilização unilateral, na medida em que amplamente disseminada no Brasil, retirando muito da força normativa do direito do trabalho, que as forças social dos trabalhadores e institucional do Estado não conseguem recuperar.

A organização dos trabalhadores e a luta sindical são fundamentais para a obtenção de direitos, pressão e fiscalização sobre o Estado e para efetiva transformação do sistema produtivo. Mas o desemprego enfraquece a atividade sindical. A fragmentação da classe trabalhadora enfraquece a atividade sindical.

Faz-se necessário unir as forças progressistas do Estado e a atuação livre e combativa dos sindicatos. O Estado deve garantir a plenitude da atividade sindical e do exercício da greve. A greve, quando submetida à Justiça do Trabalho, deve ser apreciada como direito fundamental consagrado na Constituição Federal.

A liberdade sindical plena não possibilita o afastamento do poder do Estado como normatizador em prol dos trabalhadores, uma vez que mesmo a luta sindical encontra obstáculos no poder econômico do empregador, potencializado pelo medo do desemprego.

Na Constituição Federal de 1988, restou mantido o princípio da unicidade sindical (artigo $8^{\circ}$, II): "é vedada a criação de mais de uma organização sindical, em qualquer grau, representativa de categoria profissional ou econômica, na mesma base territorial, que será definida pelos trabalhadores ou empregadores interessados, não podendo ser inferior à área de um Município".

\footnotetext{
${ }^{1147}$ GRAZIA, Giuseppina Rosaria De. A redução e redistribuição do tempo de trabalho em questão. Tese de
} doutorado. Departamento de Sociologia da FFLCH-USP, São Paulo, 2003, p. 167-168. 
Se por um lado a unicidade sindical protege contra uma fragmentação excessiva da representação sindical, que poderia ocorrer sob um sistema de liberdade plena, com possibilidade de criação de centenas e de até milhares de sindicatos representativos da mesma categoria na mesma base territorial, por outro incentiva a predominância de sindicatos pouco combativos, na medida em que não necessitam disputar a adesão dos trabalhadores por meio de conquistas.

A defesa da unicidade sindical foi realizada por juristas do porte de Evaristo de Moraes e Oliveira Viana, no bojo de uma perspectiva pública para a entidade sindical e de atribuição de efeitos erga omnes, dentro da categoria, para as normas coletivas pactuadas, independentemente de filiação.

Mas a falta de combatividade e a fragilidade da representação sindical têm conduzido a resultados muito modestos em favor dos trabalhadores. As normas coletivas inovam muito pouco em relação aos direitos estabelecidos por outras modalidades normativas. Não raro, a negociação coletiva tem sido utilizada para a retirada de direitos fixados heteronomamente, em manifesta inconstitucionalidade de tal procedimento por violação do princípio da melhoria da condição social do trabalhador, que se extrai do conjunto histórico-institucional-normativo do direito do trabalho e do artigo $7^{\circ}$, "caput", da Constituição Federal.

Uma solução poderia ser a pluralidade sindical, com limitação para a criação da entidade sindical, de acordo com certo percentual do conjunto dos trabalhadores da categoria na mesma base territorial, como, por exemplo, $5 \%$ ou $10 \%$, a fim de evitar a fragmentação excessiva e o surgimento de sindicatos enfraquecidos.

Um outro ponto sensível é a questão das contribuições sindicais obrigatórias, que, em relação à unicidade sindical, funciona como a outra "face da moeda", ou seja, o outro elemento essencial da atual estrutura sindical, mantendo com a unicidade um caráter de implicação direta, na medida em que ambas decorrem daquele caráter público da entidade sindical e, por consequência, de suas normas, e na medida em que sob a pluralidade sindical surgiriam obstáculos à distribuição das contribuições e estaria 
ausente o argumento de que o não sindicalizado deve contribuir compulsoriamente porque se beneficia das normas coletivas fixadas para sua categoria.

Armando Boito Júnior observa que um trunfo que a estrutura sindical coloca à disposição do peleguismo é o perfil atrasado do contingente de sindicalizados, onde o pelego consegue, através do assistencialismo propiciado pelas contribuições sindicais obrigatórias, formar grandes clientelas eleitorais. ${ }^{1148}$

Extinta a contribuição sindical obrigatória, a receita do sindicato adviria predominantemente de mensalidade dos associados, que atualmente representa pouco no conjunto das receitas. É sabido que os níveis de sindicalização são muito baixos e sofreram queda significativa nas últimas décadas, como reflexo de diversos problemas enfrentados pela classe trabalhadora, tais como sua complexificação e fragmentação. É possível, portanto, imaginar o enfraquecimento das entidades sindicais, em um cenário de ausência das contribuições sindicais. Uma sugestão poderia ser a de rateio da contribuição sindical entre todas as entidades criadas sob o regime de pluralidade, proporcionalmente ao número de sindicalizados, como critério de representatividade. Por outro lado, a necessidade de legitimar a representação traria aos sindicatos maior combatividade e poderia auxiliar para o aumento dos associados.

O fato é que a estrutura sindical, como está, com a unicidade e a contribuição sindical obrigatória, desemboca no reduzido espírito de luta de considerável parcela das entidades sindicais brasileiras, o que tem significado mecanismo de cerceamento do princípio da melhoria da condição social do trabalhador, cuja concretização depende muito da ação das entidades sindicais.

Pelos princípios do direito do trabalho, a negociação coletiva é fonte normativa e o seu conteúdo prevalece sobre o de outras fontes, sempre que se revelar mais favorável ao trabalhador: aplicação da técnica de supremacia da norma mais favorável.

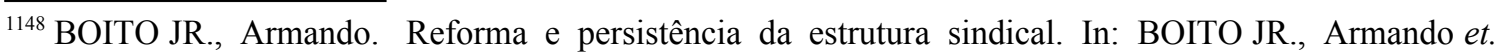
al. O sindicalismo brasileiro nos anos 80. Rio de Janeiro: Paz e Terra, 1991, p. 89. 
Nas últimas décadas foram várias as tentativas de imprimir uma nova espécie de predominância jurídica do negociado em face do legislado, o que na verdade significa a possibilidade de reduzir direitos trabalhistas por negociação coletiva. Tal pretensão do capital, caso acolhida, romperia com a imperatividade do direito do trabalho e imprimiria ao inciso XXVI do artigo $7^{\circ}$ da Constituição Federal um sentido diverso daquele que emana do texto constitucional.

É que o prestígio às convenções e acordos coletivos de trabalho por meio do seu reconhecimento constitucional expresso encontra-se no contexto de um direito dos trabalhadores, conforme expressamente menciona o "caput" do artigo $7^{\circ}$ da Carta Magna. Além disso, o princípio da melhoria da condição social do trabalhador, expresso também no "caput" do referido artigo, na expressão "além de outros que visem à melhoria de sua condição social" vincula de maneira completa o conteúdo das normas coletivas aos interesses dos trabalhadores, sob pena de inconstitucionalidade.

A redução ou retirada de direitos por negociação coletiva é uma negação da história de luta dos trabalhadores pela legitimidade dessa fonte normativa, como instrumento de avanços mais profundos e céleres do que os provenientes do Estado, na medida em que nas convenções e acordos coletivos seriam fixados direitos obtidos pelo confronto direto da coletividade trabalhadora, representada pelas entidades sindicais, com o capital.

A agressividade da exploração capitalista se intensificou nas últimas décadas. Os motivos que levaram os trabalhadores a lutar por direitos e a se unir em sindicatos continuam os mesmos, e mais presentes do que nunca. $\mathrm{O}$ que mudou foram os mecanismos de exploração, com as novas tecnologias e os novos métodos produtivos, com maior poder de domínio sobre o trabalhador. O que houve foi uma ofensiva do capital.

A mídia a serviço do capital não tem nenhum pudor em combater os direitos trabalhistas, em se utilizar do discurso de que a modernidade é a desregulamentação e a flexibilização das normas trabalhistas, quando os efeitos que tais medidas podem gerar, de intensificação da exploração do trabalhador, são mais antigos do 
que as normas de proteção, obviamente. A desproteção é completamente antiquada e ultrapassada.

Moderna, no sentido de progressista, de fato, seria a intensificação da proteção e a afirmação política da classe trabalhadora, para a construção de uma sociedade solidária e igualitária, em que o ser humano tivesse a oportunidade de se humanizar e fosse visto como mais importante do que as coisas.

A argumentação de que os direitos trabalhistas não se coadunam com a nova realidade do trabalho somente tem sentido se com isso estiver sendo dito que ante a desorganização da classe trabalhadora e a ameaça de desemprego não se faz necessário manter o mínimo de direitos para a força de trabalho, entendendo-se, equivocadamente, o espírito do tempo como autorização para ampliar ainda mais a exploração. É preciso clareza quanto ao momento presente e quanto à má intenção desse discurso.

É por isso que se afigura equivocada a proposta de criação do Acordo Coletivo de Trabalho com Propósito Específico (ACTPE) ou Acordo Coletivo Especial (ACE), apresentada pelo Sindicato dos Metalúrgicos do ABC (Santo André, São Bernardo do Campo e São Caetano do Sul), em 30 de novembro de 2011, à Presidência de República e à Câmara dos Deputados, com a finalidade de possibilitar a flexibilização de direitos por norma coletiva. Se a referida modalidade de acordo coletivo puder ter algum benefício para a categoria dos metalúrgicos do $\mathrm{ABC}$ (o que parece ser improvável), com certeza traria muitos prejuízos à classe trabalhadora brasileira. É mais um instrumento de precarização das condições de trabalho e de destruição do direito do trabalho e do Estado Social.

Mesmo agindo coletivamente, há limitações na atuação dos trabalhadores. As dificuldades de união, de mobilização, de representação adequada pelo órgão sindical, somam-se a um desafio central que é a ameaça do desemprego. O sindicato mais forte da mais organizada categoria não está em posição de igualdade com o empregador, ante o poder deste de dispensar os empregados, principalmente se houver uma interpretação de um direito potestativo de dispensa, que embora não tenha nenhum sentido jurídico ainda encontra considerável ressonância nas esferas jurídicas. Enquanto se pensar a empresa sob 
a perspectiva de direito individual de seus "proprietários" e não como ente dotado de função social, os trabalhadores estarão em desvantagem. Nesse cenário, a ameaça de desemprego é uma arma poderosa de que o capital tem se utilizado habitualmente.

A autonomia coletiva deve estar a serviço da justiça social e da melhoria da condição de vida e de trabalho da classe trabalhadora.

As normas estatais não devem ser mínimas (o caráter mínimo deve apenas significar a impossibilidade de redução em prejuízo do trabalhador). Elas devem ser suficientes para a plenitude da qualidade de vida dos trabalhadores e para seu fortalecimento enquanto classe social. As normas decorrentes de negociação coletiva devem partir sempre do patamar heterônomo. Tais normas somente podem aumentar os direitos dos trabalhadores, nunca regredi-los.

O Estado deve zelar para que as normas estatais de proteção sejam cumpridas e que a negociação coletiva as tenha como ponto de partida, para a melhoria e nunca como possibilidade de modificação em prejuízo do trabalhador.

O Estado deve zelar para que a classe trabalhadora possa usufruir plenamente do direito de greve, como instrumento de melhoria de sua condição social e mecanismo imprescindível para se apresentar perante o capital, em uma ordem jurídica que vê como legítima a atividade empresarial a serviço exclusivo do lucro, como se oferecer trabalho fosse um favor, como se o mínimo oferecido para a subsistência já fosse tudo o que coubesse ao trabalhador.

A negociação coletiva que não parta da observância das normas estatais deve ser precedida de greve, para que os trabalhadores se sintam unidos e que o capital possa negociar na perspectiva adequada, de melhoria da situação dos trabalhadores.

O capital nunca vai prescindir da força de trabalho dos trabalhadores. Até mesmo para desenvolver a tecnologia é necessária a força de trabalho. Para aplicar a tecnologia é necessária a força de trabalho. O capital nada mais é do que trabalho "morto" 
(acumulado) e depende sempre do trabalho vivo, que se realiza no suor de cada dia de todo trabalhador.

Cabe ao Estado interferir para que a economia da nação caminhe na direção do pleno emprego. O pleno emprego e a garantia efetiva do direito de greve possibilitam negociação coletiva mais adequada, que poderá observar o caráter protetivo do direito do trabalho.

\subsection{9 - A INTENSIFICAÇÃO DOS PRESSUPOSTOS ECONÔMICOS E SOCIAIS PARA A APLICAÇÃO DO DIREITO DO TRABALHO}

Até mesmo nesta segunda década do século XXI, o ideário neoliberal ainda fundamenta campanhas da mídia, que insiste em divulgar que tudo o que é público não funciona bem ou é ruim. Os meios de comunicação de massa ainda estão predominantemente vinculados aos interesses do capital (muitas vezes do capital internacional) e procuram a adesão das pessoas a medidas como a privatização e a destruição de um projeto nacional.

O capital procura permanentemente meios de destruir o arcabouço de proteção trabalhista. $\mathrm{O}$ ataque aos direitos dos trabalhadores é permanente, sob a pecha do “custo Brasil”, o capital procura convencer a opinião pública de que a retirada de direitos poderá contribuir para o desenvolvimento do país.

A virulência e os riscos da ideologia neoliberal ainda não estão debelados no Brasil. Deixaram suas raízes nas relações políticas, econômicas e sociais e geram obstáculos para maiores avanços na diminuição da desigualdade social.

A globalização modificou o padrão de acumulação capitalista, em razão da prevalência do setor financeiro e da rentabilidade de seus ativos e em decorrência da dominação dos fluxos de informação. ${ }^{1149}$

\footnotetext{
${ }^{1149}$ CAMPOS, Fernando Marques de. Os direitos sociais e sua função no capitalismo. Dissertação de mestrado. Faculdade de Direito da USP, São Paulo, 2010, p. 54.
} 
No capitalismo sempre se observou a criação incessante de novas alternativas e modelos para o aprimoramento da produção e reprodução do capital e para o capital desviar-se das amarras legais. ${ }^{1150}$ "O Direito do Trabalho nasceu e sobreviveu acompanhando essa lógica", em um contínuo processo de tentar "inibir a superexploração e buscar a melhoria constante da condição social e econômica daqueles que vendem sua força de trabalho ..."1151

Mesmo na realidade gerada pelo novo paradigma do processo produtivo (na verdade mera "implementação de técnicas para fugir das amarras do direito social"), o direito do trabalho tem grande importância e mais se intensificam os pressupostos de sua aplicação, na medida em que a nova realidade intensificou a exploração do trabalho pelo capital. ${ }^{1152}$

\footnotetext{
${ }^{1150}$ SOUTO MAIOR, Jorge Luiz. Os princípios do Direito do Trabalho e sua negação por alguns posicionamentos jurisprudenciais. In: MELO FILHO, Hugo Cavalcanti et.al. (coord.). $O$ mundo do trabalho, volume I: leituras críticas da jurisprudência do TST: em defesa do direito do trabalho. São Paulo: LTr, 2009, p. 205.

${ }^{1151}$ Ibid., p. 205.

${ }^{1152}$ Ibid., p. 205.
} 


\section{4 - O DIREITO SOCIAL}

\section{1 - PRINCÍPIOS GERAIS E RACIONALIDADE}

O direito social representa uma transformação do direito, na perspectiva valorativa: as pessoas são juridicamente solidárias e têm direitos em razão do compromisso do pacto de solidariedade e não por benevolência. Essa racionalidade jurídica busca a promoção em concreto do bem-estar social, por meio do caráter obrigacional do direito e coercitivo do Estado, impondo a realização de certas condutas. ${ }^{1153}$

Trata-se de uma perspectiva jurídica correspondente com o Estado que foi sendo consolidado a partir do final do século XIX e início do século XX, não mais como um mero Estado-poder, voltado para as garantias individuais dos cidadãos proprietários, mas um Estado com a missão de proporcionar melhores condições de vida para os membros da coletividade, criando estruturas de ampliação e equalização das oportunidades e zelando para que a destrutividade social do sistema capitalista não extrapolasse determinados limites.

A partir dessa perspectiva, o Estado passou a ter obrigações sociais diretas, a participar da vida econômica e a impor obrigações para os agentes econômicos, incorporando ao sistema jurídico a perspectiva de interesse público e buscando substituir o individualismo egoísta gerado pela competição e pela busca da reprodução do capital, por laços mais amplos.

A revolução industrial e a consolidação do capitalismo intensificaram a problemática dos acidentes de trabalho e o enfrentamento jurídico dessa problemática, mediante o estabelecimento de obrigações que pudessem prevenir e reparar os danos gerados com tais acidentes, representou "um dos principais impulsos para a formação do direito social e do seu consequente Estado social". ${ }^{1154}$

\footnotetext{
${ }^{1153}$ SOUTO MAIOR, Jorge Luiz \& CORREIA, Marcus Orione Gonçalves. O que é Direito Social? In: CORREIA, Marcus Orione Gonçalves (org.). Curso de direito do trabalho - Volume I : teoria geral do direito do trabalho. São Paulo: LTr, 2007, p. 26.

${ }^{1154}$ SOUTO MAIOR, Jorge Luiz. Os princípios do Direito do Trabalho e sua negação por alguns posicionamentos jurisprudenciais. In: MELO FILHO, Hugo Cavalcanti et. al. (coord.). O mundo do
} 
A racionalidade do direito social foi uma tentativa de superação dos valores do liberalismo e teve como fundamento a proteção do direito à vida ${ }^{1155}$ e sua supremacia frente aos valores econômicos.

É por isso que as tentativas de implantação do Estado neoliberal, com o retorno ao Estado mínimo viabilizador apenas dos interesses do capital, geraram tantos ataques aos direitos sociais, por comporem uma outra racionalidade.

Somente a dimensão social e não a perspectiva individualista é que proporciona a concretização de valores existenciais densos:

Como explica Paulo Bonavides 'Os direitos sociais fizeram nascer a consciência de que tão importante quanto salvaguardar o indivíduo, conforme ocorreria na concepção clássica dos direitos da liberdade, era proteger a instituição, uma realidade social muito mais rica e aberta à participação criativa e à valoração da personalidade que o quadro tradicional da solidão individualista, onde se formara o culto liberal do homem abstrato e insulado, sem a densidade dos valores existenciais, aqueles que unicamente o social proporciona em toda plenitude ${ }^{1156}$.

Alan Oliveira Pontes observa que no modelo solidarista são consideradas "bem-vindas todas as contribuições dos participantes, sejam elas decorrentes da espontaneidade dos contribuintes ou da atuação coercitiva do poder estatal". ${ }^{1157}$ E acrescenta que a "solidariedade social nada mais é do que a cooperação de cada indivíduo com os demais e com toda a sociedade decorrente da interatividade existente entre todos os

trabalho, volume I: leituras críticas da jurisprudência do TST: em defesa do direito do trabalho. São Paulo: LTr, 2009, p. 227.

${ }^{1155}$ SOUTO MAIOR, Jorge Luiz. Os princípios do Direito do Trabalho e sua negação por alguns posicionamentos jurisprudenciais. In: MELO FILHO, Hugo Cavalcanti et. al. (coord.). $O$ mundo do trabalho, volume I: leituras críticas da jurisprudência do TST: em defesa do direito do trabalho. São Paulo: LTr, 2009, p. 227.

${ }^{1156}$ Ibid., p. 228

${ }^{1157}$ PONTES, Alan Oliveira. O princípio da solidariedade social na interpretação do direito da seguridade social. Dissertação de mestrado. Faculdade de Direito da USP, São Paulo, 2006, p. 115. 
membros". ${ }^{1158}$ Por fim, conclui que uma "sociedade mais solidária somente será alcançada quando o resultado do trabalho coletivo for redistribuído com mais igualdade entre as pessoas, e nesse ponto o Estado atua como a figura mais importante na realização de uma efetiva política social". ${ }^{1159}$

Jorge Luiz Souto Maior esclarece que o direito social não é a harmonização de dois sistemas, o capitalista e o socialista, mas uma dimensão do próprio capitalismo, decorrente da experiência histórica de que o liberalismo não dava suporte para a viabilidade do sistema, eis que se fez necessária a proteção do ser humano mediante a limitação dos interesses econômicos. ${ }^{1160}$ Diz que "Não se trata de uma proteção submetida a uma condição de viabilidade do modelo econômico. Trata-se de uma proteção que submete o poder econômico a um teste de validade": 1161

...Se o modelo capitalista for capaz de assegurar a eficácia das proposições contidas no Direito Social e, mais especificamente, no Direito do Trabalho, terá reforçado o seu argumento de legitimidade, do contrário, deverá perecer e dar lugar a outro modelo de sociedade. ${ }^{1162}$

O direito social é uma perspectiva jurídica que se aproxima mais do direito do trabalho e da seguridade social e dos direitos da personalidade, ${ }^{1163}$ mas sua racionalidade atinge todas as situações em que se vislumbra a necessidade de proteção social, decorrente de um estado de sujeição e de inferioridade que agrida a condição humana. Além disso, não se volta apenas ao Estado, mas a todos os cidadãos.

Atualmente, a abrangência subjetiva e objetiva dos direitos sociais é extremamente maior. Assim, estes não se caracterizariam, no nosso

\footnotetext{
${ }^{1158}$ PONTES, Alan Oliveira. O princípio da solidariedade social na interpretação do direito da seguridade social. Dissertação de mestrado. Faculdade de Direito da USP, São Paulo, 2006, p. 117.

${ }^{1159}$ Ibid., p. 210.

${ }^{1160}$ SOUTO MAIOR, Jorge Luiz. Curso de direito do trabalho: teoria geral do direito do trabalho, volume I: Parte I. São Paulo: LTr, 2011, p. 648.

${ }^{1161}$ Ibid., p. 648.

${ }^{1162}$ Ibid., p. 648-649.

${ }^{1163}$ SOUTO MAIOR, Jorge Luiz \& CORREIA, Marcus Orione Gonçalves. O que é Direito Social? In: CORREIA, Marcus Orione Gonçalves (org.). Curso de direito do trabalho - Volume I : teoria geral do direito do trabalho. São Paulo: LTr, 2007, p. 27.
} 
entender, como uma categoria distinta dos direitos público e privado, mas permeariam ambos nos instantes em que ocorressem traços comuns distintivos e que necessitassem de ser tratados sob a perspectiva da proteção social maximizada. Expliquemos: pode haver direito social tanto em áreas tradicionalmente afetas ao direito privado (como exemplo certas relações de consumo ou aquelas estabelecidas por pequenos contratantes do sistema financeiro de habitação) ou também ao direito público (como exemplo tradicional tem-se o direito previdenciário, mas também seria possível a sua constatação no direito sanitário ou no direito tributário. ${ }^{1164}$

O direito social é uma racionalidade jurídica. Os direitos sociais consubstanciados nos direitos do trabalho e previdenciário e nas políticas públicas de cidadania, como saúde, educação, moradia etc integram o direito social e sua racionalidade. Mas também o direito civil atual, quando, por exemplo, trata dos negócios jurídicos ou da função social do contrato aproxima-se da racionalidade do direito social, assim como em todos os demais ramos do direito existe atualmente essa possibilidade de nova perspectiva.

A Constituição Federal de 1988 consagrou amplamente a dimensão do direito social. No artigo $1^{\circ}$ estabeleceu que o Brasil constitui-se em Estado Democrático de Direito e incluiu entres os seus fundamentos a dignidade da pessoa humana, a cidadania e os valores sociais do trabalho. No artigo $3^{\circ}$, indicou como objetivos fundamentais da República a construção de uma sociedade livre, justa e solidária, o desenvolvimento nacional, a erradicação da pobreza e da marginalização, a redução das desigualdades sociais e regionais, a promoção do bem de todos, sem preconceitos e discriminação. No artigo $4^{\circ}$, estabeleceu o princípio da prevalência dos direitos humanos como um dos que regem as relações internacionais do país.

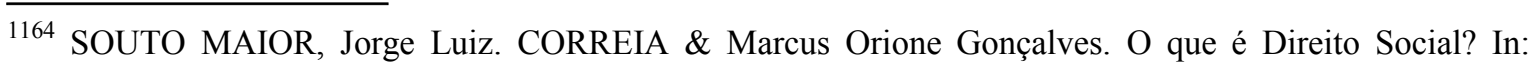
CORREIA, Marcus Orione Gonçalves (org.). Curso de direito do trabalho - Volume I : teoria geral do direito do trabalho. São Paulo: LTr, 2007, p. 24. 
A Constituição Federal, no capítulo II do título dos direitos e garantias fundamentais tratou dos direitos sociais. No artigo $6^{\circ}$, indicou como direitos sociais a educação, a saúde, o trabalho, a moradia, o lazer, a segurança, a previdência social, a proteção à maternidade e à infância, bem como a assistência aos desamparados. No artigo $7^{\circ}$, reconheceu os direitos dos trabalhadores, determinando que outros também seriam reconhecidos na medida em que melhorassem a condição social dos trabalhadores. No artigo $8^{\circ}$, disciplinou a liberdade de associação profissional ou sindical e no artigo $9^{\circ}$ assegurou o direito de greve.

No título VIII, referente à ordem social, foram traçadas normas referentes à seguridade social (artigos 194 e 195), à saúde (artigos 196 a 200), à previdência social (artigos 201 a 202), assistência social (artigo 203 a 204), à educação, cultura e desporto (artigos 205 a 217), à ciência e tecnologia (artigos 218 a 219), à comunicação social (artigos 220 a 224), ao meio ambiente (artigo 225), à família, à criança, ao adolescente e ao idoso (artigos 226 a 230) e ao índios (artigos 231 a 232).

Em diversos outros dispositivos e de modo predominante em toda a Constituição, que foi chamada por Ulisses Guimarães, a "Carta Cidadã", percebe-se a criação de uma perspectiva voltada para a construção de uma sociedade igualitária e solidária.

Sérgio Alberto de Souza lembra que o catálogo constitucional dos direitos sociais não é exaustivo, mas apenas exemplitificativo: é um rol mínimo, que não pode, nem deve, ser diminuído pelo legislador. ${ }^{165}$ Não se admite regressão. ${ }^{1166}$ Um verdadeiro regime democrático deve assegurar a proteção dos fracos, que são, afinal, as pessoas mais numerosas (CF, art.60, parágrafo $\left.4^{\mathrm{o}}, \mathrm{IV}\right) .{ }^{1167}$ Só existe democracia quando o Estado está embasado na proteção da autonomia da vontade dos mais fracos, jurídica, econômica e politicamente. ${ }^{1168}$

\footnotetext{
${ }^{1165}$ SOUZA, Sérgio Alberto de. Direito, globalização e barbárie - estudos críticos de temas de direito do trabalho e de direitos humanos sob a ótica de uma leitura não-liberal. São Paulo: LTr, 1998, p. 36.

${ }^{1166}$ Ibid., p. 36.

${ }^{1167}$ Ibid., p. 36.

${ }^{1168}$ Ibid., p. 36-37.
} 
Jorge Luiz Souto Maior ${ }^{1169}$ indica os seguintes princípios do Direito Social: a) "organizar, por meio do Direito e do Estado, o modo de produção capitalista"; b) "superar os valores liberais em prol da construção da justiça social"; c) "quebrar o individualismo e o empreendedorismo egoístas, submetendo-os a um projeto de sociedade solidária"; d) "construir a justiça social por meio de políticas de distribuição da riqueza produzida e, em especial, pelo estabelecimento de uma função social à propriedade"; e) "erradicar a pobreza e reduzir progressivamente as desigualdades entre as classes sociais, até a completa eliminação da divisão"; f) "efetivar a igualdade entre os homens, sem qualquer tipo de discriminação ou preconceito"; g) "garantir a liberdade no contexto da igualdade plena"; h) "possibilitar a democracia política"; i) "resgatar e preservar a dignidade humana"; j) "enunciar, evolutivamente, e promover o valor social do trabalho e as prestações integrais da Seguridade Social"; k) " manter uma posição crítica de si mesmo".

\section{2 - AS IDEIAS EMBRIONÁRIAS DO DIREITO SOCIAL}

A criação do direito social, mediante as transformações de um direito que era estritamente liberal, acompanharam as transformações do Estado, como não poderia deixar de ser, dada a possibilidade até mesmo de identificação de Estado com o Direito. Pode-se dizer que as mesmas razões que levaram às alterações do Estado estão na base das que forçaram a construção de uma nova racionalidade jurídica, embora ainda em construção, no sentido de disputa de espaço com a liberal, que embora ultrapassada, enraizou-se na consciência social, principalmente das classes dominantes, por lhes ser conveniente.

As alterações jurídicas praticadas por Bismarck na Alemanha apontavam para a criação do direito social. Nas Constituições do México de 1917 e de Weimar, de 1919, constavam os direitos sociais e a construção da nova racionalidade jurídica.

\footnotetext{
${ }^{1169}$ SOUTO MAIOR, Jorge Luiz. Curso de direito do trabalho: teoria geral do direito do trabalho, volume I: parte I. São Paulo: LTr, 2011, p. 628.
} 
Mario de la Cueva ${ }^{1170}$ explica que no século XIX Otto von Gierke defendia que no curso da história existira um direito social criado pelas corporações, cujos caracteres eram sua autonomia e a circunstância de que considerava o homem não como pessoa plenamente individual, mas em suas relações com um corpo social, e que esses ordenamentos jurídicos, que desapareceram em grande medida na Idade moderna, estavam encontrando um campo novo nas corporações socioeconômicas do século XIX. De la Cueva observa $^{1171}$ que Georges Scelle, em 1922, afirmara que o direito do trabalho havia quebrado o princípio da unidade do direito comum e criado um direito de classe, uma legislação defensora do trabalho em suas relações com o capital. Diz que, para Radbruch, o direito do trabalho determina o tratamento que deve outorgar-se ao homem na prestação de seu trabalho e que, por meio desse ramo jurídico, a classe trabalhadora, depois de mais de um século de luta, impôs à burguesia e a seu Estado a implantação de um mínimo de direitos sociais. ${ }^{1172}$

O Brasil foi marcado pelas condições históricas de seu nascimento, na lógica da exploração colonialista e pela manutenção do escravismo. Durante a República Velha, pouco foi feito para a incorporação da massa de ex-escravos à cidadania. Após a incipiente organização dos trabalhadores e as grandes greves de 1917 a 1920, teve início uma reconstrução da ordem jurídica, que somente ganhou impulso a partir da Revolução de 1930.

A construção do direito social no Brasil partiu desse contexto de nação com grandes exclusões e desigualdades sociais. A implantação dos direitos sociais foi transformando as relações sociais, de modo que, em 1960, o país viveu o momento de menor desigualdade social de sua história, até ter esse processo interrompido pela ditadura civil-militar, a partir de 1964, com forte caráter concentrador de renda.

O neoliberalismo chegou ao Brasil com muita força, na década de 1990, e produziu grande ataque aos direitos sociais, embora a partir de 1988 tivéssemos uma Constituição Federal que consagrava a racionalidade do direito social.

${ }^{1170}$ CUEVA, Mario de la. El nuevo derecho mexicano del trabajo. 4. ed. México: Editorial Porrúa, 1977, p. 71.

${ }^{1171}$ Ibid., p. 71.

${ }^{1172}$ Ibid., p. 72 
A reestruturação produtiva que veio no bojo do neoliberalismo, com implantação de técnicas toyotistas, como a da horizontalização da produção e a dos sistemas de estoques mínimos e de produção conforme a demanda, tiveram profundo impacto no mundo do trabalho, com intensa precarização por meio da ampliação do trabalho informal, de terceirizações, do trabalho em condições análogas à de escravo, da ampliação da rotatividade da mão de obra, da ampliação da jornada de trabalho, rebaixamento dos salários e desvirtuamento da natureza salarial das contraprestações pagas ao trabalhador.

Após a Constituição Federal de 1988, notam-se avanços no que se refere à implantação dos direitos sociais referentes aos benefícios garantidos pelo Estado, como os da assistência social, por exemplo. Exceção a esse quadro é a aposentadoria, que sofreu restrições e chegou a adquirir até mesmo um viés privatizante, a partir da Emenda Constitucional n. 20/98, por meio do incentivo à previdência privada.

Assim, ocorreram avanços em matéria de políticas públicas voltadas, principalmente, para a assistência social e transferência de renda, mas também para áreas como, por exemplo, educação, saúde (implementação do SUS) e moradia (Programa "Minha Casa Minha Vida"). Houve um aperfeiçoamento pró-cidadão, em tais direitos sociais, embora com abertura de possibilidades para participação e ganhos pelo capital, como no caso da saúde e da educação, nas quais há segmentação de classes, com os serviços inteiramente públicos para os pobres e serviços privados para as classes média e alta, subsidiados pelo Estado, por meio do welfare fiscal (abatimento no Imposto de Renda).

Mas no que se refere aos direitos sociais pertinentes ao núcleo central capitalista (relações de trabalho), houve retrocesso nas últimas décadas e a Constituição Federal de 1988 conseguiu evitar apenas a derrocada completa, mas não um aperfeiçoamento normativo pró-capitalista e prejudicial aos trabalhadores. Apenas o salário mínimo foi exceção a essa regra, eis que contou com valorização, nos governos Lula e Dilma. Mas, de resto, houve forte ataque aos direitos sociais trabalhistas, por meio da 
intensificação da terceirização, da ampliação da jornada com bancos de horas, do desvirtuamento do salário e de negociações coletivas prejudicias aos trabalhadores, entre outras formas de agressão.

\section{3 - DIREITOS SOCIAIS E ECONOMIA - A QUESTÃO DA INFLAÇÃO}

Conforme esclarece Pierre Salama, ${ }^{1173}$ "o crescimento da inflação é produto de um conflito distributivo", na medida em que é o grupo social dos empresários quem fixa os preços e os salários e define a taxa de lucro, de modo que a "aceleração do processo inflacionário deriva da exacerbação do conflito em torno dessa fixação".

A inflação, portanto, não se produz porque há um excesso de oferta de moeda, mas porque há um conflito social em torno da fixação de preços e salários e definição da margem de lucro pelo capitalista.

Emir Sader explica que o aumento de salário diminui a mais-valia (quantidade de riqueza produzida pelo trabalhador e não remunerada pelo capitalista), mas ao "aumentar o preço das mercadorias que os trabalhadores comprarão, os capitalistas transferem os maiores gastos com força de trabalho e recuperam as taxas de exploração". 1174

Os meios de comunicação de massa no Brasil costumam criticar indiretamente e, às vezes até diretamente, o crescimento dos salários, imputando aos trabalhadores a responsabilidade pelo aumento da inflação, mas silenciam quanto ao fato de que é a fixação unilateral da margem de lucros empresariais que define o preço e, portanto a inflação. Nada dizem os economistas a serviço do capital quanto ao peso dos lucros no processo inflacionário.

${ }^{1173}$ SALAMA, Pierre. A trama do neoliberalismo. Mercado, crise e exclusão social. In: Pós-Neoliberalismo. As políticas sociais e o Estado democrático. SADER, Emir; GENTILI, Pablo (org.). 5. ed. Rio de Janeiro: Paz e Terra, 2000, p. 179.

${ }^{1174}$ SADER, Emir. A exploração. In: SADER, Emir (org.). Sete pecados do capital. Rio de Janeiro: Record, 2000, p. 67-68. 
Quando existe inflação e os salários não são reajustados, isso gera prejuízo para o trabalhador. O capitalista não sofre prejuízos, eis que aumenta os preços, na busca de maiores lucros, valendo-se da escassez relativa ou absoluta.

A inflação não deveria ser combatida mediante diminuição do poder de compra do trabalhador, seja por meio de defasagem salarial ou desemprego, sob pena de gerar agravamento dos problemas e das desigualdades sociais.

Existem outros fatores secundários de implicação, no tocante à inflação, referentes aos hábitos de consumo, ao incentivo ao consumo e ao crédito. O incentivo ao endividamento para o consumo deve ser combatido pelo Estado. Deve haver informação e formação que contribua para que o trabalhador se proteja e escape do consumismo e do endividamento. $\mathrm{O}$ acesso ao consumo consciente pelo trabalhador deve ocorrer mediante aumento da renda e não mediante endividamento.

Octavio Ianni explica que os investimentos produtivos dependem de capitais como os provenientes de lucros ou da poupança total da sociedade (espontânea ou forçada). ${ }^{1175} \mathrm{~A}$ inflação representa poupança forçada, pois a elevação dos preços reduz a remuneração real dos assalariados. ${ }^{1176}$ "Poupanças e lucros, pois, são as formas sob as quais o capital se apresenta antes de transformar-se em investimentos industriais" e ambos os casos são "cristalizações do capital, que dizem respeito às relações entre os empresários e as classes que recebem salários". ${ }^{1177}$ Para o empresariado, a inflação representa uma técnica de capitalização, capital para investimento. ${ }^{1178}$ Há na inflação, portanto, um “processo espoliativo". 1179

\footnotetext{
${ }^{1175}$ IANNI, Octavio. O Estado e o desenvolvimento econômico no Brasil. Tese apresentada ao concurso para provimento da cadeira de Professor de Sociologia II da FFLCH-USP, São Paulo, 1964, p. 149-150.

${ }_{1176}$ Ibid., p. 150.

${ }^{1177}$ Ibid., p. 149.

${ }_{1178}$ Ibid., p. 150.

${ }^{1179}$ Ibid., p. 151.
} 


\section{4 - O DIREITO DO TRABALHO}

\subsection{1 - ASPECTOS GERAIS}

Para uma adequada compreensão do direito do trabalho, do seu conteúdo, da sua natureza e de sua razão histórica, faz-se necessária, previamente, uma análise histórico-social, ${ }^{1180}$ eis que esse ramo jurídico surgiu como resposta política do capitalismo aos problemas sociais, mas também como possibilidade de manutenção do sistema. Neste último aspecto, observa Jaime Montalvo Correa, reside o caráter contraditório dessa resposta. $^{1181}$

Para Mario de la Cueva, a separação dos homens em proprietários de terra e de riqueza e em sem-terras-e-sem-riqueza é a causa geradora da divisão e da luta de classes das sociedades que vivem no sistema da propriedade privada. ${ }^{1182}$ Diz que a burguesia do século XIX conseguiu a elevação da propriedade privada e das liberdades de indústria e comércio à categoria de direitos naturais do homem, positivando-os nos Códigos Civis e obrigando o respeito a esses direitos, direitos dos proprietários, por meio do direito penal. ${ }^{1183}$

De la Cueva sustenta que a burguesia impôs-se ao poder real e à nobreza. Com o constitucionalismo social do início do século XX, nas Constituições do México (1917) e de Weimar (1919) foi a classe trabalhadora que se impôs frente à burguesia, como um novo fator real de poder, por meio da organização em sindicatos, greves e negociações coletivas de trabalho. ${ }^{1184}$ As diferenças entre os direitos da burguesia e dos trabalhadores são as existentes entre os direitos individuais do homem (direito imposto ao Estado para que assegurasse a livre exploração das riquezas e da força de trabalho) e os direitos sociais dos trabalhadores e camponeses (direitos de uma classe social de luta e pressão para

\footnotetext{
${ }^{1180}$ BORRAJO, E. Sindicalismo obrero en Francia, Madrid (CSIC), 1956, p. 17. Apud CORREA, Jaime Montalvo. Fundamentos de derecho del trabajo. Madrid: Editorial Civitas, 1975, p. 20.

${ }^{1181}$ CORREA, Jaime Montalvo, op. cit., p. 21.

${ }^{1182}$ CUEVA, Mario de la. El nuevo derecho mexicano del trabajo. 4. ed. México: Editorial Porrúa, 1977, p. 88.

${ }^{1183}$ Ibid., p. 88.

${ }^{1184}$ Ibid., p. 88.
} 
diminuir a exploração do trabalho pelo capital). ${ }^{1185}$ Assim, os direitos sociais representaram uma novidade na história: era a primeira vez que uma classe social obtinha o direito de lutar contra outra, sobressaindo-se, neste particular, o direito de greve, equivalente a uma declaração e operação de guerra. ${ }^{1186}$

O direito do trabalho não surgiu no século XIX, eis que até então ainda imperava a racionalidade liberal e a racionalidade desse ramo jurídico é diversa dos postulados liberais, porque está vinculada a um projeto de sociedade em que haja respeito à condição humana, em uma perspectiva que parte da igualdade humana fundamental e busca a construção da justiça social. O descumprimento das normas desse ramo jurídico representa a quebra desse projeto.

O desrespeito a essa construção jurídica, que muitas vezes vem acompanhado da retórica de que é preciso melhorar a eficiência econômica das empresas, não é apenas uma agressão aos trabalhadores, como sujeitos de direitos, constitui a quebra de um projeto de sociedade, sem nada pôr em seu lugar, pois bem se sabe, desde sempre, o sucesso econômico de uns não gera, nem nunca gerará, por consequência natural, desenvolvimento social, distribuição de renda e respeito à condição humana. ${ }^{187}$

No ensinamento de Mario de la Cueva, o direito do trabalho é um direito de classe, um direito protetor dos trabalhadores, necessário enquanto perdurar a divisão de classes sociais, divisão que é produto das injustiças e da dinâmica do modo de produção capitalista. $^{1188}$

${ }^{1185}$ CUEVA, Mario de la. El nuevo derecho mexicano del trabajo. 4. ed. México: Editorial Porrúa, 1977, p. 89.

${ }^{1186}$ Ibid., p. 89

${ }^{1187}$ SOUTO MAIOR, Jorge Luiz. Os princípios do direito do trabalho e sua negação por alguns posicionamentos jurisprudenciais. In: MELO FILHO, Hugo Cavalcanti et. al. (coords.). O mundo do trabalho, volume I: leituras críticas da jurisprudência do TST: em defesa do direito do trabalho. São Paulo: LTr, 2009, p. 202.

${ }^{1188}$ CUEVA, Mario de la. Derecho mexicano del trabajo. Prologo da segunda edição. Mexico: Libreria de Porrua Hnos. Y Cia., 1943, p. 213-214. 
No Brasil, as relações de trabalho sempre foram marcadas por intensa exploração dos trabalhadores, seja da mão de obra escrava, seja da imigrante e posteriormente da assalariada. A classe trabalhadora começou a se organizar no início do século XX. O movimento de construção nacional desencadeado a partir de 1930, permeado pela industrialização e urbanização, trouxe a estruturação do direito do trabalho no Brasil, como forma de evitar a pauperização do trabalhador e de buscar uma certa modalidade de pacificação nas relações produtivas. De um lado, o direito do trabalho possibilitou o desenvolvimento econômico, notadamente do setor industrial, e de outro possibilitou que o país iniciasse o processo de inclusão social das classes dominadas.

O surgimento do direito do trabalho no Brasil está muito marcado pelos esforços para viabilizar o contexto de transformação da sociedade agrárioexportadora de raiz escravista para uma sociedade industrial. Até então, havia histórico de intervenção do Estado nas relações de trabalho, mas em favor das classes dominantes (por meio da manutenção da escravidão e da facilitação da imigração) e não para a proteção do trabalhador. A lógica que predominou nesse momento de estruturação do direito do trabalho foi a da conciliação e da colaboração de classes sociais. Criava-se o direito do trabalho, mas para não incomodar muito a burguesia.

A inclusão social da classe trabalhadora se fez de maneira gradativa e lenta. Quando do surgimento do direito do trabalho no Brasil, a inclusão se fez apenas para os trabalhadores urbanos da indústria e dos serviços, deixando de fora os trabalhadores rurais e os domésticos, por exemplo. Além disso, a massa de trabalhadores informais sempre foi absurdamente grande no país.

$\mathrm{O}$ artigo $7^{\circ}$ da CLT estabeleceu que os preceitos da Consolidação, salvo quando expressamente determinado em contrário, não se aplicavam aos empregados domésticos e aos trabalhadores rurais. Somente com as leis 5.859/72 e 5889/73 os trabalhadores domésticos e rurais, respectivamente, tiveram uma proteção mínima trabalhista em face dos empregadores, embora quanto aos rurais, o Estatuto do Trabalhador Rural, de 1963, já trouxera alguns direitos sociais, mas que tiveram pouca aplicabilidade. 
Quando a burguesia brasileira quis ampliar a exploração da força de trabalho, para ampliar seus lucros, aliou-se aos interesses estrangeiros e aos militares, instalando o terrorismo de Estado, que, por meio de agentes públicos, praticou homicídios e torturas, e, no que se refere às relações de produção, chegou até mesmo a manipular índices inflacionários, na década de 1970.

Na década de 1990, sob forte ataque neoliberal, o direito do trabalho sofreu sérias desfigurações, com desvirtuamento de aspectos pertinentes à formação da relação empregatícia, gerando grande tendência de empurrar milhares de trabalhadores para a informalidade; à formação de contratos de trabalho precarizados, mediante a terceirização e modalidades de trabalho a prazo determinado; à forte ampliação da jornada, mediante expedientes como o de instituição de banco de horas; às sutis armadilhas, como as tentativas de retirada de natureza salarial das contraprestações pagas em razão do trabalho.

A negociação coletiva, grande conquista dos trabalhadores, foi desvirtuada e transformada em instrumento de destruição de direitos trabalhistas básicos, eis que a burguesia desfigurou a referida modalidade de pactuação, como forma de ignorar todos os pressupostos que levaram ao surgimento do direito do trabalho, notadamente a desigualdade entre as partes, em nada mitigada pela representação sindical, em um contexto de predomínio de sindicatos pelegos e "de carimbo" e pela situação econômica de desemprego e jurídica de amplas possibilidades de dispensas imotivadas.

O contexto de surgimento do direito do trabalho, como um direito que não deveria incomodar muito, um direito de conciliação das classes sociais, fez com que sua implementação não se realizasse "para valer", ou seja, não foi um direito levado a sério ou pelo menos não tão a sério quanto o país necessitava. Aliás, faz parte da tradição brasileira a edição de normas jurídicas que não são levadas a sério. As tais "leis para inglês ver". Não é por outra razão que na cultura brasileira existe um elemento social peculiar no campo da eficácia das normas, que é traduzido pela expressão "pegar", nem todas as leis "pegam", ou seja, são reconhecidas como normas heterônomas de cumprimento obrigatório. 
É claro que nas circunstâncias do direito do trabalho está o fato de que as forças instintivas do capital, de busca frenética pela ampliação dos lucros, em uma sociedade que dá legitimidade para esse modo de procedimento, representam uma missão bastante complexa para a eficácia de um ramo jurídico que se propõe a interferir nesse mecanismo.

Já na década de 1920, quando da lei de férias, o empresariado usou da tática de retardar a regulamentação. E isso não foi diferente para diversos institutos de direito do trabalho, desde então.

Todos esses aspectos fizeram com que o direito do trabalho fosse permanentemente descumprido. Possibilitaram a existência de uma quantidade imensa de trabalhadores sob o regime de trabalho informal, sem registro em CTPS. Possibilitaram que, mesmo sob a vigência de contratos formalizados, a maior dos direitos fosse descumprida, notadamente os devidos quando do encerramento do contrato.

A judicialização dos conflitos trabalhistas e os problemas estruturais da Justiça do Trabalho, que levavam à demora na solução dos litígios, incentivavam o descumprimento da legislação. Além disso, uma jurisprudência conservadora da Justiça do Trabalho, em diversos aspectos, e a disseminação da prática de acordos judiciais irrisórios, fraudulentos do próprio vínculo empregatício, em muito contribuíram para o enfraquecimento da proteção do direito do trabalho. Os acordos judiciais se tornaram meios de abrandamento dos deveres e das obrigações dos empregadores. Na verdade, os acordos foram incorporados ao planejamento empresarial, no campo do custo da força de trabalho, incentivando com sua lógica a precarização e a intensificação da exploração do trabalhador.

Uma estrutura sindical distorcida, pela dinâmica da unicidade sindical e da contribuição sindical obrigatória, gerou um contexto de predomínio de sindicatos não combativos. Sindicatos dependentes do Estado e autônomos em relaçãos trabalhadores, cuja sindicalização não se revelava necessária para as receitas das entidades. 
Nas explicações de Jaime Montalvo Correa, ${ }^{1189}$ o direito do trabalho foi uma resposta defensiva da burguesia frente à ação emancipadora da classe trabalhadora (e não filantrópica ou de preocupação com a situação penosa dos trabalhadores). E a contradição do direito do trabalho ocorre porque esse direito concretiza melhorias para os trabalhadores, mas limita as possibilidades de emancipação, na medida em que os vincula à ordem capitalista de produção, favorável aos detentores do capital (legalização da exploração da força de trabalho e acondicionamento no marco normativo dessa exploração). ${ }^{1190}$ Mas Correa observa, contudo, que há no direito do trabalho normas protetivas e outras que mais do que a proteção apontam para a emancipação dos trabalhadores. ${ }^{1191}$

Segundo Mario de la Cueva, o direito coletivo do trabalho representa não somente a igualdade do trabalho e do capital para criação do direito individual do trabalho, mas, em muitas ocasiões, a supremacia do trabalho sobre o capital, em razão do direito de greve. ${ }^{1192}$ Diz que esse direito coletivo do trabalho não foi uma concessão da burguesia, mas uma imposição da classe trabalhadora ${ }^{1193}$ e que a classe trabalhadora deve conscientizar-se de que precisa conquistar os objetivos do direito do trabalho, na luta contra o capital. ${ }^{1194}$

Para Mario de la Cueva, a "ideia de proteção da classe trabalhadora pelo Estado burguês agride a dignidade do trabalho, porque ela não é um criança que necessite de tutor" ${ }^{1195}$ Neste particular, parece-nos que a classe trabalhadora não pode prescindir da proteção do Estado, notadamente nos aspectos que favoreçam sua organização e luta direta em face do capital, porque os tempos atuais, em se considerando o cenário mundial, são de excesso de mão de obra e de redução das oportunidades de emprego, enfraquecendo o poder dos trabalhadores de manutenção das conquistas e de sua ampliação. Além disso, o Estado sempre terá uma forte presença na economia do país, podendo influenciar a questão do pleno emprego e, portanto, as condições de luta dos trabalhadores por direitos.

\footnotetext{
${ }^{1189}$ CORREA, Jaime Montalvo. Fundamentos de derecho del trabajo. Madrid: Editorial Civitas, 1975, p. 149.

${ }^{1190}$ Ibid., p. 149.

${ }^{1191}$ Ibid., p. 149.

1192 Ibid., p. 105.

${ }^{1193}$ CUEVA, Mario de la. El nuevo derecho mexicano del trabajo. 4. ed. México: Editorial Porrúa, 1977, p.105.

${ }^{1194}$ Ibid., p. 105.

${ }^{1195}$ Ibid., p. 106.
} 
Jorge Luiz Souto Maior indica os seguintes princípios do direito do trabalho: ${ }^{1196}$ a) "limitar a liberdade em nome da promoção da igualdade"; b) "buscar a melhoria da condição social (de vida e de trabalho) dos trabalhadores"; c) "elevar a condição humana dos trabalhadores"; d) "democratizar as relações de trabalho"; e) "promover a solidariedade"; f) "possibilitar a organização coletiva dos trabalhadores"; g) "instrumentalizar a luta dos trabalhadores por direitos"; h) "internacionalizar os valores de proteção jurídica dos trabalhadores".

E acrescenta que o direito do trabalho deve ser concebido "como o instrumento jurídico que incentiva o desenvolvimento de práticas emancipatórias, a partir de um equacionamento crítico da realidade". ${ }^{1197}$ Trata-se de um ramo jurídico que é "a essência dos Direitos Sociais" e que possui a função de regular o modo de produção capitalista para a concretização da justiça social e para a "convivência pacífica entre os homens". ${ }^{1198}$

\subsection{2 - O CARÁTER INSTRUMENTAL DO DIREITO DO TRABALHO}

O direito do trabalho possui um caráter instrumental, de concretização de justiça social, mediante a imposição de limites éticos ao capitalismo.

Do ponto de vista da teoria geral do Direito do Trabalho, a verificação do relevante papel dos instrumentos jurídicos para a imposição de limites éticos ao capitalismo não se trata meramente de uma opção do julgador e, sim, de preservar a própria utilidade da existência de um ramo do direito voltado, especificamente, a regular a relação entre o capital e o trabalho. Afinal, como já dissemos em outra oportunidade, "se o direito do trabalho não

${ }^{1196}$ SOUTO MAIOR, Jorge Luiz. Curso de direito do trabalho: teoria geral do direito do trabalho, volume I: parte I. São Paulo: LTr, 2011, p. 627.

${ }_{1197}^{1}$ Ibid., p.621.

${ }^{1198}$ IDEM. Os princípios do direito do trabalho e sua negação por alguns posicionamentos jurisprudenciais. In: MELO FILHO, Hugo Cavalcanti et. al. (coord.). O mundo do trabalho, volume I: leituras críticas da jurisprudência do TST: em defesa do direito do trabalho. São Paulo: LTr, 2009, p. 198. 
servir como instrumento de luta para a realização de justiça social não serve para nada, e portanto, não precisa existir como ciência jurídica autônoma. ${ }^{1199}$

O direito correlaciona-se com a realidade, podendo ser utilizado para mantê-la ou para transformá-la. ${ }^{1200}$ Mas, a transformação da realidade pelo direito é sua tarefa civilizatória. ${ }^{1201}$

Para Mario de la Cueva, a finalidade suprema do direito do trabalho é outorgar aos trabalhadores e às suas famílias uma existência e um nível econômico "decorosos", mediante a satisfação de todas as necessidades materiais para o pleno desenvolvimento das faculdades físicas e espirituais. ${ }^{1202}$

\subsection{3 - FUNDAMENTOS DO DIREITO DO TRABALHO}

Jaime Montalvo Correa, ${ }^{1203}$ explicando o surgimento do direito do trabalho, noticia que o desenvolvimento das forças produtivas levou a uma modificação da estrutura social e ao surgimento e fortalecimento da classe trabalhadora, tanto sob o aspecto quantitativo, com o aumento do número de trabalhadores assalariados, principalmente na indústria, quanto qualitativo, com a consolidação da consciência de classe e o aperfeiçoamento das suas atitudes.

Explica que o nascimento da classe proletária ocorreu precisamente com a tomada de consciência da situação de opressão e da possibilidade de superá-la ou pelo

\footnotetext{
1199 SOUTO MAIOR, Jorge Luiz. Os princípios do direito do trabalho e sua negação por alguns posicionamentos jurisprudenciais. In: MELO FILHO, Hugo Cavalcanti et. al. (coord.). $O$ mundo do trabalho, volume I: leituras críticas da jurisprudência do TST: em defesa do direito do trabalho. São Paulo: LTr, 2009, p. 207.

${ }^{1200}$ IDEM. Curso de direito do trabalho: teoria geral do direito do trabalho, volume I: Parte I. São Paulo: LTr, 2011, p. 645.

${ }^{1201}$ MORAES, Maria Celina Bodin de. O conceito de dignidade humana: substrato axiológico e conteúdo normativo. In: SARLET, Ingo Wolfgang (org.). Constituição, direitos fundamentais e direito privado. 2. ed. Porto Alegre: Livraria do Advogado, 2006, p. 108.

${ }^{1202}$ CUEVA, Mario de la. El nuevo derecho mexicano del trabajo. 4. ed. México: Editorial Porrúa, 1977, p. 113.

1203 CORREA, Jaime Montalvo. Fundamentos de derecho del trabajo. Madrid: Editorial Civitas, 1975, p. 148 .
} 
menos amenizá-la. ${ }^{1204}$ A pressão que a classe trabalhadora passou a exercer obrigou a uma mudança no sistema jurídico (as ideias liberais impediam a elaboração de normas estatais para disciplinar as relações de trabalho) e a burguesia, detentora do poder, começou a elaborar normas reparadoras das consequências sociais da autonomia individual dos trabalhadores, em um primeiro momento, e, posteriormente, normas reparadoras da própria autonomia individual. ${ }^{1205}$

G. Lyon-Caen entende que o direito do trabalho representa o acúmulo de concessões da burguesia (argumenta que às vezes foram outorgadas antes mesmo de serem reclamadas), a fim de tornar a exploração dos trabalhadores suportável e com isso manter a "paz social". ${ }^{1206}$

Montalvo Correa explica que o fundamento histórico do surgimento da legislação social foi a defesa da ordem social burguesa capitalista e esse aspecto permanece no direito do trabalho atual. ${ }^{1207}$ Mas, diz que a pressão dos trabalhadores gera uma variação no eixo central da composição de interesses da relação capital versus trabalho e o direito do trabalho continuará buscando esse novo equilíbrio. ${ }^{1208}$

Manoel Carlos Toledo Filho explica que "o direito do trabalho serve principalmente aos interesses do capital, consubstanciando um eficaz mecanismo de defesa do patrimônio e dos interesses dos empregadores", ${ }^{1209}$ uma vez que os limites impostos pelo referido ramo jurídico à possibilidade de exploração da classe trabalhadora fizeram com que o trabalhador se sentisse minimamente protegido e, com isto, restasse "narcotizado" o seu "ímpeto revolucionário". ${ }^{1210}$ Acrescenta: "Fortalecer o direito do trabalho (...) significa robustecer a lógica do sistema capitalista, cultivando uma massa de

\footnotetext{
${ }^{1204}$ CORREA, Jaime Montalvo. Fundamentos de derecho del trabajo. Madrid: Editorial Civitas, 1975, p. 148.

1205 Ibid., p. 148-149.

${ }^{1206}$ LYON-CAEN, G. Ideologias y doctrinas en derecho del trabajo. Derecho Laboral, Buenos Aires, n. 10, p. 585, 1971. Apud CORREA, Jaime Montalvo, op. cit., p. 153-154.

${ }^{1207}$ CORREA, Jaime Montalvo, op. cit., p. 153-154.

${ }^{1208}$ Ibid., p. 153-154.

1209 TOLEDO FILHO, MANOEL CARLOS. Direito do capital. Disponível em http://www.anamatra.org.br/artigos/direito-do-capital. Acesso em 22.08.2013.

${ }^{1210}$ Ibid.
} 
trabalhadores minimamente satisfeitos, ademais de garantir um mercado consumidor consistente". ${ }^{1211}$

Jaime Montalvo Correa explica que as normas de direito social podem ter alcances diferenciados. O poder público pode elaborar normas "reparadoras da situação material dos trabalhadores, sem alterar a essência de sua situação no processo produtivo"1212 e também elaborar normas "que podem favorecer a progressiva emancipação da classe trabalhadora". ${ }^{213}$ A classe trabalhadora "pretende em última instância superar um sistema de relações de produção de que é vítima inevitável", ${ }^{1214}$ promovendo uma "transformação radical no sistema produtivo", 1215 mas "ao mesmo tempo sente a necessidade de buscar melhorias reparadoras concretas, que, porém, geram estabilidade no sistema que referida classe pretende questionar". ${ }^{1216}$ Trata-se do caráter contraditório do direito social. ${ }^{1217}$

Normas como as referentes à jornada de trabalho, salários, seguridade social representam o atendimento de reivindicações de aspectos concretos da prestação laboral, servindo, por outro lado, para favorecer o fomento do consumo e com isso beneficiar a própria expansão capitalista. ${ }^{1218}$ Diferentemente, as normas que favorecem a associação sindical e a greve potencializam a autonomia coletiva e têm um poder maior de alteração da estrutura das relações de produção, por meio do fortalecimento da classe trabalhadora. ${ }^{1219}$

O poder instalado nas sociedades capitalistas prefere elaborar normas que satisfaçam as reivindicações concretas dos trabalhadores, possibilitando "melhorias controladas que não afetam a estrutura da relação de produção", a elaborar "normas que suprimam as travas do fortalecimento da classe que pretende a superação da divisão

${ }^{1211}$ TOLEDO FILHO, MANOEL CARLOS. Direito do capital. Disponível em http://www.anamatra.org.br/artigos/direito-do-capital. Acesso em 22.08.2013.

${ }_{1212}$ CORREA, Jaime Montalvo. Fundamentos de derecho del trabajo. Madrid: Editorial Civitas, 1975, p. 154.

${ }^{1213}$ Ibid., p. 154.

${ }^{1214}$ Ibid., p. 154.

${ }^{1215}$ Ibid., p. 154.

${ }^{1216}$ Ibid., p. 154.

${ }^{1217}$ Ibid., p. 154.

${ }^{1218}$ Ibid., p. 155.

${ }^{1219}$ Ibid., p. 155. 
social". ${ }^{1220}$ Nesse ponto, para Montalvo Correa, surge uma tensão entre autonomia privada coletiva e intervenção estatal. ${ }^{1221}$

No início, quando a classe operária desenvolveu um “mínimo de identidade", pretendeu conseguir a liberdade de associação, considerada à época compatível com os próprios princípios liberais de então e suficiente para equilibrar o potencial negociador dos trabalhadores. ${ }^{1222}$ Havia uma "fé sem limites no laissez-faire coletivo". ${ }^{1223}$

Mario de la Cueva esclarece que "as ideias de igualdade e de liberdade andam juntas, eis que a igualdade sem a liberdade não existe e a liberdade não floresce onde falta igualdade". ${ }^{1224}$ As "primeiras lutas dos trabalhadores se dirigiram à conquista das liberdades de coalização, de negociação e contratação coletivas e de greve"1225 e essas liberdades coletivas perseguiam o propósito de igualdade de direito entre o trabalho e o capital para a fixação das condições de trabalho. ${ }^{1226}$

Para Marx, a emancipação do proletariado deve ser obra do próprio proletariado. ${ }^{1227}$ Com a influência do anarquismo e do marxismo, o movimento operário, já em uma fase de maior amadurecimento, passou a entender que "somente a associação libertaria o proletariado de sua opressão", por meio de uma revolução social estrutural, que contestasse "a própria ideia de Estado e qualquer forma de governo". ${ }^{1228}$

Posteriormente, percebeu-se que era necessário, "sem deixar de questionar o poder político da burguesia, arrancar as leis que amenizassem em alguma medida a dureza das condições materiais e sociais dos trabalhadores". ${ }^{122}$ Mas, Jaime Montalvo Correa diz

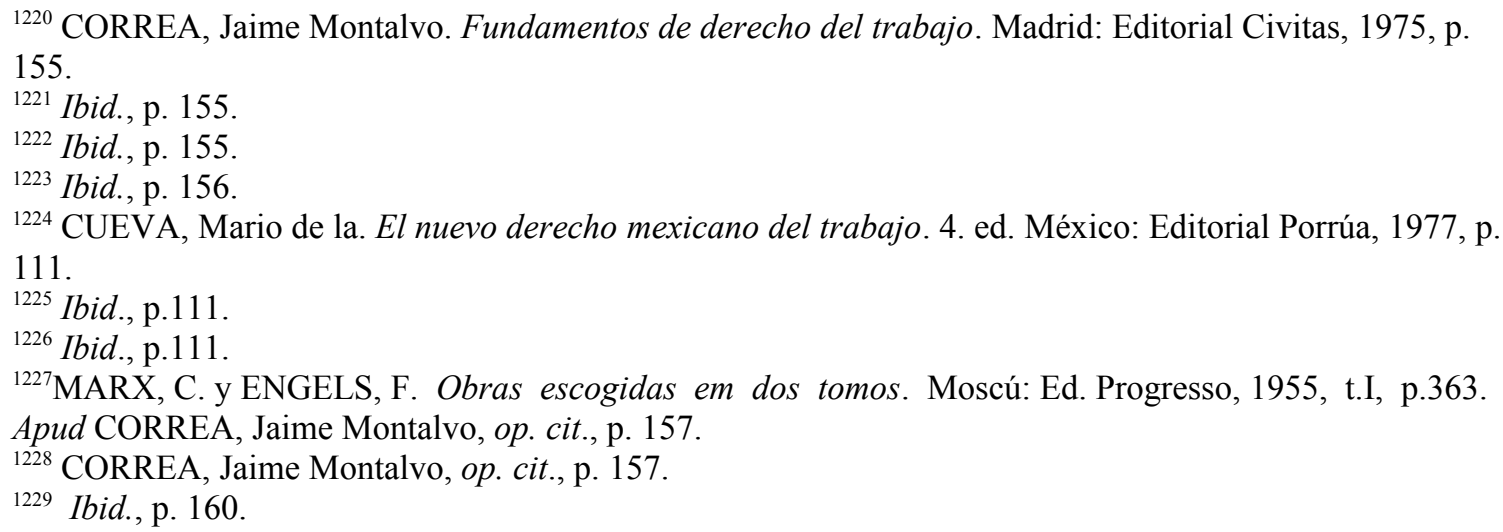


que uma dúvida continuou na história do movimento dos trabalhadores: "até que ponto as reformas parciais da ordem social paralisam e inclusive negam a possibilidade da transformação radical do sistema produtivo?"1230

Sobre estas últimas questões, é possível observar que, nas últimas décadas, a fragmentação da classe trabalhadora e a ampliação do desemprego retiraram grande parte do poder de emancipação dos trabalhadores por suas próprias mãos. A participação do Estado e a participação dos trabalhadores no Estado apresentam-se cada vez mais importantes para o enfrentamento da problemática pertinente à exploração do trabalho pelo capital. As possibilidades de transformação profunda do sistema produtivo, embora não tenham desaparecido do horizonte, parecem exigir cada vez mais um envolvimento em conquistas que possam ir consolidando um novo cenário de maior fortalecimento da classe trabalhadora.

\subsection{4 - O CONCEITO E AS CARACTERÍSTICAS ESSENCIAIS DO DIREITO DO TRABALHO}

Jorge Luiz Souto Maior apresenta o seguinte conceito de direito do trabalho, ressaltando o caráter dinâmico de suas "regras e princípios historicamente instituídos" e a função de organizar o modelo de produção capitalista, em bases de melhoria progressiva das condições de trabalho e de vida dos trabalhadores e de construção de uma sociedade justa, solidária e democrática:

...ramo do Direito (Social) composto de normas dinâmicas, extraídas de regras e princípios historicamente instituídos, que, integrado ao patrimônio jurídico da classe trabalhadora e direcionado pelo Estado (Social), organiza o modelo de produção capitalista, regulando as relações de emprego, consideradas pelo aspecto da exploração do capital sobre o trabalho, numa perspectiva nacional e internacional, com vistas a limitar os

${ }^{1230}$ CORREA, Jaime Montalvo. Fundamentos de derecho del trabajo. Madrid: Editorial Civitas, 1975, p. 160. 
interesses estritamente econômicos para preservar a paz mundial e construir a justiça social por meio da instrumentalização da melhoria progressiva das condições de trabalho e de vida dos trabalhadores, legitimando a atuação política destes, promovendo a solidariedade, impulsionando a democracia e proporcionando a distribuição da riqueza produzida, além de favorecer o exercício da ética e o desenvolvimento da racionalidade necessária para a preservação e a elevação da condição humana (dignidade humana). ${ }^{1231}$

Com a Revolução Industrial e as transformações das técnicas produtivas e do modo de produção, generalizaram-se as relações de trabalho assalariado e os conflitos sociais. ${ }^{1232}$ A resposta política a esses conflitos foram as normas de direito do trabalho, por meio das quais o proletariado pretendia modificar as relações de produção e o capital mantê-las. ${ }^{1233}$

Para Jaime Montalvo Correa, o direito do trabalho é o sistema de “princípios e normas emanados do Estado e dos próprios interlocutores sociais no exercício da autonomia coletiva, para regular a força de trabalho prestada para outrem na relação de trabalho". ${ }^{1234}$ A "própria essência desse ramo jurídico destaca princípios especiais orientadores da interpretação e aplicação de suas regras, mediante correção ou ajuste dos critérios interpretativos e aplicativos comuns". ${ }^{1235}$

Defende que "A autonomia privada coletiva e a intervenção estatal são as duas alternativas dialéticas na regulação ou ordenação das relações individuais do trabalho". ${ }^{1236}$ Em um determinado momento histórico, "quebrou-se o dogma da autonomia individual como fonte normativa das relações de trabalho" 1237 e, posteriormente, "sem

\footnotetext{
${ }^{1231}$ SOUTO MAIOR, Jorge Luiz. Curso de direito do trabalho: teoria geral do direito do trabalho, volume I: Parte I. São Paulo: LTr, 2011, p. 620-621.

${ }^{1232}$ CORREA, Jaime Montalvo. Fundamentos de derecho del trabajo. Madrid: Editorial Civitas, 1975, p.227.

${ }^{1233}$ Ibid., p.228.

${ }^{1234}$ Ibid., p. 230.

${ }^{1235}$ Ibid., p. 230

${ }^{1236} \mathrm{Ibid}$, . p. 231.

${ }^{1237}$ Ibid., p.231.
} 
prejuízo da participação da vontade individual na constituição da relação de trabalho, a regulação passou a ser realizada pelo aparato normativo do Estado e pelos atores sociais, estes mediante a autonomia coletiva". ${ }^{1238}$

Jaime Montalvo Corrrea indica como características essenciais do direito do trabalho a sua historicidade (desenvolve-se vinculado à realidade econômico-social, à realidade histórica), o seu sentido protetivo e o seu sistema de fontes e técnicas próprias. ${ }^{1239}$

\subsection{5 - O CARÁTER EXPANSIVO DO DIREITO DO TRABALHO}

O dinamismo histórico conduz ao caráter expansivo do direito do trabalho, atraindo sempre novas atividades laborais e "mostrando a sua vocação de direito da atividade profissional". ${ }^{1240}$

A força expansiva do direito do trabalho faz com que a finalidade do direito do trabalho seja abranger a totalidade da classe trabalhadora, assim considerados os que no processo econômico estão em posição oposta à da burguesia ${ }^{1241}$ e que, por não serem detentores dos meios de produção, vivem do próprio trabalho.

No Brasil, o direito do trabalho também foi abrangendo novas categorias de trabalhadores. De um direito específico do operariado fabril, passou a incluir também os trabalhadores do ramo de serviços urbanos. Na década de 1970, incluiu os domésticos e rurais (quanto a estes últimos, o Estatuto do Trabalhador Rural, na década de 1960, já havia iniciado uma proteção normativa, mas que acabou tendo pouca efetividade).

Ainda restam muitas categorias excluídas da proteção legal trabalhista, tais como as dos trabalhadores eventuais, o "chapa", nas cidades, o "boia fria", no campo, e a diarista, nas residências. Essa exclusão marginaliza grande quantidade de trabalhadores e

\footnotetext{
${ }^{1238}$ CORREA, Jaime Montalvo. Fundamentos de derecho del trabajo. Madrid: Editorial Civitas, 1975, p. 231.

${ }^{1239}$ Ibid., p.234.

${ }^{1240}$ Ibid., p. 234.

${ }^{1241}$ CUEVA, Mario de la. El nuevo derecho mexicano del trabajo. 4. ed. México: Editorial Porrúa, 1977, p. 92.
} 
favorece a fraude à legislação trabalhista, mediante a tentativa de enquadramento de número cada vez maior de trabalhadores em tais situações.

Em reflexão anterior a respeito do trabalho dos "chapas", tivemos oportunidade de defender que, enquanto trabalhador subordinado, referido profissional insere-se "na dinâmica própria da relação de produção capitalista e a ausência de reconhecimento de vínculo empregatício representa séria agresssão à dignidade humana, aos princípios da melhoria da condição social do trabalhador e da continuidade da relação de emprego". 1242

É de ressaltar, por fim, que ainda existem milhões de trabalhadores informais no Brasil. Estima-se que em 2013 sejam cerca de $46 \%{ }^{1243}$ do conjunto de trabalhadores brasileiros. Vale dizer, o direito do trabalho precisa expandir-se muito para que as garantias mínimas possam chegar ao mundo do trabalho.

\subsection{6 - O CONDICIONAMENTO POLÍTICO E ECONÔMICO DO DIREITO DO TRABALHO}

Jaime Montalvo Correa observa que existe forte condicionamento político do direito do trabalho, não apenas quanto às diretrizes do Estado, mas também dos próprios trabalhadores, quando vinculados a correntes mais revolucionárias, reformistas ou integracionistas e por isso apresentando condutas diversas. ${ }^{1244}$

A importância da política para o direito do trabalho não somente se refere a seu condicionamento pelos grandes sistemas de ideias, mas também nas medidas de

$\overline{1242}$ OLIVEIRA, Aparecido Batista de. Os limites jurídicos do trabalho eventual: uma análise da figura do "chapa". In: SOUTO MAIOR, Jorge Luiz \& GNATA, Noa Piatã Bassfeld (orgs.). Trabalhos marginais. São Paulo: LTr, 2013, p. 246.

${ }^{1243}$ SINGER, André Vitor. Palestra proferida no IX Sécs-USP: Brasil pós-88: transformações, continuidade e desafios. Disponível em: http://www.viomundo.com.br/politica/armando-boito-jrgrande-burguesia-interna-domina-governo-dilma.html. Acesso em 16-09-2013.

${ }^{1244}$ CORREA, Jaime Montalvo. Fundamentos de derecho del trabajo. Madrid: Editorial Civitas, 1975, p. 235. 
"política social”, como, por exemplo, uma determinada concepção de política de emprego que influencia as normas referentes às dispensas dos trabalhadores. ${ }^{1245}$

As condições de trabalho sofrem implicações das leis da economia capitalista, como se observa pela forte oposição do setor econômico a elevações salariais ou aperfeiçoamento da seguridade social, por exemplo, mas o direito do trabalho também influi no desenvolvimento da vida econômica. ${ }^{1246}$

A política de valorização do salário mínimo, a partir de 2004, gerou grande impacto positivo na economia do Brasil. Não é verdade, portanto, que o direito não tenha influência na econômia.

\subsection{7 - O CARÁTER HISTÓRICO-SOCIAL DO DIREITO DO TRABALHO}

O surgimento do direito do trabalho ocorreu "em um marco histórico específico, como resposta a determinados problemas sociais, e seu desenvolvimento experimenta os altos e baixos da história do movimento operário". ${ }^{1247}$ Quando uma norma resolve determinados problemas, surgem outros que requerem novas normas, ${ }^{1248}$ acompanhando a dinâmica própria das transformações históricas e sociais.

Ainda com relação ao caráter histórico-social do direito do trabalho, podese observar que no interior do referido ramo jurídico existem múltiplas contradições (por exemplo, o próprio contrato de trabalho e a greve, esta com os seus significados destrutivo e construtivo), que refletem, na verdade, as contradições das relações de produção do sistema capitalista. ${ }^{1249} \mathrm{O}$ contrato de trabalho é garantia e proteção para o trabalhador, mas é também o marco de sua exploração pelo capital. A greve é um deixar de trabalhar para voltar a trabalhar.

\footnotetext{
${ }^{1245}$ CORREA, Jaime Montalvo. Fundamentos de derecho del trabajo. Madrid: Editorial Civitas, 1975, p. 235.

1246 Ibid., p. 236.

${ }^{1247}$ Ibid., p. 234.

${ }^{1248}$ Ibid., p. 234.

${ }^{1249}$ Ibid., p. 237.
} 
Enquanto ramo jurídico diretamente vinculado à categoria essencial do sistema capitalista, qual seja, a da produção, o direito do trabalho é por essência contraditório, na medida em que interage com as mais variadas situações sociais do sistema e este, por essência é contraditório: o capital possui interesses antagônicos aos dos trabalhadores, mas na lógica capitalista ambos coexistem no mesmo fim produtivo.

O capital, durante longo período histórico, para produzir, e portanto, atingir seus interesses, precisou reunir os trabalhadores, e essa reunião por sua vez, favoreceu a união dos trabalhadores, que atuava no sentido contrário aos interesses do capital ${ }^{1250}$. Para continuar explorando os trabalhadores, o capital foi obrigado a realizar certas concessões, consubstanciadas nas normas de direitos sociais, e os trabalhadores, para obterem alguns direitos, foram obrigados a aceitar a continuidade da exploração.

Essa dimensão estruturalmente contraditória do direito do trabalho faz com que no menor deslize hermenêutico, passe-se de uma perspectiva protetiva para uma opressiva. Além disso, essa dimensão contraditória e os obscurecimentos que ela proporciona favorecem retóricas aparentemente bem intencionadas, mas que escondem a intensificação da extração da mais valia e o aprofundamento da desigualdade social.

É o que ocorre, por exemplo, quando procura-se atribuir à participação nos lucros e resultados um caráter indenizatório, sob alegação de que facilitará a ampliação dos rendimentos do trabalhador. Na verdade, o fenômeno subjacente é o de ruptura de laços jurídicos protetivos de uma categoria essencial do direito do trabalho, que é a do salário, mediante a sua substituição por uma contraprestação desprotegida. Somente ao empregador é que ela interessa verdadeiramente. Diferentemente de uma participação nos lucros e resultados ancorada em efetiva transparência dos valores dos lucros e resultados e a eles expressamente vinculada por métodos seguros, como o de fixação de percentual de participação e não meros valores insignificantes aleatória e unilateralmente fixados pelo empregador, na prática atual o único detentor das informações econômicas efetivas da empresa. ${ }^{1250}$ VIANA, Márcio Túlio. A terceirização revisitada - algumas críticas e sugestões para um novo tratamento
da matéria. Revista Ltr, São Paulo, vol.77, n. 02, p.143, fevereiro de 2013 . 
Da mesma forma, a retirada do Estado da relação entre capital e trabalho, sob o argumento de que favorecerá o fortalecimento dos sindicatos e da atuação dos próprios trabalhadores, poderá ser utilizada para a desagregação dos trabalhadores e para a destruição dos direitos trabalhistas, em um contexto em que paire uma ideologia autoritária de cerceamento pelo Estado das atividades associativas e reivindicativas dos grupos sociais. Além disso, se há retirada da normatização heterônoma, sem a construção de pressupostos econômicos e sociais fortalecedores da classe trabalhadora, a negociação coletiva sempre atuará na direção dos interesses do capital, pois os trabalhadores negociarão sob a ameaça de desemprego ou de retaliações.

O Estado deve garantir o pleno emprego, para acabar com o adversário oculto, o desemprego, parceiro do capital na hora da negociação, e deve garantir direitos trabalhistas progressivamente ampliados, para elevar o patamar de negociação entre as partes. Deve atuar incisivamente na garantia do direito de sindicalização, nos aspectos coletivo (criação e gestão de entidades associativas pelos trabalhadores) e individual (direito de associar-se ou desassociar-se livremente), bem como no direito de greve, já há décadas erigido a direito fundamental, mas permanentemente desrespeitado por limitações excessivas da legislação infraconstitucional e da jurisprudência.

Frente a esse caráter contraditório do direito do trabalho, o princípio da melhoria da condição social do trabalhador é um instrumental imprescindível. A todo momento, o profissional do direito deve tê-lo presente, a fim de separar o joio do trigo, no emaranhado das contradições que as situações da vida social trazem, no aspecto da relação de trabalho e do inexorável conflito entre o capital e o trabalho. O menor deslize poderá transformar uma norma de proteção ao trabalhador em norma de interesse predominante do capital.

\subsection{8 - O CARÁTER PROTETIVO DO DIREITO DO TRABALHO}

O caráter protetivo se revela nas medidas de caráter protecionista, destinadas a mitigar os desequilíbrios surgidos pelas imposições patronais das condições 
de trabalho. ${ }^{1251}$ Concretiza-se no desenvolvimento de uma legislação e de princípios protecionistas de caráter imperativos e na criação de órgãos garantidores da operatividade da referida legislação e princípios. ${ }^{1252}$

O sistema de técnicas de pressão e de negociação se refere às greves e às fontes próprias do direito do trabalho, as convenções e acordos coletivos de trabalho. ${ }^{1253} \mathrm{~A}$ greve é um "instrumento básico de negociação coletiva". ${ }^{1254}$

O caráter protetivo também se faz presente no momento da elaboração legislativa da norma, de sua interpretação e de sua aplicação, por meio da inspiração do princípio da melhoria da condição social do trabalhador e de outros integrantes de seu núcleo, como o da proteção ("in dubio, pro operario" e da supremacia da norma e da condição mais favoráveis ao trabalhador), o da primazia da realidade e o da continuidade da relação de emprego.

\subsection{9 - O CARÁTER MÍNIMO DO DIREITO DO TRABALHO}

Segundo Mário de la Cueva, o direito do trabalho é um direito unitário (composto por várias partes com características secundárias diversas), em que os princípios procedem dos mesmos fundamentos, quais sejam as necessidades materiais e espirituais da classe trabalhadora e a justiça social. ${ }^{1255}$ Trata-se de um direito mínimo (as condições de trabalho não podem ser inferiores às fixadas em lei) que, ante seu caráter dinâmico, pretende a elevação constante das condições e níveis de existência dos seres humanos. ${ }^{1256}$

O direito do trabalho deve ser capaz de garantir a completa satisfação material, psíquica e existencial da pessoa humana, em uma perspectiva de constante aprimoramento social. Nesse processo, os avanços já obtidos devem ser sempre

${ }^{1251}$ CORREA, Jaime Montalvo. Fundamentos de derecho del trabajo. Madrid: Editorial Civitas, 1975, p. 237.

${ }^{1252}$ Ibid., p. 237.

${ }^{1253}$ Ibid., p. 238.

${ }^{1254}$ Ibid., p. 238.

${ }^{1255}$ CUEVA, Mario de la. El nuevo derecho mexicano del trabajo. 4. ed. México: Editorial Porrúa, 1977, p.93-94.

${ }^{1256}$ Ibid., p. 97. 
considerados o patamar mínimo para progressiva ampliação. Não deve buscar apenas o mínimo necessário para o trabalhador, como, por exemplo, os meios necessários para a reprodução da força de trabalho, mas partir das conquistas obtidas como patamar de propulsão para novos avanços.

Os contratos individuais e as negociações coletivas jamais podem rebaixar o patamar fixado em lei. As novas leis devem ampliar os direitos já assegurados.

\subsubsection{0 - O DIREITO DO TRABALHO COMO UM DIREITO INCONCLUSO}

Mário de la Cueva ressalta que o direito do trabalho é um direito inconcluso, constantemente atento às novas necessidades humanas e sempre aberto ao acréscimo de mais direitos em seu catálogo, que somente fechar-se-á quando surgir uma nova estrutura social. ${ }^{1257}$ Esse caráter de inconclusividade está relacionado com o de direito mínimo. ${ }^{1258}$

Assim, sempre haverá possibilidade de ampliação e aprofundamento das normas de favorecimento dos trabalhadores. Sempre haverá uma dimensão mais próxima da efetiva justiça social.

\subsubsection{1 - A IMPERATIVIDADE DO DIREITO DO TRABALHO}

Jaime Montalvo Correa observa que o direito do trabalho é um direito imperativo porque foi esse traço o único que possibilitou diminuir a exploração da força de trabalho. ${ }^{1259}$ Quanto maior o intervencionismo estatal nas relações de trabalho, maior será o caráter público das normas do direito do trabalho. ${ }^{1260}$

\footnotetext{
${ }^{1257}$ CUEVA, Mario de la. El nuevo derecho mexicano del trabajo. 4. ed. México: Editorial Porrúa, 1977, p. 98.

${ }^{1258}$ Ibid., p. 98.

${ }^{1259}$ Ibid., p. 99.

${ }^{1260}$ CORREA, Jaime Montalvo. Fundamentos de derecho del trabajo. Madrid: Editorial Civitas, 1975, p.239-245.
} 
Tarso Fernando Genro argumenta que a intervenção do Estado nas relações de trabalho, ao reduzir a "liberdade" dos patrões, "desloca uma parcela de liberdade em favor dos trabalhadores". ${ }^{1261}$

Conforme ressaltamos em monografia de conclusão do curso de especialização em Direito do Trabalho e da Seguridade Social na Faculdade de Direito da USP, a Consolidação das Leis do Trabalho possui dispositivos para "assegurar validade jurídica apenas aos atos das partes harmônicos com os princípios do direito do trabalho, notadamente os da proteção ao trabalhador, da realidade e da irrenunciabilidade de direitos". ${ }^{1262}$

Neste sentido, destacam-se os artigos $9^{\circ}, 444$ e 468 da CLT, cujas normas, assecuratórias do caráter imperativo do direito do trabalho, configuram elementos estruturais desse ramo jurídico.

O artigo $9^{\circ}$ da CLT prevê a nulidade de pleno direito dos "atos praticados com o objetivo de desvirtuar, impedir ou fraudar a aplicação dos preceitos" contidos na Consolidação das Leis do Trabalho. Trata-se de uma norma genérica, irradiando-se o seu princípio por todo o sistema jurídico trabalhista, seja na formação do contrato (inclusive nos atos anteriores), na execução, no término (inclusive nos atos posteriores), nos elementos caracterizadores da relação de trabalho, enfim, em todo e qualquer momento da relação jurídica trabalhista se faz presente a proteção do artigo $9^{\circ}$ da CLT. ${ }^{1263}$

Na ocasião, já alertávamos que em muitas situações há a criação de mecanismos por parte do empregador para tentar escapar à legislação trabalhista, como, por exemplo, tentando descaracterizar o vínculo empregatício ou a natureza salarial dos pagamentos realizados ao empregado. ${ }^{1264} \mathrm{E}$ que, por outro lado, "a renúncia de direitos por

${ }^{1261}$ GENRO, Tarso. Introdução crítica ao direito. Porto Alegre: Sérgio Antonio Fabris Editor. 1988, p. 36. 1262 OLIVEIRA, Aparecido Batista de. Os contornos jurídicos do artigo $9^{\circ}$ da CLT. Monografia de conclusão do curso de especialização em Direito do Trabalho e da Seguridade Social. Faculdade de Direito da USP, São Paulo, 2008, p. 9.

${ }^{1263}$ Ibid., p. 9.

${ }^{1264}$ Ibid., p. 10. 
parte do empregado poderia representar a derrocada de todo o sistema protetivo trabalhista". ${ }^{1265}$

A proibição de utilização de meios para impedir, fraudar ou desvirtuar a legislação trabalhista abrange inclusive os atos posteriores ao encerramento do contrato, de modo que a racionalidade do artigo $9^{\circ}$ da CLT deve inspirar até mesmo o momento em que o capital e o trabalho se encontram em litígio judicial, impedindo que, por meio de acordos judiciais, seja descumprido o direito do trabalho.

O artigo 444 da CLT dispõe que as "relações contratuais de trabalho podem ser objeto de livre estipulação das partes interessadas em tudo quanto não contravenha às disposições de proteção ao trabalho, aos contratos coletivos que sejam aplicáveis e às decisões das autoridades competentes".

As partes têm autonomia para, mesmo no plano individual, estabelecer livremente o objeto do contrato de trabalho, mas não poderão estipular cláusulas que, prejudiciais ao empregado, contrariem as normas e decisões estatais e pactos negociados no âmbito sindical. É a disciplina do artigo 444 da Consolidação das Leis do Trabalho. ${ }^{1266}$

Dessa forma, quaisquer cláusulas ou condições de trabalho pactuadas em contradição com as normas de proteção ao trabalho não possuem autorização para serem estabelecidas, uma vez que o artigo 444 da CLT expressamente proíbe tais normas. O artigo $9^{\circ}$ da CLT incidiria fulminando de nulidade norma que objetivasse desvirtuar, impedir ou fraudar o disposto no artigo 444 da CLT. ${ }^{1267}$

Por força do artigo 468 da CLT, no decorrer do contrato de trabalho, somente são cabíveis alterações contratuais pactuadas por ambas as partes e, mesmo assim, são válidas apenas as que não tragam prejuízos ao empregado. ${ }^{1268}$ Entendemos que se a alteração é benéfica ao trabalhador, não será difícil ao empregador obter a sua adesão, sem

\footnotetext{
${ }^{1265}$ OLIVEIRA, Aparecido Batista de. Os contornos jurídicos do artigo $9^{\circ}$ da CLT. Monografia de conclusão do curso de especialização em Direito do Trabalho e da Seguridade Social. Faculdade de Direito da USP, São Paulo, 2008, p. 10.

${ }^{1266} \mathrm{Ibid}$., p. 51.

${ }^{1267}$ Ibid., p. 25.

${ }^{1268}$ Ibid., p. 35.
} 
prejuízo de apreciação judicial posterior. $\mathrm{Na}$ impossibilidade de consenso, caberá ao empregador utilizar-se dos meios legais, inclusive a ação judicial declaratória da licitude da mudança pretendida, com as medidas de urgência eventualmente cabíveis. Se é prejudicial, é nula e portanto não pactuável.

\section{5 - OS PRINCÍPIOS JURÍDICOS}

\subsection{1 - ASPECTOS GERAIS}

Princípios jurídicos são normas diretrizes essenciais que estruturam, enraízam, identificam e dão sentido ao direito. Diretrizes porque consubstanciam comandos norteadores, orientadores. Essenciais porque abrangem aspectos nucleares, imprescindíveis. Estruturantes, na medida em que dão consistência no essencial, enraízam porque dão a profundidade necessária para perenizar o ser, identificam porque traçam os elementos distintivos e dão sentido ao apontar para uma finalidade.

Para Miguel Reale, os princípios "são verdades fundantes de um sistema de conhecimento" 1269 e para Bandeira de Mello são "mandamentos nucleares de um sistema, verdadeiro alicerce dele, disposicão fundamental que se irradia sobre diferentes normas compondo-lhes o espírito e servindo de critério para sua exata compreensão e inteligência". ${ }^{1270}$

Américo Plá Rodrigues observa que os princípios jurídicos são "linhas diretrizes que informam algumas normas e inspiram direta ou indiretamente uma série de soluções". ${ }^{1271}$

\footnotetext{
${ }^{1269}$ REALE, Miguel. Lições preliminares de direito. São Paulo: Saraiva, 1988, p. 299. Apud SOUTO MAIOR, Jorge Luiz. Curso de direito do trabalho: teoria geral do direito do trabalho, volume I: Parte I. São Paulo: LTr, 2011, p. 625.

${ }^{1270}$ MELLO, Celso Antônio Bandeira de. Elementos de direito administrativo. São Paulo: RT, 1986, p.230. SOUTO MAIOR, Jorge Luiz, op. cit., p. 625.

${ }_{1271}$ PLÁ RODRIGUEZ, Américo. Principios de direito do trabalho. Tradução de Wagner D.Giglio. São Paulo: LTr, 1993, p. 16.
} 
Norberto Bobbio explica que no ordenamento jurídico existem princípios expressos e não-expressos, sendo que estes últimos "podem ser constatados por meio da abstração de normas específicas e pela comparação das demais normas do sistema". ${ }^{1272}$

Os princípios jurídicos possuem força normativa e orientam a criação de novas normas, a interpretação das existentes e a integração de lacunas. ${ }^{1273}$ Para Paulo Bonavides, os princípios positivados constitucionalmente guiam e fundamentam todas as demais normas instituídas na ordem jurídica. ${ }^{1274}$ Segundo Gomes Canotilho "além de conduzirem a interpretação das normas constitucionais, os princípios também vinculam o legislador no momento de criação das leis". ${ }^{2275}$

Karl Larenz diz que os princípios são normas de grande relevância para o ordenamento jurídico, na medida em que estabelecem fundamentos normativos para a interpretação e aplicação do Direito, deles decorrendo, direta ou indiretamente, normas de comportamento. ${ }^{1276}$

Os princípios, juntamente com as regras, compõem as normas, mas possuem maior grau de abstração em relação às regras e reagem diferentemente, em caso de colisões. Na colisão de regras, apenas uma será considerada válida. Na colisão entre princípios, o afastamento de um princípio para determinado caso concreto não significará a invalidade do princípio, que poderá prevalecer e revelar-se plenamente válido em outra situação.

No ensinamento de Bandeira de Mello, com o qual concordamos inteiramente, descumprir um princípio é muito mais grave do que descumprir uma regra,

${ }^{1272}$ BOBBIO, Norberto. Teoria do Ordenamento Jurídico. Tradução de Maria Celeste Cordeiro Leite dos Santos. 7. ed. Brasília: Ed. Univ. de Brasília, 1996, p. 159. Apud PONTES, Alan Oliveira. O princípio da solidariedade social na interpretação do direito da seguridade social. Dissertação de mestrado. Faculdade de Direito da USP, São Paulo, 2006, p. 58-59.

${ }^{1273}$ SOUTO MAIOR, Jorge Luiz. Curso de direito do trabalho: teoria geral do direito do trabalho, volume I: Parte I. São Paulo: LTr, 2011, p. 625.

${ }^{1274}$ BONAVIDES, Paulo. Curso de direito constitucional. 12. ed. São Paulo: Malheiros, 2002, p. 263. Apud PONTES, Alan Oliveira, op. cit., p. 58.

${ }^{1275}$ CANOTILHO, José Joaquim Gomes. Direito constitucional e teoria da constituição. 4. ed. Coimbra: Livraria Almedina, [2000], p.1129. Apud PONTES, Alan Oliveira, op. cit., p.53-54.

${ }^{1276}$ LARENZ, Karl. Richtiges Recht,. München, Beck, 1979 p.6; Methodenlehre der Rechtswissenschaft, 6. ed., München, Beck, 1991, p. 474. Apud ÁVILA, Humberto. Teoria dos princípios - da definição à aplicação dos princípios jurídicos. 11. ed. São Paulo: Malheiros, 2010, p. 35-36. 
porque o princípio condensa intensa carga valorativa e abstrata, de modo que, ao descumpri-lo, violam-se vários comandos e subvertem-se valores fundamentais do sistema jurídico. ${ }^{1277}$ Por isso, em caso de conflito entre um princípio e uma regra, consideramos que deve prevalecer o princípio.

Para Josef Esser, princípios são aquelas normas que estabelecem fundamentos para que determinado mandamento seja encontrado. ${ }^{1278}$ Mais do que uma distinção baseada no grau de abstração da prescrição normativa, a diferença entre os princípios e as regras seria uma distinção qualitativa. ${ }^{1279} \mathrm{O}$ critério distintivo dos princípios em relação às regras seria, portanto, a função de fundamento normativo para a tomada de decisão. ${ }^{1280}$

Para Canaris, duas características afastariam os princípios das regras: a) o conteúdo axiológico: os princípios, ao contrário das regras, possuem um conteúdo axiológico explícito e careceriam, por isso, de regras para sua concretização; b) o modo de interação com outras normas: os princípios, ao contrário das regras, receberiam seu conteúdo de sentido somente por meio de um processo dialético de complementação e limitação. ${ }^{1281}$

Segundo Humberto Ávila, quanto menos específico for o fim pretendido pelo princípio, menos controlável será sua realização, razão pela qual diante de um princípio deve-se observar os dispositivos relacionados ao princípio, relacionar os dispositivos em função dos princípios fundamentais, tentar diminuir a vagueza dos fins por meio da análise das normas constitucionais que possam, de forma direta ou indireta, restringir o âmbito de aplicação do princípio. ${ }^{1282} \mathrm{O}$ autor sugere, ainda, pesquisa de casos paradigmáticos que possam iniciar esse processo de esclarecimento das condições que

\footnotetext{
${ }^{1277}$ MELLO, Celso Antônio Bandeira de. Curso de Direito Administrativo, $19^{a}$ ed., p. 889, nota de rodapé. Apud ÁVILA, Humberto. Teoria dos princípios - da definição à aplicação dos princípios jurídicos. 11. ed. São Paulo: Malheiros, 2010, p. 103.

${ }^{1278}$ ESSER, Josef. Grundsatz und norm in der richterlichen fortbildung des privatrechts. Tübingen, Mohr, Siebeck, 4. tir., p. 51. Apud ÁVILA, Humberto, op. cit., p. 35.

${ }^{1279}$ ESSER, Josef, op.cit., p. 51. Apud ÁVILA, Humberto, op. cit., p. 35.

${ }^{1280}$ ESSER, Josef, op. cit., p. 51. Apud ÁVILA, Humberto, op. cit., p. 35.

${ }^{1281}$ CANARIS, Claus-Wilhelm. Systemdenken und Systembegriff in der Jurisprudenz. Berlin, Duncker und Humblot, 1983, p. 50, 53 e 55. Apud ÁVILA, Humberto, op. cit., p. 36.

1282 ÁVILA, Humberto, op. cit., p. 91.
} 
compõem o estado ideal de coisas a ser buscado pelos comportamentos necessários à sua realização. ${ }^{1283}$

Explica que os "princípios, por serem normas imediatamente finalísticas, estabelecem um estado ideal de coisas a ser buscado, que diz respeito a outras normas do mesmo sistema, notadamente as regras". ${ }^{1284}$

Esclarece que a atuação dos princípios sobre outras normas ocorre de forma direta, sem intermediação ou interposição de um outro princípio ou regra, ou indireta, com a intermediação de outra norma. ${ }^{1285}$ No plano da eficácia indireta, os princípios exercem funções, por exemplo, definitória, delimitando algum comando mais amplo estabelecido em sobreprincípio axiologicamente superior, ou, em relação às normas de abrangência mais restrita; interpretativa (restringindo ou ampliando sentidos) e bloqueadora (afastando elementos expressamente previstos que sejam incompatíveis com o estado ideal de coisas a ser promovido). ${ }^{1286}$

Defende que os sobreprincípios exercem as funções típicas dos princípios (interpretativa e bloqueadora), mas não as funções integrativa (que pressupõe atuação direta) e definitória (que pressupõe maior maior especificação, enquanto os sobreprincípios atuam para ampliar em vez de especificar). ${ }^{1287} \mathrm{~A}$ "função que os sobreprincípios exercem distintivamente é a função rearticuladora, já que eles permitem a interação entre os vários elementos que compõem o estado ideal de coisas a ser buscado". ${ }^{1288}$

Os princípios protegem determinados bens jurídicos (ações, estados ou situações cuja manutenção ou busca é devida) e permitem avaliar os elementos de fato que lhes são importantes. ${ }^{1289}$ Trata-se de "um procedimento retrooperativo, pois são os princípios que determinam quais são os fatos pertinentes, mediante uma releitura

\footnotetext{
${ }^{1283}$ ÁVILA, Humberto. Teoria dos princípios - da definição à aplicação dos princípios jurídicos. 11. ed. São Paulo: Malheiros, 2010, p. 91.

${ }^{1284}$ Ibid., p. 97.

${ }^{1285}$ Ibid., p. 97.

${ }^{1286}$ Ibid., p. 98

${ }^{1287}$ Ibid., p. 99

${ }^{1288}$ Ibid., p. 99.

${ }^{1289}$ Ibid., p. 100.
} 
axiológica do material fático". ${ }^{1290} \mathrm{E}$ conclui, "O Direito não escolhe os fatos, mas oferece critérios que podem ser posteriormente projetados aos eventos para a construção dos fatos". ${ }^{2291}$

Depois de selecionados os fatos pertinentes, serão valorados, "de modo a privilegiar os pontos de vista que conduzam à valorização dos aspectos desses mesmos fatos, que terminem por proteger aqueles bens jurídicos". ${ }^{1292} \mathrm{O}$ intérprete deverá buscar o ângulo ou ponto de vista cuja avaliação seja suportada pelos princípios constitucionais, deverá "conceitualizar a situação com base nos fins jurídicos". ${ }^{2} 293$

Embora os princípios descrevam "um estado de coisas a ser buscado", não definem "previamente o meio cuja adoção produzirá efeitos que contribuirão para promovê-lo", razão pela qual "necessitam da complementação de outros princípios no processo de aplicação" e "a decisão deverá ser tomada por meio da ponderação quantitativa entre os princípios concretamente colidentes". ${ }^{1294}$

Assim, para Humberto Ávila, em caso de conflito entre um princípio e uma regra do mesmo nível hierárquico, deverá prevalecer a regra porque exerce uma função definitória (de concretização) e possui uma rigidez maior, de modo que sua superação somente é admissível se houver razões suficientemente fortes, seja na própria finalidade subjacente à regra seja nos princípios superiores. ${ }^{1295}$

Defende que princípio não vale mais do que regra, porque "na verdade, eles possuem diferentes funções e finalidades" ${ }^{1296}$ e a regra, mais do que incorporar valores, os cristaliza e possui um conteúdo do seu comando mais intelegível do que o comando dos princípios. $^{1297}$

\footnotetext{
${ }^{1290}$ ÁVILA, Humberto. Teoria dos princípios - da definição à aplicação dos princípios jurídicos. 11. ed. São Paulo: Malheiros, 2010, p. 100.

${ }^{1291}$ Ibid., p. 100.

1292 Ibid., p. 101.

${ }^{1293}$ Ibid., p. 101.

${ }^{1294}$ Ibid., p. 101.

${ }^{1295}$ Ibid., p. 103.

1296 Ibid., p. 103.

${ }^{1297}$ Ibid., p. 104.
} 
Perante um conflito entre princípio e regra, Ávila propugna que deve-se verificar inicialmente se há hierarquia entre as normas, como no caso de normas constitucionais e infraconstitucionais. ${ }^{1298}$ Além disso, pondera que "não é admissível afastar, nem ampliar além do limite semântico intransponível, uma regra constitucional com base num princípio, por ser a regra a própria solução constitucional para determinado conflito de interesses". ${ }^{299}$ A regra com seu caráter decisório pretende uma solução para o conflito e busca evitar que controvérsias entre valores morais ressurjam no momento da aplicação da norma. ${ }^{1300}$

No caso do direito do trabalho, a hierarquia das normas se dá em função da proteção ao trabalhador, de modo que deve prevalecer sempre a que lhe for mais favorável.

Ávila esclarece que no caso dos princípios constitucionais, "o Poder Legislativo pode escolher os meios para promover os fins", enquanto no caso das regras constitucionais, “ele está previamente vinculado ao meio constitucionalmente escolhido". ${ }^{1301}$

Nas Constituições contemporâneas existem "valores, diretrizes, comandos ou objetivos a serem alcançados por todo o sistema normativo e pelos operadores do Direito". ${ }^{1302}$ Os "valores encontram-se no plano axiológico, enquanto os princípios estão no plano deontológico". ${ }^{1303}$ "Os valores, juridicamente falando, ora se apresentam como autênticas normas, inseridas no próprio Texto Constitucional, ora servem como diretrizes interpretativas". ${ }^{1304}$ São "positivados, em geral, por meio dos denominados 'princípios constitucionais'. São os princípios constitucionalmente adotados que apresentam a carga axiológica incorporada pelo ordenamento jurídico". ${ }^{1305}$

\footnotetext{
1298 ÁVILA, Humberto. Teoria dos princípios - da definição à aplicação dos princípios jurídicos. 11. ed. São Paulo: Malheiros, 2010, p. 105.

${ }^{1299}$ Ibid., p. 108.

${ }^{1300}$ Ibid., p. 109.

${ }^{1301}$ Ibid., p. 112.

${ }^{1302}$ Ibid., p. 22.

${ }^{1303}$ Ibid., p. 22.

${ }^{1304}$ Ibid., p. 24.

${ }^{1305}$ Ibid., p. 24.
} 
Alan Oliveira Pontes observa que, para Ruy Samuel Espíndola, princípio "seria o pensamento chave, a baliza normativa que dá origem a todas as demais idéias, pensamentos ou normas, e nele todas estas se reconduzem e/ou se subordinam". ${ }^{1306}$

Os princípios jurídicos indicam o modo de adequado equacionamento dos problemas sociais. No magistério de Jorge Luiz Souto Maior, os princípios "estabelecem um método para o Direito que, de forma concreta, fixam o modo pelo qual os problemas sociais devem ser equacionados, buscando-se nas regras positivas os efeitos necessários". ${ }^{1307}$

Sérgio Alberto de Souza defende que os princípios de direito são abstrações muito amplas e que podem carregar conquistas parciais dos estruturalmente dominados. ${ }^{1308}$ Quando confrontados esses princípios com a luta de classes, podem ter um significado que negue o originário, que era carregado pela ideologia das classes dominantes. ${ }^{1309}$ Os princípios cumprem, assim, uma missão dialética e transformadora. ${ }^{1310}$

Para Gomes Canotilho, entre os princípios que impõem ao Estado a realização de fins e a execução de tarefas está o princípio de correção das desigualdades da riqueza e do rendimento. ${ }^{1311} \mathrm{Se}$ esses princípios impositivos não forem cumpridos, caracteriza-se a omissão constitucional. ${ }^{1312}$

Para Ronald Dworkin, existe distinção entre princípios e políticas, na medida em que política são os padrões que estabelecem um objetivo a ser alcançado enquanto princípios são "padrões que devem ser observados de modo a assegurar uma

\footnotetext{
${ }^{1306}$ ESPÍNDOLA, Ruy Samuel. Conceito de princípios constitucionais. São Paulo: RT, 1999, p. 47-48. Apud PONTES, Alan Oliveira. O princípio da solidariedade social na interpretação do direito da seguridade social. Dissertação de mestrado. Faculdade de Direito da USP, São Paulo, 2006, p. 52.

1307 SOUTO MAIOR, Jorge Luiz. Curso de direito do trabalho: teoria geral do direito do trabalho, volume I: Parte I. São Paulo: LTr, 2011, p. 630.

${ }^{1308}$ SOUZA, Sérgio Alberto de. Direito, globalização e barbárie - estudos críticos de temas de direito do trabalho e de direitos humanos sob a ótica de uma leitura não-liberal. São Paulo: LTr, 1998, p. 35.

${ }^{1309}$ Ibid., p. 35.

${ }^{1310}$ Ibid., p. 35.

1311 CANOTILHO, José Joaquim Gomes. Direito constitucional e teoria da constituição. 4. edição. Coimbra: Libraria Almedina, [2000], p. 1130. Apud PONTES, Alan Oliveira, op. cit., p. 54.

${ }^{1312}$ CANOTILHO, José Joaquim Gomes, op. cit., p. 1136. Apud PONTES, Alan Oliveira, op. cit., p. 54.
} 
exigência de justiça, de equidade ou de alguma outra dimensão da moralidade". ${ }^{1313}$ Conforme observa Alan Oliveira Pontes, o que Dworkin denomina política é o que Canotilho chama de princípios constitucionais impositivos. ${ }^{1314}$

\subsection{2 - OS PRINCÍPIOS DE DIREITO DO TRABALHO}

Jaime Montalvo Correa observa que a determinação legal de que em casos de omissões sejam aplicados os princípios gerais de direito é de aplicação geral, não somente ao direito civil, mas a todo o direito. ${ }^{1315}$

A CLT, no artigo $8^{\circ}$, estabelece a aplicação subsidiária no direito do trabalho de "princípios e normas gerais de direito, principalmente do direito do trabalho, e, ainda, de acordo com os usos e costumes, o direito comparado, mas sempre de maneira que nenhum interesse de classe ou particular prevaleça sobre o interesse público".

Para Bayon Chacon, não existem princípios gerais tipicamente trabalhistas, mas a aplicação dos princípios gerais a cada ramo específico segundo o conteúdo destes ramos. ${ }^{1316}$ Pérez Botija diz que "é o laboral um ordenamento tão específico, que nem todos os princípios gerais de Direito lhe são aplicáveis". ${ }^{1317}$

Montalvo Correa explica que, na definição de Alonso Garcia, os princípios específicos informadores do direito do trabalho são "aquelas linhas diretrizes ou postulados que inspiram o sentido das normas laborais e configuram a regulação das relações de trabalho com amparo em critérios distintos dos aplicáveis em outros ramos do Direito". ${ }^{1318}$

\footnotetext{
${ }^{1313}$ DWORKIN, Ronald. Levando os Direitos a Sério. Tradução de Nelson Boeira. São Paulo: Martins Fontes, 2002, p. 36. Apud PONTES, Alan Oliveira. O princípio da solidariedade social na interpretação do direito da seguridade social. Dissertação de mestrado. Faculdade de Direito da USP, São Paulo, 2006, p. 54.

${ }^{1314}$ PONTES, Alan Oliveira, op. cit., p. 55.

1315 CORREA, Jaime Montalvo. Fundamentos de derecho del trabajo. Madrid: Editorial Civitas, 1975, p. 239.

${ }^{1316}$ CHACON, Gaspar Bayon \& BOTIJA, Eugênio Perez. Manual de derecho del trabajo. 9. ed. Madrid: M. Pons, 1973-1974, p.148. Apud CORREA, Jaime Montalvo, op. cit., p. 239.

${ }^{1317}$ BOTIJA, Pérez. Curso de derecho del trabajo. 6. ed. Madrid: Tecnos, 1960, p. 84. Apud CORREA, Jaime Montalvo, op. cit., nota de rodapé, p. 239.

1318 GARCIA, Alonso. Derecho del trabajo, t. I, Barcelona (Bosch), 1960, p.247. Apud CORREA, Jaime Montalvo, op. cit., p. 239.
} 
E Correa cita os seguintes princípios trabalhistas: "pro operário", da irrenunciabilidade de direitos do trabalhador, da estabilidade no emprego, do rendimento, da igualdade de tratamento, da irretroatividade debilitada e da adequação social. ${ }^{1319}$

Defende que em nenhum princípio se manifesta o caráter protetivo do ordenamento laboral como no princípio "pro operario", mas concorda com De La Villa ao atribuir apenas caráter interpretativo a este princípio, e não normativo ou orientador da ação legislativa. ${ }^{1320}$ Neste ponto, colocamo-nos em posição divergente dos referidos autores, por considerar essa perspectiva muito restritiva, na medida em que a construção da justiça social depende da realizabilidade e da elaboração progressiva de normas favoráveis ao trabalhador.

Montalvo Correa distingue os princípios interpretativos dos critérios específicos do direito do trabalho para resolução de conflitos normativos, exemplificando com os da norma mínima, da norma mais favorável e da condição mais benéfica. ${ }^{1321}$

\subsection{3 - A INTERPRETAÇÃO DO DIREITO}

Humberto Ávila explica que as normas são os sentidos construídos a partir da interpretação sistemática de textos normativos. ${ }^{1322}$ Os dispositivos se constituem no objeto da interpretação, as normas, no seu resultado. ${ }^{1323}$ Nem sempre que há um dispositivo há uma norma, nem sempre que há uma norma há dispositivo. ${ }^{1324}$

Há desvinculação entre o texto e os seus sentidos, de modo que a função da ciência do direito não pode ser considerada como mera descrição do significado, quer na

1319 CORREA, Jaime Montalvo. Fundamentos de derecho del trabajo. Madrid: Editorial Civitas 1975, p. 239.

${ }^{1320}$ Ibid., p. 239-240.

${ }^{1321}$ Ibid., p.239-243.

1322 ÁVILA, Humberto. Teoria dos princípios - da definição à aplicação dos princípios jurídicos. 11. ed. São Paulo: Malheiros, 2010, p. 30.

${ }^{1323}$ Ibid., p. 30.

${ }^{1324}$ Ibid., p. 30. 
perspectiva da comunicação de uma informação ou conhecimento a respeito de um texto, quer naquela da intenção do seu autor. ${ }^{1325}$

A compreensão do significado como o conteúdo conceitual de um texto pressupõe a existência de um significado intrínseco que independa do uso ou da interpretação, mas isso não existe: o significado não é algo incorporado ao conteúdo das palavras, mas algo que depende precisamente de seu uso e interpretação. ${ }^{1326}$

A concepção que aproxima o significado da intenção do legislador pressupõe a existência de um autor determinado e de uma vontade unívoca fundadora do texto, o que também não ocorre: o processo legislativo qualifica-se justamente como um processo complexo que não se submete a um autor individual, nem a uma vontade específica. ${ }^{1327}$ Vale dizer, a interpretação não se caracteriza como um ato de descrição de um significado previamente dado, mas como um ato de decisão que constitui a significação e os sentidos de um texto. ${ }^{1328}$

A atividade do intérprete - quer julgador, quer cientista - não consiste em meramente descrever o significado previamente existente dos dispositivos, mas constituir esses significados. ${ }^{1329}$ A aplicação do direito não envolve uma atividade de subsunção entre conceitos prontos antes mesmo do processo de aplicação. ${ }^{1330}$ Mas Humberto Ávila alerta que afirmar que o significado depende do uso não é o mesmo que sustentar que ele só surja com o uso específico e individual, uma vez que há traços de significado mínimos incorporados ao uso ordinário ou técnico da linguagem. ${ }^{1331}$

Então, pode-se afirmar que o intérprete não só constrói, mas reconstrói sentido, tendo em vista a existência de significados incorporados ao uso linguístico e construídos na comunidade do discurso: reconstrói a partir dos textos normativos e a partir

${ }_{1325}$ ÁVILA, Humberto. Teoria dos princípios - da definição à aplicação dos princípios jurídicos. 11. ed. São Paulo: Malheiros, 2010, p. 31.

${ }_{1326}^{13}$ Ibid., p. 31.

${ }^{1327}$ Ibid., p. 31.

${ }^{1328} \mathrm{Ibid}$., p. 31-32.

${ }^{1329}$ Ibid., p. 32.

${ }^{1330}$ Ibid., p. 32.

${ }^{1331}$ Ibid., p. 32. 
da linguagem que possui núcleos de sentido constituídos pelo uso e que preexistem ao processo interpretativo individual. ${ }^{1332}$

Alan Oliveira Pontes explica que existem dois conceitos de interpretação, o do modelo clássico, em que interpretar significa extrair o significado da norma e o modelo defendido por J.J. Gomes Canotilho e Eros Grau, de que "o jurista interpreta os textos normativos para deles extrair as normas jurídicas", ${ }^{1333}$ ou seja, "as normas resultam da interpretação das disposições normativas". ${ }^{1334}$ Assim, também para Eros Grau a “interpretação do direito não é uma atividade de conhecimento, mas sim constitutiva, portanto, decisional, embora não discrionária", ${ }^{1335}$ de modo que "o significado da norma é produzido pelo intérprete". ${ }^{1336}$ À luz de tais ensinamentos, Alan Oliveira Pontes conclui que os "textos normativos por si próprios nada dizem enquanto não interpretados e efetivamente convertidos em normas, de modo que as normas são o que os intérpretes disserem o que elas significam". ${ }^{1337}$

Para Luis Roberto Barroso, deve-se buscar a vontade da lei e não a vontade do legislador. ${ }^{1338}$ No mesmo sentido, Francesco Ferrara diz que o "relevante é o elemento espiritual, a voluntas legis, embora deduzida através das palavras do legislador". ${ }^{1339}$

Entre as correntes hermenêuticas do direito comum destacam-se três: Escola Exegética, Histórica e do Direito Livre.

\footnotetext{
${ }^{1332}$ ÁVILA, Humberto. Teoria dos princípios - da definição à aplicação dos princípios jurídicos. 11. ed. São Paulo: Malheiros, 2010, p. 33.

${ }^{1333}$ PONTES, Alan Oliveira. O princípio da solidariedade social na interpretação do direito da seguridade social. Dissertação de mestrado. Faculdade de Direito da USP, São Paulo, 2006, p. 20.

${ }^{1334}$ Ibid., p. 21.

${ }^{1335}$ GRAU, Eros Roberto. Ensaio e discurso sobre a interpretação/aplicação do direito. São Paulo: Malheiros, 2002, p.56. Apud PONTES, Alan Oliveira, op. cit., p.21.

${ }^{1336}$ GRAU, Eros Roberto, op. cit., p.72 . Apud PONTES, Alan Oliveira, op. cit., p. 21.

${ }^{1337}$ PONTES, Alan Oliveira, op. cit., p. 22.

${ }^{1338}$ BARROSO, Luís Roberto. Interpretação e aplicação da Constituição. 5. ed. São Paulo: Saraiva, 2003, p. 145. Apud PONTES, Alan Oliveira, op. cit., p. 25.

${ }^{1339}$ FERRARA, Francesco. Interpretação e aplicação das leis. Traduzido por Manuel A. Domingues de Andrade. 4. Ed. Coimbra: Armélio Amado Editor, Sucessor, 1987, p. 128. Apud PONTES, Alan Oliveira, op. cit., p. 25.
} 
Para a Escola Exegética o "intérprete do direito é um escravo da lei" ${ }^{1340}$ e deve buscar na lei a intenção do legislador ${ }^{1341}$. A Escola Histórica caracteriza-se por maior flexibilidade diante do texto legal. Amauri Mascaro Nascimento noticia que Savigny expressou os fundamentos dessa corrente, no sentido de que o "direito é um produto da história, surgindo da consciência do povo (Volksgeist)"1342, de modo que o trabalho do julgador "não pode restringir-se à aplicação dos preceitos nos termos gramaticais em que se encontram, mas sim segundo as condições e as circuntâncias da cultura do momento da prestação jurisdicional". ${ }^{1343}$

Para a Escola do Direito Livre, a lei não contém "todos os comandos necessários para abranger todos os fatos que ocorrem na vida concreta" e por isso, "a sentença é, também, um ato criativo, de justa distribuição do direito". ${ }^{1344}$ Fundamenta-se na questão da mutação social e atribui caráter criativo à função interpretativa, devendo o intérprete criar o direito "na avaliação dos interesses que se chocam". ${ }^{1345}$

Luis Recaséns Siches defende que a razão histórica é mais racional do que a razão matemática, quando aplicada à interpretação jurídica. ${ }^{1346}$ Há que se utilizar a lógica na interpretação jurídica, desde que seja uma lógica razoável, pertinente ao que é humano ou a razão vital histórica, que é diferente do campo exclusivamente racional. ${ }^{1347} \mathrm{~A}$ interpretação jurídica deve se basear na eficácia dos meios para se atingir a realização dos fins propostos. ${ }^{1348}$ Do mesmo modo que o legislador elabora as leis objetivando realizar da melhor maneira possível as exigências de justiça, também o juiz deverá interpretar as leis de modo que sua aplicação aos casos concretos importe na realização do maior grau de justiça. ${ }^{1349}$

${ }^{1340}$ NASCIMENTO, Amauri Mascaro. Curso de direito do trabalho. 11. ed. São Paulo: Saraiva, 1995, p. 185.

${ }^{1341}$ Ibid., p. 186.

${ }^{1342}$ Ibid., p. 186.

${ }^{1343}$ Ibid., p. 187.

${ }^{1344}$ Ibid., p. 188.

${ }^{1345}$ Ibid., p. 189.

${ }^{1346}$ RECASÉNS SICHES, Luis. Nueva filosofia de la interpretación del derecho. México - Buenos Aires: Fondo de Cultura Econômica, [1956], p. 130. Apud PONTES, Alan Oliveira. O princípio da solidariedade social na interpretação do direito da seguridade social. Dissertação de mestrado.

Faculdade de Direito da USP, São Paulo, 2006, p. 27-28.

${ }^{1347}$ PONTES, Alan Oliveira, op. cit., p. 28.

${ }^{1348}$ Ibid., p. 28.

${ }^{1349}$ Ibid., p. 28. 
A adequada valoração dos fatos se faz mediante a compreensão histórica da realidade e os princípios jurídicos representam um guia para a interação do intérprete com a norma, a sociedade e com a realidade:

\begin{abstract}
Neste sentido, a valoração do fato, buscando-lhe um resultado necessário, não se faz a partir das regras positivadas, mas por uma compreensão histórica que transcende o estritamente jurídico e que fornece a possibilidade concreta de o aplicador do Direito se situar na realidade. Os princípios jurídicos constituem, ao mesmo tempo, um guia para essa interação com a sociedade e o argumento juridicamente válido e, portanto, necessário, para se atribuir o resultado ao fato analisado. ${ }^{1350}$
\end{abstract}

Nas situações em que as leis positivas aparentemente representarem obstáculo à justiça social, a utilização dos princípios jurídicos para integração das lacunas ou interpretação pode contribuir para a aplicação do direito de forma mais consentânea com aquele ideal de justiça.

Em sentido mais amplo, a luta pelo direito, considerado o instrumento de realização de justiça, pode significar uma luta contra as leis, se estas se apresentarem imperfeitas para dar as respostas pretendidas, bem como uma luta por determinado sentido da norma posta. A elaboração das leis e demais regras, portanto, é apenas parte dessa luta, pois o direito não se confunde com tais dispositivos. O direito é um passo além que se constrói pela organização e valoração das regras, tornando-as normas sem desprezar a ética, a moral e o sentido do justo, - pela identificação dos princípios que regem o sistema jurídico, pela integração das lacunas deixadas pelas normas e, principalmente, pela interpretação das diversas

${ }^{1350}$ SOUTO MAIOR, Jorge Luiz. Curso de direito do trabalho: teoria geral do direito do trabalho, volume I: Parte I. São Paulo: LTr, 2011, p. 630. 
disposições normativas, quando se consegue, com certas limitações, direcionar o sentido da norma para tal ou qual objetivo. ${ }^{1351}$

Os principais métodos jurídicos de interpretação são o gramatical, em que se verifica o sentido do texto gramatical das normas jurídicas, o alcance das palavras; o lógico, em que se investiga a razão que justifica o preceito; a sistemática, em que se estabelece uma conexão entre os diferentes conteúdos normativos; o teleológico, pelo qual se busca a finalidade da norma; o sociológico, em que se analisam os fatores e realidades sociais; o histórico-evolutivo, em que se verifica a adaptação do texto às novas circunstâncias sociais, à luz da evolução histórica; o extensivo, em que se corrige a falha de a norma ter dito menos do que queria dizer; o restritivo, em que se corrige a falha de a norma ter dito mais do que queria dizer e o autêntico, em que a interpretação é dada pelo próprio órgão da qual emanou a norma.

A respeito da interpretação, Carlos Maximiliano ensina:

Interpretar é explicar, esclarecer; dar o significado de vocábulo, atitude ou gesto; reproduzir por outras palavras um pensamento exteriorizado; mostrar o sentido verdadeiro de uma expressão, de frase, sentença ou norma, tudo o que na mesma se contém. ${ }^{1352}$

Mas Carlos Maximiliano ressalta que "para atingir o ideal de justiça" é necessário "compreender bem os fatos", inspirar-se "pelo nobre interesse pelos destinos humanos", "compenetrar-se dos sofrimentos e aspirações das partes", fazer do direito "um auxiliar da idéia (sic), hoje vitoriosa, da solidariedade social". ${ }^{1353}$

Homero Batista Mateus da Silva explica que "a busca da finalidade da norma é indubitavelmente a melhor forma de interpretação do dispostivo legal e a melhor

\footnotetext{
${ }^{1351}$ SOUTO MAIOR, Jorge Luiz. O direito do trabalho como instrumento de justiça social. São Paulo: LTr, 2000, p. 238-239.

${ }^{1352}$ MAXIMILIANO, Carlos. Hermenêtica e aplicação do direito. 12. ed. Rio de Janeiro: Forense, 1992, p. 9. ${ }^{1353}$ Ibid., p. 101.
} 
forma de se obter uma interpretação, digamos, razoável". ${ }^{1354}$ Diz que o "excesso de apego ao sentido gramatical das normas tende apenas a afastar o alcance pretendido da realidade dos fatos". ${ }^{1355}$

Para Miguel Reale, a interpretação das normas tem sempre caráter unitário, devendo suas diversas formas ser consideradas momentos necessários de uma unidade de compreensão (unidade do processo hermenêutico). ${ }^{1356}$

As regras de interpretação do direito do trabalho oferecem certas singularidades, decorrentes da desigualdade material existente entre as partes da relação de trabalho. Algumas legislações determinam que "Em caso de dúvida sobre o alcance das disposições deste Código, os juízes as aplicarão no sentido mais favorável aos trabalhadores" (Código do Equador) ou de acordo com "o interesse dos trabalhadores em harmonia com a conveniência social" (Códigos da Costa Rica e da Guatemala). ${ }^{1357}$

Para Amauri Mascaro Nascimento, ${ }^{1358}$ a verificação se a disposição é ou não mais favorável ao trabalhador deverá observar os seguintes critérios: a comparação deve ser iniciada aproximando o teor das duas regras e considerando-se a situação da coletividade dos trabalhadores interessados e não a de um trabalhador tomado isoladamente; a questão não depende da apreciação subjetiva dos interessados e tem que se resolvida objetivamente, inspirando-se nos motivos que hajam levado a ditar regra hierarquicamente mais elevada; a confrontação de ambas as regras deve efetuar-se de maneira concreta, perquirindo se a regra inferior é, na espécie, mais ou menos favorável aos trabalhadores; a possibilidade de melhorar a condição dos trabalhadores, por constituir exceção ao princípio da intangibilidade da regra imperativa hierarquicamente mais

\footnotetext{
${ }^{1354}$ SILVA, Homero Mateus da. Curso de direito do trabalho aplicado. Parte Geral. 2. ed. revista e ampliada. Rio de Janeiro: Elsevier, 2013, p. 269.

${ }^{1355}$ Ibid., p. 269.

${ }^{1356}$ REALE, Miguel. Fontes e Modelos do Direito: para um novo paradigma hermenêutico. São Paulo: Saraiva, 1994, p. 111-112. Apud PONTES, Alan Oliveira. O princípio da solidariedade social na interpretação do direito da seguridade social. Dissertação de mestrado. Faculdade de Direito da USP, São Paulo, 2006, p. 49--50.

${ }^{1357}$ NASCIMENTO, Amauri Mascaro. Curso de direito do Trabalho. 11 ${ }^{\mathrm{a}}$ ed. São Paulo: Saraiva, 1995, p.190-191.

${ }^{1358}$ Ibid., p. 191-192.
} 
elevada, conduz a reputar ilícita uma disposição se houver dúvida de que seja mais favorável aos interesses dos trabalhadores.

Paul Durand e Jaussaud entendem que o particularismo do direito do trabalho justifica uma completa independência dos métodos de interpretação do direito comum e a adoção de um método próprio. Dizem que em caso de dúvida sobre o alcance de uma lei trabalhista, deve-se adotar a interpretação mais favorável ao trabalhador, eis que o legislador exprimiu, de certa maneira, a decisão de intervir pelos interesses dos trabalhadores. ${ }^{1359}$

Para Mario de la Cueva, ${ }^{1360}$ a interpretação do direito do trabalho deve levar em consideração que se trata de um estatuto que traduz a aspiração de uma classe social para obtenção de melhoria das condições de vida, uma vez que esse ramo jurídico possui conteúdo econômico e não meramente de princípios abstratos, embora os propósitos do direito do trabalho traduzam um ideal de justiça, como reflexo das necessidades econômicas. Assim, na interpretação, é preciso investigar, antes de mais nada, que norma é aplicável, pois a função das fontes formais do direito do trabalho não é, como no direito civil, cobrir as lacunas da lei, mas melhorá-las em benefício dos trabalhadores.

Já Mario Deveali, conforme explica Amauri Mascaro Nascimento, ${ }^{1361}$ defende "que uma disposição legal concilia os interesses dos empregadores, dos trabalhadores e da coletividade e, nesse caso, interpretar em favor dos trabalhadores importaria em romper esse equilíbrio que está no propósito da lei”. ${ }^{1362}$

Para Mascaro Nascimento, ${ }^{1363}$ o direito do trabalho deve ser interpretado segundo a jurisprudência axiológica ou de valores e na escala de valores não é possível deixar de reputar os sociais como mais importantes que os individuais, os coletivos mais importantes que os particulares. Diz que, segundo essa perspectiva, o princípio in dubio ${ }^{1359}$ NASCIMENTO, Amauri Mascaro. Curso de direito do Trabalho. 11. ed. São Paulo: Saraiva, 1995, p. 192.

${ }^{1360}$ CUEVA, Mario de la. Derecho mexicano del trabajo. Mexico, Porrúa, 1960, s/p. Apud NASCIMENTO, Amauri Mascaro, op. cit., p. 192-193.

${ }^{1361}$ NASCIMENTO, Amauri Mascaro, op. cit., p. 200.

${ }^{1362}$ DEVEALI, Mario. Lineamentos de derecho del trabajo. Buenos Aires, 1956, s/p. Apud NASCIMENTO, Amauri Mascaro, op. cit., p. 200.

${ }^{1363}$ NASCIMENTO, Amauri Mascaro, op. cit., p. 202. 
pro operario deve ser rearticulado e perde bastante da sua expressão, eis que se justificou plenamente apenas na fase em que o fim do direito do trabalho era exclusivamente a proteção do trabalhador, e considera que o material jurídico de que dispõe o direito do trabalho para assentar as suas diretrizes interpretativas ainda é pobre, e pequena é a contribuição dos pensadores que se dedicam a esse ramo do saber. ${ }^{1364}$

Entendemos que o princípio da melhoria da condição social do trabalhador impõe que na experiência jurídica, em seus aspectos de criação, interpretação e aplicação, haja uma tomada de posição em favor dos trabalhadores, que representam os economicamente menos favorecidos, na relação de produção. Impõe que se leve em consideração o ato expoliativo intrínseco ao sistema produtivo capitalista, consubstanciado na extração da mais-valia pelo empregador; que sejam levadas em consideração as desigualdades sociais existentes no Brasil, as pésssimas condições de vida dos trabalhadores, em sua luta diária para a sobrevivência, bem como as agressivas mudanças dos métodos produtivos e suas consequências para a vida das pessoas.

Enfim, o princípio da melhoria da condição social do trabalhador impõe que não se fique indiferente à injustiça social. Que todos aqueles que conseguirem deixar de priorizar os seus interesses individuais imediatos não se omitam e tomem partido em prol de uma perspectiva social cada vez mais igualitária. Do contrário, o direito estará a serviço da injustiça social, promovendo a desigualdade, a miséria e o sofrimento humano.

\section{6 - A DIRETRIZ AXIOLÓgICA DA CONSTITUIÇÃO FEDERAL DE 1988 - O PARADIGMA DA DIGNIDADE HUMANA}

A dignidade da pessoa humana trata-se de fundamento da República Federativa do Brasil, nos termos do artigo $1^{\circ}$, inciso IIII, da Constituição Federal.

Mario de la Cueva explica que o conceito de dignidade humana teve início na Patrística e reapareceu nas escolas de direito natural pós-renascentistas, particularmente

\footnotetext{
${ }^{1364}$ NASCIMENTO, Amauri Mascaro. Curso de direito do Trabalho. 11. ed. São Paulo: Saraiva, 1995, p.
} 203. 
em Pufendorf. ${ }^{1365}$ Hegel cunhou a seguinte frase: "sê pessoa e considera os demais como pessoa". ${ }^{1366}$

A "dignidade humana consiste nos atributos que corresponde ao homem pelo só fato de ser homem". ${ }^{1367}$ Diz respeito a um traço da essência humana, que faz o ser humano merecer estima e honra. ${ }^{1368} \mathrm{Na}$ antiguidade, era qualidade usada para a espécie humana como um todo, sem personificação, mas a partir do cristianismo, passou a ser considerada atributo também de cada indivíduo.

Foi o cristianismo que, pela primeira vez, concebeu a idéia (sic) de uma dignidade pessoal, atribuída a cada indivíduo. $\mathrm{O}$ desenvolvimento do pensamento cristão sobre a dignidade humana deu-se sob um duplo fundamento: o homem é um ser originado por Deus para ser o centro da criação; como ser amado por Deus, foi salvo de sua natureza originária através da noção de liberdade de escolha, que o torna capaz de tomar decisões contra o seu desejo natural. ${ }^{1369}$

Na obra "Crítica da Razão Prática", Immanuel Kant, em 1788, apresentou suas ponderações a respeito da moralidade, condensadas no "imperativo categórico", fórmula de valor universal e incondicional, que entre outros aspectos, reconhecia que a pessoa humana deveria sempre ser considerada um fim e nunca um meio:

O imperativo categórico está contido na sentença: “Age de tal modo que a máxima de tua vontade possa sempre valer simultaneamente como um princípio para uma legislação geral”. Esta formulação foi desdobrada por Kant em três máximas morais.

\footnotetext{
${ }^{1365}$ CUEVA, Mario de la. El nuevo derecho mexicano del trabajo. 4. ed. México: Editorial Porrúa, 1977, p. 112.

${ }^{1366}$ Ibid., p. 112.

${ }^{1367}$ Ibid., p. 112.

${ }^{1368}$ MORAES, Maria Celina Bodin de. O conceito de dignidade humana: substrato axiológico e conteúdo normativo. In: SARLET, Ingo Wolfgang (org,). Constituição, direitos fundamentais e direito privado. 2. ed. Porto Alegre: Livraria do Advogado, 2006, p. 110.

1369 Ibid., p. 110-111.
} 
São elas: i) “Age como se a máxima de tua ação devesse ser erigida por tua vontade em lei universal da natureza", o que corresponde à universalidade da conduta ética, válida em todo o tempo e lugar; ii) "Age de tal maneira que sempre trates a humanidade, tanto na tua pessoa como na pessoa de outrem, como um fim e nunca como um meio", que representa o cerne do imperativo, pois afirma a dignidade dos seres humanos como pessoas; iii) "Age como se a máxima de tua ação devesse servir de lei universal para todos os seres racionais", que exprime a separação entre o reino natural das causas e o reino humano dos fins, atribuindo à vontade humana uma vontade legisladora geral. ${ }^{1370}$

O imperativo categórico orienta-se pelo princípio da dignidade humana, distinguindo com nitidez as pessoas das coisas, de modo que preço diz respeito a coisas e dignidade ao ser humano, razão pela qual o ser humano jamais pode ser transformado em meio para alcançar fins. ${ }^{1371}$

A dignidade humana, como fundamento da República Federativa do Brasil, irradia a sua força normativa por todo o ordenamento jurídico, garantindo proteção a todos os que se encontram em situação de fragilidade ou de inferioridade.

Neste ambiente, de um renovado humanismo, a vulnerabilidade humana será tutelada, prioritariamente, onde quer que ela se manifeste. De modo que terão precedência os direitos e as prerrogativas de determinados grupos considerados, de uma maneira ou de outra, frágeis e que estão a exigir, por conseguinte, a especial proteção da lei. Nestes casos estão as crianças, os adolescentes, os idosos, os portadores de deficiências físicas e mentais, os não-proprietários, os consumidores, os contratantes em situação de inferioridade, as vítimas de acidentes anônimos e de

1370 MORAES, Maria Celina Bodin de. O conceito de dignidade humana: substrato axiológico e conteúdo normativo. In: SARLET, Ingo Wolfgang (org,). Constituição, direitos fundamentais e direito privado. 2. ed. Porto Alegre: Livraria do Advogado, 2006, p. 113.

${ }^{1371}$ Ibid., p. 113-114. 
atentados a direitos da personalidade, os membros da família, os membros de minorias, dentre outros. ${ }^{1372}$

A solidariedade social integra o desdobramento do princípio da dignidade humana, eis que este é composto por quatro postulados, os de que "o sujeito moral (ético) reconhece a existência dos outros como sujeitos iguais a ele", que são "merecedores do mesmo respeito", dotados "de vontade livre, de autodeterminação" e que integram o grupo social e têm a garantia de não serem marginalizados. ${ }^{1373}$

Dessa forma, ao estabelecer os objetivos fundamentais da República Federativa do Brasil, a Constituição, coerente com o princípio da dignidade humana e a consequente solidariedade social, fixou, no artigo $3,^{\circ}$ as seguintes metas prioritárias: "construir uma sociedade livre, justa e solidária" (inciso I); "erradicar a pobreza e a marginalização e reduzir as desigualdades sociais e regionais" (inciso III).

Constata-se, portanto, no texto constitucional expressa referência à solidariedade, princípio jurídico a ser observado por todos. ${ }^{1374}$ Esse princípio da solidariedade social se destina a garantir a implementação da justiça social, com o desenvolvimento de uma sociedade livre e justa, sem excluídos ou marginalizados. ${ }^{1375}$

1372 MORAES, Maria Celina Bodin de. O conceito de dignidade humana: substrato axiológico e conteúdo normativo. In: SARLET, Ingo Wolfgang (org,). Constituição, direitos fundamentais e direito privado. 2. ed. Porto Alegre: Livraria do Advogado, 2006, p. 116.

${ }^{1373}$ Ibid., p. 117.

${ }^{1374}$ Ibid., p. 138.

${ }^{1375}$ Ibid., p. 140. 


\section{7 - O PRINCÍPIO DA MELHORIA DA CONDIÇÃO SOCIAL DO TRABALHADOR}

\subsection{1 - A JUSTIFICAÇÃO DO PRINCÍPIO}

O direito do trabalho decorre das necessidades sociais geradas pelo sistema capitalista, eis que neste sistema a reprodução do capital se faz por meio do lucro, mediante a produção e troca de mercadorias, inserindo-se o trabalho como elemento da produção (transformado também em mercadoria de troca) e, portanto, essencial à lógica do sistema. Apenas no capitalismo o trabalho é mercantilizado e se torna objeto de um contrato. ${ }^{1376} \mathrm{O}$ lucro é a diferença entre o valor pago para a produção (mercadoria trabalho) e o valor obtido pelo capitalista com a venda da mercadoria produzida. Com o advento do capitalismo, a economia deixou de girar em torno da subsistência e passou a girar em torno da troca com finalidade de lucro e de acumulação.

Emir Sader $^{1377}$ esclarece que nas sociedades anteriores ao capitalismo, a exploração da força de trabalho ocorria de maneira explícita: os escravos da antiguidade pertenciam aos seus donos e recebiam apenas o mínimo necessário para sobreviver; os servos da gleba pertenciam à terra e esta ao senhor feudal, a quem entregavam parte da produção ou parte de seu tempo de trabalho, de modo que também ficavam apenas com o mínimo necessário para sobreviver. No capitalismo, as pessoas são iguais perante a lei, mesmo que o "tráfico de escravos e a exploração do trabalho escravo tenha sido parte integrante da acumulação de riquezas por parte de todas as potências capitalistas, como conhecemos no caso ao longo de quase quatro séculos". ${ }^{1378}$

Questionando como é possível a exploração da mão de obra em condições de igualdade jurídica, Emir Sader ${ }^{1379}$ explica que isso decorre da transformação do trabalho

\footnotetext{
${ }^{1376}$ MACHADO, Gustavo Seferian Scheffer. A ideologia do contrato de trabalho. Contribuição à leitura marxista da relação jurídica laboral. Dissertação de mestrado. Faculdade de Direito da USP, São Paulo, 2012, p. 63.

${ }^{1377}$ SADER, Emir. A exploração. In: SADER, Emir (org.). Sete pecados do capital. Rio de Janeiro: Record, 2000, p. 66-67.

${ }^{1378}$ Ibid., p. 67.

${ }^{1379}$ Ibid., p. 67.
} 
humano em mercadoria como outra qualquer e sua compra e venda no mercado, no qual o "trabalhador só é remunerado por uma parte do que ele entrega ao capitalista", de modo que "a troca na realidade não representa valores iguais" e o "salário esconde os mecanismos de exploração da força de trabalho".

A lógica da circulação de mercadorias (troca) preside esse sistema nascido com a expansão do comércio e com a hegemonia dos comerciantes (burgueses). Para essas circulações, revelou-se importante o desenvolvimento dos conceitos de autonomia pessoal e de vinculação de um indivíduo a outro apenas por sua vontade. Para a construção do atual sistema, fazia-se necessário romper com o modo de funcionamento da sociedade anterior (feudal), baseado em relações pessoais (senhor e servo), e passar para um modelo lastreado na igualdade jurídica formal e na autonomia individual.

Para a propagação de um novo modelo econômico, em que as relações de troca foram-se tornando generalizadas (todos se tornaram proprietários e consumidores em potencial), revelou-se importante dotar as partes das relações econômicas de igualdade e de liberdade jurídicas formais: o encontro no mercado se dá entre proprietários (cada um possui algo para trocar) dotados de liberdade (a troca ocorre por ato espontâneo de vontade de cada um). O instrumento dessa troca é o contrato.

Também como elemento constitutivo do sistema, houve o desapossamento de grande quantidade de pessoas, que passaram a ter apenas a sua força de trabalho para sobreviver. Kashiura Jr. observa que "a existência de uma grande massa de nãoproprietários submetidos à medida comum dos proprietários é condição de funcionamento da organização produtiva capitalista”. ${ }^{1380}$

Em uma sociedade organizada à base do comércio e da troca, essa força de trabalho foi transformada em mercadoria (e objeto de contrato), a única com a peculiaridade de produzir valor. Os trabalhadores passaram a ser proprietários dessa mercadoria e de acordo com a construção jurídica então consolidada, passaram a realizar a troca dessa mercadoria pelo salário (outra mercadoria), em condições de igualdade formal

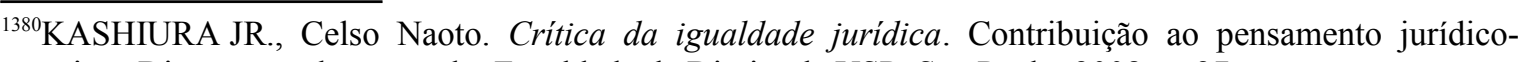
marxista. Dissertação de mestrado. Faculdade de Direito da USP, São Paulo, 2008, p. 27.
} 
com o capitalista, adquirente da mercadoria trabalho. Para fins jurídicos, cada um dos contratantes tinha a liberdade formal de participar ou não da relação jurídica.

Mas essa dimensão abstrata e formal oculta a situação real de cada uma das partes, eis que o trabalhador passou a depender da venda da única mercadoria que possui (sua força de trabalho) para sobreviver, enquanto o capitalista depende da aquisição da força de trabalho para obter lucro, em um cenário geralmente de excesso de oferta de mão de obra.

No campo da economia, o fetichismo da mercadoria faz esquecer que a produção e a circulação são relações entre homens ao fazer aparecer apenas a coisa em sua dimensão acabada e autônoma, no campo do direito o fetichismo do sujeito faz esquecer a submissão do homem à coisa ao fazer aparecer apenas o sujeito abstrato autônomo. Esses dois fetichismos formam o sustentáculo central da ideologia burguesa. ${ }^{1381}$

Esse modelo de atribuição de plena validade a dimensões formais, que não possuíam correspondência com a realidade material, favorecia a parte que, no plano real e econômico, era mais forte, qual seja a capitalista, que obtinha vantagem no ato da troca de uma mercadoria (o salário) por outra (o trabalho), levando os trabalhadores a uma situação cada vez pior em termos materiais de vida, com superexploração por meio de jornadas de trabalho excessivas e de salários muito baixos (insuficientes até mesmo para as necessidades básicas). Na verdade essa vantagem obtida pelo capitalista na compra da mercadoria trabalho é a essência do lucro (mais-valia) e, portanto, do sistema.

O contrato é onde os ápices da racionalidade de mercado e da racionalidade jurídica se manifestam. É através dele que mercadorias e pessoas são postas em circulação, que meios de produção e força de trabalho são ligados, que o valor se realiza. É nele e para ele que a liberdade e a igualdade, que os sujeitos de

\footnotetext{
${ }^{1381}$ KASHIURA JR., Celso Naoto. Crítica da igualdade jurídica. Contribuição ao pensamento jurídico-
} marxista. Dissertação de mestrado. Faculdade de Direito da USP, São Paulo, 2008, p. 24. 
direito, a vontade e a propriedade privada surgem e se realizam plenamente. $^{1382}$

Marx esclarece a dinâmica da mais-valia e revela a contradição entre a forma mercantil da força de trabalho e o seu conteúdo real:

A mais-valia que constitui o capital adicional número I resulta da compra da força de trabalho por uma parte do capital original, compra que se enquadra nas leis da troca de mercadorias, e que, encarada juridicamente, pressupõe livre disposição por parte do trabalhador de suas próprias faculdades, e, do lado do possuidor do dinheiro e das mercadorias, livre disposição sobre os valores que lhe pertencem. O capital adicional número II resulta do número I, sendo, portanto, conseqüência da relação anterior. Cada transação particular corresponde sempre à lei da troca de mercadorias, comprando sempre o capitalista a força de trabalho e vendendo-se sempre o trabalhador, e admitimos que pelo valor real. Nessas condições, é evidente que o direito de propriedade privada, baseado sobre a produção e circulação das mercadorias, se transmuta em seu oposto, em virtude de sua própria dialética interna, inexorável. No início, havia uma troca de equivalentes, depois, a troca é apenas aparente: a parte do capital que se troca por força de trabalho é uma parte do produto alheio, do qual o capitalista se apropriou sem compensar com um equivalente. ${ }^{1383}$

A liberdade formal, sob a perspectiva do trabalhador, reduz-se à possibilidade de oferecer sua força de trabalho para a venda (celebrar pactos voluntários), distanciando-se da liberdade real, eis que para o trabalhador não resta outra alternativa, na medida em que a venda é necessária para a sobrevivência.

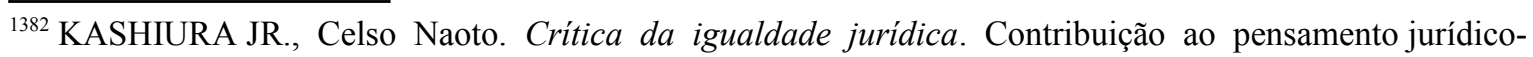
marxista. Dissertação de mestrado. Faculdade de Direito da USP, São Paulo, 2008, p. 41.

${ }^{1383}$ MARX, Karl. O capital, s/ed, s/a, s/p. Apud VIANNA, Luiz Werneck. Liberalismo e sindicato no Brasil. 4. ed. Belo Horizonte: Editora UFMG, 1999, p. 46.
} 
Os homens não receberam a personalidade jurídica abstrata para que pudessem se relacionar como iguais, mas para que pudessem voluntariamente se colocar à disposição da exploração. A análise do sujeito jurídico explica não apenas a troca equivalente, baluarte do capitalismo, mas também o âmago de sua injustiça. ${ }^{1384}$

O sistema capitalista, por meio dessa apropriação injusta dos resultados do trabalho pela classe dos proprietários dos meios de produção, mantém a maioria das pessoas na classe dos não proprietários, mantendo, assim, a divisão de classes.

É falsa a crença de que a liberdade jurídica coincide com a igualdade econômica. O direito do trabalho, "mais que um limite para a liberdade de contratação, é um esforço para estabelecer a igualdade econômica entre capital e trabalho e fazer possível uma autêntica liberdade de contratação". ${ }^{1385}$

Nesse contexto, o direito do trabalho alterou a racionalidade da teoria geral do direito, mitigando a perspectiva meramente formal das relações jurídicas, com vistas a preservar o próprio sistema capitalista, colocando limites à exploração do trabalho pelo capital, a partir do reconhecimento de que havia desigualdade e necessidade de proteção do trabalhador.

O Direito do Trabalho emerge como uma conquista da classe trabalhadora contra o pacto original do liberalismo, impondo limites legais - externos - ao homem apetitivo. É como leis de exceção, sublinha Marx, que as leis de proteção ao trabalho aparecem durante a primeira metade do século XIX, criando um ramo do direito ao largo das relações privadas, puramente mercantis. ${ }^{1386}$

\footnotetext{
${ }^{1384}$ KASHIURA JR, Celso Naoto. Crítica da igualdade jurídica. Contribuição ao pensamento jurídicomarxista. Dissertação de mestrado. Faculdade de Direito da USP, São Paulo, 2008, p. 31.

${ }^{1385}$ CUEVA, Mario de la. Derecho mexicano del trabajo. Segunda Edicion. Mexico: Libreria de Porrua Hnos. Y Cia., 1943, p. 225.

${ }^{1386}$ VIANNA, Luiz Werneck. Liberalismo e Sindicato no Brasil. 4. ed. Belo Horizonte: Editora UFMG, 1999, p. 47.
} 
A classe trabalhadora, ao se organizar e reivindicar por direitos sociais, denuncia a forma mercantil do modo de produção capitalista. Sua ação torna evidente o caráter falacioso do contratualismo liberal, determinando o desmascaramento da sua expressão mercantil e jurídica e revelando seu conteúdo de relação de exploração - o mercado não consiste apenas numa arena mercantil, mas também política e social, onde a classe operária busca forçar a ampliação dos seus direitos. Nessa medida, desprende-se da ideologia do indivíduo, e o direito que emerge como fruto da sua ação parte de postulados antitéticos ao liberalismo, afirmando-se desde logo como de natureza pública. ${ }^{1387}$

Dessa forma, constata-se que o historicamente consagrado princípio da proteção do empregado é de extrema relevância para o direito do trabalho. Seus propósitos estão relacionados com a situação de desigualdade econômica existente entre as partes das relações de trabalho. O princípio parte do pressuposto de uma intervenção jurídica no mercado de trabalho, na relação de troca da força de trabalho pela contraprestação.

Ocorre que mesmo revelando um grau de generalidade, além de amplitude e eficiência de aplicabilidade, é possível observar e distinguir um critério mais amplo e mais profundo que inspira o próprio princípio da proteção: trata-se do princípio da melhoria da condição social do trabalhador. É para melhorar a situação do trabalhador que o direito do trabalho o protege.

Vale dizer, ante as injustiças sociais geradas pelo sistema capitalista, houve a necessidade de estruturação de um ramo jurídico para o reconhecimento da problemática e para a atribuição de expressão jurídica aos interesses dos agentes explorados na relação de trabalho própria do referido sistema, quais sejam os trabalhadores. Tratava-se de mecanismo natural de busca de equilíbrio no sistema jurídico, a partir de seus próprios pressupostos (transformação dos agentes sociais em sujeitos de direito, garantia das

\footnotetext{
${ }^{1387}$ VIANNA, Luiz Werneck. Liberalismo e Sindicato no Brasil. 4. ed. Belo Horizonte: Editora UFMG,
} 1999, p.48. 
relações de troca por institutos jurídicos), em um processo dialético de interação com as transformações sociais.

A racionalidade do direito do trabalho era de interferência em favor do trabalhador, na medida em que a ordem jurídica até então vigente representava a atuação normativa em prol do capital, sendo desnecessária qualquer alteração para a manutenção do status quo. No direito do trabalho que, naqueles tempos iniciais, vai-se consolidando, observa-se o mote de melhorar a condição social do trabalhador.

O princípio da melhoria da condição social do trabalhador, que se extrai da racionalidade das normas e instituições do direito do trabalho, pretende a proteção do trabalhador na relação de trabalho porque isso lhe é benéfico e melhora sua condição social. O mercado em que a força de trabalho é oferecida é viciado por um sistema estruturalmente composto por excesso de oferta de mão de obra, na medida em que a concentração de renda lança a esmagadora maioria das pessoas no grupo daqueles que sobreviverão oferecendo sua força de trabalho ao capital. Por isso, deixar que as condições de trabalho sejam regidas apenas pelas regras desse mercado seria a condução inevitável à superexploração e à pauperização do trabalhador. Colocar limites, por exemplo, estabelecendo o salário mínimo e as jornadas máximas de trabalho podem possibilitar a proteção do trabalhador enquanto parte do contrato.

Contudo, parece-nos que o princípio da melhoria da condição social do trabalhador pretende mais. Não apenas fornecer critérios de criação, interpretação de normas (legais, regulamentares ou contratuais) e de resolução de conflitos. Sem deixar de abranger o relacionamento entre empregado e empregador (que pressupõe o mercado da força de trabalho), também viabilizar, por meio do direito, alterações mais amplas de justiça social, que interfiram na estrutura social de modo a favorecer a classe trabalhadora, alçando-a a posição de relevância social cada vez maior. O princípio parte do pressuposto de que a norma jurídica deverá intervir em uma relação histórica mais ampla e subjacente à relação de trabalho, embora com ela estruturalmente enlançada, a relação social de dominantes e dominados, com vistas a modificar sempre para melhor a situação de vida dos dominados. 
Ao normatizar a relação de trabalho, mediante o estabelecimento de limites à exploração do trabalhador, a interferência sinaliza a nocividade da injustiça social gerada pelas desigualdades sociais e pela modalidade de domínio da classe detentora dos meios de produção, e com isso aponta para mudanças estruturais mais amplas, na direção de um modelo mais igualitário, que pressupõe, portanto, a melhoria da condição social do trabalhador.

Um princípio de proteção que se instrumentalize para um reequilíbrio do contrato de trabalho, embora de grande relevância e justiça, possui efeitos mais limitados que o princípio maior, voltado à justiça social de modo geral e para a alteração da posição das classes sociais. Melhorar o contrato, embora se revele imprescindível e urgente, ainda é permitir a mercantilização da força de trabalho e a extração da mais-valia. Ainda é manter a estrutura de um sistema essencialmente injusto.

Proteger o trabalhador na relação contratual é muito importante, mas será que essa proteção é suficiente para fazer avançar a justiça social? Que outra proteção o direito poderia oferecer ao trabalhador para não apenas evitar sua superexploração, mas possibilitar a melhoria da sua condição social e, no limite, o término da própria exploração, ou seja, uma alteração no regime de apropriação do resultado do trabalho: mudança na estrutura do próprio sistema. Parece-nos que além da publicização da relação de trabalho por meio de normas estatais, a garantia plena dos direitos de associação e de reivindicação, um sistema generoso de previdência e assistência social e o oferecimento de serviços públicos de qualidade (melhoria das oportunidades), mediante a radicalização de um Estado Social, sempre em uma perspectiva dinâmica e apontada para a proteção da pessoa e do fortalecimento dos laços de solidariedade social, podem construir um patamar civilizatório que se aproximará cada vez mais de uma sociedade sem exploração do homem pelo homem. 
Com base no ensinamento de Federico de Castro, ${ }^{1388}$ Plá Rodrigues indica três funções para os princípios: informadora, porque "inspiram o legislador, servindo de fundamento para o ordenamento jurídico"1389; normativa, eis que "atuam como fonte supletiva, no caso de ausência de lei" ${ }^{1390}$ e por isso "são meios de integração do direito"; ${ }^{1391}$ e interpretadora, na medida em que "operam como critério orientador do juiz ou do intérprete". ${ }^{1392}$

Entendemos que a dimensão normativa dos princípios extrapola o aspecto meramente supletivo e integrativo. Trata-se de norma tanto quanto as regras, mas de relevância ainda maior porque expressam fundamento axiológico, estabelecem comandos norteadores, essenciais, distintivos e finalísticos.

O princípio da melhoria da condição social do trabalhador revela-se capaz de desempenhar todas as funções atribuíveis a um principio normativo (caráter de eficácia máxima), pois orienta a criação de novas normas, a interpretação das já existentes (critério de criação da norma do caso concreto) e a aplicação e conflito de normas, mediante o desenvolvimento de nova hierarquia normativa (tendo como elemento central o critério de beneficiar o trabalhador), a integração de lacunas e o respeito à condição de vida mais benéfica anterior a alguma norma).

Plá Rodrigues"1393 evita o que chamou de "controvertida concepção do direito de classe que foi exposto por De La Cueva", com intuito de afastar o princípio da proteção de "concepção ideológica ou política". Esclarece ${ }^{1394}$ que Mario de la Cueva, em sua obra "Derecho Mexicano del Trabajo" escrevera:

O Direito do Trabalho, como diria Savigny, continua vivendo na consciência popular e assim tem que ser, porque nenhum ramo do

\footnotetext{
${ }^{1388}$ CASTRO, Federico de. Derecho civil de España. 2. ed. Madri, s/ed, 1949, p. 473. Apud PLÁ RODRIGUEZ, Américo. Princípios de direito do trabalho. Tradução de Wagner Giglio. São Paulo: LTr, 1993, p. 18.

${ }^{1389}$ PLÁ RODRIGUEZ, Américo, op. cit., p. 18.

${ }^{1390}$ Ibid., p. 18.

${ }^{1391}$ Ibid., p. 18.

1392 Ibid., p. 18.

${ }^{1393}$ PLÁ RODRIGUEZ, Américo, op. cit., p. 32-33.

${ }^{1394}$ Ibid., nota de rodapé, p. 32.
} 
direito, em qualquer tempo, esteve tão estreitamente vinculado à vida do povo como o Direito do Trabalho. A missão do intérprete há de consistir, pois, em conservar-lhe esse caráter e, por isso, a primeira e por sua vez a regra básica de interpretação do Direito do Trabalho consiste em julgá-lo de acordo com sua natureza, isto é, como estatuto que traduz a aspiração de uma classe social para obter, imediatamente, uma melhoria em suas condições de vida. ${ }^{1395}$ (Sublinhado no original).

Nesse ponto, divergimos de Plá Rodrigues, por considerarmos que os aspectos essenciais indicados pelo referido autor e de modo geral consagrados pela doutrina para o núcleo do princípio da proteção ("in dubio, pro operario" e supremacia da norma e da condição mais benéficas ao trabalhador) direcionam-se para a melhoria das condições de vida da classe trabalhadora, e não há nesse particular nenhum aspecto mais ideológico do que o de qualquer outra norma jurídica.

O princípio da melhoria da condição social do trabalhador incorpora o princípio da proteção ("in dubio por operario", regra da aplicação da norma mais favorável e regra da condição mais benéfica), além dos demais principais princípios destacados pela doutrina jurídica, quais sejam os da irrenunciabilidade dos direitos trabalhistas, da continuidade da relação de emprego e da primazia da realidade.

Cabe-nos perguntar: que tipo de melhoria? Seria apenas a do mercado de trabalho? Para obter-se a consistência do princípio e a superação de uma perspectiva meramente contratual, cabe uma análise da situação histórica do trabalhador, suas dificuldades, exploração pelo capital, aspirações e lutas.

A dimensão dos contratos de trabalho, em suas fases ante, durante e post execução contratual interessa ao princípio da melhoria da condição social do trabalhador, eis que é na relação de produção que o sistema capitalista promove a desigualdade

${ }^{1395}$ CUEVA, Mario de la. Derecho mexicano del trabajo. Segunda Edicion. México: Libreria de Porrua Hnos. Y Cia., 1943, p. 334. 
econômica e a exploração do trabalho pelo capital (extração da mais-valia), fornecendo o quadro de desigualdades, injustiça e destruição inerentes ao sistema.

Mas, por que não pensar também no processo de criação das normas sociais lato sensu, abrangendo a intensificação da proteção contra as agressões à saúde do trabalhador e vulnerabilidades outras como as decorrentes de desemprego e senilidade, bem como normas que dizem respeito a distribuição de oportunidades, como as relacionadas a educação e saúde, normas referentes à estrutura de ampla e verdadeira participação na gestão da empresa e na vontade do Estado. E principalmente, normas que possam viabilizar a união dos trabalhadores e sua atuação coletiva. Vale dizer, o princípio da melhoria da condição social do trabalhador se propõe a fortalecer econômica, social e politicamente o homem que vive do trabalho (e que é a maioria no conjunto da sociedade).

É um princípio de oposição à dinâmica do sistema capitalista, cujas engrenagens voltadas para a crescente ampliação da produção e reprodução dos lucros transforma o homem em mercadoria, desumanizando e oprimindo, por meio de um completo controle de suas condições existenciais, inclusive e principalmente, mas não apenas, sob o aspecto econômico. Trata-se de um sistema que tende à concentração de renda e à desigualdade social.

Por detrás do capital está o capitalista e uma classe social, a burguesia. Da mesma forma, no que se refere à classe trabalhadora, em que pessoas de carne e osso a integram e entregam a energia que fornecerá o trabalho. Apenas à classe social dos trabalhadores interessa o fim da divisão de classes sociais, pois apenas essa classe é explorada na dinâmica dessa divisão.

O princípio de direito social da melhoria da condição social do trabalhador diz que a racionalidade de construção de direitos relacionados ao trabalhador deve ser a de melhorar a sua condição social. Não diz que a racionalidade será de facilitar a ampliação do capital ou a organização da vida econômica do país. A racionalidade do princípio é de que o capital deve se subordinar ao trabalho, porque é no trabalho que está o elemento humano da produção. 
É claro que há no princípio várias facetas contraditórias que podem ser enfatizadas de modo diferenciado, gerando concepções e modelos diversos de direito do trabalho e de direito social. A implementação da melhoria traz variadas possibilidades. Na medida em que tanto o capitalista quanto o trabalhador dependem do caráter social do trabalho para a sobrevivência, a regulação da apropriação do resultado do trabalho traz possibilidades muito díspares, desde um modelo de distribuição equalizada até a intensificação máxima da apropriação da mais-valia pelo capital, sob um discurso que ressalte a dependência do trabalhador e oculte a do burguês, ou que ressalte a justiça da relação de troca sem questionar a troca em si.

O princípio da proteção busca corrigir as desigualdades na relação contratual. Não questiona diretamente o nascedouro das desigualdades. Insere-se na dinâmica do sistema, para seu melhor funcionamento possível, inclusive melhorando a condição do trabalhador no contrato de trabalho.

Sabemos que o contrato é um dos pilares do sistema capitalista, na medida em que possibilita a transformação das pessoas em sujeitos de direito e viabiliza as trocas mercantis por meio da igualdade e liberdade formais.

Mário de la Cueva ${ }^{1396}$ mostra que o capitalismo liberal produziu a divisão da sociedade em classes sociais. $\mathrm{O}$ direito do trabalho representou um estatuto e condições mínimas para que os trabalhadores participassem do processo de produção, e por essa razão, trata-se de um direito de classe, um direito protetor dos trabalhadores. E o será enquanto subsistir a injustiça do regime capitalista e a divisão da sociedade em classes sociais.

Durante a idade média, havia um direito corporativo, que buscava a proteção dos mestres e não dos companheiros e aprendizes. Não havia ainda um direito do trabalho. Com a implantação do capitalismo, o liberalismo admitiu apenas um sistema de direito, que era baseado na igualdade e liberdade formais entre as partes. Posteriormente,

${ }^{1396}$ CUEVA, Mario de la. Derecho mexicano del trabajo. 2. ed. México: Libreria de Porrua Hnos. Y Cia., 1943, p. 213. 
foi-se formando uma nova racionalidade, a de que a produção deve atender às necessidades coletivas e não exclusivamente ao lucro individual.

Mario de la Cueva ${ }^{1397}$ observa que desde o século XIII surgiram organizações dos companheiros, ao lado das corporações de ofício. Os companheiros eram explorados pelos mestres, tendo sido combatidos até mesmo pela nobreza, que não aceitava nenhum espírito de rebelião, e posteriormente pela burguesia. A aspiração dos companheiros não ultrapassava o marco da vida medieval, pois pretendiam apenas a supressão das restrições para a obtenção do grau de mestre, sem almejarem a transformação econômica e social do regime, pretendiam apenas a satisfação de suas necessidades humanas, não chegando a almejar direitos de classe. Diferentemente dos companheiros, a burguesia tinha a pretensão de alteração dos regimes político e econômico. Os artesãos pretendiam a manutenção da ordem corporativa enquanto a burguesia pretendia a supressão das regulamentações da economia.

Mario de la Cueva ${ }^{1398}$ esclarece que o direito do trabalho possui duas finalidades, uma imediata de melhoria das condições de vida dos trabalhadores (a mesma bandeira dos companheiros da idade média) e outra mediata, de, associada a outros meios, transformação do regime, com distribuição mais justa da riqueza e supressão das classes sociais. E prossegue, ratificando que o direito do trabalho é o direito de uma classe social, da classe trabalhadora:

O direito do trabalho é pois um direito protetor de uma classe social e se funda na imperiosa necessidade do proletariado de melhorar seu nível de vida, e espera e isto é fundamental, que se opere a transformação do mundo para um regime mais justo. $\mathrm{O}$ direito do trabalho não é uma finalidade última, mas uma ordenação transitória, isto é, uma medida exigida por uma classe social para evitar a exploração de que é vitima. O direito do trabalho tem ademais um fundamento nacional, pois o melhor de uma Nação são

${ }_{1397}$ CUEVA, Mario de la. Derecho mexicano del trabajo. 2. ed. México: Libreria de Porrua Hnos. Y Cia., 1943, p. 214-215.

1398 Ibid., p. 215. 
suas forças trabalhadoras; um povo poderá sempre refazer seus capitais perdidos, se tem espírito de trabalho ... a prosperidade e a união da Nação não poderá alcançar-se senão à base da elevação real da vida dos trabalhadores; o mais é ilusão, paz forçada durante alguns anos e preparação para uma nova luta de classes. ${ }^{1399}$

Sequer a necessidade individual do trabalhador é protegida, mas sim o interesse do proletariado, enquanto classe, buscando subordinar o capital ao trabalho. A relação individual de trabalho não é uma simples relação entre trabalhador e patrão. É uma relação de classes sociais. O direito do trabalho é um direito transitório, necessário apenas para evitar a exploração de uma classe por outra e para contribuir na construção da igualdade entre as classes sociais, mediante o fortalecimento da classe trabalhadora.

O direito do trabalho pode transformar-se em instrumento de melhoria da condição social do trabalhador, desde que dele o trabalhador se aproprie e o maneje como mecanismo de luta, em conjunto com setores do aparato estatal desvinculados dos interesses e da ideologia da burguesia.

\subsection{2 - A POSITIVAÇÃO DO PRINCÍPIO DA MELHORIA DA CONDIÇÃo SOCIAL DO TRABALHADOR}

O princípio da melhoria da condição social do trabalhador decorre de todo o conjunto de normas de direito social e sua existência independe de previsão legal expressa. A positivação, contudo, constitui medida que o fortalece em todas as dimensões, como fonte informadora da produção legislativa e de interpretação e aplicação do direito. A constitucionalização, no capítulo dos direitos fundamentais, ressalta a posição de supremacia do princípio, integrando-o ao núcleo central da ordem jurídica brasileira.

O princípio em estudo encontra-se positivado no artigo $7^{\circ}$, “caput", da Constituição Federal de 1988, que estabelece: "São direitos dos trabalhadores urbanos e

1399 CUEVA, Mario de la. Derecho mexicano del trabajo. 2. ed. México: Libreria de Porrua Hnos. Y Cia., 1943, p. 216-217. 
rurais, além de outros que visem à melhoria de sua condição social". O referido artigo integra o capítulo II, referente aos direitos sociais, do título II, que trata dos direitos e garantias fundamentais.

O enunciado desse artigo diz muito. Determina de modo axiologicamente soberano que os direitos previstos no artigo $7^{\circ}$ devem melhorar a condição social do trabalhador e que outros direitos ainda ali não elencados também devem realizar esse objetivo. Assim, a interpretação e aplicação dos direitos do artigo $7^{0}$ jamais poderão se afastar dessa direção, de estatuto de proteção dos trabalhadores. Entre os próprios direitos do artigo $7^{\circ}$ estabelece-se uma relação de maior ou menor realizabilidade jurídica, conforme se adequem ao fim estabelecido no "caput". Por exemplo, muito maiores são as possibilidades concretas de aplicabilidade da norma geral do inciso VI, de irredutibilidade salarial, do que a da exceção prevista no mesmo dispositivo, de redutibilidade mediante convenção ou acordo coletivo, eis que, concretamente, a hipótese excetiva somente seria admissível se indubitavelmente representasse melhoria da condição social do trabalhador, e isso seria uma situação dificilmente concretizável.

A norma de melhoria da condição social do trabalhador produz efeitos inibitórios e limitativos de outras estabelecidas na Constituição Federal que com ela se conflituem, embora na dimensão abstrata mantenham coexistência jurídica. A referida norma esteriliza por inconstitucionalidade todo o regramento infraconstitucional que se distancie do princípio que expressa. Impossibilita a criação de novas normas que envolvam o trabalhador, mas que possuam finalidade diversa, eis que determina expressamente que devem melhorar a condição social do trabalhador.

A doutrina costuma atribuir ao artigo $7^{\circ}$, "caput", da Constituição Federal a positivação do princípio da norma favorável ao trabalhador, na medida em que "ao estabelecer as diretrizes fundamentais dos direitos dos trabalhadores, o faz como garantias mínimas". ${ }^{1400}$ Também costuma-se atribuir ao referido artigo a positivação do princípio da proteção. No desenvolvimento do presente estudo, mostraremos que esses aspectos integram o princípio da melhoria da condição social do trabalhador.

\footnotetext{
${ }^{1400}$ NASCIMENTO, Amauri Mascaro. Curso de direito do trabalho. 11. ed. São Paulo: Saraiva, 1995, p.
} 180. 
O princípio da melhoria da condição social do trabalhador depende de uma perspectiva que leve em consideração a luta de classes e a posição dos trabalhadores no processo produtivo, e que parta do pressuposto de que a alteração jurídica que o direito visa promover se presta a proteger o ser humano e não viabilizar a exploração da força de trabalho pelo capital.

Assim, partindo do pressuposto de um direito reconhecedor da existência de desvantagem econômica entre o trabalhador e o capitalista, notadamente em uma sociedade de tão profundas desigualdades sociais, o princípio da melhoria da condição social do trabalhador significa que a experiência jurídica, em qualquer de suas dimensões, colocando-se na perspectiva do trabalhador, deve ser capaz de fortalecer a classe trabalhadora, a partir da melhoria ampla de condições de vida e trabalho e da valorização do humano na relação de produção, com vistas à construção de uma sociedade justa e solidária, inclusive mediante gestão e apropriação dos meios de produção pelos trabalhadores, a fim de eliminar a divisão de classes sociais, patamar que se insere nos desdobramentos da melhoria de sua condição.

O princípio ora estudado conecta-se às raízes do direito social (solidariedade, justiça social, pacificação pela justiça social, proteção à dignidade humana e coletivização dos interesses) e à ideia da esfera do trabalho como a de um poder privilegiado para determinar a consciência e a ação social. Na medida em que de um lado há um ser humano tentando sobreviver e manter sua humanidade e de outro o capital, tentando se reproduzir e se acumular, mediante a exploração do humano, a atuação do direito em prol do trabalhador se insere na racionalidade do direito social.

Pode-se representar figurativamente a principiologia do direito do trabalho por meio de um círculo com camadas concêntricas, em cujo núcleo está o princípio da melhoria da condição social do trabalhador e em uma outra camada, mais externa, mas muito próxima, o da proteção, ambos integrantes do mesmo foco de luz normativa. 
A referência à melhoria da condição social do trabalhador passou a constar nos textos constitucionais, a partir da Constituição Federal de 1934, e sempre no título "Da ordem econômica e social", com exceção da Constituição Federal de 1937, em que constava no título "Da ordem social", até chegar à Constituição de 1988, na qual foi inserido no título "Dos direitos e garantias fundamentais".

Vale dizer, desde que o Estado Social brasileiro ingressou em sua fase de consolidação jurídica, a partir do movimento político de 1930, o princípio teve positivação constitucional. E não poderia ser diferente, porque a superação do ideário estritamente liberal e individualista por uma perspectiva social e coletivista somente se revelou possível pela mitigação do princípio da igualdade formal e pelo reconhecimento da existência de diferenças econômicas que desfavoreciam o trabalhador e que deveriam ser modificadas pela ordem jurídica, mesmo que outros interesses também estivessem presentes e, na maior parte do tempo, até acabassem por predominar (como, por exemplo, o de atrair mão de obra para a indústria e viabilizar a exploração da força de trabalho pelo capital industrial), no contexto das contradições do sistema capitalista e do Estado que lhe dá suporte.

Após a superação do modelo escravista de produção, predominante durante séculos no Brasil, e início da formação do capitalismo, a classe trabalhadora ainda sofria as consequências de uma estruturação social extremamente desfavorável, em razão dos padrões de uma sociedade recém saída daquela ordem escravocrata. Havia forte preconceito contra o trabalho manual e contra o trabalhador imigrante. A questão social era tratada como caso de polícia, em uma ordem jurídica própria do Estado Liberal vigente, voltada para a proteção dos interesses das classes conservadoras (oligarquias fundiárias e burguesia industrial nascente).

Nesse contexto, as tentativas de organização e mobilização dos trabalhadores não despertavam a atenção e a preocupação da elite. Os direitos alcançados em negociações diretas com o capital eram descumpridos, logo após o encerramento dos movimentos de pressão dos trabalhadores, porque não haviam sido assegurados em lei. 
As diversas transformações da sociedade brasileira no início do século XX, como a ascensão das classes sociais urbanas e o desenvolvimento da industrialização, e mesmo uma certa organização da classe trabalhadora urbana (vide as grandes greves de 1917 a 1920) contribuíram para a transformação da ordem jurídica, principalmente a partir de 1930, no sentido de estabelecer direitos que pudessem melhorar as condições de vida e trabalho dos trabalhadores, dentro do processo de estruturação do capitalismo nacional.

As questões de trabalho foram deixando de ser consideradas questões de polícia, para se tornar questões de política (o que todavia não afastou a atuação de órgãos repressivos do Estado), com a legitimação de certas reivindicações do proletariado. O poder público passou a buscar a pacificação das classes sociais, por meio de normas que, entre outros aspectos, tentava evitar a pauperização dos trabalhadores urbanos, atender algumas das suas principais necessidades e reivindicações, atrair mão de obra para as cidades e controlar a atividade e a organização política desses trabalhadores, atraindo-os para o apoio ao governo.

Tudo isso contribuía para a expansão industrial e para a racionalidade da máxima mercantilização dos fatores de produção. Nesse momento, a legislação trabalhista ainda ficou restrita aos trabalhadores urbanos da indústria e do comércio, revelando a inserção dos direitos sociais e a melhoria da condição social dos trabalhadores na lógica contraditória do sistema capitalista, na medida em que o favorecimento da força de trabalho ocorria, mas de modo gradual e apenas no que se mostrava imprescindível para o atendimento prioritário dos interesses do capital.

Contudo é inegável que a legislação representou para os trabalhadores urbanos a obtenção de antigas reivindicações e sinalizou um marco inicial de proteção normativa em face dos empregadores. Mais que isso, o estabelecimento de um salário mínimo, do direito a férias, da limitação de jornada, entre outros aspectos, e posteriormente a elaboração da Consolidação das Leis do Trabalho, iniciaram a construção de uma nova ordem jurídica (lastreada em uma nova racionalidade), transformando as relações de trabalho de privadas em relações dotadas de certo caráter público, nas quais o Estado podia e devia intervir, para evitar a superexploração do trabalhador, a sua pauperização, a 
competição incontrolada entre as diversas categorias profissionais e a canalização das insatisfações para o confronto e a violência.

A Consolidação das Leis do Trabalho, em 1943, mais do que mera sistematização, representou a construção de um monumento normativo de intensa transformação na concepção jurídica brasileira. O princípio da liberdade contratual absoluta, no sentido de celebrar os contratos e de fixar o conteúdo, deixava de existir nas relações de trabalho. Era uma racionalidade que reconhecia a desigualdade material entre empregado e empregador e a vulnerabilidade a que o sistema havia lançado uma multidão de despossuídos que tinha na venda da força de trabalho o único meio de sobrevivência.

A normatização de direitos sociais, que estava em andamento, foi dando densidade para a constituição do Estado Social brasileiro, alterando a racionalidade jurídica que vigorava até então.

As redações constitucionais anteriores à Constituição Federal de 1988 do princípio em estudo foram as seguintes: a) 1934 - Art.121 - “A lei promoverá o amparo da produção e estabelecerá as condições do trabalho, na cidade e nos campos, tendo em vista a proteção social do trabalhador e os interesses econômicos do País. Parágrafo $1^{\circ}-\mathrm{A}$ legislação do trabalho observará os seguintes preceitos, além de outros que colimem melhorar as condições do trabalhador"; b) 1937- Art. 136 - "O trabalho é um dever social. O trabalho intelectual, técnico e manual tem direito a proteção e solicitude especiais do Estado. A todos é garantido o direito de subsistir mediante o seu trabalho honesto e este, como meio de subsistência do indivíduo, constitui um bem que é dever do Estado proteger, assegurando-lhe condições favoráveis e meios de defesa"; c) 1946: Art.157 - "A legislação do trabalho e a da previdência social obedecerão os seguintes preceitos, além de outros que visem a melhoria da condição dos trabalhadores"; d) 1967 e 1969 - Artigos 158 e 165, respectivamente - "A Constituição assegura aos trabalhadores os seguintes direitos, além de outros que, nos termos da lei, visem à melhoria, de sua condição social”.

No "caput" do artigo 121 da Constituição Federal de 1934, houve referência ao amparo da produção e à proteção social do trabalhador, bem como aos interesses 
econômicos do país, e somente no parágrafo $1^{\circ}$, ao se referir à legislação do trabalho, consta a finalidade de melhorar as condições do trabalhador. No artigo $7^{\circ}$ da Constituição Federal de 1988, o texto faz referência apenas ao trabalhador.

A Constituição de 1937, no seu artigo 136, menciona a proteção do Estado ao trabalho honesto, referenciado como o meio de subsistência do indivíduo. A proteção imediata é ao trabalho honesto e somente mediatamente ao trabalhador, havendo, ainda, referência ao trabalho como meio de subsistência. Na Constituição de 1988, a proteção é ao trabalhador.

A Constituição de 1946 diz que a melhoria da condição dos trabalhadores (termo genérico condição, sem especificar social ou econômica) deve inspirar outros preceitos a serem obedecidos pela legislação do trabalho e da previdência, ou seja, de certa forma vincula a melhoria da condição dos trabalhadores à esfera da legislação do trabalho e da previdência. Em 1988, a melhoria da condição social do trabalhador foi prevista como um objetivo do direito, de modo geral, e não apenas do direito do trabalho ou previdenciário.

As Constituições de 1967 e 1969 mencionaram que a melhoria da condição social dos trabalhadores, a ser perseguida por outros direitos, seria definida em lei. $\mathrm{Na}$ Constituição de 1988, não há essa restrição ou circunscrição ao âmbito da lei.

Constata-se, portanto, que o princípio da melhoria da condição social do trabalhador foi positivado constitucionalmente desde 1934, mas em nenhum momento o enunciado constitucional foi tão amplo e profundo como o que consta no artigo $7^{\circ}$, "caput", da Constituição Federal de 1988, que, além de esclarecer expressamente que os direitos indicados no referido artigo são direitos dos trabalhadores (e não dos trabalhadores e empregadores, dos empregadores, da atividade laborativa, da atividade econômica, do sistema produtivo, da atividade empresarial, do emprego, da paz social, da conciliação das classes sociais etc.), vincula tais direitos ao princípio e aponta para a criação de outros sob o mesmo fim e parâmetro valorativo. 
Dessa forma, a interpretação de cada direito previsto no artigo $7^{\circ}$ da Constituição Federal de 1988 deve ser realizada levando-se em consideração a perspectiva do interesse do trabalhador, restando esterilizada qualquer pretensão de apropriação de tais direitos por outro objetivo. Vale dizer, o reconhecimento das normas coletivas, o tratamento da participação nos lucros e resultados e do tempo no trabalho, a proteção da relação de emprego, do salário, da maternidade, da paternidade, do mercado de trabalho da mulher etc. estão expressamente imantados pelo princípio da melhoria da condição social do trabalhador. Exemplificativamente, não se pode usar a negociação coletiva para reduzir direitos ou discipliná-los de modo a não melhorar a condição social do trabalhador.

Para Homero Batista Mateus da Silva, “o art. $7^{\circ}$ (da Constituição Federal de 1988) diz respeito a direitos dos trabalhadores e não a direitos trabalhistas em geral ou direitos do empregador". ${ }^{1401}$

Concordamos que o enunciado normativo do artigo $7^{\circ}$ proclama direitos dos trabalhadores, mas observamos, porém, que a expressão "além de outros que visem à melhoria de sua condição social" estende aos direitos trabalhistas em geral o princípio. E ressaltamos, não apenas aos direitos trabalhistas ou previdenciários, mas a todas as normas que possam de algum modo interferir nas condições de vida dos trabalhadores.

É de se registrar que os direitos elencados na Constituição são apenas o mínimo, eis que outros deverão ser criados para o fim de melhorar a condição social do trabalhador.

Jorge Luiz Souto Maior ${ }^{1402}$ observa que diversos doutrinadores demonstraram a essencialidade do princípio da melhoria da condição social do trabalhador ao conceito de direito do trabalho: Octavio Bueno Magano dizia que “... definimos o Direito do Trabalho como o conjunto de princípios, normas e instituições, que se aplicam à relação de trabalho, tendo em vista a proteção do trabalhador e a melhoria de sua condição

\footnotetext{
${ }^{1401}$ SILVA, Homero Batista Mateus da. Em busca do tempo perdido - o aviso prévio proporcional ao tempo de serviço e a lei n. 12.506/2011. Revista LTr, São Paulo, vol. 76, n. 09, p.1059, setembro de 2012.

${ }^{1402}$ SOUTO MAIOR, Jorge Luiz. Os princípios do direito do trabalho e sua negação por alguns posicionamentos jurisprudenciais. In: MELO FILHO, Hugo Cavalcanti et. al. O mundo do trabalho, volume I: leituras críticas da jurisprudência do TST: em defesa do direito do trabalho - São Paulo: LTr, 2009, p. 248.
} 
social"; 1403 Amauri Mascaro Nascimento enunciava que "O direito do trabalho tende à realização de um valor: a justiça social"1404 e Mario de la Cueva explicava que "El derecho del trabajo (...) es un derecho para el hombre ... sus preceptos e institucionaes tienen como finalidad inmediata, no solamente proteger la energia humana de trabajo, sino, más bien, asegurar a cada hombre una posición social adecuada”. ${ }^{1405}$

O princípio de melhoria da condição social do trabalhador aponta para uma finalidade. Há essencialidade do elemento finalístico, qual seja a transformação, para melhor, da situação do trabalhador.

Melhoria dá a ideia de mudança, transformação. Dessa forma, constata-se que o princípio da melhoria da condição social do trabalhador aponta para alterações imediatas, tais como correções das desigualdades contratuais por meio do princípio da proteção, mas volta o seu olhar para o futuro (perspectiva mediata), almejando alterações do próprio regime (as normas de proteção já existentes serão sempre o ponto mínimo de partida para consecutivas alterações benéficas ao trabalhador), residindo aí seu caráter permanentemente provisório, dinâmico e revolucionário.

Por ser a essência do direito do trabalho, o princípio da melhoria da condição do trabalhador possui um caráter de atração-repulsão: a esquerda o defende como garantia, mas o critica atribuindo-lhe um aspecto reformista e não revolucionário (mantém a lógica capitalista de divisão de classes sociais); a direita o utiliza para manter o status quo, mas o critica porque limita seus interesses econômicos, e busca enfraquecê-lo. $\mathrm{O}$ direito do trabalho incomoda os capitalistas e a mídia a eles vinculada, o que demonstra que "o paciente ainda respira", ou seja, ainda há esperanças para esse ramo jurídico, sob o aspecto emancipatório.

\footnotetext{
${ }^{1403}$ MAGANO, Octavio Bueno. Direito do trabalho e direito econômico. Revista LTr, 39/732, s/a. Apud SOUTO MAIOR, Jorge Luiz. Os princípios do direito do trabalho e sua negação por alguns posicionamentos jurisprudenciais. In: MELO FILHO, Hugo Cavalcanti et. al. O mundo do trabalho, volume I: leituras críticas da jurisprudência do TST: em defesa do direito do trabalho - São Paulo: LTr, 2009, p. 248.

${ }^{1404}$ NASCIMENTO, Amauri Mascaro. Curso de direito do trabalho. São Paulo: Saraiva, 1989, p. 36. Apud SOUTO MAIOR, Jorge Luiz, op. cit., p. 248.

${ }^{1405}$ CUEVA, Mário de la. Derecho mexicano del trabajo. Mexico: Porrúa, 1960, p.453. Apud SOUTO MAIOR, Jorge Luiz, op. cit., p. 248.
} 
O princípio possui um caráter dinâmico, eis que melhoria dá a ideia de mudança, movimento e transformação. A linha de chegada pode ser sempre ampliada "ad infinitum": não há um patamar máximo de melhoria a ser atingido, apenas um estatuto que é o mínimo, podendo-se ampliá-lo, a fim de buscar a completa reestruturação da sociedade (dimensão revolucionária). As aspirações centram-se no tempo presente, mas projetam-se também para o futuro.

Além disso, o princípio da melhoria da condição social do trabalhador encontra-se em consonância com a retórica constitucional, de positivação do princípio e dos direitos sociais e da dignidade humana.

Contudo, o capitalismo por meio do desemprego e das atuais formas de organização do processo produtivo conseguiu fragmentar a classe trabalhadora. A consciência de classe está enevoada. A luta de um grupo de indivíduos contra outra classe que os explora os forma em classe. Mas, atualmente, o capital conseguiu fazer com que grande parte da luta se faça entre trabalho versus trabalho.

O princípio da melhoria da condição social do trabalhador tem diversos destinatários: o Estado, como ente criador de normas e agente social; os capitalistas, como a classe social que deve ceder ou ser forçada a ceder, para que o proletariado possa melhorar; os trabalhadores, a fim de que se unam e lutem por participação na criação de normas e na gestão da empresa e da nação e lutem por melhores condições de vida; aos sindicatos, para que fiscalizem as condições de trabalho e exijam o cumprimento da diretriz constitucional por empresários e pelo Estado. 


\subsection{3 - CONTEXTUALIZAÇÃO PRINCIPIOLÓGICA E EXPLICITAÇÃO DO CONTEÚDO}

Qual a relação do princípio da melhoria da condição social do trabalhador com outros princípios do direito do trabalho, tais como o da justiça social, o "pro operario", o da proteção ("in dubio pro operario", supremacia da norma e da condição mais benéficas ao trabalhador), o da imperatividade, o da indisponibilidade, da irrenunciabilidade, da vedação da alteração contratual prejudicial ao trabalhador, da irredutibilidade salarial, da realidade, da continuidade da relação empregatícia?

De início, pode-se observar que todos esses princípios estão conectados à mesma problemática da desigualdade econômica real existente entre o trabalhador e o tomador dos serviços, no processo de produção capitalista.

A imperatividade do direito do trabalho diz que as normas desse ramo jurídico se aplicam às relações de trabalho, independentemente da vontade das partes dessa relação, e que as autonomias individual e coletiva somente alcançam os aspectos permitidos pelas normas estatais. As normas dispositivas cedem lugar às obrigatórias.

Homero Batista Mateus da Silva distingue a indisponibilidade, que "torna o direito inatingível por qualquer forma ou procedimento, não se sensibilizando nem mesmo com a transação judicial ou com a prescrição da pretensão deduzida em juízo", ${ }^{1406}$ da irrenunciabilidade, que “... admite que em Juízo as partes deduzam cláusula de acordo ou que o empregador invoque a perda de prazo para a pretensão do empregado..." ${ }^{1407}$ Além disso, defende que "o princípio da irrenunciabilidade costuma se esgotar no curso da relação de emprego", ${ }^{1408}$ esclarecendo que a renúncia em Juízo deve ser entendida como a “concessão recíproca na forma de acordo e, ainda, o deixar escoar o prazo rumo à perda da exigibilidade ou perda da coerção do direito, que estão no cerne do tema da prescrição da pretensão". ${ }^{1409}$

\footnotetext{
${ }^{1406}$ SILVA, Homero Batista Mateus da. Curso de direito do trabalho aplicado. Vol.1: parte geral. 2.ed. Rio de Janeiro: Elsevier, 2013, p. 259.

${ }^{1407}$ Ibid., p. 260.

${ }^{1408}$ Ibid., p. 260.

${ }^{1409}$ Ibid., p. 260.
} 
Para Maurício Godinho Delgado, o princípio da indisponibilidade "traduz a inviabilidade técnico-jurídica de poder o empregado despojar-se, por sua simples manifestação de vontade, das vantagens e proteções que lhe asseguram a ordem jurídica e o contrato". ${ }^{1410}$ Esclarece que "para a ordem justrabalhista, não serão válidas quer a renúncia, quer a transação que importe objetivamente em prejuízo ao trabalhador". ${ }^{4411}$

Consideramos que pela dimensão do princípio da indisponibilidade aplicável ao direito do trabalho, os direitos trabalhistas são irrenunciáveis e as transações devem ser admitidas apenas em hipóteses que possam efetivamente melhorar a condição social da classe trabalhadora.

Homero Batista Mateus da Silva esclarece que, pelo princípio da primazia da realidade, "a forma - documentos, anotações, murais, nomenclaturas - nunca poderá se sobrepor ao conteúdo - cotidiano, expectativas, costumes, condições mais favoráveis etc."1412 Nas palavras de Maurício Godinho Delgado: “A prática habitual - na qualidade de uso - altera o contrato pactuado, gerando direitos e obrigações novos às partes contratantes (respeitada a fronteira da inalterabilidade contratual lesiva)". ${ }^{1413}$

O princípio da vedação da alteração contratual lesiva ao trabalhador diz que as mudanças nas cláusulas contratuais e nas condições de trabalho nunca poderão prejudicar o trabalhador. A irredutibilidade salarial insere-se na linha do princípio da vedação da alteração contratual lesiva, no que se refere ao salário.

Do princípio da continuidade extrai-se que o contrato de trabalho é celebrado "preferencialmente para durar"1414 Vale dizer, interessa ao direito do trabalho "a permanência do vínculo empregatício, com a integração do trabalhador na estrutura e dinâmica empresariais", ${ }^{1415}$ na medida em que se o trabalhador "está submetido a contrato

\footnotetext{
${ }^{1410}$ DELGADO, Maurício Godinho. Curso de direito do trabalho. 4. ed. São Paulo: LTr, 2005, p. 201 ${ }^{1411}$ Ibid., p. 202.

${ }^{1412}$ SILVA, Homero Batista Mateus da. Curso de direito do trabalho aplicado. Vol.1: parte geral. 2.ed. Rio de Janeiro: Elsevier, 2013, p. 260.

${ }^{1413}$ DELGADO, Maurício Godinho, op. cit., p. 208.

${ }^{1414}$ SILVA, Homero Batista Mateus da, op. cit., p. 266.

1415 DELGADO, Maurício Godinho, op. cit., p. 209.
} 
precário, provisório, de curta duração (ou se está desempregado), fica sem o lastro econômico e jurídico necessário para se impor no plano de suas demais relações econômicas na comunidade". ${ }^{1416}$

O princípio da melhoria da condição social do trabalhador, embora muito próximo e interrelacionado, distingue-se, sob certos aspectos, dos demais. Todos estão conectados entre si, em uma relação de maior ou menor especificidade e de compartilhamento de conteúdos e sentido. Os demais princípios são desdobramentos do princípio da melhoria da condição social do trabalhador e dele decorrem. Quando se fala, por exemplo, em princípio da proteção está-se falando do princípio da melhoria da condição social do trabalhador porque aquele está contido neste. É para melhorar a condição social do trabalhador que o direito o protege e se estruturou como norma indisponível, irrenunciável, não passível de alteração contratual prejudicial ao trabalhador, que prioriza a realidade e a continuidade do contrato.

Mas a abrangência do princípio da melhoria da condição social do trabalhador é maior, no sentido de que se revela uma diretriz de direito social apta a iluminar e juridicizar todos os segmentos do direito, dada a centralidade do trabalho na sociedade capitalista e tendo em vista a divisão das classes sociais subjacente à quase totalidade das experiências sociais. O princípio em estudo trata-se de mecanismo de justiça social e encontra-se no ápice da construção do direito social, com ampla irradiação de efeitos.

Partindo do entendimento de que o sistema capitalista de produção, baseado no individualismo e na competição, tende a concentrar renda e a produzir desigualdade social, e que tal dinâmica conduz à desumanização e à destruição da sociedade humana e da natureza, o princípio da melhoria da condição social do trabalhador se apresenta como um elemento dinâmico de redirecionamento do sistema, pois conduz à distribuição dos recursos econômicos e culturais produzidos pela humanidade e à concretização da solidariedade. Somente a classe social que se encontra em posição mais desvantajosa ou

${ }^{1416}$ DELGADO, Maurício Godinho. Curso de direito do trabalho. 4. ed. São Paulo: LTr, 2005, p. 210. 
que esteja experimentando a opressão gerada pela divisão de classes sociais pode ter interesse no fim do sistema de classes.

O modelo de sociedade instalado a partir da hegemonia do sistema capitalista de produção foi expressando as contradições do sistema e exigindo transformações. A racionalidade do direito liberal com o caráter individualista e de exclusão dos menos favorecidos revelou-se prejudicial para o próprio sistema. A alteração da perspectiva, para uma dimensão de solidariedade social, apontou para a construção de uma nova forma de organizar a convivência humana. É nesse contexto que se descortina o princípio da melhoria da condição social do trabalhador, como diretriz desse processo de transformação.

Conforme observa Jorge Luiz Souto Maior, pelo princípio da melhoria da condição social do trabalhador, as normas trabalhistas possuem um caráter mínimo e devem ser progressivamente aprimoradas, no sentido da ampliação da satisfação dos interesses da classe social inferiorizada economicamente na relação entre o capital e o trabalho. ${ }^{1417}$ Além disso, acrescentamos que não apenas as normas trabalhistas, também as demais, como as previdenciárias, civis, penais, administrativas, processuais, políticas stricto sensu etc., que, na essência, também se prestam a regular a convivência social no modelo de produção vigente, devem incorporar essa diretriz principiológica.

A racionalidade de buscar o que é coletivamente relevante, quebrando a diretriz individualista, conduz à perspectiva de priorização dos interesses da classe inferiorizada socialmente, na medida em que a desigualdade fragiliza o organismo social. O princípio da melhoria da condição social do trabalhador se propõe a instrumentalizar as alterações estruturais da sociedade, em uma perspectiva coletiva.

Por essa razão, o interesse de justiça social, que naturalmente implica distribuição de renda e, portanto, atuação normativa em favor dos trabalhadores, coincide com o interesse público, no sentido em que estabelecido no artigo $8^{\circ}$ da CLT, quando determina que "As autoridades administrativas e a Justiça do Trabalho, na falta de

${ }^{1417}$ SOUTO MAIOR, Jorge Luiz. Curso de direito do trabalho: teoria geral do direito do trabalho, volume I: Parte I. São Paulo: LTr, 2011, p. 632. 
disposições legais ou contratuais, decidirão (...), mas sempre de maneira que nenhum interesse de classe ou particular prevaleça sobre o interesse público”. Feriria o interesse público uma decisão que tivesse por embasamento uma dimensão individualista; que reforçasse a valorização dos lucros do capitalista em prejuízo do trabalhador; que se destinasse à manutenção da atividade econômica empresarial como um fim em si mesmo, apesar de violadora de direitos sociais; que enfraquecesse a classe trabalhadora ou conspurcasse os princípios de proteção ao humano na relação de produção.

Um interesse público abstrato que não estivesse vinculado à concretização da justiça social seria mero instrumento ideológico da burguesia, como fórmula retórica vazia de sentido e sempre utilizável para justificar a chancela estatal às mais inconfessáveis situações de exploração do ser humano. Por exemplo, em uma situação de continuidade prolongada de greve, o término, sob argumento de que o interesse público está sendo lesado, depende das condições em que ocorrer: se não houver o atendimento das reivindicações dos trabalhadores, o interesse público terá sido equiparado aos interesses classistas empresariais.

O direito se realiza no ato de escolhas do conteúdo normativo a ser expresso, da interpretação do conteúdo e da determinação das suas implicações na vida. $\mathrm{O}$ jurídico decorre de processos de priorizações e seleções. Conforme esclarece Márcio Túlio Viana, "Se, nas ciências exatas, fazemos sobretudo descobertas, no Direito fazemos principalmente escolhas". ${ }^{1418}$ Amauri Mascaro Nascimento, por sua vez, ensina que "A concretização da norma é (...) um ato de escolha e que exige uma tarefa de cognição de uma determinada situação e da tipicidade descrita na norma"1419 (grifo nosso). O princípio da melhoria da condição social do trabalhador orienta esse processo de escolhas jurídicas.

Não se trata da melhoria da situação específica deste ou daquele trabalhador, mas da dimensão de melhoria da classe trabalhadora (trabalhador coletivo), que naturalmente reflete na melhoria individual. Muitas vezes uma situação jurídica pode ser momentânea e particularmente benéfica para um determinado trabalhador, mas

1418 VIANA, Márcio Túlio. A terceirização revisitada - algumas críticas e sugestões para um novo tratamento da matéria. Revista LTr, São Paulo, vol.77, n. 02, p. 144, fevereiro de 2013.

${ }^{1419}$ NASCIMENTO, Amauri Mascaro. Interpretação, integração e aplicação do direito do trabalho. São Paulo: Revista LTr, São Paulo, vol.73, n. 08, p. 903, agosto de 2009. 
prejudicial para a dinâmica de fortalecimento da classe social trabalhadora, como no caso, por exemplo, de determinados acordos judiciais, que se prestam a enfraquecer a força normativa do direito do trabalho, por contrariarem a imperatividade e a irrenunciabilidade de suas normas.

A concepção do estado de bem-estar social conta com essa diretriz de direito social e de melhoria da condição social do trabalhador. Também é possível observar que as tentativas de destruição do estado de bem-estar social, realizadas pelo neoliberalismo, atuaram na direção oposta ao princípio ora estudado.

De fato, o neoliberalismo preconizou abertamente a retirada de direitos sociais, apelidados de "custo Brasil", como forma de revitalizar a reprodução do capital por meio da ampliação e intensificação da extração da mais-valia (lucros). Representou a defesa sem pudor da tese de que o Estado deveria viabilizar a ampliação da exploração da força de trabalho pelo capital, mediante desemprego, rebaixamento salarial e desproteção dos mais variados aspectos do mundo do trabalho, mesmo que tudo isso representasse concentração de renda, ampliação das desigualdades sociais, miséria e violência. No Brasil, a retórica neoliberal teve o cinismo de buscar tornar-se hegemônica mesmo sob a consagração e a positivação constitucional do princípio da melhoria da condição social do trabalhador como direito fundamental e o paradigma da dignidade humana como fundamento da República.

Durante os governos Collor, Itamar e, principalmente, FHC, na década de 1990, o Estado se contaminou pela ideologia neoliberal e procurou combater diversos aspectos essenciais do Estado Social, atendendo notadamente aos interesses do capital internacional. Praticou-se uma política econômica recessiva, com redução dos gastos sociais e favorecimento da financeirização da economia, o que gerava muito desemprego. A ampliação dos lucros empresariais foi buscada em mecanismos como a ampliação das dispensas, reduções de salários, flexibilização de direitos trabalhistas (leia-se destruição de direitos), desregulamentação da esfera do trabalho, aumento da produtividade e da competitividade, por meio de novas formas de gestão da força de trabalho, que 
representavam intensificação da precarização das relações trabalhistas, como, por exemplo, mediante o incentivo à terceirização e aos contratos por prazo determinado.

Todo esse quadro de transformação da ordem jurídica e econômica em prejuízo do trabalhador era manifestamente inconstitucional, ferindo gravemente o princípio da melhoria da condição social do trabalhador. O distanciamento da diretriz axiológica da Constituição era gritante. O capital buscava a construção de um discurso legitimador de tamanhas ilicitudes, mediante a subversão do sentido da proteção do trabalhador, apresentando-a como a causa do desemprego e do atraso para o ingresso do país em uma propalada "modernidade". A par de elevadíssimo grau de cinismo e de ousadia para o descumprimento da Constituição, a técnica jurídica utilizada foi a apropriação do sentido de diversos institutos, como, por exemplo, a negociação coletiva (que passou a ser utilizada como instrumento de redução de direitos), a natureza jurídica das parcelas pagas em contraprestação ao trabalho (com desvirtuamento da natureza salarial) e a compensação de jornada, transformada em mecanismo de desvirtuamento dos limites do tempo de trabalho, entre outros.

Essas medidas representavam uma ofensiva do capital para intensificar a exploração da força de trabalho. Em razão do enfraquecimento do sistema protetivo, ampliavam-se as desigualdades materiais existentes entre o capital e o trabalho e que justificaram a construção de balizas normativas para a proteção do trabalhador. Era um retrocesso histórico. Uma vitória da força bruta do poder econômico sobre a racionalidade jurídico-política defensiva do elemento humano da relação de trabalho.

Conforme observou Giuseppina Rosária De Grazia, as “vigorosas lutas do fim dos anos 70 e início da década de 80, embora importantes, não conseguiram gerar um novo bloco hegemônico que conseguisse se contrapor ao bloco dominante". ${ }^{1420} \mathrm{Com}$ isso, no auge do neoliberalismo no Brasil, o arcabouço decorrente do princípio da melhoria da condição social do trabalhador foi transformado em alvo do ataque desse bloco dominante e os problemas sociais aumentaram, com forte crescimento do desemprego, de relações de

\footnotetext{
${ }^{1420}$ GRAZIA, Giuseppina Rosaria De Grazia. A redução e redistribuição do tempo de trabalho em questão.
} Tese de doutorado. Departamento de Sociologia da FFLCH-USP, São Paulo, 2003, p.12. 
trabalho informais, de concentração de renda e de diminuição da participação da renda do trabalho na renda nacional.

A partir dos governos Lula e Dilma, houve uma mitigação do discurso neoliberal. Buscou-se o fomento ao pleno emprego e a ampliação dos direitos sociais, mediante programas de transferência de renda e valorização do salário mínimo. Mas diversos aspectos prejudiciais aos trabalhadores e intensificados na década anterior foram mantidos, como o reconhecimento de validade jurídica à disseminação da terceirização, ao desvirtuamento da natureza de parcelas contraprestativas e ao abuso na extrapolação dos limites de jornada de trabalho, entre outros.

O princípio da melhoria da condição social do trabalhador, portanto, encontra-se no núcleo do direito social e não apenas dos direitos sociais que dão suporte àquele, enquanto racionalidade jurídica. $\mathrm{O}$ direito social trata-se da expressão normativa do Estado Social que, embora tenha suplantado o Estado Liberal, processa-se em constante tensão com as forças destrutivas decorrentes dos instintos do sistema capitalista, que nas últimas décadas se tipificaram como forças neoliberais, buscando inspiração na retórica do liberalismo econômico, mas apresentando pretensões ainda mais reprováveis, do ponto de vista social.

\subsection{4 - DISTINÇÕES}

De acordo com o magistério de Américo Plá Rodriguez, ${ }^{1421}$ o princípio da proteção se desdobra em três outros princípios: do "in dubio pro operario", da norma mais favorável ao trabalhador e da condição mais benéfica. Essas três diretrizes mais concretas estão no núcleo do princípio da proteção.

Pelo princípio do "in dubio pro operario", Plá Rodrigues menciona que "no caso de que uma norma seja suscetível de entender-se de vários modos, deve-se preferir a

${ }^{1421}$ PLÁ RODRIGUEZ, Américo. Principios de direito do trabalho. Tradução de Wagner Giglio. São Paulo: LTr, 1993, p. 42-43. 
interpretação mais favorável ao trabalhador". ${ }^{1422} \mathrm{O}$ autor distingue entre princípio "pro operario" e "in dubio pro operario", explicando que a dúvida decorre "da possível confusão engendrada por aqueles que denominam o princípio de proteção de princípio pro operario". ${ }^{1423}$ Defende que o pressuposto para a aplicação do princípio do "in dubio pro operario" é a possibilidade de interpretação de uma norma "de diversas maneiras, isto é, quando há uma verdadeira dúvida". ${ }^{1424}$

Contudo, observamos que se analisada a realidade (e, portanto, também o direito) com sutileza, podemos perceber que a dúvida lhe é inerente, ou pelo menos certo grau dela, dada a condição de percepção predominante através de nossos órgãos sensoriais e intelectuais e considerando a dinâmica de incessante transformação a que tudo está permanentemente submetido. Existem realmente os fatos ou são apenas interpretações? Parece-nos, portanto, que a aplicação do princípio, sob qualquer de seus ângulos, revela-se permanentemente necessária. O direito frente à vida real é sempre lacunoso, pois expressa uma fórmula de sentido limitada perante a complexidade da existência humana. Dessa forma, há uma ligação entre o critério "pro operario" (mais genérico e mais próximo do princípio da melhoria da condição social do trabalhador) e o "in dubio pro operario". Ambos distinguem-se, mas convergem para o mesmo vértice, consistente no princípio tema deste estudo.

Pelo princípio da melhoria da condição social do trabalhador, inspirador do princípio da proteção, o critério do "in dubio pro operario" faz-se presente não apenas quando há mais de uma possibilidade de aplicação da norma, mas sempre como fase inicial de interpretação de qualquer norma jurídica e, com muito mais razão, em situações de lacunas e naquelas em que a lei assecuratória de um direito trabalhista disse menos do que pretendia ou uma lei restritiva de um direito social disse mais do que queria dizer. É preciso expandir o critério protetor em favor do trabalhador.

${ }^{1422}$ PLÁ RODRIGUEZ, Américo. Principios de direito do trabalho. Tradução de Wagner Giglio. São Paulo: LTr, 1993, p. 43

${ }^{1423}$ Ibid., p. 45.

${ }^{1424}$ Ibid., p. 45. 
Humberto Ávila explica que o significado de uma norma não é algo que está incorporado ao conteúdo das palavras, ${ }^{1425}$ mas algo que depende do uso e da interpretação e que a interpretação é um ato de decisão que constitui a significação e os sentidos de um texto. ${ }^{1426}$ Vale dizer, a atividade do intérprete consiste em reconstituir os significados da norma, a partir do texto normativo e dos "significados mínimos incorporados ao uso ordinário ou técnico da linguagem". ${ }^{1427}$

Maurício Godinho Delgado propugna pela exclusão do princípio “in dubio pro operario", sob o fundamento de que o princípio da norma mais favorável abrange as dimensões "informadora", "interpretativa/normativa" e "hierarquizante" no direito do trabalho $^{1428} \mathrm{e}$, portanto, já englobaria o "in dubio pro operario", no tocante à dimensão interpretativa, ${ }^{1429}$ e que, no aspecto processual, "a teoria do ônus da prova (...) e o largo espectro de presunções (...) já franqueam (...) possibilidades mais eficazes de reprodução, no processo, da verdade real". ${ }^{1430}$

Mesmo em matéria probatória, a presunção de igualdade formal das partes padece do mesmo defeito inerente ao contrato de trabalho, desequilibra a relação em favor do empregador, que detém maior capacidade probatória, eis que detentor de informações, documentos, laudos periciais particulares e, na maioria das vezes, maior disponibilidade de testemunhas. Pelo critério do "in dúbio, pro operário", deve-se analisar em cada ponto quem detém a maior capacidade probatória e atribuir-lhe o ônus, com vistas à proteção do trabalhador e à melhoria de sua condição social. As regras de direito processual do trabalho, instrumentais que são, também estão submetidas ao princípio da melhoria da condição social do trabalhador.

O direito não é compartimentado de forma estanque. Há comunicação entre os diversos momentos da experiência jurídica. Pouco adianta proteger o trabalhador com leis materiais se não se estender a proteção à dimensão processual, da qual depende em

\footnotetext{
${ }^{1425}$ ÁVILA, Humberto. Teoria dos princípios - da definição à aplicação dos princípios jurídicos. 11. ed. São Paulo: Malheiros, 2010, p. 31.

${ }^{1426}$ Ibid., p. 31-32.

${ }^{1427}$ Ibid., p. 32-33.

${ }^{1428}$ DELGADO, Maurício Godinho. Curso de direito do trabalho. 4. ed. São Paulo: LTr, 2005, p. 199.

${ }^{1429}$ Ibid., p. 213.

${ }^{1430}$ Ibid., p. 214.
} 
grande parte a validade daqueles direitos. Trata-se de desdobramento dos princípios da melhoria da condição social e da proteção do trabalhador.

Não se está defendendo a atribuição de direitos a um trabalhador que não os tenha. Nem a quebra da imparcialidade do órgão jurisdicional. O que se está preconizando é a busca da racionalidade do direito do trabalho e uma forma de olhar a norma jurídica, o litígio, os fatos, as provas e as regras distributivas dos ônus probatórios, à luz das peculiaridades do trabalho e do capital, enquanto fenômenos subjacentes às partes trabalhistas, cujas desigualdades econômicas e contratuais levam a diferenciações que podem determinar a decisão. Botelho de Mesquita, em relação ao compromisso do juiz com a lei e com a justiça, nas palavras de Bedaque, esclarece que "Deve ele ser independente e neutro com relação a interesses outros, pois, no que se refere àqueles amparados pela lei não há independência ou neutralidade possível". ${ }^{1431}$

Humberto Ávila ${ }^{1432}$ explica que até mesmo a compreensão de fatos e provas recebe a influência das normas jurídicas, uma vez que por ocasião da aplicação da norma existe um exame de pertinência, consistente na análise de quais fatos entre todos são pertinentes, e um exame de valoração, mediante a decisão de quais os pontos de vista, entre todos os possíveis, são adequados para interpretar os fatos, com vistas à proteção dos bens protegidos pelos princípios jurídicos. Esclarece que "as normas jurídicas são decisivas para a interpretação dos próprios fatos: não se interpreta a norma e depois o fato, mas o fato de acordo com a norma e a norma de acordo com o fato, simultaneamente". ${ }^{1433}$ Nesse processo, os princípios fornecem parâmetros para os exames de pertinência e de valoração, na medida em que indicam um estado ideal a ser buscado. ${ }^{1434}$

Ávila esclarece que o intérprete trabalha com fatos construídos pela mediação do discurso do próprio intérprete. ${ }^{1435}$ "A existência mesma do fato não depende

${ }^{1431}$ MESQUITA, José Ignácio Botelho de. Da ação civil. São Paulo: RT, 1975, p. 64. Apud BEDAQUE, José Roberto dos Santos. Poderes instrutórios do juiz. 2. ed. revista e ampliada. São Paulo: Ed. Revista dos Tribunais, 1994, p. 84.

1432 ÁVILA, Humberto. Teoria dos princípios - da definição à aplicação dos princípios jurídicos. 11. ed. São Paulo: Malheiros, 2010, p. 99.

${ }^{1433}$ Ibid., p. 99.

${ }^{1434}$ Ibid., p. 99.

${ }^{1435}$ Ibid., p. 100. 
da experiência, mas da argumentação". ${ }^{1436} \mathrm{O}$ intérprete seleciona os eventos situados no centro dos interesses protegidos pelas normas jurídicas e obtém o evento pertinente, qual seja aquele necessário à identificação de um bem jurídico protegido por um princípio. ${ }^{1437}$ São “os princípios que determinam quais são os fatos pertinentes, mediante uma releitura axiológica do material fático". ${ }^{1438} \mathrm{O}$ direito, por meio dos princípios, oferece critérios para a construção dos fatos. ${ }^{1439}$

Mozart Victor Russomano defende que "sempre, o juiz deve avaliar a prova em função da relevância do fato e da condição social da parte" ${ }^{1440}$ (grifos do autor). Esclarece que o direito processual do trabalho transplantou o princípio do direito processual penal de que "na dúvida, decide-se em favor da parte socialmente desvalida" 1441 e conclui: "a dúvida, quer resulte da análise da prova produzida, quer decorra da interpretação de norma jurídica, autoriza o Juiz a decidir o pleito em favor da parte socialmente menos favorecida, ou seja, do trabalhador". ${ }^{1442}$

Prossegue Mozart Victor Russomano esclarecendo que na "questão de fato, a prova indica qual a lei aplicável ao caso concreto e quando, em face da prova, puderem ser aplicadas duas ou mais normas ao mesmo fato, dever-se-á usar a norma que seja mais favorável ao trabalhador". ${ }^{1443}$ Além disso, lembra o autor, o princípio da norma mais favorável ao trabalhador aplica-se também na "solução dos conflitos espaciais de leis nacionais e estrangeiras". ${ }^{144}$

Explica que a chamada teoria da inversão do ônus da prova se situa dentro da tese da avaliação da prova segundo a relevância do fato e a condição social das partes. ${ }^{1445} \mathrm{O}$ princípio de que a parte que alega sempre deve provar encontra oposição em

\footnotetext{
${ }^{1436}$ ÁVILA, Humberto. Teoria dos princípios - da definição à aplicação dos princípios jurídicos. 11. ed. São Paulo: Malheiros, 2010, p. 100.

${ }^{1437}$ Ibid., p. 100.

${ }^{1438}$ Ibid., p. 100.

${ }^{1439}$ Ibid., p. 100.

${ }^{1440}$ RUSSOMANO, Mozart Victor. Novos temas de direito do trabalho. Rio de Janeiro: Forense, 1985, p.136.

${ }^{1441}$ Ibid., p. 136.

${ }^{1442}$ Ibid., p. 136.

${ }_{1443}$ Ibid., p. 137.

${ }^{1444}$ Ibid., p. 137.

${ }^{1445}$ Ibid., p. 137.
} 
situações como a "dificuldade do trabalhador em produzir provas até a originalidade da situação processual, quando a parte alega o óbvio, o ordinário, o habitual, sem poder demonstrá-lo". ${ }^{1446}$

Uma situação mais geral a ser levada em consideração, no que se refere à garantia de direitos por meio de ações judiciais, diz respeito ao ônus de suportar os riscos da falta de patrimônio do devedor, como, por exemplo, na hipótese de existência de subcontratações. Na hipótese de terceirização, exigir que o trabalhador esgote as possibilidades de execução da empresa terceirizada, antes de executar a tomadora dos serviços, é impor-lhe sacrifícios injustos no que se refere à demora para a satisfação de seu crédito e também representa uma inversão valorativa em favor da tomadora dos serviços, que permanecerá na cômoda posição de expectadora, enquanto o trabalhador aguarda o seu crédito alimentar e se desgasta para as tentativas de execução. No caso de "contrato de empreitada entre o dono da obra e o empreiteiro" (OJ n. 191 da SDI-1 do TST), a situação ainda é mais grave, porque retirar a responsabilidade do tomador dos serviços é atribuir os riscos e ônus todos ao trabalhador, quando o reconhecimento de tal responsabilidade poderia deixar com o contratante o ônus de litigar posteriormente em face do empreiteiro inadimplente.

Plá Rodriguez esclarece que a aplicação do critério do "in dubio pro operario" poderá estender um benefício ou diminuir um prejuízo ${ }^{1447}$. O autor traz a observação de Alonso Garcia, de que em caso de "dúvida sobre qual a interpretação mais favorável ao trabalhador, a equidade aconselha adotar-se a opção do próprio trabalhador". ${ }^{1448}$

Pelo princípio da aplicação da norma mais favorável ao trabalhador, há uma nova estruturação da questão da hierarquia das normas, atribuindo-se supremacia àquela que melhor proteger o trabalhador e melhorar a sua condição social.

\footnotetext{
${ }^{1446}$ RUSSOMANO, Mozart Victor. Novos temas de direito do trabalho. Rio de Janeiro: Forense, 1985, p. 137.

${ }^{1447}$ PLÁ RODRIGUEZ, Américo. Princípios de direito do trabalho. Tradução de Wagner Giglio. São Paulo: LTr, 1993, p. 51

${ }^{1448}$ GARCIA, Manual Alonso. Derecho del trabajo. Barcelona, s/ed, 1960, t. I, p. 253 . Apud PLÁ RODRIGUEZ, Américo, op. cit., p.52
} 
Para Maurício Godinho Delgado, o operador do direito deve optar pelo princípio da norma mais favorável ao trabalhador no instante de elaboração da regra ("princípio orientador da ação legislativa"), no contexto de confronto entre regras concorrentes ("princípio orientador do processo de hierarquização de normas trabalhistas") ou no contexto de interpretação das regras jurídicas ("princípio orientador do processo de revelação do sentido da regra trabalhista"). ${ }^{1449}$

No que se refere ao processo de hierarquização de normas, Godinho Delgado defende que "o encontro da regra mais favorável não se pode fazer mediante uma separação tópica e casuística de regras, acumulando-se preceitos favoráveis ao empregado". ${ }^{1450}$ Por isso, rejeita a teoria da acumulação. ${ }^{1451}$

Quanto ao processo de interpretação de normas, diz que o operador do direito não poderá realizar "uma simplista opção mais benéfica para o obreiro (escolher, por exemplo, uma alternativa inconsistente de interpretação, porém mais favorável)". ${ }^{4452}$ Acrescenta que ao se chegar em "dois ou mais resultados interpretativos consistentes, é que procederá o intérprete à escolha final orientada pelo princípio da norma mais favorável". ${ }^{1453}$

O artigo 620 da CLT estabelece que "As condições estabelecidas em Convenção, quando mais favoráveis, prevalecerão sobre as estipuladas em Acordo".

Para a escolha da norma mais favorável ao trabalhador, faz-se necessária a análise objetiva do conteúdo das normas e a perspectiva de que a racionalidade deve ser a de proteção da coletividade trabalhadora.

Outra questão é saber qual a unidade de medida para a comparação, ou seja, se cada uma das disposições ou cada norma em conjunto. Neste aspecto, existe a possibilidade de realizar-se a comparação com base em cada dispositivo de cada norma, aplicando cada um que se revelar mais vantajoso ao trabalhador (teoria da acumulação);

\footnotetext{
${ }^{1449}$ DELGADO, Maurício Godinho. Curso de direito do trabalho. 4. ed. São Paulo: LTr, 2005, p. 199.

${ }^{1450}$ Ibid., p. 200.

${ }^{1451}$ Ibid., p. 200.

${ }^{1452}$ Ibid., p. 200-201.

${ }^{1453}$ Ibid., p. 200-201.
} 
aplicar-se as cláusulas mais vantajosas (teoria da incindibilidade das cláusulas); aplicar-se os institutos mais vantajosos (teoria da incindibilidade dos institutos) e aplicar-se a norma que apreciada na totalidade se revele mais vantajosa (teoria do conjunto ou do conglobamento).

À luz do princípio da melhoria da condição social do trabalhador, entendemos que o critério mais adequado seria a análise de cada dispositivo que contenha um conteúdo normativo de sentido intelegível, aplicando-se o mais vantajoso de cada norma, ou seja, a teoria da acumulação (fracionamento do conteúdo de textos normativos e aproveitamento dos direitos mais benéficos de cada texto), uma vez que a análise da vantagem considerada no conjunto revela-se passível de distorções que podem conduzir ao prejuízo para o trabalhador. Da mesma forma, as teorias da incindibilidade das cláusulas e dos institutos podem dificultar a apreensão da norma mais benéfica ou representar desvio do núcleo central que é descobrir a norma mais favorável.

Em uma situação em que a norma coletiva estabelecesse adicional de horas extraordinárias de $75 \%$ mas considerasse ordinária a jornada praticada até a $10^{\mathrm{a}}$ ou $12^{\mathrm{a}}$ diária, a solução mais consentânea com o princípio da melhoria da condição social do trabalhador seria aplicar o adicional de $75 \%$ (estabelecido na norma coletiva) para todas as horas laboradas a partir da $8^{\mathrm{a}}$ diária ou da $44^{\mathrm{a}}$ semanal (na hipótese de existência de acordo de compensação válido), parâmetros estabelecidos constitucionalmente $-\mathrm{CF}$, art. $7^{\circ}$, inciso XIII.

No caso não se trata de aplicar o adicional normativo de $75 \%$ e também o de 50\%, mas o mais benéfico ao trabalhador. A aplicação de uma teoria da acumulação em que novos aspectos normativos podem ser agregados ao direito do trabalhador deve ser prestigiada. É preciso preservar a finalidade criadora de direitos dos instrumentos normativos. Caso contrário, uma aplicação da teoria do conglobamento significaria desprezar aspectos normativos de determinados direitos, em prejuízo do trabalhador. Seria desconsiderar normas jurídicas válidas e em tal atitude hermenêutica não haveria nada de jurídico, mas apenas a aplicação do espírito da ideologia do capital. 
$\mathrm{Na}$ hipótese exemplificativa de norma coletiva que estabelecesse um acréscimo de quinze dias no aviso prévio para trabalhadores com mais de quarenta e cinco anos, ao aviso prévio legal de trinta dias com acréscimo de três por ano de serviço (Lei n. 12.506/2011), deveriam ser acrescidos os quinze dias da norma coletiva, para os trabalhadores que preencham o critério da idade.

As normas previstas em legislação especial para determinadas profissões também devem ser apreciadas à luz do princípio da melhoria da condição social do trabalhador e não devem prevalecer se estabelecerem direitos menos benéficos. Por exemplo, o artigo 15 da Lei 5.889/73, ao estabelecer o direito ao trabalhador rural de um dia por semana para procurar outro trabalho durante o aviso prévio não prevalece perante a norma mais benéfica do artigo 488 da CLT, de redução de duas horas diárias ou de sete dias no período.

Da mesma forma que no direito do trabalho a hierarquia das normas está baseada no princípio da melhoria da condição social do trabalhador (ou em sua dimensão mais específica, neste aspecto, que é o princípio da norma mais favorável), e não na supremacia deste ou daquele diploma legislativo, a teoria da acumulação é a única adequada para a concretização do princípio nuclear do direito do trabalho. A teoria do conglobamento (apreensão global de cada conjunto normativo) possibilita a aplicação de dispositivos prejudiciais ao trabalhador e dificulta a análise de um benefício como um todo. Trata-se de expediente técnico favorável ao capital e destinado a viabilizar os seus interesses e a fraude à finalidade do direito do trabalho.

Neste particular, cabe ressaltar que a manutenção do emprego não é um bem que justifique a transação de direitos em prejuízo do trabalhador, sob pena de regredir-se para o período anterior ao desenvolvimento do direito do trabalho, em que a desigualdade econômica era fator de completa supressão da liberdade e fonte de opressão. A análise comparativa da norma mais favorável deve ter como pressuposto que não se permuta salário ou outras condições de trabalho pelo emprego em si. Não merece acolhida, portanto, a tese de que um sistema flexível de direito do trabalho "salva o mais importante, 
que é o trabalhador e seu emprego", ${ }^{1454}$ tendo em vista que a mitigação dos direitos sociais somente gera mais desigualdade social e opressão, enfraquece o mercado consumidor interno e em nada contribui para a prosperidade dos povos, como se pode observar pela grave situação econômica atual da Europa.

No que se refere à condição mais benéfica, conforme esclarece Plá Rodrigues, o critério "pressupõe a existência de uma situação concreta, anteriormente reconhecida, e determina que ela deve ser respeitada, na medida em que seja mais favorável ao trabalhador que a nova norma aplicável". ${ }^{455}$

Condição é o estatuto jurídico ou de fato a que o trabalhador esteja submetido e que impede alterações prejudiciais. Pelo princípio da melhoria da condição social do trabalhador deve haver permanente e progressivo acréscimo de benefícios ao trabalhador, nunca o decréscimo. O conjunto de benefícios jurídicos de que usufrui o trabalhador constitui um patrimônio adquirido e que não pode ser reduzido ou suprimido.

Esse princípio expressa a vertente trabalhista da teoria jurídica geral do direito adquirido, mas com nuances protetivas mais sutis.

A Súmula n. 51, inciso I, do Tribunal Superior do Trabalho ilustra uma das aplicações do princípio da condição mais benéfica: “As cláusulas regulamentares, que revoguem ou alterem vantagens deferidas anteriormente, só atingirão os trabalhadores admitidos após a revogação ou alteração do regulamento".

Mas, acrescentamos que as novas alterações constitucionais, legais, de normas coletivas, de regulamentos de empresa, de contratos de trabalho, todas devem partir do pressuposto de ter o patamar anterior como piso a ser sempre melhorado. A supressão genérica de normas benéficas à classe trabalhadora viola o princípio da melhoria da condição social e deve ser repudiada. Com muito mais razão, na hipótese em que um trabalhador usufrua de um direito social e ocorra revogação da norma positiva, os efeitos

${ }^{1454}$ MARTINS FILHO, Ives Gandra da Silva. Os pilares do direito do trabalho - princípios e sua densidade normativa. Revista LTr, São Paulo, vol. 76, n. 07, p.781, julho de 2012.

${ }^{1455}$ PLÁ RODRIGUEZ, Américo. Princípios de direito do trabalho. Tradução de Wagner Giglio. São Paulo: LTr, 1993, p. 60. 
da norma revogada subsistem para aquele trabalhador, porque a alteração prejudicial violou princípio normativo fundamental.

As leis novas que retirem direitos anteriormente garantidos infringem o princípio da condição mais benéfica, em relação aos trabalhadores que já se beneficiavam da norma, e infringem o princípio da melhoria da condição social do trabalhador, em sua dimensão normativa mais ampla, em relação aos trabalhadores de modo geral. Trata-se de procedimento inconstitucional e ilícito.

A título de exemplo, pode-se citar a alteração realizada pela Lei n. 12.740, de 08.12.2012, que incluiu os trabalhadores expostos à eletricidade no artigo 193 da CLT, referente ao adicional de periculosidade, e acabou por conter uma normatização prejudicial, em determinado ponto, na medida em que a Lei n. 7.369, de 1985, estabelecia base de cálculo mais benéfica: enquanto o artigo 193 da CLT prevê que a base de cálculo será "o salário sem os acréscimos resultantes de gratificações, prêmios ou participações nos lucros da empresa", o artigo $1^{\circ}$ da Lei n. 7.369/85 estabelecia que o "empregado que exerce atividade no setor de energia elétrica, em condições de periculosidade, tem direito a uma remuneração adicional de trinta por centro sobre o salário que perceber".

Da mesma forma, a Lei n. 12.619/12 trouxe normas benéficas sobre o trabalho dos motoristas, mas ao prever a inclusão do tempo de espera na jornada, diz que não será considerado jornada extraordinária e estabelece o adicional de $30 \%$ (parágrafos $8^{\circ}$ e $9^{\circ}$ do artigo $235-\mathrm{C}$ da CLT, acrescido por força da referida lei). O adicional de $30 \%$ é inferior ao fixado constitucionalmente em $50 \%$ para a extrapolação de jornada.

São exemplos de algumas normas recentes que trazem a questão da violação ao princípio da melhoria da condição social do trabalhador, em alguns de seus pontos. Nesses casos, aos trabalhadores que laborem em periculosidade por exposição aos riscos da eletricidade é devido o adicional de periculosidade de $30 \%$ sobre o complexo salarial e não apenas sobre o salário básico, dada a inconstitucionalidade da alteração legal, neste particular. Aos trabalhadores motoristas que extrapolarem suas jornadas de trabalho, 
mesmo que essa extrapolação se dê no contexto classificado pela Lei 12.619/12 como de tempo de espera, o adicional devido será o de no mínimo 50\%.

Registre-se que, no tocante aos trabalhadores do ramo dos transportes, bem observou José Antônio Ribeiro de Oliveira Silva: a jornada de trabalho, principalmente do subsetor de cargas "é muito longa, havendo uma quantidade acentuada de casos de doenças laborais, inclusive por problemas posturais - aliados às excessivas jornadas, com pausas insuficientes -, o que merece uma atenção especial do governo". ${ }^{1456}$

Como desdobramento da regra da condição mais benéfica e da progressiva melhoria da condição social do trabalhador, a fixação de prazo de vigência de normas coletivas e a diminuição de direitos por norma coletiva posterior ferem o princípio. Além disso, em caso de norma coletiva com prazo de vigência, o decurso do prazo sem a celebração de nova negociação conduz à conclusão de que os benefícios da norma anterior devem permanecer válidos aos trabalhadores da categoria, até que nova negociação possa ampliá-los.

A Súmula n. 277 do Tribunal Superior do Trabalho, com sua atual redação, determina que os direitos previstos em norma coletiva integram o contrato de trabalho até nova negociação. E não poderia ser diferente, a teor da norma que se extrai do artigo 114, parágrafo $2^{\circ}$, da Constituição Federal, quando estabelece que na recusa de qualquer das partes à negociação coletiva ou à arbitragem, a Justiça do Trabalho poderá decidir o conflito, observando o respeito "às disposições mínimas legais de proteção ao trabalho, bem como as convencionadas anteriormente".

Octávio Bueno Magano já distinguia cláusulas normativas de cláusulas obrigacionais, defendendo a integração das cláusulas normativas aos contratos individuais, a teor do artigo 611 da CLT. ${ }^{1457}$ Para Magano, as cláusulas normativas "correspondem ao

\footnotetext{
${ }^{1456}$ SILVA, José Antônio Ribeiro de Oliveira. A flexibilização da jornada de trabalho e seus reflexos na saúde do trabalhador. Revista LTr, São Paulo, vol.77, n. 02, p.191, fevereiro de 2013.

${ }^{1457}$ MAGANO, Octavio Bueno. Convenção Coletiva de trabalho. In: MAGANO, Octávio Bueno (coord.). Curso de direito do trabalho em homenagem a Mozart Victor Russomano. São Paulo: Saraiva, 1985, p. 503. Apud PESSOA, Roberto; PAMPLONA FILHO, Rodolfo. A nova velha questão da ultra-atividade das normas coletivas e a Súmula n. 277 do Tribunal Superior do Trabalho. Revista LTr, São Paulo, vol.77, n. 02, p.152, fev. 2013.
} 
conceito de condições de trabalho, aptas a se tornarem parte integrante de contratos individuais, conceito esse que se reflete no art.611 da CLT", ${ }^{1458}$ enquanto as cláusulas obrigacionais dos instrumentos normativos são aquelas "que geram direitos e obrigações entre as partes convenentes", tais como "deveres de paz e de influência" e "mecanismos de administração da convenção coletiva". ${ }^{1459}$

Adequada ao princípio da melhoria da condição social do trabalhador, a incorporação das cláusulas normativas aos contratos de trabalho vigentes quando de sua pactuação deve ocorrer de forma que, encerrada a vigência da norma, tais direitos permaneçam no contrato de trabalho. Norma coletiva posterior não pode reduzi-los, apenas aumentá-los, sempre em benefício do trabalhador. Neste sentido, de não admissão de modificação em norma coletiva posterior, salvo se mais benéfica ao trabalhador, temos os exemplos dos ordenamentos jurídicos da Argentina, Uruguai, Paraguai, Venezuela, México e Bélgica, ${ }^{1460}$ dentre outros países.

Amauri Mascaro Nascimento ${ }^{1461}$ admite duas hipóteses de não aplicação da norma mais favorável ao trabalhador, a de leis proibitivas do Estado, "como as salariais de indexação orientadoras de diretrizes econômicas em períodos de inflação" e as de negociações coletivas para atender a situações de crise da empresa, em que se pactuam "reduções transitórias de direitos dos trabalhadores, como a redução de salários ou a redução destes e da jornada de trabalho", com base nos incisos VI e XIII do artigo $7^{\circ}$ da Constituição Federal de 1988.

\footnotetext{
${ }_{1458}$ MAGANO, Octavio Bueno. Convenção Coletiva de trabalho. In: MAGANO, Octávio Bueno (coord.). Curso de direito do trabalho em homenagem a Mozart Victor Russomano. São Paulo: Saraiva, 1985, p. 503. Apud PESSOA, Roberto \& PAMPLONA FILHO, Rodolfo. A nova velha questão da ultra-atividade das normas coletivas e a Súmula n. 277 do Tribunal Superior do Trabalho. Revista LTr, São Paulo, vol.77, n. 02, p.152, fev. 2013.

${ }^{1459}$ MAGANO, Octavio Bueno, op. cit., p. 503. Apud PESSOA, Roberto \& PAMPLONA FILHO, Rodolfo, op. cit., p. 152 .

${ }^{1460}$ PESSOA, Roberto \& PAMPLONA FILHO, Rodolfo, op. cit., p. 153.

${ }^{1461}$ NASCIMENTO, Amari Mascaro. Curso de direito do trabalho. 11. ed. São Paulo: Saraiva, 1995, p.179180.
} 
$\mathrm{O}$ argumento de Mascaro Nascimento, para a hipótese de leis proibitivas do Estado, é de que a regra benéfica não pode ser aplicada, porque a leis proibitivas visam à melhoria da organização social e não a proteção do trabalhador. ${ }^{1462}$

Mas, questiona-se: no caso da inflação e da crise da empresa, a redução de direitos dos trabalhadores não se trataria de mero favorecimento do empresariado? É possível uma melhoria da organização social que não tenha o objetivo de proteção do trabalhador, elemento social que fornece a energia produtiva da sociedade? Por que razão seria exigível impor ao trabalhador defasagens salariais para combater a inflação, quando é evidente que existem outros meios? Por que razão reduzir direitos trabalhistas, de caráter alimentar e, portanto, imprescindíveis para a sobrevivência do trabalhador e de sua família, para sanar dificuldades financeiras da empresa, se é óbvio que existem outros meios? Essas situações indicadas deveriam contar com soluções que não sacrificassem o trabalhador, tais como maior solidariedade (mesmo que heteronomamente imposta) e contribuição da burguesia (a classe que fixa os preços e gera a inflação) e utilização do sistema de crédito bancário em caso de dificuldades empresariais.

Não se vislumbra nenhuma norma que não deva ser juridicizada pelo princípio da melhoria da condição social do trabalhador, direito humano constitucional de caráter fundamental.

Cabe-nos refletir sobre as hipóteses em que a própria Constituição fixa uma norma que é desfavorável ao trabalhador. Por exemplo, o inciso VI do artigo $7^{\circ}$ da Constituição Federal, que permite a redutibilidade salarial, por meio de convenção ou acordo coletivo de trabalho. Também os incisos XIII e XIV do artigo $7^{\circ}$, que possibilitam, respectivamente, a compensação de jornada, no módulo semanal, e a ampliação da jornada de seis horas para oito horas, nos turnos ininterruptos de revezamento.

Homero Batista Mateus da Silva explica que muitos autores propõem que a “norma coletiva pode promover as alterações maléficas na redução salarial e na expansão

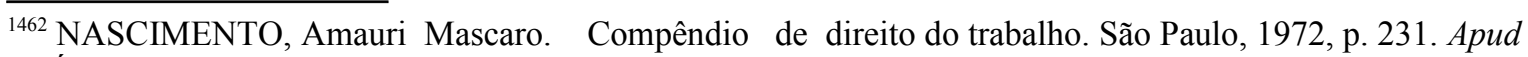
PLÁ RODRIGUEZ, Américo. Princípios de direito do trabalho. Tradução de Wagner Giglio. São Paulo: LTr, 1993, p. 56. 
gratuita de jornada, mas desde que traga outros benefícios aos empregados, como cesta básica, vale refeição, estabilidade, plano de saúde ...". ${ }^{1463}$ Mas observa que a jurisprudência atual do TST, por meio da Súmula n. 423, de 10/10/2006, considera que a ampliação da jornada nos turnos ininterruptos de revezamento, por negociação coletiva, sequer exige contrapartida. ${ }^{1464}$

Em situações como essas, há no próprio texto constitucional uma agressão ao princípio da melhoria da condição social do trabalhador. A matéria está em situação de contradição axiológica e passa a exigir reformas, a fim de corrigir o preceito, adequando-o à diretriz de justiça social. No mínimo, a interpretação de tais dispositivos deve levar em consideração os riscos de sua dissonância do princípio maior estabelecido no "caput" do artigo $7^{\circ}$ da Constituição Federal. Assim, a aplicação dessas possibilidades de prejuízo ao trabalhador deixadas pelo texto constitucional deve compatibilizar-se com o princípio maior, de melhoria da condição social do trabalhador, positivado no "caput" do mencionado artigo. Somente quando indubitavelmente viabilizem a melhoria da condição do trabalhador e apenas nos limites dessa finalidade é que a redução salarial, a compensação de jornada e a ampliação da jornada (no caso dos turnos ininterruptos de revezamento) poderão ter realizabilidade.

$\mathrm{O}$ inciso XXIX do artigo $7^{\circ}$ da Constituição Federal estabeleceu o prazo prescricional para o ajuizamento de ação quanto a créditos resultantes das relações de trabalho. O instituto é de todo prejudicial ao trabalhador. A norma deveria determinar a imprescritibilidade, reconhecendo a relevância do recebimento integral do crédito trabalhista como instrumento de justiça social. A única pacificação efetiva seria a decorrente do completo respeito aos direitos dos trabalhadores.

Considerando a inserção do referido inciso no artigo que proclama os direitos dos trabalhadores e enfatiza o objetivo da melhoria de sua condição social, a interpretação do prazo prescricional somente teria sentido como limite para sua não redução, e, ainda assim, como instituto a ser observado apenas na hipótese de acentuada

\footnotetext{
${ }^{1463}$ SILVA, Homero Batista Mateus da. Curso de direito do trabalho aplicado, vol.1: parte geral. $2^{\mathrm{a}}$ ed. Rio de Janeiro: Elsevier, 2013, p. 257.

${ }^{1464}$ Ibid., p. 257.
} 
liberdade de exercício do direito de ação, mediante a plenitude de proteção contra despedida arbitrária ou sem justa causa.

Quando da redação original do inciso XXIX do artigo $7^{\circ}$ da Constituição Federal de 1988, reconheceu-se ao trabalhador rural a fluência do prazo prescricional apenas após a extinção do contrato de trabalho. A Emenda Constitucional n. 28, de 20 de maio de 2000, unificou a prescrição para trabalhadores urbanos e rurais, permitindo também para estes últimos a fluência do prazo durante o contrato de trabalho, em manifesto prejuízo. Flagrante a inconstitucionalidade da Emenda, que representou completo retrocesso e violação do princípio constitucional da melhoria da condição social do trabalhador.

Maurício Godinho Delgado defende que "todo o complexo de regras, princípios e institutos que compõem" 1465 o direito do trabalho estão inspirados no propósito de "proteção à parte hipossuficiente na relação empregatícia - o obreiro -, visando retificar (ou atenuar), no plano jurídico, o desequilíbrio inerente ao plano fático do contrato de trabalho". ${ }^{1466}$ Por essa razão, inclui ${ }^{1467}$ no princípio da proteção, princípios como o da imperatividade e o da indisponibilidade das normas trabalhistas e o da continuidade da relação empregatícia, entre outros.

Entendemos que o princípio "pro operario" abrange todos os elementos do princípio da proteção, mas possui um caráter mais generalizante, no sentido de melhorar de forma geral as condições de vida e de trabalho do proletariado na sociedade, e não apenas na relação contratual.

O princípio da melhoria da condição social do trabalhador abrange o princípio "pro operário" e todos os demais por este abrangidos, como o da proteção. Mas traz um aspecto de questionamento da dinâmica das classes sociais, por meio do fortalecimento da classe trabalhadora. Nele há referência expressa à condição social do trabalhador.

\footnotetext{
${ }^{1465}$ DELGADO, Maurício Godinho. Curso de direito do trabalho. 4. ed. São Paulo: LTr, 2005, p. 199.

${ }^{1466}$ Ibid., p. 198.

${ }^{1467}$ Ibid., p. 198.
} 
Américo Plá Rodriguez observa que no direito constitucional positivo uruguaio o princípio da proteção foi incorporado sob a expressão básica " $\mathrm{O}$ trabalho está sob a proteção especial da lei”. ${ }^{1468}$

Os critérios de criação, interpretação e aplicação de normas jurídicas relacionadas ao trabalho consubstanciam práticas fundamentais até o presente momento reconhecidas para viabilizar a proteção do trabalhador na relação de trabalho e, em consequência, dão concreção ao princípio da melhoria da condição social do trabalhador, que integra e dá fundamento ao da proteção.

Mais abrangente que o princípio da melhoria da condição social do trabalhador poderíamos indicar os princípios da justiça social, pelo qual busca-se a construção de uma sociedade mais igualitária e justa, e da dignidade humana, que expressa a valorização da condição humana e a transformação da pessoa em fim e não meio.

Em razão do princípio da melhoria da condição social do trabalhador, compete à Justiça do Trabalho apreciar os dissídios individuais e coletivos que the são apresentados sob a perspectiva de cumprimento da finalidade do direito do trabalho. Os direitos elencados no artigo $7^{\circ}$ da Constituição Federal são direitos dos trabalhadores. $\mathrm{O}$ direito do trabalho é um estatuto de proteção e viabilização dos interesses dos trabalhadores, devendo a Justiça do Trabalho dirimir os conflitos sob essa perspectiva, valendo-se da direção axiológica da melhoria das condições sociais dos trabalhadores e das técnicas interpretativas e integrativas decorrentes do princípio.

O combate firme ao descumprimento do direito do trabalho representa um passo mínimo, significativo e necessário para a melhoria da condição social do trabalhador. Não é possível tolerar a utilização da força de trabalho sem a formalização dos contratos e sem o respeito aos direitos básicos, como salário mínimo, limitação da jornada, descansos semanais remunerados, férias, $13^{\circ}$ salário, FGTS e medidas de proteção da saúde e da integridade física e psicológica do trabalhador, entre outros.

\footnotetext{
${ }^{1468}$ PLÁ RODRIGUEZ, Américo. Principios de direito do trabalho. Tradução de Wagner D. Giglio. São
} Paulo: LTr, 1993, p. 41. 
Cabe ainda à Justiça do Trabalho garantir a plenitude das ações coletivas dos trabalhadores, notadamente da greve. A negociação coletiva decorrrerá naturalmente do embate gerado pela plenitude da greve. Cabe à Justiça do Trabalho garantir que essa negociação não resulte em fixação de normas menos benéficas aos trabalhadores. Quando tais normas forem estabelecidas, principalmente em razão da fragilidade da representação sindical da categoria de trabalhadores ou de ameaça de desemprego, a Justiça do Trabalho declarará a nulidade das cláusulas que não cumpram o princípio central trabalhista.

Além da teoria do conglobamento, instrumentalizada que é para a proteção do capital e para a desfiguração do direito do trabalho, por meio da chancela de negociações coletivas desvantajosas para os trabalhadores, outras teorias se prestam ao mesmo objetivo, notadamente as teorias da adaptação setorial e conjuntural e a da reserva do possível.

Pela teoria da adaptação setorial e conjuntural, existe a necessidade de “adaptação das normas legais à flutuação periódica das condições econômicas de um determinado setor ou em face das alterações estruturais desse segmento, de modo a preservar empregos, sem precarização das condições laborais". ${ }^{469}$ Tal teoria se presta aos interesses do capital e desconsidera a função do direito do trabalho de proteção do trabalhador, permitindo a retirada de direitos em nome de "alterações estruturais", que na verdade significam a implementação de formas de preservação do lucro e de ampliação ou manutenção dos níveis de exploração da força de trabalho. O trabalhador é o último a ser considerado quando se empunha a "teoria da adaptação setorial e conjuntural".

Tanto quanto ou mais cínica é a teoria da reserva do possível, pela qual "as prestações sociais ou econômicas impostas ao Estado ou às empresas têm limites na capacidade financeira das entidades que por elas são responsáveis". ${ }^{1470}$ Trata-se da completa subjugação do sistema de proteção social aos interesses do capital. É exigir que os trabalhadores e a parcela menos favorecida da sociedade aceitem a injustiça social

\footnotetext{
${ }^{1469}$ MARTINS FILHO, Ives Gandra da Silva. Os pilares do direito do trabalho - princípios e sua densidade normativa. Revista LTr, São Paulo, vol.76, n. 07, p.781, julho de 2012.

${ }^{1470}$ Ibid., p. 781.
} 
somente pelo fato de que os opressores alegam não terem capacidade financeira para agirem de forma diferente. Se uma empresa não tem condições de manter relações de trabalho lícitas e justas não tem nenhuma razão para existir. Diferentemente de uma pessoa natural, que é um ser dotado de atributos físicos, psíquicos e espirituais, a empresa é uma atividade organizada para a produção de riquezas e deve ter, como condição mínima de existência, o atendimento da sua função social.

\section{8 - DILEMAS ATUAIS DO DIREITO DO TRABALHO À LUZ DO PRINCÍPIO DA MELHORIA DA CONDIÇÃO SOCIAL DO TRABALHADOR}

\subsection{1 - DELIMITAÇÃO}

São vários os dilemas atuais do direito do trabalho que requerem uma análise crítica, à luz do princípio da melhoria da condição social, mas, neste trabalho, proponho-me a tratar dos seguintes: terceirização; o regime do FGTS e a rotatividade da mão de obra; e a instituição do banco de horas e o excesso de jornada de trabalho. Trata-se de aspectos ilustrativos de alterações no direito do trabalho, realizadas para oferecer ao capital maior flexibilidade na exploração da força de trabalho, com vistas à ampliação dos lucros. Do ponto de vista dos trabalhadores, tais alterações representaram maior precarizacão do mercado de trabalho e ampliação da injustiça social.

\subsection{2. - A TERCEIRIZAÇÃO}

Entre as medidas pertinentes ao modo de produção toyotista está a terceirização, que atende ao interesse do capital por uma produção flexibilizada, adequada às oscilações do mercado e às necessidades diversificadas e instáveis da demanda. Para o campo do trabalho, a terceirização representa precarização, com empregos de pior qualidade, mais instáveis e com menores salários, além de intensificar a fragmentação da classe trabalhadora e enfraquecer a luta sindical. 
Ora, se o terceirizado é um homem que a empresa aluga ou arrenda, é evidente que a terceirização sempre precariza. Ela rouba a sua dignidade. Trata-o como um animal ou um objeto. E isso sem falar na instabilidade que esse modelo semeia - o que, naturalmente, é outro fator de precarização. Desse modo, terceirização que não precariza é uma contradição em seus próprios termos ${ }^{1471}$ (grifo do autor).

A terceirização é uma das formas que o capital buscou para ampliar suas margens de lucro e adaptar-se ao período da acumulação "flexível". Marcio Pochmann esclarece que enquanto nas economias desenvolvidas o trabalho terceirizado tem como objetivo patronal a ampliação dos ganhos de produtividade, no Brasil a motivação tem sido a redução do custo do trabalho, mediante a substituição dos postos por outros com condições inferiores para os trabalhadores. ${ }^{1472}$

Por meio da terceirização, constrói-se uma rede de subcontratações, que tenta promover a desvinculação entre o capital e o trabalho, ${ }^{1473}$ na medida em que a introdução de um terceiro na relação produtiva distancia e de certa forma busca "tornar invisível” o proprietário do meio de produção, que é o verdadeiro beneficiário da força de trabalho. ${ }^{1474} \mathrm{O}$ "empregador aparente" quase sempre se trata de pessoa desprovida de capital e, portanto, sem capacidade para arcar com o pagamento integral dos direitos do empregado. ${ }^{1475}$ Conforme observa Jorge Luiz Souto Maior, a "cobrança dos créditos trabalhistas fica, sensivelmente, dificultada pela névoa que repousa sobre as relações empregatícias, no trabalho terceirizado, dificultando a identificação do real empregador". ${ }^{1476}$ Márcio Túlio Viana, por sua vez, assevera:

\footnotetext{
${ }^{1471}$ VIANA, Márcio Túlio. A terceirização revisitada - algumas críticas e sugestões para um novo tratamento da matéria. Revista LTr, São Paulo, Vol.77, n. 02, p.144, fevereiro de 2013.

${ }^{1472}$ POCHMANN, Marcio. Nova classe média? O trabalho na base da pirâmide social brasileira. São Paulo: boitempo, 2012, p. 109.

${ }^{1473}$ SOUTO MAIOR, Jorge Luiz. A supersubordinação - invertendo a lógica do jogo. Rev.Trib. Reg. Trab. $3^{a}$ Reg, Belo Horizonte, v.48 n.78, p.177, jul/dez-2008.

${ }^{1474}$ COUTINHO, Grijalbo Fernandes. Terceirização: o golpe mais duro contra o direito laboral. Revista da Associação Latino-Americana de Juizes do Trabalho, ano 6, n. 8, p. 35, abril de 2012.

${ }^{1475}$ SOUTO MAIOR, Jorge Luiz, op. cit., p. 192.

${ }^{1476}$ IDEM. O Direito do Trabalho como instrumento de justiça social. São Paulo: LTr, 2000, p. 320.
} 
De fato, em geral, quanto mais se avança para as últimas malhas da rede, mais frágeis são as empresas. Elas fazem aquele "servico sujo" que a empresa principal - mais visível - não quer ou não pode fazer. E é também desse modo que as pequenas empresas lidam com a concorrência, cada qual tentando oferecer um contrato menos oneroso (e assim, mais apetitoso) para a grande. ${ }^{1477}$

$\mathrm{Na}$ busca incessante de lucro e no espírito de concorrência próprio do sistema capitalista, as empresas subcontratadas quase sempre desconsideram os limites estabelecidos pelo direito do trabalho. Há um enfraquecimento da rede de proteção do trabalhador e maior rebaixamento das condições de vida e de trabalho.

Marcus Orione Gonçalves Correia esclarece que a terceirização causa prejuízos para o trabalhador, para a sociedade e até mesmo para a empresa que a adota:

A terceirização traz prejuízos não somente ao trabalhador mas também à sociedade e à empresa que a adota.

Para o trabalhador, os prejuízos são os mais óbvios. Promove o sucateamento do valor de seu trabalho, além de diminuir a sua proteção jurídica perante o tomador do serviço. Na verdade, gera postos de trabalho em condições menos dignas.

A terceirização implica técnica de descentralização gerencial da atividade, com o natural descolamento da atividade terceirizada da administração direta da empresa que a adota.

Isso acarreta maiores possibilidades de deterioração da qualidade do serviço prestado, o que afeta não só o seu consumidor, mas a própria imagem empresarial. ${ }^{1478}$

Não têm sido raras as notícias de jornal em que grandes empresas se valem de terceirização e as subcontratadas submetem os empregados a condições análogas à de

\footnotetext{
${ }^{1477}$ VIANA, Márcio Túlio. A terceirização revisitada - algumas críticas e sugestões para um novo tratamento da matéria. Revista LTr, São Paulo, Vol.77, n. 02, p. 143, fevereiro de 2013.

1478 CORREIA, Marcus Orione Gonçalves. O Brasil precarizado. Disponível em $<$ http:/www.epds.com.br/site/index.php?link=revista\&act=ver\&id=25>, acesso em 22.8.2013.
} 
escravo. Quando o problema vem à tona, essas tomadoras alegam que desconheciam a situação do trabalho, embora, contraditoriamente, conforme observa Vladimir Safatle, tenham sido extremamente cuidadosas com publicidade e propaganda institucional. ${ }^{1479}$

Em 1986, o Tribunal Superior do Trabalho editou a Súmula n. 256, que considerava ilegal a contratação de trabalhadores por empresa interposta e reconhecia que o vínculo empregatício se formava diretamente com o tomador dos serviços. A Súmula, contudo, considerava lícita a terceirização em trabalho temporário e em serviços de vigilância, acolhendo as Leis n. 6.019/74 e 7.102/83, e, portanto, deixando uma fenda no sistema por onde passariam outras situações de trabalho.

O pior ainda estava por vir, eis que, cedendo às pressões dos interesses econômicos e violando os princípios basilares do direito do trabalho, notadamente o da melhoria da condição social do trabalhador, o Tribunal Superior do Trabalho editou a Súmula n. 331, ${ }^{1480}$ em 21.12.1993, abrindo a possibilidade jurídica de maior intensificação da prática da terceirização, notadamente ao acrescentar a hipótese de serviços especializados ligados à atividade-meio do tomador.

A Súmula n. 331 do Tribunal Superior do Trabalho, ao reconhecer validade jurídica à figura da terceirização, acolhe no direito a mercantilização do ser humano e contraria o princípio da melhoria da condição social do trabalhador, precarizando as relações de trabalho.

\footnotetext{
${ }^{1479}$ SAFATLE, Vladimir. Escravos da modernidade. Folha de S. Paulo, terça-feira, 21 de fevereiro de 2012. A2 opinião.

${ }^{1480}$ Atualmente, a Súmula conta com a seguinte redação: CONTRATO DE PRESTAÇÃO DE SERVIÇOS LEGALIDADE - INCISO IV ALTERADO PELA RES. 96/2000, DJ 18.9.2000. I - A contratação de trabalhadores por empresa interposta é ilegal, formando-se o vínculo diretamente com o tomador dos serviços, salvo no caso de trabalho temporário (Lei n. 6.019, de 3.1.1974). II - A contratação irregular de trabalhador, mediante empresa interposta, não gera vínculo de emprego com os órgãos da administração pública direta, indireta ou fundacional (art.37, II, da CF/1988); III - Não forma vínculo de emprego com o tomador a contratação de serviços de vigilância (Lei n. 7.102, de 20.6.1983) e de conservação e limpeza, bem como a de serviços especializados ligados à atividade-meio do tomador, desde que inexistente a pessoalidade e a subordinação direta. IV - $\mathrm{O}$ inadimplemento das obrigações trabalhistas, por parte do empregador, implica a responsabilidade subsidiária do tomador dos serviços, quanto àquelas obrigações, inclusive quanto aos órgãos da administração direta, das autarquias, das fundações públicas, das empresas públicas e das sociedades de economia mista, desde que hajam participado da relação processual e constem também do título executivo judicial (art.71 - da Lei n. 8.666, de 21.6.1993). Histórico: Revisão do Enunciado n. 256 - Res. 4/1986, DJ 30.9.1986. Redação Original - Res. 23/1993, DJ 21.12.1993. COSTA, Armando Casimiro et. al. (coord.). Consolidação das Leis do Trabalho. 36. ed. São Paulo: LTr, 2009, p. 723.
} 
A terceirização, portanto, contou com o afrouxamento do sistema normativo trabalhista, que adotou postura leniente na matéria, notadamente por meio da jurisprudência do Tribunal Superior do Trabalho. A expansão dessa modalidade de contratação da força de trabalho ocorreu na década de 1990, quando o ideário neoliberal passou a ser implantado no Brasil. Embora tenha surgido no bojo das alterações dos métodos produtivos, não se pode desconsiderar a relevância que teve a edição da Súmula $n$. 331 pelo TST, para a proliferação das terceirizações.

Atualmente encontra-se em andamento no Congresso Nacional o projeto de lei n. 4.330/2004, que amplia as possibilidades de terceirização, permitindo que seja realizada mesmo na atividade-fim da empresa. Tal projeto deve ser rejeitado, porque inconstitucional, na medida em que viola o princípio da melhoria da condição social do trabalhador e contribui para a precarização das relações de trabalho no Brasil.

Marcio Pochmann esclarece que "o trabalho terceirizado responde cada vez mais por uma parcela maior do total das ocupações geradas no Brasil e, por serem postos de trabalho de menor remuneração, absorvem mão de obra de salário base". ${ }^{1481}$

As novas técnicas da terceirização chegam até mesmo a retirar o trabalhador terceirizado da fábrica ${ }^{1482}$ ou empresa tomadora e isso dificulta ainda mais a participação do trabalhador em movimento associativo e a construção de uma identidade de classe. ${ }^{1483}$ Conforme lembra Giuseppina Rosaria De Grazia, ${ }^{1484}$ mesmo quando os trabalhadores laboram na mesma unidade produtiva, há segmentação da força de trabalho em duas camadas, a dos trabalhadores fixos (melhor remunerados, muitas vezes melhor qualificados e com a proteção dos direitos trabalhistas) e a dos precários (sem boas condições de trabalho e segurança jurídica e marginalizados das negociações sindicais), de modo que

${ }^{1481}$ POCHMANN, Marcio. Nova classe média? O trabalho na base da pirâmide social brasileira. São Paulo: boitempo, 2012, p. 110.

${ }^{1482}$ SOUTO MAIOR, Jorge Luiz. A supersubordinação - invertendo a lógica do jogo. Rev.Trib. Reg. Trab. $3^{a}$ Reg, Belo Horizonte, v. 48 n. 78, p. 192, jul/dez-2008.

${ }^{1483}$ COUTINHO, Grijalbo Fernandes. Terceirização: o golpe mais duro contra o direito laboral. Revista da Associação Latino-Americana de Juizes do Trabalho, ano 6, n. 8, p. 35, abril de 2012.

${ }^{1484}$ GRAZIA, Giuseppina Rosaria De. A redução e redistribuição do tempo de trabalho em questão. Tese de doutorado. Departamento de Sociologia da FFLCH-USP, São Paulo, 2003. p. 161. 
essa separação dificulta a ação coletiva dos trabalhadores de modo geral da unidade. $\mathrm{O}$ problema também foi detectado por Márcio Túlio Viana:

A terceirização externa quebra a classe operária em termos objetivos, na medida em que viabiliza a produção em pequenas unidades, na forma de rede; a interna a divide em termos subjetivos, pois mistura num mesmo lugar trabalhadores efetivos da tomadora, a uma categoria de subempregados, oscilantes e - por assim dizer- ciganos, sem pátria ${ }^{1485}$ (grifos do autor).

... a terceirização também fragmenta por fora e por dentro a classe trabalhadora: afinal, o terceirizado de hoje pode se tornar o empregado direto amanhã, e vice e versa, o que leva cada um a ambicionar ou a temer o destino do outro. Por tabela, a terceirização pressiona para baixo as condições de trabalho não só dos terceirizados, mas dos empregados da tomadora e - em sentido mais amplo - do mercado de trabalho em geral ${ }^{1486}$ (grifo do autor).

Para Jorge Luiz Souto Maior, a terceirização deve gerar vínculo empregatício entre o trabalhador e a tomadora, quando a empresa prestadora não tem uma atividade empresarial específica, atuando como mera intermediadora de mão de obra, e a contratação não se dá por prazo determinado, nem para serviços não contínuos da tomadora. ${ }^{1487}$

Márcio Túlio Viana ${ }^{1488}$ defende a aplicação das seguintes medidas, em face da terceirização: incidir o artigo $2^{\circ}$, parágrafo $2^{\circ}$, da CLT, no caso de terceirização externa (de atividades empresariais); adicionar ao critério de separação de atividades-meio das atividades-fim o da precarização das condições de trabalho e/ou salário, de modo a possibilitar a formação de vínculo empregatício com a tomadora, mesmo em caso de

\footnotetext{
${ }^{1485}$ VIANA, Márcio Túlio. A terceirização revisitada - algumas críticas e sugestões para um novo tratamento da matéria. Revista LTr, São Paulo, Vol.77, n. 02, p.143, fevereiro de 2013.

${ }^{1486}$ Ibid., p. 144.

${ }^{1487}$ SOUTO MAIOR, Jorge Luiz. O direito do trabalho como instrumento de justiça social. São Paulo: LTr, 2000, p. 320.

${ }^{1488}$ VIANA, Márcio Túlio, op. cit., p. 147-148.
} 
atividade-meio; na dúvida se é atividade-meio ou atividade-fim, aplicar a interpretação mais favorável ao trabalhador e concluir que se trata de atividade-fim; "estender a todos os terceirizados o princípio da isonomia das condições de trabalho e salário"; "Reforçar as normas existentes, garantindo explicitamente aos terceirizados o grau necessário de segurança e higiene no trabalho"; "Substituir o critério da responsabilidade subsidiária pelo da responsabilidade solidária"; "Proibir a terceirização no curso da greve, salvo na hipótese do art. $9^{\circ}$, parágrafo $1^{\circ}$, da Lei n. 7.783"; "Proibir a terceirização nos seis meses que se sucederem a despedidas coletivas"; construir uma interpretação que permita a representação dos terceirizados tanto pelo sindicato profissional correspondente ao da categoria das empresas fornecedoras de mão de obra quanto à das empresas tomadoras de serviços, ou não sendo possível, inserir os terceirizados em sindicatos dos trabalhadores da categoria da tomadora dos serviços.

Enfim, a terceirização é incompatível com um direito do trabalho voltado para a proteção do trabalhador. É prática violadora do paradigma normativo da Constituição Federal (dignidade da pessoa humana e melhoria da condição social do trabalhador) e deve receber do direito o mais intenso repúdio.

\subsection{3 - O REGIME DO FGTS E O PROBLEMA DA ALTA ROTATIVIDADE DA MÃO DE OBRA}

A facilidade com que atualmente os empregadores rompem os contratos de trabalho representa sério prejuízo aos trabalhadores e viola o princípio constitucional e trabalhista da melhoria da condição social do trabalhador, na medida em que torna insegura a obtenção dos meios de subsistência, impondo ao trabalhador e à sua família os percalços dessa instabilidade quanto aos recursos materiais para a existência. Em um modelo de sociedade em que o trabalhador, despossuído de outros bens e fontes de renda, tem apenas a sua força de trabalho para sobreviver, a vulnerabilidade é imensa, caso a decisão de encerramento imotivado do contrato seja considerada um direito potestativo do capital. 
Além disso, a precária proteção da manutenção do contrato de trabalho enfraquece o poder de reivindicação da força de trabalho, notadamente em contextos de desemprego. No Brasil, há alta rotatividade de mão de obra e os contratos de trabalho, em sua maioria, não atingem longa duração. ${ }^{1489}$ Trata-se de mais um fator que precariza as condições de trabalho no país.

Conforme esclareceu Jaime Montalvo Correa, o caráter protetivo do ordenamento jurídico trabalhista se manifesta, entre outros, no princípio da "estabilidade no emprego", que também decorre da aceitação da premissa de desigualdade das partes na relação individual do trabalho e do fato de que o trabalhador compromete a sua própria pessoa na referida relação, de modo que a conservação do posto de trabalho fortalece a posição jurídica do trabalhador. ${ }^{1490}$ Entre outros aspectos, esse princípio aponta para a necessidade de o Estado buscar o pleno emprego, a fim de garantir também o direito ao trabalho. ${ }^{1491}$

A Constituição Federal de 1946 constitucionalizou um direito que já estava previsto no capítulo VII do título IV da Consolidação das Leis do Trabalho (artigos 492 a 500): estabilidade no emprego. O referido direito teve suas origens nas primeiras leis de instituição das Caixas de Aposentadorias e Pensões (como a de n. 4.682, de 24 de fevereiro de 1923), que pretendiam manter o empregado no emprego, a fim de possibilitar o equilíbrio atuarial das entidades. Posteriormente, com a lei n. 62 de 1935, a estabilidade foi desvinculada dos benefícios previdenciários.

A CLT garantia o direito à estabilidade no emprego aos empregados que contasse com mais de dez anos de serviço, considerando como de serviço o tempo à disposição do empregador. Os bancários possuíam legislação especial sobre o assunto e adquiriam estabilidade com apenas dois anos de serviço. A estabilidade consistia no direito do empregado não exercente de cargo de confiança de não ser dispensado do serviço, salvo em decorrência de justa causa, apurada em processo judicial.

\footnotetext{
${ }^{1489}$ SILVA, Homero Batista Mateus da. Curso de direito do trabalho aplicado, vol. 2: jornadas e pausas. 2. ed. revista e ampliada. Rio de Janeiro: Elsevier, 2013, p. 72.

${ }^{1490}$ CORREA, Jaime Montalvo. Fundamentos de derecho del trabajo. Madrid: Editorial Civitas, 1975, p.241.

${ }^{1491}$ Ibid., p. 241.
} 
De modo geral, os sistemas jurídicos costumam dar duas espécies de tratamento ao instituto da estabilidade, em uma garantindo a permanência no emprego mediante reintegração e em outra somente o pagamento de uma indenização, que apenas dificulta a ruptura do contrato de trabalho. ${ }^{1492}$

A legislação brasileira garantia a permanência no emprego e apenas possibilitava a conversão pela Justiça do Trabalho em indenização quando a reintegração se revelasse desaconselhável (CLT, art.496), em razão de incompatibilidade entre empregado e empregador, decorrente do dissídio.

No Brasil, contudo, havia-se disseminado a prática de conversão da reintegração em pagamento da indenização. Conforme noticia Luiz Werneck Vianna, ${ }^{1493}$ a “incompatibilidade entre empregador e empregado, de matéria a ser provada, transformouse em presumida, fazendo com que o direito de propriedade do emprego fosse convertido numa indenização por tempo de serviço".

Alguns doutrinadores combateram essa distorção do instituto da estabilidade, como, por exemplo, Mozart Victor Russomano:

\begin{abstract}
Além de requerer que se comprove a existência de incompatibilidade pessoal e profunda que impeça ou desaconselhe a reintegração, a lei declara que aquela medida é uma faculdade do magistrado. As partes, pois, não podem substituir a conversão da reintegração pelo pagamento em dinheiro. ${ }^{1494}$
\end{abstract}

O prazo para a aquisição da estabilidade era longo, de dez anos, e até lá, conforme observou Luiz Werneck Vianna, ${ }^{1495}$ o assalariado não estável, que era a maioria,

\footnotetext{
${ }^{1492}$ SOUZA, Sérgio Alberto de. Direito, globalização e barbárie - estudos críticos de temas de direito do trabalho e de direitos humanos sob a ótica de uma leitura não-liberal. São Paulo: LTr, 1998, p. 5556.

${ }^{1493}$ VIANNA, Luiz Werneck. Liberalismo e sindicato no Brasil. 4. ed. Belo Horizonte: Editora UFMG, 1999, p. 337-338.

${ }^{1494}$ RUSSOMANO, Mozart Vitor. A estabilidade do trabalhador na empresa. Rio de Janeiro: Ed. José Konfino, 1970, s/p. Apud VIANNA, Luiz Werneck, op. cit., p. 338.

${ }^{1495}$ VIANNA, Luiz Werneck, op. cit., p. 339.
} 
ficava entregue às vicissitudes do mercado de trabalho. $\mathrm{O}$ referido autor esclarece que em 1935 o mercado de trabalho urbano estava relativamente estagnado, não existindo um exército de reserva de mão de obra, de modo que interessava ao capital "estimular o assalariado para a obtenção da estabilidade, com o que se pretendia lograr a intensificação da sua disciplina no trabalho, ao menos nos 10 primeiros anos de serviço". ${ }^{1496}$ Contudo, a partir de meados de década de 1950, já estava constituído um exército de reserva de mão de obra e passou a interessar ao capital industrial o fim de estabilidade. ${ }^{1497}$

A estabilidade no emprego acabou sendo removida, de acordo com os interesses do capital, mediante a instituição do Fundo de Garantia por Tempo de Serviço (FGTS), pela Lei n. 5.107 de 13.09.1966. Luiz Werneck Vianna observa que a mudança foi feita de forma a dissimular a sua intenção real, ${ }^{1498}$ que era promover uma política de livre dispensa do empregado, e que houve o uso do artifício da opção, para atender à exigência constitucional, na medida em que a estabilidade não podia ser retirada por legislação infraconstitucional. A opção possuía mero valor formal, eis que assinada quando da celebração do contrato de trabalho, ${ }^{1499}$ momento em que o trabalhador, na prática, não a podia recusar.

O FGTS, arrecadado previamente à dispensa, possibilitava à empresa “inteira liberdade para acelerar a rotatitividade da mão-de-obra, aproveitando-se da abundância do fator trabalho no mercado". ${ }^{1500}$ Luiz Werneck Vianna ressalta a rotatividade, a concorrência entre trabalhadores por empregos escassos e a intensificação da exploração da mão de obra como consequências dessa política que substituiu a garantia de emprego pelo FGTS:

O sucedâneo dessa política, além de intensificar a concorrência entre os trabalhadores por empregos escassos, estaria na intensificação da exploração da mão-de-obra atingida pela rotatividade. Esse processo se cumpriria pela inexistência de um

\footnotetext{
${ }_{1496}$ VIANNA, Luiz Werneck. Liberalismo e Sindicato no Brasil. 4. ed. Belo Horizonte: Editora UFMG, 1999 , p. 339-340.

${ }^{1497}$ Ibid., p. 343-344.

${ }^{1498}$ Ibid., p. 344.

${ }^{1499}$ Ibid., p. 345.

${ }^{1500}$ Ibid., p. 346.
} 
salário válido para toda uma categoria profissional. $\mathrm{O}$ aumento concedido em dissídio coletivo aproveita apenas a mão-de-obra empregada à época do atendimento da reivindicação. Esse aumento pode ser burlado pela despedida do empregado e sua subseqüente contratação por outra empresa, a salários inferiores àqueles reajustados pelo dissídio (...) A partir de 1967, quando os efeitos típicos da legislação do FGTS começam a fazer-se sentir, nota-se um extraordinário aumento do nível de dispensa às vésperas dos dissídios das categorias profissionais. ${ }^{1501}$

Com a Constituição Federal de 1988, o regime do Fundo de Garantia por Tempo de Serviço passou a constituir-se regra para todos os contratos de trabalho (CF, $\operatorname{art.} 7^{\circ}$, III), independentemente de opção, e generalizou-se na comunidade jurídica uma interpretação constitucional, no sentido de que a estabilidade no emprego havia sido extinta.

A proteção da relação de emprego constou no artigo $7^{\circ}$, inciso I, da Constituição Federal, como direito dos trabalhadores para a melhoria de sua condição social, nos seguintes termos: "relação de emprego protegida contra despedida arbitrária ou sem justa causa, nos termos de lei complementar, que preverá indenização compensatória, dentre outros direitos". Vale dizer, existe previsão constitucional de proteção contra a dispensa imotivada e a determinação para que uma lei complementar explicite essa proteção, prevendo diversas medidas, entre elas, mas não apenas, uma indenização compensatória. A referida lei complementar, contudo, passados vinte e cinco anos da promulgação do texto constitucional, ainda não foi editada, revelando-se mais uma absurda omissão do Poder Legislativo, em matéria de direitos sociais.

Maurício Godinho Delgado observa que, nesse aspecto, a Constituição trouxe "diretriz instigadora da busca de novo sistema de regulação das rupturas contratuais por ato empresarial". ${ }^{1502}$ Jorge Luiz Souto Maior explica que o inciso I do artigo $7^{\circ}$ da

\footnotetext{
${ }^{1501}$ VIANNA, Luiz Werneck. Liberalismo e sindicato no Brasil. 4. ed. Belo Horizonte: Editora UFMG, 1999, p. 347-348.

${ }^{1502}$ DELGADO, Maurício Godinho. Curso de direito do trabalho. 4. ed. São Paulo: LTr, 2005, p. 1238.
} 
Constituição Federal fixa a premissa de que "está vedada a extinção imotivada da relação de trabalho" 1503 e a "complementação a esta norma, no máximo, diz respeito ao alcance dos efeitos do descumprimento da garantia constitucional e não à sua imediata aplicabilidade". ${ }^{1504}$ Assim, esclarece, "para a produção de tais efeitos, diante da inércia do legislador infraconstitucional, o aplicador do Direito está autorizado a utilizar dos métodos integrativos para fazer valer a vontade do constituinte". ${ }^{1505}$

O artigo 10, I, do Ato das Disposições Constitucionais Transitórias elevou a multa prevista na Lei n. 5.107 de 13.09.1966, de 10\% para 40\%, em caso da dispensa mencionada no inciso I do artigo $7^{\circ}$ da Constituição Federal de 1988, até que seja promulgada a lei complementar.

Para Sérgio Alberto de Souza, a elevação da multa de 10\% para 40\% sobre os depósitos do FGTS revela-se medida insuficiente para a proteção da relação de emprego. ${ }^{1506}$ Diz que seria a "anulação do direito proclamado, reduzi-lo a um mero acréscimo percentual da indenização", ${ }^{1507}$ eis que "Estabilidade é defesa contra a dispensa". ${ }^{1508}$ Esclarece que a "medida de garantia de emprego, como a estabilidade, não se confunde com a medida de ressarcimento pelo emprego perdido, ou com medida de organização da rescisão contratual", ${ }^{1509}$ uma vez que a "estabilidade é a antítese da indenização e do aviso prévio, porque aquela afirma um direito que estes negam - o direito de não ser despedido". ${ }^{1510}$ No mesmo sentido, Jorge Luiz Souto Maior observa que "proteger o emprego é mantê-lo vigente". ${ }^{1511}$

\footnotetext{
${ }^{1503}$ SOUTO MAIOR, Jorge Luiz. Proteções jurídicas em face da cessação da relação de emprego. In: SOUTO MAIOR, Jorge Luiz \& CORREIA, Marcus Orione Gonçalves (orgs.). Curso de direito do trabalho. Vol. 2 - Direito individual do trabalho. São Paulo: LTr, 2008, p. 239.

${ }^{1504}$ SOUTO MAIOR, Jorge Luiz. Proteções jurídicas em face da cessação da relação de emprego. In: SOUTO MAIOR, Jorge Luiz \& CORREIA, Marcus Orione Gonçalves (orgs.). Curso de direito do trabalho. Vol. 2 - Direito individual do trabalho. São Paulo: LTr, 2008, p. 240.

${ }^{1505}$ Ibid., p. 240.

${ }^{1506}$ SOUZA, Sérgio Alberto de. Direito, globalização e barbárie - estudos críticos de temas de direito do trabalho e de direitos humanos sob a ótica de uma leitura não-liberal. São Paulo: LTr, 1998, p. 57.

${ }^{1507}$ Ibid., p. 57.

${ }^{1508}$ Ibid., p. 57.

${ }^{1509}$ Ibid., p. 57.

${ }^{1510}$ Ibid., p. 57.

${ }^{1511}$ SOUTO MAIOR, Jorge Luiz, op .cit., p. 243.
} 
Constata-se que as garantias que procuravam fixar o trabalhador no emprego, reconhecendo no posto de trabalho a imprescindibilidade para a subsistência do trabalhador e de sua família, foram muito abaladas com a interpretação que a comunidade jurídica fez e que por ora continua prevalecendo, da legislação da década de 1960, referente ao FGTS, e da disciplina constitucional da matéria em 1988, em razão, neste último aspecto, da universalização do FGTS e principalmente da omissão do legislador em elaborar uma lei complementar que pudesse efetivamente viabilizar a proteção ao emprego.

No âmbito da OIT, houve a aprovação da Convenção n. 158, sobre o “término da relação de trabalho por iniciativa do empregador", em 22 de junho de 1982. Essa convenção entrou em vigor, no plano internacional, em 23 de novembro de 1985 . O Congresso brasileiro aprovou a convenção pelo Decreto Legislativo n. 68/1992 e o Executivo Federal a ratificou em 5.1.1995. Contudo, o Presidente da República, Fernando Henrique Cardoso, assinou o Decreto n. 2.100, de 20.12.96, por meio do qual tornou pública a denúncia da referida Convenção. ${ }^{1512}$

Nesse contexto, as dificuldades para a implantação de um sistema efetivo de estabilidade no emprego aumentaram muito. O próprio termo estabilidade sofreu certo desgaste social, em razão do bombardeio ideológico promovido pelo empresariado. É possível verificar que a rotatividade da mão de obra não se trata de consequência imprevista ou inesperada para as relações de trabalho, mas de uma realidade desejada pelo capital, na medida em que possibilita grande margem de manobra na utilização da força de trabalho, com vistas ao aumento de lucro, por meio do rebaixamento dos salários, da concorrência entre os trabalhadores para angariar e manter os postos de trabalho e do enfraquecimento do poder de reivindicação da classe trabalhadora.

No sistema atual, a multa de $40 \%$ sobre o FGTS representa uma restrição à rotatitividade da mão de obra. Tênue restrição, que tem sido insuficiente para a proteção da relação de trabalho. Contudo, é algo que já está, de certa forma, incorporado à consciência jurídica da sociedade. Talvez atualmente a melhor maneira de proteger a relação de emprego, em face da rotatividade da mão de obra, seja a elevação da referida multa, para

$\overline{1512}$ SOUZA, Sérgio Alberto de. Direito, globalização e barbárie - estudos críticos de temas de direito do trabalho e de direitos humanos sob a ótica de uma leitura não-liberal. São Paulo: LTr, 1998, p. 60-62. 
$100 \%, 200 \%, 300 \%$, por exemplo. O impacto econômico da medida poderia contribuir para que o empregador evitasse o rompimento dos contratos de trabalho.

Mas é preciso observar que em um cenário de muita rescisória ampliada, certamente o capital buscaria formas de esquivar-se de seu pagamento, mediante intensificação da prática de dispensas sob alegação de justa causa. Por isso, em conjunto com a elevação da multa incidente sobre o FGTS para as hipóteses de dispensa, seria conveniente que a lei fixasse uma indenização ao trabalhador, para a hipótese de dispensa sem justa causa que judicialmente fosse descaracterizada. Em tal caso, a indenização deveria ser fixada em patamar capaz de efetivamente inibir a fraude.

Enfim, a extinção da estabilidade no emprego, promovida pela Lei n. 5.107 de 13.09.1966, representou séria violação do princípio da melhoria da condição social do trabalhador. Em contrapartida, forneceu ao capital um instrumento poderoso de exploração da força de trabalho, antecipando-se à lógica toyotista e neoliberal de disponibilização da mão de obra conforme as oscilações da demanda, no interesse exclusivo do empregador. Tratou-se de mudança incompatível com um direito do trabalho voltado para a proteção do trabalhador, razão pela qual faz-se imprescindível que a proteção do emprego prevista na Constituição Federal seja efetivada, urgentemente, com base no princípio da melhoria da condição social do trabalhador.

\subsection{4 - O BANCO DE HORAS E O ABUSO NAS HORAS EXTRAORDINÁRIAS}

José Antônio Ribeiro de Oliveira observa que a Revolução Industrial trouxe um "aumento intensivo e extensivo da jornada" ${ }^{1513}$ de trabalho e que a extenuante carga de trabalho foi a causa principal do surgimento de muitas doenças. ${ }^{1514}$ Diz que a "luta histórica pela redução da jornada de trabalho tem acompanhado a própria trajetória do Direito do Trabalho", lembrando que a primeira convenção da OIT, aprovada na primeira reunião, em

\footnotetext{
${ }^{1513}$ SILVA, José Antônio Ribeiro de Oliveira. A flexibilização da jornada de trabalho e seus reflexos na saúde do trabalhador. Revista LTr, São Paulo, vol.77, n. 02, p. 181, fevereiro de 2013.

${ }^{1514}$ Ibid., p. 182.
} 
1919, fixara a jornada máxima em oito horas diárias e 48 horas semanais, fazendo restrições ao trabalho extraordinário. ${ }^{1515}$

Explica que, para Arnaldo Süssekind, ${ }^{1516}$ os fundamentos para a limitação do tempo de trabalho são de natureza biológica, a fim de combater os "problemas psicofisiológicos oriundos da fadiga e da excessiva racionalização do serviço"; social, para possibilitar "ao trabalhador viver, como ser humano, na coletividade à qual pertence"; e econômica, porque "acarreta, pelo combate à fadiga, um rendimento superior na execução do trabalho".

No que se refere aos efeitos da jornada de trabalho excessiva na saúde, devem ser levados em consideração os aspectos quantitativo, referente à quantidade de tempo de trabalho, e o qualitativo, “que se refere à 'distribuição' da jornada ao longo do dia, da semana, do mês ou inclusive do ano, na perversa anualização do tempo de trabalho" ${ }^{1517}$ É nesse aspecto qualitativo que assumem grande relevância os "acordos de compensação (banco de horas)...”1518

A Constituição Federal, nos incisos XIII e XIV do artigo $7^{\circ}$, estabeleceu o limite de oito horas diárias de trabalho para a jornada, reduzido para seis horas diárias no trabalho em turnos ininterruptos de revezamento, de modo que a única maneira de prorrogar diariamente a jornada de trabalho era mediante compensação de horários, pactuada em acordo ou convenção coletiva de trabalho. ${ }^{1519} \mathrm{E}$ desde o advento da CLT, em 1943, essa compensação ocorria por meio do módulo semanal. ${ }^{1520}$

Dessa forma, é possível observar que a Constituição Federal regulou a questão da duração do trabalho, fixando os limites diário e semanal e autorizando apenas a

${ }^{1515}$ SILVA, José Antônio Ribeiro de Oliveira. A flexibilização da jornada de trabalho e seus reflexos na saúde do trabalhador. Revista LTr, São Paulo, vol.77, n. 02, p. 182, fevereiro de 2013.

${ }^{1516}$ SÜSSEKIND, Arnaldo et. al. Instituições de direito do trabalho, v. 2, 16. ed. atualizada por Arnaldo Süssekind e João de Lima Teixeira Filho. São Paulo: LTr, 1996, p. 774. Apud SILVA, José Antônio Ribeiro de Oliveira. A flexibilização da jornada de trabalho e seus reflexos na saúde do trabalhador. Revista LTr, São Paulo, vol.77, n. 02, p. 183, fevereiro de 2013.

${ }^{1517}$ SILVA, José Antônio Ribeiro de Oliveira, op. cit., p.183.

${ }^{1518}$ Ibid., p. 183.

${ }^{1519}$ Ibid., p. 185.

${ }^{1520}$ Ibid., p. 185. 
compensação, sem extrapolação do módulo semanal. No inciso XVI do artigo $7^{\circ}$, mencionou "remuneração de serviço extraordinário superior, no mínimo, em cinqüenta por cento à do normal". Vale dizer, referiu-se a serviço extraordinário, que deve ser interpretado como situações excepcionais e de curta duração, e não a extrapolação permanente da jornada.

Nesse sentido, Maurício Godinho Delgado explica que a Constituição Federal não mencionou a possibilidade de "jornada meramente suplementar por acordo bilateral ou coletivo"1521, o que pode ser interpretado como restrição, pela Carta Magna, "a situações estritamente excepcionais, no país, a prática lícita de prestação de efetivas horas extras..." ${ }^{1522}$ Assim, com base nessa leitura da Constituição, configuram irregularidade trabalhista, as "horas meramente suplementares que não sejam resultantes de acordo de compensação e nem se confundam com as horas suplementares decorrentes de circunstâncias excepcionais mencionadas pela ordem jurídica". ${ }^{1523}$

Homero Batista Mateus da Silva também apresenta sério questionamento acerca da possibilidade de transformação de horas extraordinárias em prática ordinária:

A questão é saber se a hora extraordinária pode ser ordinária, se a excepcionalidade pode ser a regra e se dois trabalhadores podem fazer o serviço de três. O que está por trás, não resta dúvida, é o barateamento da mão de obra, pois até determinada quantidade, minuciosamente calculada pelo patronato, a hora extraordinária sai mais em conta do que a admissão de novo empregado, a tempo parcial ou a tempo integral, formando-se uma lógica perversa. ${ }^{1524}$

Contudo, sob o ideário do neoliberalismo e no conjunto de ataques que o capital vem realizando nas últimas décadas aos direitos dos trabalhadores, houve a sanção da Lei n. 9.601/98, em janeiro de 1998, pelo Presidente Fernando Henrique Cardoso, no

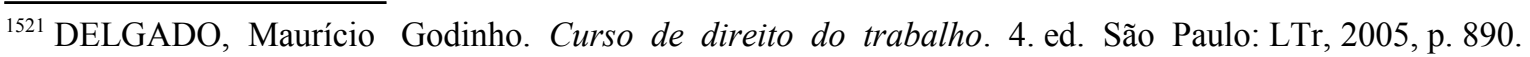
${ }^{1522}$ Ibid., p. 890-891.

${ }^{1523}$ Ibid., p. 891.

${ }^{1524}$ SILVA, Homero Batista Mateus da. Curso de direito do trabalho aplicado, vol. 2: jornadas e pausas. 2. ed. revista e ampliada. Rio de Janeiro: Elsevier, 2013, p. 47. 
auge do radicalismo neoliberal no Brasil. Essa lei, além de disciplinar a figura do "novo contrato de trabalho a prazo determinado", procurarando generalizar no país os contratos por prazo determinado, mediante inúmeros incentivos, tais como a redução de direitos dos trabalhadores, e a redução de encargos sociais, abordou outros temas também de extrema gravidade para o mundo do trabalho, entre eles o que diz respeito à jornada de trabalho.

É que o artigo $6^{\circ}$ da Lei 9.601/98 alterou o parágrafo $2^{\circ}$ do artigo 59 da CLT e, instituindo o banco de horas, permitiu que o empregador usufruísse da prestação de jornada extraordinária pelo empregado e deixasse de pagar a hora suplementar correspondente, ampliando o sistema de compensação, que até então deveria ser realizada dentro da mesma semana em que trabalhada, e que passava a ser permitida pelo prazo de até cento e vinte dias.

Os neoliberais, não satisfeitos com tamanha agressão aos direitos dos trabalhadores e com o forte impacto na precarização das condições de trabalho, editaram medida provisória, em agosto de 1998, também assinada pelo Presidente Fernando Henrique Cardoso, possibilitando o aumento do prazo para a compensação das horas extras para um ano.

Esse sistema de compensação transfere ao empregado os ônus e riscos da atividade econômica do empregador, arcando o trabalhador com o sacrifício à sua saúde e à sua vida social, no interesse único e exclusivo da atividade empresarial e da busca de lucros pelo capitalista:

Permitir que o empregador exija trabalho suplementar dos empregados durante vários meses do ano, com a faculdade de compensar a "sobrejornada" mediante a redução do horário de trabalho em outros dias - quase sempre da maneira que melhor lhe convier -, significa, simplesmente, a transferência dos riscos da atividade econômica para o trabalhador, em manifesta violação da norma de ordem pública prevista no caput do art. $2^{\circ}$ da Consolidação. A toda evidência, o capitalista exigirá a prestação de 
horas suplementares nos períodos de "pico" de produção ou de vendas e as compensará nos períodos de baixa produtividade ou de escassez nas vendas. ${ }^{1525}$

Trata-se de abominável retrocesso. Desde o surgimento do capitalismo que o excesso de jornada de trabalho trouxe preocupações aos trabalhadores e esteve no centro de suas reivindicações por melhorias das condições de trabalho. Há quase um século a limitação da jornada tornou-se norma internacional, enunciada pela Convenção n. 1 da OIT, de 1919. Com o ataque do capital ao trabalho, promovido pela ideologia neoliberal, as limitações da jornada de trabalho começaram a ruir e um dos principais instrumentos dessa destruição é o sistema de compensação de jornada, chamado banco de horas.

$\mathrm{Na}$ prática, a compensação realizada pelas empresas sequer leva em consideração um acréscimo de 50\% no tempo a ser compensado. Ora, se a hora extraordinária deve ser paga com acréscimo, no mínimo, de 50\%, então, quando compensada, jamais poderia ser desconsiderado esse aspecto, intrínseco ao sofrimento impingido ao trabalhador na extrapolação da jornada.

Homero Batista Mateus da Silva esclarece que o banco de horas "mancha, de modo indelével, o caráter de repouso da folga compensatória ou da compensação da jornada excessiva, por postergar de forma demasiadamente longa o termo final desse evento, ou, em determinados casos, por anulá-lo". ${ }^{1526}$ Observa que na situação em que sequer chega a ocorrer a compensação, ante o término do contrato, com o pagamento das horas extraordinárias no termo de rescisão, o que houve foi um empréstimo do trabalhador ao empregador, que assim "pode quitar a dívida normalmente no termo de rescisão, pagando o mesmo adicional de 50\%, sem nenhum tipo de atualização monetária". ${ }^{1527}$ Defende que a lei deveria ter previsto pelo menos um adicional maior, como de $75 \%$ ou $100 \%$, em tal hipótese, a fim de inibir a prática, "sem prejuízo de algum outro tipo de

\footnotetext{
${ }^{1525}$ SILVA, José Antônio Ribeiro de Oliveira. A flexibilização da jornada de trabalho e seus reflexos na saúde do trabalhador. Revista LTr, Sào Paulo, vol.77, n. 02, p.185, fevereiro de 2013.

${ }^{1526}$ SILVA, Homero Batista Mateus da. Curso de direito do trabalho aplicado, vol. 2: jornadas e pausas. 2. ed. revista e ampliada. Rio de Janeiro: Elsevier, 2013, p. 74.

${ }^{1527}$ Ibid., p. 72-73.
} 
punição, como o cancelamento do banco de horas em caso de sistemática frustração ao espírito do repouso correspondente". ${ }^{1528}$

Jorge Luiz Souto Maior explica que o banco de horas é inconstitucional, na medida em que incentiva a utilização do trabalho em jornada extraordinária e contraria o ideal do pleno emprego, fixado como princípio da ordem econômica no inciso VIII do art. 170 da Constituição Federal. ${ }^{1529}$ Também para José Antônio Ribeiro de Oliveira, há flagrante inconstitucionalidade na atual redação do parágrafo $2^{\circ}$ do artigo 59 da CLT, que permitiu o banco de horas no período de um ano, em razão de violação à norma referente à compensação (semanal - artigo $7^{\circ}$, XIII) e aos princípios básicos da sociedade brasileira estabelecidos no artigo $1^{\circ}$ da Constituição Federal. ${ }^{1530}$ Concordamos inteiramente com o pensamento dos referidos juristas.

Se dentro da lógica de produção capitalista existem períodos de variação da demanda por produtos, exigindo maior utilização da força de trabalho em determinadas épocas do ano, essa situação deve ser equacionada com a contratação de trabalhadores e não com a extrapolação da jornada dos contratados.

Um dos maiores desafios para a classe trabalhadora é o desemprego, que a enfraquece perante o capital, na medida em que este pode contar com um exército cada vez maior de reserva de mão de obra. Assim, o combate pelo direito do trabalho à utilização de jornada extraordinária é fundamental para o combate ao desemprego e para a melhoria da condição social do trabalhador. A fórmula do banco de horas atende somente aos interesses do capital e se revela extremamente prejudicial à classe trabalhadora.

\footnotetext{
${ }^{1528}$ SILVA, Homero Batista Mateus da. Curso de direito do trabalho aplicado, vol. 2: jornadas e pausas. 2. ed. revista e ampliada. Rio de Janeiro: Elsevier, 2013, p. 73.

${ }^{1529}$ SOUTO MAIOR, Jorge Luiz. O direito do trabalho como instrumento de justiça social. São Paulo: LTr, 2000, p. 329.

${ }^{1530}$ SILVA, José Antônio Ribeiro de Oliveira. A flexibilização da jornada de trabalho e seus reflexos na saúde do trabalhador. Revista LTr, São Paulo, vol.77, n. 02, p.185, fevereiro de 2013.
} 


\section{CONCLUSÃO}

O princípio da melhoria da condição social do trabalhador se depreende do conjunto de aspirações e conquistas histórico-jurídico-políticas dos trabalhadores, bem como da experiência normativa concreta do direito do trabalho, e integra o núcleo central desse ramo jurídico, na condição de elemento teleológico, indicando suas finalidades essenciais, quais sejam proteger o trabalhador e possibilitar o fortalecimento da classe trabalhadora, na dinâmica das lutas intrínsecas ao modelo capitalista de produção.

As contradições de um direito elaborado para proteger, mas que não atinge plenamente a sua finalidade, vinculam-se às contradições próprias do direito como um todo e do sistema capitalista, na medida em que o direito busca regular normativamente um sistema econômico que de tudo se apropria, tudo absorve e tudo canaliza para a finalidade de reprodução do capital. O próprio direito do trabalho foi apropriado como forma de sobrevivência do sistema, inicialmente a fim de evitar rompimentos mais intensos e em determinadas fases da evolução histórica do capitalismo como instrumento de domesticação da força de trabalho e de viabilização ou até aprofundamento da extração da mais-valia.

O sistema capitalista, baseado no individualismo, na competição, na busca incessante de reprodução do capital, na transformação do trabalho humano em mercadoria, na extração da mais-valia, na subordinação do valor de uso ao valor de troca das coisas, engendra profundas contradições na sociedade, no Estado e necessariamente no direito.

A verificação das condições e amplitude de concretização da missão histórico-social do princípio ora estudado depende da análise do contexto histórico de surgimento e desenvolvimento do Estado Social e do direito que lhe corresponde, o direito social, a partir da superação de uma perspectiva jurídica individualista do direito liberal, que era voltado para a consolidação dos interesses estritos da burguesia que acabara de alcançar a hegemonia no poder político e que assegurava apenas a igualdade civil formal. $\mathrm{O}$ Estado e o direito sociais representaram uma mudança de racionalidade, apontando para 
dimensões de solidariedade social, como categoria jurídica, e de igualdade política e social, em direção a sociedades materialmente mais igualitárias.

O Estado acompanha a mudança do sistema capitalista, que está sempre em transformação. Até mesmo o Estado Social atende, de certa forma, aos interesses do capital, na medida em que possibilita algum nível de equilíbrio social frente à destrutividade própria da competição e da reificação e mercantilização da força de trabalho (e portanto da pessoa), garantindo a preservação do sistema. Possibilita, ainda, o financiamento por um fundo público de parte dos recursos necessários à reprodução da força de trabalho, o que beneficia o capital, que acaba se apropriando de uma parcela maior de mais-valia (porque o salário, dentro dessa lógica, deixa de incorporar certas necessidades básicas). Apesar disso, a todo momento, o instinto ilimitado de ampliação dos lucros, comandado que é por forças predominantemente irracionais e fáusticas, pressiona para a alteração no Estado e no direito, a fim de ampliar a exploração direta da força de trabalho e de se apropriar do fundo público constituído para a ação daquele ente teoricamente apresentado como abstrato e neutro, construído para gerir os interesses da coletividade.

$\mathrm{Na}$ fase inicial, a igualdade formal civil revelou-se instrumento jurídico essencial do novo sistema, na medida em que possibilitava a construção de relações sociais a partir do paradigma da liberdade contratual (e subjacentemente do paradigma da propriedade), notadamente a de celebrar contratos de trabalho, e garantia e ampliava o acúmulo de riqueza da classe dominante, detentora dos meios de produção, por meio da ocultação de uma exploração inevitável para o trabalhador, mas construída juridicamente como liberdade. Por meio do trabalho assalariado, o capital consegue se reproduzir, mediante a apropriação de uma diferença entre o valor obtido com a venda do produto e o valor pago ao trabalhador para produzi-lo. A troca no mercado de trabalho se dá sempre e necessariamente em bases essencialmente desfavoráveis ao vendedor da força de trabalho.

Assim, a par de constituir-se, desde sempre, condição existencial do ser humano, o trabalho foi transformado em mercadoria, no sistema capitalista. A sobrevivência do homem sempre dependeu e dependerá da transformação da natureza pelo 
trabalho, atividade que acaba por gerar também relações sociais e revelar o caráter histórico da existência, na medida em que, ao transformar com sua própria ação as condições de sua sobrevivência, o homem constrói a sua história.

Mas se inicialmente o trabalho atendia às necessidades vitais da sociedade $\mathrm{e}$ o produto do trabalho estava vinculado ao valor de uso da coisa e a um modelo que não necessitava de hierarquias e de dominação, posteriormente a construção de relações de troca e a produção para atender a essas relações, com o objetivo de lucro, vinculam a produção ao valor de troca, subordinando o valor de uso, de modo que a produção deixa de acompanhar as necessidades humanas, e estas é que passam a ser criadas para atender aos interesses da produção.

Intensifica-se a divisão social do trabalho e a divisão social entre proprietários e não proprietários dos meios de produção, reservando-se aos proprietários a decisão unilateral sobre o que, quanto, por que preço, por quem e para quem produzir. É nitidamente um modelo de sociedade desvinculado de democracia real. Trata-se de um modelo de sociedade de classes antagônicas (a divisão básica é entre burguesia e classe trabalhadora), em que o interesse de uma se contrapõe, necessariamente, ao interesse da outra: são interesses antagônicos e irreconciliáveis, porque o da burguesia é o de se apropriar de algo que pertence ao trabalhador.

Com a chegada da burguesia ao poder político, ela se constitui enquanto classe social, nasce o Estado e o capitalismo se consolida. A formação da classe burguesa se completa, eis que a ordem jurídica dominante legitima a propriedade privada dos meios de produção, a exploração do trabalho assalariado, a desigualdade de riquezas e outras condições necessárias para viabilizar o sistema capitalista.

Para a classe trabalhadora, que pode ser identificada no processo produtivo como aquela que não detém a propriedade dos meios de produção e se vê forçada pelas necessidades de sobrevivência a vender sua força de trabalho, a constituição como classe política ativa depende da aquisição de consciência de si e das alterações sociais que interessam para sua emancipação, ou, na linha do pensamento de Lukács, depende não 
apenas da consciência "em si" (aspecto quantitativo), mas da consciência "para si" (identidade própria e ação unificadora).

Além da divisão social básica entre classe burguesa e classe trabalhadora, é possível identificar outros estratos sociais relevantes, como a classe média, o subproletariado e o lumpemproletariado.

A classe média, que Marx chamou de pequena burguesia, indicando que, embora não fosse proprietária dos meios de produção, poderia ser proprietária privada de bens móveis e imóveis, e revelando, ainda, a aproximação social e ideológica com a burguesia, atualmente, a rigor, constitui-se apenas pelas burocracias estatal e empresarial, os integrantes do serviço público, a pequena propriedade fundiária e o pequeno comércio não filiado às grandes redes de oligopólios transnacionais, eis que houve o assalariamento de grande parte dos profissionais liberais e a transformação em força produtiva dos pequenos empresários dependentes do capital transnacional.

Trata-se de uma classe social definida muito mais por sua posição ideológica que econômica, na medida em que não detém o poder do Estado, como a burguesia, nem o social, como a classe trabalhadora organizada. É fragmentada e imbuída de individualismo competitivo. Alimenta o imaginário da ordem e da segurança, porque aspira tornar-se parte da classe dominante. A sua atuação assegura a hegemonia ideológica da classe dominante, na medida em que dissemina essa ideologia por toda a sociedade, nos meios de comunicação, na escola, na religião e nas demais instituições de que participa. No Estado social, destaca-se realizando a gestão da articulação entre o público e o privado.

Subproletariado é uma fração de classe constituída pelos trabalhadores precarizados, notadamente do mercado de trabalho informal e que, consequentemente, apresentam uma situação de intensa pobreza. O seu projeto social é integrar-se ao proletariado, com quem tem o interesse comum do pleno emprego, que cria condições de luta favoráveis à classe trabalhadora como um todo. O lumpemproletariado é uma parcela de pessoas muito pobres, marginalizadas, que sequer conseguem a inserção em empregos precários informais. 
Concluímos, portanto, que a posse dos meios de produção continua sendo o elemento central na divisão das classes sociais, separando a classe dominante da "classeque-vive-do-trabalho", na expressão cunhada por Ricardo Antunes. E que a melhoria da condição social do trabalhador não pode simplesmente significar o acesso a bens móveis e imóveis, embora essa dimensão a integre, mas deve contar com um projeto de participação política e de reformulação de valores sociais, em direção a um modelo cada vez mais coletivo e humanizador.

Nas últimas décadas, o capital, para sua recomposição, impôs uma dinâmica muito destrutiva ao mundo do trabalho, buscando intensa precarização, mediante a utilização de trabalho em condições análogas à de escravo, informal, terceirizado, por prazo determinado, por tempo parcial etc. Em termos mundiais, intensificou-se o desemprego, inclusive, mas não apenas, pelo desenvolvimento tecnológico. Houve diminuição do setor industrial e ampliação do setor de serviços. Intensificaram-se a heterogeneidade entre os assalariados e a polarização entre trabalhadores qualificados e não qualificados, empregados e subempregados e desempregados. Tudo isso representou complexificação, fragmentação e desagregação da classe trabalhadora, cujo desafio atual é unificar os laços de pertencimento de classe.

Mas a observação das condições de vida dos trabalhadores, mesmo que distribuídos por variadas peculiaridades, revela, contudo, que algo de comum ainda permanece: o forte caráter exploratório do capital, gerando péssimas condições de vida e de trabalho a todos, com altos níveis de estresse, pela pressão por aumento de produtividade e pela ameaça de desemprego, de rebaixamento de salários, da perda crescente de direitos e desregulamentações. Enfim, a precarização é um processo que atinge gradativamente a todos os que vivem do seu próprio trabalho.

Dessa forma, constata-se que permanecem presentes os elementos para a união de forças e construção de um projeto comum. A luta por direitos sociais (e trabalhistas em especial) pode representar esse projeto comum e aglutinar os trabalhadores. E o direito do trabalho que se preste a essa finalidade somente pode ser um direito coerente 
com o princípio da melhoria da condição social do trabalhador. Um direito que, partindo da constatação da divisão entre as classes sociais, sirva de instrumento de confrontação aos interesses da classe dominante e não de uma conciliação de classes voltada para a manutenção do status quo. Um direito emancipatório não pode esconder a luta de classes.

No caso brasileiro, as relações sociais de modo geral e de trabalho em particular foram profundamente marcadas pelos elementos históricos de constituição da nação e do capitalismo.

O modo de produção dominante no Brasil durante o período colonial e na maior parte do século XIX foi o escravismo colonial, com a produção realizada pela mão de obra escrava. O escravismo servia à classe dominante como um negócio rentável (no caso do tráfico) e como forma de fixar o trabalhador nas grandes propriedades, tendo em vista que havia grande quantidade de terras disponíveis e isso dificultaria a fixação na condição de assalariado.

A superação do modelo de sociedade escravista não se fez por razões humanitárias, mas decorreu da formação de uma burguesia liberal, no século XIX, que iniciou a construção de um projeto de formação do capitalismo no Brasil. Os abolicionistas estavam engajados na formação do Estado capitalista brasileiro. Além disso, o custo da mão de obra escrava era maior do que o da assalariada, nas bases da época.

O modo de produção capitalista é incompatível com o trabalho escravo, porque o desenvolvimento do capitalismo depende da formação de um mercado de mão de obra despossuída, abundante e juridicamente livre para ser assalariada e firmar contratos de trabalho, rescindíveis quando convier ao empregador.

O imigrante foi a alternativa inicial para a implementação do projeto de substituição da mão de obra escrava. As condições de trabalho dos imigrantes, porém, eram precárias e o grau de exploração semelhante ao dos escravos ou dos assalariados da fase inicial do capitalismo na Europa. Os atritos dos colonos com os proprietários de terra 
eram frequentes e chegaram a ocorrer greves. Muitos imigrantes se fixaram diretamente ou se deslocaram para os centros urbanos.

Em torno da produção cafeeira começou a formação do capitalismo na região de São Paulo, mas durante a Primeira República, de modo geral, o Brasil continuou predominantemente agrícola e preocupado prioritariamente com os interesses agroexportadores.

As condições de trabalho durante a Primeira República eram péssimas (baixos salários, jornadas excessivas, ambientes insalubres, exploração do trabalho de mulheres, crianças e adolescentes), eis que não havia normas estatais de proteção ao trabalhador. Tratava-se de uma sociedade recém-saída da ordem escravocrata e as relações de trabalho estavam fortemente influenciadas pelos padrões herdados daquele sistema. A classe operária sofria forte preconceito contra o trabalho manual e contra o trabalhador imigrante. A questão social era tratada como caso de polícia.

O Estado de então era um Estado liberal, que apenas assegurava a liberdade de contratação (e de exploração pelo capitalista da força de trabalho) e apenas intervinha quando considerava existir ameaça à ordem pública, mediante ação policial contra manifestações operárias. Era um Estado constituído para defender os interesses das oligarquias fundiárias (e no conflito com o operariado os industriais também podiam contar com a proteção desse Estado), de modo que o jogo político era feito sem necessidade de agradar a massa operária nascente.

A burguesia industrial nascente foi-se identificando como parte das classes conservadoras, porque surgia em um contexto social em que, para defender seus interesses, não precisava alterar a relação entre dominantes e dominados existente no Brasil.

Houve tentativas de organização e de mobilização dos trabalhadores por meio de partidos operários, sindicatos e greves, mas os movimentos eram esparsos e raramente despertavam a atenção e a preocupação da elite. Passado o momento de pressão junto aos empregadores, os direitos se perdiam porque não haviam sido assegurados em 
lei. O jovem proletariado brasileiro tentava resistir como podia à exploração capitalista $\mathrm{e}$ frente a isso o patronato apelava aos serviços dos órgãos de repressão do Estado. Apenas a partir de 1917 é que movimentos significativos de trabalhadores urbanos ocorreram, com um ciclo importante de greves entre 1917 e 1920, reivindicando reajustes salariais e melhores condições de trabalho, e então, pela primeira vez, o Estado cogitou seriamente da elaboração de uma legislação trabalhista.

Durante as primeiras décadas do século XX, notadamente nos períodos da Primeira Guerra Mundial e a partir da crise de 1929, iniciou-se um processo de substituição de importações de produtos manufaturados pela produção interna. A indústria começava a se desenvolver e a necessitar de mão de obra, sendo que o crescimento vegetativo das populações urbanas não era suficiente para abastecer o setor, que juntamente com o terciário, expandia-se. Por isso, a elevação do padrão de subsistência e a promessa de ascensão social serviram como atrativos para trabalhadores, notadamente do campo.

Com a ascensão das classes sociais urbanas e o desenvolvimento da indústria e do comércio, surgiram as condições para que a partir da Revolução de 1930 houvesse uma ruptura estrutural na sociedade brasileira e o desenvolvimento do Estado burguês, mas a derrota da elite agrário-comercial não significou, contudo, uma derrota completa nem de amplas proporções, apenas uma vitória parcial das outras classes dominantes, que foram obrigadas a pactuar com aquela.

O Estado nascente distinguia-se do anterior pela centralização do poder, pela atuação econômica voltada para a promoção da industrialização, pela atuação social, tendente a dar algum tipo de proteção aos trabalhadores urbanos. O poder público passou a funcionar de forma mais adequada às exigências e possibilidades estruturais do sistema capitalista, reformando as condições de funcionamento das forças produtivas (estabelecendo a legislação trabalhista e sindical), as relações internas de produção e as relações com a economia internacional. O Estado passou a promover o capitalismo nacional mediante o suporte no aparelho de Estado e em uma aliança entre a burguesia industrial e setores da classe trabalhadora urbana. 
A partir de Getúlio Vargas, o problema proletário deixou de ser considerado apenas questão de polícia, para começar a ser tratado também como questão de política. $\mathrm{O}$ proletariado passou a ser visto como interlocutor legítimo e foram legitimadas certas reivindicações suas. O poder público se inseriu como mediador, com o objetivo de pacificação das classes sociais (entre a classe vendedora e a compradora de força de trabalho) e de busca de cooptação das entidades sindicais para colaboração no mecanismo dirigente do Estado (a atuação governamental delimitou as condições, as possibilidades e os limites da atividade sindical e vinculou o sindicato ao aparelho estatal, como elemento das estruturas de dominação política e da apropriação econômica, então vigentes).

A legislação trabalhista vinha para estabelecer a harmonia e a tranquilidade entre empregados e empregadores urbanos. No cerne da doutrina da "paz social" havia uma política de controle e de dominação da atividade e organização política do proletariado, repressão dos esforços organizatórios da classe trabalhadora urbana fora do controle do Estado e atração dessa classe para o apoio ao governo. Tudo isso contribuía para a expansão industrial e para a racionalidade da máxima mercantilização dos fatores de produção. Enquanto a burguesia ainda estava presa aos seus interesses mesquinhos e imediatos de classe, o governo Vargas buscava equacionar a questão operária de um modo que favorecia aos objetivos gerais e de longo prazo da classe dominante.

Chama a atenção o fato de a legislação trabalhista ter inicialmente ficado restrita aos trabalhadores urbanos. Os trabalhadores rurais eram a maioria da força de trabalho e juntamente com o empregados domésticos não receberam nenhuma proteção. É claro que para isso também contribuiu o aspecto de que os trabalhadores urbanos já se encontravam mais organizados e com maior capacidade reivindicativa. Mas essa segmentação tão drástica corrobora a percepção de que não era predominantemente com o interesse dos trabalhadores que o Estado estava preocupado na época.

Mas, por outro lado, é inegável que a legislação representou para os trabalhadores a obtenção de antigas reivindicações e sinalizou um marco inicial de proteção normativa em face dos empregadores. Mais que isso, o estabelecimento de um 
salário mínimo, do direito a férias, da limitação de jornada, entre outros aspectos, e posteriormente a elaboração da Consolidação das Leis do Trabalho, iniciaram a construção de uma nova ordem jurídica (lastreada em uma nova racionalidade), transformando as relações de trabalho de privadas em relações dotadas de certo caráter público, nas quais o Estado podia e devia intervir, para evitar a superexploração do trabalhador, a sua pauperização, a competição incontrolada entre as diversas categorias profissionais e a canalização das insatisfações para o confronto (as greves de 1917 a 1920 foram em grande parte geradas pela tendência pauperizadora de então). A intervenção estatal estabelecia os limites inferiores da exploração dos trabalhadores.

A Consolidação das Leis do Trabalho, em 1943, mais do que mera sistematização, representou a construção de um monumento normativo de intensa transformação na concepção jurídica brasileira. O princípio da liberdade contratual absoluta, no sentido de celebrar os contratos e de fixar o conteúdo, deixava de existir nas relações de trabalho. Era uma racionalidade que reconhecia a desigualdade material entre empregado e empregador e a vulnerabilidade a que o sistema havia lançado uma multidão de despossuídos, que tinham na venda da força de trabalho o único meio de sobrevivência.

Por isso, o artigo $9^{\circ}$ da CLT estabeleceu a nulidade de atos que desvirtuassem, impedissem ou fraudassem a Consolidação. O artigo 444 impediu a estipulação de cláusulas contrárias às disposições estatais e de normas coletivas de proteção ao trabalhador. O artigo 468 impediu a alteração contratual unilateral pelo empregador e aquela que, mesmo pactuada, fosse prejudicial ao trabalhador. Vale dizer, estava ganhando corpo no direito do trabalho uma estruturação positiva que indicava expressamente a finalidade de proteção do trabalhador e de melhoria de sua condição social. Não era apenas um conglomerado de direitos, mas um instrumental poderoso de nova expressão das relações de trabalho no plano normativo. A ordem jurídica decididamente tomava partido em prol do trabalhador, mesmo que também existissem outras intenções do Estado e da classe dominante.

Deve-se observar que a possibilidade de rompimento da ordem capitalista pelo excesso de exploração dos trabalhadores não se revela uma certeza mecânica. A 
miséria pode representar forte elemento de subjugação e enfraquecimento dos dominados. A fome e o desespero conduzem à insatisfação social, mas não, necessariamente, à luta. Por isso, a tensão que se pode fazer nos antagonismos de classe deve partir do pressuposto de ampliação de direitos dos trabalhadores. A ampliação e a efetivação de direitos poderão representar o fortalecimento da classe trabalhadora e a possibilidade de questionamento da ordem, muito mais do que a retirada de direitos e a pauperização dos dominados.

Enfim, analisando o evolver da história, é possível concluir que a normatização de direitos sociais, notadamente trabalhistas e previdenciários, passou a constituir o Estado Social brasileiro, alterando a racionalidade jurídica que vigorava até então. Da mesma forma que a "voluntas legis" não se confunde com a "voluntas legislatoris", pode-se dizer que o potencial transformador dos direitos sociais não se confunde com a intenção do Estado quando de sua elaboração, podendo frutificar dimensões emancipatórias não previstas na ocasião.

De modo geral, o período de 1945 a 1964 não trouxe avanços significativos em matéria de direitos sociais, salvo no que se refere à maior estuturação da atividade sindical e ao aumento da participação popular nas atividades políticas.

O processo de mudança social iniciado por Vargas ainda não havia esgotado suas possibilidades progressistas quando foi interrompido pelo golpe de 1964 e pela implantação da ditadura civil-militar. A partir de então, o Estado procurou garantir e organizar pela força bruta a dominação, exercida através de uma estrutura de classes subordinada às frações superiores de uma burguesia altamente oligopolista e transnacionalizada. Houve violenta repressão às Ligas Camponesas e intervenção em sindicatos. Foram criados obstáculos à greve. Adotou-se a prática de compressão de salários, mediante a fixação de fórmulas de reajuste inferiores à inflação, e de manipulação de índices inflacionários. O salário mínimo foi desvalorizado. Incentivou-se a rotatividade da mão de obra. Houve abandono ou retardamento dos programas sociais pelo Estado, ligados à saúde, educação e habitação, entre outros. O período foi perverso em matéria social, aumentando drasticamente a concentração de renda e as desigualdades sociais. 
A política trabalhista brasileira no período de 1964 a 1985 caracterizou-se principalmente pela contenção máxima dos movimentos individuais e coletivos dos trabalhadores e pela redução dos níveis salariais, dentro de táticas e técnicas de combate à inflação e de redução dos custos da produção.

Simultaneamente, a partir da década de 1970, começou a se expandir no mundo a ideologia neoliberal, que preconizava a destruição da proteção social do Estado, mediante a retirada de direitos e a canalização dos recursos públicos para os interesses imediatos do capital, em um contexto de globalização econômica, multinacionalização empresarial e livre trânsito financeiro internacional, que favorecia o capital financeiro internacional e as economias centrais do capitalismo. Entre os principais objetivos, muito pouco disfarçados, estavam a precarização das condições de trabalho e o retorno à livre pactuação entre as forças produtivas, em um cenário de desemprego e de excesso de mão de obra, radicalizando a extração da mais-valia e a subjugação do trabalhador.

Paralelamente à expansão da ideologia neoliberal, ocorria uma transformação no modo de produção, com desmonte do método fordista-taylorista (que até então reunia os trabalhadores para produzir e com isso possibilitava uma determinada forma de união e luta) e a implantação do método toyotista, marcado pela exteriorização e horizontalização da produção, com a transferência a "terceiros" de grande parte do processo produtivo, e pela busca frenética de redução do custo do trabalho, mediante a intensificação do aproveitamento do tempo e da subordinação do trabalhador.

No Brasil, o neoliberalismo chegou com toda força, na década de 1990, sob os governos Collor, Itamar e, principalmente, FHC, quando se radicalizou o processo de flexibilização (leia-se destruição) das normas de proteção dos trabalhadores nas relações de trabalho (mediante a elaboração de normas estatais e decisões judiciais prejudiciais aos trabalhadores e de valorização de negociações coletivas destrutivas de direitos) e abertura econômica e financeira indiscriminada, sobrevalorização cambial e elevação dos juros. $\mathrm{O}$ desemprego e a precarização de condições de trabalho se intensificaram. 
O Estado, que até então representava algum obstáculo à agressividade do capital internacional, passou a ser combatido como um inimigo, sob a propaganda de uma nova "modernidade". Disseminaram-se as práticas de privatizações e transferências, por preços módicos, do patrimônio público ao capital privado, inclusive internacional.

A partir do governo Lula, houve uma certa inflexão no modelo de neoliberalismo radical praticado no período $\mathrm{FHC}$, mediante a diminuição dos processos de privatização, redução de juros e a adoção de políticas sociais, notadamente de transferência de renda às parcelas mais pobres da população, por meio do Programa Bolsa-Família, e de valorização do salário mínimo. A ativação econômica que essas políticas geraram contribuiu para a redução do desemprego, intensa redução do lumpemproletariado (marginalizados sem colocação no mercado de trabalho) e redução do subproletariado, mediante a incorporação no mercado de trabalho formal e de consumo de milhões de brasileiros.

Mas a desigualdade social no Brasil ainda é imensa. Ainda não retornamos ao índice de Gini de 1960, embora estejamos perto disso. A participação da renda do trabalho na renda nacional somente há pouco tempo recuperou os percentuais do início da década de 1990. O salário mínimo somente em 2009 recuperou o valor de compra que possuía em 1960. Mais de $40 \%$ da população economicamente ativa se encontra no mercado de trabalho informal, laborando sem registro em CTPS ou desenvolvendo pequenas atividades econômicas por conta própria (vendedores ambulantes, por exemplo), sem nenhuma proteção previdenciária e trabalhista.

As relações de trabalho continuam marcadas por intensa exploração: baixos salários, de modo geral; contratos de trabalho não formalizados; contratos de trabalho precários, principalmente em razão da terceirização; alta rotatividade da mão de obra; abuso nas jornadas de trabalho. O neoliberalismo conseguiu ampliar as injustiças contra o trabalhador nas relações de trabalho.

As normas de direito do trabalho regulam a relação de produção, o conjunto de atos materiais por meio dos quais uma classe social dominante apropria-se da riqueza 
produzida pela classe dominada. Nesse conflito, não há neutralidade: ou a norma atua na proteção do ser humano que trabalha ou na dinâmica da produção de lucros para o capitalista explorador.

As limitações que ao longo dos séculos o direito do trabalho impôs ao capital, por exemplo, mediante a fixação de um salário mínimo e de limitações de jornadas, bem como a possibilidade de associação e reivindicação dos trabalhadores, entre outros aspectos, representaram certa proteção do trabalhador. Isso pode ser observado pelo fato de que o capital busca escapar das normas do direito do trabalho, desvirtuá-las (mediante o estabelecimento de normas que aparentemente beneficiam o trabalhador, mas que na realidade o prejudicam, como é o caso da participação nos lucros e resultados, tal qual normatizada no Brasil) ou destruí-las (por exemplo, no caso da extinção da estabilidade no emprego ou da implementação das compensações de horário que destroem os limites constitucionais de jornada). O direito do trabalho no Brasil ainda incomoda o capital e por isso ainda é possível perceber na essência desse direito a finalidade de proteger o trabalhador.

A proteção atua para tornar uma troca intrínseca e necessariamente desvantajosa para o trabalhador (a venda da força de trabalho por salário) em relação dotada de certo equilíbrio (ou tensão), a ponto de possibilitar a sobrevivência desse trabalhador (ou seja, evitar a superexploração). E a partir desse mecanismo de reconhecimento dos antagonismos de interesses, por meio do direito do trabalho, o trabalhador pode adquirir a consciência de sua posição no processo produtivo e na sociedade, em um contexto de classe, a partir do compartilhamento com outros trabalhadores da luta por direitos. Por meio do direito do trabalho, a classe trabalhadora pode confrontar o capital. Pode fazer-lhe exigências. Pode mostrar a sua força coletiva. Pode exigir mudanças.

Portanto, o direito do trabalho não se trata de apenas um conjunto de normas para regular as relações de trabalho (dimensão que ele sempre ultrapassa), mas um conjunto de normas para melhorar a condição social do trabalhador. 
É possível imprimir na dinâmica das normas trabalhistas essa direção de proteção da classe trabalhadora. E esse aspecto poderá ser intensificado ou mitigado de acordo com a apropriação que os trabalhadores fizerem do direito do trabalho. Em uma sociedade capitalista, o capital sempre procurará transformar todos os instrumentos possíveis, inclusive os jurídicos, a serviço da sua reprodução. Por isso, há e sempre haverá no cerne do direito do trabalho uma disputa por sua apropriação.

O princípio da melhoria da condição social do trabalhador significa que a experiência jurídica, em qualquer de suas dimensões, colocando-se na perspectiva do trabalhador, deve ser capaz de fortalecer a classe trabalhadora, a partir da melhoria ampla de suas condições de vida e trabalho e da valorização do humano na relação de produção, com vistas à construção de uma sociedade justa e solidária.

O princípio da melhoria da condição social do trabalhador conecta-se às raizes do direito social (solidariedade, justiça social, pacificação pela justiça social, proteção à dignidade humana e coletivização dos interesses) e à ideia da esfera do trabalho como a de um poder privilegiado para determinar a consciência e a ação sociais.

O princípio de melhoria da condição social do trabalhador aponta para uma finalidade. Há essencialidade do elemento finalístico, qual seja a transformação, para melhor, da situação do trabalhador. O princípio revela-se o elemento finalístico do direito do trabalho, ou seja, a sua razão de existir. Se fosse para atender aos interesses do capital, seria apenas necessário que não existisse direito do trabalho e que as próprias partes fixassem os parâmetros dessa relação, inexoravelmente desigual, o que conduziria à imposição unilateral da vontade do capital.

Não foi por outra razão que desde a Constituição Federal de 1934, na década em que a consolidação do Estado Social brasileiro ganhou impulso, que o princípio da melhoria da condição social do trabalhador figura nas constituições federais. E não poderia ser diferente, porque a superação do ideário estritamente liberal e individualista por uma perspectiva social e coletivista somente se revelou possível pela mitigação do princípio da igualdade formal e pelo reconhecimento da existência de diferenças 
econômicas que desfavoreciam o trabalhador e que deveriam ser modificadas pela ordem jurídica, mesmo que outros interesses também estivessem presentes e, na maior parte do tempo, até acabassem por predominar (como, por exemplo, o de atrair mão de obra para a indústria e viabilizar a exploração da força de trabalho pelo capital industrial), no contexto das contradições do sistema capitalista e do Estado que lhe dá suporte.

O princípio decorre de todo o conjunto de normas de direito social e sua existência independe de previsão legal. A positivação, contudo, constituiu medida que o fortaleceu em todas as dimensões, como fonte informadora da produção legislativa e de interpretação e aplicação do direito. A constitucionalização atual, no capítulo dos direitos fundamentais, ressalta a posição de supremacia do princípio, integrando-o ao núcleo central da ordem jurídica brasileira.

$\mathrm{Na}$ Constituição Federal de 1988, restou positivado no artigo 7º "caput", em que consta: "São direitos dos trabalhadores urbanos e rurais, além de outros que visem à melhoria de sua condição social”. O referido artigo integra o capítulo II, referente aos direitos sociais, do título II, que trata dos direitos e garantias fundamentais.

Vale dizer, os direitos estabelecidos no artigo $7^{\circ}$ da Constituição Federal são direitos dos trabalhadores e não direitos dos trabalhadores e empregadores, dos empregadores, da atividade laborativa, da atividade econômica, do sistema produtivo, da atividade empresarial, do emprego, da paz social, da conciliação das classes sociais etc.. Tais direitos estão vinculados à melhoria da condição social dos trabalhadores e o texto constitucional aponta para a criação de outros com o mesmo fim e parâmetro valorativo. Assim, os direitos previstos no referido artigo devem melhorar a condição social do trabalhador e outros direitos ainda ali não elencados também devem realizar esse objetivo. A interpretação e aplicação dos direitos do artigo $7^{\circ}$ jamais poderão se afastar dessa direção, de estatuto de proteção dos trabalhadores.

O princípio de direito social da melhoria da condição social do trabalhador diz que a racionalidade de construção de direitos relacionados ao trabalhador deve ser a de melhorar a sua condição social. Não diz que a racionalidade será de facilitar a ampliação 
do capital ou a organização da vida econômica do país. A racionalidade do princípio é de que o capital deve se subordinar ao trabalho, porque é no trabalho que está o elemento humano da produção.

Por isso, a interpretação de cada direito previsto no artigo $7^{\circ}$ da Constituição Federal de 1988 deve ser realizada levando-se em consideração a perspectiva do interesse do trabalhador. Entre os direitos do artigo $7^{\circ}$, estabelece-se uma relação de maior ou menor realizabilidade jurídica, conforme se adequem ao fim estabelecido no "caput". Além disso, a norma constitucional de melhoria da condição social do trabalhador produz efeitos inibitórios e limitativos de outras estabelecidas na Constituição Federal, que com ela se conflituem, e esteriliza, por inconstitucionalidade, todo o regramento infraconstitucional que se distancie do princípio que expressa. A referida norma impossibilita a criação de novas normas com finalidade diversa, eis que determina expressamente que devem melhorar a condição social do trabalhador.

A expressão "além de outros que visem à melhoria de sua condição social" estende aos demais direitos em geral o princípio. Ao fazer referência a outros direitos, entende-se que os direitos elencados na Constituição são apenas o mínimo, eis que outros deverão ser criados para o fim de melhorar a condição social do trabalhador.

O princípio da melhoria da condição social do trabalhador pretende a proteção do trabalhador na relação de trabalho porque isso lhe é benéfico e melhora sua condição social. E pretende mais. Não apenas fornecer critérios de criação, interpretação de normas (legais, regulamentares ou contratuais) e de resolução de conflitos, mas viabilizar, por meio do direito, alterações mais amplas de justiça social, que interfiram na estrutura social de modo a favorecer a classe trabalhadora, alçando-a a posição de relevância social cada vez maior.

Em toda a dimensão dos contratos de trabalho, em suas fases preparatória, executória e pós-executória incide o princípio da melhoria da condição social do trabalhador. Mas o princípio abrange também o processo de criação das normas sociais lato sensu, abrangendo, por exemplo, a proteção contra as agressões à saúde do trabalhador 
e vulnerabilidades outras como a decorrente de idade avançada ou desemprego, bem como normas que dizem respeito a distribuição de oportunidades, como as relacionadas a educação, normas referentes à estrutura de ampla e verdadeira participação na gestão da empresa e na vontade do Estado. E principalmente, normas que possam viabilizar a união dos trabalhadores e sua atuação coletiva. Vale dizer, o princípio da melhoria da condição social do trabalhador se propõe a fortalecer econômica, social e politicamente o homem que vive do trabalho e que é a maioria no conjunto da sociedade.

Pelo princípio da melhoria da condição social do trabalhador, sequer a necessidade individual do trabalhador é protegida prioritariamente pelo direito do trabalho, mas sim o interesse da classe trabalhadora. A relação individual de trabalho não é uma simples relação entre trabalhador e patrão. É uma relação de classes sociais. O direito do trabalho é um direito transitório, necessário apenas para evitar a exploração de uma classe por outra e para contribuir na construção da igualdade entre as classes sociais, mediante o fortalecimento da classe trabalhadora.

A perspectiva de melhoria da condição social do trabalhador por meio do direito do trabalho constitui o cerne desse ramo jurídico e dá-lhe sentido, descortinando a sua função na sociedade e a possibilidade de contribuir para a emancipação do ser humano.

No direito do trabalho existem instrumentos para a realização da finalidade imediata de melhoria das condições de trabalho e de vida dos trabalhadores, partindo do pressuposto de aperfeiçoamento da relação de trabalho e do modelo capitalista de produção, mas também há os mecanismos voltados para a finalidade mediata de transformação da própria sociedade, por meio de completa substituição do modo de produção vigente, como os mecanismos de atuação coletiva dos trabalhadores. O princípio ora estudado se presta à realização de ambos os fins.

Os princípios jurídicos atuam no momento de criação da norma, no momento da interpretação e da aplicação. O princípio da melhoria da condição social do trabalhador revela-se capaz de desempenhar todas as funções atribuíveis a um princípio 
normativo (caráter de eficácia máxima), pois orienta a criação de novas normas, a interpretação das já existentes e a aplicação.

O princípio ora estudado incorpora o princípio da proteção (cujo núcleo central pode ser expresso pelas técnicas do "in dubio por operario" e da supremacia da norma mais favorável e da condição mais benéfica ao trabalhador), além dos demais principais princípios destacados pela doutrina jurídica, quais sejam os da irrenunciabilidade dos direitos trabalhistas, da continuidade da relação de emprego e da primazia da realidade.

Diversos são os métodos que a experiência jurídica tem adotado para a criação, interpretação e aplicação do direito. Mas, no sistema capitalista, apenas um método que, partindo da constatação da divisão das classes sociais inerentes ao referido sistema, coloque o ser humano como elemento central e enxergue o mundo sob a perspectiva dos interesses das classes inferiorizadas socialmente, poderá dar sentido à ciência jurídica e possibilitar as alterações progressivas e necessárias para a construção de uma sociedade viável.

No decorrer da história, as relações sociais muitas vezes revelam movimentos dialéticos de avanço, retrocesso e novo avanço, no que se refere ao equacionamento de soluções justas para os dilemas e conflitos. A superação de contradições conduz a novas contradições no sistema capitalista e exige a permanente busca de proteção do elemento humano da relação de produção, permanentemente em transformação.

Desse processo dinâmico e contraditório e da consolidação do sistema capitalista, surgiu o direito do trabalho, com o potencial de intervir em favor de uma classe social explorada na relação entre o capital e o trabalho, marcada inexoravelmente pela tensão de interesses irreconciliáveis das classes sociais envolvidas nessa relação.

Das normas do direito do trabalho, observa-se o pressuposto teórico de melhorar as condições sociais e econômicas dos trabalhadores, independentemente de 
intenções diversas das classes dominantes representadas no Estado. O pressuposto é de que esse ramo jurídico possa contribuir para a formação da vontade de um Estado democrático de direito social, mediante a afirmação política da classe trabalhadora e sua participação no referido ente, mas também possibilitar a concretização da confrontação e da luta de classes, pela organização coletiva dos trabalhadores, sempre sob a inspiração do mesmo princípio da melhoria da condição social.

A experiência histórica demonstrou a necessidade de elaboração normativa tendente à melhoria das condições de vida do trabalhador e o fruto dessa elaboração tem sido o direito do trabalho, sob a inspiração do princípio ora estudado. A possibilidade de elaboração de normas de proteção aos trabalhadores em um sistema voltado para os interesses dos capitalistas revelou a complexidade do sistema, com suas contradições e capacidade de adaptação.

Os influxos de linhas ideológicas internas ao sistema capitalista, como a do neoliberalismo, geraram nos últimos quarenta anos um movimento de alteração em muitos aspectos da experiência jurídica trabalhista, distanciando-a do princípio da melhoria da condição social do trabalhador e voltando o direito do trabalho para a proteção imediata dos interesses do capital. Trata-se de uma nova ofensiva do capital e da tentativa de subverter o equilíbrio obtido durante as décadas anteriores. Temas centrais do direito do trabalho sofreram desvirtuamento, em razão de abordagens legislativa, doutrinária e jurisprudencial que se distanciaram do princípio da melhoria da condição social do trabalhador.

$\mathrm{Na}$ atualidade, convivem no Brasil formas produtivas tayloristas-fordistas e toyotistas, adquirindo grande complexidade o mundo do trabalho e as formas de exploração da força de trabalho pelo capital. No processo de internacionalização do capital e da produção, as empresas multinacionais atuam no país, usufruindo de seus recursos naturais, da força de trabalho e da própria renda do trabalhador-consumidor. A única forma de impedir que todos esses recursos sejam canalizados para as regiões centrais do capitalismo mundial é avançar na proteção do trabalhador brasileiro, garantindo sua integridade física e psíquica, bem como condições de melhoria progressiva da renda. 
Um direito do trabalho que não tenha o propósito imediato de melhorar as condições de vida do trabalhador é paradoxal, por contrariar a racionalidade jurídica que lhe é essencial. A legitimidade e finalidade enraízam-se no ideal de proteção da classe social inferiorizada no sistema capitalista.

Não se trata, portanto, de buscar no direito do trabalho a regulamentação mínima para a acumulação e reprodução do capital e da força de trabalho, mas de resgatar a carga transformadora que é essencial ao direito do trabalho, por meio do princípio nuclear ora estudado, rumo à progressiva melhoria das condições de trabalho, com vistas à distribuição da renda, diminuição das desigualdades sociais e afirmação política dos trabalhadores.

O destino do ser humano é sua emancipação, como se depreende dos atributos de racionalidade concedidos pela natureza. O cultivo de uma crença energizada de possibilidade de construção de relações humanas e sociais mais justas é também uma atitude crítica, na medida em que incorpora como método a dinamicidade e lança o impulso para a ação. É preciso olhar as relações sociais como algo mutável e passível de constante aperfeiçoamento. Não há nada de natural nas injustiças sociais.

O princípio da melhoria da condição social do trabalhador, como centro irradiador de sentido ao direito, contribui para a civilização do capitalismo. Até onde o direito do trabalho consegue chegar é algo que somente a experiência histórica poderá ir dizendo, mas o horizonte que o princípio ora estudado revela é amplo e permitirá grandes avanços, notadamente em se considerando que não fixa um ponto a chegar, mas um processo progressivo de transformação da sociedade.

O limite não deve ser dado aprioristicamente. Quando se olha para o horizonte, deve-se buscar a linha mais distante que a visão puder alcançar. O limite será dado pelo caminhar, no caminho. Então, somente então, saberemos quais perspectivas eram inviáveis para determinado momento histórico, mas nunca antes de nos colocarmos em realização. Quando nos pusermos em processo, mantendo em nossa consciência o firme 
propósito de não indiferença à injustiça social, levantaremos nosso olhar para frente e vislumbraremos novas perspectivas, em permanente transformação, que sempre há de estar na essência do existir. 


\section{REFERÊNCIAS BIBLIOGRÁFICAS}

ABRAMO, Laís W. A subjetividade do trabalhador frente à automação. In: NEDER, R.T. et al. (orgs.). Automação e movimento sindical. São Paulo: Hucitec, 1988.

ALVES, Giovanni. O novo (e precário) mundo do trabalho. São Paulo: Boitempo, 2000.

ANDERSON, Perry \& CAMILLER, Patrick (orgs.). Um mapa da esquerda na Europa Ocidental. Rio de Janeiro: Contraponto, 1994.

ANDERSON, Perry et. al. A trama do neoliberalismo - Mercado, crise e exclusão social. In: SADER, Emir \& GENTILI, Pablo (org.). Pós-neoliberalismo: as políticas sociais e o Estado democrático. Rio de Janeiro: Paz e Terra, 1995.

ANDERSON, Perry. Balanço do neoliberalismo. In: SADER, Emir \& GENTILI, Pablo (org.). Pós-neoliberalismo. As políticas sociais e o Estado democrático. 5. ed. Rio de Janeiro: Paz e Terra, 2000.

ANTUNES, Ricardo. Adeus ao trabalho? São Paulo, Campinas: Cortez/Unicamp, 1995.

- Trabalho, reestruturação produtiva e algumas repercussões no sindicalismo brasileiro. In: ANTUNES, Ricardo (org.). Neoliberalismo, trabalho e sindicatos - reestruturação produtiva na Inglaterra e no Brasil. 2. ed. São Paulo: Boitempo, 2002.

. Os sentidos do trabalho. Ensaio sobre a afirmação e a negação do trabalho. São Paulo: Boitempo Editorial, 2006.

. O neoliberalismo e a precarização estrutural do trabalho na fase de mundialização do capital. In: SILVA, Alessandro da. et al (coord.). Direitos humanos: essência do direito do trabalho. São Paulo: LTr, 2007.

ARTS, W. \& GELISSEN, J. Models of the welfare state. In: CASTLES, F. et. al. (eds). The Oxford handbook of the welfare state. Oxford: Oxford University Press, 2010.

ASCHCRAFT, Richard. A análise do liberalismo em Weber e Marx. In: COHN, G. (org.). Sociologia: para ler os clássicos. Rio de Janeiro: Livros Técnicos e Científicos, 1977.

ÁVILA, Humberto. Teoria dos princípios - da definição à aplicação dos princípios jurídicos. 11. ed., rev. São Paulo: Malheiros, 2010.

AZNAR, Guy. Trabalhar menos para trabalharem todos. São Paulo: Página Aberta, 1995.

BARBOSA, Thiago Ramos. Os movimentos sociais de trabalhadores e seus reflexos históricos no direito do trabalho: o papel da classe operária na formação do direito do trabalho. Dissertação de mestrado. Faculdade de Direito da USP, São Paulo, 2009. 
BARROSO, Luís Roberto. Interpretação e aplicação da Constituição. 5. ed. São Paulo: Saraiva, 2003.

BEDAQUE, José Roberto dos Santos. Poderes instrutórios do juiz. 2. ed. revista e ampliada. São Paulo: Ed. Revista dos Tribunais, 1994.

BERNARDO, João. Reestruturação capitalista e os desafios para os sindicatos. Lisboa: Mimeo, 1996.

BIHR, Alain. Du "Grand Soir" a "L'Alternative": le mouvement ouvrier européen en crise. Les Editions Ouvriéres: Aris. Edição brasileira - São Paulo: Boitempo (Col. Mundo do Trabalho), 1998.

BOBBIO, Norberto. Teoria do ordenamento jurídico. Tradução de Maria Celeste Cordeiro Leite dos Santos. 7. ed. Brasília: Editora Universidade de Brasília, 1996.

BOITO JR., Armando. Reforma e persistência da estrutura sindical. In: BOITO JR., Armando et al. (orgs.). O sindicalismo brasileiro nos anos 80. Rio de Janeiro: Paz e Terra, 1991.

. Estado, politica e classes sociais: ensaios teóricos e históricos. São Paulo: Editora UNESP, 2007.

BONAVIDES, Paulo. Curso de direito constitucional. 12. ed. São Paulo: Malheiros, 2002.

BORRAJO, E. Sindicalismo obrero em Francia. Madrid: CSIC, 1956.

BOTIJA, Pérez. Curso de derecho del trabajo. 6. ed. Madrid: Tecnos, 1960.

BRUNHOFF, Suzanne de. A hora do mercado, crítica do neoliberalismo. São Paulo: Editora da UNESP, 1991.

CACCIAMALI, Maria Cristina. Distribuição de renda no Brasil: persistência do elevado grau de desigualdade. In: PINHO, D \& VASCONCCELLOS, M.A.S. Manual de economia. São Paulo: Saraiva, 2002. Disponível em http://www.fea.usp.br/feaecon/media/livros/file 529.pdf, acesso em 31-08-2013.

CHACON, Gaspar Bayon \& BOTIJA, Eugênio Perez. Manual de derecho del trabajo. 9. ed. Madrid: M. Pons, 1973-1974.

CAMACHO, Daniel. Movimentos sociais: algumas discussões conceituais. In: SCHERERWARREN, Ilse \& KRISCHKE, Paulo J. (orgs.). Uma revolução no cotidiano? Os novos movimentos sociais na América Latina. São Paulo: Brasiliense, 1987.

CAMPOS, Fernando Marques de. Os direitos sociais e sua função no capitalismo. Dissertação de mestrado. Faculdade de Direito da USP, São Paulo, 2010. 
CANARIS, Claus - Wilhelm. Systemdenken und systembegriff in der jurisprudenz. Berlin: Duncker und Humblot, 1983.

CANOTILHO, José Joaquim Gomes. Direito constitucional e teoria da constituição. 4. ed. Coimbra: Livraria Almedina, [2000].

CARVALHO, Ruy Quadros. Tecnologia e trabalho industrial. São Paulo: Ed. L.P.M., 1987.

CASTLES, F.G. The future of the welfare state - crisis myths and crisis realities. Oxford: Oxford University Press, 2004.

. The english speaking countries. In: CASTLES, F. et al (eds.). The Oxford handbook of the welfare state. Oxford: Oxford Unviersity Press, 2010.

CASTRO, Federico de. Derecho civil de España. 2. ed. Madri, s/ed, 1949.

CASTRO, J.A.; MOSTAFA, J.; HERCULANO, P. Os gastos com a política social: alavanca para o crescimento com distribuição de renda. Comunicado Ipea, n.75. Brasília: IPEA, 2011.

CASTRO, Nadya A. Modernização e trabalho no complexo automotivo brasileiro. In: CASTRO, N. A. (org.). A máquina e o equilibrista: inovações na indústria automobilística brasileira. Rio de Janeiro: Paz e Terra, 1995.

CHAUÍ, Marilena. Uma nova classe trabalhadora. In: SADER, Emir (org.). 10 anos de governos pós-neoliberais no Brasil: Lula e Dilma. São Paulo: Boitempo; Rio de Janeiro: FLACSO Brasil, 2013.

CORREA, Jaime Montalvo. Fundamentos de derecho del trabajo. Madrid: Editorial Civitas, 1975.

CORREIA, Marcus Orione Gonçalves. O Brasil precarizado. Disponível em http://www.epds.com.br/site/index,php?link=revista\&act=ver\&id=25, acesso em 22-082013.

CORIAT, Benjamin. Autômatos, robôs e a classe operária. Novos Estudos Cebrap. São Paulo, v. 2, n. 2, s/p, jul.1983.

COSTA, Armando Casimiro; FERRARI, Irany; MARTINS, Melchíades Rodrigues. Consolidação das Leis do Trabalho. 36. ed. São Paulo: LTr, 2009.

COUTINHO, Grijalbo Fernando. Terceirização: o golpe mais duro contra o direito laboral. Revista da Associação Latino-Americana de Juizes do Trabalho, s/loc., ano 6, n. 8, p.35, abr. 2012.

CUEVA, Mario de la. Derecho mexicano del trabajo. 2. ed. Mexico: Livreria de Porrua Hnos. Y Cia., 1943. 
. Derecho mexicano del trabajo. Prólogo da 2. ed. Mexico: Libreria de Porrua Hnos. Y Cia., 1943. 1960 Derecho mexicano del trabajo. S/ed. Mexico: Livreria de Porrua Hnos. Y Cia., . El nuevo derecho mexicano del trabajo. 4. ed. Mexico: Editorial Porrúa SA, 1977.

DEDECCA, Claudio S. Reestruturação produtiva e mercado de trabalho. Seminário realizado pelo Cebrap e Desep/CUT. Cadernos de Pesquisa, Cebrap. São Paulo, n. 1, p. 29-59, 1994.

DELGADO, Mauricio Godinho. Curso de direito do trabalho. 4. ed. São Paulo: LTr, 2005. DEVEALI, Mario. Lineamentos de derecho del trabajo. Buenos Aires: s/ed., 1956.

DIAS, Everardo. História das lutas sociais no Brasil. São Paulo: Edaglit, 1962.

DWORKIN, Ronald. Levando os direitos a sério. Tradução de Nelson Boeira. São Paulo: Martins Fontes, 2002.

ENGELS, Friedrich. A origem da família, da propriedade privada e do Estado. Tradução de Ciro Mioranza. 2. ed. São Paulo: Escala, s/a.

ESPÍNDOLA, Ruy Samuel. Conceito de princípios constitucionais. São Paulo: RT, 1999.

ESPING-ANDERSEN, G. The three worlds of welfare capitalism. Princeton: Princeton University Press, 1990.

1999.

. Social foundation of postindustrial economics. Oxford: Oxford University Press,

. The incomplete revolution: adapting to women's new roles. Cambridge: Polity Press, 2009.

ESSER, Josef. Grundsatz und norm in der richterlichen fortbildung des privatrechts. Tübingen, Mohr, Siebech, 1990.

FALEIROS, Vicente de Paula. A politica social do Estado capitalista. 7. ed. São Paulo: Cortez, s.d.

FAUSTO, Boris. História concisa do Brasil. 2. ed. São Paulo: Ed. da Universidade de São Paulo, 2009.

FERRARA, Francesco. Interpretação e aplicação das leis. Traduzido por Manuel A. Domingues de Andrade. 4. ed. Coimbra: Armélio Amado Editor, Sucessor, 1987. 
FERNANDES, Ana Elizabete Simões da Mota. Cultura da crise e seguridade social: um estudo sobre as tendências da previdência e da assistência social brasileira nos anos 80 e 90. São Paulo: Cortez, 1995.

FIORI, José Luis. Adeus à classe trabalhadora? Disponível em http://www.forumsocialmundial.org.br, acesso em 04-05-2003.

FOLHA DE S.PAULO. 13.jun.2010, p. B4.

FURTADO, Celso. O longo amanhecer: reflexões sobre a formação do Brasil. Rio de Janeiro: Paz e Terra, 1999.

GARCIA, Alonso. Derecho del trabajo, t. I. Barcelona: Bosch, 1960.

GENRO, Tarso Fernando. Contribuição à crítica do direito coletivo do trabalho. São Paulo: LTr, 1988.

. Introdução crítica ao direito. Estudos de filosofia do direito e direito do trabalho. Porto Alegre: Sergio Antonio Fabris Editor, 1988.

GORENDER, Jacob. A burguesia brasileira. São Paulo: Brasiliense (Col. Tudo é História), 2004.

GORZ, André. Adeus ao proletariado. Rio de Janeiro: Forense Universitária, 1982.

GRAZIA, Giuseppina Rosaria De. A redução e redistribuição do tempo de trabalho em questão. Tese de doutorado. Departamento de Sociologia da FFLCH-USP, São Paulo, 2003.

GRAU, Eros Roberto. Ensaio e discurso sobre a interpretação/aplicação do direito. São Paulo: Malheiros, 2002.

GRAY, J. False Dawn: the delusions of global capitalism. London: Granta, 1998.

GRUPO KRISIS. Manifesto contra o trabalho. Mimeo, 1999.

GUIMARÃES, Juarez. Comunicação oral em debate na UFMG, em 14-10-2010.

HARVEY, David. Condição pós-moderna. Uma pesquisa sobre as origens da mudança cultural. 12. ed. Tradução de Adail Ubirajara Sobral e Maria Stela Gonçalves. São Paulo: Loyola, 1992.

HYMAN, Richard. Europeização ou erosão das relações laborais? In: ESTANQUE, Elísio et. al. (orgs.). Mudanças no trabalho e ação sindical: Brasil e Portugal no contexto da transnacionalização. São Paulo: Cortez, 2005.

IANNI, Octavio. O Estado e o desenvolvimento econômico no Brasil. Tese apresentada ao concurso para provimento da cadeira de Professor de Sociologia II da FFLCH-USP, São Paulo, 1964. 
. Estado e planejamento econômico no Brasil (1930-1970). Rio de Janeiro: Civilização Brasileira, 1971.

Teorias da globalização. 8. ed. Rio de Janeiro: Civilização Brasileira, 2000.

IPEA. Pobreza, desigualdade e políticas públicas. Comunicado da Presidência, n. 38, p. 7, 12.jan.2010.

. Dimensão, evolução e projeção da pobreza por região e por estado do Brasil. Comunicados do Ipea, n.58, p.8, 13.jul.2010.

KASHIURA JÚNIOR, Celso Naoto. Crítica da igualdade jurídica. Contribuição ao pensamento jurídico marxista. Dissertação de mestrado. Faculdade de Direito da USP, São Paulo, 2008.

KEHL, Maria Rita. O fetichismo. In: SADER, Emir (org.). Sete pecados do capital. Rio de Janeiro: Record, 2000.

KELSEN, Hans. Teoria pura do direito. Tradução de João Baptista Machado. Revisão para a edição brasileira: Silvana Vieira. 3. ed. São Paulo: Martins Fontes, 1991.

KERSTENETZKY, Celia Lessa. O Estado do bem-estar social na idade da razão. A reinvenção do Estado Social no mundo contemporâneo. Rio de Janeiro: Elsevier, 2012.

KHAIR, Amir. Entraves ao desenvolvimento. O Estado de S. Paulo, 4.jul.2010, s/p.

LACROIX, J. Por que o trabalho? Palestra apresentada na 51 a sessão das Semanas Sociais da França, celebradas em Lyon em 1964, e publicadas em Los trabajadores em la sociedad contemporânea. Barcelona: Nova Terra, 1966.

LARENZ, Karl. Methodenlehre der Rechtswissenschaft. 6. ed. München: Beck, 1991. Richtiges Recht. München: Beck, 1979.

LEITE, João Antônio Pereira. Estudos de direito do trabalho e direito previdenciário. Porto Alegre: Síntese, 1979.

LEITE, Márcia de Paula. Inovação tecnológica e relações de trabalho: a experiência brasileira à luz do quadro internacional. In: CASTRO, N. A. (org.). A máquina e o equilibrista: inovações na indústria automobilística brasileira. Rio de Janeiro: Paz e Terra, 1995.

LYON-CAEN, G. Ideologias y doctrinas en derecho del trabajo. Derecho Laboral. Buenos Aires, n. 10, p. 585, 1971. 
MACHADO, Gustavo Seferian Scheffer. A ideologia do contrato de trabalho. Contribuição à leitura marxista da relação jurídica laboral. Dissertação de mestrado. Faculdade de Direito da USP, São Paulo, 2012.

MAGANO, Octavio Bueno. Convenção Coletiva de Trabalho. In: MAGANO, Octavio Bueno (coord.). Curso de direito do trabalho em homenagem a Mozart Victor Russomano. São Paulo: Saraiva, 1985.

. Direito do trabalho e direito econômico. Revista LTr, São Paulo, 39/732, s.a.

MARTINS, N. Sen's capability aprroach and post keynesianism: simillarities, distinctions, and the Cambridge tradition. Journal of Post Keynesian Economics, v. 31, n.4, p. 691-706, Summer 2009.

MARTINS FILHO, Ives Gandra da Silva. Os pilares do direito do trabalho - princípios e sua densidade normativa. Revista LTr, São Paulo, v.76, n. 07, p.781, julho de 2012.

MARX, Karl \& ENGELS, Friedrich. Manifesto Comunista. Rio de Janeiro: Horizonte, 1945.

Obras escogidas em dos tomos, $t$. I. Moscú: Ed. Progresso, 1955.

. O Manifesto Comunista. Tradução de Maria Lúcia Como. Ed. Especial. Rio de Janeiro: Nova Fronteira, 2011.

MARX, Karl. The economic and philosophic manuscript of 1844. New York, s/ed., 1964. . O Capital, v. I. New York, s/ed., 1967.

. O Capital. V. I, livro $1^{\text {o }}$, tomo I. 3. ed. São Paulo: Nova Cultural, 1988.

O 18 Brumário de Luís Bonaparte. In: MARX, Karl. A revolução antes da revolução. São Paulo: Expressão Popular, 2008.

MASCARO, Alysson Leandro. Filosofia do direito. 2. ed. São Paulo: Atlas, 2012.

MATTOSO, Jorge. O Brasil desempregado. São Paulo: Ed. Fund. Perseu Abramo, 1999.

MAXIMILIANO, Carlos. Hermenêutica e aplicação do direito. 12. ed. Rio de Janeiro: Forense, 1992.

MELLO, Celso Antônio Bandeira de. Elementos de direito administrativo. São Paulo: RT, 1986.

. Curso de Direito Administrativo. 19. ed. São Paulo: Malheiros, 2005.

MESQUITA, José Ignácio Botelho de. Da ação civil. São Paulo: RT, 1975. 
MÉSZÁROS, István. Beyond capital (towards a theory of transition). London: Merlin Press, 1995.

MICHALET, Charles-Alberto. O capitalismo mundial. Rio de Janeiro: Paz e Terra, 1984.

MONREAL, Eduardo. El derecho como obstáculo al cambio social. Mexico: Siglo Veintiuno Editores, 1980.

MORAES, Maria Celina Bodin de. O conceito de dignidade humana: substrato axiológico e conteúdo normativo. In: SARLET, Ingo Wolfgang (org.). Constituição, direitos fundamentais e direito privado. 2. ed. Porto Alegre: Livraria do Advogado, 2006.

MORAES FILHO, Evaristo de. O problema do sindicato único no Brasil. Rio de Janeiro: Ed. A Noite, 1952.

NASCIMENTO, Amauri Mascaro. Compêndio de direito do trabalho. São Paulo: s/ed, 1972.

. Curso de direito do trabalho. São Paulo: Saraiva, 1989.

. Curso de direito do trabalho. 11. ed., rev. e aum. São Paulo: Saraiva, 1995.

- Interpretação, integração e aplicação do direito do trabalho. Revista LTr, São Paulo, v.73, n. 08, p. 903, ago.2009.

NERI, Marcelo. A nova classe média: o lado brilhante dos pobres. Rio de Janeiro: CPS/FGV, 2010. Disponível em http://cps.fgv.br. Consultado em 26-06-2012.

NETTO, José Paulo. Crise do socialismo e ofensiva neoliberal. 3. ed. São Paulo: Cortez, 2001.

O’DONNELL, Guillermo. Análise do autoritarismo burocrático. São Paulo: Paz e Terra, 1990.

OFFE, Claus. Trabalho: a categoria-chave da sociologia? Revista Brasileira de Ciências Sociais, São Paulo, v. 4, n. 10, p. 5-20, junho de 1989.

OLIVEIRA, Aparecido Batista de. Os contornos jurídicos do artigo $9^{\circ}$ da CLT. Monografia de conclusão do curso de especialização em Direito do Trabalho e da Seguridade Social. Faculdade de Direito da USP, São Paulo, 2008.

.Os limites jurídicos do trabalho eventual: uma análise da figura do "chapa". In: SOUTO MAIOR, Jorge Luiz \& GNATA, Noa Piatã Bassfeld (orgs.). Trabalhos marginais. São Paulo: LTr, 2013. 
OLIVEIRA, Francisco de. Para não passar de equilibrista a bêbado. In: CASTRO, N. A. (org.). A máquina e o equilibrista: inovações na indústria automobilística brasileira. Rio de Janeiro: Paz e Terra, 1995.

Os direitos do antivalor. A economia política da hegemonia imperfeita. Petrópolis: Vozes, 1998.

. Crítica à razão dualista - o ornitorrinco. São Paulo: Boitempo, 2006.

OLIVEIRA, Paulo Eduardo Vieira de. Direito do trabalho e cidadania. Revista do Tribunal Regional do Trabalho da 15 Região, Campinas, n. 31, p. 65, 2007.

PESSOA, Roberto \& PAMPLONA FILHO, Rodolfo. A nova velha questão da ultraatividade das normas coletivas e a Súmula n. 277 do Tribunal Superior do Trabalho. Revista LTr, São Paulo, v. 77, n. 02, p.152-153, fev.2013.

PIERSON, C. Beyond the welfare state - the new political economy of welfare. Cambridge: Polity Press, 2006.

PLÁ RODRIGUEZ, Américo. Principios de direito do trabalho. Tradução de Wagner D. Giglio. São Paulo: LTr, 1993.

POCHMANN, Marcio. Desenvolvimento, trabalho e renda no Brasil. São Paulo: Fundação Perseu Abramo, 2010.

. O emprego na globalização. São Paulo: Boitempo, 2011.

. Inflexão distributiva. Folha de S. Paulo, 23. jan. 2011, Ilustríssima.

. Nova classe media? O trabalho na base da pirâmide social brasileira. São Paulo:

Boitempo, 2012.

POLANYI, K. The great transformation. Boston: Beacon, 1957.

PONTES, Alan Oliveira. O princípio da solidariedade social na interpretação do direito da seguridade social. Dissertação de mestrado. Faculdade de Direito da USP, São Paulo, 2006.

POULANTZAS, Nicos. Pouvoir politique et classes sociales. Paris: François Maspero, 1968.

RANGEL, Ignacio. A inflação brasileira. Rio de Janeiro: Tempo Brasileiro, 1963.

REALE, Miguel. Lições preliminares de direito. São Paulo: Saraiva, 1988.

Fontes e modelos do direito: para um novo paradigma hermenêutico. São Paulo: Saraiva, 1994. 
RECASÉNS SICHES, Luis. Nueva filosofia de la interpretación del derecho. MéxicoBuenos Aires: Fondo de Cultura Econômica, [1956].

RIFKIN, Jeremy. O fim dos empregos. São Paulo: Makron Books, 1995.

ROSSETTI, José Paschoal. Introdução à economia. 15. ed. São Paulo: Atlas, 1991.

RUAS, R. Notas acerca da implantação de programas de qualidade e produtividade em setores industriais brasileiros. Texto apresentado na II Reunião da Rede FrancoLatinoamericana sobre Trabalho e Tecnologias, Buenos Aires, nov. 1992.

RUSSOMANO, Mozart Vitor. A estabilidade do trabalhador na empresa. Rio de Janeiro: Ed. José Konfino, 1970.

. Novos temas de direito do trabalho. Rio de Janeiro: Forense, 1985.

RUSSOMANO JÚNIOR, Victor. Política trabalhista brasileira: (análise crítica). Rio de Janeiro: Forense, 1998.

SADER, Emir. A exploração. In: SADER, Emir (org.). Sete pecados do capital. Rio de Janeiro: Record, 2000.

. A trama do neoliberalismo. Mercado, crise e exclusão social. In: SADER, Emir \& GENTILI, Pablo (orgs.). Pós-neoliberalismo: as políticas sociais e o Estado democrático. 5. ed. Rio de Janeiro: Paz e Terra, 2000.

. A construção de hegemonia pós-neoliberal. In: SADER, Emir (org.). 10 anos de governos pós-neoliberais no Brasil: Lula e Dilma. São Paulo: Boitempo; Rio de Janeiro: FLACSO Brasil, 2013.

SAFATLE, Vladimir. A esquerda que não teme dizer seu nome. São Paulo: Três Estrelas, 2012.

. Escravos da modernidade. Folha de S. Paulo, terça-feira, 21 de fevereiro de 2012, p. A2 opinião. opinião.

Os limites do lulismo. Folha de S. Paulo, terça-feira, 17 de abril de 2012, p. A2 . Estado-mãe. Folha de S. Paulo, 21 de maio de 2013, p. A2.

SALAMA, Pierre. A trama do neoliberalismo. Mercado, crise e exclusão social. In: PósNeoliberalismo. As políticas sociais e o Estado democrático. SADER, Emir \& GENTILI, Pablo (orgs.). 5. ed. Rio de Janeiro: Paz e Terra, 2000.

SALOMÃO FILHO, Calixto et al. Concentração, estruturas e desigualdade. As origens coloniais da pobreza e da má distribuição de renda. São Paulo: Grupo Direito e Pobreza Instituto de Direito do Comércio Internacional e Desenvolvimento - IDCID, 2008. 
SANTOS, Boaventura de Souza. Pela mão de Alice: o social e o político na pósmodernidade. São Paulo: Cortez, 1997.

SAYER, A. Radical political economy: a critique. Oxford: Blackwell, 1995.

SCHMITZ, Hubert. O fordismo está vivo no Brasil. Novos Estudos Cebrap. São Paulo, n. 27, 1990.

SICSÚ, João. Dois projetos em disputa. Teoria e Debate, n. 88, p.14, maio/jun-2010.

. Re-visões do desenvolvimento. Inteligência, n. 49, p. 92, jul/2010. Disponível em www.insightnet.com.br. Consultado em 20.jul.2010.

SILVA, Homero Batista Mateus da. Em busca do tempo perdido - o aviso prévio proporcional ao tempo de serviço e a lei n. 12.506/2011. Revista LTr, São Paulo, v. 76, n. 09, p. 1059, setembro de 2012.

. Curso de direito do trabalho aplicado, vol. 1: parte geral. 2. ed. revista e ampliada. Rio de Janeiro: Elsevier, 2013.

. Curso de direito do trabalho aplicado, vol. 2: jornadas e pausas. 2. ed. revista e ampliada. Rio de Janeiro: Elsevier, 2013.

SILVA, José Afonso da. Aplicabilidade das normas constitucionais. 6. ed. São Paulo: Malheiros, 2003.

SILVA, José Antônio Ribeiro de Oliveira. A flexibilização da jornada de trabalho e seus reflexos na saúde do trabalhador. Revista LTr, São Paulo, v. 77, n. 02, p. 181-191, fev. 2013.

SILVA, Walküre Lopes Ribeiro da. Crise de representatividade e participação dos sindicatos em políticas ativas de emprego. Tese apresentada para concurso de Professor Titular de Direito do Trabalho da Faculdade de Direito da USP, São Paulo, 2001.

SINGER, André Vitor. Os sentidos do lulismo: reforma gradual e pacto conservador. São Paulo: Companhia das Letras, 2012.

. Palestra proferida no IX Sécs-USP: Brasil pós-88, transformações, continuidade e desafios. Disponível em http://www.viomundo.com.br/politica/armando-boito-jr--grandeburguesia-interna-domina-governo-dilma.html. Acesso em 16-09-2013.

SINGER, Paul. Dominação e desigualdade. Estrutura de classe e repartição da renda no Brasil. Rio de Janeiro: Paz e Terra, 1981.

1987.

O capitalismo: sua evolução, sua lógica e sua dinâmica. São Paulo: Moderna, 
SOUTO MAIOR, Jorge Luiz. O direito do trabalho como instrumento de justiça social. São Paulo: LTr, 2000.

. Proteções jurídicas em face da cessação da relação de emprego. In: SOUTO MAIOR, Jorge Luiz \& CORREIA, Marcus Orione Gonçalves (orgs.). Curso de direito do trabalho. Vol. 2 - Direito individual do trabalho. São Paulo: LTr, 2008.

A supersubordinação - invertendo a lógica do jogo. Revista do Tribunal Regional do Trabalho da $3^{a}$ Região - Belo Horizonte, v. 48, n.78, p.171-177, jul/dez-2008.

. Os princípios do direito do trabalho e sua negação por alguns posicionamentos jurisprudenciais. In: MELO FILHO, Hugo Cavalcanti et al (coords.). O mundo do trabalho, volume I: leituras críticas da jurisprudência do TST: em defesa do direito do trabalho. São Paulo: LTr, 2009.

. Curso de direito do trabalho: teoria geral do direito do trabalho, volume I: parte I. São Paulo: LTr, 2011.

SOUTO MAIOR, Jorge Luiz \& CORREIA, Marcus Orione Gonçalves. O que é Direito Social: In: CORREIA, Marcus Orione Gonçalves (org.). Curso de direito do trabalho volume I: teoria geral do direito do trabalho. São Paulo: LTr, 2007.

SOUZA, Sérgio Alberto de. Direito, globalização e barbárie - estudos crítidos de temas de direito do trabalho e de direitos humanos sob a ótica de uma leitura não-liberal. São Paulo: LTr, 1998.

STANDING, G. Globalization, labour flexibility and insecurity: the era of market regulation. European Journal of Industrial Relations, 3 (1), pp.7-37.

SÜSSEKIND, Arnaldo et. al. Instituições de direito do trabalho, v. 2. 16. ed., atual. por Arnaldo Süssekind e João de Lima Teixeira Filho. São Paulo: LTr, 1996.

TITMUS, R. Social Policy: an introduction. New York: Pantheon Books, 1974.

TOLEDO FILHO, Manoel Carlos. Direito do capital. Disponível em http://www.anamatra.org.br/artigos/direito-do-capital. Acesso em 22-08-2013.

VARGAS, Getúlio. Mensagem apresentada ao Poder Legislativo em 3 de maio de 1935. Rio de Janeiro: Imprensa Nacional, 1935.

. As diretrizes da nova política do Brasil. Rio de Janeiro: José Olympio, 1942.

VIANNA, Luiz Werneck. Liberalismo e sindicato no Brasil. 4. ed. rev. Belo Horizonte: Editora UFMG, 1999.

VIANA, Márcio Túlio. Novos rumos para o direito do trabalho. In: VIANA, Márcio Túlio; RENAUT, Luiz Otávio Linhares (coord.). O que há de novo em direito do trabalho. São Paulo: LTr, 1997. 
. A terceirização revisitada - algumas críticas e sugestões para um novo tratamento da matéria. Revista LTr, São Paulo, v. 77, n. 02, p. 143-148, fev. 2013.

VIOLA, Eduardo \& MAINWARING, Scott. Novos movimentos sociais - cultura política e democracia: Brasil e Argentina. In: SCHERER-WARREN, Ilse \& KRISCHKE, Paulo J. (orgs.). Uma revolução no cotidiano? Os novos movimentos sociais na América Latina. São Paulo: Brasiliense, 1987. 


\section{RESUMO}

A presente pesquisa teve por objetivo estudar o princípio da melhoria da condição social do trabalhador, como elemento central e teleológico do direito do trabalho, a fim de verificar aspectos relevantes para a contextualização sociológica, histórica e jurídica desse ramo do direito e contribuir para a construção de uma racionalidade de justiça social. Partindo da intrínseca relação do direito do trabalho com o sistema capitalista de produção e com o conflito de classes sociais inerente ao referido sistema, questionou-se o papel desse ramo jurídico, como instrumento de emancipação da classe trabalhadora ou de preservação dos interesses do capital. A finalidade da doutrina da conciliação das classes sociais e alguns dos principais aspectos de sua implementação no Brasil foram trazidos para o conjunto analítico. Foram analisados os reflexos das transformações do Estado e, portanto, do direito, para o princípio da melhoria da condição social do trabalhador, a partir das mudanças de uma estrutura normativa liberal para a social, passando pelo impacto da ideologia neoliberal e da reestruturação produtiva das últimas décadas. A dinâmica normativa dos princípios e em especial do princípio da melhoria da condição social do trabalhador e a verificação de aspectos importantes da relação deste princípio com outros centrais do direito do trabalho foram abordadas. Foram revisitadas as principais técnicas e situações jurídicas de aplicação do princípio em estudo, a partir da perspectiva de direito social e da contribuição para o fortalecimento da classe trabalhadora. Por fim, apresentouse uma reflexão, à luz do princípio da melhoria da condição social do trabalhador, a respeito da problemática da terceirização, da rotatividade da mão de obra e do excesso de jornada de trabalho.

Palavras chave: Capitalismo. Classes sociais. Estado - liberal, social e neoliberal. Direito social. Direito do trabalho. Princípios jurídicos. Princípio da melhoria da condição social do trabalhador. 


\begin{abstract}
This research aimed to study the principle of improvement of worker's social conditions, as a central and teleological element of Labor Law in order to analise relevant aspects for the sociological, historical and legal contextualization of this branch of Law and also to contribute to the development of social justice rationality. Based on the intrinsic relationship of Labor Law with the production capitalist system and also based on the class conflict which is inherent in the previously mentioned system, the role of this branch of Law was questioned as an emancipation tool for the working class or as a tool for preserving the interests of the capital. The purpose of the doctrine of reconciliation of social classes and some of the key aspects of its implementation in Brazil were scrutinized. Reflections of state transformations were analyzed and therefore the right to the principle of improvement of the worker's social conditions were also analyzed, based on changes which would alter a liberal regulatory framework into a social one, through the impact of neoliberal ideology and of the restructuring of productive decades. The dynamics of normative principles and in particular the principle of improvement of worker's social condition and the analysis of important aspects of its relationship with other central principles of Labor Law were addressed. The main technical and legal situations of application of the principle being studied were rewied from the perspective of Social Law and from the perspective of contribution to strengthening of the working class. Finally, a reflection, under the light of the principle of improvement of worker's social condition, about the issues of outsourcing, labor turnover and excessive working hours presented.
\end{abstract}

Keywords: Capitalism. Social classes. State - liberal, social and neoliberal. Social Law. Labor Law. Legal principles. Principle of improvement of the worker's social conditions. 